\title{
Structural analysis of the Rubjerg Knude Glaciotectonic Complex, Vendsyssel, northern Denmark
}

Stig A. Schack Pedersen 


\section{Geological Survey of Denmark and Greenland Bulletin 8}

\section{Keywords}

Northern Jylland, Denmark, Weichselian, glacial geology, glaciotectonics, thin-skinned thrust faulting, balanced cross-section, thrustfault dynamics, imbricate duplexes, mud diapirs, piggyback basins.

\section{Cover}

The coastal cliff (99 m high at its highest point) at Rubjerg Knude on the west coast of Vendsyssel, northern Denmark. The lower two-thirds of the cliff, beneath the prominent dark sub-horizontal surface, forms part of the cross-section through the Rubjerg Knude Glaciotectonic Complex displaying imbricated thrust sheets composed of the Lønstrup Klint Formation (bluish-grey colour) and the overlying Rubjerg Knude Fomation (yellow colour), both of Late Weichselian age. The thrust sheets are truncated by a glaciotectonic unconformity (the prominent surface), upon which the Kattegat Till Formation is only preserved as a boulder bed due to subsequent aeolian erosion of the till matrix. The upper third of the cliff comprises recent aeolian dune sands that have accreted over the last 100 years and now encroach on the Rubjerg Knude lighthouse, the top of which is just visible above the clifftop. Photo: Stig A. Schack Pedersen (August 1984).

Chief editor of this series: Adam A. Garde

Editorial board of this series: John A. Korstgård, Geological Institute, University of Aarhus; Minik Rosing, Geological Museum, University of Copenhagen; Finn Surlyk, Geological Institute, University of Copenhagen

Scientific editor of this volume: Jon R. Ineson

Editorial secretaries: Esben W. Glendal and Birgit Eriksen

Illustrations: Benny M. Schark and Alice Rosenstand

Digital photographic work: Benny M. Schark

Graphic production: Knud Gr@phic Consult, Odense, Denmark

Printers: Schultz Grafisk, Albertslund, Denmark

Manuscript submitted: 8 August 2003

Final version approved: 11 February 2005

Printed: 15 December 2005

This monograph has been accepted by the Faculty of Natural Sciences, University of Copenhagen, for public defence of the degree of Doctor of Science.

ISSN 1604-8156

ISBN 87-7871-168-1

\section{Geological Survey of Denmark and Greenland Bulletin}

The series Geological Survey of Denmark and Greenland Bulletin replaces Geology of Denmark Survey Bulletin and Geology of Greenland Survey Bulletin.

\section{Citation of the name of this series}

It is recommended that the name of this series is cited in full, viz. Geological Survey of Denmark and Greenland Bulletin. If abbreviation of this volume is necessary, the following form is suggested: Geol. Surv. Den. Green. Bull. 8, 192 pp.

\section{Available from}

Geological Survey of Denmark and Greenland (GEUS)

Øster Voldgade 10, DK-1350 Copenhagen K, Denmark

Phone: +45 381420 00, fax: +45 381420 50, e-mail: geus@geus.dk

or

Geografforlaget ApS

Rugårdsvej 55, DK-5000 Odense C, Denmark

Phone: +45 634416 83, fax: +45 634416 97, e-mail: go@geografforlaget.dk 


\section{Contents}

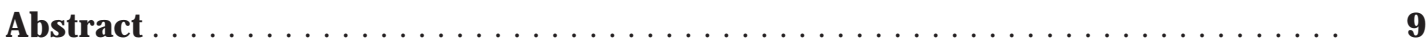

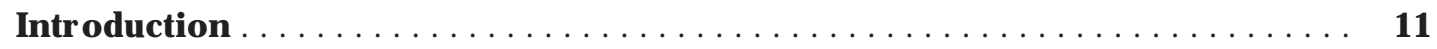

History of the present investigation $\ldots \ldots \ldots \ldots \ldots \ldots \ldots \ldots \ldots \ldots \ldots \ldots \ldots \ldots \ldots \ldots$

Objectives ......................................... 14

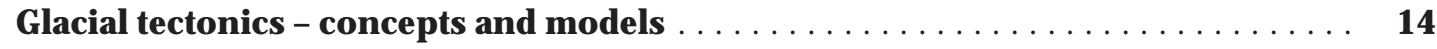

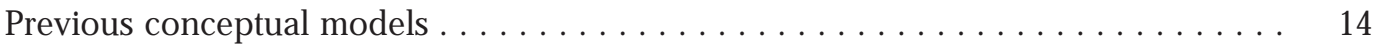

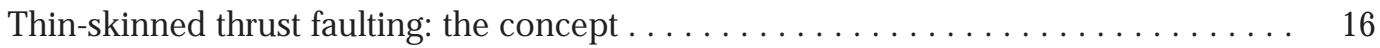

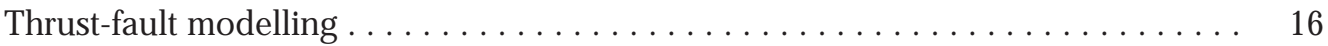

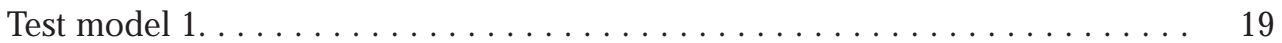

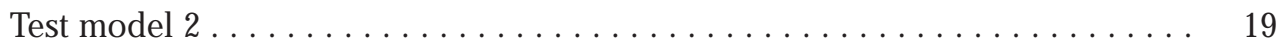

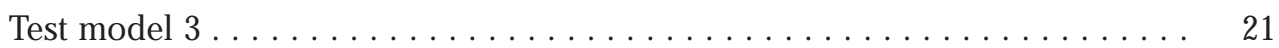

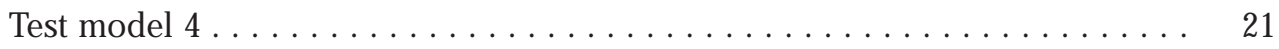

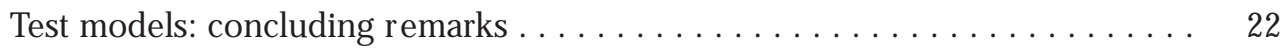

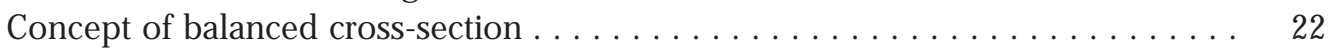

Location and construction of the Rubjerg Knude cross-section . . . . . . . . . . 23

Location. .................................... 23

Photogrammetric work. . . . . . . . . . . . . . . . . . . . 23

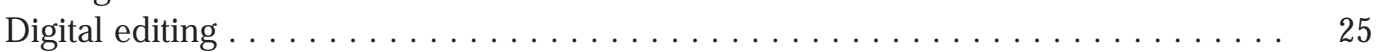

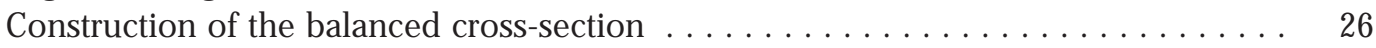

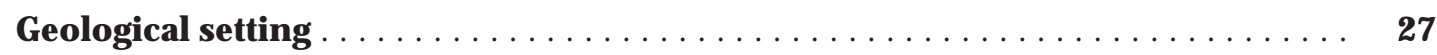

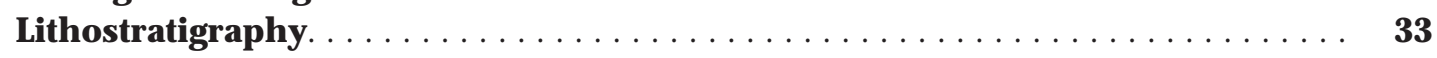

Skærumhede Group . . . . . . . . . . . . . . . . . . . . . . . . . . . 33

Stortorn Formation . . . . . . . . . . . . . . . . . . . . . . . . . . . 35

Lønstrup Klint Formation . . . . . . . . . . . . . . . . . . . . . . . . . . . . . . 39

Upper Weichselian lithostratigraphic units . . . . . . . . . . . . . . . . 43

Rubjerg Knude Formation . . . . . . . . . . . . . . . . . . . . 43

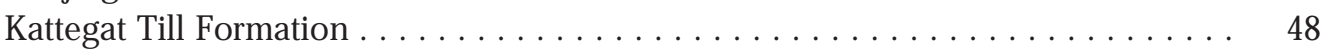

Ribjerg Fomation ............................ 50

Mid Danish Till Formation ........................... 53

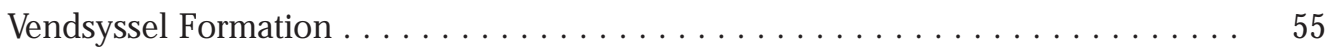

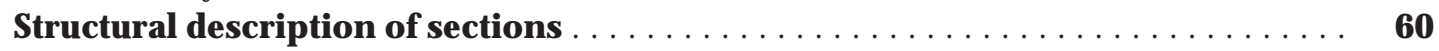

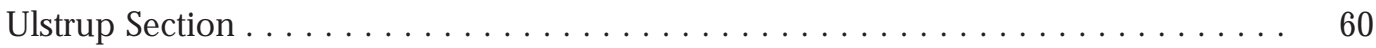

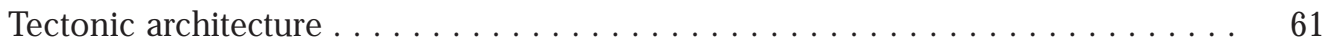

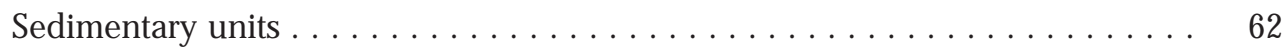

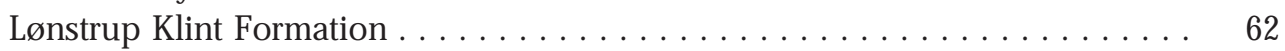

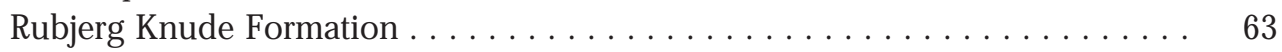

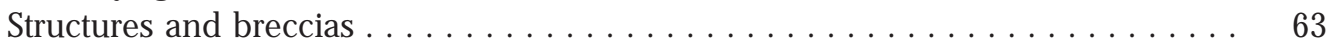

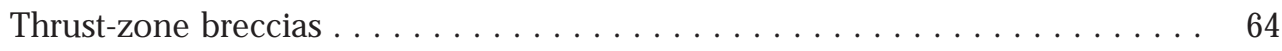

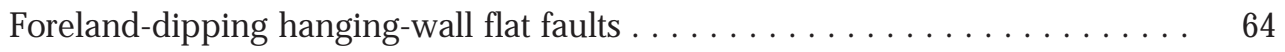

Collapse structure in the Ulstrup Rende . . . . . . . . . . . . . . . 66

Interpretation of structural development $\ldots \ldots \ldots \ldots \ldots \ldots \ldots \ldots \ldots \ldots$

Stensnæs Section . . . . . . . . . . . . . . . . . . . . . . . . 70

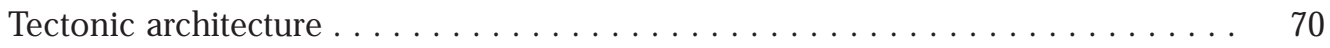

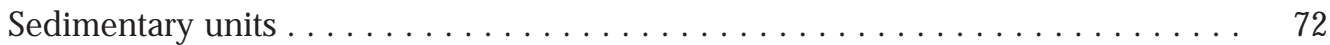

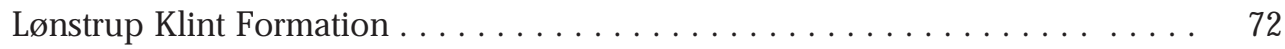

Rubjerg Knude Formation . . . . . . . . . . . . . . . . . . . . . . 73

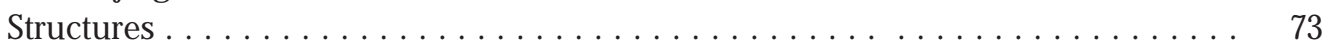




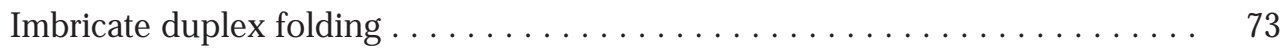

Extensional faults . . . . . . . . . . . . . . . . . . . . . . . 73

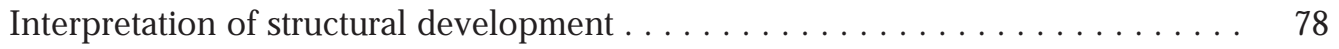

Martørv Bakker Section . . . . . . . . . . . . . . . . . . . . . . . . . . . 78

Tectonic architecture ............................ 79

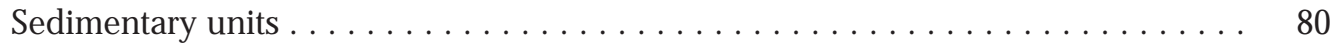

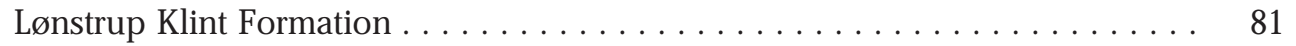

Rubjerg Knude Formation . . . . . . . . . . . . . . . . . . . . . . . . 81

Structures ................................. 82

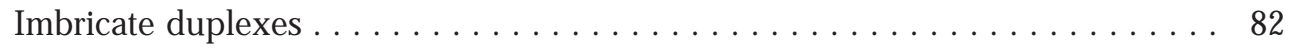

Normal fault. . . . . . . . . . . . . . . . . . . . . . 82

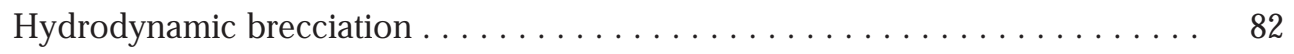

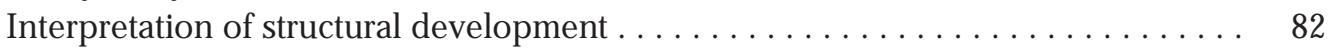

Kramrende Section ................................. 84

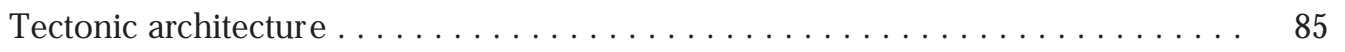

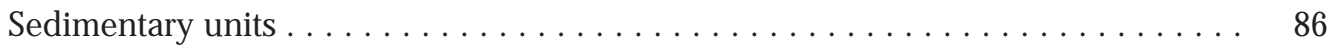

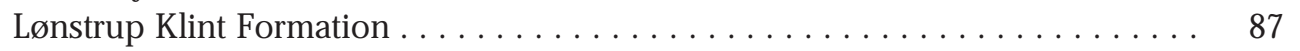

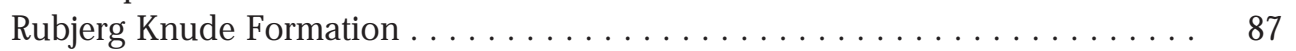

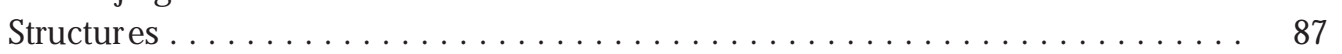

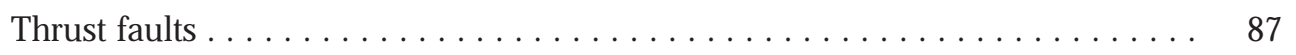

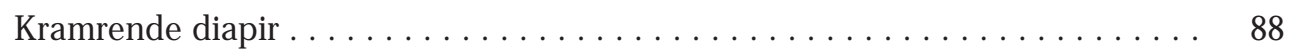

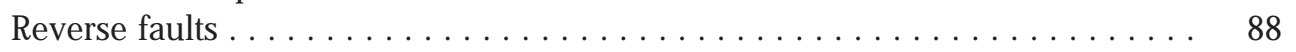

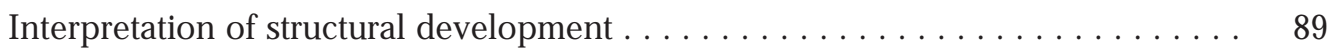

Brede Rende Section . . . . . . . . . . . . . . . . . . . . . . . . . . 90

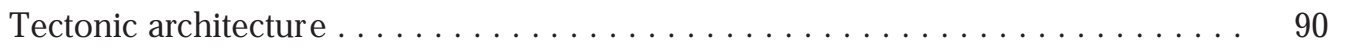

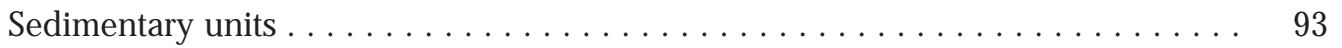

Lønstrup Klint Formation . . . . . . . . . . . . . . . . . . . . . . . . . . . . 93

Rubjerg Knude Formation . . . . . . . . . . . . . . . . . . . . . . . . . . . . . . . . 94

Structures.................................. 94

Diapir structures . . . . . . . . . . . . . . . . . . . . . . 96

Brede Rende normal fault . . . . . . . . . . . . . . . . . . . . . . . . . . . . . . . 97

Frost wedges . . . . . . . . . . . . . . . . . . . . . . . . . . . . 97

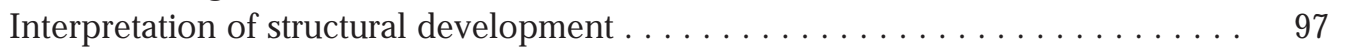

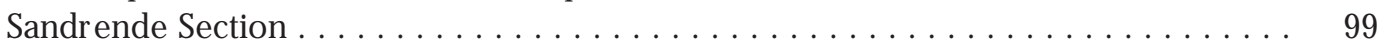

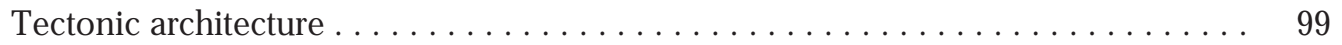

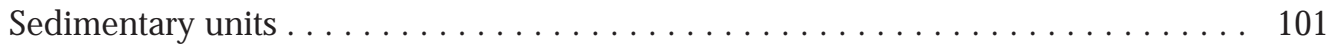

Lønstrup Klint Formation . . . . . . . . . . . . . . . . . . . . . . . . . 101

Rubjerg Knude Formation . . . . . . . . . . . . . . . . . . . . . . . . . . 101

Structures and breccias .............................. 103

Normal faults ......................................... 103

Diapir structures . . . . . . . . . . . . . . . . . . . . . . . . . . . . . . . . 104

Frost wedge . . . . . . . . . . . . . . . . . . . . . . . . . . . 104

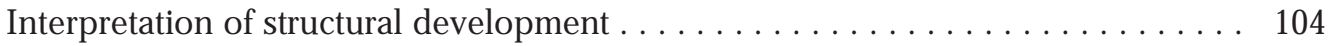

Stenstue Rende Section . . . . . . . . . . . . . . . . . . . . . . . . . . . . . 105

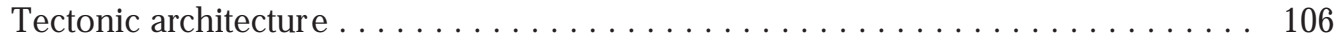

Sedimentary units . . . . . . . . . . . . . . . . . . . . . . 107

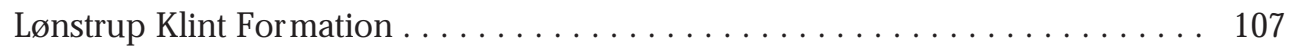

Rubjerg Knude Formation . . . . . . . . . . . . . . . . . . . . . . . . . . 108

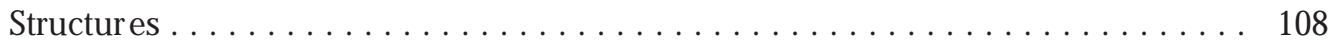

Thrust-fault structures . . . . . . . . . . . . . . . . . . . . . . . . 108

Hanging-wall anticlines . . . . . . . . . . . . . . . . . . . . . . . . . . . 109 


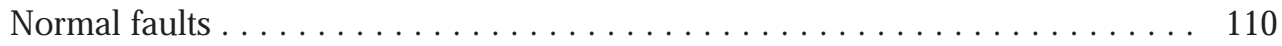

Slump folding . . . . . . . . . . . . . . . . . . . . . . . . . . . . . . . . . . 110

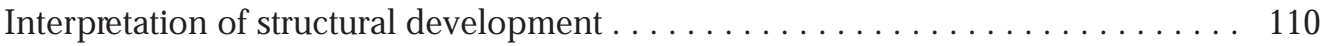

Grønne Rende Section . . . . . . . . . . . . . . . . . . . . . . . . 111

Tectonic architecture . ............................... 112

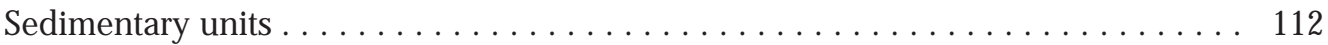

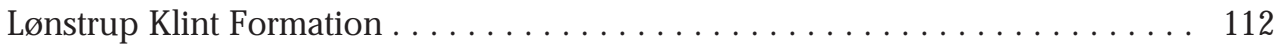

Rubjerg Knude Formation . . . . . . . . . . . . . . . . . . . . . . . . 112

Structures .................................... 113

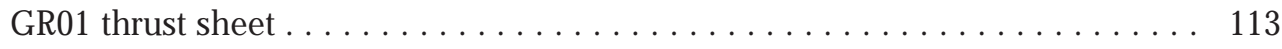

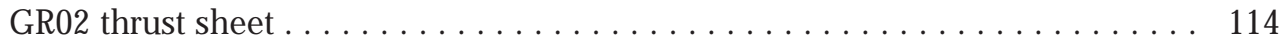

GR03 thrust sheet . . . . . . . . . . . . . . . . . . . . . . . . . . . 114

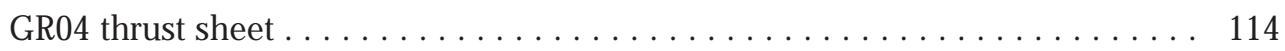

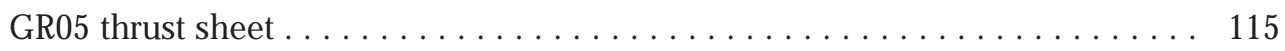

GR06 thrust sheet . . . . . . . . . . . . . . . . . . . . . . . . . 115

GR07 thrust sheet . . . . . . . . . . . . . . . . . . . . . . . . . . . . . 116

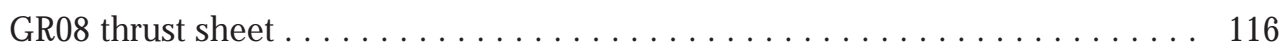

GR09 thrust sheet . . . . . . . . . . . . . . . . . . . . . . . . . . . 116

GR10 thrust sheet . . . . . . . . . . . . . . . . . . . . . . . . . 116

GR11 thrust sheet . . . . . . . . . . . . . . . . . . . . . . . . . 117

GR12 thrust sheet . . . . . . . . . . . . . . . . . . . . . . 117

GR13 thrust sheet . . . . . . . . . . . . . . . . . . . . . . . . . . . . . 117

Interpretation of structural development . . . . . . . . . . . . . . . . . . 117

Rubjerg Knude Fyr Section . . . . . . . . . . . . . . . . . . . . . . . . . 118

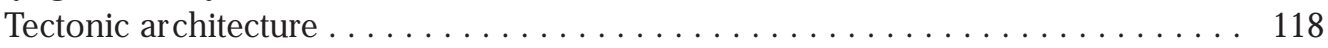

Sedimentary units . . . . . . . . . . . . . . . . . . . . . . . . . . . . . 121

Structures . . . . . . . . . . . . . . . . . . . . . . . . . . . . . . 122

Anastomosing thrust-fault brecciation . . . . . . . . . . . . . . . . . . . . . . . . 122

Interpretation of structural development . . . . . . . . . . . . . . . . . . . . . . 122

Stortom Section . . . . . . . . . . . . . . . . . . . . . . . . . . . . . . . 122

Tectonic architecture . . . . . . . . . . . . . . . . . . . . . . . . . . 123

ST01 thrust sheet . . . . . . . . . . . . . . . . . . . . . . . . . . . . . . . 123

ST02 thrust sheet . . . . . . . . . . . . . . . . . . . . . . . . . . . . . . . . 123

ST03 thrust sheet . . . . . . . . . . . . . . . . . . . . . . . . . 123

ST04 thrust sheet . . . . . . . . . . . . . . . . . . . . . . 123

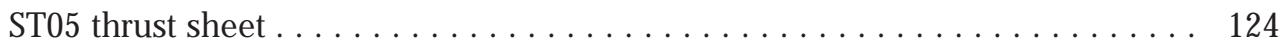

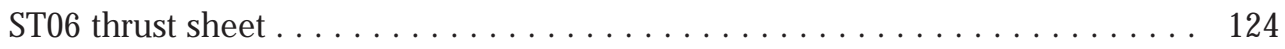

ST07 thrust sheet . . . . . . . . . . . . . . . . . . . . . . . . . 124

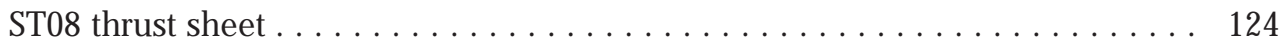

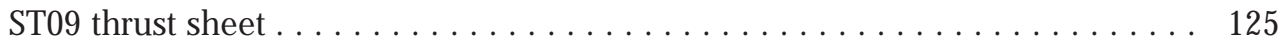

ST10 thrust sheet . . . . . . . . . . . . . . . . . . . . . . . 125

Sedimentary units . . . . . . . . . . . . . . . . . . . . . . 126

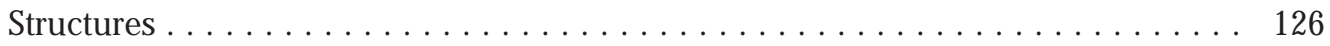

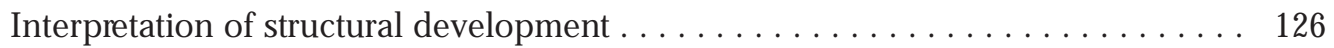

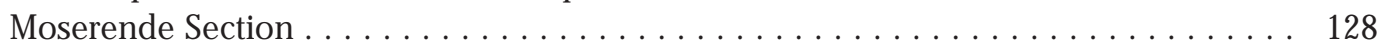

Tectonic architecture . . . . . . . . . . . . . . . . . . . . . 128

MR01 thrust sheet . . . . . . . . . . . . . . . . . . . . . . . . 129

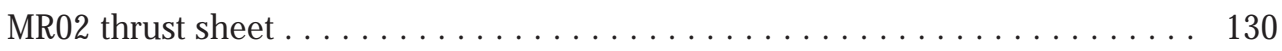

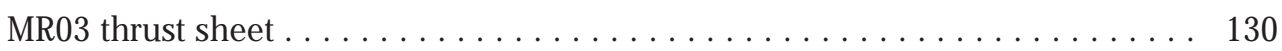

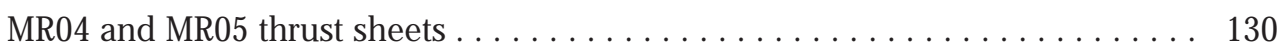

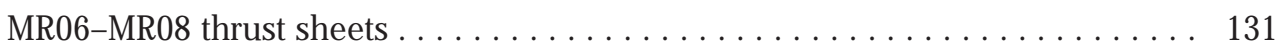




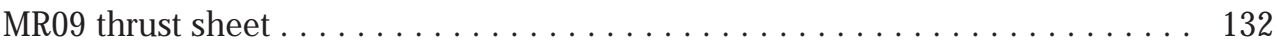

MR10 thrust sheet . . . . . . . . . . . . . . . . . . . . . . . . . . . . . . . . 132

MR11 thrust sheet ................................. 132

MR12 thrust sheet .................................. 132

MR13 thrust sheet ................................ 133

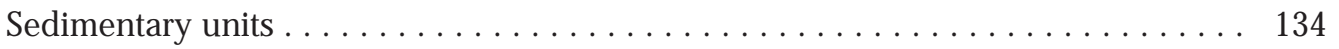

Lønstrup Klint Formation . . . . . . . . . . . . . . . . . . . . . . . . . . . . . 134

Rubjerg Knude Formation . . . . . . . . . . . . . . . . . . . . . . . . . . . . . . 134

Structures ...................................... 134

Diapir structures . . . . . . . . . . . . . . . . . . . . . . . . . 135

Thrust faults . . . . . . . . . . . . . . . . . . . . . . . . 135

Footwall synclines . . . . . . . . . . . . . . . . . . . . . . . . 135

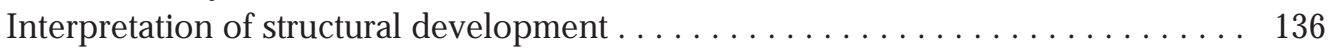

Mårup Kirke Section . . . . . . . . . . . . . . . . . . . . . . . . . . . . 137

Tectonic architecture . . . . . . . . . . . . . . . . . . . . . . . . . . . . 138

MK01 thrust sheet. . . . . . . . . . . . . . . . . . . . . . . . . . . . . . . . 139

MK02-MK04 thrust sheets . . . . . . . . . . . . . . . . . . . . . . . . . . . . . . . . . . . . 139

MK05-MK07 thrust sheets . . . . . . . . . . . . . . . . . . . . . . . . . . . . . . . . . . . . . . 139

MK08-MK10 thrust sheets . . . . . . . . . . . . . . . . . . . . . . . . . . . . . . . . . 140

MK11-MK20 thrust sheets . . . . . . . . . . . . . . . . . . . . . . . . . . . . . . 140

Sedimentary units . . . . . . . . . . . . . . . . . . . . . . . . . 141

Structures . . . . . . . . . . . . . . . . . . . . . . . . . . . . . . . . . . . . . . . . 141

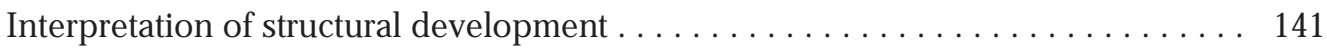

Fault-bend-fold model for duplex units . . . . . . . . . . . . . . . . . . . . . . . . . . . 141

Characterisation of thrust duplex MK11-MK20 . . . . . . . . . . . . . . . . . . . . 143

Discussion of structural development . . . . . . . . . . . . . . . . . . . . . . . 143

Ribjerg Section . . . . . . . . . . . . . . . . . . . . . . . . . . . . . . . . . . . . . . . 144

'Store Blå' and 'Lille Blå'. . . . . . . . . . . . . . . . . . . . . . . . . . . . . . . . . . . . . . . . . 144

Tectonic architecture . . . . . . . . . . . . . . . . . . . . . . . . . . . . . . . . 145

Sedimentary units . . . . . . . . . . . . . . . . . . . . . . . . . . . . . . . . 146

Skærumhede Group . . . . . . . . . . . . . . . . . . . . . . . . . . . . . . . . . . . . 146

Blå-unconformity . . . . . . . . . . . . . . . . . . . . . . . . . . . . . . 146

Ribjerg Formation . . . . . . . . . . . . . . . . . . . . . . . . . . . 146

Mid Danish Till Formation . . . . . . . . . . . . . . . . . . . . . . . . . . . . 147

Vendsyssel Formation . . . . . . . . . . . . . . . . . . . . . . . . . . . 147

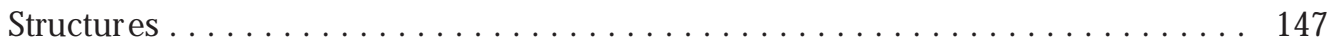

Interpretation of glacial geology and stratigraphic development . . . . . . . . 147

Dynamic development of the thin-skinned thrust faulting . . . . . . . . . . . . 148

Moserende Section ...................................... 148

Moserende Section: summary data . . . . . . . . . . . . . . . . . . . . . 149

Stortorn Section . . . . . . . . . . . . . . . . . . . . . . . . . . . . . 149

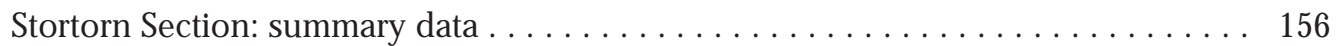

Rubjerg Knude Fyr Section . . . . . . . . . . . . . . . . . . . . . . 156

Rubjerg Knude Fyr Section: summary data . . . . . . . . . . . . . . . . 156

Grønne Rende Section ............................... 156

Grønne Rende Section: summary data . . . . . . . . . . . . . . . . . . . 157

Stenstue Rende Section . . . . . . . . . . . . . . . . . . . . . . . . . . . 157

Stenstue Rende Section: summary data . . . . . . . . . . . . . . . . . . . 161

Sandrende Section . . . . . . . . . . . . . . . . . . . . . . . . 161

Sandrende Section: summary data . . . . . . . . . . . . . . . . . . . . . . 163

Brede Rende Section . . . . . . . . . . . . . . . . . . . . . . . . . . . . 163 
Brede Rende Section: summary data . . . . . . . . . . . . . . . . 166

Kramrende Section ................................ 166

Kramrende Section: summary data . . . . . . . . . . . . . . . . 168

Martørv Bakker Section . . . . . . . . . . . . . . . . . . . . . . . . . 168

Martørv Bakker Section: summary data . . . . . . . . . . . . . . . . . . . 170

Stensnæs Section . . . . . . . . . . . . . . . . . . . . . . . . . . 170

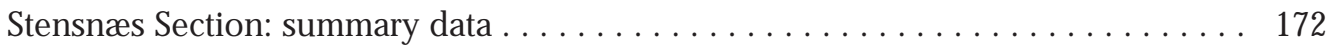

Ulstrup Section . . . . . . . . . . . . . . . . . . . . . . . . . . . . 173

Ulstrup Section: summary data . . . . . . . . . . . . . . . . . . . . . . 174

Summary of dynamic development. . . . . . . . . . . . . . . . . . . . . 174

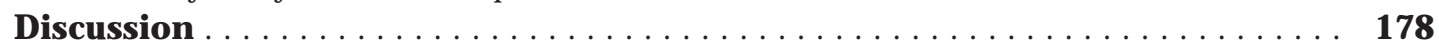

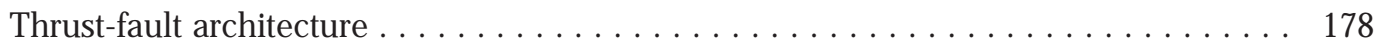

Balanced cross-section . . . . . . . . . . . . . . . . . . . . . . . 179

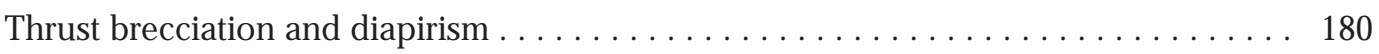

Thrust-fault dynamics . . . . . . . . . . . . . . . . . . . . . . . . 181

Syntectonic deposition . . . . . . . . . . . . . . . . . . . . . . . . 181

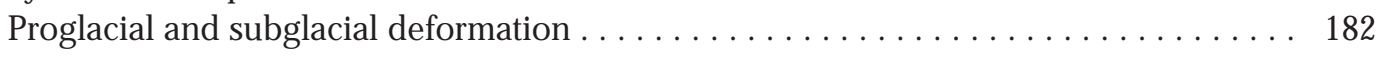

Glacial geological conditions . . . . . . . . . . . . . . . . . . . . . 183

Conclusions . . . . . . . . . . . . . . . . . . . . . . . . . . . . . . . 185

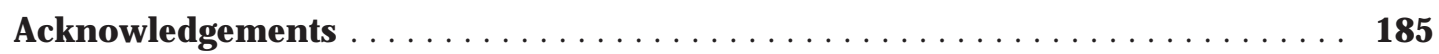

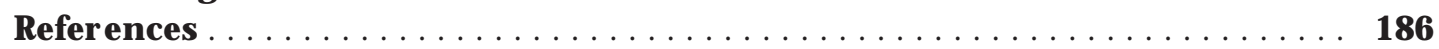

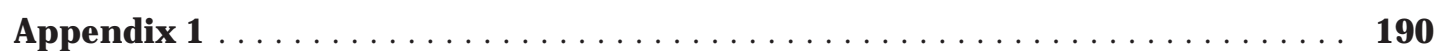

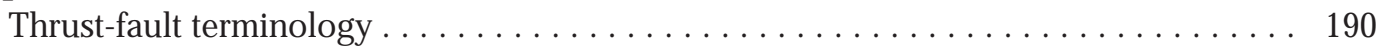

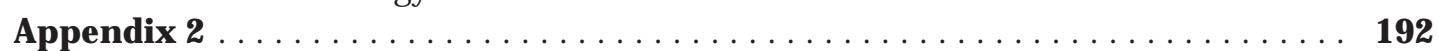

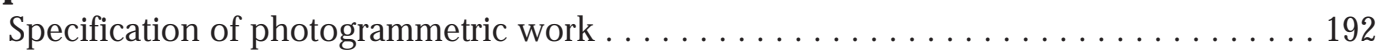





\section{Abstract}

Pedersen, S.A.S. 2005: Structural analysis of the Rubjerg Knude Glaciotectonic Complex, Vendsyssel, northern Denmark. Geological Survey of Denmark and Greenland Bulletin 8, $192 \mathrm{pp}$.

The Rubjerg Knude Glaciotectonic Complex is a thin-skinned thrust-fault complex that was formed during the advance of the Scandinavian Ice Sheet (30000 - 26000 B.P.); it is well exposed in a $6 \mathrm{~km}$ long coastal profile bordering the North Sea in northern Denmark. The glaciotectonic thrust-fault deformation revealed by this cliff section has been subjected to detailed structural analysis based on photogrammetric measurement and construction of a balanced cross-section. Thirteen sections are differentiated, characterising the distal to proximal structural development of the complex. The deformation affected three stratigraphic units: the Middle Weichselian arctic marine Stortorn Formation, the mainly glaciolacustrine Lønstrup Klint Formation and the dominantly fluvial Rubjerg Knude Formation; these three formations are formally defined herein, together with the Skærumhede Group which includes the Stortorn and Lønstrup Klint Formations. The Rubjerg Knude Formation was deposited on a regional unconformity that caps the Lønstrup Klint Formation and separates pre-tectonic deposits below from syntectonic deposits above.

In the distal part of the complex, the thrust-fault architecture is characterised by thin flatlying thrust sheets displaced over the footwall flat of the foreland for a distance of more than $500 \mathrm{~m}$. Towards the proximal part of the complex, the dip of the thrust faults increases, and over long stretches they are over-steepened to an upright position. The lowest décollement zone is about $40 \mathrm{~m}$ below sea level in the proximal part of the system, and shows a systematic step-wise change to higher levels in a distal (southwards) direction. The structural elements are ramps and flats related to hanging-wall and footwall positions. Above upper ramp-hinges, hanging-wall anticlines developed; footwall synclines are typically related to growth-fault sedimentation in syntectonic piggyback basins, represented by the Rubjerg Knude Formation. Blocks and slump-sheets constituting parts of the Lønstrup Klint Formation were derived from the tips of up-thrusted thrust sheets and slumped into the basins. Mud diapirs are a prominent element in the thrust-fault complex, resulting from mud mobilisation mainly at hanging-wall flats and ramps.

Shortening during thrust-fault deformation has been calculated as 50\%. Only about $11 \%$ of the initial stratigraphic units subjected to thrust faulting has been lost due to erosion. The thrust-fault deformation was caused by gravity spreading of an advancing ice sheet. Overpressured mud-fluid played an important role in stress transmission. The average velocity of thrust-fault displacement is estimated at $2 \mathrm{~m}$ per year, which led to compression of a $12 \mathrm{~km}$ stretch of flat-lying sediments, c. $40 \mathrm{~m}$ in thickness, into a thrust-fault complex $6 \mathrm{~km}$ in length. The thrust-fault complex is truncated by a glaciotectonic unconformity, formed when the advancing ice sheet finally overrode the complex. When this ice sheet melted away, a hilland-hole pair was formed, and meltwater deposits derived from a new ice-advance (NE-Ice) filled the depression. The NE-Ice overran the complex during its advance to the main stationary line situated in the North Sea. When this ice in turn melted away (c. 19000 - 15000 B.P.), the glacial landscape was draped by arctic marine deposits of the Vendsyssel Fo mation (new formation defined herein).

\section{Author's address}

Geological Survey of Denmark and Greenland, Øster Voldgade 10, DK-1350 Copenhagen K, Denmark. E-mail: sasp@geus.dk 


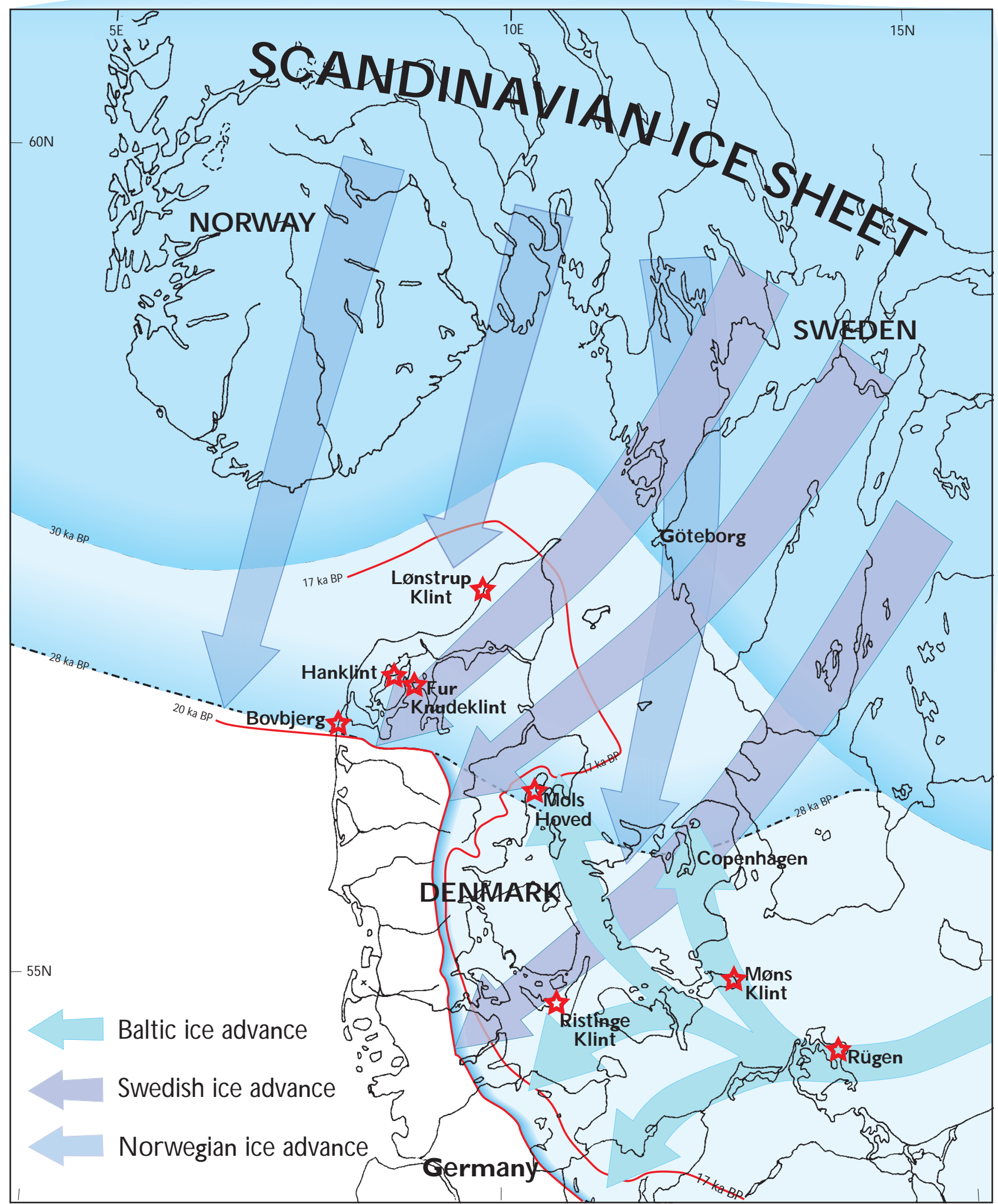

Fig. 1. Map of the Danish Basin indicating the distribution of the Scandinavian Ice Sheet during the three main ice advance events, with source areas in southem Norway, central Sweden and the Baltic, in the Middle-Late Weichselian. The approximate timing of the stationary lines are given; the early progressive ice advance is indicated in black, the subsequent late ice border lines in red. The locations of major glaciotectonic complexes formed during the ice advances are indicated by asterisks. 


\section{Introduction}

Glaciotectonic studies in Denmark have a long tradition, and an important part of structural geology studies in Denmark concern glacial tectonic defomation resulting from the southward advance of the Scandinavian Ice Sheet in the Pleistocene (Fig. 1). The description of the geological structures dates back to Puggaard (1851), who made one of the first extensive and detailed Danish structural analyses of a tectonic complex and provided a classic cross-section of Møns Klint. Johnstrup (1874) established the concept of glacial deformation. The next milestone in glacial tectonic studies in Denmark was by Jessen $(1918,1931)$, whose detailed survey of Lønstrup Klint (Fig. 1) included a structural analysis and an attempt at a glaciodynamic interpretation of the deformation structures observed. The Lønstrup Klint coastal section includes the Rubjerg Knude Glaciotectonic Complex, which is the subject of this study (Fig. 2). A Danish school of glaciotectonic studies subsequently developed (Madsen 1916; Jessen 1931; Gry 1940, 1941; Rosenkrantz 1944; Berthelsen 1973, 1975, 1978, 1979; Sjørring 1974, 1977, 1981, 1983; Rasmussen 1975; Petersen 1978; Houmark-Nielsen 1987, 1988; Pedersen 1987, 1993, 1996, 2000; Pedersen \& Petersen 1988, 1995, 1997; Pedersen et al.1988; Klint \& Pedersen 1995; Jakobsen 1996), which has naturally been stimulated by geologists working with glaciotectonic structural geology internationally (Banham 1977, 1988; Stephan 1980; Aber 1982, 1993; Ehlers 1983; van der Wateren 1985, 1992; Boulton 1986; Boulton \& Hindmarsh 1987; Croot 1987, 1988; Meer 1987; Goldthwait \& Matsch 1988; Aber et al. 1989; Hart 1990; Hart \& Watts 1997; Bennett 2001).

The similarity in structural geometry between glaciotectonic terrains and orogenic belts has led to prolonged debate. Are glaciotectonic terrains scale models for orogenic deformation? Or does the soft and synsedimentary nature of glaciotectonics differ in principle from that of fold belt deformation? Arguments for deformational similarity have been put forward by Berthelsen (1978, 1979), Banham (1988), Aber et al. (1989), van der Wateren (1992) and Pedersen (1987, 2000). These structural geologists share the opinion that the terminology of structural geology related to orogenic belts is applicable in the description and discussion of glaciotectonic complexes. The main differences between deformation in metamorphically altered rocks and glaciotectonic deformation of soft sediments are: (1) the presence of 'free' water, which enables liquefaction and fluidisation, (2) the velocity of the deformation, and (3) the shallowness of penetrative deformation. In contrast, deformation of metamorphic rocks commonly involves alteration and recrystallisation of minerals, processes that never apply to glaciotectonics.

The advantage ofa study of glaciotectonic complexes is that the structures are at a scale that allows them to be studied in a single exposure, in contrast to fold belts where extensive field mapping and expensive geophysical investigations are typically required for adequate documentation of the structures. Furthermore, many glaciotectonic complexes are geologically young, which means that the upper structural levels are still preserved and interpretation of the full dynamic development of structural complexes is possible. The structural architecture of glaciotectonic complexes may therefore serve as inspiration for the interpretation of thin-skinned structural relationships in fold belts and thrust-fault deformation terrains. The structural analysis of the Rubjerg Knude Glaciotectonic Complex is presented as a mesoscopic model of a thinskinned thrust-fault complex (Plates 1, 2).

\section{History of the present investigation}

This study focuses on the structural framework and dynamic development of the glacial tectonic thrustfault complex at Rubjerg Knude, Lønstrup Klint. It is based on twenty years of investigations of the Lønstrup Klint cliff section. The author took up the study of glacial tectonic thrust-fault structures after having concluded a Ph.D. thesis on thin-skinned thrust faulting in the North Greenland fold belt (Pedersen 1979, 1981, 1982, 1986a, 1987). A large part of the study of the fold belt structures in Peary Land, North Greenland, was photogrammetric mapping (Pedersen 1979, 1981), undertaken at a time when geological mapping by computer-assisted photogrammetry was under development in Copenhagen. This project was an integrated collaboration between the Geological Survey ofG reenland, the Institute of Surveying and Photogrammetry of the Technical University of Denmark (DTU), the Geological Museum (GM) and the Geological Institute (GI) of the University of Copenhagen. In the years 


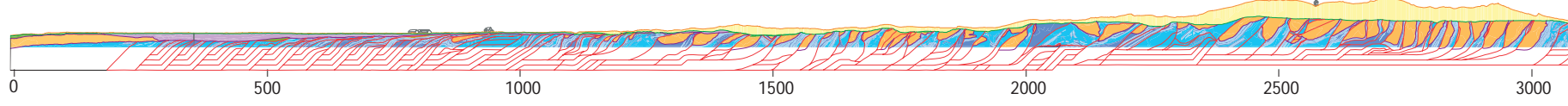

\section{Ribjerg}
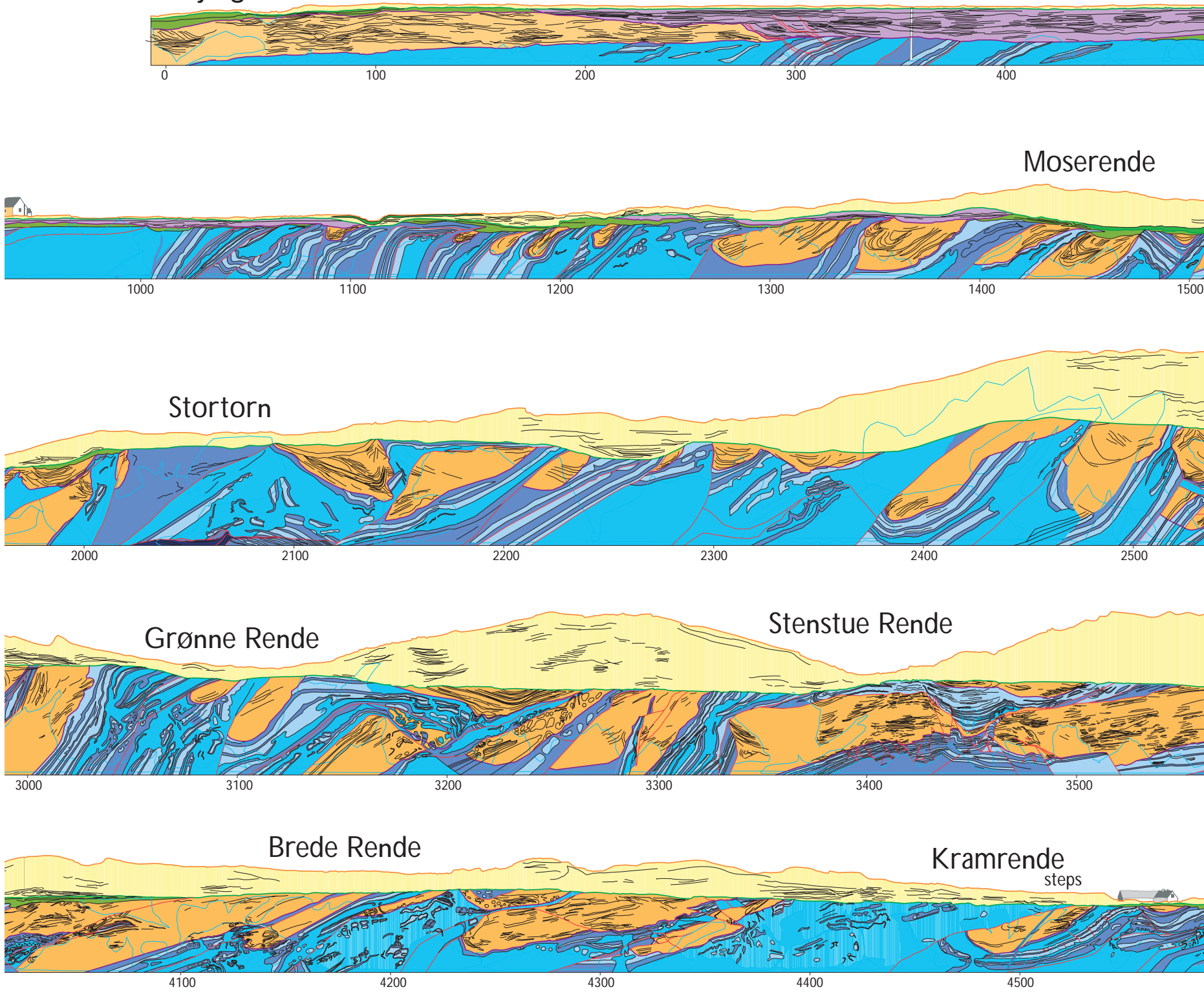

\section{Stensnæs}

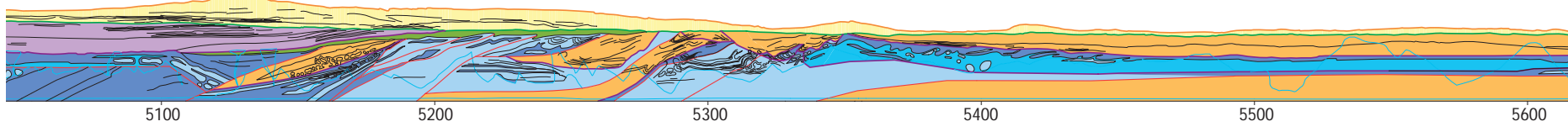

Fig. 2. Geological cross-section of the Rubjerg Knude Glaciotectonic Complex. For details and legend, see Plate 1.

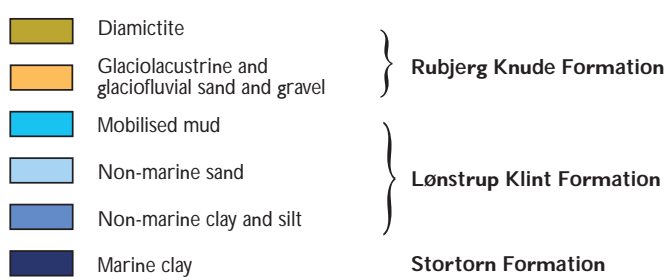


up to 1990, techniques of geological mapping and construction of geological cross-sections based on multimodel photogrammetric analysis were developed and made available at DTU (Dueholm 1992). Initial investigations in co-operation with K. Dueholm (DTU) and A.K. Pedersen (GM) proved the applicability of multimodel photogrammetry in the study of glaciotectonic cross-sections in Denmark by an examination of the Møns Klint cliff section (Pedersen 2000). Subsequently, the photogrammetric investigation of the Rubjerg Knude cliff section was initiated, and forms the basis of the present work.

\section{Objectives}

The objectives of the study of the Rubjerg Knude Glaciotectonic Complex can be summarised as follows.
1. A description of an exceptionally well-exposed glaciotectonic complex, which can be taken as an example of a very low friction thrust-fault wedge, presented as a detailed cross-section based on multimodel photogrammetric measurements of the $\mathrm{Ru}$ bjerg Knude cliff section.

2. A demonstration of the techniques of balanced cross-section construction that permit interpretation of the unexposed parts of the thrust-fault complex.

3 . The construction of a model for the dynamic development of the proglacial thrust system that demonstrates the sequential evolution of increasing deformation intensity and the interplay with syntectonic depositional processes.

4. An interpretation of deformation processes within the framework of Danish glacial stratigraphy in the late Pleistocene (late Middle to Late Weichselian c. 30000 - 20000 years B.P.).

\section{Glacial tectonics - concepts and models}

\section{Previous conceptual models}

The basic concept of glacial processes acting as the deformation agent was formulated by Johnstrup (1874). His concept was primarily focused on the formation of the spectacular cliffs at Møns Klint in south-eastern Denmark and on Rügen in north-eastern Germany. However, subsequently Johnstrup (1882) also included the formation of the steeply inclined floes exposed in the Lønstrup Klint cliff section in the classic examples of glacial deformation in Denmark. (The term floes is frequently used in the old glacial geology literature inspired by the idea that the dislocated sheets were ground- or permafrozen; in a structural geological context, floes are identical to thrust sheets or thrustsheet segments.) Johnstrup's main conclusions concerning the glaciotectonic origin of the deformation at Lønstrup Klint were: (1) the dislocations are superficial without extending down to a deep root zone, and are restricted to surface phenomena, (2) the direction of movement indicated from the dip of the dislocated floes corresponds to a uniform direction of ice advance, and (3) the dislocated floes formerly constituted one undisturbed area. The detailed mapping and construction of the cross-section was presented by Jessen (1918) in his geological description of the Vendsyssel map sheet. However, the final detailed description of the dislocations at Lønstrup Klint was published later (Jessen 1931).

In 1927, George Slater included a study of the Lønstrup Klint section as part of his thesis for a D.Sc. degree at the University of London, which also included a study of glacial deformation at Møns Klint. The most striking conclusion was that the glacial deformation at Lønstrup Klint was caused by englacial deformation. Slater (1927, p. 312) summarised thus: “... 2. The deposits represent the final positions of englacial material after the melting of the interstitial ice. 3. The type of structure is analogous to that seen in decaying Arctic glaciers, and is due to the arresting of movement of the frontal part of an overloaded ice-sheet. 4. The structure has been built up in the reverse direction to the line of movement." Slater (1927) interpreted the Lønstrup Klint section as a variety of glacial tectonics he termed 'the stagnant-glacier type'.

Subsequently, Axel Jessen and Karl Gripp exchanged ideasaboutproglacially formed glaciotectonic structures, and concluded that the structures Jessen had observed at Lønstrup Klint were similar to those that Gripp (1929) described from the foreland of the ad- 
Fig. 3. A model for structural balancing of the dislocated floes in the Lønstrup Klint section suggested by Gry (1941). In his model, the displacement surfaces were regarded as cylindrical sections and due to the suggested amount of displacement about $80 \%$ of the dislocated floes was subsequently eroded away.
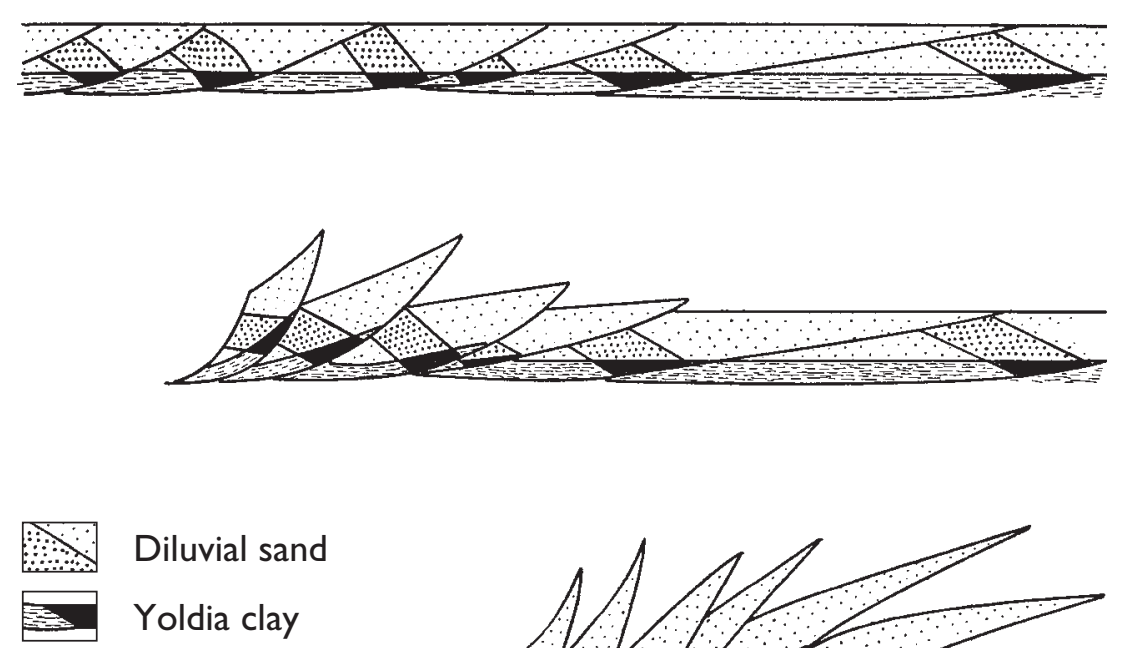

vancing Holmströms Gletscher on Spitsbergen. In his detailed and comprehensive description of his investigations, Jessen (1931) concluded that the disloctions cannot have formed englacially, but must be the result of pressure building up due to loading at the margin of the advancing ice. This pressure spreads out laterally into the clayey units, which in the foreland react by splitting up into fractured dislocation sheets compressed in front of the advancing ice masses.

Jessen (1931) also discussed the difficulty related to the displacement of the sheets without fracturing of the lithological units resulting in a complete collapse during deformation, and he pointed out that Johnstrup (1882) had suggested that the deformed layers could have been ground-frozen. Jessen's (1931) more subjective arguments against Slater's work concern the fact that Slater (1927) did not refer to Jessen's (1918) substantial work on Vendsyssel and in particular his published cross-section of Lønstrup Klint. Jessen pointed out that major anticlines in Slater's crosssection between Mårup Kirke and Rubjerg Knude Fyr do not exist, and that Slater's (1927) misinterpretation must be ascribed to his superficial investigations which did not allow him to check the way-up relationship of each limb in the fold structure (Jessen 1931).

In his work on the glaciotectonic deformation of Palaeogene diatomites with ash layers in the Limfjorden region, Gry (1940) compared these with the deformation at Lønstrup Klint and supported the proglacial deformation concept of Gripp (1929) and Jessen (1931). Furthermore, Gry proposed a gravity-spreading model for the deformation and attempted a very early balanced cross-section in the consideration of restoration of thedislocated thrust sheets (Fig. 3). However, Gry (1940) proposed a cylindrical model for the thrust surfaces, and in his 'back-stripping' cross-section the floes were displaced along circular fault lines. Thus, in his dynamic consideration the floes were assigned a standing position with their frontal parts 'up in the air' (Fig. 3), and he consequently concluded that more than $80 \%$ of the upper sand-series at Lønstrup had been eroded away by the advancing ice.

In contrast to this point of view, Pedersen (1987) suggested that a large proportion of the upper sandseries was deposited syntectonically; this removed the requirement that a large part of the floes or thrust sheets had been eroded away. Pedersen (1987) interpreted the glaciotectonic thrust-fault complex as an example of gravity-spreading deformation, viewed in the light of the gravity-spreading experimental model presented by Bucher (1956) and with reference to comparable gravity-spreading deformation in soft sedimentary rocks exemplified by the mudlumps in the Mississippi Delta (Morgan et al. 1968). Furthermore, the mudlumps or mud diapirs in the Lønstrup Klint imbricate fanwere described, and interpreted as an integral part of a conceptual dynamic model for thrust-fault related mud diapirism and syntectonic sedimentation (Fig. 4).

Sadolin et al. (1997) elaborated on the model of syntectonic sedimentation in the Lønstrup Klint section. Based on detailed sedimentological studies, they pointed out the importance of the unconformity that separates the lower muddy units (their unit A), from 
the upper sandy units (their units B-D). The lower unit A was interpreted to have been deposited in a lake isolated from the former marine Kattegat-Skagerrak basin by either a damming of the advancing ice, in accordance with ideas also presented by Jessen (1918, 1931), or simply by isolation of the lake basin due to lowering of sea level in the late Pleistocene (Sadolin et al. 1997). The unconformity was interpreted to reflect a major drainage event of the lake basin before a shallow lacustrine basin was established, characterised by incursions of glaciofluvial deposition (units B-D of Sadolin et al.1997). During the deposition of units $\mathrm{C}$ and $\mathrm{D}$, glaciotectonic thrusting commenced contemporaneously with the rise of mud diapirs and the formation of normal faults due to mass adjustments in the mobilised mud in the subsurface (Sadolin et al. 1997; Fig. 5).

The conceptual model presented here aims at an interpretation based on the concepts of thin-skinned thrust-fault tectonics. Although the scale is an order of magnitude smaller than in typical orogenic belts, it has not been found appropriate to introduce special terminology for the deformation structures in the Rubjerg Knude Glaciotectonic Complex. The concept of thrust-fault deformation and related structures is summarised in the following chapter.

\section{Thin-skinned thrust faulting: the concept}

It is difficult to judge exactly when the concept of thin-skinned thrust faulting nucleated, as it represents a gradual evolution of ideas over the last 25 years or more. However, Boyer \& Elliot (1982) appear to have been the first to give a conceptual introduction to the basic principle of thin-skinned thrust faulting. Suppe $(1983,1985)$ improved the concept by defining and describing the geometry and kinematics of fault-bend folding. Jamison (1987) and Schirmer (1988) contributed with further improvements of geometric analysis of fold development in overthrust terranes and thrust-fault hanging-wall successions. McClay (1992) presented a glossary of thrust tectonic terms, and Erickson \& Jamison (1995) demonstrated viscous-plastic finite-element models of fault-bend folds. In 1997, an entire volume of the Joumal of Structural Geology was devoted to thrust-fault tectonics. Among the papers that particularly inspired and supported this study of glaciotectonic thrust faulting were those of Contre-
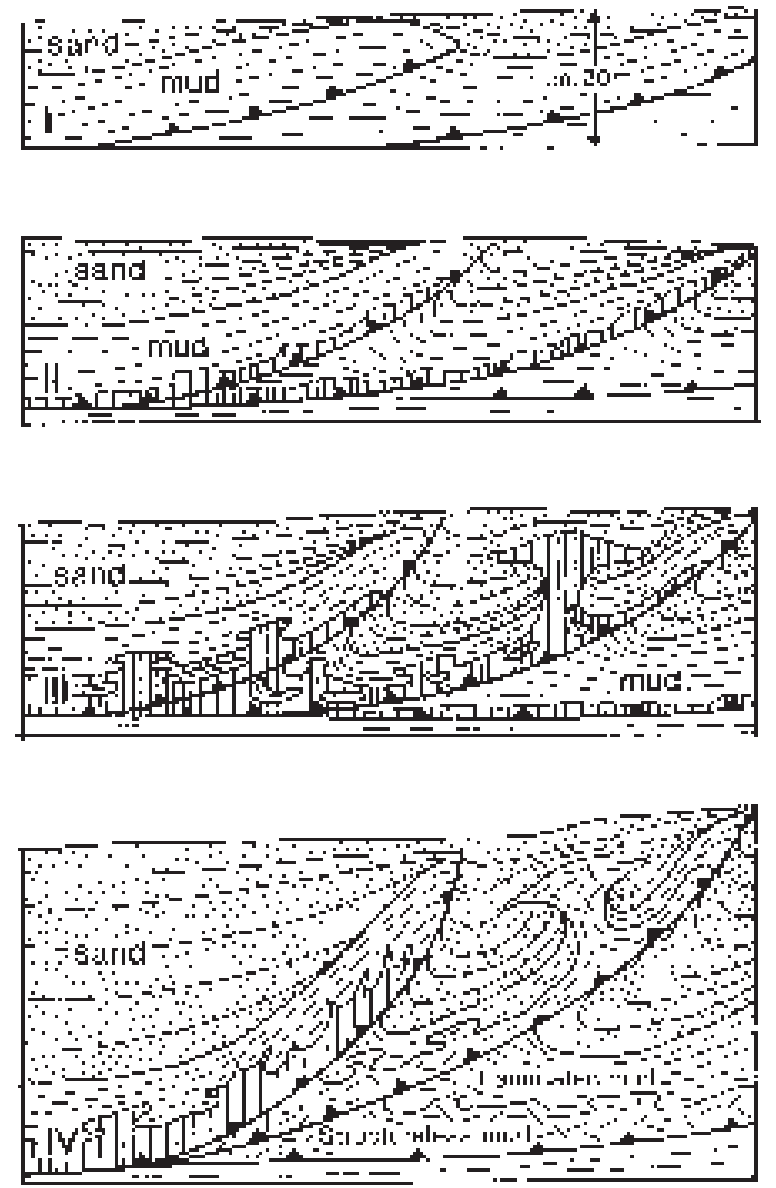

Fig. 4. A four-stage model for the development of mud diapirs related to thrust faulting in Lønstrup Klint suggested by Pedersen (1987). Note that in the model the thrust zone of the hanging-wall ramp constitutes mobilised mud and that syntectonic deposits accumulate 'piggyback' between the thrust sheets.

ras \& Sutter (1997), Medwedeff \& Suppe (1997) and Mitra \& Sussman (1997).

\section{Thrust-fault modelling}

To better understand the range of possible configurations of different structural frameworks of thrust-fault complexes, a series of computer models were tested with the aid of the program AUTOFAULT, a 'Balanced Cross Section Program' within the AutoCAD system frame (Ozkaya 1994). Four of these test models are demonstrated here to illustrate the thin-skinned thrustfault concept (Figs 6-9).

The basic function of the model is to define and construct a layer package onto which a thrust fault is added and given a certain displacement. The program then calculates the configuration of the thrust sheet 

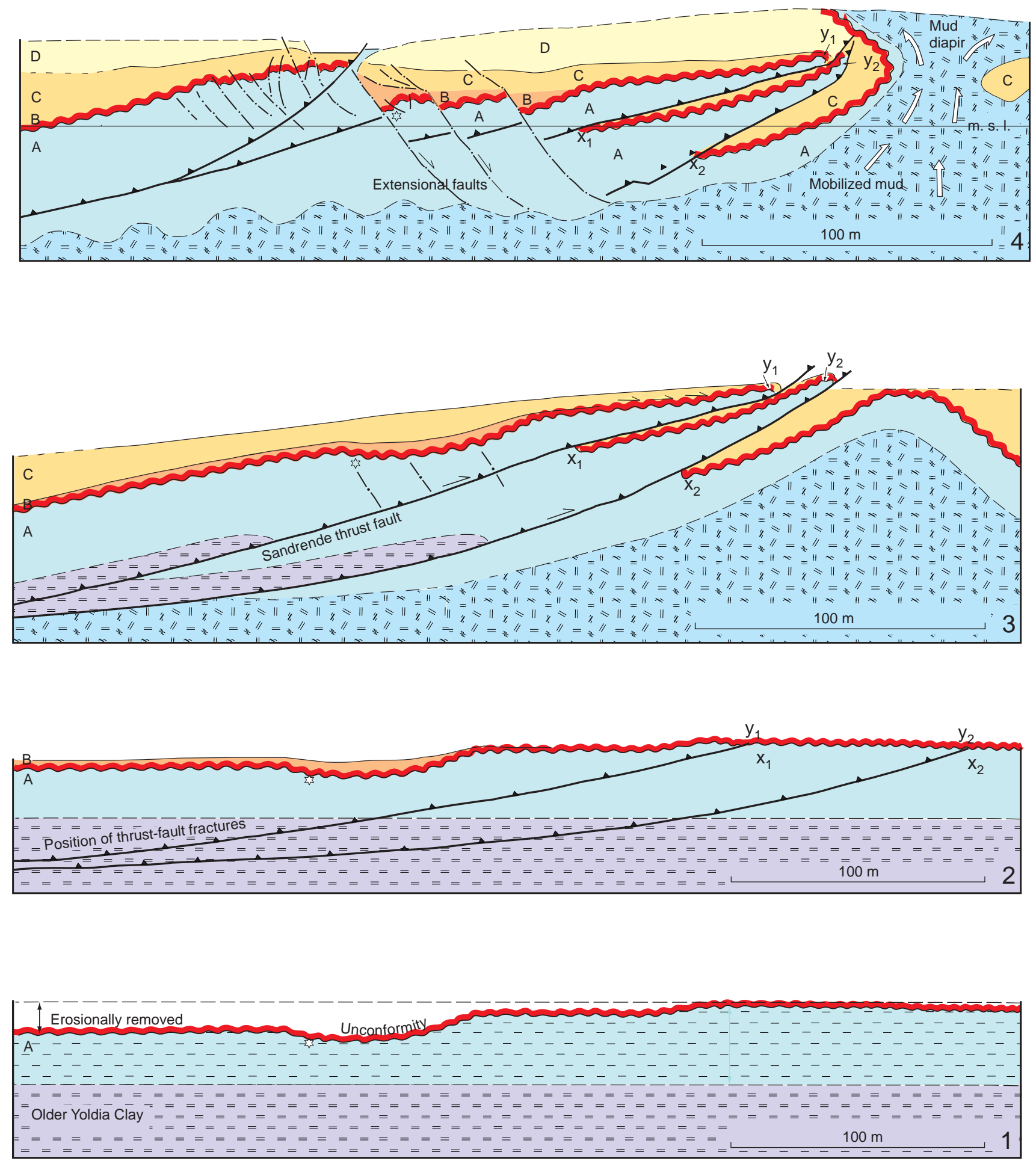

Fig. 5. The structural and depositional development of the Sandrende Section suggested by Sadolin et al. (1997). The model summarises four stages of development initiating with the formation of the regional erosional unconformity (1). Unit B was deposited in topographic lows above the unconformity, and thrust faulting initiated contemporaneously with the deposition of unit $\mathrm{C}\left(\mathbf{x}_{1}-\mathbf{y}_{1}\right.$ and $\mathbf{x}_{2}-\mathbf{y}_{2}$ denote same reference points separated by the thrusts, where $\mathrm{x}=$ footwall syncline and $\mathrm{y}=$ hanging-wall anticline) (2). Propagation along the thrust faults continued and unit $\mathrm{C}$ was deposited during increasing tilting of the thrust sheet. Normal-fault fractures formed in connection with the incipient diapirism (3). The Sandrende diapir rose during deposition of unit D and normal faulting propagated. In the proximal part of the thrust sheet, a network of conjugate extensional faults developed and interference between a new-formed satellite thrust and the nomal faults affected the complex. The tip of the thrust sheet was bent due to drag along the side of the rising diapir (4). Star symbol provides a reference point through the development stages. 

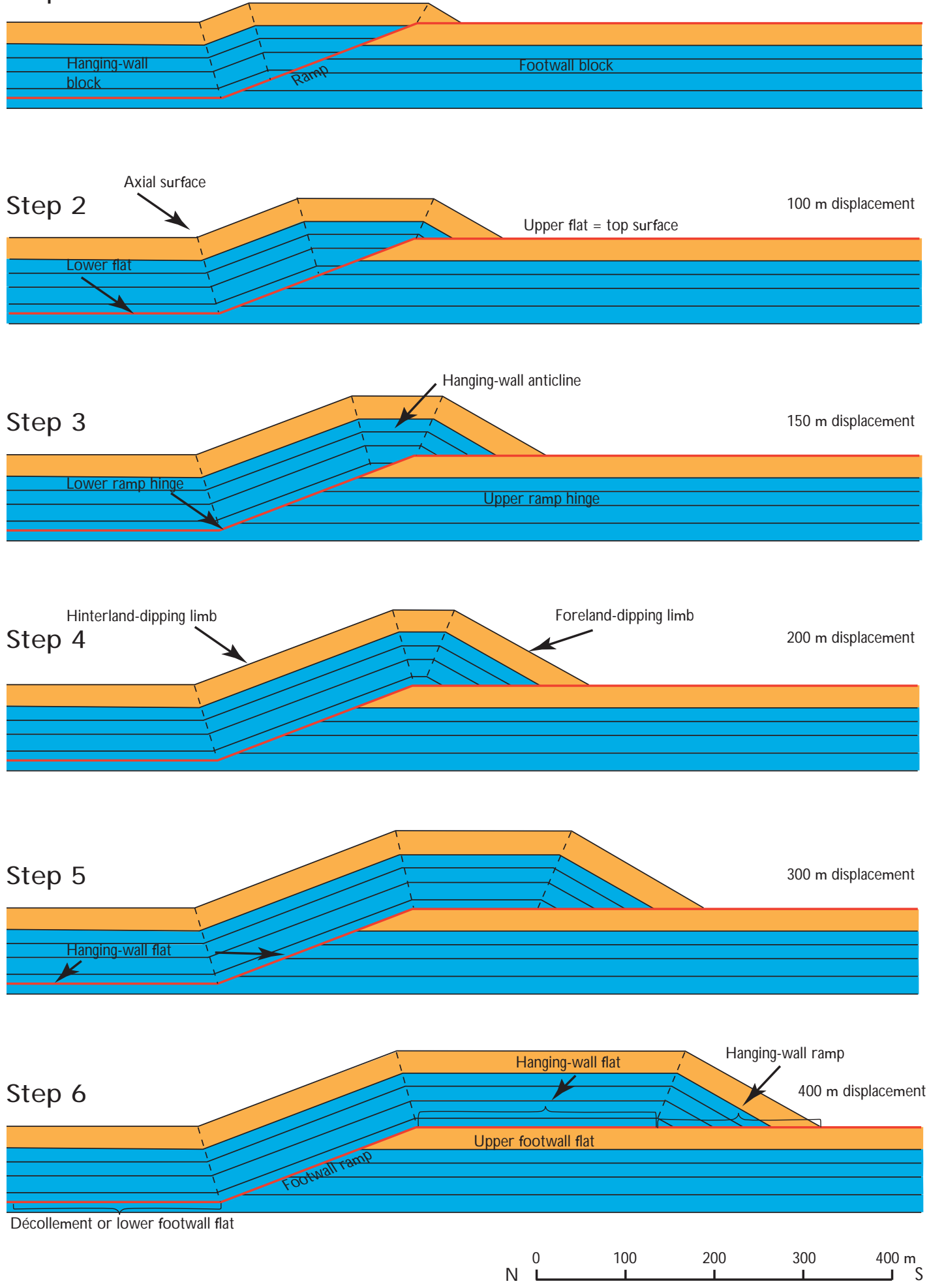

Fig. 6. Test model 1 of thrust-fault deformation constructed with the computer program AUTOFAULT (Ozkaya 1994). The model demonstrates the development of simple ramp propagation given increasing displacements. In the first four steps, the displacement is sequentially increased by $50 \mathrm{~m}$, whereas a displacement of $100 \mathrm{~m}$ is added to steps 5 and 6 . Note that a 'typical upright anticline' develops when the displacement is about twice the thickness of the layer package displaced. Moreover, the model illustrates the terminology applied in the text and defined in Appendix 1. 
for the specific model constructed. Thus the program gives the 'differential' calculation model to an induced 'integration' solution configuration. Further thrust faults can be added, and be given new displacements, such that rather complex models can be constructed. However, a few limitations of the program hamper realistic comparisons with nature. Thus the program cannot handle inclinations exceeding $60^{\circ}$. In general this is not a problem as ramp angles typically range between $10^{\circ}$ and $35^{\circ}$ and for rock mechanical reasons never exceed $45^{\circ}$ (Ozkaya 1994). However, the problem of steep inclinations becomes important in complexes including superimposed deformation. A second limitation is that testing with superimposed displacements requires a construction with an upper flat located within the model. This results in an unrealistically high number of shallow upper flats in the models, as illustrated below in test model 4 (see Fig. 9). Thirdly, the program cannot accommodate cross-cutting thrust-fault relationships, which limits the spacing and dip of ramps. Nevertheless, the test models give a good introduction to the thrust-fault concept, and demonstration of models with basic layer package dimensions approaching the scale of thrust sheets involved in the Rubjerg Knude Glaciotectonic Complex can be achieved.

A glossary of the thrust-fault terms used here is given in Appendix 1; note that only contractional thrust-fault structures are considered.

\section{Test model 1}

The first AUTOFAULT model displays a simple thrust fault with one ramp connecting a lower and an upper flat (Fig. 6). The development of thrust-fault structures, in particular the fault-bend folding of the hangingwall anticline, is demonstrated in six steps with increasing displacement. The ramp angle is $25^{\circ}$, and the layer package constitutes a lower unit $25 \mathrm{~m}$ thick where the lower flat (or the décollement zone) is located. Above this, one $25 \mathrm{~m}$ and two $20 \mathrm{~m}$ thick layers have been constructed, with a $30 \mathrm{~m}$ thick uppermost layer (Fig. 6). The model approaches the assumptions of parallel behaviour with preservation of layer thickness, no net distortion where layers are horizontal, and conservation of bed length (Suppe 1983).

Step 1 shows the gentle hanging-wall anticlinal folding after $50 \mathrm{~m}$ displacement. Note the flat-topped nature of the hanging-wall anticline, which makes it almost insignificant. The backlimb of the anticline dips toward the left, parallel to the ramp, and the axial surfaces defined by the bend above the lower ramp hinge and the bend of the hanging-wall anticline define two kink bands dipping steeply to the right. By comparing steps 1 and 2 it can be seen that the spacing between the kink bands increases with increasing displacement.

Step 2 gives the configuration after $100 \mathrm{~m}$ displacement. Here the forelimb dipping towards the foreland to the right starts to be a significant part of the structure. Note the increase in spacing between the kink bands in the backlimb structure. The kink bands define minor zones of weakness, which could develop into small reverse faults as in the thrust model demonstrated by Wiltschko (1979). These are referred to as back thrusts.

Step 3 shows the structural development after 150 $\mathrm{m}$ displacement. Note that the flat-topped hangingwall anticline now has a more angular upright form, where the kink bands fanning up from the positions near the upper ramp hinge approach each other. However, in the model the anticline maintains its flat-topped structure and retains two axial surfaces (kink bands).

Step 4 demonstrates the formation of the upright, angular hanging-wall anticline, where the amount of displacement is close to the length of the thrust-fault ramp. Due to the geometric adjustments the hangingwall ramp is shorter than the footwall ramp. The displacement is $200 \mathrm{~m}$ corresponding to about two times the thickness of the thrust sheet.

Step 5 shows the structural development after 300 $\mathrm{m}$ displacement. The hanging-wall anticline becomes even more flat-topped and the space between its axial surface kink bands increases. Note that the forelanddipping forelimb is linked to the hanging-wall ramp displaced along the footwall flat, and the hinterlanddipping backlimb corresponds to the hanging-wall flat bent up along the footwall ramp.

Step 6, with a displacement of $400 \mathrm{~m}$ demonstrates that the main structural configuration is maintained, except for the increase in spacing between the backlimb and the forelimb.

\section{Test model 2}

The second AUTOFAULT model demonstrates the propagation along a thrust fault differentiated into a décollement zone, a lower ramp, an intermediate flat, an upper ramp and an upper flat bringing the thrust fault up to the top surface (Fig. 7). The model is con- 

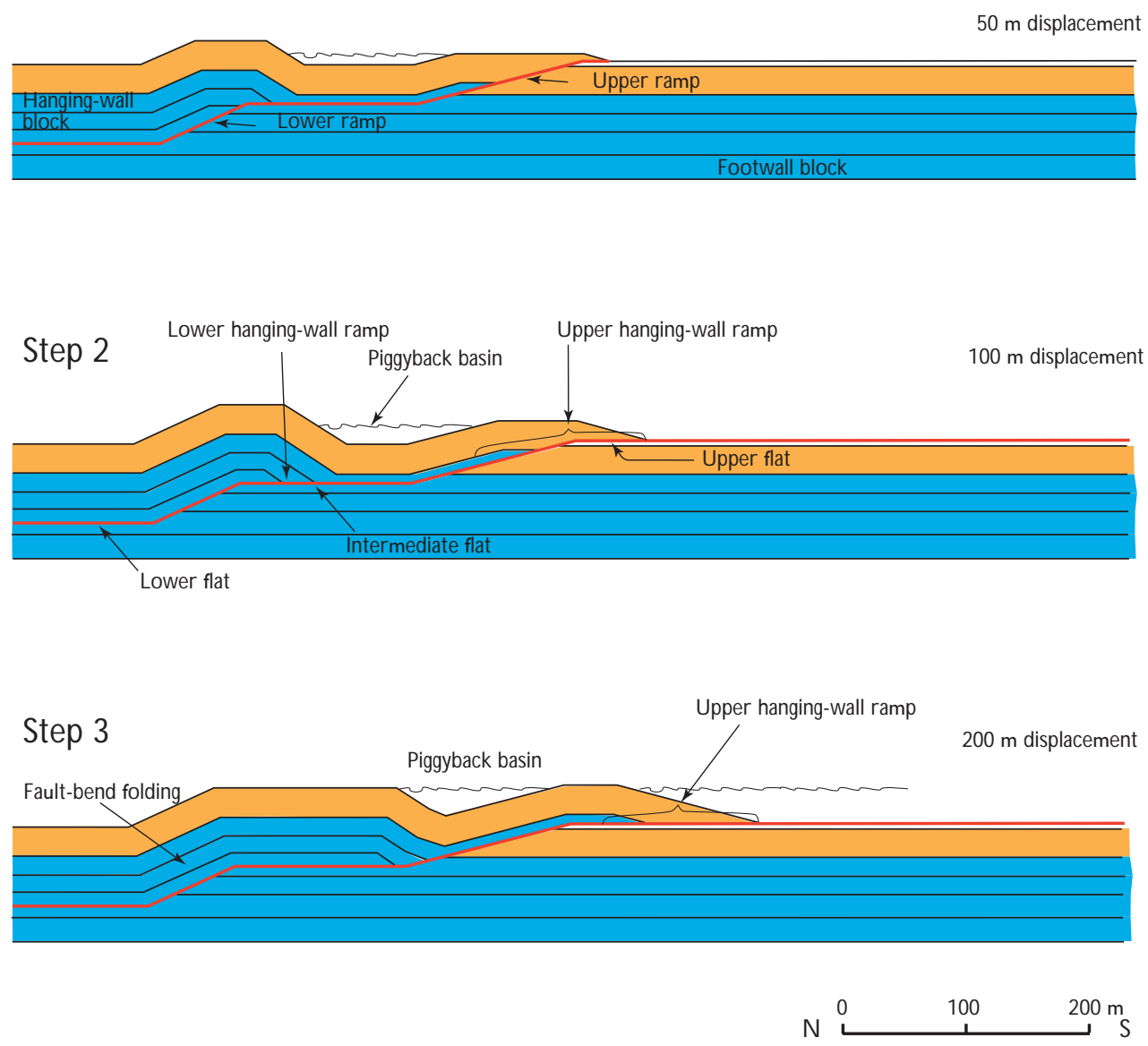

Fig. 7. Test model 2 of thrust-fault deformation constructed with the computer program AUTOFAULT. The model demonstrates the development of thrust-fault propagation along a lower and an upper ramp and the connecting flats. Note in this model the formation of two anticlines divided by a syncline, the depression of which is the obvious location of a piggyback basin.

structed with two lower units, $40 \mathrm{~m}$ in thickness; the décollement zone is located in the second layer. The lower layers mimic the lower clay units of the Lønstrup Klint stratigraphy, and two c. $25 \mathrm{~m}$ thick layers overlie them. The top layer is $50 \mathrm{~m}$ thick, but while not comparable to any part of the stratigraphy in the Lønstrup Klint section, its construction yields a better demonstration of the development envisaged. The lower ramp is given a dip of $25^{\circ}$ and the upper ramp a dip of only $15^{\circ}$ to reflect the principle of increasing angle of fracturing with increasing depth (Hobbs et al. 1976; Pedersen 1996). The distance between lower and upper ramps along the intermediate flat is c. 250 $\mathrm{m}$, and three steps are presented in Fig. 7.

Step 1 is given $50 \mathrm{~m}$ displacement and two hanging-wall anticlines immediately appear. The steep ramp clearly initiates the formation of an upright anticline with steeply dipping limbs. Between the two hanging-wall anticlines, an intervening syncline forms above the intermediate flat. The involute surface of the syncline provides the location for a broad, shallow basin.

Step 2 shows the structural development after 100 $\mathrm{m}$ displacement. This demonstrates clearly that the intervening syncline is an obvious site for a piggyback basin to develop. Note that the steeply dipping forelimb of the hanging-wall anticline above the lower ramp would be the obvious site for erosion and the source of material feeding into the piggyback basin.

Step 3 demonstrates that with a displacement of 200 $\mathrm{m}$, the piggyback basin becomes narrow and is elevated to a higher position as a consequence of the displacement up along the upper ramp; it is eventually lifted out of the position for being a centre of deposition. With increasing displacement, the frontal part of the thrust sheetdevelopsinto a wedge-shape structure. 

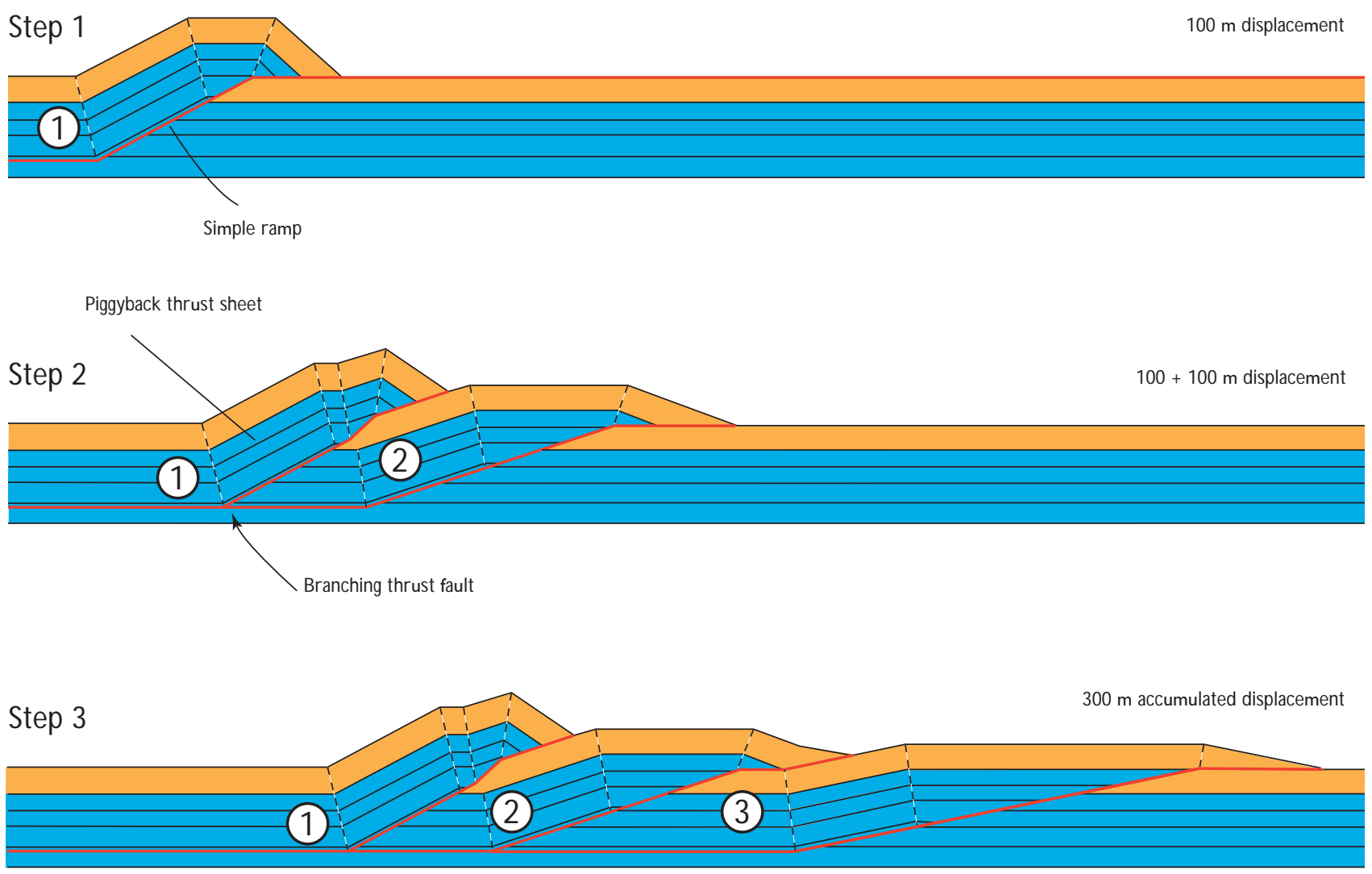

Branching thrust-fault imbricate fan

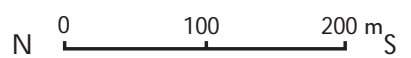

Fig. 8. Test model 3 of thrust-fault deformation constructed with the computer program AUTOFAULT. The model demonstrates the formation of an imbricate fan by successive thrust-fault splays branching up from the main décollement zone. The encircled numbers refer to the sequential phase of thrust imbrication. The model is probably not comparable to structures formed in nature, but can be regarded as an introduction to test model 4 (Fig. 9).

\section{Test model 3}

The third AUTOFAULT model aims at constructing an imbricate complex by branching faults fanning up from the same décollement level (Fig. 8). The model is constructed with a lower $20 \mathrm{~m}$ thick unit in the top of which the décollement zone is located. Above the décollement zone, three units with a combined thickness of $50 \mathrm{~m}$ form the lower part of the thrust sheets, and the succession is capped by an upper $20 \mathrm{~m}$ thick unit. In three sequential steps, the principle of piggyback thrusting is demonstrated (Fig. 8).

Step 1 shows $100 \mathrm{~m}$ displacement along a deeprooted ramp dipping $30^{\circ}$. Note the normal architecture of the hanging-wall anticline results from the ramping (compare with Fig. 6, step 3).

Step 2 demonstrates the re-orientation of the piggyback thrust sheetby the introduction of $100 \mathrm{~m}$ displacement along a $18^{\circ}$ dipping ramp in front of and below the first thrust fault. Note that the accumulated dis- placement of the first thrust sheet amounts to c. $200 \mathrm{~m}$.

Step 3 shows an additional $100 \mathrm{~m}$ displacement along a low-angle $12^{\circ}$ dipping ramp. Although the model demonstrates the main architecture of the imbricate fan illustrated by Pedersen (1987), it is a fairly simple model which may have only little relevance to natural conditions.

\section{Test model 4}

The final AUTOFAULT model demonstrates the more likely formation of a steeply dipping imbricate fan or duplex (Fig. 9). The model is given the same stratigraphic units as in Test Model 3 (Fig. 8). A longer décollement zone is located in the middle of the lowermost unit, in addition to an intermediate flat in the third layer, while the upper flats are located within the uppermost unit. The initial steps in the construc- 
tion of this model are similar to the examples demonstrated above, and hence only the final two steps are illustrated (Fig. 9). However, these give a convincing illustration of the increase of dips in an imbricate thrustfault complex.

Step 1 illustrates the final structural architecture after $140 \mathrm{~m}$ displacement of thrust sheet 1 along the décollement zone, the lower ramp, the intermediate flat, an upper ramp and onto the upper flat (dips of ramps c. $25^{\circ}$ ). Thrust sheets $2-5$ were formed by branching ramps (dip of ramps c. $15^{\circ}$ ) with a displacement of c. $80 \mathrm{~m}$ added to each thrust fault. Finally, the leading thrust sheet (6) is displaced $90 \mathrm{~m}$ along the lower décollement zone and a deep-rooted $30^{\circ}$ dipping ramp. Note that the branching ramp imbricates are carried piggyback on thrust sheet 6 . Furthermore, it should be noted that a long trailing segment of thrust sheet 6 occurs between the décollement zone and the intermediate flat. If this trailing segment becomes chopped up into duplexes between the two deep-rooted ramps, it will affect the overlying imbricates by vertical elevation and the formation of antiformal stacks.

Step 2 illustrates the over-steepening of the imbricates stacked onto the backlimb of the hanging-wall anticline of thrust sheet 6 arising from the addition of $100 \mathrm{~m}$ displacement to step 1 along the leading thrust rooting down to the lower décollement zone.

\section{Test models: concluding remarks}

A set of principles may be derived from the test models.

1. The level of elevation of the reference surface is directly related to the number and sizes of ramps the thrust sheet has passed. A ramp rooting down to a deep flat level corresponds to a high elevation of the topmostreference surface. In contrast, if a top reference surface is positioned at the same level as in the foreland, the thrusting corresponds to a translation along a flat.

2. The steeper the ramp, the earlier its time of formation. Gently dipping ramps are initiated at a late stage of deformation in areas proximal to the foreland.

3. The thickness of a piggyback basin reflects its duration as depocentre. Thus a small thickness of piggyback basin fill indicates an early trapping of the basin by overthrusting of a hanging-wall block.

4. A thick succession in the piggyback basin reflects a long period of translation of the thrust sheet along a long flat.
Fig. 9. Test model 4 of thrustfault deformation constructed with the computer program AUTOFAULT. The model demonstrates an imbricate fan (see Fig. 8) subjected to faultbend folding during piggyback translation of an underlying hanging-wall flat propagation along a footwall ramp. The footwall ramp propagation will consequently result in increasing dips of the thrust sheets in the imbricate fan. Encircled numbers indicate successive thrust sheets.

\section{Concept of balanced cross-section}

The principle of the balanced cross-section in structural analysis of thrust-fault systems was elegantly outlined by Dahlström (1969) and further improved by Suppe (1985). The application of balanced crosssections in glaciotectonics has been demonstrated by Croot (1987), Klint \& Pedersen (1995) and Pedersen (1996).

In the construction of the balanced section, two different functions are applied: (1) the line balance, and (2) the volume balance, which in a 2-D crosssection corresponds to area balance. The first function concems the length of displacement, whereas the second function concerns the preservation of volume in the deformed cross-section compared with the restored undefomed cross-section (for demonstration see Plate 2). The basic method of balancing a crosssection (Dahlström 1969) is restoration by defining a pinpoint to be fixed to the foreland and then restoring the thrust sheets back to their initial pre-deformational position. Thus one begins at the foreland and then by line balancing the thrust sheets are pulled back sequentially to their position prior to displacement. This requires a measure of displacement, which is the essential, but often difficult figure to achieve without some range of uncertainty.

Details conceming the construction of the balanced cross-section of the Rubjerg Knude Glaciotectonic Complex (Plate 2) are given below. 


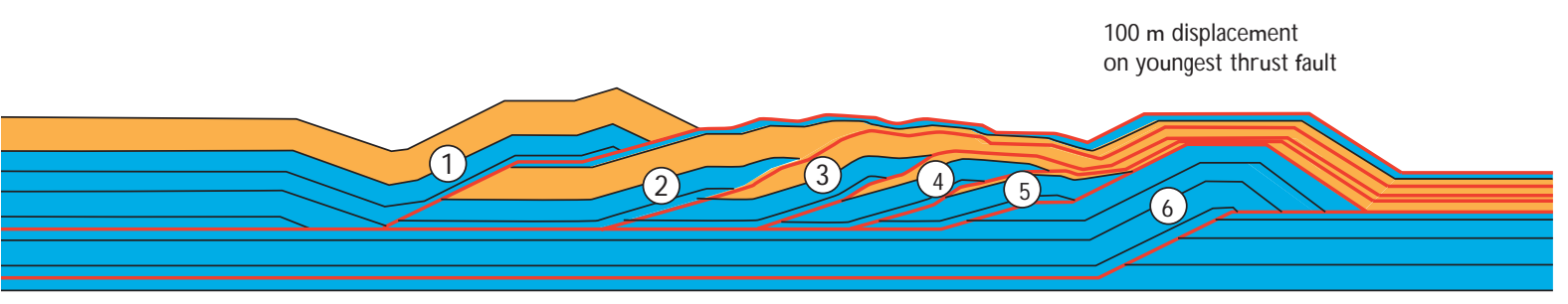

$200 \mathrm{~m}$ displacement

on youngest thrust fault

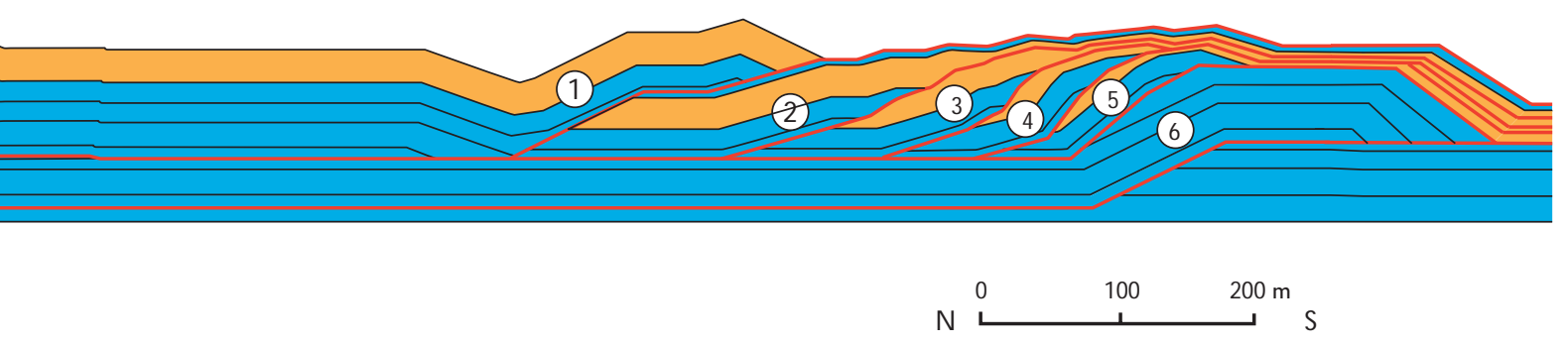

\section{Location and construction of the Rubjerg Knude cross-section}

\section{Location}

The Rubjerg Knude cross-section is $6124 \mathrm{~m}$ long and extends from the coastal cliff immediately south of Lønstrup, Ribjerg, to about $300 \mathrm{~m}$ north of the ramp leading down to the beach at Nørre Lyngby (Fig. 2, Plate 1). The strike of the section is $17^{\circ}$, which is nearly parallel to the direction of the coastline. This is also approximately perpendicular to the main concentration ofstructural strikes (bedding, thrust faults and fold axes; Fig. 10). The cross-section was consequently constructed to fit a general plane of orthographic projection with a projection axis striking $107^{\circ}$.

The Rubjerg Knude cross-section covers only the Rubjerg Knude Glaciotectonic Complex. Thus it is not asextensive as the cross-section of Lønstrup Klint constructed by Jessen $(1918,1931)$, which extends from the cliff at the northern fringe of Lønstrup to the northern part of the beach at Løkken (see Fig. 12). The UTM co-ordinates (zone 32, ED50) of the end points of the Rubjerg Knude cross-section are 547512, 6370243 (N-end point) and 545251, 6364783 (S-end point).

\section{Photogrammetric work}

The cross-section of Rubjerg Knude Glaciotectonic Complex (Plate 1) is based on a multi-model photogrammetric investigation of the cliff section using the method described by Dueholm (1992). Oblique photographs were taken from a Cessna fixed-wing aircraft with a Minolta XG2 camera with known optical specifications, calibrated at the laboratory of photogrammetry at the Technical University of Denmark. Standard $24 \times 36 \mathrm{~mm}$ diapositive colour film was used, and the photographs were taken with $66 \%$ overlap from a distance of 200-300 m with an inclination angle of c. $35^{\circ}$, which provided the basis for setting up 67 stereoscopic models. In the laboratory, the orientation of the stereo-models was carried out based on ground control points adapted from two sets of vertical aerial photographs at a scale of 1:25 000, namely D9202 G 1365-66 and KMS 9203 A509-10 taken in May 1992.

The stereoscopic instrument used was a Kern DSR 15 analytic plotter with a DEC VMS operating system and the special attached GEOPROGRAM developed 
A

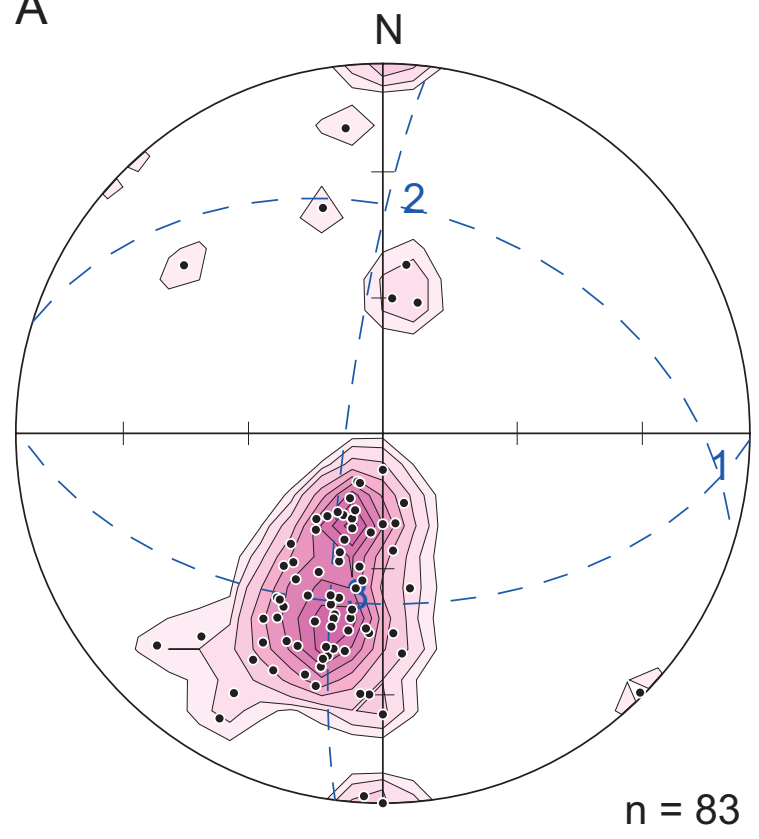

C

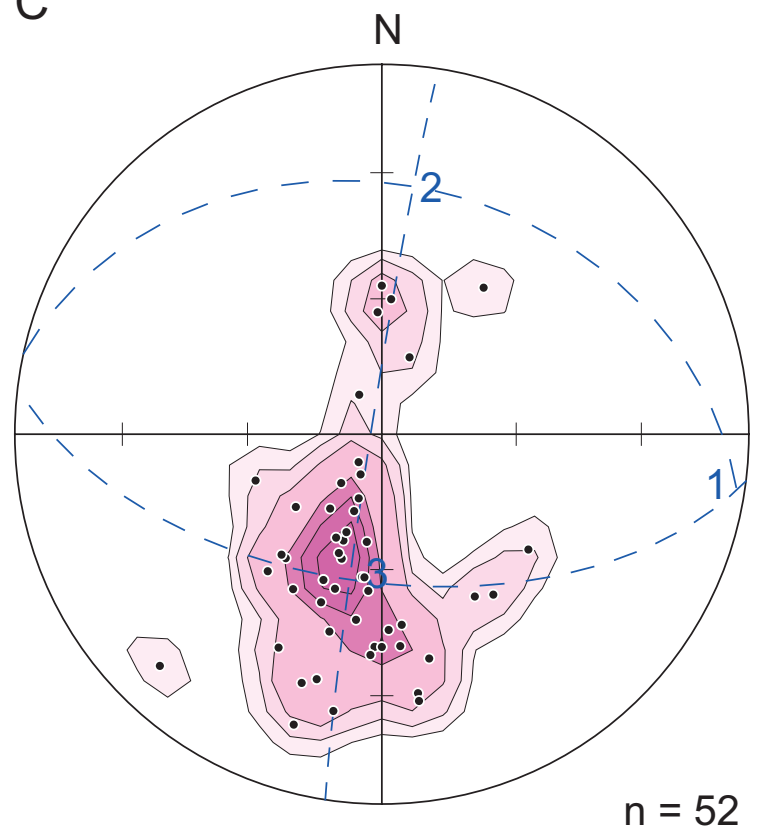

B

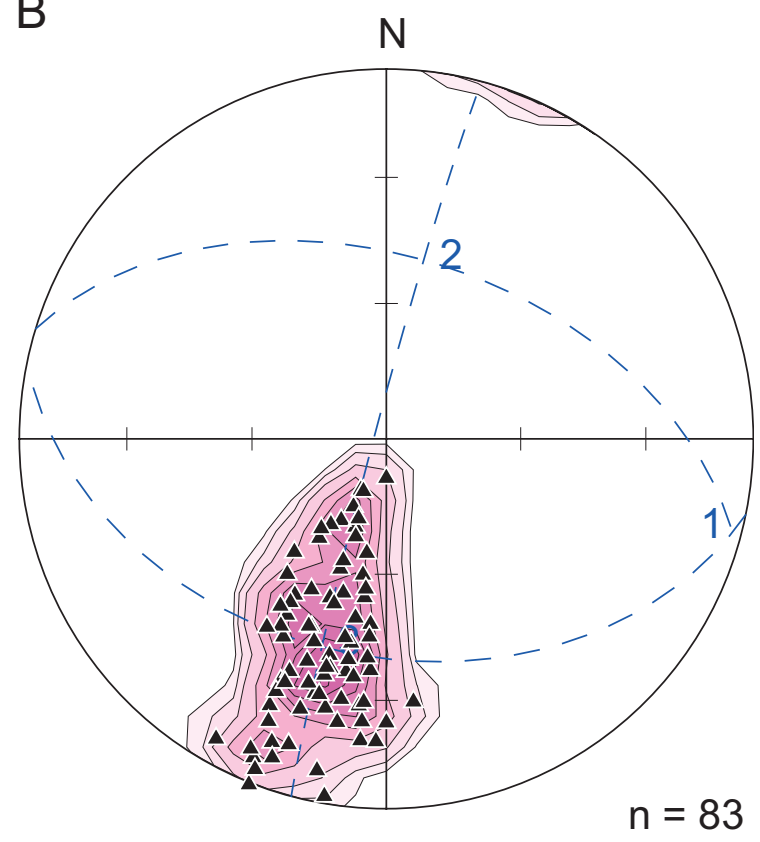

$\mathrm{D}$

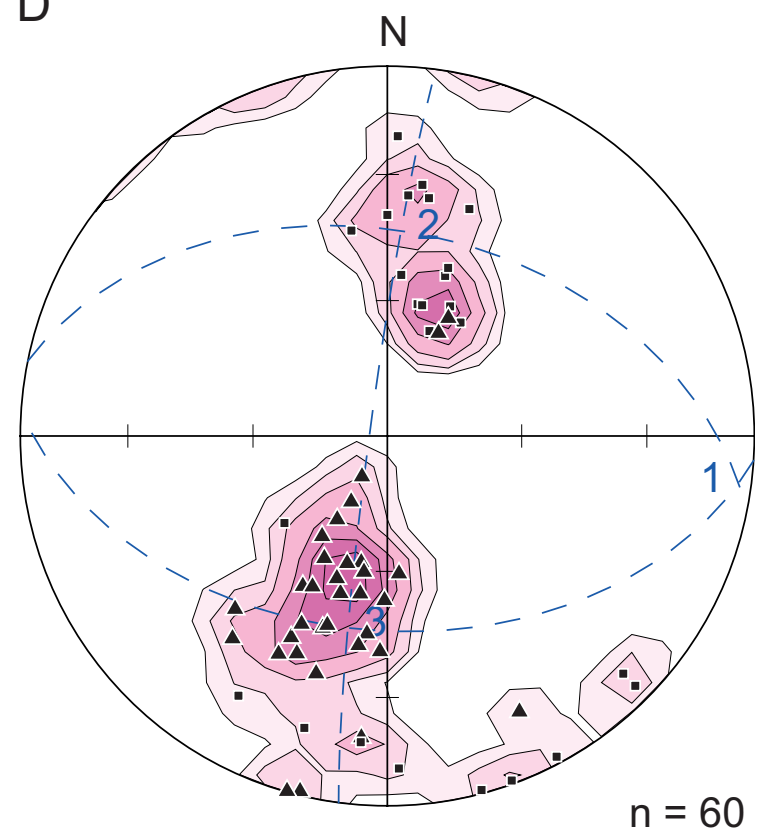

Fig. 10. Stereographic projection diagrams of the orientation of structural elements in the Rubjerg Knude cross-section. The stereograms, lower hemisphere, equal area (Schmidt) net, display the concentration of the poles to bedding planes (black dots) or thrust planes (black triangles). A and Bare measurements taken from Jessen (1931), and $\mathbf{C}$ and $\mathbf{D}$ are data produced in this study. Contour intervals are $1,2.5,5,7.5,10,12.5$, and $15 \%$. The density point in all four diagrams is close to $197^{\circ} / 35^{\circ}$. Comparing the two sets of diagrams demonstrates that the structural orientation has been maintained despite c. 100 years erosion corresponding to c. $125 \mathrm{~m}$ retreat of the coastal cliff section. Black squares (D) indicate normal fault planes. Blue lines/numbers indicate principal compression axes. 


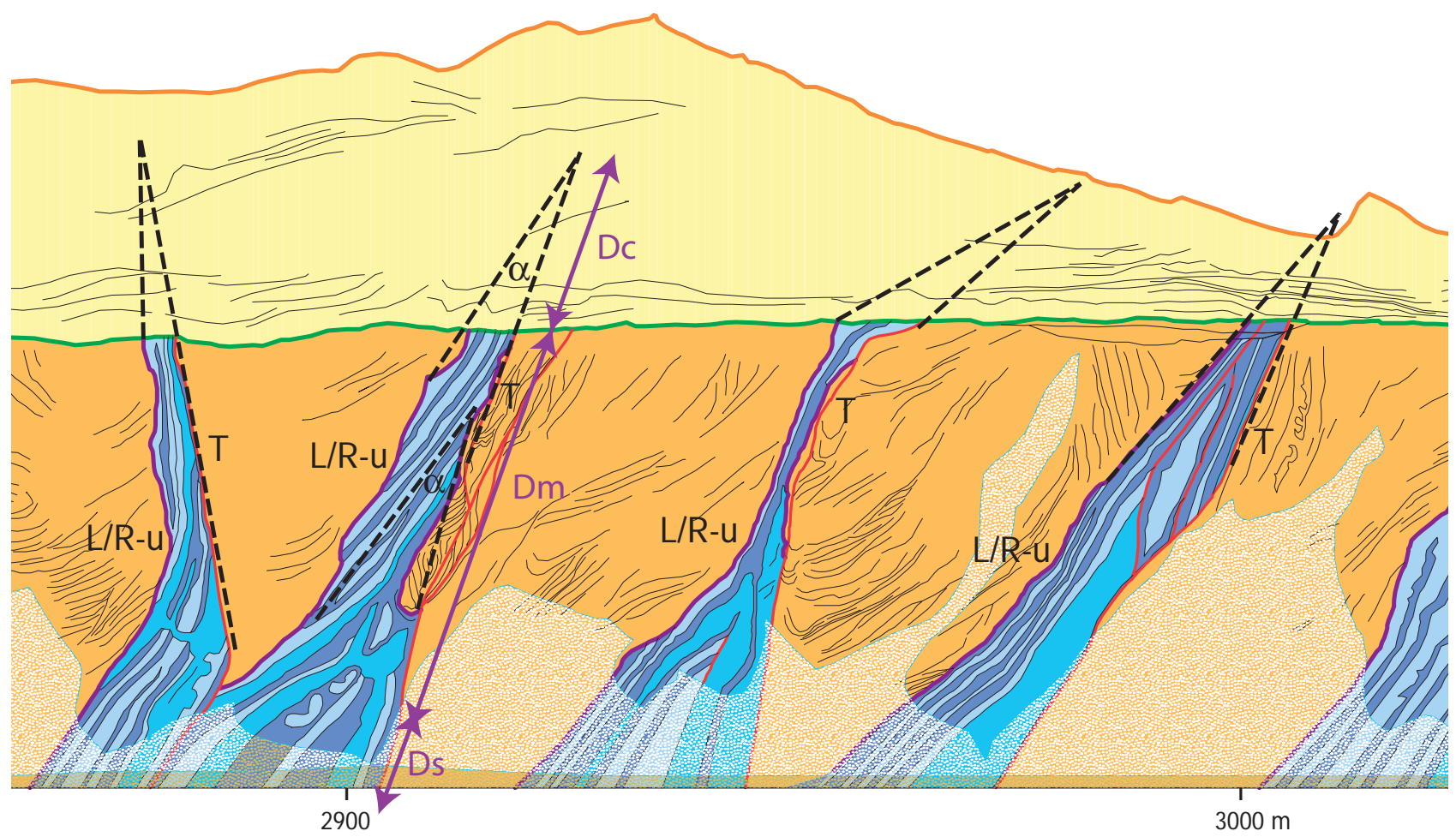

Fig. 11. Illustration of the method used for estimation of the displacement for the balanced cross-section. Above the main erosional unconformity at the top of the cliff, the extension of the thrust sheet tip is constructed by the intersection between the thrust fault (T) and the L/R-unconformity ( $\mathbf{L} / \mathbf{R}-\mathbf{u})$ based on the angle $(\mathbf{\pm})$ between the bedding of the thrust sheet and the hanging-wall ramp. Dm, displacement measured; Dc, displacement constructed from tip-extension; Ds, displacement estimated from the interpretation of thrust-fault trace under the scree cover. The section illustrated is part of the Rubjerg Knude Fyr Section (Plate 1).

by Dueholm (1992). In the stereoscopic models, the geological features were outlined by the floating mark and digitised by the attached computer. The digitised data were stored for the later construction of the crosssection and the transformation for other programs applied for the management of the cross-section display. The scale of the Rubjerg Knude cross-section in the analytic plotter version is 1:500, and the accuracy of the plotted data is about $25 \mathrm{~cm}$ (for further details, see Appendix 2).

\section{Digital editing}

In order to represent the cross-section in a publishable display, the digitised data were transferred to ARCINFO at the GIS-laboratory at the Geological Survey. Here it was transformed into an ARC-VIEW project, which served as the computer tool for editing the crosssection. Thus all areas were converted to closed polygons, which were annotated to fit the legend of lithologies. During this editing, interpretations were made to finish the display of the cross-section, in particular interpretations of the scree-covered parts of the section. This was carried out contemporaneously with the construction of the balanced cross-section (see below), and a few additional corrections were added to the Rubjerg Knude cross-section. Some new exposures along the cliff section appeared in 1997-1999, which added to a better understanding of the structures in the transition from the frontal part of the glaciotectonic complex to its foreland. These have been incorporated into the ARC-VIEW project.

The final editing of the cross-section concerned the balanced cross-section. The construction of the balanced section was digitised and transformed into an ARC-VIEW project, and the subsequent interpretation of the extension of the thrust-fault ramps below sea level was added. Thus the Rubjerg Knude cross-section comprisesa display of the exposed part of the cliff section with lithological and structural identity added as themes. Furthermore, the cross-section includes an interpretation of the thrust-fault structures in the subsurface. Finally, a balanced construction was added 
Table 1. The distribution of areas in the balanced cross-section (Plate 2)

\begin{tabular}{|c|c|c|c|c|c|}
\hline \multicolumn{3}{|c|}{ Balance (Plate 2A) } & \multicolumn{3}{|c|}{ Ramps (Plate 2B) } \\
\hline Section* & $\begin{array}{l}N \text { umber } \\
\text { of areas }\end{array}$ & Area $\left(m^{2}\right)$ & Section* & $\begin{array}{l}N \text { umber } \\
\text { of areas }\end{array}$ & Area $\left(\mathrm{m}^{2}\right)$ \\
\hline O1UL & 5 & 23048 & 01UL & 13 & 24302 \\
\hline $02 \mathrm{SN}$ & 13 & 8965 & $02 \mathrm{SN}$ & 18 & 8536 \\
\hline 03MB & 15 & 28443 & 03MB & 21 & 30944 \\
\hline 04KR & 10 & 24158 & 04KR & 22 & 18390 \\
\hline 05BR & 28 & 34143 & 05BR & 40 & 33548 \\
\hline 06SR & 28 & 33218 & 06SR & 49 & 31588 \\
\hline 07SS & 32 & 26421 & 07SS & 31 & 23973 \\
\hline $08 \mathrm{GR}$ & 55 & 49842 & $08 \mathrm{GR}$ & 47 & 45118 \\
\hline 09RF & 30 & 22827 & 09RF & 26 & 21458 \\
\hline 10ST & 54 & 43674 & 10ST & 41 & 36656 \\
\hline $11 M R$ & 69 & 51902 & $11 M R$ & 55 & 45342 \\
\hline $12 \mathrm{MK}$ & 95 & 82226 & $12 \mathrm{MK}$ & 87 & 62763 \\
\hline 13BL & 8 & 17922 & $13 \mathrm{BL}$ & 2 & 14313 \\
\hline N rLy & 2 & 5437 & $13 \mathrm{RI}$ & 1 & 4405 \\
\hline \multirow[t]{2}{*}{ PTR } & 3 & 2538 & MD & 1 & 472 \\
\hline & & & Ve & 4 & 9818 \\
\hline
\end{tabular}

* The annotated numbers of sections (05BR) correspond to the sequential location of each section in a distal-proximal order, and the capitalised letters refer to the general abbreviation of the section names (see Plate 2).

to the cross-section project, such that each thrust sheet is annotated in a balanced restored cross-section as well as in the structural cross-section displaying the geometry of the ramps and flats (Plate 2).

\section{Construction of the balanced cross-section}

The construction of the balanced cross-section for the Rubjerg Knude Glaciotectonic Complex was based on the geological cross-section, which displays the geometry of the thrust sheets in sufficient detail to allow calculations of their displacements and cross-sectional areas (Plates 1, 2). The method of balancing necessitates that the thrust sheet closest to the foreland is the first to be restored to its pre-deformational position. Therefore, the balancing works backwards from the distal to the proximal deformation area, and con- sequently the annotation of the thrust sheets begins with the first thrust sheet restored. In the balanced cross-section of the Rubjerg Knude Glaciotectonic Complex, the thrust sheets are additionally annotated according to that part of the cliff in which they occur: two capital letters refer to the name of the section and a number refers to its position from leading edge to trailing end of the section. Thus, KR01 is the thrust sheet nearest to the foreland in the Kramrende Section. A thrust fault is referred to according to the thrust sheet it displaces. However, the trailing footwall ramp is referred to the annotation of the footwall block, which underlies the hanging-wall ramp/flat of the thrust sheet displaced over it. Thus the KR02 hanging-wall ramp is displaced up along the KR01 footwall ramp.

Although one of the basic conditions in constructing balanced sections is the preservation of volumes, which in the areas strongly affected by mud remobili- 
sation and diapirism is difficult to maintain, the exercise has been carried out to match a balanced section to the mapped and interpreted thrust-fault framework. So despite the uncertainties and the demand for interpretation of the geometry and magnitude of eroded thrust sheet tapers, the construction of the balanced sectionadded significantly to the understanding of the duplex framework (Plate 2B).

In the Rubjerg Knude cross-section (Plate 1), the displacement is measured and estimated mainly from the distance between the intersection of the L/R-unconformity (the unconformity between the Lønstrup Klint and Rubjerg Knude Formations, see below) and the footwall ramp, and the intersection of the L/Runconformity and the hanging-wall ramp (Fig. 11). However, the tips of the thrust sheets are generally eroded away, so the first approximation is from the L/R-unconformity footwall point to the point where the hanging-wall ramp is truncated by the glaciotectonic unconformity at the top of the cliff. The second approximation is the addition of the distance estimated from the size of the tip eroded away. This estimate is based on a simple geometric construction of the tip-triangle from the dips of the hanging-wall ramp and the L/Runconformity, respectively (Fig. 11). This line balance is subsequently controlled by the width of the piggyback basin more or less corresponding to the upper footwall flat. All the measured displacements are strictly restricted to the minimum distance to avoid unrealistic exaggerations. Therefore the actual displacements might be slightly greater.

The area balance is based on a calculation of all the areas annotated in Plate 2. The computer-supported calculation was carried out with the ARC-INFO program, and the calculations of the areas in the balanced cross-section and the ramp cross-section deviate by less than $10 \%$ (Plate 2A, B). This is regarded as a reasonable correspondence considering the various sources of error (Table 1). In general, the sections have a smaller area in the ramp cross-section (Plate 2B) due to the erosion of areas above the main headof-cliff unconformity, and in most sections the number of areas is higher due to the increased complexity of the geometry in the reconstructed structural cross-section (Plate 2B).

\section{Geological setting}

The Rubjerg Knude Glaciotectonic Complex incorporates deformed sedimentary deposits that belong to the upper part of the mainly marine succession known previously as the Skærumhede series (Jessen et al. 1910). This succession was deposited in the northern part of the Danish Basin in the late Pleistocene, after thelate Saalian terrestrial glaciation retreated from Denmark (Houmark-Nielsen 1987, 1999; Knudsen 1994). The major source area for deposits in this part of the Danish Basin is the Scandinavian basement in southern Norway and central Sweden, that comprises Precambrian Fennoscandian granites and gneisses overlain by Palaeozoic metasediments, including Permian volcanics and their related intrusive magmatic rocks of the Oslo province (Oftedahl 1981). The extrabasinal indicator boulders reflect these source areas, which were situated between thecentres of ice-cap nucleation and the depositional basin (Milthers 1909; Smed 1995).

The boundary between the northern part of the Danish Basin and the south-western part of the ele- vated Scandinavian basement is covered by the Skagerrak, the sea covering a deep depression (about 500 m deep) known as the Norwegian Channel (Sejrup et al. 1987, 1994, 1998). One of the important discussions concerning the glaciation of Denmark during the last stadial focuses on how the ice from Norway advanced across the Skagerrak about 30000 years ago. The problem involves the dynamics of the ice stream along the southern coast of Norway, the so-called Norwegian Channel Ice Stream, and the interaction between the marine and terrestrial parts of the ice cap in southwest Norway (Larsen et al. 2000). Associated problems include the filling of the deep trench in Skagerrak, and the termination of marine conditions in Skagerrak, Vendsyssel, and the northern North Sea as well as the Kattegat (for locations, see Fig. 12).

The marine environment referred to as the Older Yoldia Sea, which extended into the Vendsyssel region, formed in the Late Saalian, and the climatic change from a mild climate in the Eemian to a glacial 


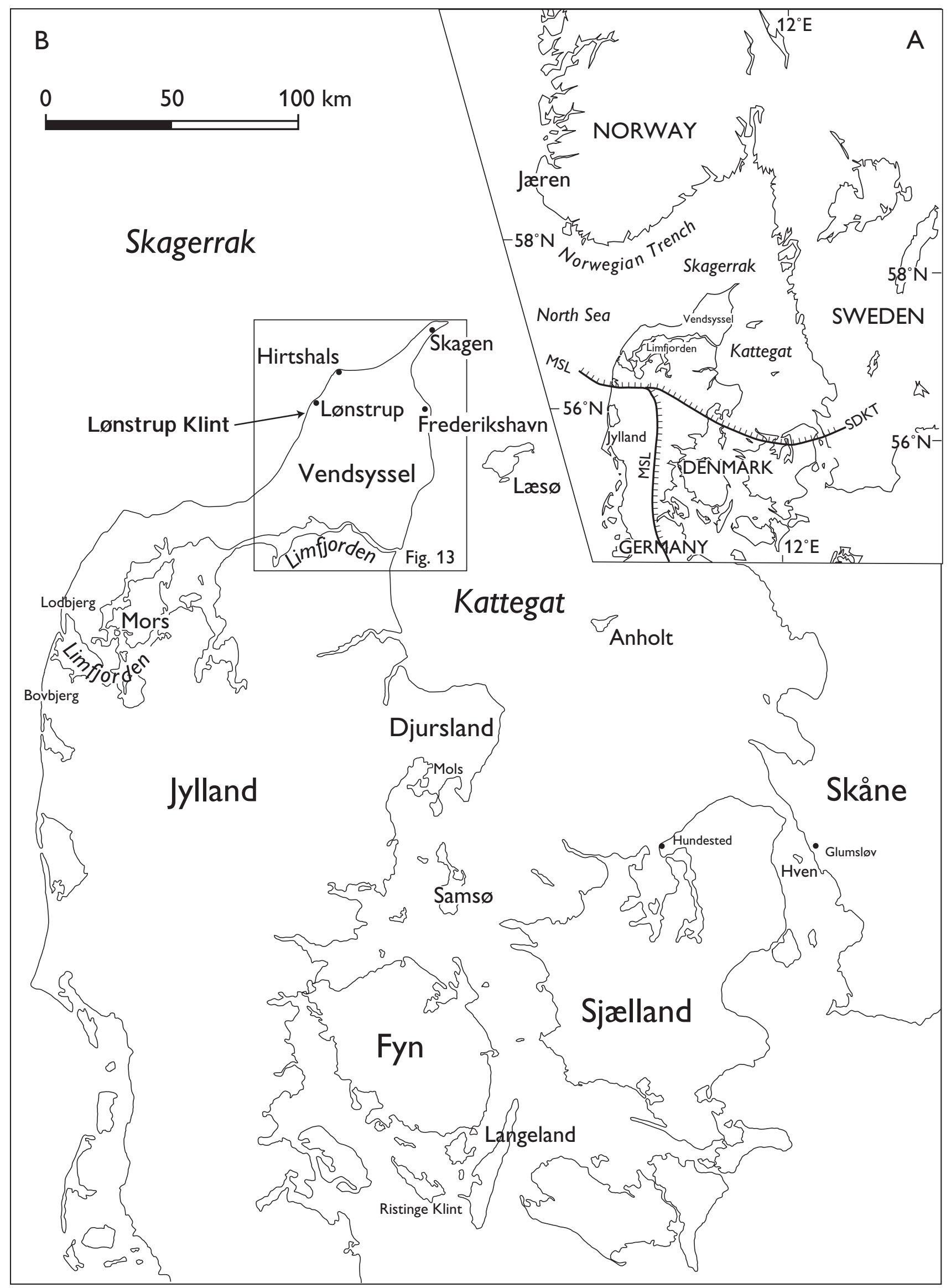


climate in the Weichselian is recorded in a series of wells drilled in north Jylland and the Kattegat region (Knudsen \& Lykke-Andersen 1982; Lykke-Andersen 1987; Lykke-Andersen \& Knudsen 1991; Knudsen 1994). Towards the end of the Middle Weichselian the Scandinavian Ice Sheet over southern Norway built up. The ice streams were drained from a main spillway in Oslo Fjord moving out through the Norwegian Channel along the coastline of southern Norway (Larsen et al. 2000). A change in the dynamics of the Scandinavian Ice Sheet over southern Norway forced the glaciers to progress south-westward across the Norwegian Channel. The ice advanced into the northern North Sea, where a glacial cover was established about 29000 years B.P. and lasted until 22000 years B.P., when the first recurrence of marine conditions (the 'Young Yoldia Sea') was recorded (Sejrup et al. 1994, 2000). This glacial coverage was probably closely connected with the fall in sea level, amounting to $120 \mathrm{~m}$ below present sea level (Fairbanks 1989; Bard et al. 1993), which could have hampered the active drainage of the Norwegian Channel Ice Stream. The ice spread southward over the Skagerrak causing the Kattegat basin to be dammed by the ice margin and terrestrial areas to be established in the central part of the North Sea (Sadolin et al. 1997; Houmark-Nielsen 1999). As a consequence, the Kattegat-Skagerrak region began to dry up due to the general sea-level fall; this is reflected in the progression from arctic marine conditions in the Skærumhede series to brackish and glaciolacustrine environments. This change took place at about 32000 years B.P. (Table 2), and may have been accentuated by the addition of meltwater from the advancing Norwegian Ice (Jessen 1918; Sadolin et al. 1997).

The dramatic drainage of the lake basin in the Kattegat towards the North Sea is recorded by a significant erosional unconformity in the sedimentary succession at Lønstrup Klint (the L/R-unconformity), dated as close to 29000 years B.P. (Sadolin et al. 1997).

\section{Facing page:}

Fig. 12. Location map. Map (A) shows the main part of the Danish Basin with the surrounding land areas. SDKT is the position of the stationary line for the Norwegian Ice Advance (SDKT is an abbreviation of southem distribution of Kattegat Till Fm). MSL is the Main Stationary Line for the Scandinavian Ice Sheet at the glacial maximum in the Late Weichselian. Map (B) gives the position of relevant geographical localities in Denmark as well as the location of Fig. 13, the geological map of Vendsyssel.
Shortly afterwards, the basin was once again dammed and shallow lacustrine and fluvial environments were established while proglacial thrust faulting was initiated reflecting the relatively fast advance of the ice margin (Sadolin et al. 1997). The thin-skinned thrust faulting in the Rubjerg Knude Glaciotectonic Complex involved an accretionary wedge extending more than $12 \mathrm{~km}$ to the south in front of the advancing ice margin. The lowermost décollement level was situated in the marine clays of the Older Yoldia Sea. After a compression ofabout 50\%, the glaciotectonic complex was formed (Pedersen 1987) leaving a large part of the area between Lønstrup and Hirtshals as a depression corresponding to the 'hole' and the Rubjerg Knude Glaciotectonic Complex to the 'hill', in a 'hill-andhole' pair in the sense of Aber et al. (1989). Subsequently the Norwegian Ice truncated the glaciotectonic complex and the deposition of the Kattegat Till Formation concealed its structures. The Norwegian Ice advanced down to a stationary line (Figs 1,12) crossing central Denmark from west to east, whose position is inferred from the distribution of the Kattegat Till Formation (Houmark-Nielsen 1987, 1999, 2003; Pedersen \& Petersen 1997).

After its termination at the stationary line (Figs 1, 12), the Norwegian Ice melted back. It was succeeded by the main south-west ice advance of the Scandinavian Ice Sheet, which extended out to the Main Stationary Line (Ussing 1903; Houmark-Nielsen 1987, 2003; Pedersen et al. 1988). In northern Jylland, the isostatic depression due to the loading of the ice sheet was substantial. The termination of the glaciation in Denmark thus resulted in interference between eustatic sea-level rise and isostatic rebound with a complex depositional development during the re-establishment of the Younger Yoldia Sea in the SkagerrakVendsyssel-Kattegat region about 17000 years ago. This may be summarised as a forced regression under progressively falling sea level due to the isostatic rise of the Vendsyssel region (Richard 1996). The Vennebjerg and Rubjerg Knude hilly islands probably formed part of a larger island archipelago extending out into the North Sea.

Terrestrial conditions were established at the end of the Weichselian. At Nørre Lyngby (Fig. 13), a depression was fomed above a neotectonic fault zone that predated Older Dryas time (Lykke-Andersen 1992). In this depression, lacustrine gyttja and fluvial sand of Older Dryas and Allerød age were deposited; a large number of mammalian remains have been found in these deposits indicating an arctic to sub-arctic rein- 
Table 2. Radiocarbon dates, Rubjerg Knude and Lønstrup Klint, Vendsyssel, northern Denmark

\begin{tabular}{|c|c|c|c|c|c|c|c|}
\hline Stratigraphic unit & Locality & Lab. ID no. & Material & $\begin{array}{c}{ }^{14} \mathrm{C} \text { age } \\
\text { ka B.P. }\end{array}$ & $\begin{array}{l}\text { Calib. age } \\
\text { ka B.P.* }\end{array}$ & $\begin{array}{l}{ }^{13} \mathrm{C} \% \\
\mathrm{PDB}^{+}\end{array}$ & Ref. $^{\ddagger}$ \\
\hline Vendsyssel Fm & Lønstrup Klint & $\mathrm{K}-858$ & Mollusc & $13.9 \pm 0.2$ & $16 \pm 1$ & & (1) \\
\hline Vendsyssel Fm & Lønstrup Klint & K-2670 & Mollusc & $14.7 \pm 0.2$ & $17 \pm 1$ & & $(2)$ \\
\hline Vendsyssel Fm & Lønstrup Klint & AAR-2134 & Mollusc & $14.5 \pm 0.2$ & $17 \pm 1$ & 0.6 & (3) \\
\hline Rubjerg Knude Fm & Sandrende & AAR-2265 & Plant & $30.9 \pm 0.5$ & $33 \pm 1$ & -27.3 & (4) \\
\hline Rubjerg Knude Fm & Lønstrup Klint & AAR-4066 & Mollusc & $43.0 \pm 1.3$ & $46 \pm 3$ & 3.3 & (5) \\
\hline Lønstrup Klint Fm & Sandrende & Ua-4454 & Moss & $29.2 \pm 1.4$ & $32 \pm 1$ & -29.1 & (4) \\
\hline Stortorn Fm & Ribjerg & AAR-4067 & Mollusc & $29.6 \pm 0.4$ & $33 \pm 1$ & 1.5 & (5) \\
\hline Stortorn Fm & Mårup Kirke & AAR-4068 & Mollusc & $30.9 \pm 0.4$ & $34 \pm 1$ & 1.7 & (5) \\
\hline Stortorn Fm & Stortorn & AAR-4069 & Mollusc & $31.3 \pm 0.4$ & $34 \pm 1$ & 1.3 & (5) \\
\hline
\end{tabular}

\footnotetext{
* Calibrated ages are calculated according to Bard et al. 1993 and Kitagawa \& van der Plicht (1998).

+ Relative to PDB standard.

₹eferences: 1: Krog \& Tauber (1974); 2: Knudsen (1978); 3: Richardt (1996); 4: Houmark-Nielsen et al. (1996); 5: this study.
}

deer steppe also populated by hunters (Jessen \& Nordmann 1915; Aaris-Sørensen 1995).

During Holocene time, the Vendsyssel region was affected by isostatic rebound (Mertz 1924). At Lønstrup Klint, this resulted in a $25 \mathrm{~m}$ elevation of the heterolithic sediments of the Younger Yoldia Sea. Bogs developed in the depressions on the glacial peneplain at the end of the Stone Age and the beginning of the Bronze Age (Jessen 1918). Up to $1.5 \mathrm{~m}$ of peat accumulated; when this is exposed in the cliff surface and blocks of peat fall down onto the beach, the peat is locally called martørv (sea-peat). The locality names Martørv Bakker (sea-peat hill) and Moserende (boggully) refer to these deposits.

The geomorphology of the cliff is strongly influenced by the thrust-fault structures. The clayey parts of the thrust sheets form ridges that form projections along the coast between gullies that are eroded out in the sandy parts (Schou 1949). Springs typically well out at the surface between the clayey and sandy units and more incised gullies (render in Danish) are formed where the drainage is concentrated. Although the location of gullies and the cliff line have retreated about $100 \mathrm{~m}$ since A. Jessen constructed the first cross-section of Lønstrup Klint, it has been possible to retain his names in the present cross-section (Plate 1). The general erosion rate of the cliff is about 1.3-1.5 m per year (Jessen 1918; Pedersen 1986b). Landslides occur very frequently, particularly at sites where mud diapirs are located in the cliff section. Where glaciofluvial deposits dominate the cliff section, there is a marked tendency for aeolian dunes to accumulate on top of the cliff (Pedersen 1986b). Wind action on the moraine plateau on top of the cliff has eroded the finegrained material away from the till deposits, leaving a stone pavement as the residual trace of the glacially truncated surface.

Aeolian sand migration intensified about 300-400 years ago (Jessen 1918), one of the consequences being the burial and abandonment of the Old Rubjerg Church. The high aeolian dunes on top of Rubjerg Knude have accumulated during the last 100 years. The Rubjerg Knude lighthouse was built in 1900 (Bendsen 1981) when dunes were less than $10 \mathrm{~m}$ high. Today the tops of the dunes are close to $100 \mathrm{~m}$ above sea level corresponding to a vertical dune accumulation of nearly 50 $\mathrm{m}$. The present-day steep nature of the dunes was probably stimulated by the artificial dune protection fences. However, the steady erosion of the cliff indicates that the lighthouse will fall into the sea about ten years from now. 


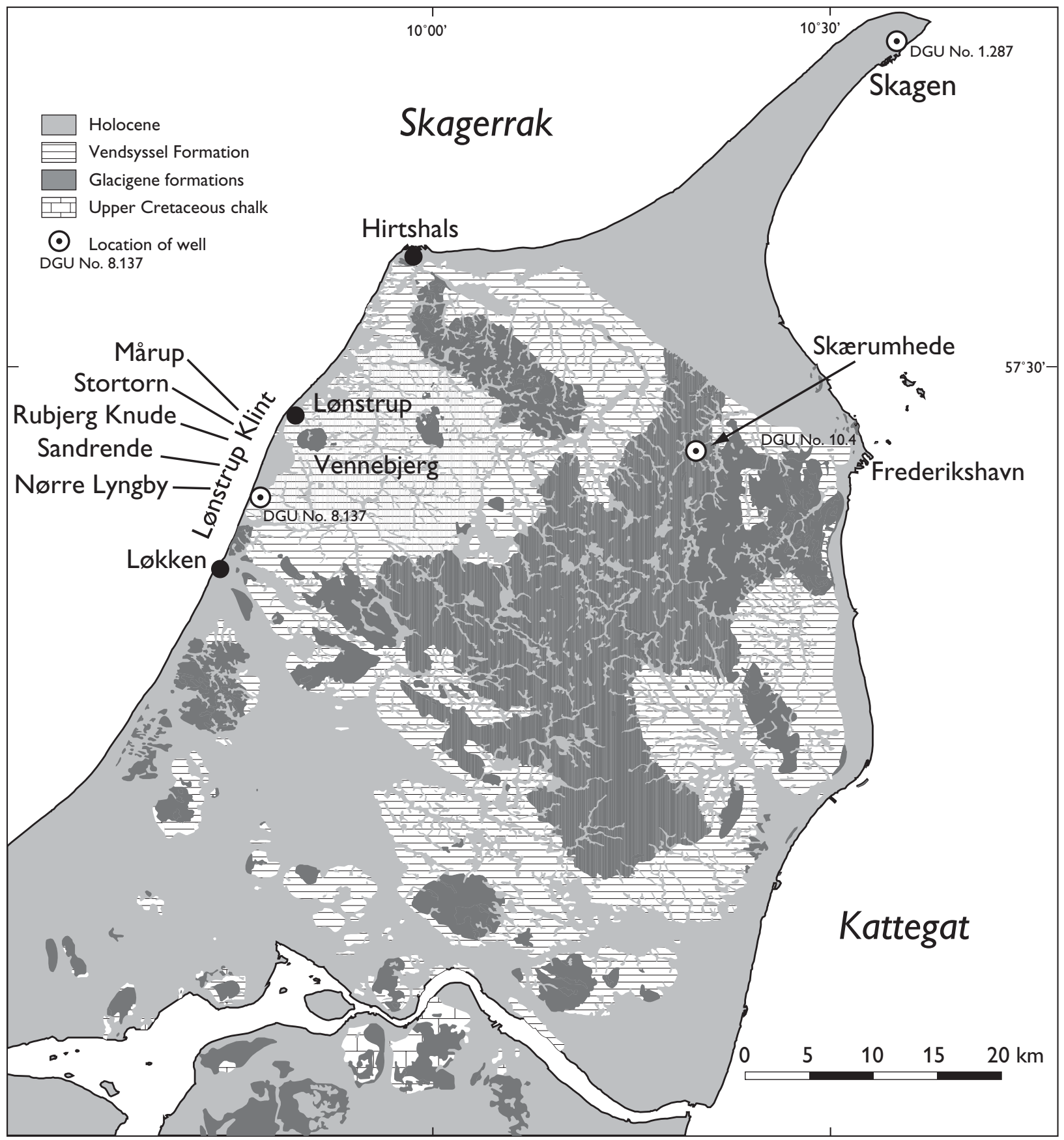

Fig. 13. Geological map of Vendsyssel showing the location of three wells referred to in the text. 


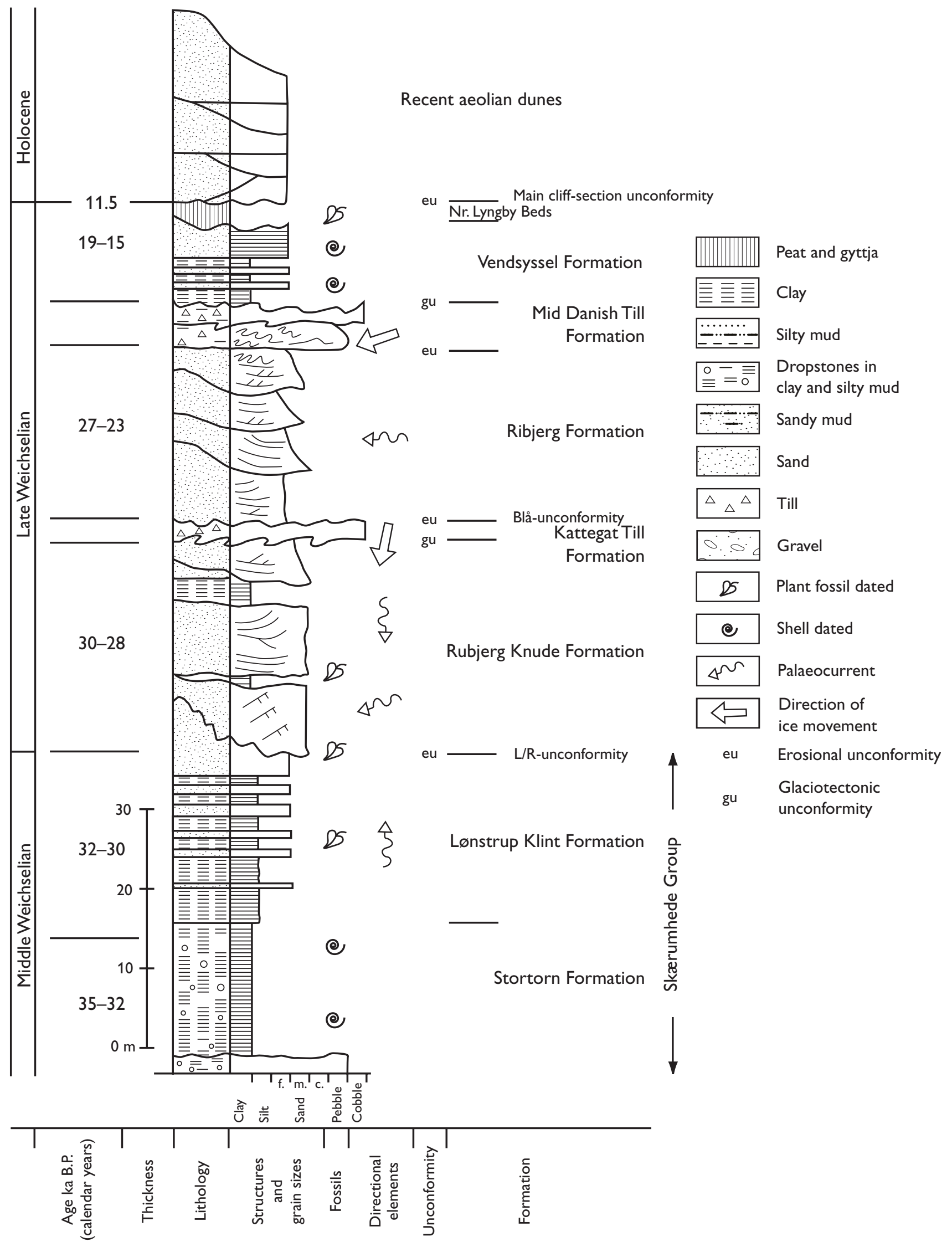




\section{Lithostratigraphy}

The upper Pleistocene in the Vendsyssel region comprises three major stratigraphic units: (1) a unit of marine sediments deposited on the erosional surface of the Saalian till, overlain by (2) a glacioterrestrial succession that in turn is succeeded by (3) a second marine deposit. The first marine unit was laid down after the retreat of the ice from the region at the end of Saalian time. During Eemian and Early to Middle Weichselian time, the Older Yoldia Sea prevailed (Jessen et al. 1910; Jessen 1918). From the end of the Middle Weichselain to the latest Late Weichselian, the area was subjected to terrestrial glaciation (HoumarkNielsen et al. 1996). After the ice melted back from the Main Stationary Line, a marine environment was re-established and persisted until isostatic rebound resulted in subaerial exposure of the seabed of the Younger Yoldia Sea (Jessen 1918; Figs 12, 13).

A new lithostratigraphical subdivision is proposed to cover the three upper Pleistocene successions (Fig. 14). The systematic stratigraphic framework is based on formations defined according to the guidelines given by Rawson et al. (2002). The lower marine unit, corresponding to the deposits representing the Older Yoldia Sea and formerly referred to as the Skærumhede series (Jessen et al. 1910), is here defined as the Skærumhede Group (new group). The group includes the Middle Weichselian Stortorn and Lønstrup Klint Formations (new formations) and an unnamed lower unit mainly including the Eemian and Lower Weichselian deposits (Figs 15, 16). Four formations are distinguished in the glacioterrestrial unit: the glaciofluvial and glaciolacustrine Rubjerg Knude Formation (new formation), the Kattegat Till Formation (Houmark-Nielsen 1987, 1999, 2003), the Ribjerg Formation (new formation) and the Mid Danish Till Formation (Houmark-Nielsen 1987, 1999, 2003). The uppermost major unit, comprising the post-glacial arctic marine younger Yoldia clay and Saxicava sand of Jessen (1918, 1931), is referred to the Vendsyssel Formation (new formation) (Fig. 14).

\section{Facing page:}

Fig. 14. Schematic stratigraphic log of the units represented in the Rubjerg Knude Glaciotectonic Complex. The fossils indicated on the $\log$ represent ${ }^{14} \mathrm{C}$-dated samples.

\section{Skærumhede Group}

new group

History. The Skærumhede Group includes most of the lithological units formerly described as the Skærumhede series (Jessen et al. 1910). These include the marine Eemian, the marine Lower Weichselian and the marine-brackish-lacustrine beds in the Middle Weichselian (Figs 14, 15; Lykke-Andersen \& Knudsen 1991; Knudsen 1994). Recognition of the group is primarily based on a research borehole behind the farm at Skærumhede, about $10 \mathrm{~km}$ west of Frederikshavn (Fig. 13), that was drilled by the Geological Survey of Denmark to investigate the source of natural gas in the vicinity of Frederikshavn (Jessen et al. 1910). The well penetrated to a depth of $235 \mathrm{~m}$ and terminated in Upper Cretaceous chalk. Above the chalk, a $20 \mathrm{~m}$ thick unit of till and glacial sediments was encountered. The till is now referred to the Saalian (Lykke-Andersen 1987), and forms the basal unit of the Quaternary succession over most of north Jylland (Fredericia 1982, 1983a, b; Pedersen 1989).

The succession above the Saalian glacial sediments was described under the heading: "The marine Skærumhede series' by Jessen et al. (1910 pp. 67, 156). This unit is c. $123 \mathrm{~m}$ thick, from $57.4 \mathrm{~m}$ to $180.3 \mathrm{~m}$ below surface, corresponding to a lower boundary at $157.1 \mathrm{~m}$ and a top at $34.2 \mathrm{~m}$ below sea level. It was subdivided into three biostratigraphic zones: 1) the Turritella ter ebra zone (74 m thick), 2) the Abra nitida zone (8.5 $\mathrm{m}$ thick) and 3) the Portlandia arctica zone (40 m thick) (Jessen et al. 1910). Additional details were added to the unit based on several glaciotectonically dislocated outcrops in the northem part of Vendsyssel by Jessen et al. (1910) and Jessen (1918, 1931).

Subsequent discussion conceming the stratigraphic position and differentiation of the Skærumhede series resulted in a new borehole, which was directed by the Geological Survey of Denmark at the Skærumhede locality in the early 1970s. Although the borehole only went down to $120 \mathrm{~m}$ below surface, it gave a good record of the lithology and macrofauna and in particular provided samples for a detailed foraminiferal investigation (Bahnson et al. 1974). 
SK/ERUMHEDE WELL

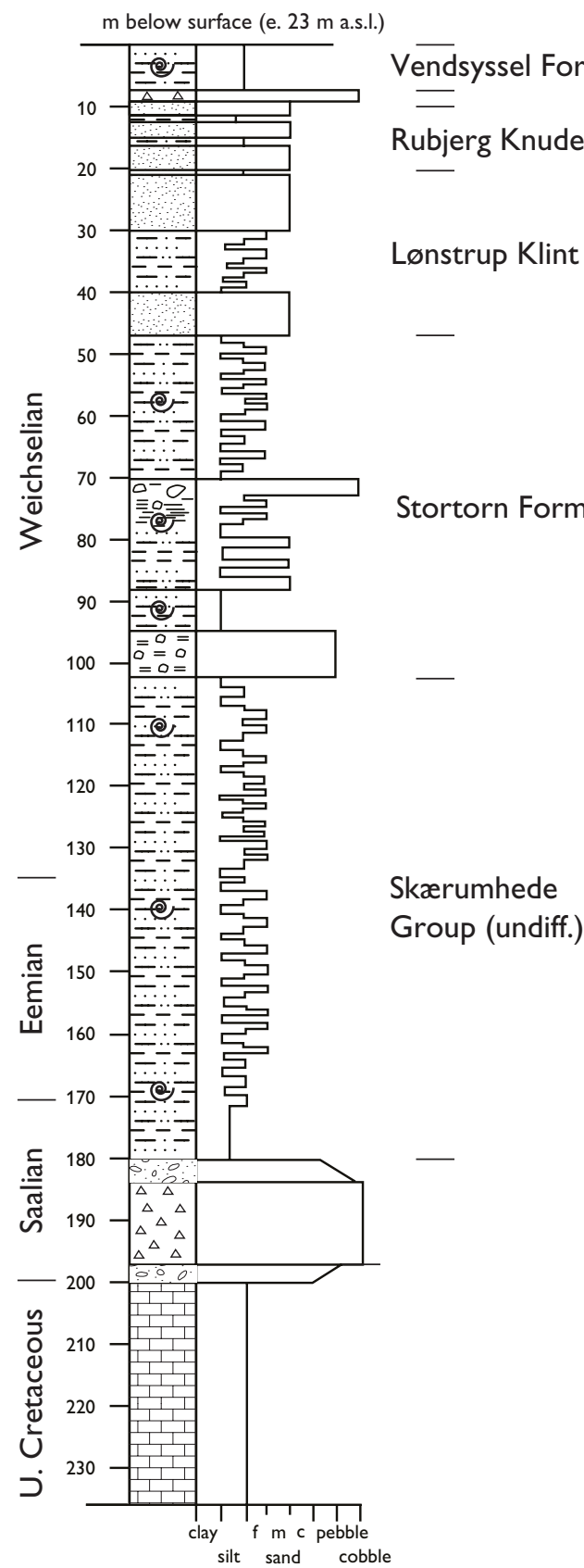

Name. The Skærumhede Group is named after the locality of Skærumhede c. $10 \mathrm{~km}$ west of Frederikshavn, Denmark (Fig. 13).

Type section. The type section is defined as the Skærumhede well (DGU No. 10.4 and 10.392) (Fig. 15), where the pioneer drill site for natural gas was situated at a barren and unfertile place caused by seepage of gas from the subsurface (Fig. 13; Jessen et al. 1910).
Fig. 15. Lithostratigraphic log of the Skærumhede well DGU No. 10.4, the type section of the Skærumhede Group and the Stortorn Formation.

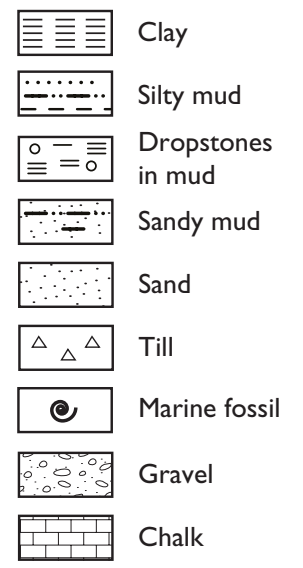

Referencesections. Reference sections are proposed in well-documented borehole sections: the Nørre Lyngby II well (DGU No. 8.137) described by Lykke-Andersen (1987), and the Skagen III well (DGU No. 1.287) recorded by Knudsen (1994) and Petersen (2004) (Fig. 16).

Lithology. The Skærumhede Group consists of rather uniform bluish-black to dark grey clay with minor intercalations of silt and fine-grained sand. The silt laminae and thin fine-grained sand beds become more common towards the top of the group. Macrofossils 
are present through most of the group but decrease in abundance towards the top (Jessen etal.1910). Dropstones are present in the middle of the group and increase in abundance towards the uppermost part, in which graded silts and sands are intercalated with grey mud.

Boundaries. The lower boundary is the unconformity on top of the Saalian till. The upper boundary is an unconformity overlain by coarse clastic sediments interpreted as a residual boulder bed (Unit B of Sadolin et al. 1997).

Thickness. The thickness of the group varies from nearly $130 \mathrm{~m}$ in the type section in the Skærumhede well, to c. $48 \mathrm{~m}$ in the Nørre Lyngby well and c. $45 \mathrm{~m}$ in the Skagen III well (Fig. 16).

Distribution. Knowledge of the distribution of the group in the vicinity of Rubjerg Knude is based on the Skærumhede well (DGU No. 10.4), the Nørre Lyngby well (DGU No. 8.137) and the Skagen well (DGU No. 1.287; Figs 13, 16). The group is also known from wells in the northem part of Vendsyssel and the islands of Læsø and Anholt in the Kattegat. According to these records, the group extends from the westem part of the Kattegat at Frederikshavn and Læsø, towards the south central part of Vendsyssel, from where it continues offshore between Anholt and Djursland (Knudsen 1994, fig. 3). The group extends offshore into the strait between Læsø and the Swedish coast. The southward extent is not known, but is probably up to about $30 \mathrm{~km}$ south of Anholt. The extent to the north is also uncertain and has not yet been mapped. It is inferred that it may occur in the western part of the Skagerrak (Knudsen 1994) and it may also extend out into the northern part of the North Sea.

Age. Theage of the group extends from the beginning oftheEemian, about130 000 years B.P. (Knudsen 1994), to the latest partof the Middle Weichselian, about 30000 years B.P. (Houmark-Nielsen 1999).

Depositional environment. At the lower boundary of the group, red corroded flints were recognised in the Skærumhede well (Jessen et al.1910) indicating that the top surface of the Saalian till had been exposed and subjected to subaerial erosion prior to the transgression that culminated in the Eemian. During the Eemian, a deep-water shelf environment was established with water depths exceeding $100 \mathrm{~m}$; in the Ear- ly Weichselian, water depths decreased dramatically to less than $50 \mathrm{~m}$ (Knudsen 1994). The decrease in water depth continued during the Middle Weichselian under increasing glacial influence.

Subdivisions. The upper Skærumhede Group is subdivided into the Stortorn and Lønstrup Klint Formations. The lower part of the group, mainly including the marine Eemian and Lower Weichselian deposits, is presently undifferentiated.

\section{Stortorn Formation}

new formation

History. In the Lønstrup Klint section, two units of grey-bluish clay subjected to glacial deformation have been distinguished, the diluvial clay and the Portlandia arctica clay (Jessen 1931). The latter unit corresponds to the so-called Older Yoldia Clay (Ældre Yoldialer in Danish), which in the Skærumhede well was referred to as the Portlandia arctica zone and in the crosssection of Lønstrup Klint is indicated to occur at three localities (Jessen 1931). The most impressive of these is the Stortorn site, where dark grey - black clay, rich in mollusc shells, crops out (Fig. 21). The site is inaccessible, or difficult of access, since the slippery clays occur in the breaker zone at the foot of the almost vertical cliff section. The other two localities are the cliff sections just beyond the town Lønstrup, locally named 'Lille Blå' (little blue), and the cliff section below the northem corner of the Mårup churchyard. At all three sites, the unit is tectonically disturbed which hampers detailed logging of the succession. In addition, the formation occurs locally in the lower thrustsheet duplexes north of Mårup Church and in the Moserende cliff section (see description of that section, below).

Name. The formation is named after the Stortorn cliff section at Lønstrup Klint. The formation is here incorporated within the lowermost thrust unit in the Stortorn Section (see below).

Type section. The type section for the formation is the Skærumhede well, DGU No. 10.4 (Figs 14, 15).

Reference sections. The reference sections for the formation are the outcrops at Stortom and north of the northern corner of Mårup churchyard (Fig. 17) in the 


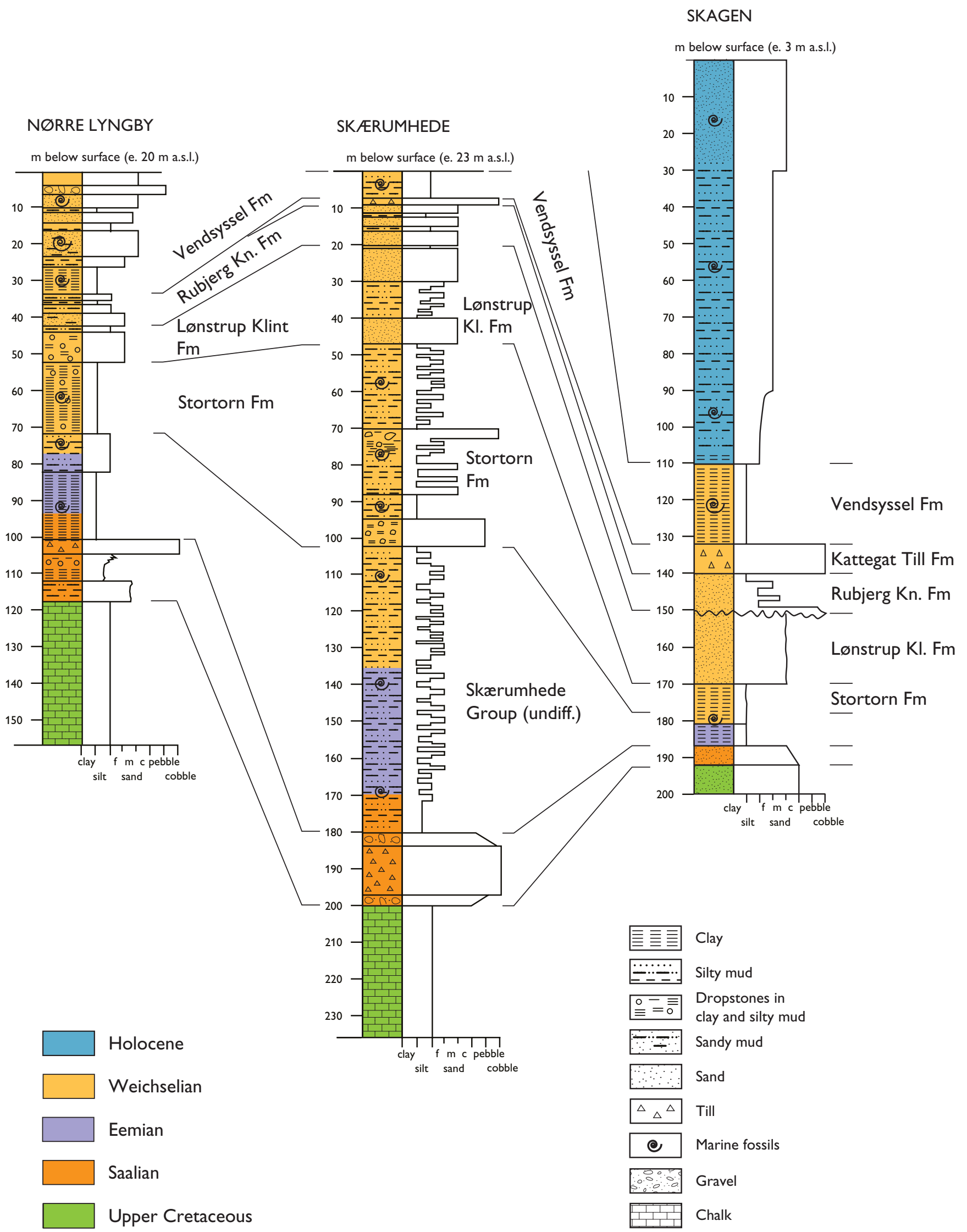




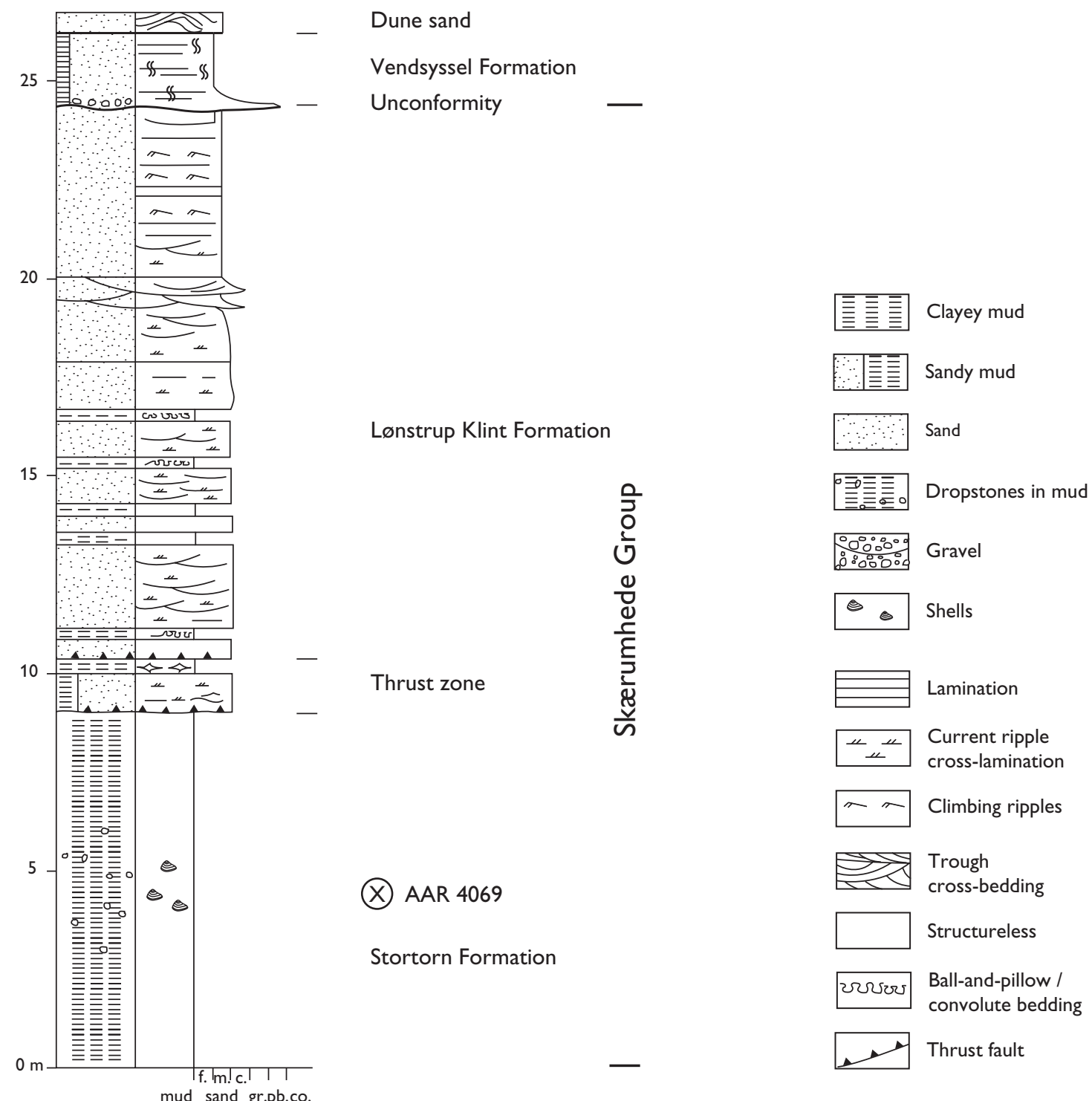

Fig. 17. Sedimentological log of the succession in the southern part of the Ribjerg Section (above the 'Store Blå'). The Stortorn Formation records an arctic marine deposit, yielding shells typical of this environment: Hiatella arctica, Mya truncata and Portlandia arctica. The boundary between the Stortorn and Lønstrup Klint Formations constitutes a thrust-fault breccia indicating differentiation into thrust-fault duplex segments of the Skærumhede Group. The Vendsyssel Formation at the top of the section was deposited on an erosional unconformity with a lag conglomerate at the base. The location of the sample collected for ${ }^{14} \mathrm{C}$ dating (AAR 4069) is indicated (see Table 2).

\section{Facing page:}

Fig. 16. Simplified lithological logs from three thoroughly documented wells in Vendsyssel (Nørre Lyngby: DGU No. 8.137; Skærumhede: DGU No. 10.4; Skagen: DGU No. 1.287, for location see Fig. 13). The logs illustrate the stratigraphic correlation of the units defined in the investigation of the Rubjerg Knude Glaciotectonic Complex. The difference in thickness of Eemian-Weichselian deposits mainly reflects the average content of sand; the Skagen well represents a deeper marine depositional environment compared to the Skærumhede well. Note that the Cretaceous deposits in the Skagen well comprise Turonian-Cenomanian greensands. The figure is based on information from Jessen et al. (1910), Bahnson et al. (1974), Lykke-Andersen (1987), Lykke-Andersen \& Knudsen (1991), Knudsen (1994) and Petersen (2004). 


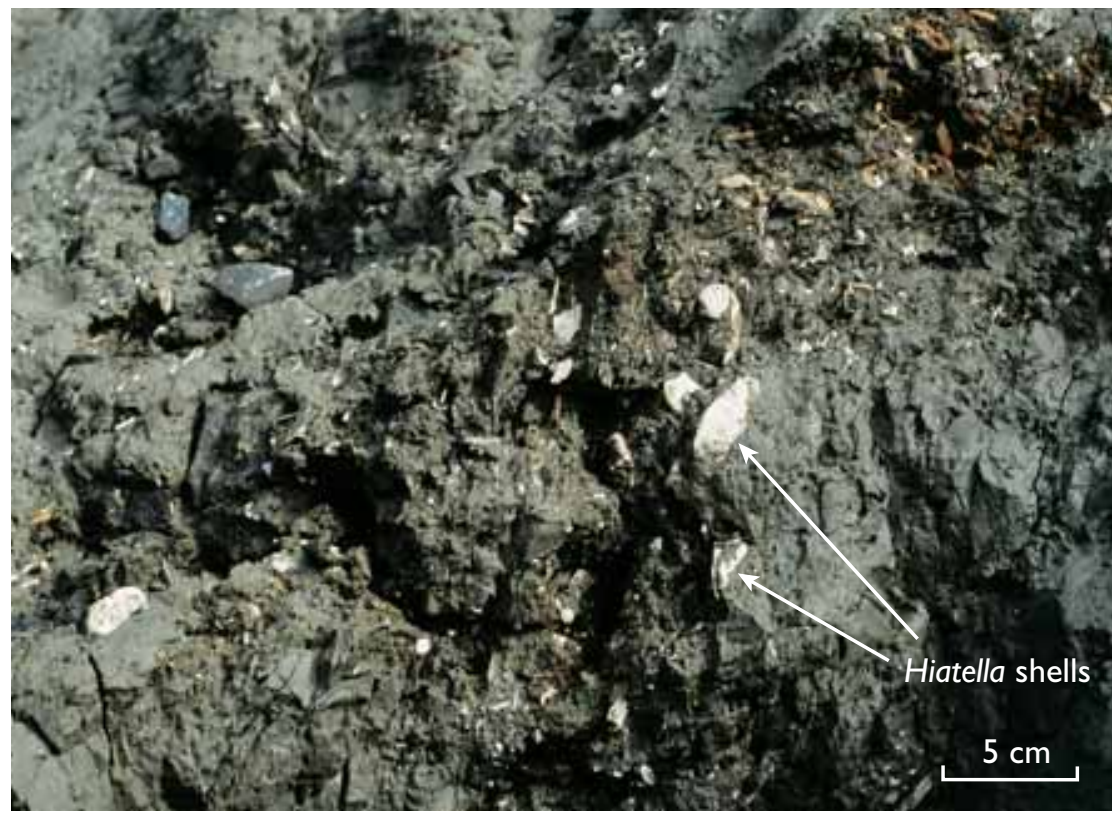

Fig. 18. The Stortorn Formation in the Stortom Section is dominated by black sticky clay. Locally, shells of Hiatella arctica and Portlandia arctica are very abundant. Dropstones are also common in the formation. Photograph: August 2001.

Lønstrup Klint coastal cliff. TheNørre Lyngby well(DGU no 8.137, Lykke-Andersen 1987) is the well closest to Stortorn where the undisturbed formation has been penetrated. Additional sections include the coastal cliff at Hirtshals displaying allochthonous peats in the black clay formation, and the Skagen III well (DGU no 1.287; Petersen 2004) that includes a clay unit, $8 \mathrm{~m}$ thick, here referred to the Stortorn Formation (Fig. 16).

Lithology. The Stortorn Formation consists of black, locally dark grey - bluish structureless clay with a large number of dropstones, which are commonly glacially striated. Lenses or irregular beds, up to $10 \mathrm{~cm}$ thick, of shell debris (gravel-size) occur scattered in the unit, and the abundance of shells in local patches gives the formationa white spotted appearance (Fig. 18). At the top of the formation, the clayey mud changes colour from dark bluish grey to violet-brown and develops recognisable lamination.

Fossils. The unit has been referred to the Portlandia arctica zone of Jessen et al. (1910) since this is the most abundant mollusc species in the clay (Bahnson et al. 1974). Macoma calcarea is another common mollusc and Hiatella arctica occurs in abundance. A list of characteristic molluscs and their distribution in the unit is given by K.S. Petersen (in: Bahnson et al. 1974). Moreover, the presence of Balanus sp. and additional erratic macrofossils are reported. The most common microfossils are the foraminifers Elphidium excavatum and Cassidulina crassa. P.B. Konradi and K.L. Knudsen (in: Bahnson etal.1974) documented and discussed the foraminiferal fauna.

Boundaries. The lower boundary of the formation is defined by a shift from clayey mud to mud with a marked increase in coarse-grained ice-rafted debris. The increased content of coarse-grained material is associated with an abundance of mollusc shells and fragments. The upper boundary of the formation is defined at the transition from marine clay showing diffuse lamination and colours varying from grey bluegreen to violet-brown, to a grey clayey and silty mud intercalated with graded silt and fine-grained sand laminae a few millimetres thick.

Thickness. The formation is about $20 \mathrm{~m}$ thick. In the Skagen III well, the formation is only about $8 \mathrm{~m}$ thick, probably due to the more offshore position and deeper water environment in this part of the basin (Petersen 2004).

Distribution. The distribution of the Stortorn Formation is identical with the distribution of the Skærumhede Group. The formation can be readily identified in the Nørre Lyngby well (Lykke-Andersen 1987; Figs 13, 16) and it has also been described from the Hirtshals cliff section (Lykke-Andersen 1971). In addition, it is known from the deeper wells in the main part of the Vendsyssel area and from the islands of Læsø and An- 
holt (Fredericia 1982, 1983a, b, 1984; Lykke-Andersen 1987).

Age. Three shell samples from the Stortorn Formation at Lønstrup Klint have been ${ }^{14} \mathrm{C}$ dated, using the Atomic Mass Spectrometric (AMS) method, for the present investigation. Two of the samples were derived from the archives of the former Geological Survey of Denmark; two shells of Hiatella arctica were chosen for dating the formation atthe Stortorn locality and from the northernmost outcrop of the formation at Lønstrup Klint ('Lille Blå', at the base of the northem part of the Ribjerg Section, collected and described by A. Jessen) (Table 2). The third sample was taken in 1996 and comprises shells of Hiatella arctica from the shellbearing clay outcrop at Stortorn (reference DGU no. 00136, AAR-4069, Table 2). These were dated to test the collection made nearly 100 years earlier and provided an age for the lowermost Stortorn Formation, namely $31300( \pm 400)$ years B.P. The age of the upper levels of the formation, as represented by the muddy sediments at the 'Lille Blå' section is slightly younger (30 000 ( \pm 400 ) years B.P. (Table 2)). The new dating of the Stortorn Formation corresponds well with previous age dates from the upper part of the SkærumhedeGroup, which gave 32000 years B.P. (Seidenkrantz \& Knudsen 1993).

Depositional environment. The presence of a boreal fauna including Mytilus edulis, Arctica islandica and Zirphaea crispata in the shell-debris gravel in an environment characterised by a bottom fauna of Portlandia arctica and Macoma calcaria led Nordmann (1928) and Jessen (1931) to conclude that the boreal shallow-water faunas of interglacial affinity were transported as ice-rafted material into more offshore arctic marine environments. The most convincing examples of such erratic material are the dropstones with Balanus sp. The Stortorn Formation is thus interpreted to have been deposited during a period of decreasing water depths in a marine environment characterised by dispersal of erratics from drifting icebergs.

\section{Lønstrup Klint Formation}

new formation

History. The characteristic development of this formation, viz. grey clayey muds interbedded with layers of fine-grained sand, occurs in the steeply inclined sheets that are prominent in the cliff of Lønstrup Klint. Due to the absence of macrofossils, this unit was named Diluvialler (diluvial clay) and the unit was correlated with the uppermost part of the Skærumhede Group in the Skærumhede well (Jessen et al. 1910; Jessen 1918, 1931). The sedimentology of the formation was described from Sandrende at Lønstrup Klint under the heading Unit A by Sadolin et al. (1997).

Name. The formation is named after the coastal cliff of Lønstrup Klint.

Type section. The type section for the formation is at Sandrende in Lønstrup Klint, situated between point 3500 and $3600 \mathrm{~m}$ in the Rubjerg Knude cross-section (Plate 1), from where a sedimentological log was provided by Sadolin et al. (1997) (Figs 13, 19).

Reference sections. Reference sections are defined at Ulstrup Rende (Fig. 20) and at Kramrende (Fig. 21) situated at $5950 \mathrm{~m}$ and $4500 \mathrm{~m}$, respectively, in the Rubjerg Knude cross-section (Plate 1). Moreover, the Skærumhede and the Skagen wells are reference sections for the western and northem development of the formation (Fig. 16).

Lithology. The formation consists of blue-grey clayey and silty laminated mud and cross-laminated beds of fine sand. The lowest part of the formation is characterised by dark grey mud, interlayered with laminated to thin-bedded clayey and silty mud. The light grey beds, $1-5 \mathrm{~cm}$ thick, grade upwards from light grey silt to dark grey clay (Fig. 22). Some of the dark grey clayey mud levels are interbedded with thin lenticular, light-coloured silt and fine-grained sand laminae (Fig. 23). Silty to fine-grained sandy beds may be up to $1 \mathrm{~m}$ thick. Dropstones occur scattered in the bluegrey mud. In the upper part of the formation, beds of light grey sand, 3-8 $\mathrm{m}$ thick, occur interbedded with a few thin beds of laminated mud. The thick sand beds are characterised by climbing ripple cross-lamination. In the cliff section at Rubjerg Knude, much of the primary bedding in the Lønstrup Klint Formation is disturbed by water-escape structures (ball-and-pillow etc.) and hydrodynamic brecciation (flame to diapir structures).

Fossils. Macrofossils have not been found in the formation and the foraminifers, dominantly Elphidium excavatatum, are interpreted to be redeposited (LykkeAndersen 1987). 


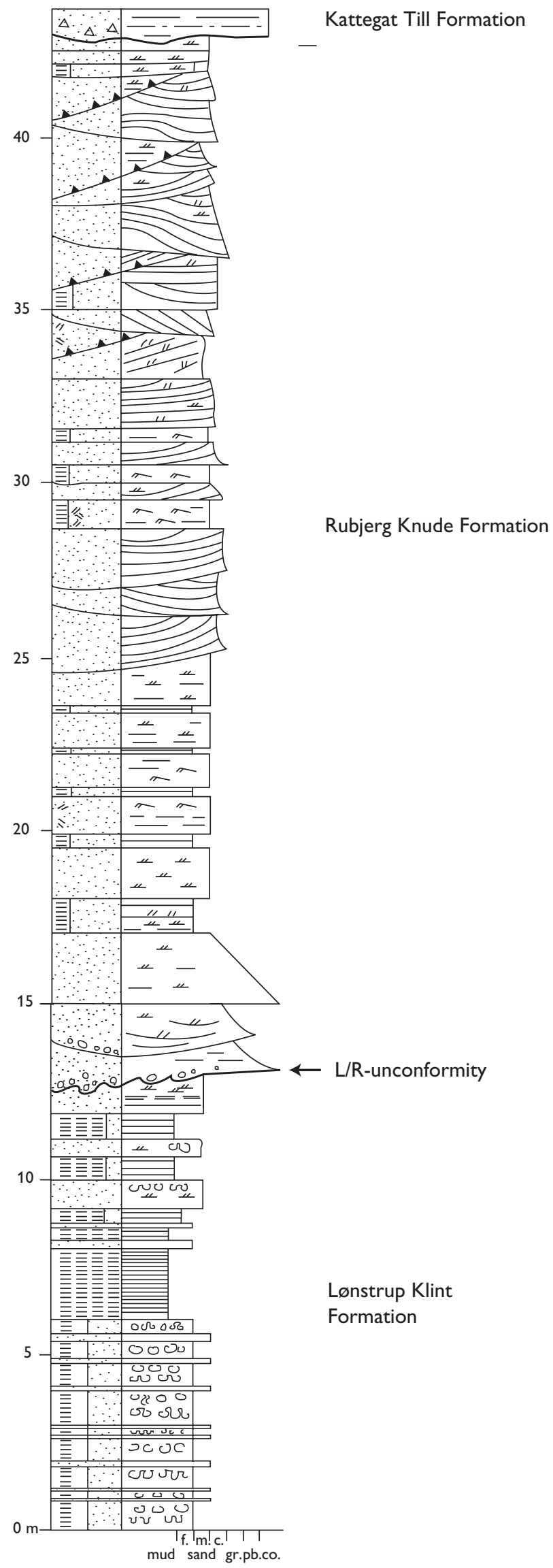

Fig. 19. Sedimentological log of the succession in the Sandrende Section, including the type sections of the Lønstrup Klint and Rubjerg Knude Formations. The Lønstrup Klint Formation represents lacustrine deposition, whereas the Rubjerg Knude Formation records a shift from fluvial to lacustrine sedimentation, returning to fluvial sedimentation in the upper levels (Sadolin et al. 1997). Note the synsedimentary small-scale thrust structures that appear in the upper levels of the Rubjerg Knude Formation indicating that the formation was deposited in a piggyback basin.

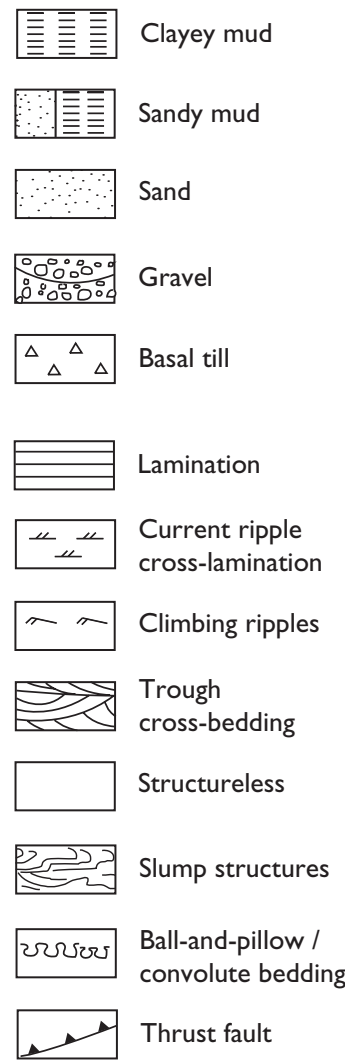




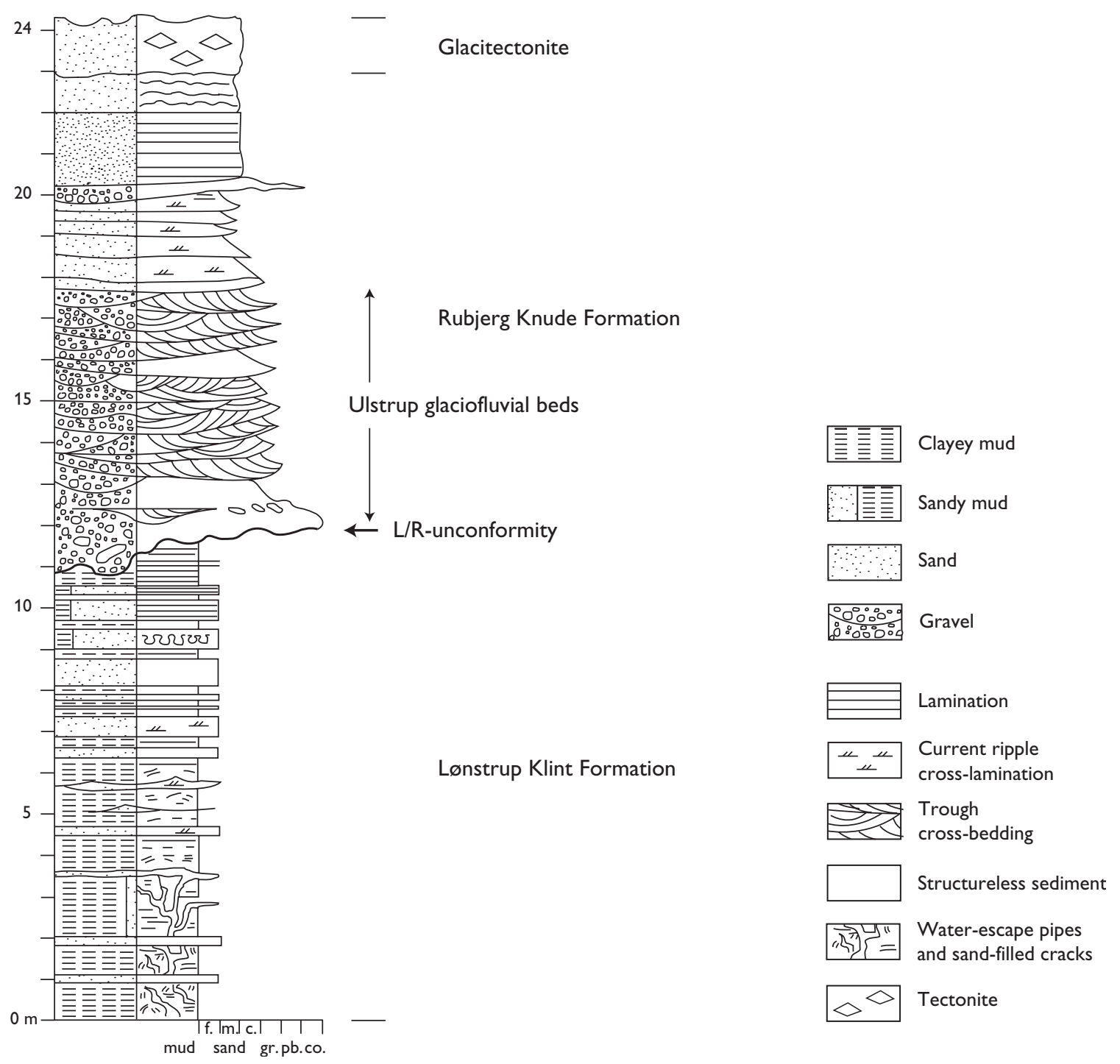

Fig. 20. Sedimentological log of the succession in the southernmost thrust sheet in the Ulstrup Section. The log was measured at Ulstrup Rende, situated at point $5980 \mathrm{~m}$ in the cross-section (Plate 1). Note the $4 \mathrm{~m}$ thick sand-crack dominated thrust zone that characterises the lower part of the Lønstrup Klint Formation, which developed during thrust-sheet translation along the hangingwall flat (Figs 46, 47). Note also that in the Rubjerg Knude Formation, the lowermost $7 \mathrm{~m}$ corresponds to the glaciofluvial 'Ulstrup beds' (Figs 28, 29).

Boundaries. The lower boundary of the Lønstrup Klint Formation is placed at the transition from the typical marine clay with a macrofossil fauna of the Stortorn Formation to unfossiliferous laminated clayey and silty muds with laminae and thin beds of fine sand. The upper boundary is the marked erosional unconformity between the Lønstrup Klint and Rubjerg Knude Formations, referred to as the L/R-unconformity (Figs 14, 24).

Thickness. The maximum thickness of the formation isabout $25 \mathrm{~m}$, but with large variations due to erosional relief at the L/R-unconformity.
Distribution. The Lønstrup Klint Formation is distributed over the main part of Vendsyssel. It is erosionally truncated at the top towards the south where underlying glacial deposits or Upper Cretaceous chalk constitute the surface geology of the coastal areas north of Limfjorden. To the east, it probably extends offshore into the middle part of Kattegat from where it is known in wells on the islands of Læsø and Anholt (Lykke-Andersen 1987; Knudsen 1994). The extent out into the North Sea to the west remains unknown. Towards the north, it extends offshore into the Skagerrak beyond Skagen, where it is recorded in the Skagen III well (Petersen 2004). 


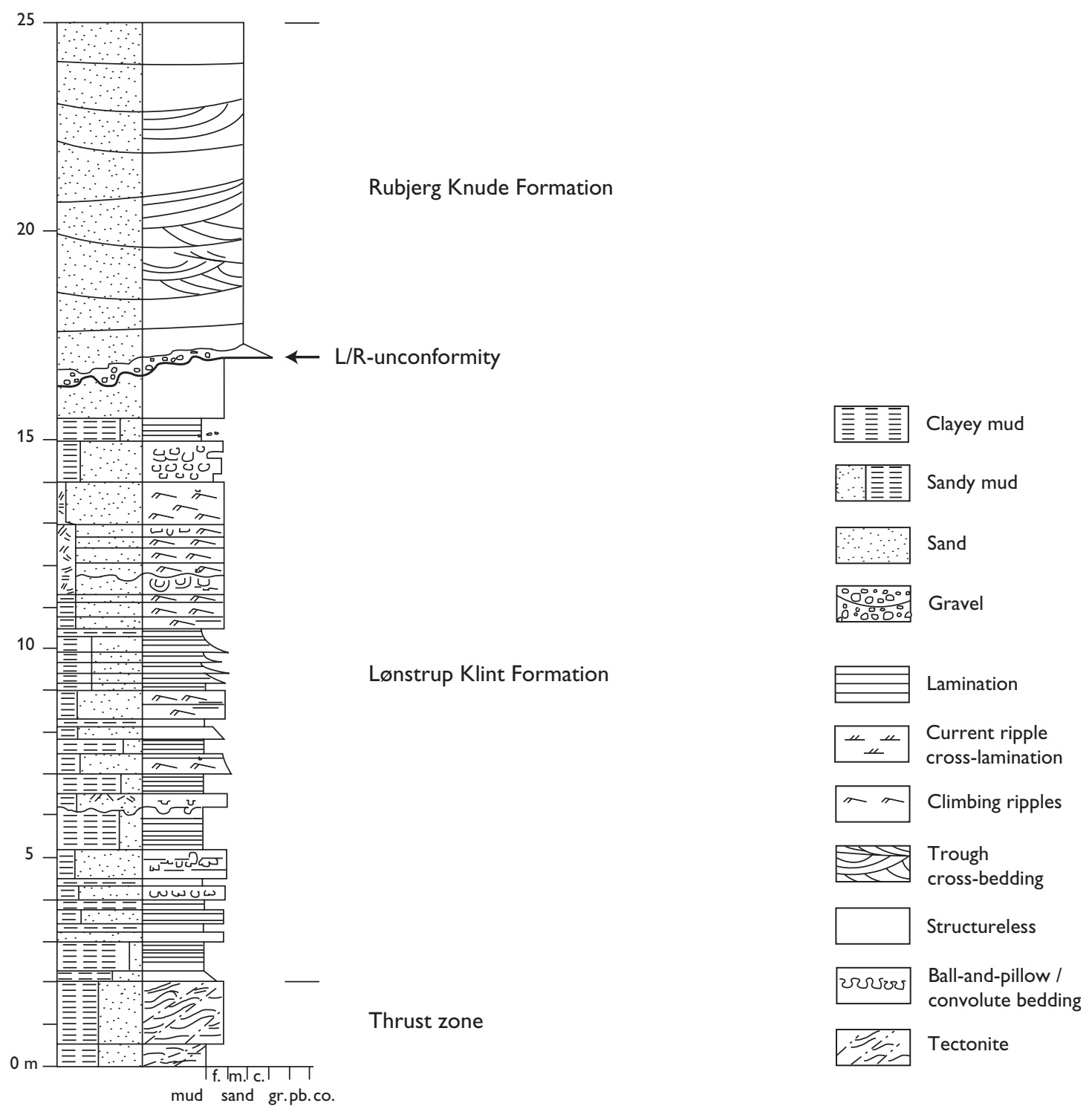

Fig. 21. Sedimentological log of the Lønstrup Klint and Rubjerg Knude Formations in the KR01 thrust sheet in the southern part of the Kramrende Section (point 4500 in Plate 1). The fine-grained, thin- to medium-bedded sandy turbidites in the Lønstrup Klint Formation are interbedded with thin layers of blue-grey silty mud. These sand beds are often disrupted into ball-and-pillow load structures (see Fig. 48). Note the tectonite at the base of the succession, related to the hanging-wall flat of the KR01 thrust sheet.

Age. ${ }^{14} \mathrm{C}$ dating of plant debris from the formation indicates an age of about 30000 B.P. (Houmark-Nielsen et al. 1996). This age is compatible with the 32000 B.P. age derived from the underlying Stortorn Formation.

Depositional environment. The transition from the Stortorn Formation to the non-fossiliferous Lønstrup Klint Formation is interpreted as a shift from a normal, arctic marine environment through brackish to a freshwater environment dominated by rapid deposition of suspended sediment supplied to the basin by meltwater. The sharp-based normally graded silt and sand beds are interpreted as fine-grained turbidites. The dark mud was deposited from suspension, whereas the lenticular sand/silt laminae represent wave-reworked, distal stom-sand layers. Sedimentation started below storm-wave base and it is suggested that the lake environment was deep and of fairly wide extent. The occurrence of numerous fine-grained sandy turbidites sourced mainly from the south probably reflects exposed land areas in the southern part of Vendsyssel during the low stand of sea level (Sadolin et al. 1997). The sand beds are interpreted to record relatively rapid sedimentation by sediment gravity 
Fig. 22. Laminated to thin-bedded clayey and silty mud in the lower part of the Lønstrup Klint Formation in the Rubjerg Knude Fyr Section. The bedding is defined by layers grading from light grey silt to dark grey clay, and the sharp-based normally graded beds are interpreted as fine-grained turbidites. The coin for scale is $2.5 \mathrm{~cm}$ in diameter. Photograph: September 1985.

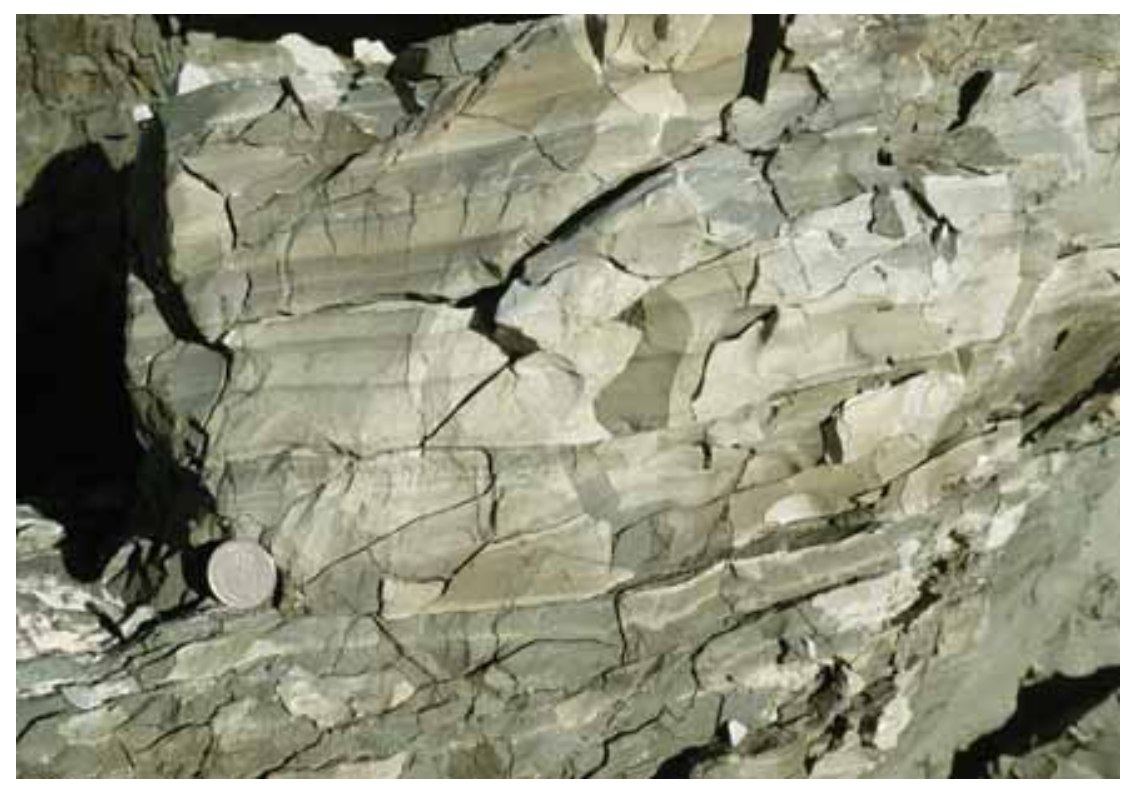

Fig. 23. Dark grey clayey mud interbedded with thin lenticular, light coloured silt and fine-grained sand laminae. The mud was deposited from suspension, whereas the lenticular laminae represent wave-reworked, distal storm-sand layers, deposited below storm-wave base.

Photograph: June 1993.

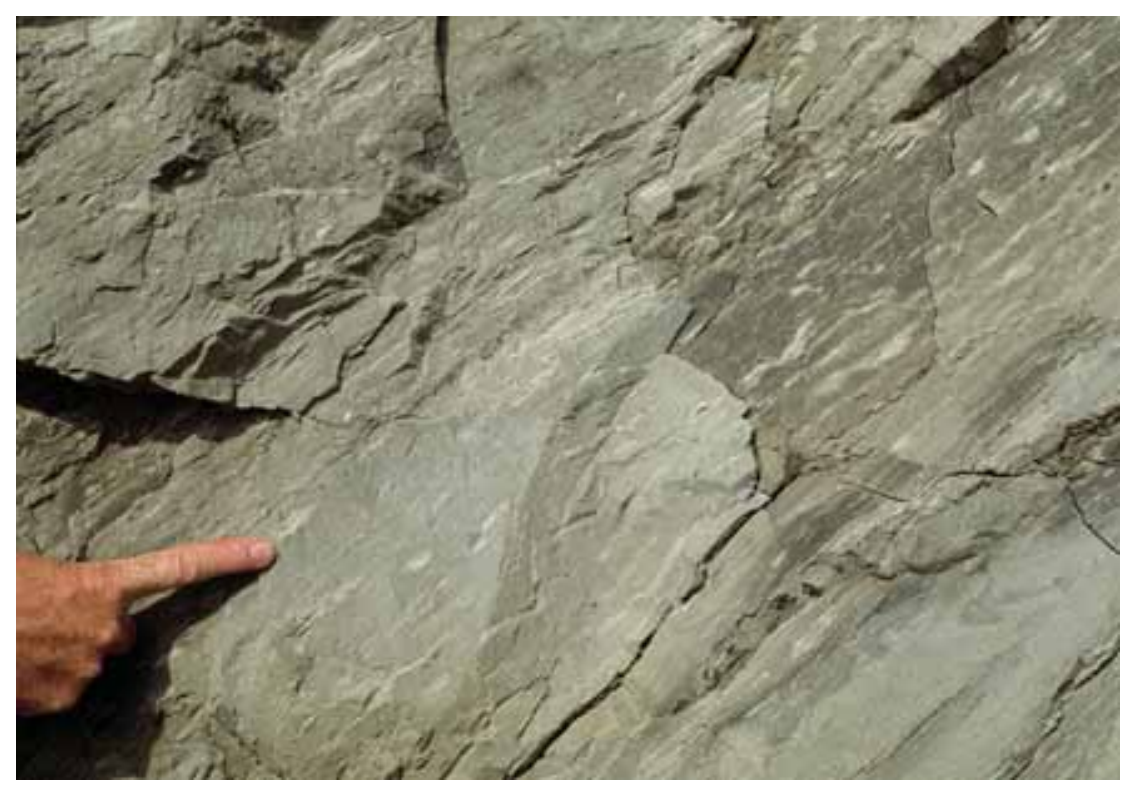

flows in a glaciolacustrine environment; the thickest of these beds may represent deposition within one summer of sediment derived from the southern slopes of the basin (Sadolin et al.1997).

Hydrodynamic deformation of the strata was initiated at a very early stage in the glaciotectonic process, as loading by the superposed Rubjerg Knude Formation and by glaciotectonic thrust sheets resulted in increasing pore-water pressure. Hydrodynamic brecciation continued during deformation until the displacements of thrust sheets ceased.

\section{UpperWeichselian lithostratigraphic units}

\section{Rubjerg Knude Formation}

new formation

History. In the steep cliff section at Rubjerg Knude, the thrust sheets, consisting of the grey-blue coloured clay of the Lønstrup Klint Formation, are depositionally overlain and structurally underlain by light-coloured yellowish sand, named Diluvialsand (diluvial sand) by Jessen $(1918,1931)$. The succession was re- 


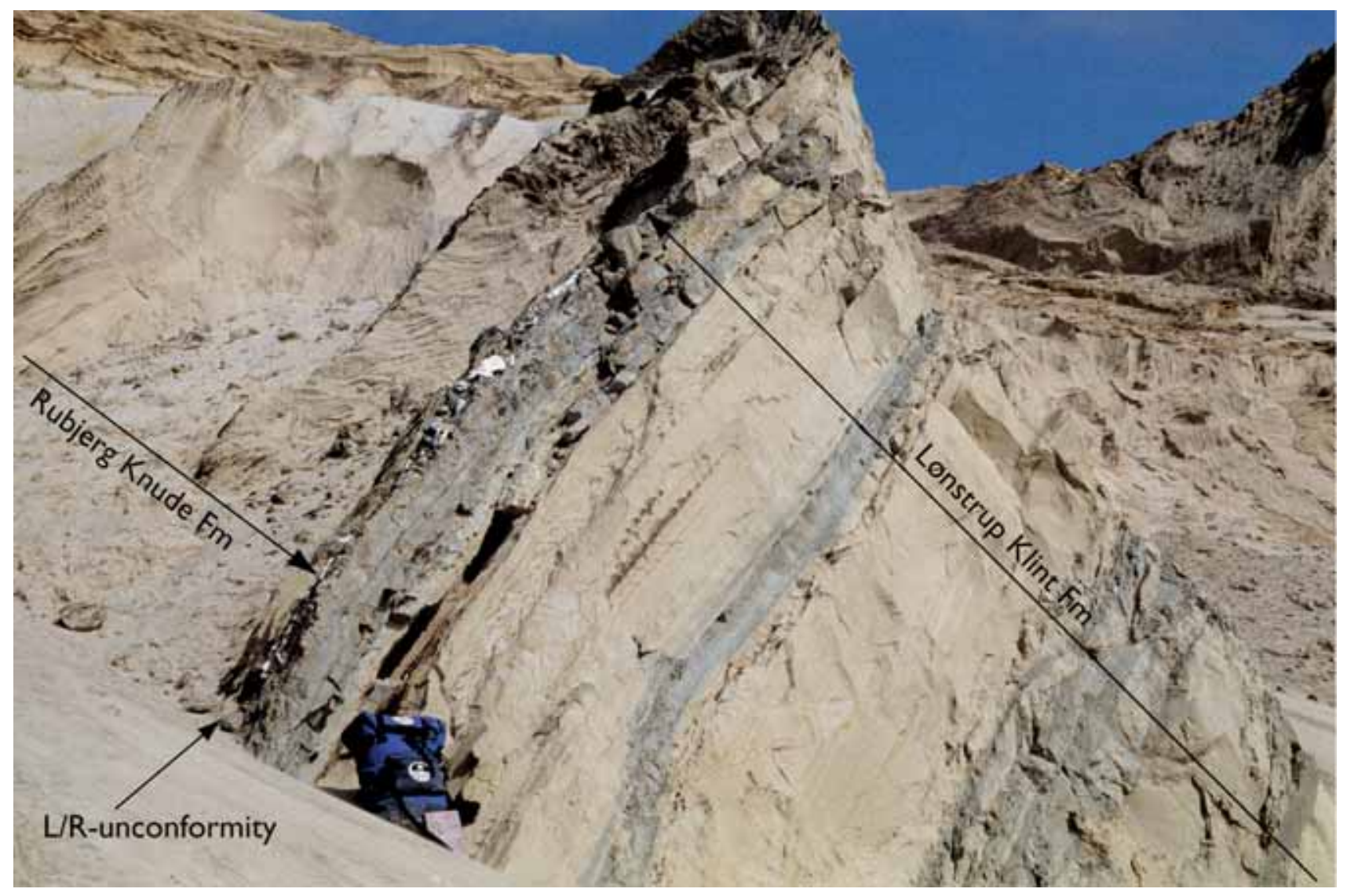

Fig. 24. The L/R-unconformity is steeply inclined in the GR08 thrust sheet. Note the large-scale cross-bedding in the basal unit of the Rubjerg Knude Formation, which onlaps the unconformity (R-onlap). Photograph: June 1993; rucksack for scale.

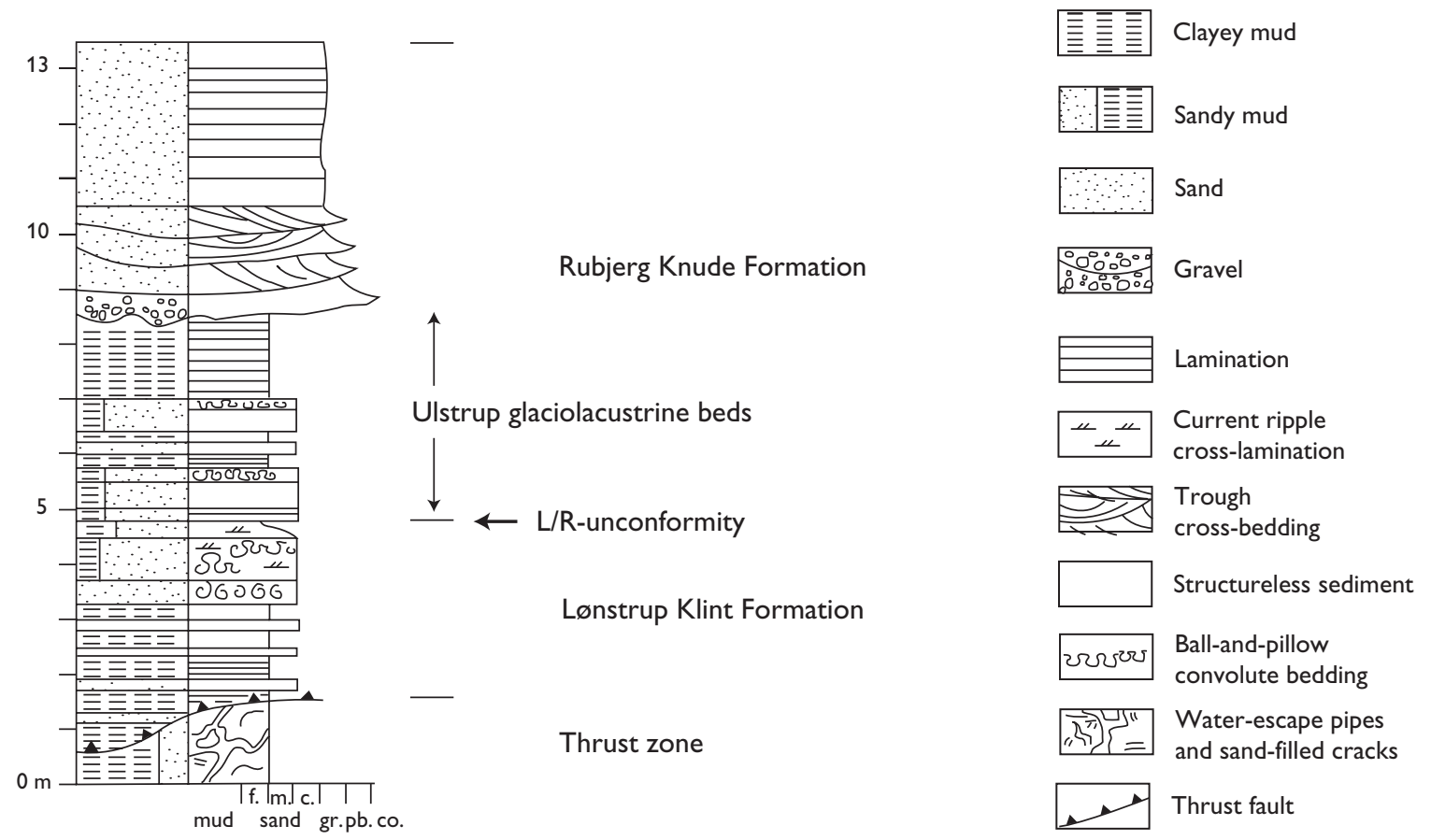

Fig. 25. Sedimentological log of the succession in the northern thrust sheet in the Ulstrup Section. The log was measured near the Ulstrup steps at point $5625 \mathrm{~m}$ in the cross-section (Plate 1). The base of the log is the hanging-wall flat of the UL02 thrust sheet and the lowermost $2 \mathrm{~m}$ constitute the thrust zone. The boundary between the Lønstrup Klint Formation and the Ulstrup glaciolacustrine beds above (lower unit of the Rubjerg Knude Formation) is a flat, non-erosional surface but can be traced to the northern part of the UL02 thrust sheet where this boundary is a clear erosional unconformity. 


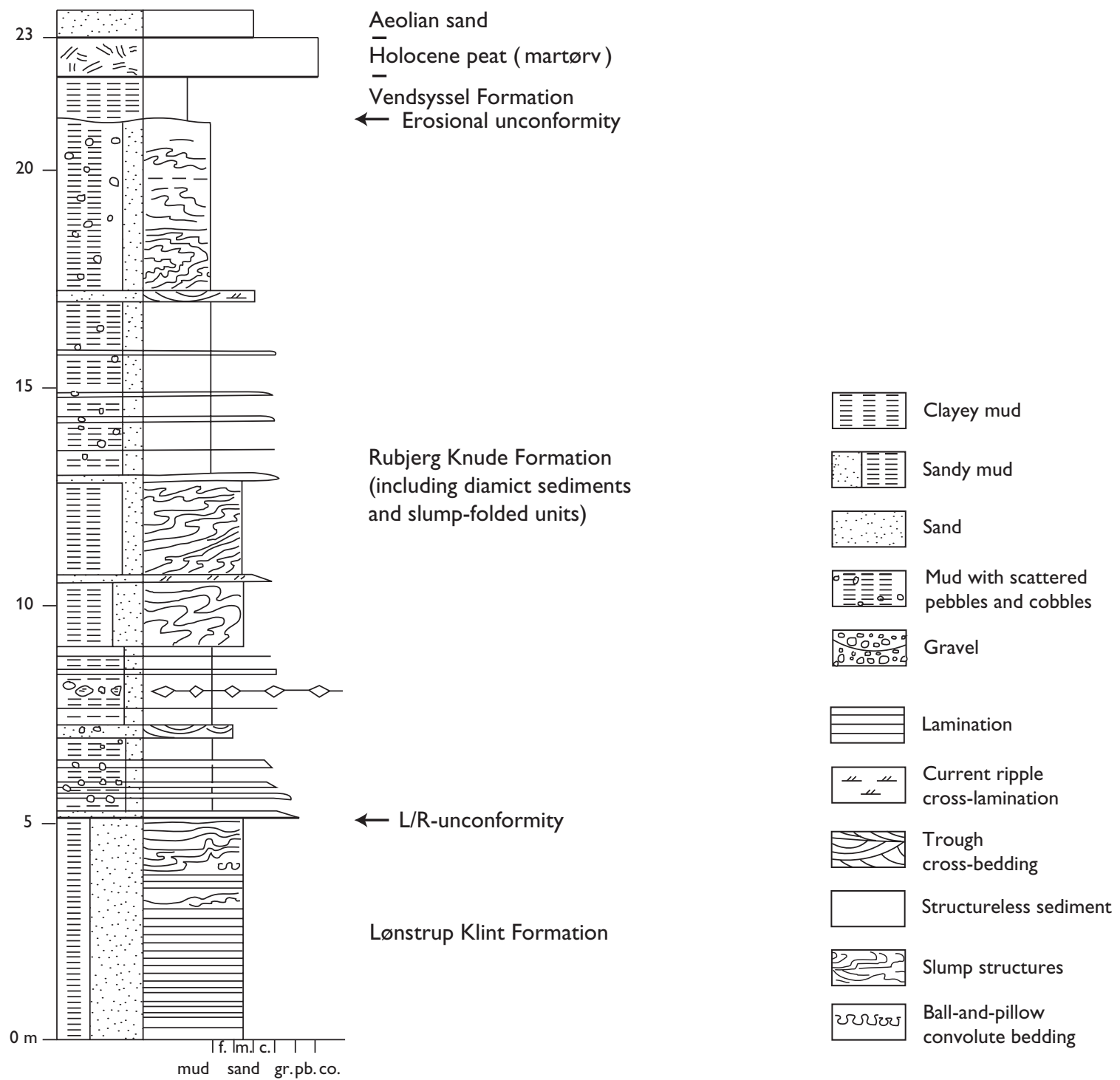

Fig. 26. Geological log of the diamict sediments and slump-fold structures, which represent the Rubjerg Knude Formation in the piggyback basin on the back of the MB02 thrust sheet in the Martørv Bakker Section, point 4880 in the cross-section (Plate 1).

ferred to as units B-D in the sedimentological study by Sadolin et al. (1997).

Name. The formation is named after Rubjerg Knude, the highest part of the Lønstrup Klint cliff..

Type section. The type section is at Sandrende in the Lønstrup Klint cliff section (Figs 13, 19).

Reference section. Four reference sections are defined, all situated in the vicinity of Rubjerg Knude. In the distal part of the Rubjerg Knude Glaciotectonic Complex, two reference sections are defined at Ulstrup. The first of these is located in Ulstrup Rende at point
$5900 \mathrm{~m}$ in the Rubjerg Knude cross-section (Plate 1) which demonstrates the presence of coarse-grained glaciofluvial channel fill deposits (Fig. 19). The second reference section at Ulstrup is located at point $5450 \mathrm{~m}$ in Plate 1 and documents the occurrence offine-grained clayey muddy glaciolacustrine beds in the formation (Fig. 25). The third reference section is situated at Martørv Bakker (point $4850 \mathrm{~m}$ in Plate 1), which demonstrates diamictitic sediments including slump units in a piggyback basin (Fig. 26). The fourth reference section is located at Moserende at point $1750 \mathrm{~m}$ in Plate 1. This section illustrates the formation in a piggyback basin situated in a proximal position in the Rubjerg Knude Glaciotectonic Complex (Fig. 27). 


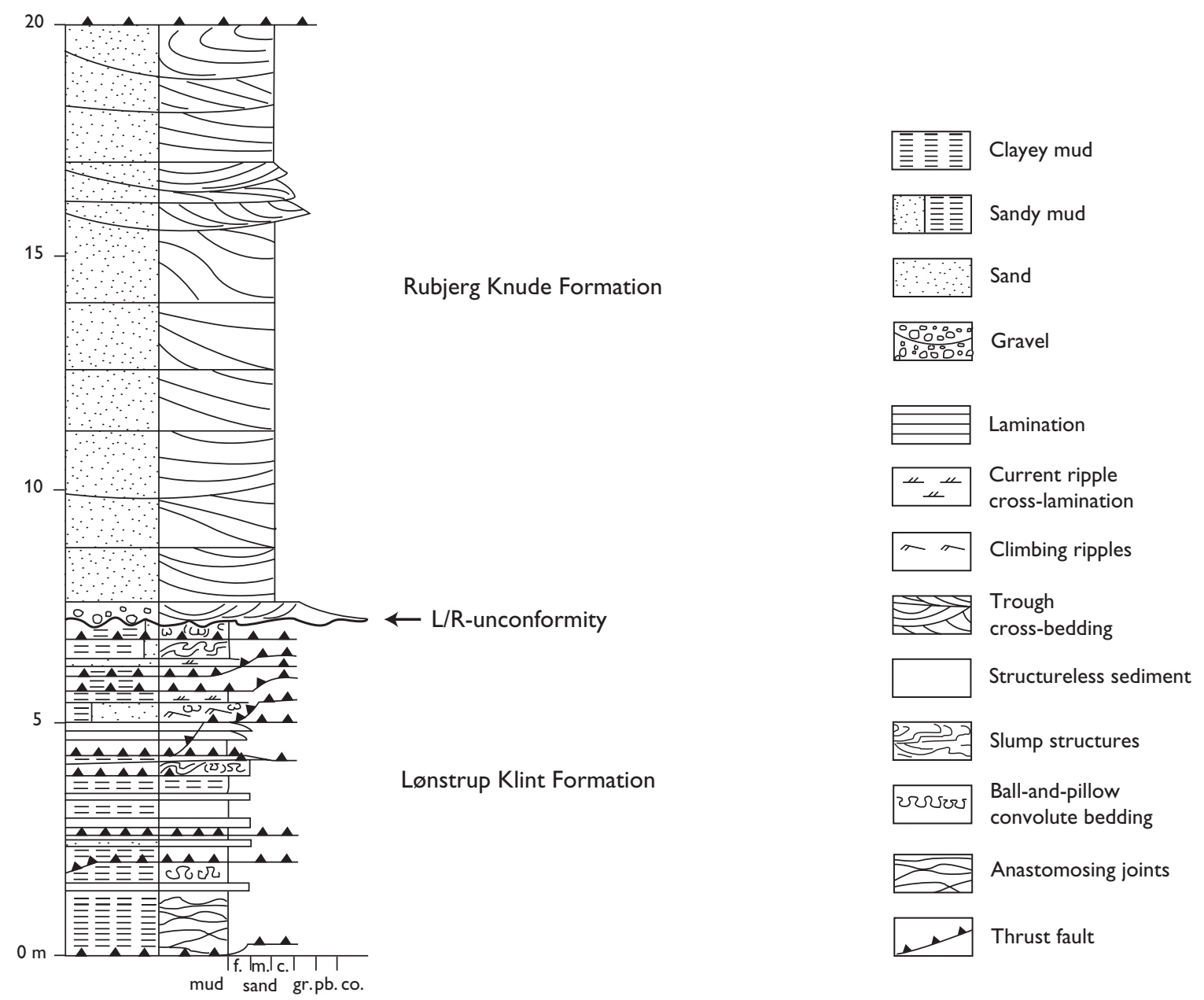

Fig. 27. Geological log of sediments and thrust faults in the MR03 thrust sheet in the Moserende Section (point 1750 in Plate 1).

Lithology. The dominant lithology of the formation is fine- to medium-grained sand. Beds of gravel occur in the lowermost 1-5 m, related to the initial deposition succeeding the formation of the erosional unconformity (the L/R-unconformity) (Figs 24, 27, 28, 29). The sediment source was partly the main central part of the Danish Basin, indicated by the content of 23-25\% flint and Upper Cretaceous chalk, and partly outwash material from the propagating ice margin, indicated by the c. $75 \%$ basement clasts (Jessen 1931). Many sand beds display small-scale current ripple lamination, and some show well-developed climbing ripples (Sadolin et al. 1997). Large-scale cross-bedded sand is observed in shallow channel fills, and some trough cross-stratification occurs in relation to growth-fault structures formed along normal faults or depressions related to the formation of synsedimentary footwall synclines (see Fig. 87). A series of large-scale accretionary cross-stratification structures are related to a shift in the substratum inclination during thrust-fault propagation (see Figs 82, 95). Clasts of clay derived from the Lønstrup Klint Formation are common, and in some of the syntectonic settings these beds rich in clay-clasts may be regarded as sedimentary clastic breccias with olistoliths or lumps of sandy mud 1-5 m in size (Fig. 56). The olistoliths represent the frontal parts of thrust sheets, which gravity-glided out into depressions formed during thrust-fault propagation. Locally, some of the depressions developed into small glaciolacustrine basins characterised by interbedded finegrained sands and sandy muds with current crosslamination; these deposits may reach a thickness of up to $5 \mathrm{~m}$ (Fig. 25).

Fossils. Redeposited fossils occur together with accumulations of twigs and amber ('ravpindelag'). Wellpreserved arctic mosses suitable for ${ }^{14} \mathrm{C}$ dating the formation have been separated from the organic debris (Houmark-Nielsen et al 1996). In the basin at Stensnæs, a large number of the mollusc shells were re- 
Fig. 28. The glaciofluvial Ulstrup beds deposited above the L/R-unconformity (L/R-u) on top of the Lønstrup Klint Formation. Note the boulder in the lowermost part of the glaciofluvial Ulstrup beds indicating the high-energy (upper flow regime) of the meltwater streams that deposited the beds (compare with Fig. 20). The divisions on the measuring pole are $20 \mathrm{~cm}$. Photograph: May 1998. Ulstrup Section, $5950 \mathrm{~m}$ in cross-section (see Plate 1).

Fig. 29. The glaciofluvial Ulstrup beds with 'fossil frozen' sand clasts that indicate ground-frozen conditions in the source area of the sand clasts; they were probably derived from the lower part of the Rubjerg Knude Formation farther north. Photograph: May 1998.
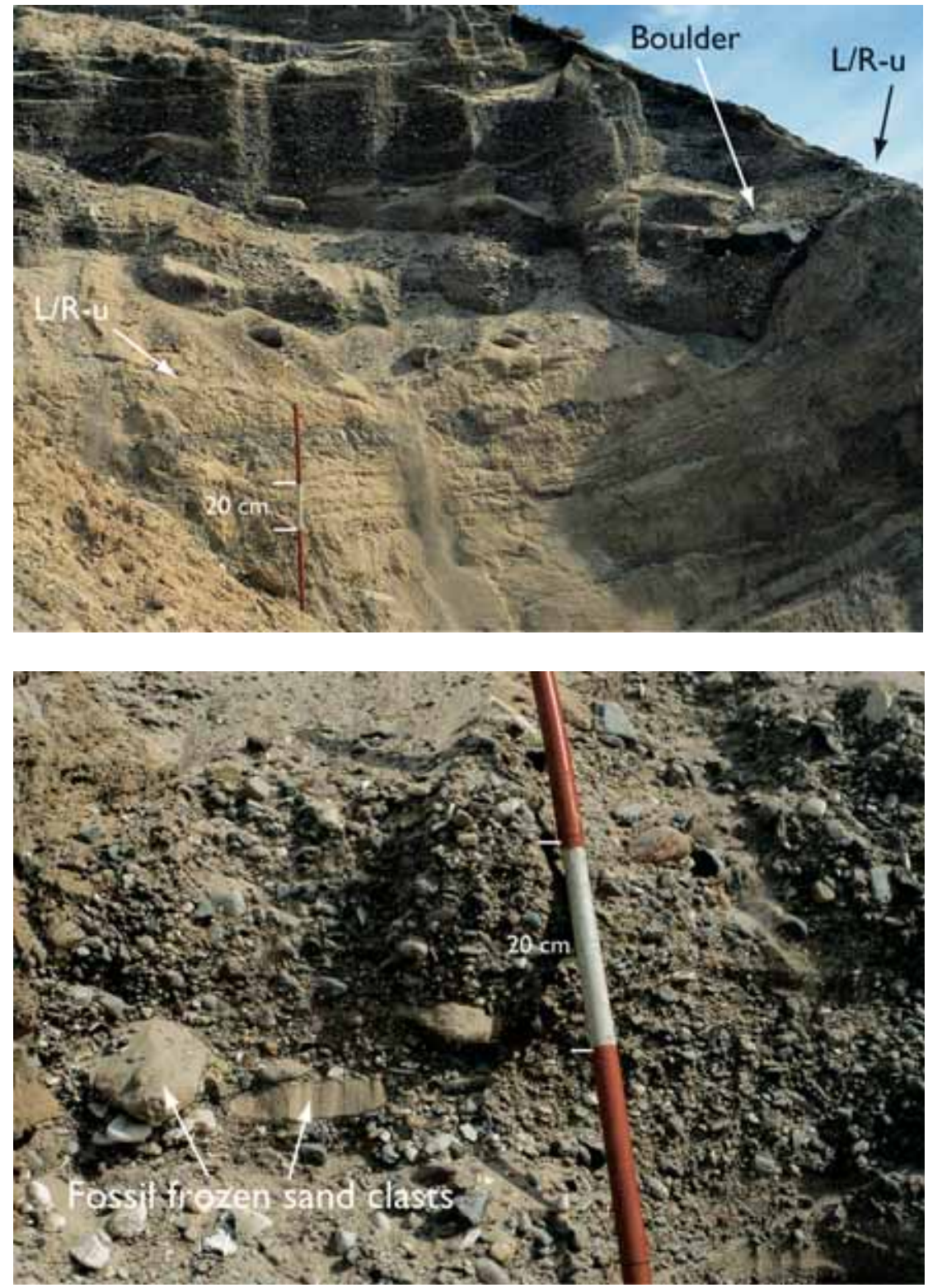

garded as a redeposited interglacial fauna by Jessen (1931). Among the shells are Astarte sp., Cardium sp., Arctica islandica, Leda pernula, Mya Truncata, Hiatella arctica; a full list of this diverse fauna is given in Jessen (1931, p. 63). An Astarte sp. shell (AAR-4066) was ${ }^{14} \mathrm{C}$ dated to $43000 \pm 1300$ years B.P. (Table 2), which must be regarded as close to an infinite age, thus supporting the suggestion of Jessen (1931) that these shells represent redeposited interglacial faunas.

Boundaries. The lower boundary of the formation is placed at the erosional L/R-unconformity capping the Lønstrup Klint Formation. This has a relief of 0.5-1 m and is commonly overlain by an up to $0.5 \mathrm{~m}$ thick clast-supported residual gravel bed. In the distal southern part of the Rubjerg Knude Glaciotectonic Complex, the L/R-unconformity is located close to sea lev$\mathrm{el}$, and is a convenient structural reference level. It represents the top level of pre-tectonic sedimentation, and is hence also a reference surface for the construction of the balanced cross-section.

The upper boundary is placed at the glaciotectonic unconformity below the Kattegat Till Formation.

Thickness. The thickness of the formation is about 25 $\mathrm{m}$, but it varies considerably according to local depositional and erosional development. 
Distribution. The Rubjerg Knude Formation was mainly deposited and preserved between the thrust sheets of the Rubjerg Knude Glaciotectonic Complex. The formation extends towards the south to the area around Nørre Lyngby where it was mapped as 'Morænesand' (moraine sand - sandy till) by Jessen (1918, 1931), and it has not been identified south of Løkken. The formation is not recognised in the area north of Lønstrup, which was mainly covered by ice during deposition of the formation. To the east it can be traced in wells about $10 \mathrm{~km}$ inland, where it pinches out due to erosion during the transgression of the Younger Yoldia Sea. The formation probably does not extend out into the North Sea to the west since it is largely situated above sea level.

Age. The formation has an age range of $30000-20000$ years B.P. based on ${ }^{14} \mathrm{C}$ dating of mosses, separated from the organic debris draping the ripple lamination, and twigs and amber layers (Houmark-Nielsen et al. 1996; Table 2). The mosses investigated were transported from a carbonate-rich source area, probably the Cretaceouschalk outcrops near Limfjorden (Fig. 13). The time span for redepositing plant debris is not regarded to exceed hundredsofyears, and the age of the formation wasthusinterpreted to be closer at29000 than 30000 years B.P. (Fig. 13; Houmark-Nielsen etal. 1996).

Depositional environment. The Rubjerg Knude Formation is interpreted to have been deposited on an outwash plain, which was dissected into smaller piggyback basins during glaciotectonic thrust faulting. During the development of the piggyback basins, deposition was controlled by the propagation of the thrust sheets. North of Lønstrup, a large depression is regarded as the hole in a hill-and-hole pair from where the piggyback basins contemporaneous with deposition of the Rubjerg Knude Fomation were dislocated to the south during the glaciotectonic deformation.

\section{Kattegat Till Formation}

History. The Rubjerg Knude Formation is truncated by a glaciotectonic unconformity and overlain by the Kattegat Till Formation (Fig. 14). The formation was erected by Houmark-Nielsen (1987) in the areas surrounding the southern part of the Kattegat and is interpreted to have been deposited during the Weichselian ice advance from Norway. Subsequent studies have demonstrated that the formation can be identified over much of the northern part of the Danish Basin (Fig. 12; Houmark-Nielsen 1999, 2003).

Name. The formation is named after the Kattegat strait (Fig. 12).

Type section. The type section is at Hundested Klint (Fig. 12; Houmark-Nielsen 1987).

Reference section. Two reference sections are defined in the Lønstrup Klint coastal section, namely the top of the Sandrende locality at point $3700 \mathrm{~m}$ in Plate 1 (Figs 19, 30) and the cliff exposure c. $400 \mathrm{~m}$ north of the Mårup church, at point $500 \mathrm{~m}$ in Plate 1 (Fig. 31).

Lithology. At the type section, the formation is a grey, clayey till only a few metres thick; the erratic clasts are dominantly crystalline rocks of Fennoscandian provenanceand Palaeozoic limestone. Foraminifers and shell fragments in the matrix have been identified as having been derived from the Skærumhede Group (Houmark-Nielsen 1987). In the Rubjerg Knude area, the till is light beige-brown weathering, dark grey and sandy with fine- to medium-grained sand in the matrix. Erratic pebbles and cobbles occur scattered in the matrix, and indicator pebbles of Permian porphyry from the Oslo region are common (1-5\% of the erratics). In the main part of Rubjerg Knude cliff section, the formation drapes the glaciotectonic complex; over large areas, it has been subjected to aeolian erosion that has removed the fine-grained matrix and left the erratics as a cobble pavement. North of the Mårup church, the formation comprises a shear till with erratics interlayered in a glaciotectonic breccia dominated by shear-deformed clayey mud derived from the top of the Skærumhede Group (Fig. 31).

In the northern part of the Lønstrup Klint cliff section (the Ribjerg Section), the Kattegat Till Formation is absent. The glacial advance, represented elsewhere by the Kattegat Till Formation, is here recorded only by a glaciotectonic unconformity and an underlying glacitectonite characterised by a dense anastomosing framework ofjointspenetrating the Skærumhede Group (Fig. 32).

Boundaries. The lower boundary of the formation is the glaciotectonic unconformity formed by the shear at the base of the advancing Norwegian Ice. Below the unconformity, a glacitectonite 1-2 m thick developed due to shear deformation of the clay and sand in the Lønstrup Klint and Rubjerg Knude Formations. 


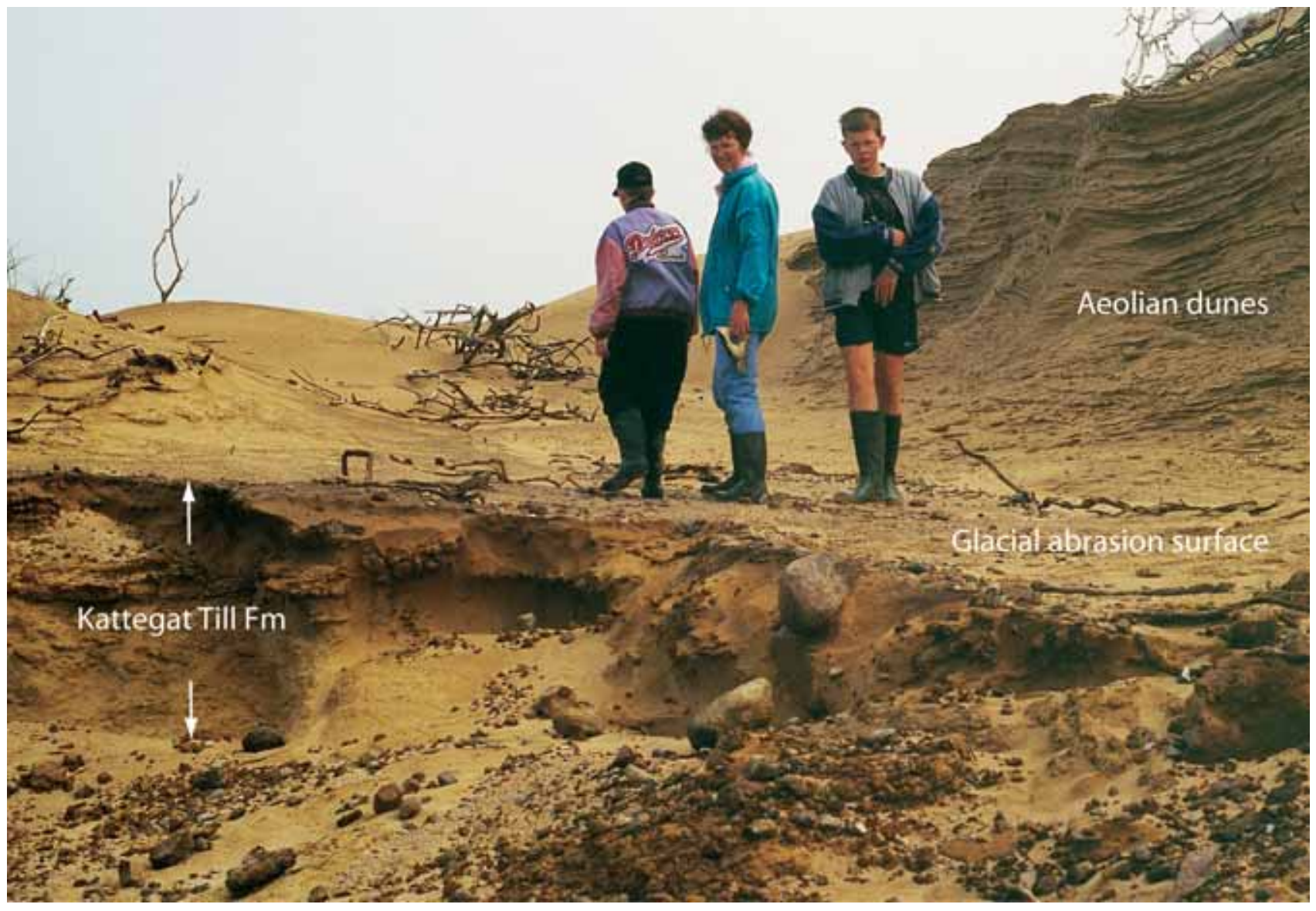

Fig. 30. The c. $1 \mathrm{~m}$ thick sandy till on top of the Sandrende Section is referred to the Kattegat Till Formation. The maximum size of the erratic clasts is $25 \mathrm{~cm}$. The marked planar erosion surface above the till was initially formed by glacial truncation, which subsequently was exposed to aeolian erosion and finally covered by dunes. Photograph: July 1993.

The upper boundary is the subaerial erosional surface above the $1.5 \mathrm{~m}$ thick sandy till, commonly reduced to a $0.25 \mathrm{~m}$ thick residual pavement.

Thickness. The fomation is up to $1.5 \mathrm{~m}$ thick at Rubjerg Knude.

Distribution. The formation has been recognised from the central and northem part of the west coast of Jylland and Vendsyssel over Djursland and Sjælland to Hven and Glumslöv in the western part of Skåne, Sweden (Fig. 12; Houmark-Nielsen 2003).

Age. The age of the Kattegat Till Formation is bracketed by the Lønstrup Klint Formation beneath (29000 years B.P.) and the Ribjerg Formation above (26000 years B.P.) (Fig. 14, Tables 2, 3). The age is estimated to be $27500 \pm 1000$ years B.P. (Houmark-Nielsen 2003).
Depositional environment. The Kattegat Till Formation is interpreted as a lodgement till. In the area between Lønstrup and Mårup church, the diamict lithology of the upper Skærumhede Group suggests that deformation of the substratum below the glaciotectonic unconformity was initiated by mud-mobilisation of water-saturated clay, silt and fine-grained sand. Material, including erratic clasts from the lodgement bed along the sole of the ice, dropped into the mudmobilised unit. During the advance of the ice, the mudmobilised zone became consolidated, and sub-horizontal anastomosing joints formed in the substratum. The depositional environment therefore changed from a wet-based glacial advance to an advance over dehydrated or even frozen substratum during the deposition of the Kattegat Till Formation at Rubjerg Knude. 

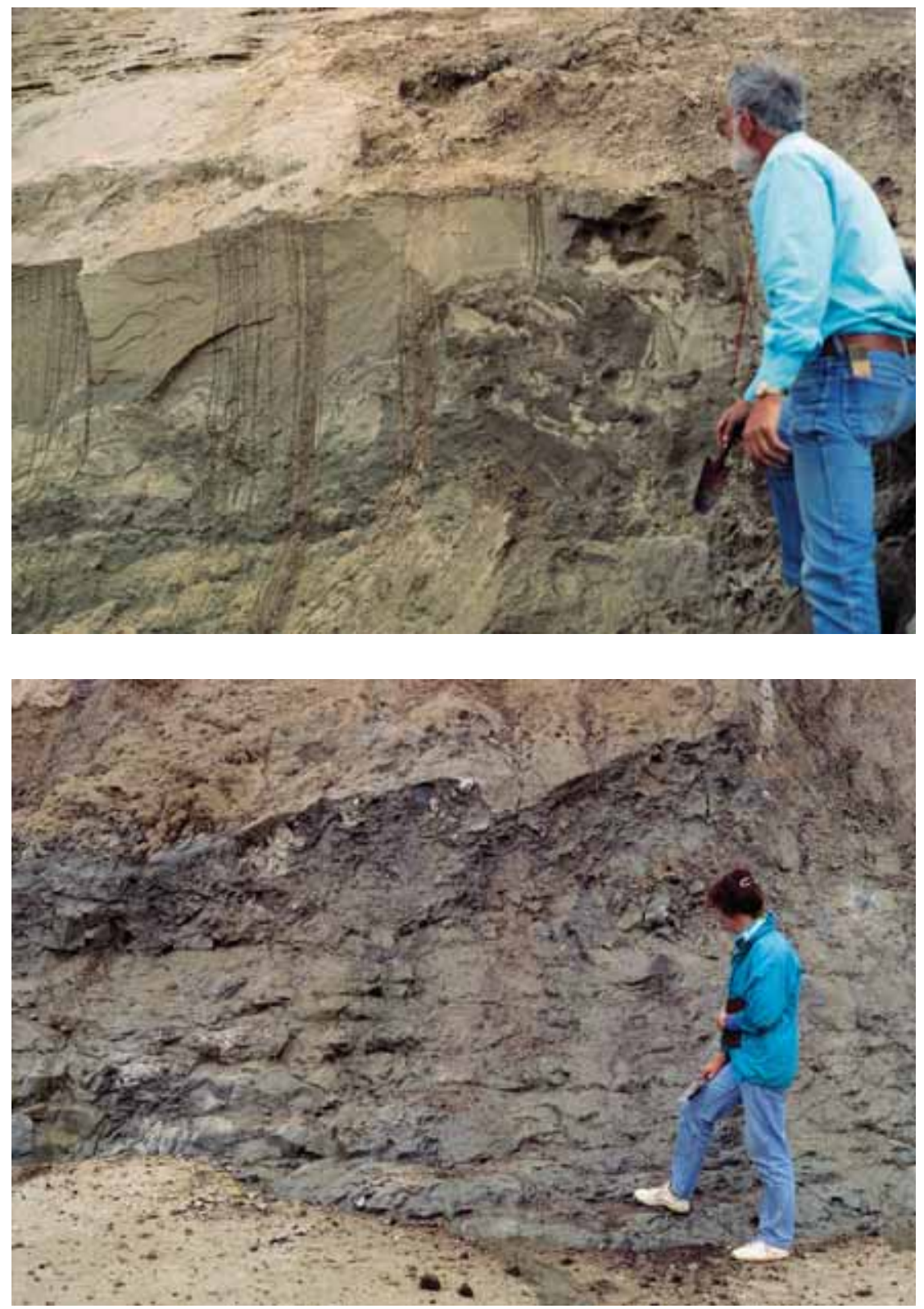

Fig. 31. A pocket of sandy till overlying a glacitectonite and associated features of subglacial deformation. The till is referred to the Kattegat Till Formation. The locality is situated c. $450 \mathrm{~m}$ north of Mårup Kirke. Photograph: July 1994.

Fig. 32. Planarparallel and elongated anastomosing shear joints that are typical of the glacitectonite at the top of the Skærumhede Group below the Blåunconfomity in the Ribjerg Section. Photograph: July 1994.

\section{Ribjerg Formation}

new formation

History. The Ribjerg Formation is a new formation proposed for the c. $25 \mathrm{~m}$ thick glaciofluvial sand unit that crops out between the northern part of the Lønstrup Klint cliff section and the northern part of the town of Lønstrup. The unit was indicated in the northernmost c. $2 \mathrm{~km}$ of the cross-section of Jessen (1931), but it was only regarded as part of the main Diluvialsand (diluvial sand). Since the formation was deposited in the Late Weichselian between ice advances from Norway and central Sweden, it might in a glaciodyna- mic context be correlated with the outwash deposits of the Tebbestrup Formation in Djursland (Larsen et al. 1977; Pedersen \& Petersen 1997).

Name. The formation is named after the hill of Ribjerg at Lønstrup.

Type section. The type section is located at the cliff below the Ribjerg hill, south-west of Lønstrup (Figs 13, 33).

Lithology. The Ribjerg Formation is characterised by fine- to medium-grained sand showing large-scale trough and channel cross-stratification (Fig. 33). At 


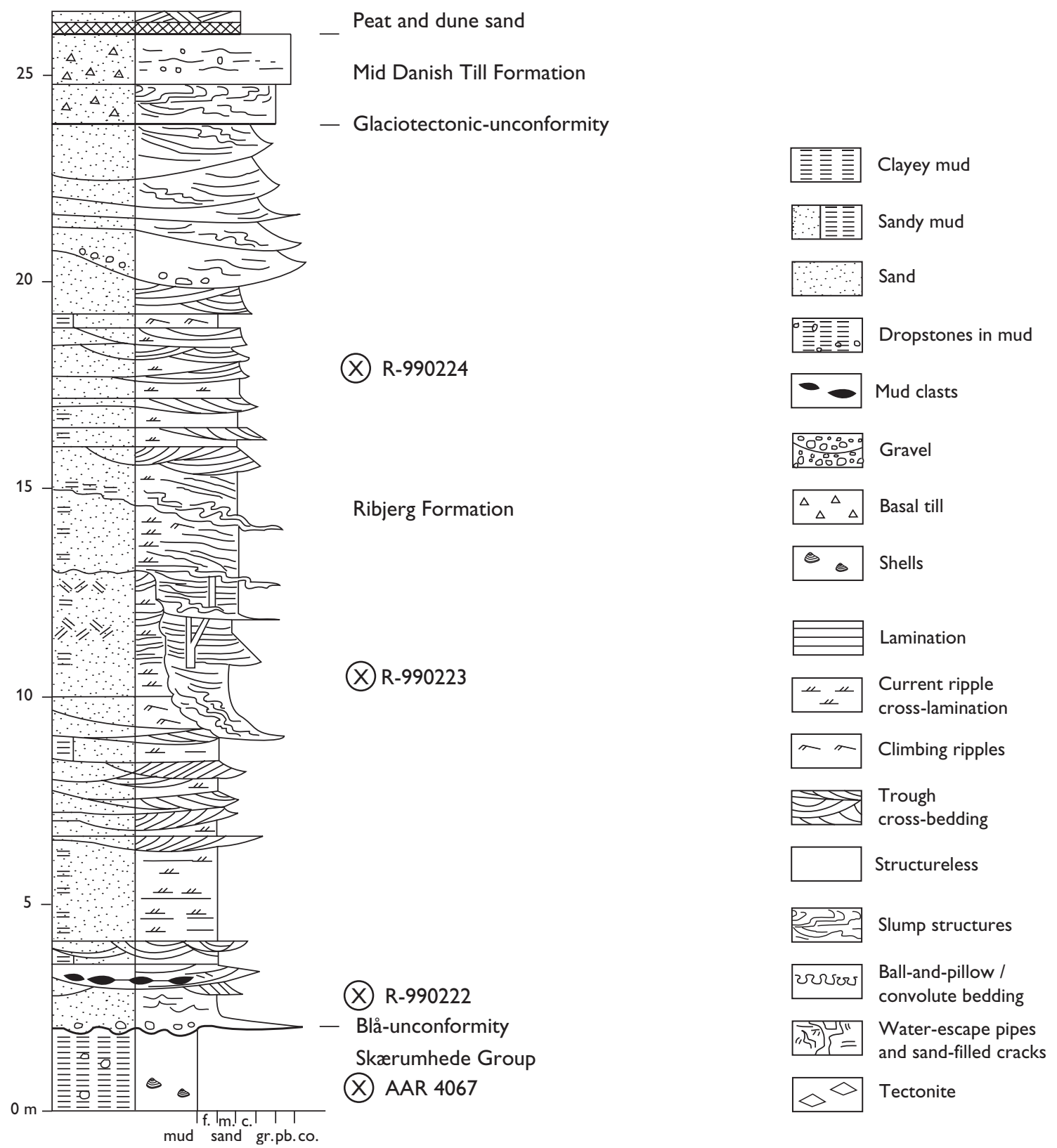

Fig. 33. Sedimentological log of the Ribjerg Formation (type section) in the northernmost part of the Ribjerg Section. The formation was deposited above the Blå-unconformity on top of the Skærumhede Group, and it is overlain by the sandy Mid Danish Till Formation. The Ribjerg Formation represents glaciofluvial deposition related to a channel-eroded foreland of an advancing glacier. Note the sand-dykes that are interpreted to have fomed by discharge of pore water due to high stream velocity. Samples collected for optically stimulated luminescence dating are indicated, together with their laboratory numbers (see Table 3).

the base of the formation, tabular grey mud clasts $(1 \times 5-10 \mathrm{~cm}$ in cross-section) fom a lag deposit in the fine-grained sand. Lamination outlined by heavy minerals occurs in the lowermost metre of the formation and current-ripple lamination with mud chips is also present (Fig. 33). The lower part of the formation is characterised by horizontal planar laminated finegrained sand interlayered with thin beds $(0.1-0.5 \mathrm{~cm}$ thick) of clay-draped current ripples. This facies is overlain by $0.5 \mathrm{~m}$ thick beds of fine- to coarse-grained trough cross-bedded sand. Troughs or channels, 2-5 $\mathrm{m}$ deep and 10-15 $\mathrm{m}$ wide, occur in the middle and upper part of the formation (Fig. 111). In the central part of the troughs, the fill shows large-scale crossstratification. Towards the margin of the troughs, the beds decrease in thickness and display small-scale 


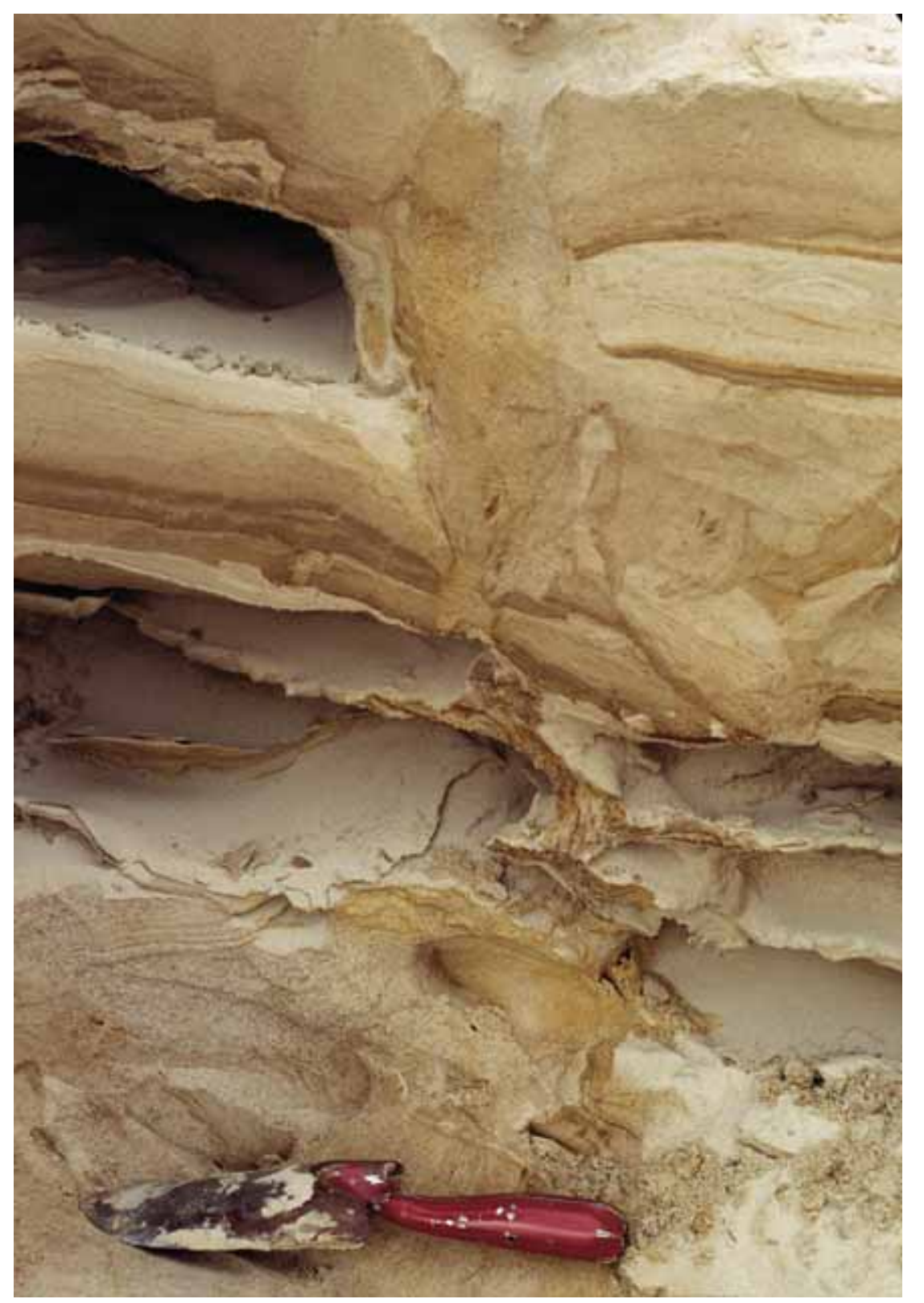

Fig. 34. Sand dyke intruded in the glaciofluvial succession of the Ribjerg Formation. The sand dykes are interpreted to have formed by pore-water discharge from the sediment due to high velocity current flux through the channels. Photograph: July 1994. Ribjerg Formation, type section. currentlamination with ripples draped by organic debris. The steeply inclined slopes (up to $30^{\circ}$ ) of the trough margins strike $88-94^{\circ}$, indicating an east-west current direction. Erosional surfaces with slumped beds and pockets of gravel recur every 1 to $3 \mathrm{~m}$ (Fig. 33). One of the most characteristic features of the formation is the large number of sand dykes and waterescape pillars, which are 5-15 $\mathrm{cm}$ wide and can be traced vertically for more than $1.5 \mathrm{~m}$ (Fig. 34). The uppermost $3 \mathrm{~m}$ of the formation comprises thick gravel beds just below the flow till related to the Mid Danish Till Formation.
Boundaries. The lower boundary of the formation is defined at the erosional unconformity forming the top of the Kattegat Till Formation or, where the erosion level penetrates deeper, the Lønstrup Klint Formation. In the northem part of the Lønstrup Klint section, the unconformity on top of the 'Lille Blă' forms the lower boundary. The upper boundary is placed at the base of the flow till that forms the lower part of the Mid Danish Till Formation (Figs 14, 33).

Thickness. The formation is about $25 \mathrm{~m}$ thick.

Distribution. The formation is only recognised in the 
Table 3. Optically stimulated luminescence dates on quartz, Rubjerg Knude and Nørre Lyngby, Vendsyssel, northern Denmark

\begin{tabular}{|c|c|c|c|c|c|c|c|}
\hline Stratigraphic unit & Locality & Lab. ID no. & Material & $\begin{array}{c}\text { Age } \\
\text { ka B.P. }\end{array}$ & $\begin{array}{c}\text { Dose }^{+} \\
\text {(Gy) }\end{array}$ & $\begin{array}{c}\text { W.C. } \\
(\%)\end{array}$ & Ref.* \\
\hline Vendsyssel Fm & Nørre Lyngby & R-829202a & Marine clay & $16 \pm 1$ & $38.9 \pm 1.3$ & 30 & (1) \\
\hline Vendsyssel Fm & Nørre Lyngby & R-829203 & Marine clay & $17 \pm 2$ & $46.0 \pm 0.8$ & 29 & (1) \\
\hline Ribjerg Fm & Ribjerg & R-990224 & Fluvial sand & $25 \pm 2$ & $45.3 \pm 0.8$ & 25 & (3) \\
\hline Ribjerg Fm & Ribjerg & R-990223 & Fluvial sand & $26 \pm 1$ & $52.6 \pm 1.5$ & 26 & (3) \\
\hline Ribjerg Fm & Ribjerg & R-990222 & Fluvial sand & $26 \pm 1$ & $53.1 \pm 1.2$ & 20 & (3) \\
\hline Lønstrup Klint Fm & Sandrende & R-970204 & Fluvial sand & $29 \pm 2$ & $57.6 \pm 1.8$ & 21 & (2) \\
\hline Stortorn Fm & Ribjerg & R-970203 & Lacust. sand & $30 \pm 2$ & $65.0 \pm 1.8$ & 25 & (2) \\
\hline
\end{tabular}

\footnotetext{
${ }^{+}$Equivalent gamma dose.

$\ddagger$ Water content (saturation).

* References: 1: Strickertson \& Murray (1999); 2: Houmark-Nielsen (2003); 3: this study.
}

vicinity of Lønstrup and towards Vennebjerg to the east. It is inferred to have been deposited over a larger area of north-western Vendsyssel, which is now covered by the Vendsyssel Formation (see below).

Age. Three samples were collected from the lower, middle and upper part of the formation for optically stimulated luminescence dating (R-990222, R-990223, R-990224; Table 3); these samples indicate an age of 26000 - 25000 years B.P.

Depositional environment. The fomation was deposited in fluvial channels cut by westward-flowing meltwater. The sand dykes and water-escape pillars are indicative of high pore-water pressure due to rapid deposition and very fast meltwater flux through the channels. The outwash deposits are interpreted as a valley sandur that formed in the depression resulting from the hole left in the hinterland of the Rubjerg KnudeGlaciotectonic Complex. The source of the meltwater was the ice margin of the advancing ice from central Sweden in the Late Weichselian.

\section{Mid D anishTill Formation}

History. The Ribjerg Formation of the Lønstrup Klint section is overlain by a $3 \mathrm{~m}$ thick grey-brown till that is referred to the Mid Danish Till Formation (Houmark-Nielsen 1987, 1999, 2003). The formation was erected by Houmark-Nielsen (1987) to encompass tills deposited in the southern and central part of Denmark during the Weichselian ice advance from central Sweden. It is known from the main part of the Danish Basin east and north of the Main Stationary Line (Fig. 12), and the records of its distribution in the northern part of Denmark have recently been summarised by Houmark-Nielsen $(1999,2003)$ (Figs 1, 12).

Name. The name of the formation reflects the prominent nature of this surface deposit in central (mid) Denmark (Fig. 12).

Type section. The type section is at Ristinge Klint on the island of Langeland (Houmark-Nielsen 1987).

Reference section. A reference section is herein defined at Ribjerg, SW of Lønstrup (Figs 13, 33).

Lithology. At the type locality, the Mid Danish Till Formation is a 5-8 $\mathrm{m}$ thick unit with at least two boulder pavements displaying NE-SW orientated glacial striation (Sjørring et al. 1982). The formation is a grey to brown mostly clayey massive till with about 50\% crystalline erratics of Fennoscandian provenance; indicator clasts from the central eastem part of Sweden (Kinne-diabase) and from Jurassic sedimentary rocks situated offshore in the Kattegat (Pedersen \& Petersen 1997) are abundant (Houmark-Nielsen 1987).

In the reference section at Ribjerg, the formation is 


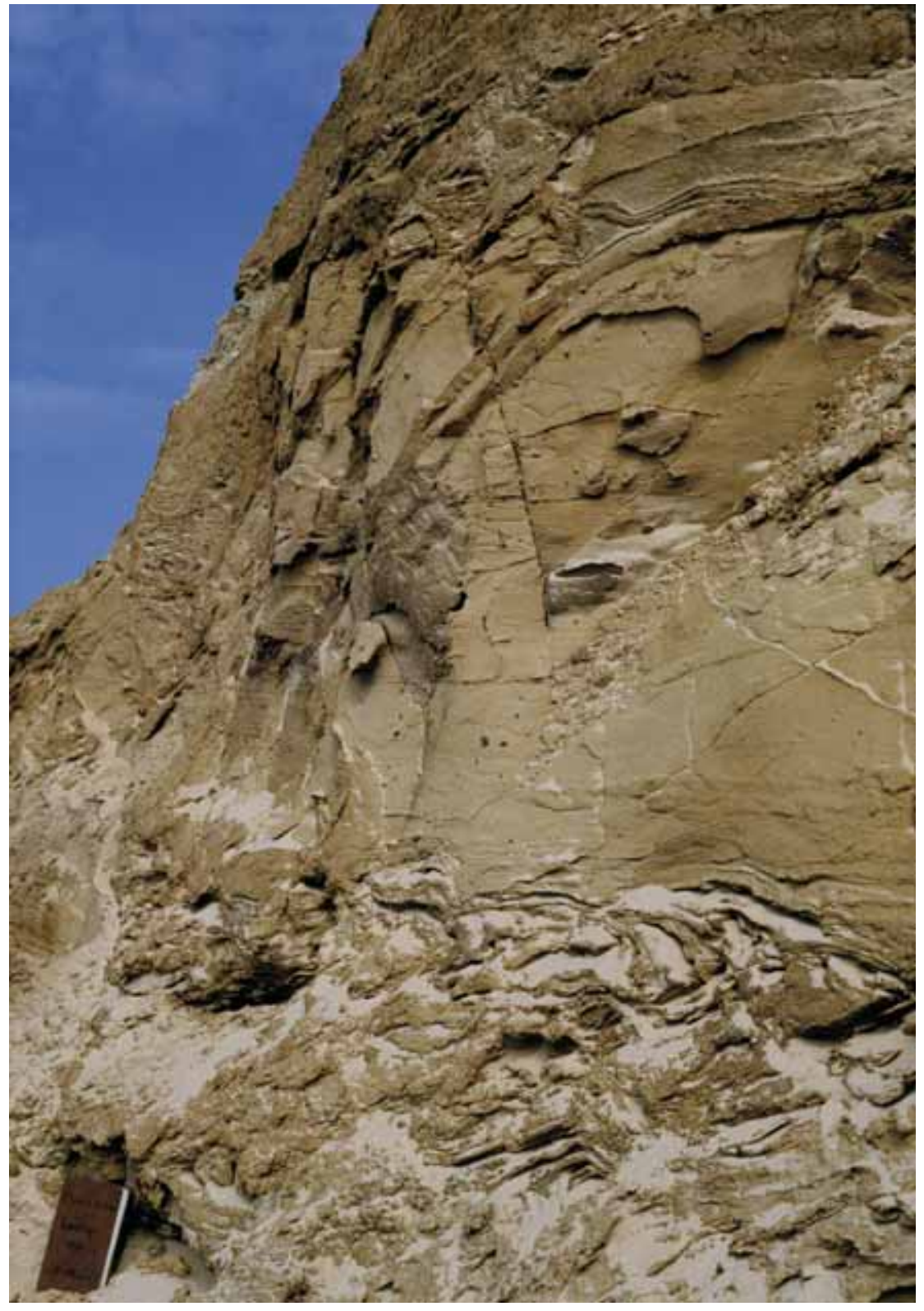

Fig. 35. The sandy till that overlies the Ribjerg Formation is divided into a lower flow till and an upper lodgement till. The flow till is characterised by slump-folded debris flow lamination indicating flow from east to west. The till unit is referred to the Mid Danish Till Formation, which was deposited by the ice advance from the east, probably about 24000 B.P. Photograph: May 1985; notebook for scale. Ribjerg Formation, type section.

a yellow-brown weathering, grey-brown, sandy till comprising a lower stratified unit and an upper massive unit (Fig. 35). The lower unit comprises laminated to finely bedded, matrix-supported diamictite with scattered pebbles. The matrix is fine-grained sand and the lamination and bedding are slump folded with NS-trending fold axes and E-dipping axial planes, indicating a westward flow direction. The upper unit is a massive, structureless matrix-supported diamictite. Erratic pebbles and cobbles are abundant and the till has a pronounced a-axis clast fabric dipping at low angles (c. $\left.3^{\circ}\right)$ towards the east $\left(100^{\circ}\right)$, indicating a shear transport direction towards the west.
Boundaries. In the reference section, the lower boundary of the formation is placed at the depositional conformity on top of the Ribjerg Formation where planar horizontal gravel beds are overlain by slumpfolded diamictites dominated by debris flow layers. The upper boundary is an erosional unconformity separating the diamictites from silt-streaked muds at the base of the Vendsyssel Formation.

Thickness. The formation reaches a thickness of more than $10 \mathrm{~m}$ at the type section at Ristinge Klint, but it is only $3 \mathrm{~m}$ thick at Ribjerg in the reference section.

Distribution. In the Rubjerg Knude area south of Ri- 


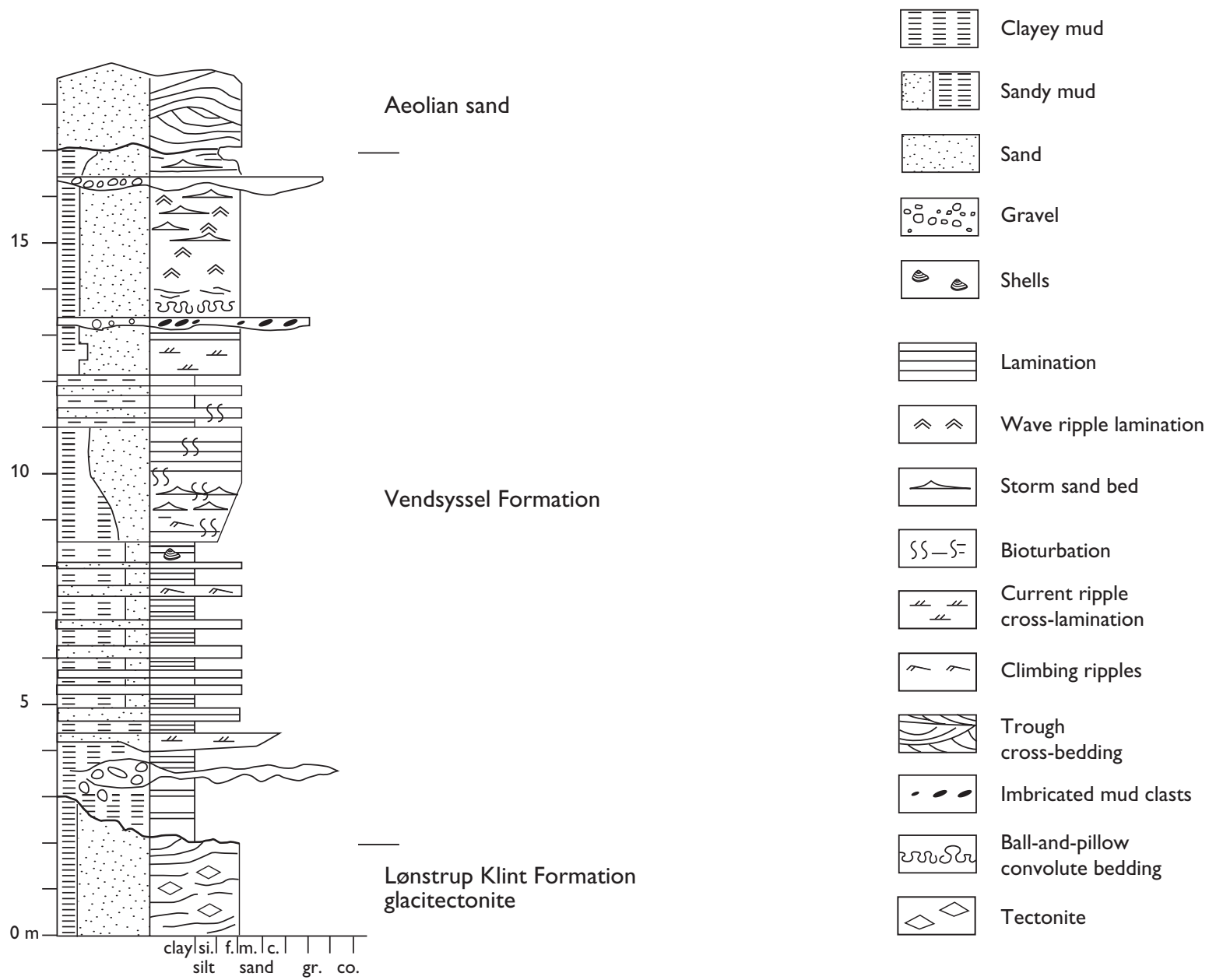

Fig. 36. Sedimentological log of the Vendsyssel Formation at the type section at Stensnæs. The section is located at point 5120 in the cross-section (Plate 1); the base of the $\log$ is $15 \mathrm{~m}$ a.s.l.

bjerg, where the Ribjerg Formation is absent, it has not been possible to differentiate occurrences of the Mid Danish Till Formation from the older Kattegat Till Formation. However, the distribution is well documented throughout the Danish Basin east and north of the Main Stationary Line (Figs 1, 12; Houmark-Nielsen 1999, 2003).

Age. The age of the Mid Danish Till Formation is bracketed by the age of the Ribjerg Fomation beneath (26000 years B.P.) and the Vendsyssel Formation above (16000 years B.P.) (Fig. 14, Tables 2, 3). The age is estimated to be $24000-20000$ years B.P. (Houmark-Nielsen 2003).

Depositional environment. The lower unit is interpreted as a flow till deposited as debris flows from an ice margin to the east, prior to the ice advance towards the west. The upper unit is interpreted as a lodge- ment till deposited at the sole of the ice during the ice advance from central Sweden towards the Main Stationary Line situated in the central part of the North Sea (Fig.12).

\section{Vendsyssel Formation}

new formation

History. North and south of Rubjerg Knude, the Mid Danish Till Formation is overlain by a succession of glaciomarine heteroliths, which are here defined as the Vendsyssel Formation. These deposits were mapped by Jessen (1899), who related them to deposition in the Younger Yoldia Sea in Vendsyssel. Jessen (1918) regarded the various facies of the Vendsyssel Formation as four stratigraphic units named the Lower Saxicava Sand, the Yoldia Clay (usually prefaced Young- 


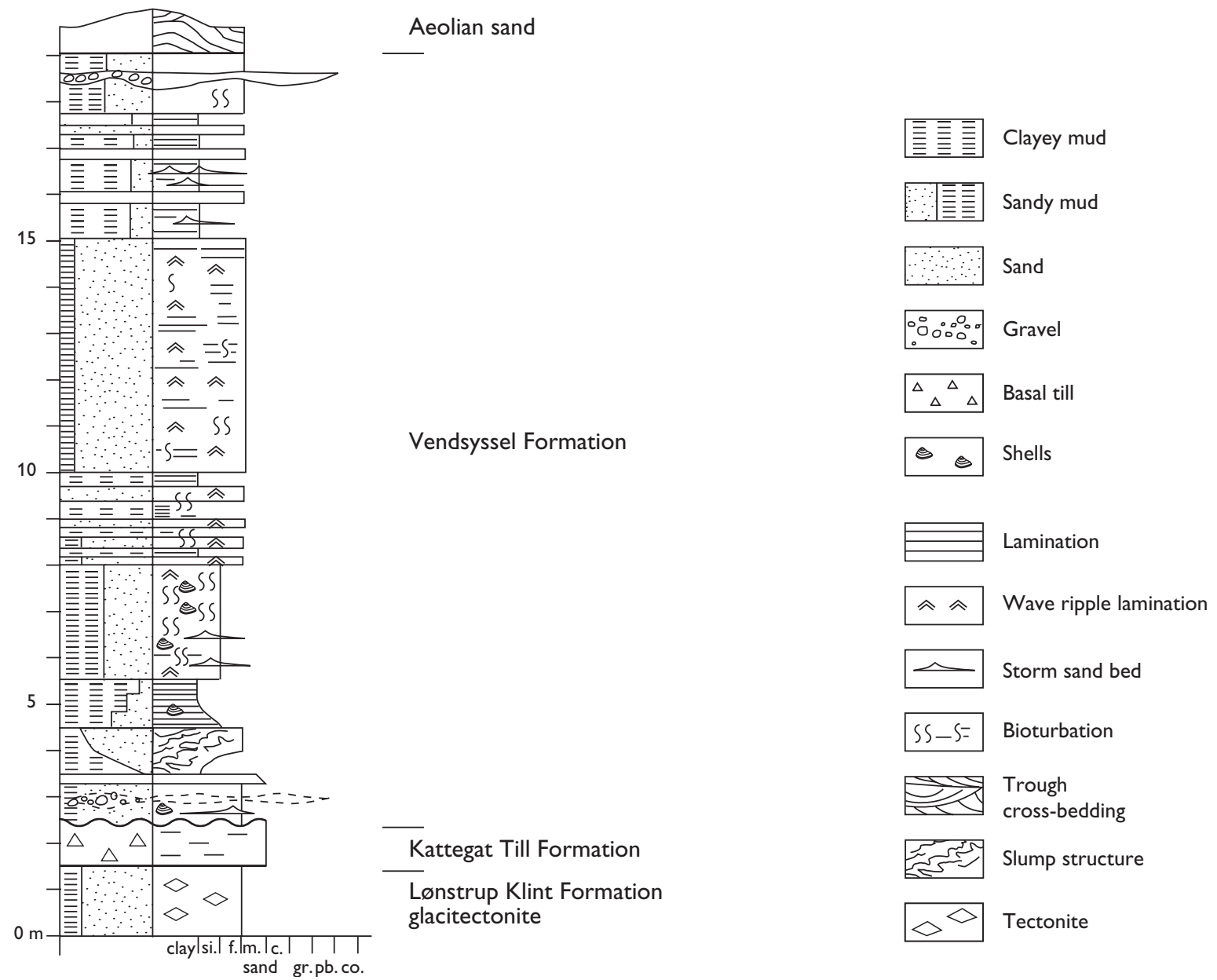

Fig. 37. Sedimentological log of the Vendsyssel Formation at the reference section, situated halfway between Lønstrup and Mårup Church at point 500 in the cross-section (Plate 1); base of the $\log$ is $10 \mathrm{~m}$ a.s.l. The slump structure recognised in the lower part of the section (at about $4 \mathrm{~m}$ ) is interpreted to have been produced by a grounding iceberg. The abundant shells in the section are Hiatella arctica and the bioturbation was due to the infaunal activity of these molluscs (see Fig. 41).

er' to distinguish it from the Older Yoldia Clay), the Upper Saxicava Sand and the Zirphaea Beds.

Name. The formation is named after the region of Vendsyssel in north Denmark (Figs 12, 13).

Type section. The type section is the coastal cliff section at Stensnæs c. $1 \mathrm{~km}$ north of Nørre Lyngby in the central part of the westcoast in Vendsyssel (Figs 13, 36).

Reference sections. Two coastal cliff sections, north and south of Rubjerg Knude, are defined as reference sections. The locality to the north is the coastal cliff c. $500 \mathrm{~m}$ south of Lønstrup, where heteroliths characterised by Hiatella burrows crop out (Fig. 37). To the south, the coastal cliff at Nørre Lyngby (north and south of the ramp leading down to the beach) prob- ably gives the thickest accessible outcrop of the formation (Fig. 38). This locality is furthermore close to the reference well DGU no. 8.137, where the maximum thickness of the formation is recorded (LykkeAndersen 1987).

Lithology. Two main lithologies dominate the formation: dark bluish-grey, clayey mud in the lower part and yellowish weathering light grey stratified heteroliths in the upper part. At the base of the formation, coarse-grained sands and gravels overlie the erosional unconformity above the Mid Danish Till Formation or older deposits (Figs 36-38). The unit referred to as the Lower Saxicava Sand by Jessen (1918) is less than $2 \mathrm{~m}$ thick and is only present locally. Accumulations ofshell debris occur in places. In general, marine clayey mud forms the lower c. $6 \mathrm{~m}$ of the formation resting 


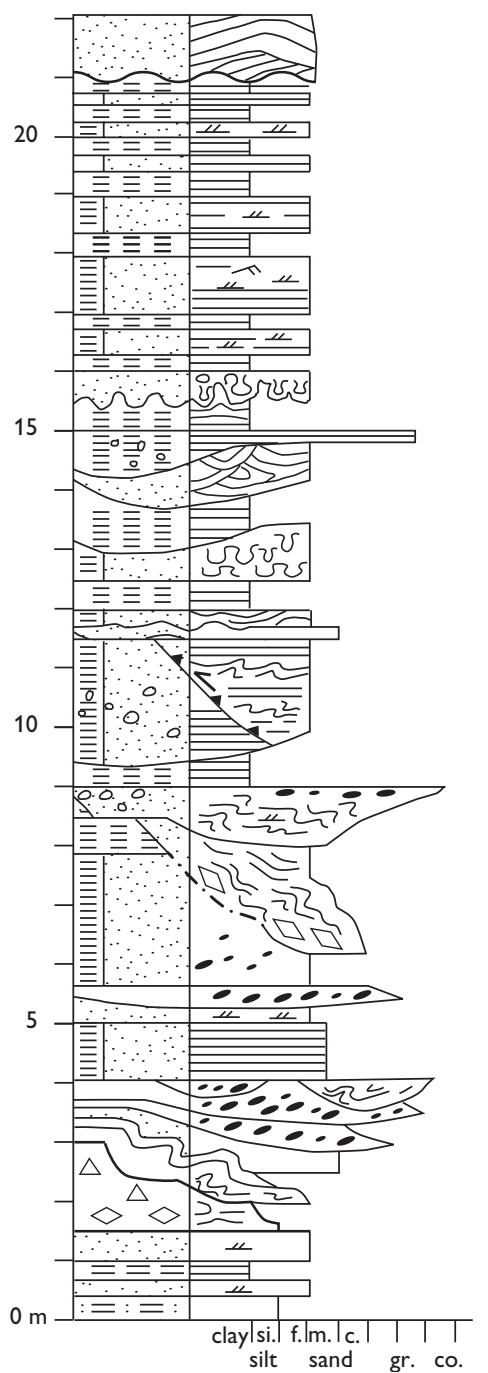

Aeolian sand

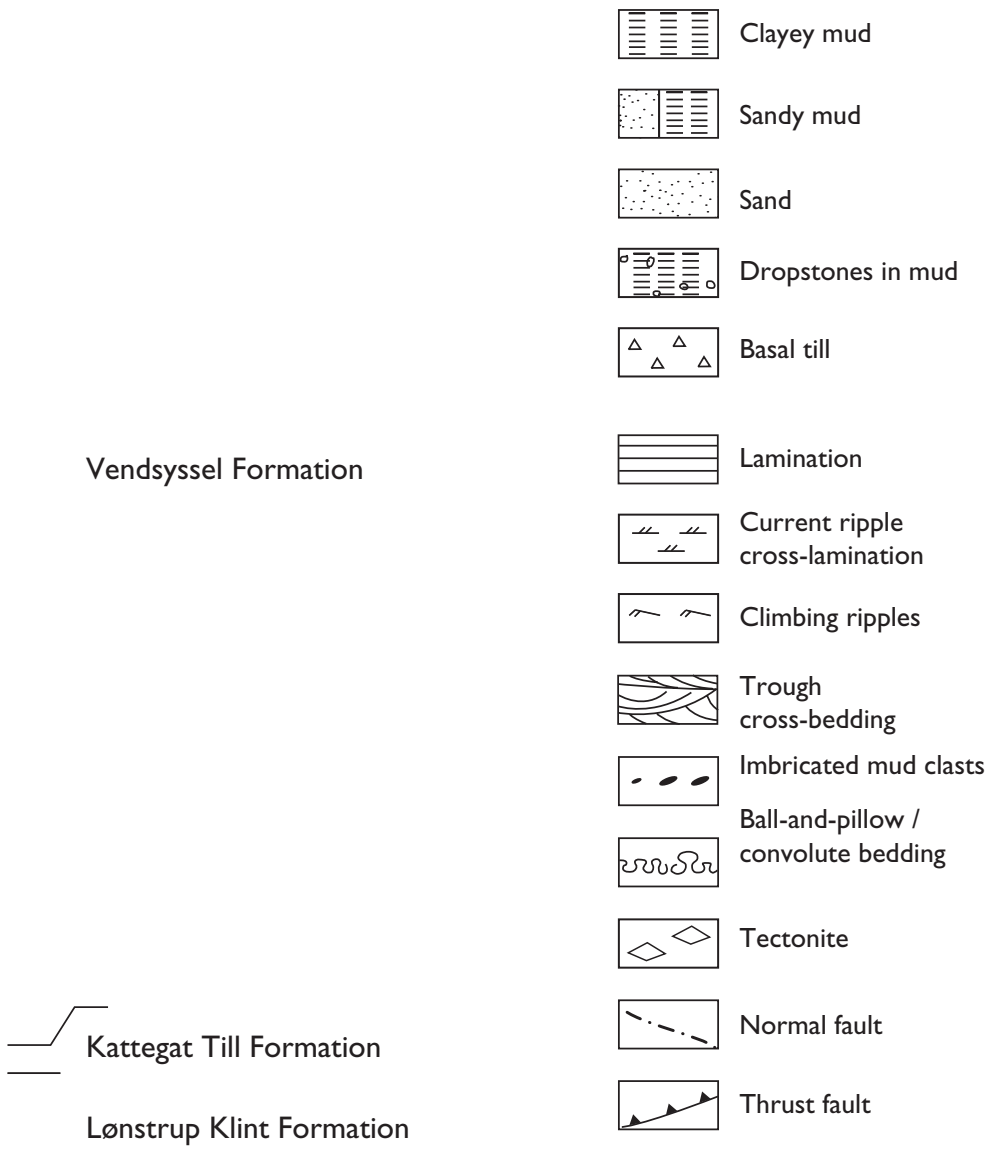

Fig. 38. Sedimentological log of the Vendsyssel Formation at the reference section, situated c. $350 \mathrm{~m}$ south of Nørre Lyngby. The beds rich in imbricated mud clasts reflect the tectonically active nature of the half-graben in which the section is located; the synsedimentary tectonic activity is further documented by the intraformational normal and thrust faults that occur in the lower half of the formation at Nørre Lyngby.

directly on the lower erosional boundary (Figs 3638); dropstones, locally to boulder size, occur in the lower part of the clayey mud unit (Figs 36, 37). The unit is highly impermeable such that groundwater wells out at the top of the clayey mud outcrops, often obscuring the exposures of the basal lithologies. Above the clayey mud unit, horizontal stratified heteroliths form a unit 6-12 $\mathrm{m}$ thick. In places, the heteroliths grade into sandy mud characterised by wave ripple lamination (Fig. 40). Dark grey laminated mud is interbedded with fine-grained sand beds up to $10 \mathrm{~cm}$ thick in which wave ripple lamination is common. At the reference section, south of Lønstrup, the heteroliths are intensively bioturbated by vertical trace fossils pro- duced by Hiatella arctica and the shells are often preserved in life position (Fig. 41).

The reference section at Nørre Lyngby is located in a half-graben structure with the steepest normal fault (dipping c. $60^{\circ} \mathrm{S}$ ) situated north of the village (LykkeAndersen 1992). South of Nørre Lyngby, the erosional unconformity below the Vendsyssel Formation dips $5-8^{\circ}$ to the north. The beds above the unconformity are characterised by sedimentary breccias of mud clasts probably derived from the Lønstrup Klint Formation (Fig. 38). In the middle part of the formation, the beds are displaced by synsedimentary faulting (Fig. 38) indicating that the half-graben formed during the deposition of the Vendsyssel Formation. 

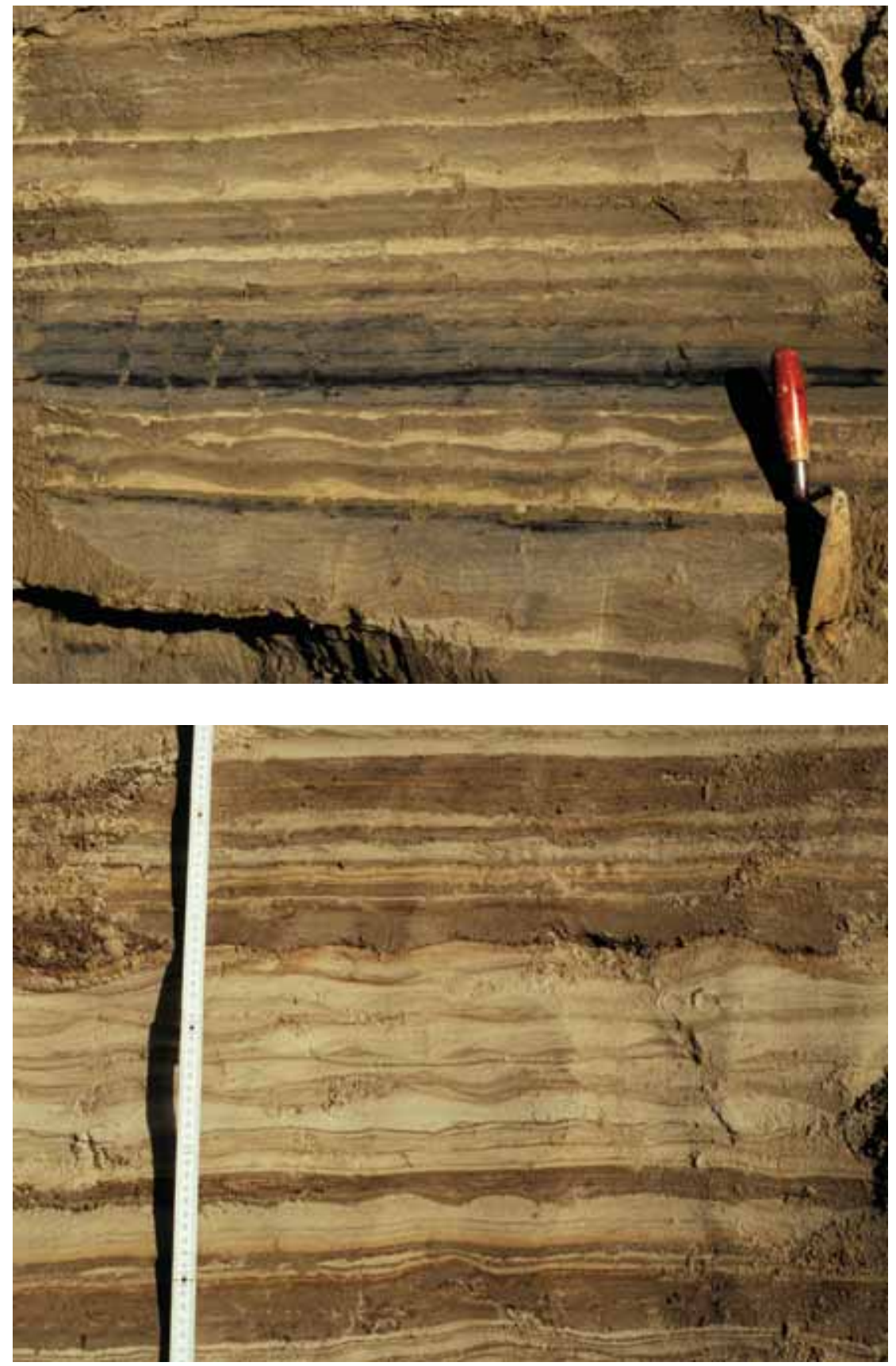

Fig. 39. Mud-dominated heteroliths in the lower Vendsyssel Formation. The light-coloured silt to very fine-grained sand beds show grading and wave ripple cross-lamination. This unit was formerly referred to as the Younger Yoldia Clay (Jessen 1918, 1931). Photograph: September 2004.

Fig. 40. Sand-rich heteroliths in the upper Vendsyssel Formation showing wave ripple cross-lamination. This sandrich heterolithic unit was formerly referred to as the Saxicava Sand (Jessen 1918, 1931). Tape divisions in centimetres. Photograph: September 2004.
In the area north-east of Hirtshals, the clayey mud is overlain bycoastal sands, theso-called Zirphaea Beds (Jessen 1918), and in the eastem part of Vendsyssel the uppermost part of the formation comprises coarsegrained sand and gravel deposited in a large spit system (Nielsen et al. 1988).

Fossils. The fossils characteristic of the formation are the molluscs Portlandia arctica, Hiatella arctica and Zirphaea crispata.
Boundaries. The lower boundary is the erosional unconformity on top of the Mid Danish Till Formation or older deposits. The upper boundary is the top surface of the landscape upon which locally lie terrestrial deposits such as the Allerød peat beds in the Nørre Lyngby bog (Jessen \& Nordmann 1915), the Boreal peat at Martørv Bakker (Jessen 1931) and recent aeolian sands (Fig. 14).

Thickness. The formation is c. $16 \mathrm{~m}$ thick at the outcrops along the coastal cliff. The formation may reach 
a thickness of up to about $25 \mathrm{~m}$ in the central part of Vendsyssel (see Fig. 125).

Distribution. The flat agricultural land in the Vendsyssel area, lying 10-40 m above sea level, defines the top of the Vendsyssel Formation, and thus can be regarded to represent the fossil seabed of the Younger Yoldia Sea.

Depositional environment. The formation reflects the establishment of marine conditions in the Vendsyssel area after the melting back of the Scandinavian Ice Cap in the Kattegat-Vendsyssel-Skagerrak region. The palaeoenvironmental development may be described in terms of six events (Richard 1996): the first event is represented by the erosional unconformity formed immediately after deglaciation. The second event was a rapid transgression with the establishment of a c. 60 $\mathrm{m}$ deep arctic marine environment. In the third event, a high sea-level stand prevailed during deposition of the clayey mud. Events four to six are stages of forced regression due to the isostatic uplift in the area, but with fluctuations due to eustatic sea-level rise.

Age. The age of the Vendsyssel Formation ranges from 17000 to 14500 B.P. (Tables 2, 3; Tauber 1966; Krog \& Tauber 1974; Knudsen 1978; Abrahamsen \& Readman 1980; Aaris-Sørensen \& Petersen 1984; Nielsen et al. 1988; Richard 1996; Houmark-Nielsen 2003).

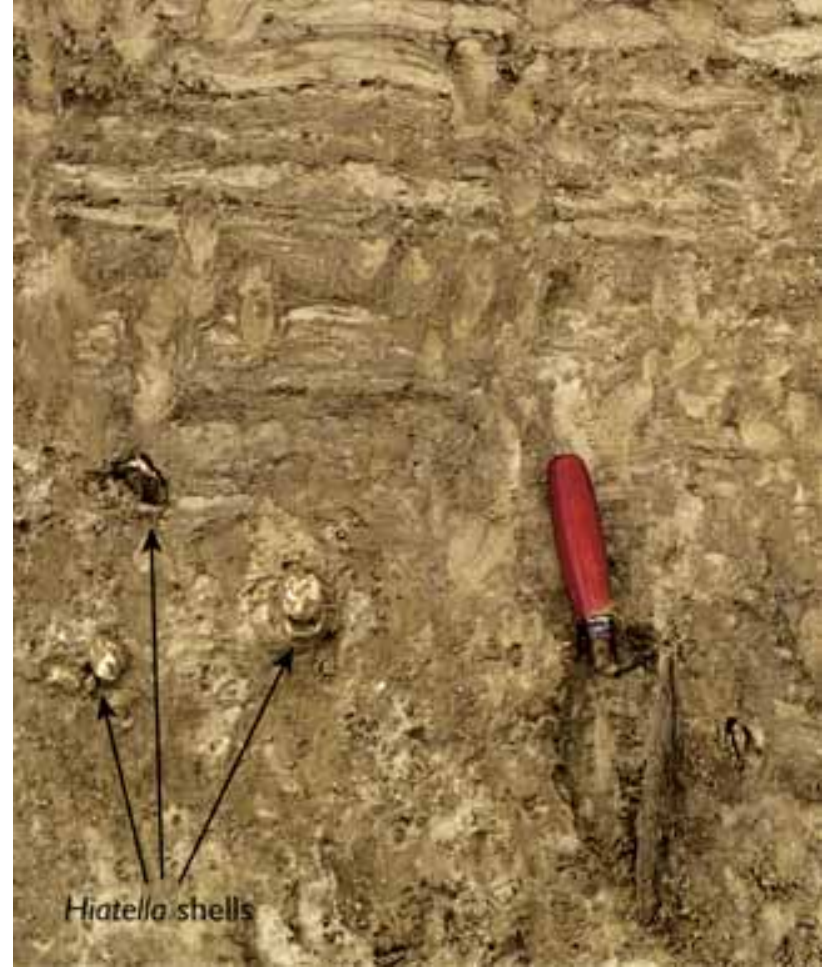

Fig. 41. At the cliff section north of Mårup Church, the sandy mud is often highly bioturbated; in places, the shells of the bivalve Hiatella arctica are found in life position in the escape trace fossils. Photograph from the middle part of the section in Fig. 37. Photograph: September 2004. 


\section{Structural description of sections}

The Rubjerg Knude Glaciotectonic Complex is differentiated into 13 structural sections, which are named after the localities recorded in the geological crosssection of Lønstrup Klint by Jessen (1918). The sections can be grouped into three zones within the complex: a distal zone (three sections farthest to the south), a central zone (seven sections in the middle part of the complex), and a proximal zone (three sections farthest to the north). They are named, from south (near Nørre Lyngby) to north (at Lønstrup): Ulstrup, Stensnæs, Martørv Bakker, Kramrende, Brede Rende, Sandrende, Stenstue Rende, Grønne Rende, Rubjerg Knude Fyr, Stortom, Moserende, Mårup Kirke and Ribjerg Sections. Three criteria were used for defining the sections: (1) the sections had to be bordered by marked footwall ramps, (2) each section should be characterised by uniform structural architecture, and (3) the sections had to be descriptively and geographically delimited. A good example of the first criteria is the steep thrust fault separating the Sandrende Section from the Stenstue Rende Section. As an example of a uniform architecture, the Grønne Rende Section can be mentioned, and finally the Mårup Kirke Section includes the long barren stretch from the Mårup church to Ribjerg at Lønstrup where the lack of geographical markers as well as characteristic footwall ramps is significant.

Each section is described separately, a general physiographic introduction being followed by four parts: (1) tectonicarchitecture, (2) sedimentary units, (3) structures, and (4) interpretation of structural development. The first descriptive part provides a general description of the macro-structures. The second part presents the sedimentary deposits, and although to some degree it repeats the lithostratigraphic descriptions of the formations (see above), the detailed observations of syntectonic sedimentation are relevant to an appreciation of the structural development in the individual sections. The third part concems the description of meso- and mini-structures (thrust faults, folds, faults, shear zones, joints, fractures, breccias, polydiapirs etc.). The description of each section is concluded with an interpretation of the formation of the structures. This interpretation should not be confused with the overall interpretation of the dynamic development of the progressive thrust-fault deformation that follows the systematic descriptions of the sections. The organisation of the section descriptions follows the general systematics of structural geology: the description of geometry, the kinematic investigation, interpretation of the dynamics and finally the analysis can be concluded by a tectonic synthesis (Dennis 1972).

The reader should note that the structural elements are numbered from distal to proximal. This is a consequence of the systematic analysis; in order to obtain an overview, the reader can compare the structural description given for each section with the dynamic development presented in the latter part of this bulletin.

\section{Ulstrup Section}

The southern frontal edge of the Rubjerg Knude Glaciotectonic Complex is positioned in the Ulstrup Section where the undeformed foreland is exposed below the hanging-wall flat of the last displaced and most distal thrust sheet (UL01, see Plate 2). One of the most interesting problems addressed in the analysis of this complex is the presence of two long thin thrust sheets that were translated southwards for about $500 \mathrm{~m}$ from their ramps to their present positions without complete internal disruption. The Ulstrup Section represents the foreland margin of the thrust-fault complex, and the two flat-lying thrust sheets extend from the southern edge of the thrust front at Tvonnet Rende to the steep ramp thrust separating the Ulstrup and Stensnæs Sections (Plate 1). The Stensnæs ramp thrust was initially regarded as the foreland thrust (Pedersen 1987), but new outcrops of the southem Ulstrup thrust exposed in 1996 and 1997 clearly demonstrated additional details of the frontal thrusting. Consequently, the long cliff section showing horizontal bedding that had previously been regarded as a primary, undeformed sedimentary unit (Fig. 42) is now interpreted as a displaced thrust sheet (UL01).

The Ulstrup Section is truncated by a broadly horizontal glaciotectonic and erosional unconformity above which aeolian sand was deposited, either as sheet sands or as small dunes, up to $10 \mathrm{~m}$ high. 


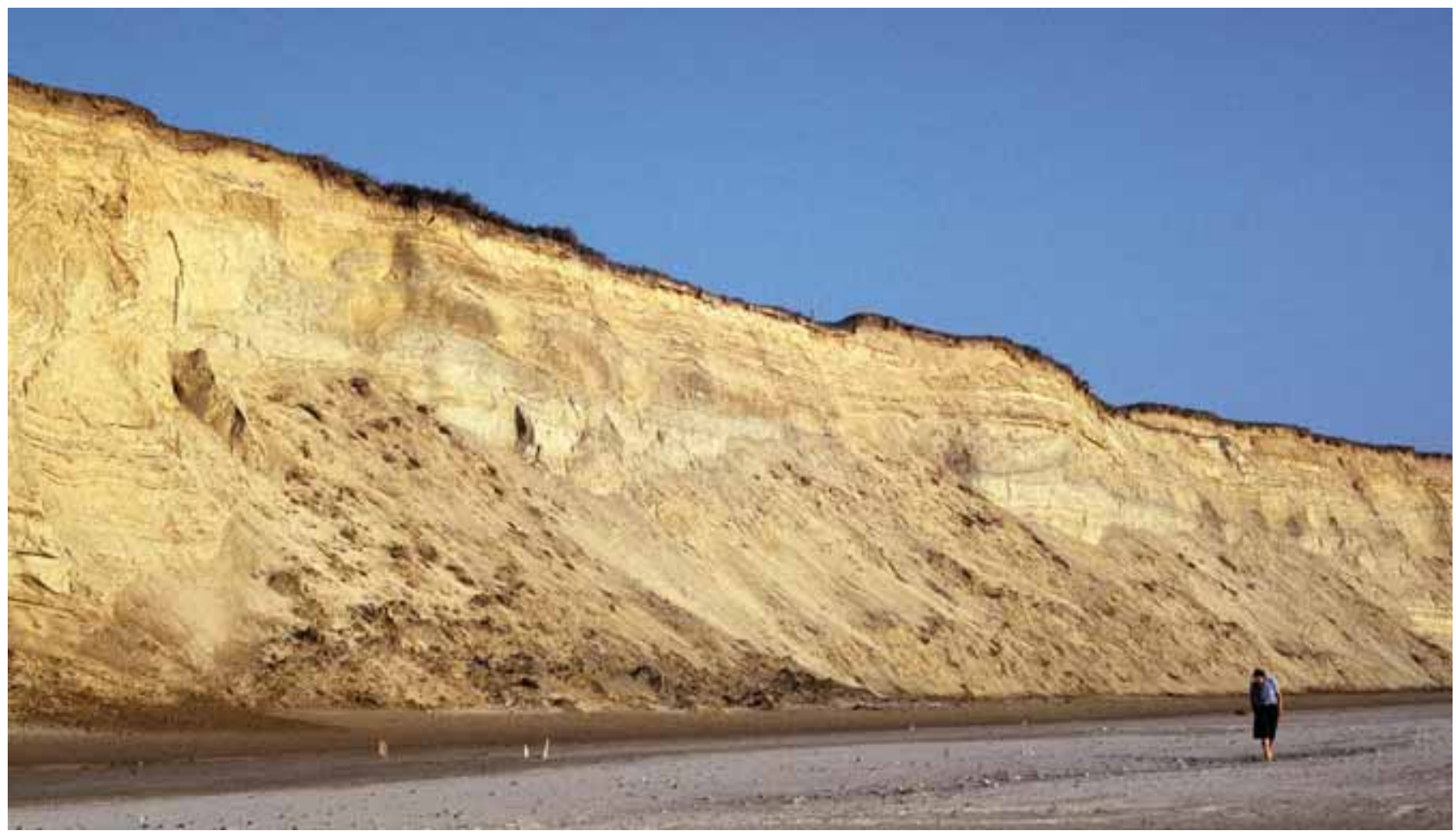

Fig. 42. The steep sandy cliff of the Ulstrup Section displays horizontal bedding of an apparently undisturbed deposit. However, structural analysis of thrust-fault relationships to the south indicates that it is a long flat thrust sheet displaced more than $500 \mathrm{~m}$ towards the foreland to the south. The cliff section is $25 \mathrm{~m}$ high and the view is towards the south. Photograph: June 1984.

\section{Tectonic architecture}

The Ulstrup Section comprises the two flat-lying thrust sheets, UL01 and UL02. The tip line of the hangingwall ramp (the edge of the frontal thrust) is situated on the northern side of Tvonnet Rende (for location, see Plate 1). Unfortunately, the precise position is obscured by late, syntectonic erosion and sedimentation at the front of the thrust-fault complex, as well as by sand scree covering the outcrops at Tvonnet Rende. The northern boundary of the section is the footwall ramp and flat of the UL02 thrust sheet, which forms a transitional zone of imbricate thrusting related to the frontal part of the Stensnæs Section.

The frontal part of the UL01 thrust sheet was displaced from the upper footwall ramp (Fig. 43) along an upper footwall flat on the top surface of the foreland. At the tip of the thrust sheet, the thrust fault dips gently towards the foreland, and a small foreland-dipping ramp is also located at point $6040 \mathrm{~m}$ in the crosssection (Plate 1, see Fig. 50). The ramps probably formed due to erosion in front of the propagating thrust-fault edge. In the central part of the UL01 thrust sheet, a synform structure is associated with a chaotic breccia, interpreted as the collapse of a frost mound or sand- mud diapir below the thrust fault; the synformal depression is referred to hereafter as Ulstrup Rende (for location, see Plate 1). The trailing end of the thrust sheet starts at the upper footwall ramp of the foreland from where the hanging-wall flat is inferred to continue along the footwall flat to the footwall ramp at its trailing end. The total length of the thrust sheet is about $750 \mathrm{~m}$ and the displacement is estimated at 350 $\mathrm{m}$, which is the distance from the footwall ramp at point $5800 \mathrm{~m}$ in the cross-section to the frontal termination in Tvonnet Rende (Plate 1). The thickness of the thrust sheet varies from 10 to $20 \mathrm{~m}$, decreasing towards the tip to the south, and increasing in thickness where syntectonic deposits fill the piggyback basin on the back of the thrust sheet. The thickness of the Lønstrup Klint Formation is only $6 \mathrm{~m}$ in the southern part of the piggyback basin due to erosion related to elevation during thrust faulting.

The UL02 thrust sheet is $600 \mathrm{~m}$ long, with the frontal edge situated on the northern side of the UL01 piggyback basin at point $5900 \mathrm{~m}$, and the trailing end disappearing into the décollement zone at point 5300 $\mathrm{m}$. The thrust fault consists of a more than $400 \mathrm{~m}$ long footwall flat on top of UL01 extending from the footwall ramp hinge at point $5360 \mathrm{~m}$ southwards to the 


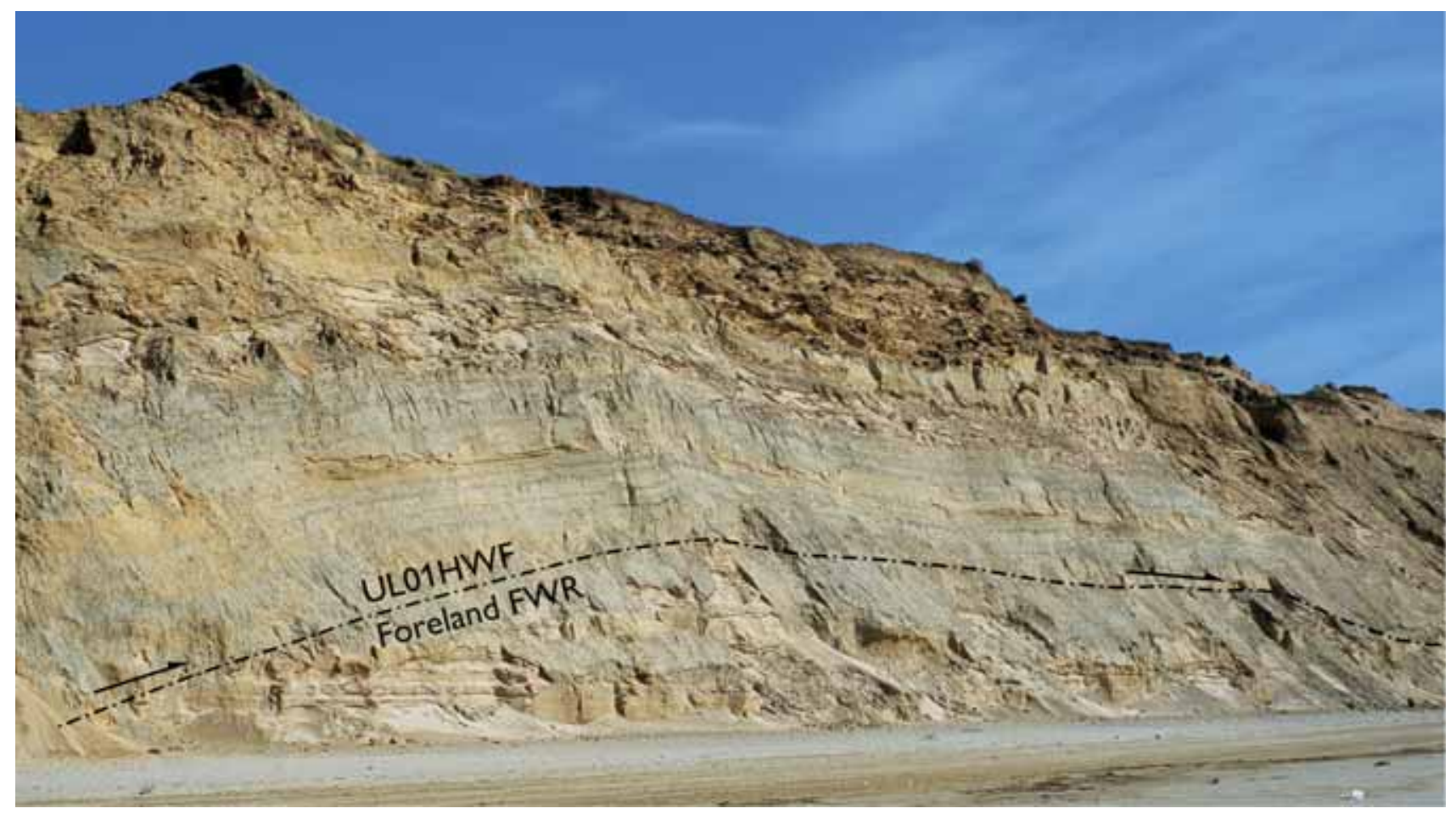

Fig. 43. The upper footwall ramp of the foreland (Foreland FWR) along which the UL01 thrust fault propagated (UL01HWF: Ulstrup thrust sheet 01 hanging-wall flat), and from where it continued for more than $300 \mathrm{~m}$ over the footwall flat of the foreland. The cliff section is $25 \mathrm{~m}$ high and south is to the right. Photograph: May 1998.

gently dipping frontal bend at point $5780 \mathrm{~m}$ in the cross-section (Plate 1). The frontal bend corresponds to the hinterland-dipping limb of the flat-topped hanging-wall anticline of UL01. This hanging-wall anticline compares well with the structure of the thrust-fault model in Fig. 6, and the southernmost c. $100 \mathrm{~m}$ of UL02 can be regarded to have been emplaced piggyback on UL01 during the translation over the frontal footwall ramp. The UL02 thrust sheet is only 5-6 m thick above the flat-topped anticline, whereas the thickness increases to $20 \mathrm{~m}$ at the trailing-end ramp. The displacement along the northern thrust fault is $550 \mathrm{~m}$, with an uncertainty of 10-25 m depending on the interpretation of the shape of the trailing-end ramp and the amount of erosion of the frontal part at the piggyback basin at Ulstrup Rende.

\section{Sedimentary units}

The sedimentary units in the Ulstrup Section comprise the upper part of the Lønstrup Klint Formation, erosional remnants of the lower part of the Rubjerg Knude Formation, and a variety of intercalations of the Rubjerg Knude Formation distinguished here as the
Ulstrup beds. The L/R-unconformity between the Lønstrup Klint and Rubjerg Knude Formations can be traced along the upper part of the UL01 thrust sheet in which it also forms the base of the piggyback basin. A few younger erosional unconformities, below and above the Ulstrup beds, are of only local significance within the Ulstrup Section.

\section{Lønstrup Klint Formation}

The mud-dominated Lønstrup Klint Formation forms the main part of the thrust sheets in the Ulstrup Section, and has an average thickness of about $10 \mathrm{~m}$ (Fig. 19). In the southem thrust sheet, the fine-grained sand beds are thin and only small-scale current ripples have been observed. A combination of load structures (balland-pillow) and waterescape structures (convolution and small-scale diapirs) are developed at certain horizons. Above the hanging-wall flat, a zone about $2 \mathrm{~m}$ thick takes the form of a mobilised mud breccia, which can be characterised as a sole thrust zone. This breccia is superimposed by beds affected by a brittle type of brecciation, forming cracks and joints in an up to 4 $\mathrm{m}$ thick zone in the lower part of the thrust sheet. 
Fig. 44. The mud-mobilised thrust-zone breccia consists of structureless mud with scattered clasts floating in the matrix. Dilation cracks filled with sand are superimposed on the mud-mobilised brecciation fabric. This reflects two phase of cataclastic deformation: a first phase of water-over-pressured brecciation (hydrodynamic brecciation), and a second phase of brittle fracturing when the mud was consolidated, dehydrated or perhaps frozen. Handle of spade is $12 \mathrm{~cm}$. Photograph: June 1997.

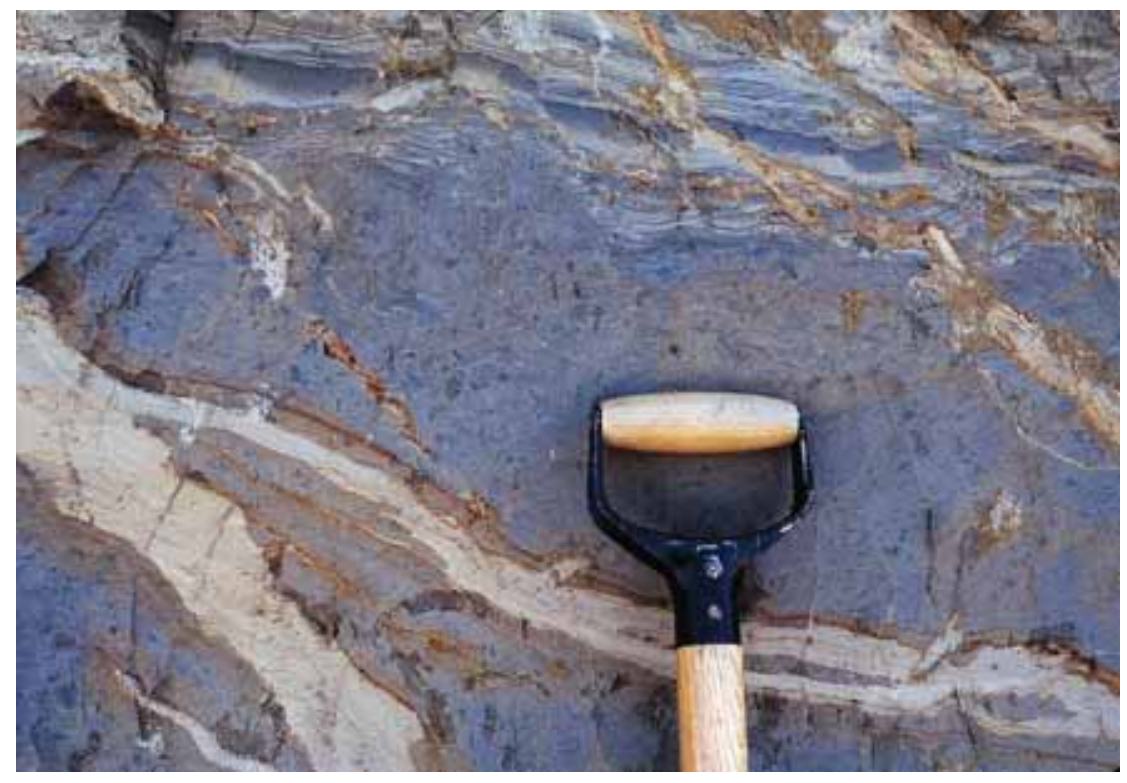

The northern thrust sheet (UL02) displays a more sandy part of the Lønstrup Klint Formation (Fig. 25). Here the sand beds are up to $1 \mathrm{~m}$ thick and waterescape structures, convolute bedding and flame structures commonly disturb the primary bedding. Balland-pillow structures are more common towards the trailing end of the thrust sheets.

\section{Rubjerg Knude Formation}

In the Ulstrup Section, the Rubjerg Knude Formation comprises three different depositional units: the main 'background' sedimentation of outwash sand, the glaciolacustrine Ulstrup beds (Fig. 25), and the coarsegrained glaciofluvial Ulstrup beds (Fig. 20).

The main depositional unit is fine- to mediumgrained meltwater sand represented in the footwall block of the foreland (Fig. 43). Small-scale current ripples occur in the parallel bedded sand, which is interlayered with c. $0.5 \mathrm{~m}$ thick trough cross-stratified beds.

The glaciolacustrine Ulstrup beds form a 3-5 m thick unit that is only found on the back of the UL02 thrust sheet (Fig. 25). This unit consists of dark bluish grey, laminated clayey mud interlayered with a few sandy beds up to $0.5 \mathrm{~m}$ in thickness. The unit was deposited on a bedding-parallel unconformity, which is only discordantly developed in the northernmost trailing part of thrust sheet UL02. The unit thins out towards the south, and disappears near the hinterland-dipping limb of the flat-topped hanging-wall anticline formed above the footwall ramp of the foreland. Intraforma- tional hydrodynamic brecciation, including small-scale diapirs and slump-like features, deformed the clayey mud; such deformation is not seen in the Lønstrup Klint Formation below the unit.

The glaciofluvial Ulstrup beds occur in the Ulstrup Rende depression between points 5900 and $6000 \mathrm{~m}$ in the cross-section (Plate 1). This unit is a c. $8 \mathrm{~m}$ thick succession of meltwater gravel fining up into coarse-grained sand (Fig. 20). Large-scale trough crossbedding dominates the succession and clasts up to boulder size occur in the lowermost $2 \mathrm{~m}$ (Fig. 28). Lithologically, the clasts are dominated by flint, but clasts of fossil frozen sand are abundant (Fig. 29).

The glaciofluvial Ulstrup beds are overlain by c. 5 $\mathrm{m}$ of medium- to coarse-grained sand of the Rubjerg Knude Formation. On the north side of the Ulstrup Rende depression, between points 5900 and $6000 \mathrm{~m}$, slump-folded sand beds and sedimentary breccias occur in the upper part of this succession, suggesting gravity gliding down the steep slope of the depression (piggyback basin of UL01).

\section{Structures and breccias}

The most important structures related to the thrust faults in the Ulstrup Section are the breccias occurring in the thrust zones above the thrust-fault surfaces. They appear to have formed by collapse of the thrust sheet during translation. The low-angle anastomosing faults that developed in the most distal part of the thrustfault complex originated similarly during translation 


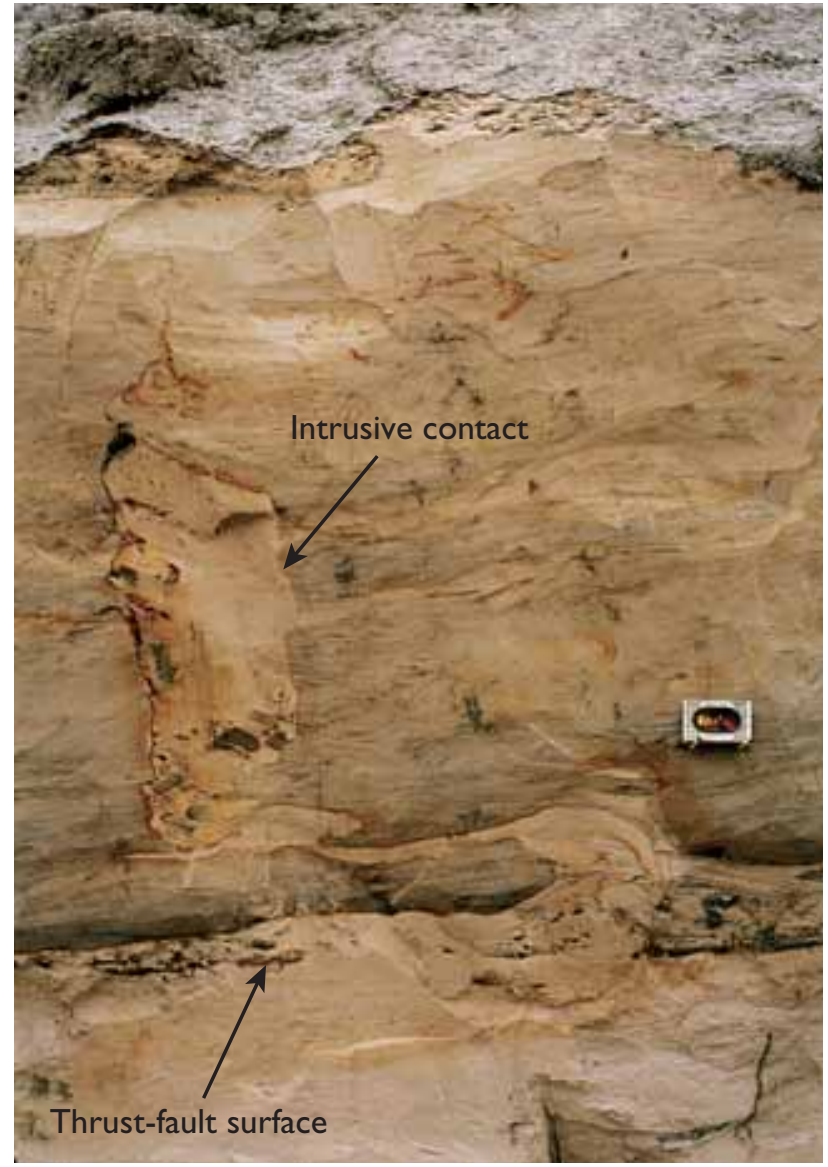

Fig. 45. Mud mobilisation along the hanging-wall flat of the UL02 thrust sheet. From the thrust-fault surface, a sandy mud fluid intruded along fractures and up into the lower part of the thrust sheet where it formed a mud-intrusion. During the initial hydrodynamic brecciation of the thrust zone, small relict segments remained at the thrust plane where they were modified and developed into elongate cataclasts in the sole of the thrust breccia zone. Photograph: July 1998; matchbox for scale.

and are associated with southerly dipping normal faults. A significant collapse structure that formed beneath the Ulstrup Rende depression is also worthy of note.

\section{Thrust-zone breccias}

The thrust-zone breccias occur above the hangingwall flat of the UL01 and UL02 thrust sheets, where they affect the mud-dominated Lønstrup Klint Formation. The thrust zone is up to $4 \mathrm{~m}$ thick in the most distal part of the thrust-fault system (southern part of UL01), and decreases in thickness to $1 \mathrm{~m}$ northwards; it can be traced along the hanging-wall flat of UL02 for a considerable distance. The thrust-zone breccia consists of mobilised mud with irregular clasts of mud scattered throughout (Fig. 44). Some patches may be more sandy and others more clayey, and lenses and layers of sand may be present. The mobilisation was apparently initiated as sandy mud-fluid that developed at the thrust-fault surface and extended up into the sedimentary unit (Fig. 45). In many cases, the initial hydrodynamic brecciation of the thrust zone left segments along the displacement surface of the thrust fault, which were modified and developed into elongated cataclasts along the sole of the breccia zone. Convolute bedding and small-scale diapirism are also present.

The mobilised mud was subsequently transected by dilation cracks and sand-filled fissures (Fig. 46). The dilation cracks form an irregular network and the sand-fill was injected into consolidated mud (Figs 44, $46,47)$. More or less horizontal sand-filled cracks have been observed in the frontal part of the UL01 thrust sheet, where they are up to $15 \mathrm{~cm}$ thick and appear up to $1 \mathrm{~m}$ above the hanging-wall flat. The sand in the cracks shows planar horizontal lamination and small-scale current ripples and a few vertical sandfilled pipes extend upwards from the cracks (Fig. 48).

Towards the frontal tip of the UL01 thrust sheet, an increasing number of bedding parallel or low-angle anastomosing fractures and small-scale faults appear to be related to an increased rate of internal gliding. This is an indication of how close the thrust sheet was to disintegration and a loss of cohesion. Zones 0.2-0.5 m thick, grading into mobilised mud, occur in between the anastomosing fractures, resulting in the destruction of bedding (Fig. 49).

\section{Foreland-dipping hanging-wall flat faults}

In the frontal part of the UL01 thrust zone, forelanddipping faults become increasingly common. These faults are either foreland-dipping $\left(20-30^{\circ} \mathrm{S}\right)$ ramps formed by the hanging-wall flat scouring into the footwall flat (Fig. 50), or sets of $50^{\circ} \mathrm{S}$ dipping normal faults with displacements of about $10 \mathrm{~cm}$. These structures are considered to be the result of partial collapse of the tip of the foreland-dipping limb of the hangingwall ramp above a low-angle hanging-wall ramp translated along the footwall flat of the foreland. 


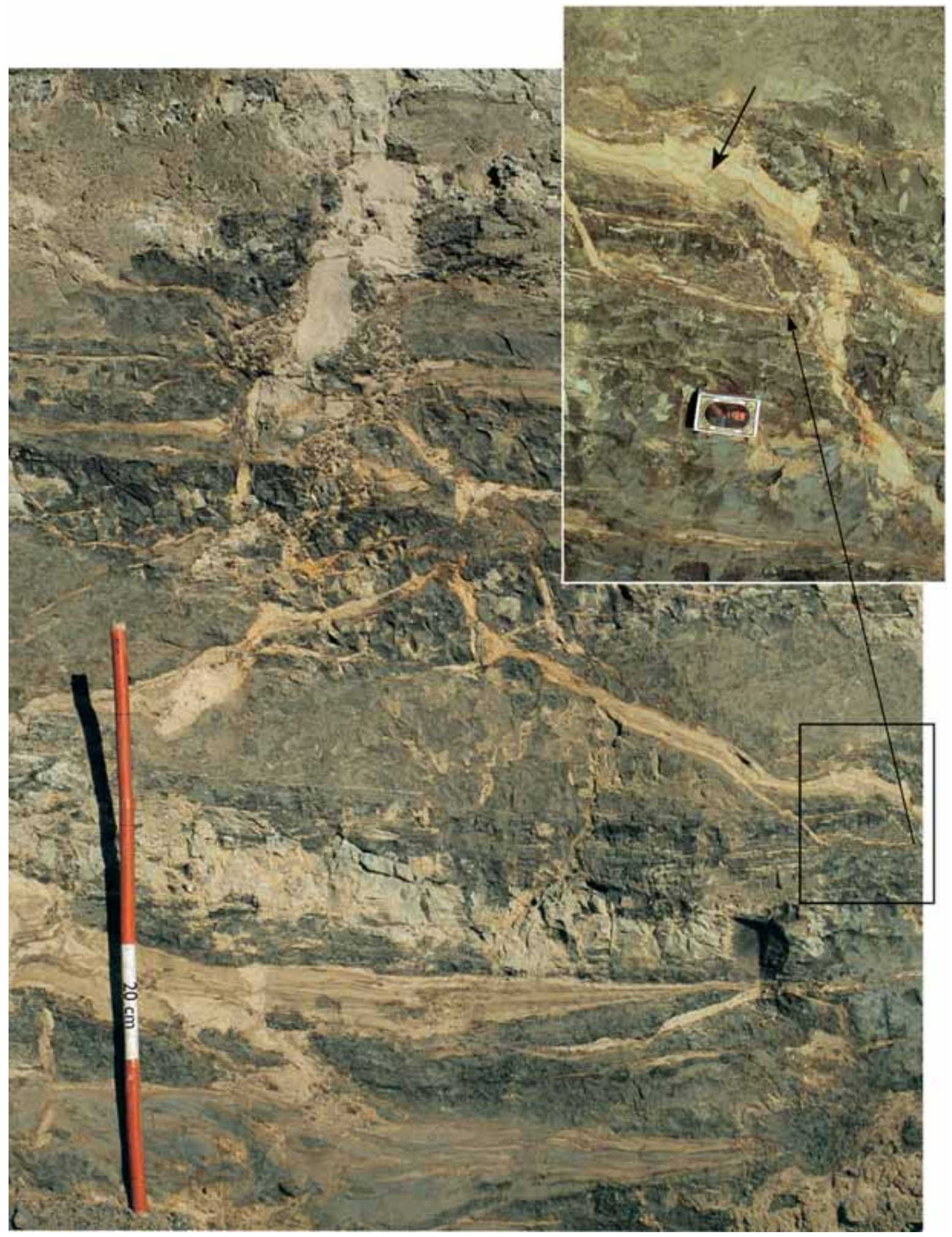

Fig. 46. Subsequent to mud mobilisation, the thrust zone was transected by dilation cracks and fissures, which form an irregular network into which sand was 'injected'. The mobilised mud had clearly become consolidated before the sand-filled cracks formed. The close-up inset illustrates the 'reverse' drag of the sand-fill (arrowed) indicating an upward direction of flow in the fissure. Photograph: May 1998. 

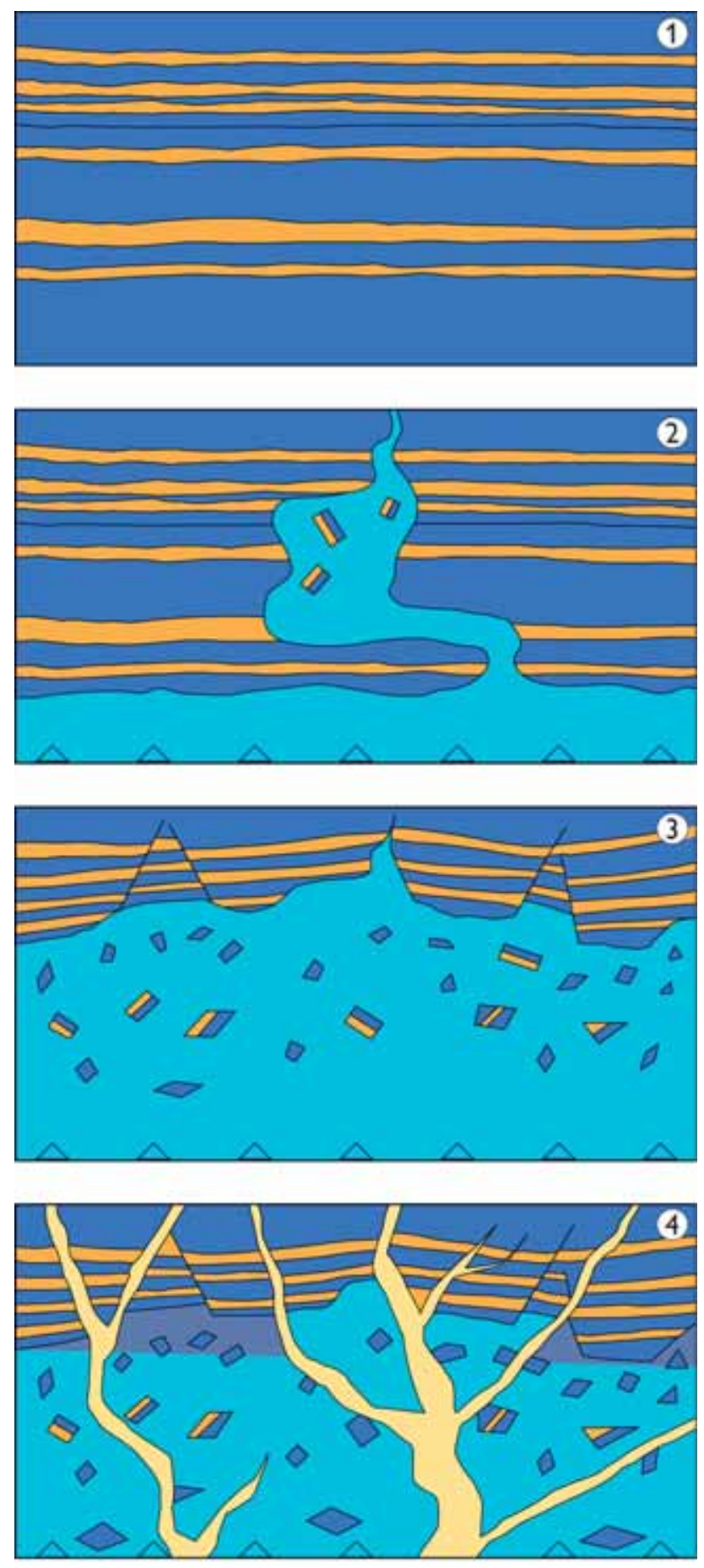

Clayey mud

Sand

\section{Collapse structure in the Ulstrup Rende}

Structures in the central part of Ulstrup Rende (Figs $51,52)$ are interpreted to represent a collapsed diapir. Theearly phase structures include thinning of the Lønstrup Klint Formation in the thrust sheet, and formation of concave troughs in its surface. Vertically or steeply dipping sand breccias with upward directed flow structures cross-cut the thrust-zone breccia. The appearance of structurelesssand pockets indicates sandfill of mobilised sediment from an over-pressured zone in the subsurface. The complex of breccias and reorientated bedding is interpreted as a collapse structure; it is considered to be responsible for the formation of the Ulstrup Rende depression, and the disruption of the thrust sheet along steeply dipping fractures. In the breccia zone, steeply dipping sand-filled cracks and normal faults formed prior to the continued deposition of the Rubjerg Knude Formation in the depression.

On the southern side of the Ulstrup Rende depression, the muddy part of the thrust sheet is displaced by steeply dipping normal faults. Downthrow is to the south, synthetic towards the depression, and the faults are thought to be related to the collapse of the diapir structure.

\section{Interpretation of structural development}

There are two reasons why the Ulstrup Section deserves special attention. The first is that it represents a foreland thrust section with long lateral transport of thin thrust sheets, the nature of which has not previously been documented. Secondly, it demonstrates the likely development of the initial stages of deformation, which the remainder of the thin-skinned thrust faulting in the Rubjerg Knude Glaciotectonic Complex also experienced before the uppermost part was eroded. Thus the first phase of thrust-fault deformation is preserved here whereas it is almost never represented in the thrust-fault sections that have been

Fig. 47. The formation of thrust-zone breccias in the distal part of the thrust-fault complex is here illustrated in four stages of development. (1) The initial undeformed sediment (Lønstrup Klint Formation) comprises clayey mud interlayered with thin sand beds. (2) A mud-fluid is formed above the thrust-fault surface (line with open triangles) from where it is injected up into the layers above (see Fig. 45). (3) Increasing mud-mobilisation results in the formation of a structureless matrix with dispersed matrixsupported clasts of the primary sediment (see Fig. 44). Note the small normal faults indicating an on-going process of collapse. (4) The mobilised mud becomes consolidated and the thrust-zone breccia develops into a more brittle stage; dilation cracks form into which water-saturated sand is injected (see Fig. 46). 
Fig. 48. A subhorizontal sand-filled fracture occurring in the frontal part of the UL01 thrust sheet. The sand-filled fracture appears about $1 \mathrm{~m}$ above the hanging-wall flat; the sand shows planar horizontal lamination and current ripple cross-lamination. The sand-filled fracture is interpreted to have formed during ground-frozen conditions, whereas the vertical sand-filled pipe probably reflects loading of the thrust sheet when it ultimately lost its carrying pore-water pressure and settled on its hanging-wall flat. Photograph: June 1997.

Fig. 49. Subhorizontal anastomosing faulting (centre left) with mud-mobilisation developed in domains between fault fractures in the frontal part of the UL01 thrust sheet. Photograph: June 1997.
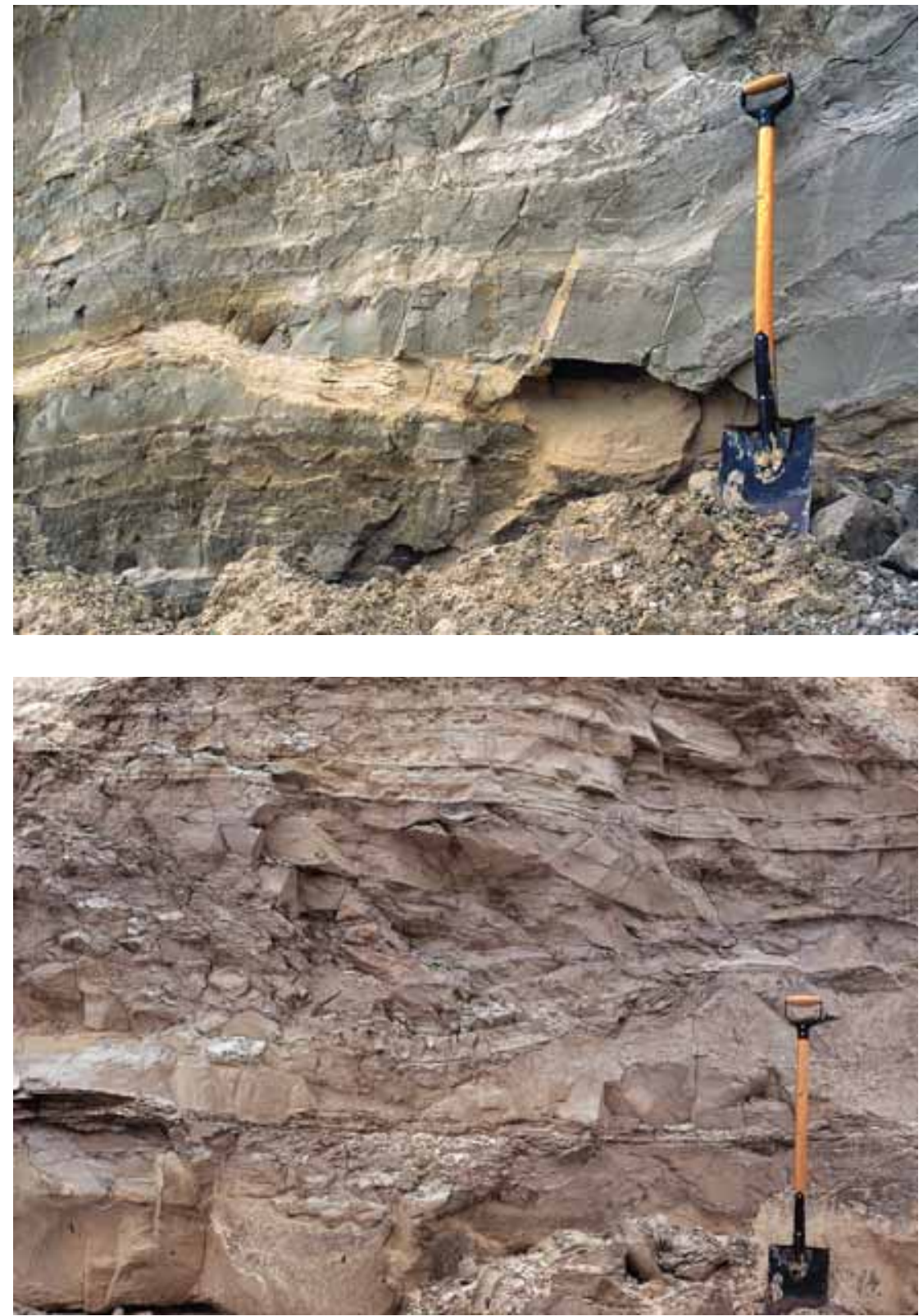

more intensely deformed. The interpretation of the structural development can be summarised in the following nine stages.

1. Initial thrust-fault fracturing and thrust-fault propagation took place during mobilisation of mud along the hanging-wall flat. At this stage, the thrust-zone breccia was formed due to high pore-water pressure in an unfrozen stage.

2. The UL01 and UL02 thrust sheets probably started to move along the décollement zone as one coherent thrust sheet, and first separated into two thrust sheets after the frontal part of the sheet had passed the most distal foreland footwall ramp.

3. The ramping up of the northern UL02 thrust sheet probably increased the pore-water pressure, and when this increase also affected the frontal part of UL01, diapirism was initiated under the central part of the southern thrust sheet.

4. The diapiric uplift and erosion took place in the elevated surface. This erosion extended through the Rubjerg Knude Formation to locally intersect the L/R-unconformity. The residual coarse clastic gravel 


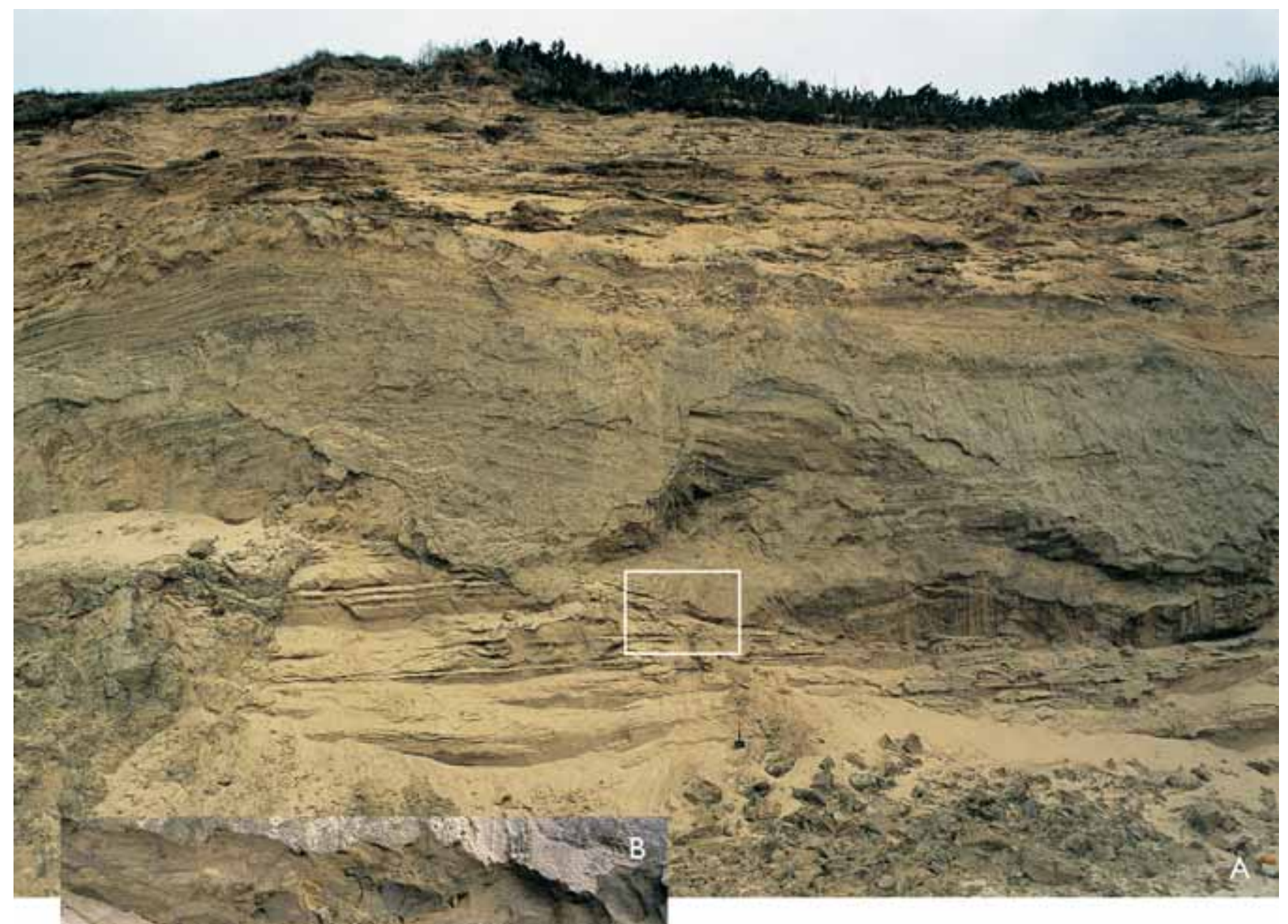

Fig. 50. A: Foreland-dipping ramping of hanging-wall flat formed by scouring-erosion of the footwall flat into the top surface of the foreland. Note in the close-up (B) that some hydrodynamic brecciation occurred in the footwall ramp just below the thrust zone. Photograph: June 1997.

on thefootwall flatat the surface of the foreland in the Ulstrup Section.

7. The consequence of the diapir collapse was the

bed on the unconformity surface was probably the original source for the large amount of coarse-grained material in the Ulstrup Rende depression.

5. The mud-sandvolcano brokethrough to the surface, and the mobilised mud and sand were extruded with the release of the high pore-water pressure.

6. The surface of the diapir collapsed and gravel and sand filled the fractured structure. The collapse was probably contemporaneous with the loss of pore pressure throughout the thrust zone. The release of over-pressure in the thrust zone resulted in the finalsettling of the thrust sheet formation of the depression in Ulstrup Rende. Redeposited coarse-grained clastic material filled the depression, generating the glaciofluvial Ulstrup beds. The occurrence of fossil frozen-sand clasts implies that part of the surface, the Rubjerg Knude Formation, was ground-frozen probably that part of the thrust sheet that had been elevated due to the propagation up over the central ramp. The ground-frozen condition was probably also responsible for freezing of the mobilised mud in the thrust zone and the subsequent development of sand-filled dilation cracks (Fig. 47) 


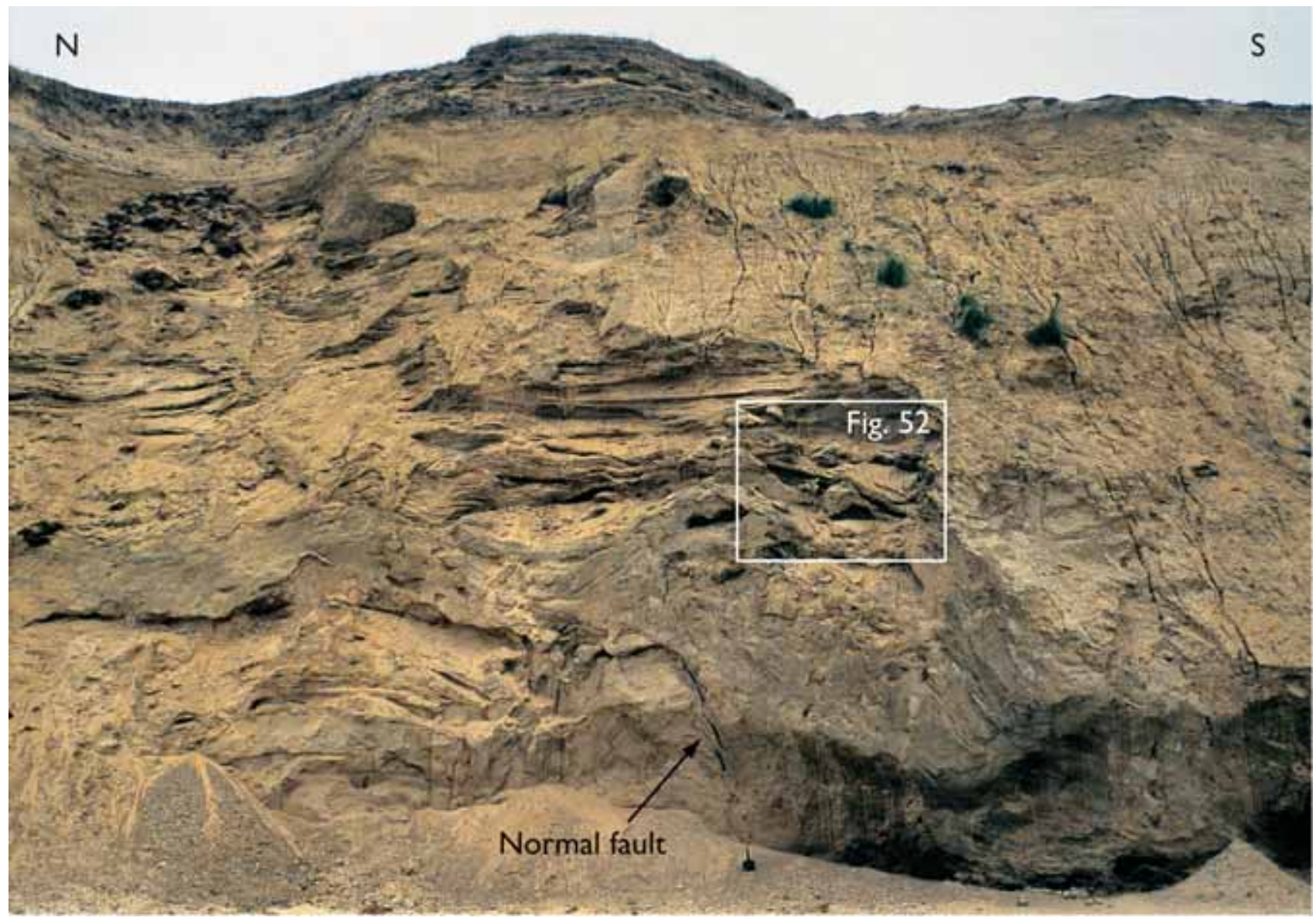

Fig. 51. The Ulstrup Rende depression is interpreted to represent a combination of a piggyback basin (according to the model in Fig. 7) and the collapse of an underlying mud diapir or frost-mound feature. Note the steep normal fault on the left side of the depression (to the north). Photograph: June 1997; spade (lower centre) for scale.

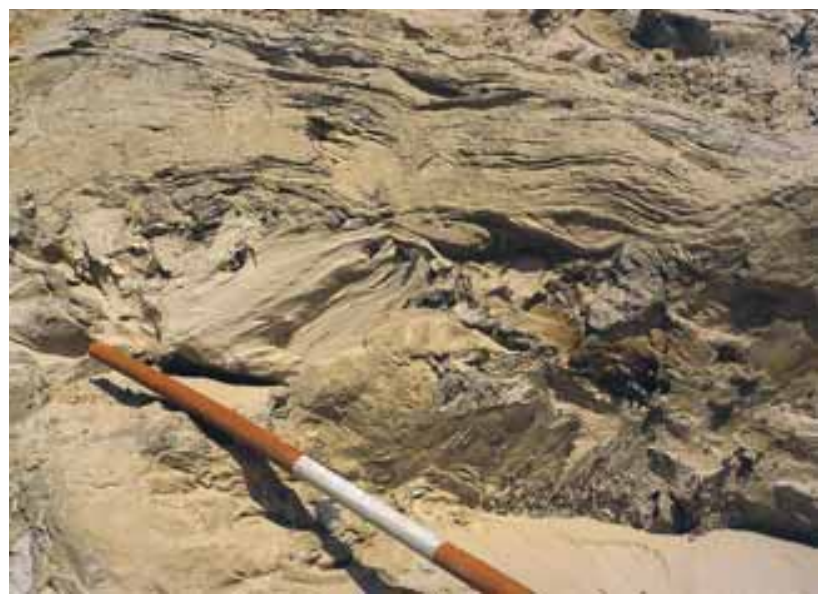

Fig. 52. Chaotic sand/gravel breccia in the centre of the Ulstrup Rende depression, which is interpreted as the result of the collapse of the diapiric structure created in the subsurface below the UL01 thrust sheet. Photograph: May 1998.
8. The depression was ultimately filled by the sand of the upper unit of the Rubjerg Knude Formation. The frontal edge of the northern thrust sheet propagated towards the northern side of Ulstrup Rende and parts of its leading tip slumped down the steep slope of the depression. This indicates the sequential and later movement of the northern thrust sheet. The depression can be interpreted in part as a piggyback basin that formed according to the model demonstrated in Fig. 7.

9. Finally, the uppermost sediments of the Rubjerg Knude Formation covered the section before the glacier advanced across the area. The uppermost metre of sand was transformed into a glaciofluvialsand-glacitectonite. 


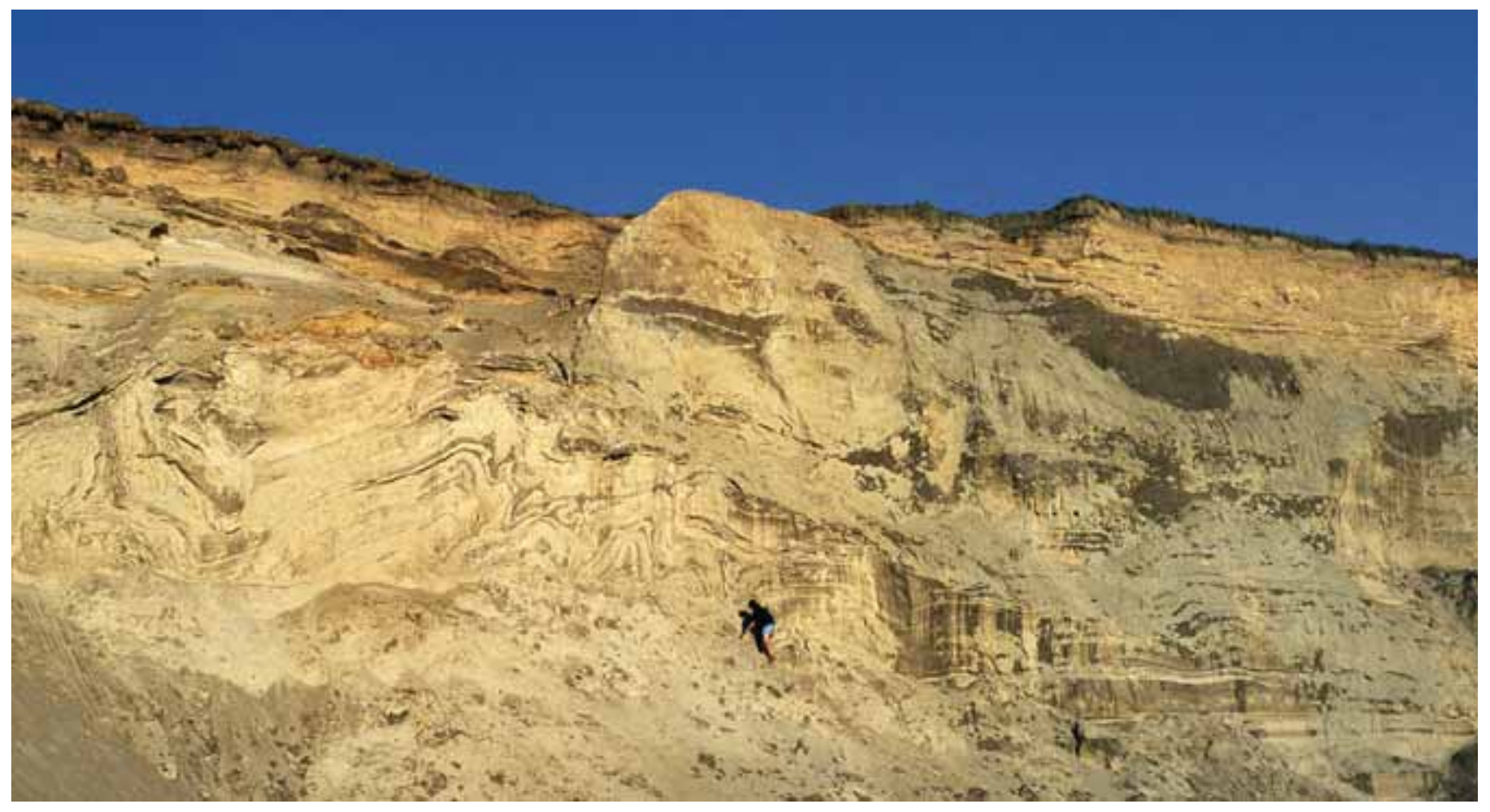

Fig. 53. The fold complex developed in the transitional imbricate zone between Ulstrup and Stensnæs Sections. Note that the thrust faults acting as flexural slip surfaces in the folding continue into the bedding-parallel thrust-fault flats to the south (right). Photograph: July 2000.

\section{Stensnæes Section}

The Stensnæs Section is named after Stensnæs, which is a minor point (Danish: sten = stone; næs (pynt) = point) at a gentle bend in the cliff section. Stones and erratic blocks, probably derived from the up to $2 \mathrm{~m}$ thick sandy till and the erosional unconformity below the Vendsyssel Formation, were formerly abundant on this part of the beach. The sandy till thins out southwards where a glaciotectonic unconformity truncates the section.

The Stensnæs Section displays the most spectacular folds in the Rubjerg Knude Glaciotectonic Complex (Fig. 53). The folds are situated at the transition from the flat-lying beds to the south (the Ulstrup Section) and the main thrust-fault imbrications to the north. The fold complex is truncated by an erosional unconformity forming a depression in which slump slides and sedimentary breccias derived from the tip of the thrust sheet were deposited after collapse and gravity gliding. In general, the fold complex is well exposed, whereas the transition further southwands is often covered by sand scree. During the years of study of the Rubjerg Knude Glaciotectonic Complex by the author, variations in the degree of exposure of the Stensnæs Section have contributed to a fuller under- standing of the structural development of the section that represents the foreland margin of the thrust-fault complex.

\section{Tectonic architecture}

The Stensnæs Section comprises four thrust sheets (SN01, SN02, SN03 and SN04, Plate 2). The southern boundary of the section is defined by the footwall ramp of UL02, although the trailing end of UL02 is here included in the description of the imbricate duplex that hosts the fold complex. The northern boundary is the hanging-wall ramp of MB01/MB02, that is thrust up along the footwall block of SN04. The thrust sheets comprise the uppermost part of the Lønstrup Klint Formation and a relatively thin cover of the overlying Rubjerg Knude Formation sediments. Two discrete piggyback basins (early and late) were formed above the SN01 and SN02 thrust sheets.

The SN01 thrust sheet is about $30 \mathrm{~m}$ thick, and although the thrust sheet includes a number of small duplex imbricates it can be subdivided into upper and lower segments. The lower segment is thrust onto the UL02 fo otwall block with a displacement of fabout30 m. The displacement of the upper segment is partitioned 
Fig. 54. Ball-and-pillow structures in the Lønstrup Klint Formation in the Stensnæs Section. Note that the size of the structures reflects the thickness of the sand beds involved. Photograph: July 2000; staff divisions are $20 \mathrm{~cm}$.
Fig. 55. Dish-and-pillar structures developed in the lowermost sandy bed above the hanging-wall flat of the SN2 thrust sheet in the Stensnæs Section. This type of water-escape structure is interpreted to have formed during the thrust-fault translation along a hangingwall flat due to the high water pressure released from the sole of the thrust sheet. Photograph: July 1998.
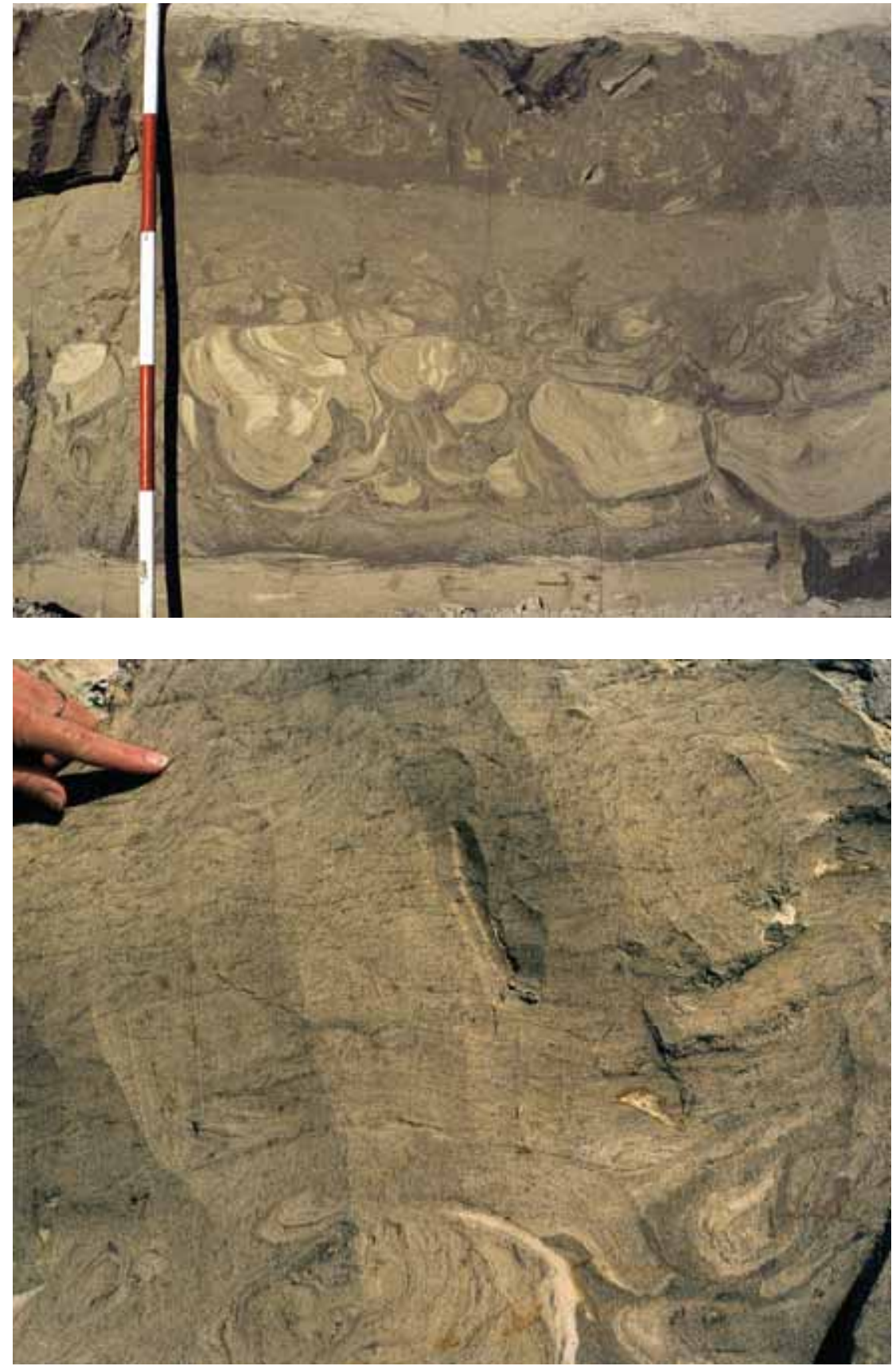

into a series of minor differential displacements ranging from minor flexural slips along bedding surfaces in the fold structures to imbricate offsets of about 1-3 m.

In the frontal part of the SNO2 thrust sheet, the Lønstrup Klint Formation is only a few metres thick, and is overlain by $10 \mathrm{~m}$ of sediments of the Rubjerg Knude Formation resting on the L/R-unconformity. At the trailing end of the thrust sheet, the Lønstrup Klint Formation is more than $15 \mathrm{~m}$ thick, whereas the Rubjerg Knude Formation is cut off by the footwall ramp of SNO2 (corresponding to the hanging-wall thrust fault for the imbricates of SN03). The accumulated displacement of SN02 amounts to $88 \mathrm{~m}$, including $15 \mathrm{~m}$ up over the footwall ramp and $73 \mathrm{~m}$ along the footwall flat of SN01.

The SN03 thrust sheet may be divided into four imbricate segments thrust onto the footwall ramp of SN02. The displacement along the hanging-wall thrust fault is $45 \mathrm{~m}$, but it was also carried piggyback on SN02 during the translation along the décollement zone, which gives an accumulated displacement of $163 \mathrm{~m}$ for the SN03 thrust sheet. 


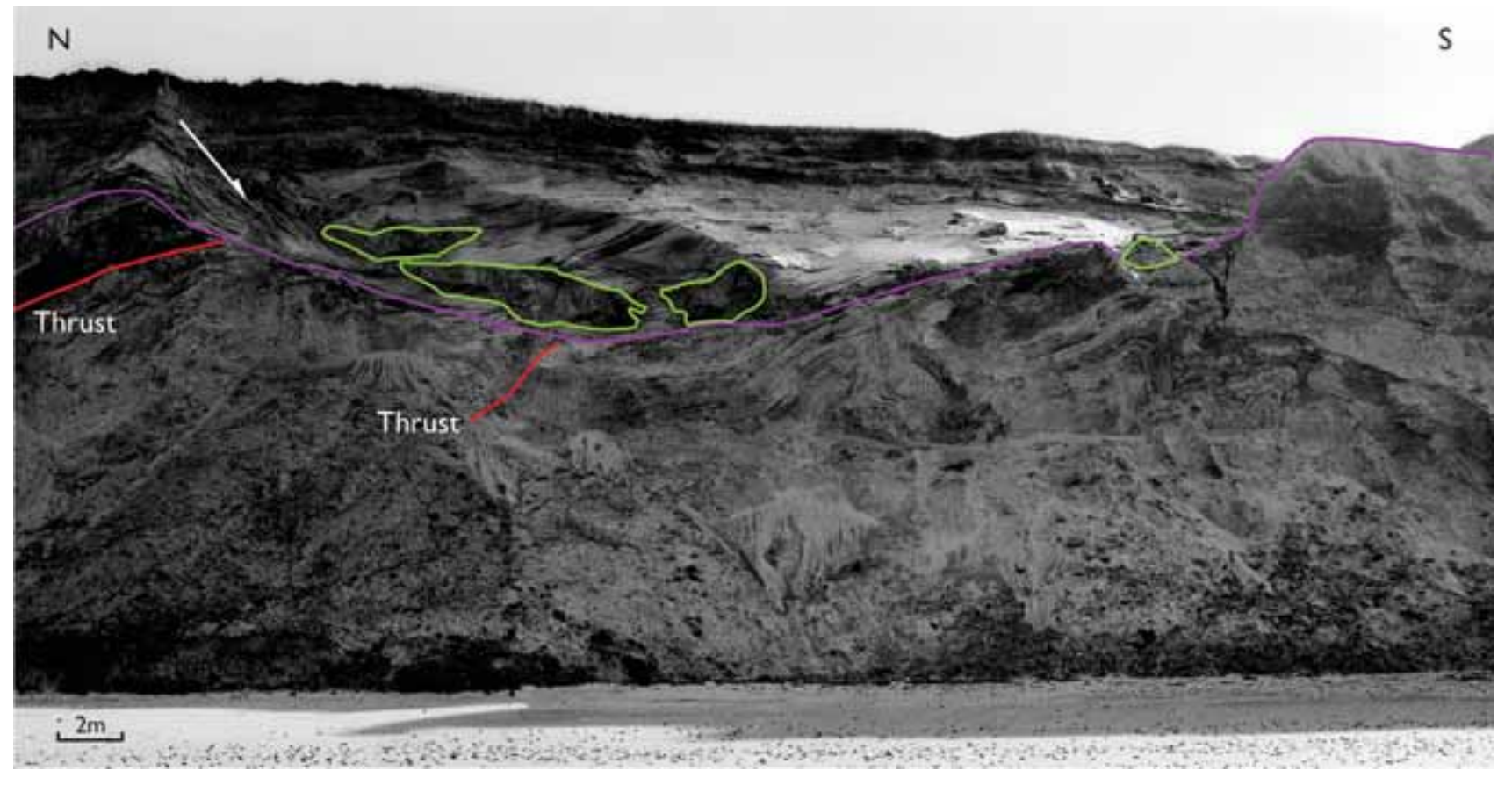

Fig. 56. The piggyback basin situated above the erosional truncation of thrust sheet UL02 and SN01 in the Stensnæs Section (SNstRu in Plate 2). Note that normal listric faults (arrow) may be traced to the trailing end of the large olistoliths (green) deposited in the meltwater sand and gravel. This is interpreted as the result of gravity gliding of the tip of a thrust sheet, which during propagation from the north collapsed subsequent to thrust faulting up above the mean level of sedimentation. Photograph: July 2000; thrusts indicated in red, unconformity indicated in purple.

The SN04 thrust sheet is about $20 \mathrm{~m}$ thick, including an up to $8 \mathrm{~m}$ thick unit of the Rubjerg Knude Formation resting on the L/R-unconformity above the Lønstrup Klint Formation; this unit increases in thickness to about $15 \mathrm{~m}$ towards the trailing end of SN04. Total displacement is about $45 \mathrm{~m}$, including a hanging-wall ramp-and-flat propagation along the footwall ramp of SN03.

\section{Sedimentary units}

The sedimentary units that crop out in the Stensnæs Section are dominated by the upper sandy parts of the Lønstrup Klint Formation. A lens of a glaciolacustrine diamictite is preserved as an imbricate thrust sheet, c. $3.5 \mathrm{~m}$ thick and $22 \mathrm{~m}$ long, and is tentatively interpreted to form part of the Rubjerg Knude Formation. The latter is mainly represented by a 6-8 $\mathrm{m}$ thick succession including the residual gravel deposited on the uneven surface of the L/R-unconformity. An upper unconformity truncates the SN01 and SN02 thrust sheets, and coarse gravel beds as well as olistoliths of the Lønstrup Klint Formation were deposited in a late piggyback basin (SnstRu in Plate 2).

\section{Lønstrup Klint Formation}

The sedimentology of the Lønstrup Klint Formation in the Stensnæs Section is similar to that described for the Ulstrup Section. The maximum thickness of the formation is about $15 \mathrm{~m}$, and lithologies are dominated by $0.2-0.8 \mathrm{~m}$ thick fine-grained sand beds with climbing ripple lamination. Thin laminae of mud and small amounts of detrital organic material commonly drape the ripples. The sand beds are interlayered with thin laminated dark grey mud beds; micro-faulting is evident in this facies. Ball-and-pillow and convolute structures are abundant (Fig. 54). In the uppermost $4 \mathrm{~m}$ of the formation, the sandy beds become thinner and the uppermost part is dominated by mud. In sand beds inferred to be situated above the hanging-wall flat, dish-and-pillar structures have been observed (Fig. 55) that are interpreted to have formed by waterescape processes related to the thrusting.

Cheel \& Rust (1986) provided a model for the development of water-escape structures in glacial outwash deposits from Ottawa, Canada. In their model, a sequential development from simple load structures through detached ball-and-pillow structures to dish structures is demonstrated. The model predicts a stra- 
tified distribution with convolute stratification at the base of a bed, ball-and-pillow structures dominating the main part, and dish structures formed in the uppermost part of the bed (or unit) resulting from excess pore-water fluid pressure. The observed waterescape structures in the Stensnæs Section as well as in the sections further to the north compare well with the model of Cheel \& Rust (1986) (Figs 54, 55; see also Fig. 77), although they suggested the triggering mechanism to be earthquakes or movements due to melting of dead-ice.

\section{Rubjerg Knude Formation}

In the Stensnæs Section, two units of the Rubjerg Knude Formation are distinguished: (1) a lower unit dominated by fine- to medium-grained glaciofluvial sand, and (2) an upper unit of varied sedimentary breccias and coarse-grained clastic deposits that infills the piggyback basin on top of the truncated thrust sheets in the section (Fig. 56). The sand deposited in the lower unit may be planar parallel stratified, or exhibit large-scale trough cross-bedding with shallow troughs, only $0.5 \mathrm{~m}$ deep. The lower unit of the $\mathrm{Ru}-$ bjerg Knude Formation is estimated to be $6-8 \mathrm{~m}$ thick, and although strongly affected by hydrodynamic brecciation, the unit compares well with the description of the lower part of the formation provided by Sadolin et al. (1997).

The upper unit was deposited on the erosional unconformity truncating the back of the UL02 thrust sheet, the fold and imbricate complex of SN01, and the tip of the SN02 thrust sheet (SnstRu in Plate 2). The central part of the basin is about $7 \mathrm{~m}$ thick, decreasing towards both the north and south forming a relatively narrow trough. The sediments in the basin consist of large-scale irregularly trough cross-bedded glaciofluvial sand and gravel. Blocks of sandy mud, which can be identified as derived from the Lønstrup Klint Formation, were deposited as sedimentary breccias in the basin. The clasts are up to $1 \times 5 \mathrm{~m}$ in size; blocks and clasts less than one metre in size were commonly rotated during redeposition. Nomal listric faults in the northern part of the basin relate to the deposition of the largest olistoliths (Fig. 56). The southern part of the basin was tilted subsequent to deposition due to the fault-bend folding of the hanging-wall flat of UL02 when it propagated along the footwall flat during the latest phase of thrust faulting. Thus the upper unit of the Rubjerg Knude Formation in the
Stensnæs Section is interpreted to have been deposited in a piggyback basin in which thrust-sheet tips thrust up from the north collapsed and gravity-glided out into the basin.

\section{Structures}

Two types of structures in the Stensnæs Section are related to thrust faulting: (1) the folding related to duplex imbricates, and (2) extensional faults related to push-from-the-rearin the trailing end of a thrust sheet.

\section{Imbricate duplex folding}

The folds in the Stensnæs Section can be described as flexural slip folds, and have amplitudes of 1-3 $\mathrm{m}$ and wavelengths of 2-5 m (Figs 53, 57, 58). The folds are very irregular in shape, however, and cannot be explained in terms of simple compression. Analysis of the flexural slip surfaces shows that the folded layers were separated into segments and that discordant relationships exist between beds in neighbouring segments. By defining the segments as small imbricate thrust sheets in a duplex, thrust-fault terminology can be applied and hanging-wall and footwall thrusts of the individual duplex segments defined. In Fig. 57 this has been done by identifying the footwall ramps (FWR), thus distinguishing five imbricate thrust sheets about $1 \mathrm{~m}$ in thickness. The folds in the imbricate duplex segments include both hanging-wall anticlines and footwall synclines. As documented by the refolding of the upper hanging-wall anticline in Fig. 57, the folds are superimposed by sequential phases of folding and thus also phases of imbricate thrusting. Figures 58 and 59 illustrate the sequential development of imbricate thrusting; the imbrication steps forward towards the footwall ramp of UL02 to the south. Note also that the hanging-wall flat of each imbricate continues into an intraformational bedding-parallel thrust fault. This can be difficult to recognise in an isolated exposure, where the flats cannot be traced back to the ramp structures in the imbricate duplex (Fig. 53).

\section{Extensional faults}

In the trailing part of the SN03 thrust sheet, listric extensional faults have been observed (Fig. 60). Displacements along the faults are up to $0.5 \mathrm{~m}$ and the 

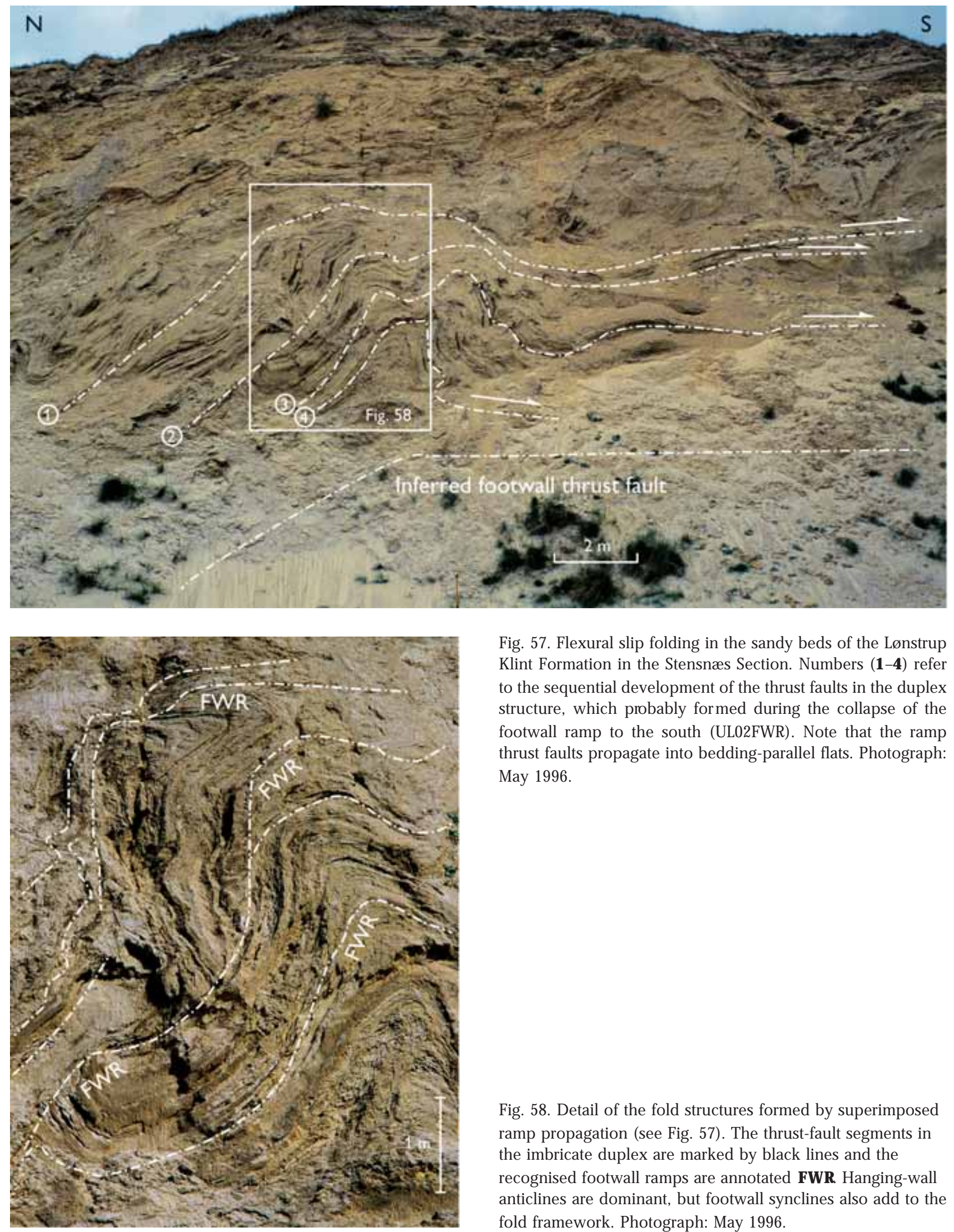

Fig. 57. Flexural slip folding in the sandy beds of the Lønstrup Klint Formation in the Stensnæs Section. Numbers (1-4) refer to the sequential development of the thrust faults in the duplex structure, which probably formed during the collapse of the footwall ramp to the south (UL02FWR). Note that the ramp thrust faults propagate into bedding-parallel flats. Photograph: May 1996.

Fig. 58. Detail of the fold structures formed by superimposed ramp propagation (see Fig. 57). The thrust-fault segments in the imbricate duplex are marked by black lines and the recognised footwall ramps are annotated FWR Hanging-wall anticlines are dominant, but footwall synclines also add to the fold framework. Photograph: May 1996. 


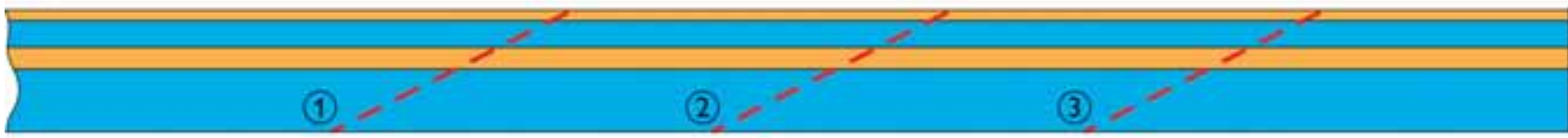
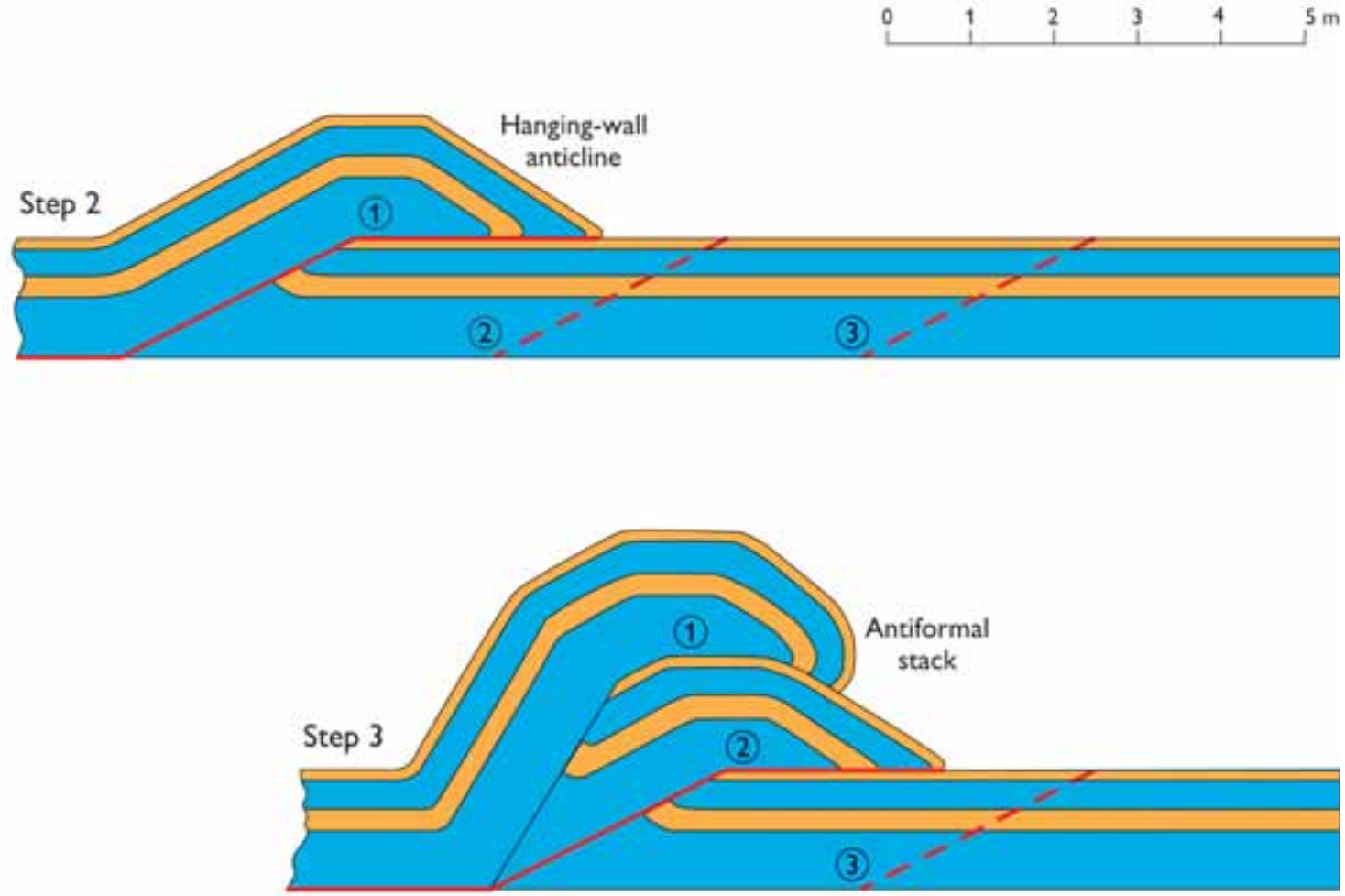

Clayey mud

Fine sand

Thrust fault

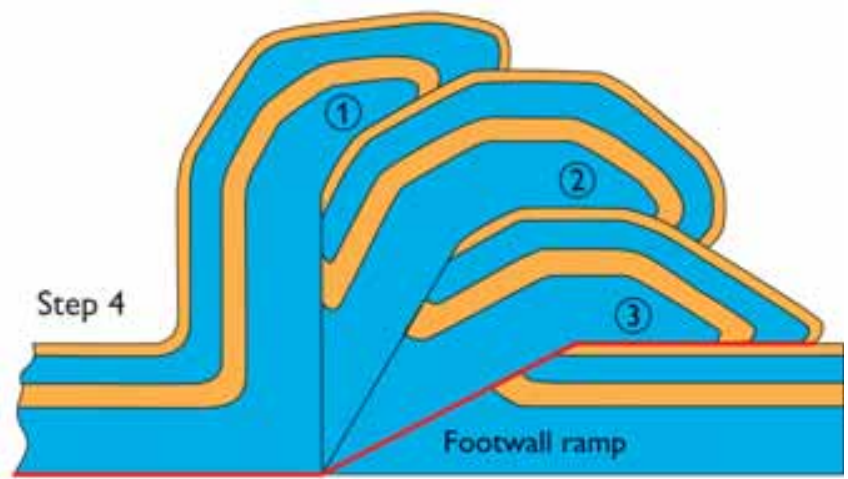

Fig. 59. Simplified model of superimposed folding formed by sequential imbrication in a duplex complex. Step 1 shows the undeformed beds with the ramps bordering the segments indicated. The numbers refer to the sequentially propagating hangingwall ramps. Step 2 shows the first hanging-wall anticline to be formed by the progressive collapse of the trailing end of the footwall block (footwall ramp collapse). Step 3 illustrates the formation of an antiformal stack during the progressive superimposed deformation. Step 4 demonstrates the developed stage of superimposed fault-bend folding comparable to the structures illustrated in Figs $57,58$. 

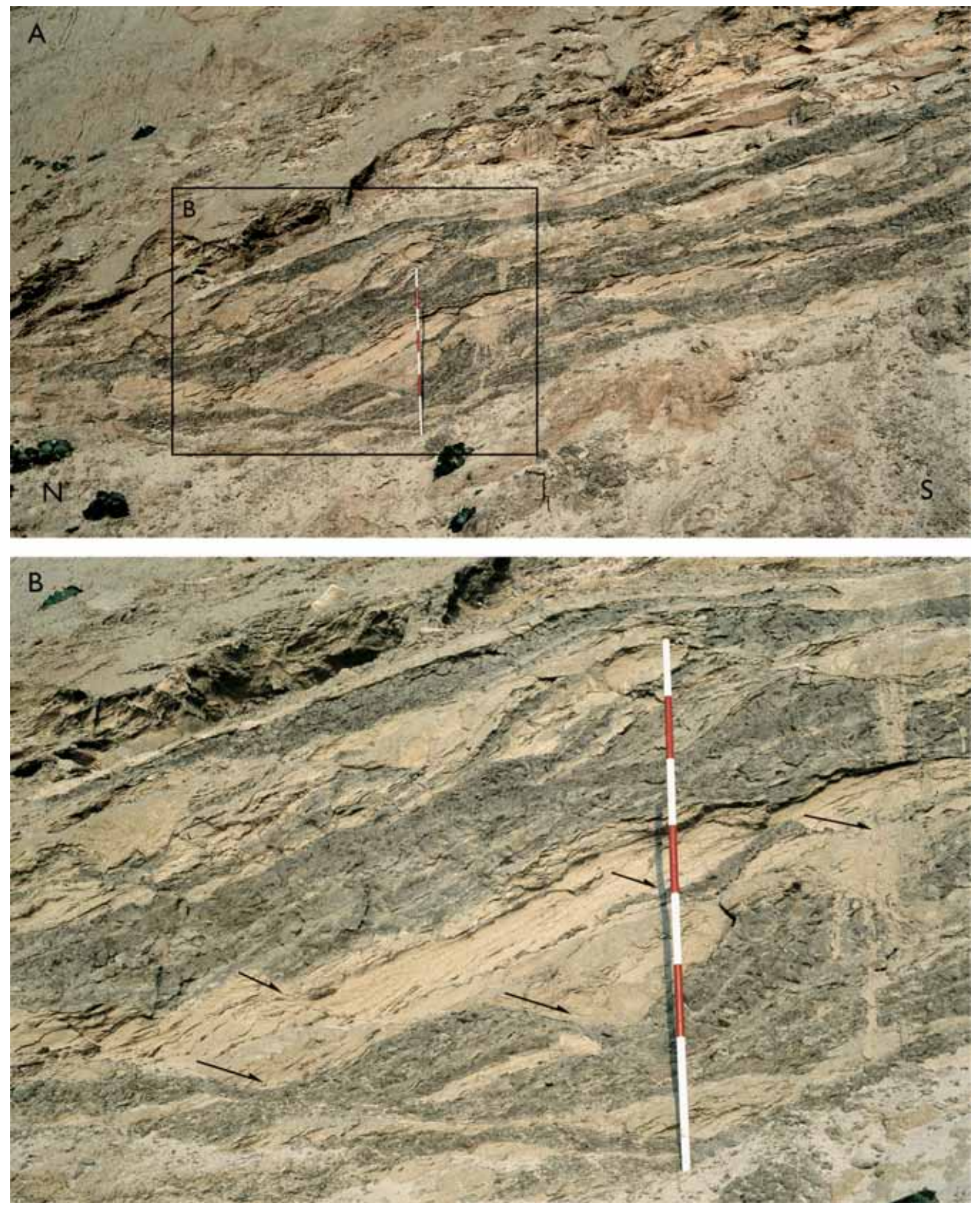

Fig. 60. Low-angle listric extensional faults in the SN03 thrust sheet, in the central part of the Stensnæs Complex. A: An overview of the macroscopic structure, where the SN04 thrust sheet ramps up along the footwall flat of SN03 and pushes it laterally in the back. The resultant extensional fault imbricates form a boudinage-like network. B: Detail of the listric extensional faults (arrows) interpreted to have been formed by push-from-the-rear. Photograph: July 1996; staff divisions are $20 \mathrm{~cm}$. 


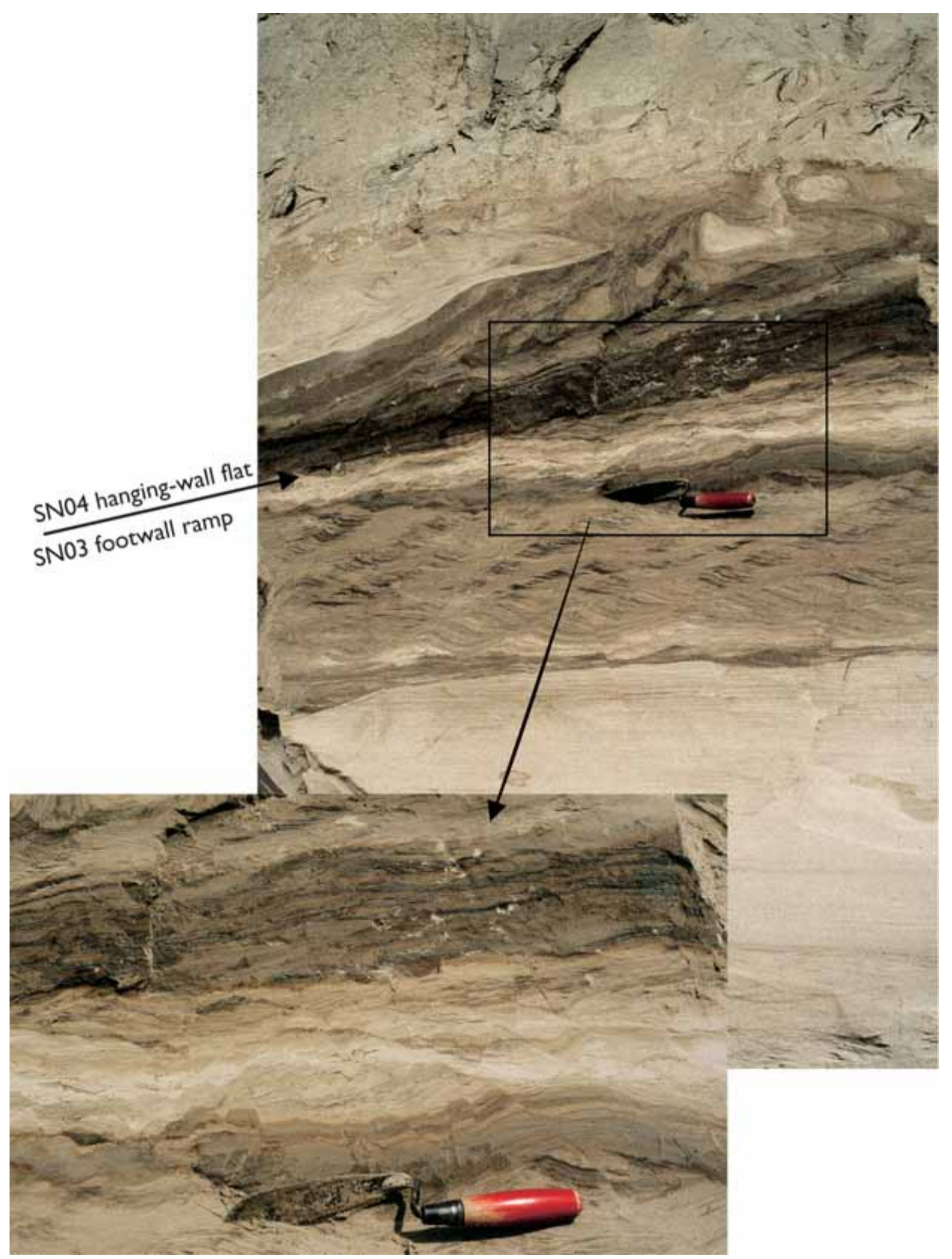

Fig. 61. Illustration of the difference between the mild deformation affecting the top of the footwall block and the strong deformation of the hanging-wall block. Only a $20 \mathrm{~cm}$ thick zone below the shear-laminated thrust-fault surface was affected by low-angle extensional faulting grading down into a minor normal fault network. It is thus evident that the elevated water pressures supporting the thrust sheet were transmitted to the hanging-wall flat, where intense hydrodynamic brecciation took place. Photograph: July 1998. 
spacing between the faults is $0.2-0.6 \mathrm{~m}$, which creates a boudinage-like network. The structures are interpreted to have been formed by push and loading of a thrust sheet ramping the formerly monoclinal fault-bend-folded thrust sheet, which responded to the gravity spreading by displacements along the extensional faults.

Similar mini-scale extensional normal faults are recognised in the footwall block below the hanging-wall flat of SN03 (Fig. 61). It is remarkable that the thrustfault deformation only weakly affects the top of the footwall block, while the hanging-wall block is strongly affected by hydrodynamic brecciation. A zone only $20 \mathrm{~cm}$ thick below the shear-laminated thrust-fault surface is affected by low-angle extensional faulting, and grades down into a minor normal fault network (Fig. 61). Isoclinal folding has been observed in the narrow shear-laminated thrust-fault zone, adding to the impression of high strain along the thrust fault. However, it is clear that the elevated water pressures supporting the thrust sheet were located in the hanging-wall flat.

\section{Interpr etation of structural development}

The formation of the imbricate duplex fold complex in the Stensnæs Section is evidently related to ramp propagation. Two footwall ramps are significant: the footwall ramp of UL01, which can be regarded as representing the footwall ramp of the foreland, and the footwall ramp of the trailing end of UL02. The UL01 footwall ramp acted as a stopping block for the forward push of the imbricate thrust sheets, and the propagation of this ramp was responsible for the general gentle northerly tilt of the structures. The UL02 footwall ramp was subjected to successive thrust-fault splay formation, and consequently imbrication and superimposed folding, which can be viewed as the collapse of the trailing end of the UL02 thrust sheet.

The imbricate duplex fold complex of the Stensnæs Section can be readily compared to the model for connecting splay duplexes of the Sevier thrust belt in the Cordilleran Fold Belt (Mitra \& Sussmann 1997). There is a close similarity with respect to the growth of the duplex by successive connecting splays of the thrust fault and the creation of folds by thrust-fault propagation. Moreover, the analysis of the imbricate duplex fold complex implies that the imbrication started at the footwall ramp in the trailing end of the system and propagated towards the foreland. It can therefore be argued that the process was one of footwall ramp collapse. A simplified model for the growth of duplexes in a connecting splay duplex system is illustrated in Fig. 59.

With respect to the thrust-fault displacement, an active and a passive stage of translation need to be distinguished.The active translation is the amount of displacement of the thrust sheet arising from propagation along its hanging-wall thrust fault. The passive translation is the amount of transport arising from the displacement of the underlying thrust sheet which carries it piggyback fashion. During this latter translation, the underlying thrust sheet may propagate footwall ramps, which will fold the actively translating thrust sheet as well as the piggyback thrust sheets into hanging-wall anticlines. This type of deformation will create an antiformal stack. The Stensnæs imbricate duplex fold complex may thus also be viewed as a mesoto macroscopic-scale antiformal stack (Fig. 59).

A roof thrust, which is $110 \mathrm{~m}$ long and about 8-12 $\mathrm{m}$ thick covers the SN01-SN02 duplex. The accumulated length of the three duplex segments is $175 \mathrm{~m}$; c. $65 \mathrm{~m}$ is thus missing in the balance calculation of the southern half of the Stensnæs Section. It is most likely that part of the initial thrust sheet has been eroded away, but up to c. $45 \mathrm{~m}$ of it might have been incorporated in a foreland-dipping frontal thrust structure preserved in the chaotic imbricate fold complex.

\section{Martørv Bakker Section}

The name Martørv Bakker is derived from the peat exposed in the coastal cliff (Danish: $\mathrm{mar}=$ sea; tørv = peat; bakker = hills), which is covered by aeolian sand dunes above the northern end of the section. In the southern part of the section, the Vendsyssel Formation forms the top unit in the cliff. The Vendsyssel Formation was deposited on an erosional unconformity above the glaciotectonic complex. All the posttectonic deposits are prone to cliff erosion and the resultant scree partly obscures the structures in the Martørv Bakker Section. In addition, the unconformity at the base of the planar-bedded Vendsyssel Formation is a focus for groundwater seep which also conceals details in the exposures. However, two important architectural elements have been recognised: (1) the common appearance of minor duplexes in the southern part of the section, and (2) the occurrence of southerly dipping normal faults in the northern part.

The southem boundary of the section is the footwall ramp of SNO4 in the trailing end of the Stensnæs 


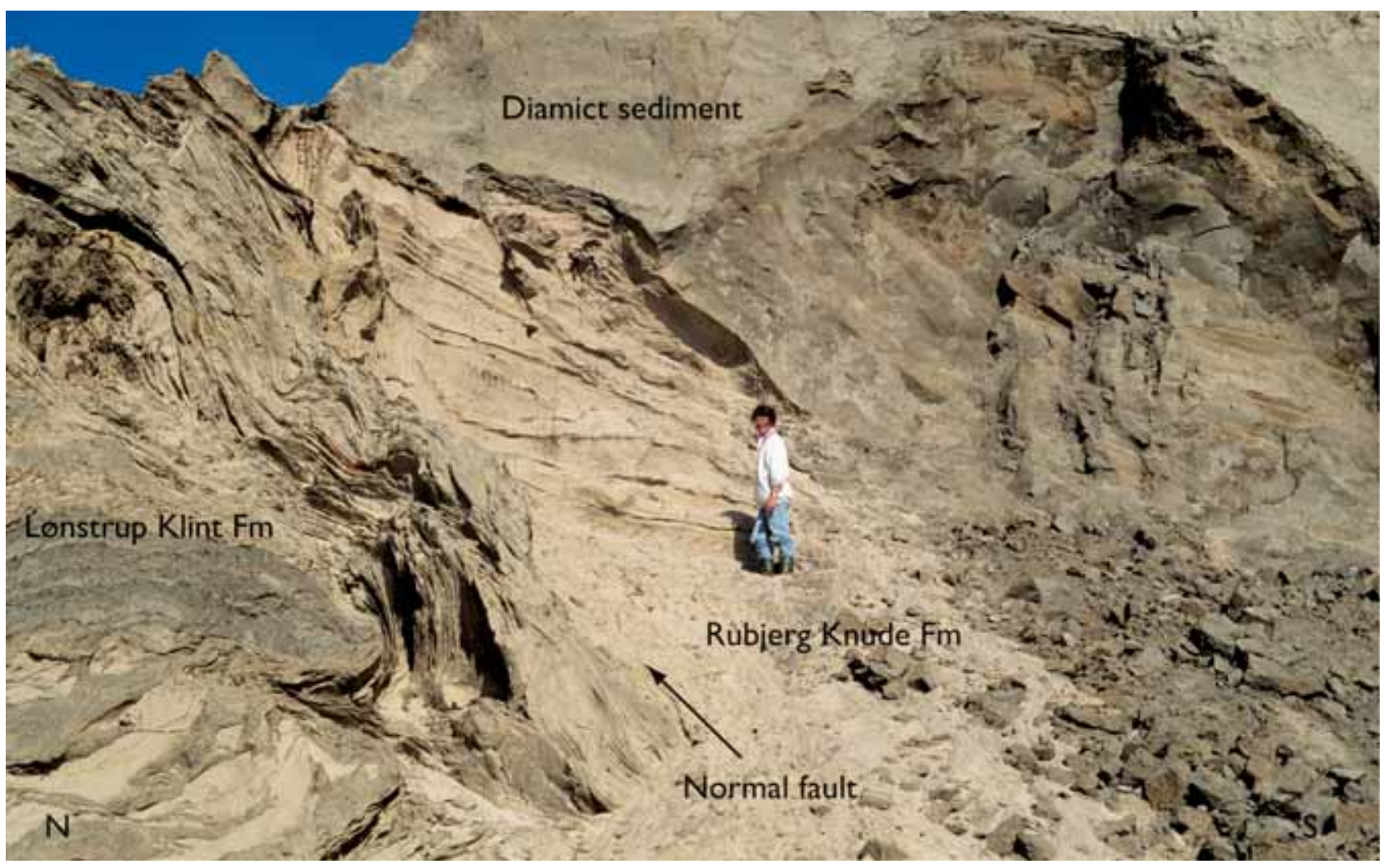

Fig. 62. The normal fault developed in the central part of the Martørv Bakker Section. In the hanging-wall block to the south, the fluvial sands of the lower part of the Rubjerg Knude Formation are preserved in a 'fault trap' along the fault plane. Diamict sediments were deposited above the sand in a piggyback basin that developed during the thrust faulting of the MB02 thrust sheet. Note that the thickness of the Lønstrup Klint Formation in the footwall block decreases downwards along the normal fault drag. This is interpreted as a foreland-dipping limb related to a hanging-wall anticline formed prior to offset by the normal faulting. The formation of the normal fault is interpreted to be related to a foreland-dipping limb of a hanging-wall anticline at the tip of a subsurface thrust-sheet segment (MB02u3 in Plate 2). Photograph: June 1993.

Section. The northem boundary is not defined by a simple reference point in the cross-section, but by the trailing end of the MB04 thrust sheet which is a combination of footwall ramp and footwall flat below the leading-edge thrust fault of the Kramrende Section.

\section{Tectonic architecture}

The Martørv Bakker Section is subdivided into four thrust sheets (MB01-MB04). The thrust sheets in the southern part of the section are subdivided into upper and lower duplex segments of which only the lower duplex segments are distinguished by separate annotations (MB02u1-MB02u3, Plate 2). In the frontal part of the section, smaller imbricate duplexes are associated with syntectonically formed hydrodynamic breccias and ball-and-pillow structures.

The MB01 thrust sheet is up to $20 \mathrm{~m}$ thick and com- prises the upper part of the Lønstrup Klint Formation. The frontal hanging-wall ramp was thrust up along the $15^{\circ}$ dipping footwall ramp of SN04, and displacement is estimated at about $55 \mathrm{~m}$. The bedding becomes steeper in the trailing end of the thrust sheet, probably due to the relatively steep dip of the ramp in the subsurface from the $20 \mathrm{~m}$ to the $10 \mathrm{~m}$ flat level.

The MB02 thrust sheet is long and flat-lying and occupies more than $400 \mathrm{~m}$ of the section. The frontal part is only $10-15 \mathrm{~m}$ thick and was displaced along its upper hanging-wall flat along the footwall flat of MB01 for a distance of about $180 \mathrm{~m}$. The trailing part of the MB02 thrust sheet is $20 \mathrm{~m}$ thick, but as indicated in the balanced cross-section it roots down to the $30 \mathrm{~m}$ décollement level (Plate 2). The thrust sheet is displaced by a prominent normal fault in the central part of the Martørv Bakker Section (Fig. 62). Above the Lønstrup Klint Formation, a marked basin developed in the hanging-wall block of the normal fault. The 

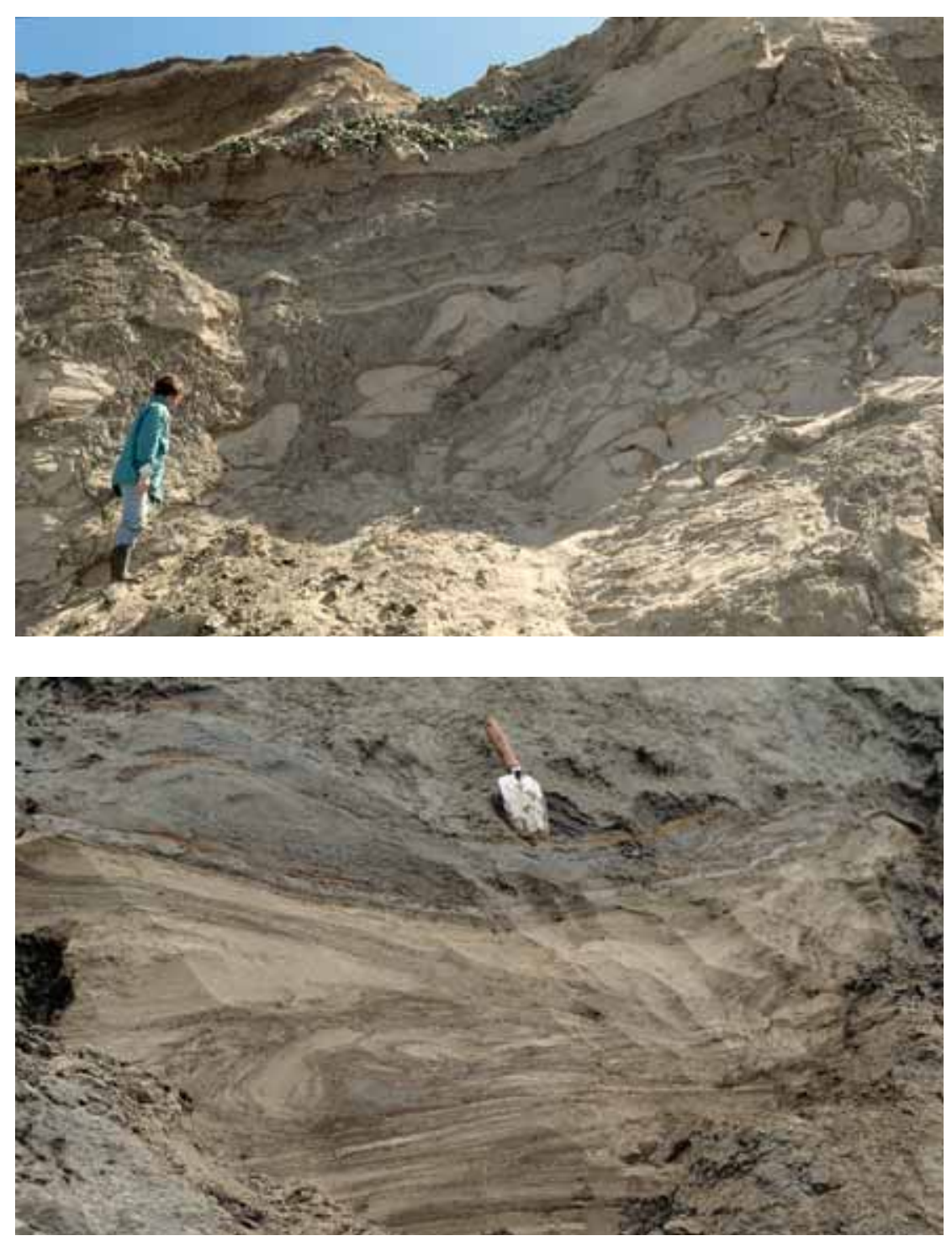

Fig. 63. Hydrodynamic brecciation in the Lønstrup Klint Formation in the northern part of the Martørv Bakker Section. Photograph: June 1993.
Fig. 64. Slump-fold structures formed in the thin-bedded sand layers enveloped in dark muds of the diamict sediments in the piggyback basin in the Martørv Bakker Section. Photograph: October 1998. sediments in this basin were described as moraine sand by Jessen $(1918,1931)$.

The MB03 thrust sheet is $30 \mathrm{~m}$ thick and made up of the Lønstrup Klint Formation, which is here strongly deformed by hydrodynamic brecciation and dislocated by a number of bedding-parallel minor thrust faults. Thefrontalpart isflat-lying, whereasthe dip of the bedding increases to $25-30^{\circ}$ at the trailing end indicating a bend over an upper hinge on top of the footwall ramp of MB02. In the exposed part of the section, the MB03 thrust sheet is only about $120 \mathrm{~m}$ long, and it is inferred that the foreland-dipping structures in the frontal part reflect re-orientation due to hanging-wall ramp propagation along the footwall flat of MB02.

The MB04 thrust sheet forms a flat-topped hanging-wall anticline above the footwall ramp of MB03.
The thrust sheet is displaced along a nomal fault parallel to the foreland-dipping bend in the top of the frontal part of MB03. The normal fault does not displace the footwall flat of MB02, and is therefore regarded as a structure related only to the framework of MB03 and MB04. The structural framework in this part of the section may be characterised as an antifomal stack, including thrust sheets MB03 below and KR01 above MB04.

\section{Sedimentary units}

The Martørv Bakker Section is dominated by the Lønstrup Klint Formation. However, the most important sedimentological feature in the section is related to 
the basin developed at the top of the hanging-wall block connected to the normal fault displacing the MB02 thrust sheet (Fig. 62). The deposits in this basin are regarded asan exotic part of the Rubjerg Knude Formation, and are described under this heading below.

The southern part of the Martørv Bakker Section is unconformably overlain by the Vendsyssel Formation, the initially glaciotectonic truncation being superimposed by a post-glacial erosional unconformity. A Holocene erosional unconformity truncates the Vendsyssel Formation as well as the glaciotectonic unconformity, and the peat deposited on this unconformity is up to $2 \mathrm{~m}$ thick in the northem part of the section, where it iscovered by modern aeolian dunes up to $20 \mathrm{~m}$ high.

\section{Lønstrup Klint Formation}

The lower part of the Lønstrup Klint Formation is mudrich. It is exposed in the northem part of the section, where it was thrust above the hanging-wall flat from the décollement surface $25-28 \mathrm{~m}$ below sea level. The upper part of the formation is dominated by $0.5-1.5$ $\mathrm{m}$ thick sand beds interlayered with thin beds of horizontally laminated mud, which typically has been mobilised to form hydrodynamic breccias. In the southern part of the section, the beds are strongly affected by ball-and-pillow deformation (Fig. 63).

\section{Rubjerg Knude Formation}

The Rubjerg Knude Formation comprises two units: (1) a lower $3 \mathrm{~m}$ thick sand unit only exposed along the prominent normal fault in the central part of the Martørv Bakker Section, and (2) a c. 15 m thick diamictite interpreted as a glaciolacustrine mud with redeposited clasts. The first unit was deposited on the L/R-unconformity, and comprises light yellowish medium-grained sand (Fig. 26). The diamictite unit rests partly on the lower sand unit, and partly on the L/Runconformity at the top of the Lønstrup Klint Formation. The diamictite is dark grey, and comprises weakly laminated mud interbedded with structureless, irregularly distributed matrix-supported beds containing
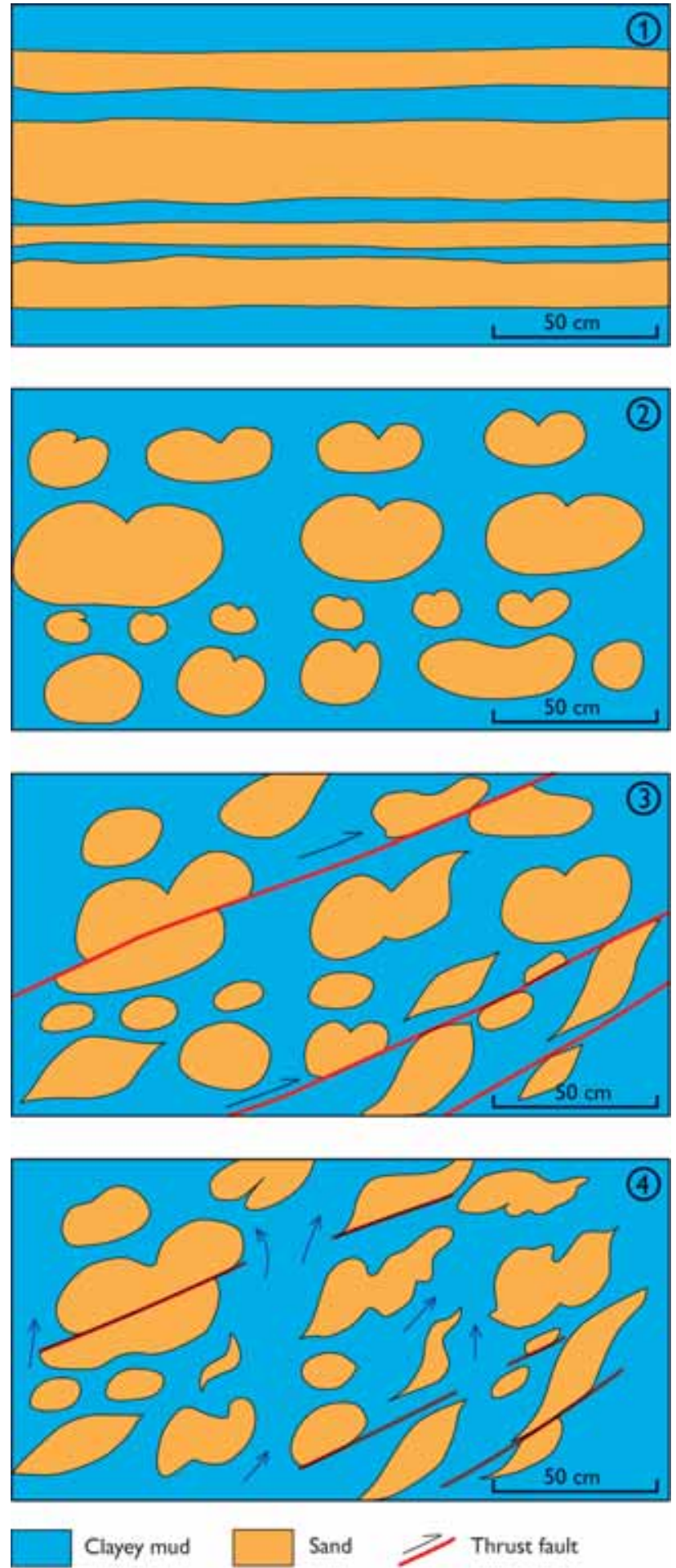

7 Direction of intrusive mud flow

Fig. 65. A schematic diagram explaining the development of the hydrodynamic brecciation displayed in Fig. 63. The formation of the structure was the result of three phases of deformation. In the first phase, a succession of sandy turbidites interbedded with mud (1) was affected by loading to form the ball-and-pillow structures (2). In the second phase, the ball-and-pillow structures were displaced by thrust faulting (3). During the third phase, the mobilised mud intruded up thorough the thrust-fault surface (4), demonstrating the syntectonic development of the hydrodynamic brecciation. 
unsorted clasts in a matrix of sandy mud (Fig. 26). In the lowermost $2 \mathrm{~m}$ of the diamictite succession, the matrix-supported clasts were probably derived by redeposition of coarse-grained material eroded from the L/R-unconformity to the north. About $3 \mathrm{~m}$ up in the succession, a c. $1 \mathrm{~m}$ thick bed occurs with clay clasts $10 \mathrm{~cm}$ in size deposited in a weakly clay-laminated and sand-streaked silty mud. This bed is overlain by three 1.5-3 m thick units of isoclinally slump-folded, thin-bedded, fine-grained sand encased in dark structureless mud (Fig. 26). These units are interpreted as slump-folded sheets derived from the Lønstrup Klint Formation (Fig. 64). The middle and upper slump-units are separated by a c. $5 \mathrm{~m}$ thick interval dominated by sandy mud with scattered clasts and a few thin sand beds. The uppermost sand bed was not affected by slumping and shows large-scale trough cross-bedding.

The lower part of the diamictite succession is strongly disturbed by hydrodynamic brecciation with mesoscopic-scale diapirs rising from the top of the Lønstrup Klint Formation and penetrating upwards into the diamict sediments. This indicates that the diamictites were part of the main sedimentation affected by glaciotectonic disturbances.

\section{Structures}

In the Martørv Bakker Section, three types of structural elements were studied: (1) imbricate duplexes dominating the southern part of the section, (2) the normal fault in the central part of the section, and 3) hydrodynamic brecciation contemporaneous with, or superimposed on, ball-and-pillow structures (Figs 63, 65).

\section{Imbricate duplexes}

The imbricate duplexes in the southern part of the section constitute rhomb-shaped segments 10 to $25 \mathrm{~m}$ in size bounded by low-angle thrust faults. Minor imbricates may occur along the thrust faults, but the thrust faults are mainly narrow fracture surfaces without significant brecciation.

A mini-scale example of duplex fomation is shown in Fig. 66. Although the structure is related to intraformational deformation of the beds, it illustrates instructively the formation of hanging-wall ramp propagation of a stacked footwall ramp. Thus the footwall ramp is formed by the trailing edges of two duplex segments that were displaced one over the other to form a single planar ramp for the propagation of the upper thrust sheet. Flame-like upright minor anticlines are interpreted as compressed hanging-wall anticlines formed during the sequential propagation of the various ramps. On top ofthe upper footwall hinge, a radial flame structure probably indicates the site of incipient diapirism (Fig. 66). The formation of foreland-dipping thrust structures above the tip of a lower duplex segment is also apparent.

\section{N ormal fault}

The normal fault in the central part of the section is an uneven fault plane striking E-W with a dip of about $45^{\circ}$ to the south. Displacement along the fault plane is about $25 \mathrm{~m}$, and a set of minor normal listric faults displace the top of the hanging-wall block (Fig. 62). The footwall block comprises the Lønstrup Klint Formation, which decreases in thickness southwards and forms an irregularly folded drag along the fault plane. At the top of the hanging-wall block, the diamict sediments described above are discordantly superposed on the light-coloured sand at the base of the Rubjerg Knude Formation.

\section{Hydrodynamic brecciation}

Ball-and-pillow structures occur in the sand-rich parts of the Lønstrup Klint Formation, where hydrodynamic mud mobilisation created chaotic breccias (Fig. 63). The initial size of the sand ball-and-pillow structures is related to the primary thickness of the beds, but subsequent to the sedimentary load deformation they were distorted and deformed during thrust-fault related mud remobilisation. In Fig. 63, the distorted ball-andpillow structures can beseen to be displaced by minor thrust faults, and these thrust faults were intruded by mobilised mud. The sequential development of this hydrodynamic brecciation is illustrated in Fig. 65, where three phases of defomation are recognised, although these probably developed progressively during thrust-fault displacement and related loading of superposed thrust sheets.

\section{Interpretation of structural development}

The thickness of MB01 implies that the décollement surface in the southern part of the section is situated 


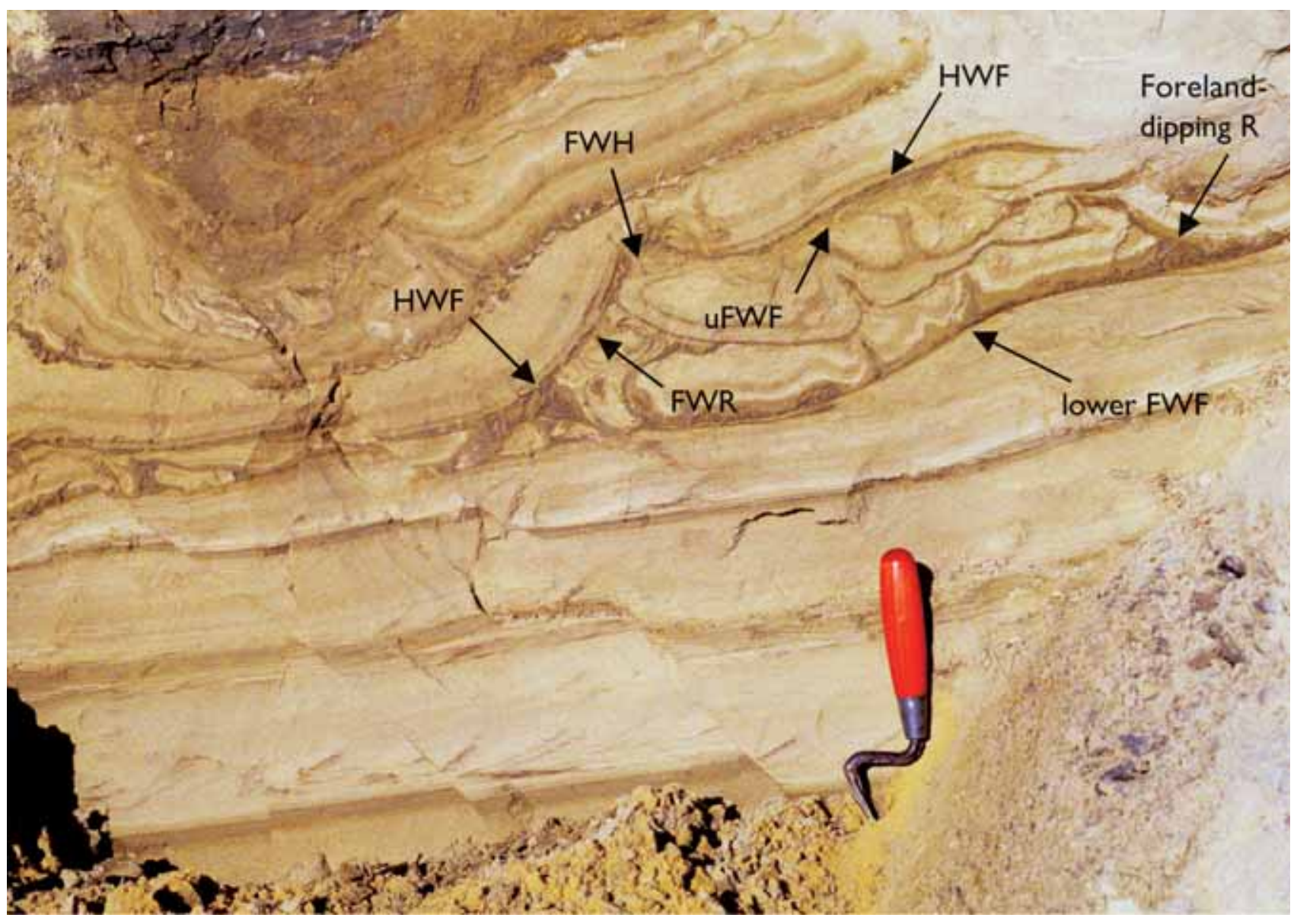

Fig. 66. A model of duplex formation is here illustrated by a mini-scale structure related to intraformational deformation of beds in the Lønstrup Klint Formation, central part of Martørv Bakker Section. The duplex comprises two segments, which were derived from the bed underlying the lower footwall flat (lower FWF). The footwall ramp for the segments is situated to the left outside the frame of the figure. The lower segment is a relatively short one, which was thrust over by the upper segment during the push from the ramping of the upper thrust sheet. During propagation up the footwall ramp, the trailing edges of the two segments were displaced to form one planar ramp for the upper thrust sheet, which was further translated over the duplex to a foreland-dipping bend created above the tip of the lower duplex segment. The flame-like upright anticlines are interpreted as compressed hanging-wall anticlines formed during the sequential propagation of the various ramps. Note the radial flame structures at the upper footwall hinge indicating incipient diapirism. The small normal faults to the left of the trowel ( $15 \mathrm{~cm}$ in size) are thought to reflect similar forelanddipping features in the subsurface. FWH, footwall hinge; FWR, footwall ramp; $\mathbf{~ F W F , ~ u p p e r ~ f o o t w a l l ~ f l a t ; ~ H W F , ~ h a n g i n g - w a l l ~ f l a t ; ~} \mathbf{R}$, ramp. Photograph: June 1993.

at the $20 \mathrm{~m}$ level. The thickness of MB03 is $30 \mathrm{~m}$, implying that the décollement level stepped down 10 $\mathrm{m}$ somewhere in the central part of the section. A lower footwall ramp and a corresponding hangingwall ramp must therefore be included in the balanced cross-section. The L/R-unconformity reference surface on top of the MB02 thrust sheet was about $20 \mathrm{~m}$ above present sea level prior to the normal fault displacement, which indicates that a duplex $20 \mathrm{~m}$ in thickness is situated below the trailing end of MB02. The lower footwall ramp responsible for the fault-propagation folding of the antiformal stack in the northem part of the section, estimated from the bend of the trailing ends of MB02 and MB03, must be situated below MB02. The structural model therefore suggests that a subsurface duplex was formed by segments of the MB02 thrust sheet situated between the 20 and $30 \mathrm{~m}$ levels (MB02u1-MB02u3). The footwall ramp thus constitutes two $10 \mathrm{~m}$ thick duplex segments stacked on top of each other.

Consequently, a hanging-wall anticline with a foreland-dipping limb formed above the hanging-wall ramp of MB02 and was translated along a footwall flat. The model further suggests that the hanging-wall 


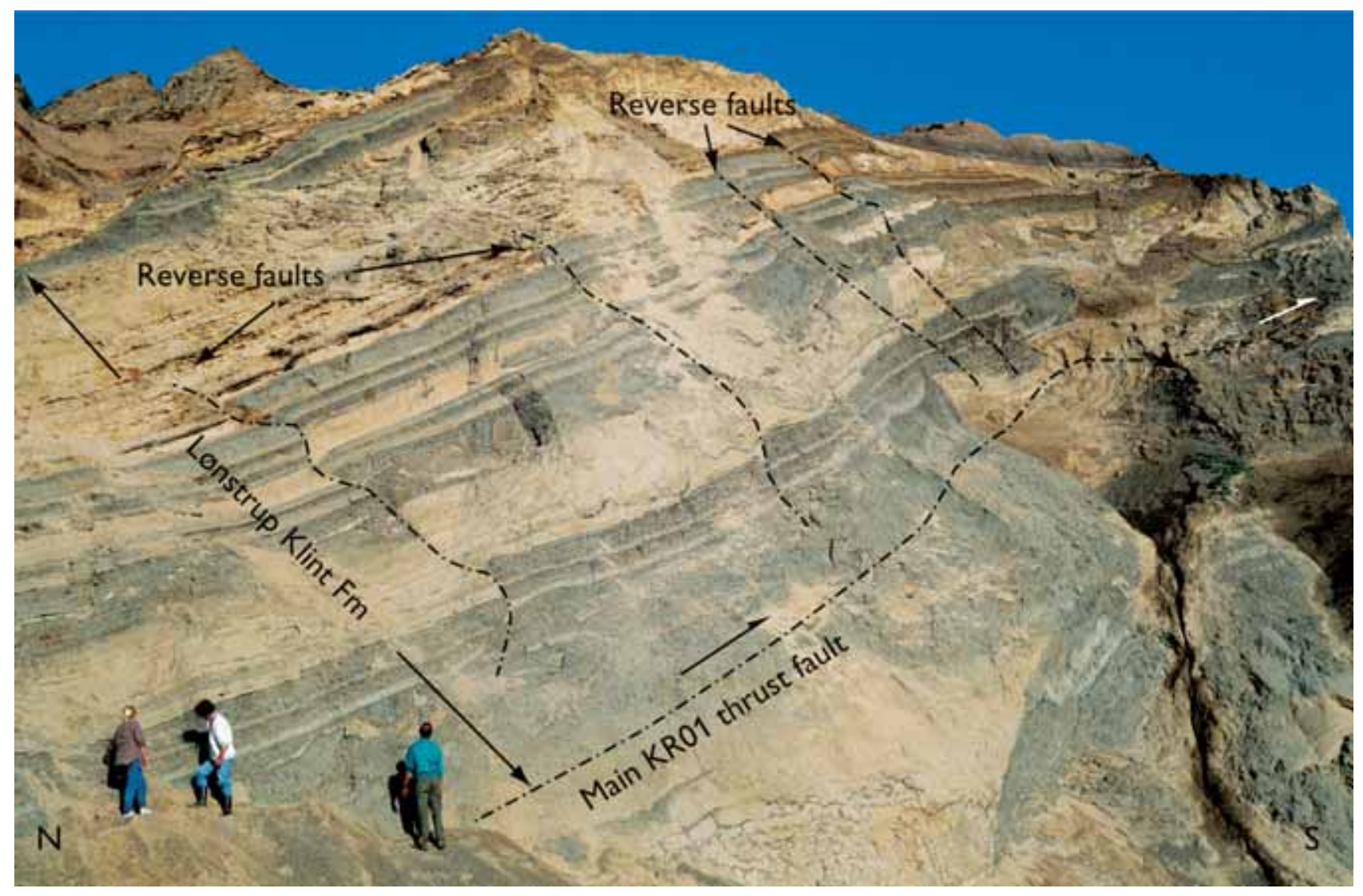

Fig. 67. The northern part of the KR01 thrust sheet where the lithostratigraphic reference section of the Lønstrup Klint Formation (Fig. 21) is situated. The thrust sheet is fault-bend-folded up along an initially low-angle (c. $8^{\circ}$ ) footwall ramp, which was subsequently folded into the present more steeply dipping orientation. Note the reverse faults interpreted as small back-thrust faults. Photograph: June 1993.

structure is a composite feature partly constructed by the hanging-wall anticline related to the tip of the MB02u3 segment folded over the footwall ramp of MB02u2, and partly by the hanging-wall anticline related to the translation of the main hanging-wall ramp of MB02 along the $10 \mathrm{~m}$ level. The foreland-dipping limb of this structure corresponds well with a $45^{\circ}$ south-dipping normal fault with a vertical displacement of about $20 \mathrm{~m}$.

It is therefore concluded that the northern slope of the diamict sedimentary basin was formed by the normal fault reflecting the foreland-dipping limb of a hanging-wall anticline. The southern more gently dipping slope of the basin was formed by the bend of MB02 due to its propagation up along the footwall ramp and flat of MB01. This footwall thrust fault is a composite imbricate duplex, which hampers the exact distinction of ramp-flat relationships. The slumpfolded units in the basin are interpreted as the result of gravity slides derived from the crest of the hang- ing-wall anticline or the tip of the MB04 thrust sheet propagating from the north. The sediments filling the basin represent redeposited material derived from the thrust-fault elevated part of the Lønstrup Klint Formation, the coarse-grained clastics on the L/R-unconformity, and the lowermost part of the Rubjerg Knude Formation. The basin is interpreted as a piggyback basin with syntectonic deposition during the translation of the MB02 thrust sheet.

\section{Kramrende Section}

From the south, the first significant macroscopic-scale diapir occurs in the Kramrende Section (the Kramrende diapir). Although mobilisation features also occur in sections farther to the south, this diapir is regarded as the most distal in the glaciotectonic thrustfault complex. The thickness of the thrust sheet hosting the Kramrende diapir suggests it is related to the 
Fig. 68. Ball-and-pillow structure developed in the sandy turbidite bed between 4 and $5 \mathrm{~m}$ in Fig. 21. The structure is interpreted as a load structure formed immediately after sedimentation. Additional load structures can be seen at the base of the sand bed, where flame structures related to the underlying clayey bed intrude the base of the sand bed. Above the balland-pillow structure, pinch and swell structures within the sand bed are also interpreted as gravity load structures. Photograph: June 1993.

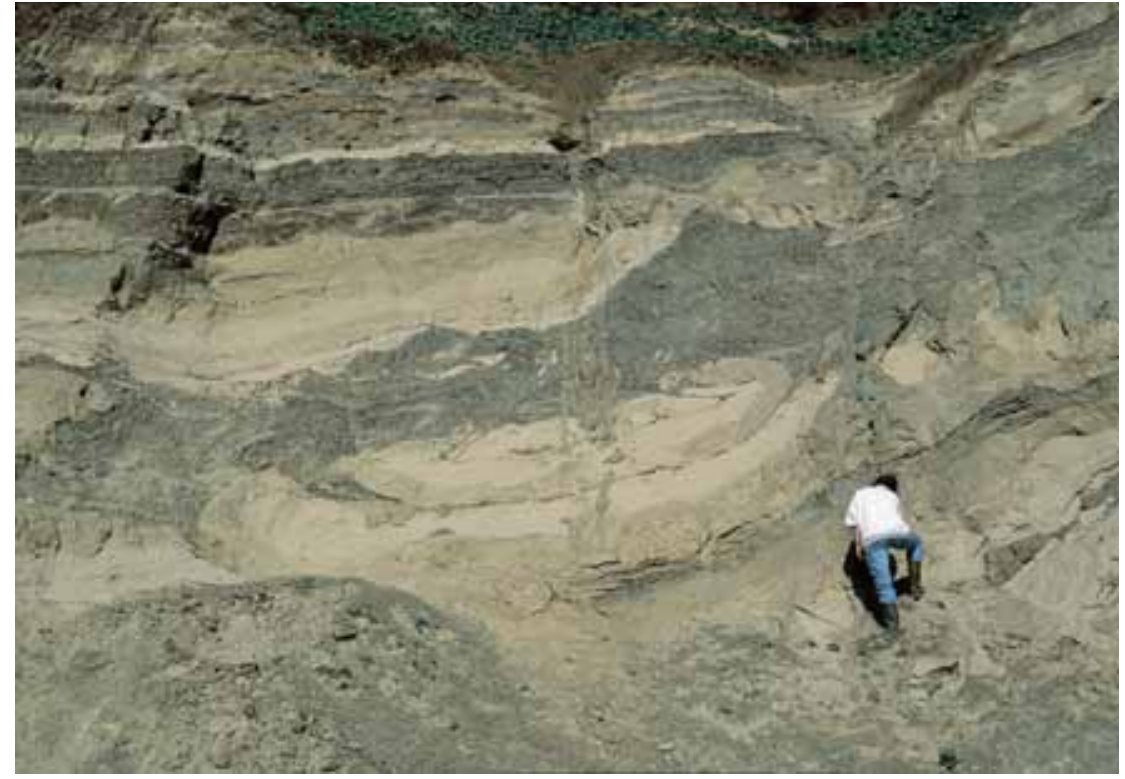

Fig. 69. In the upper part of the KR04 thrust sheet in the Kramrende Section, the Rubjerg Knude Formation forms a piggyback basin, which is overthrust by the BR01 thrust sheet in the southern part of the Brede Rende Section. The thrust fault displayed in the photograph is a hanging-wall flat for the thrust sheet BR01 (BR01HWF) and footwall ramp of thrust sheet KR04 (KR04FWR). A minor satellite thrust fault was formed below the main thrust at a late stage of fault propagation after the sand of the Rubjerg Knude Formation had been somewhat compacted. Photograph: June 1984.

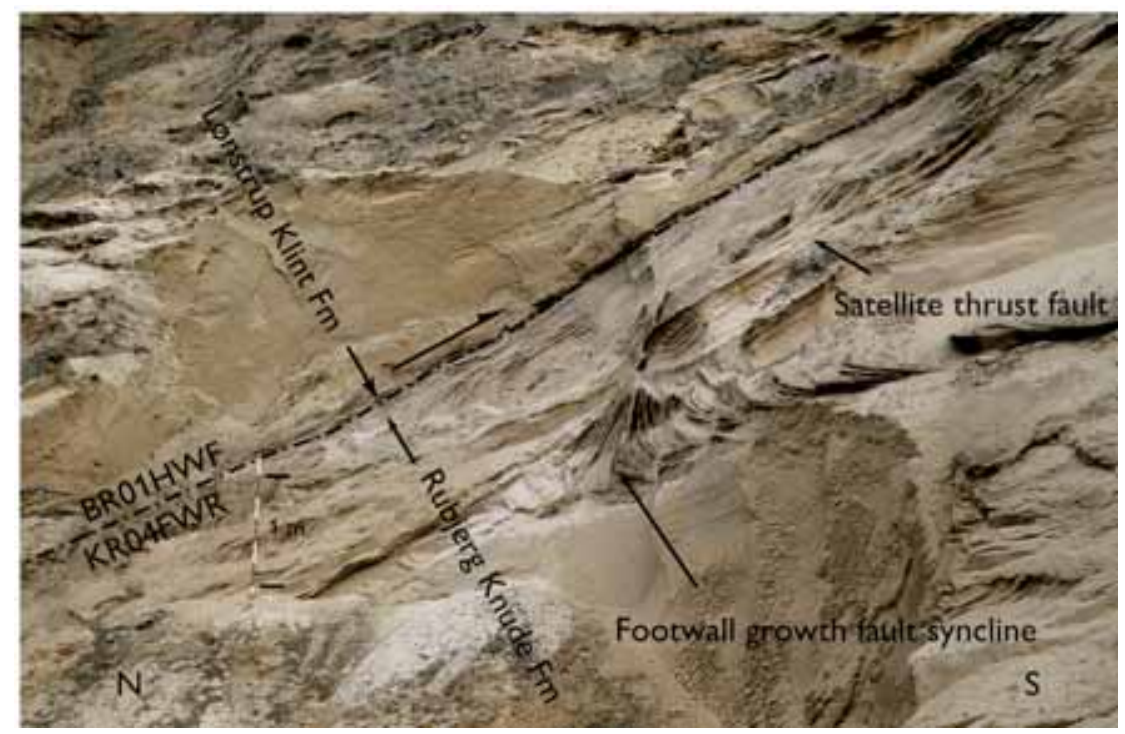

deep level of thrust-fault rooting, which is about $30 \mathrm{~m}$ below the L/R-unconformity. The thrust sheet to the south of the Kramrende diapir and two thrust sheets to the north are included in the section because they are all affected by the structures related to the diapir. The frontal edge of the Kramrende Section is formed by the footwall ramp beneath the first thrust sheet (KR01, see Plates 1, 2). This thrust fault is identical with the trailing-edge footwall ramp of the Martørv Bakker Section, which is responsible for the marked monoclinal fault-bend folding of the KR01 thrust sheet (Fig. 67). The steps to the beach are situated in the gully between the KR01 thrust sheet and the Kramrende diapir. The steps lead up to the summerhouse area at Oddervej, and are referred to as the Kramrende steps or the Oddervej Trappe.

\section{Tectonic architecture}

The Kramrende Section consists of four thrust sheets (KR01-KR04; Plates 1, 2). The frontal thrust sheet (KR01) is ramped over the MB04 footwall ramp in the Martørv Bakker trailing thrust sheet. At the north end of KR01, the L/R-unconformity is situated about c. $10 \mathrm{~m}$ a.s.l., which indicates that the KR01 hanging-wall ramp propagated along an intermediate footwall flat (FWF). The upper ramping along the MB04 footwall ramp is 

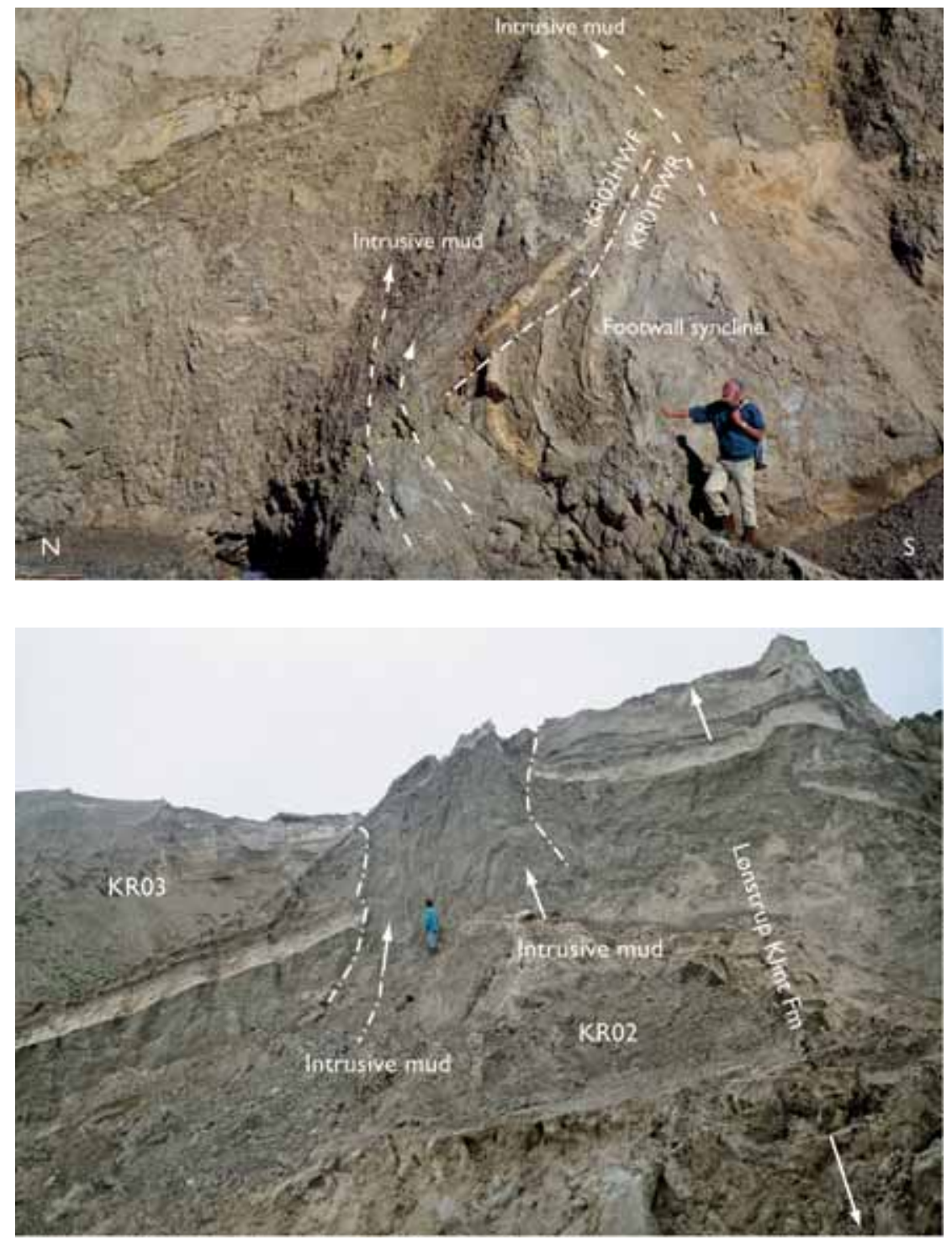

Fig. 70. The KR01 footwall syncline developed below the KR01 footwall ramp (KR01FWR), which is overlain by the KR02 hanging-wall flat (KR02HWF). Note how the mobilised mud migrated from the steeply dipping limb of the footwall syncline up into the Kramrende diapir, intrusively penetrating the thrust fault. Photograph: June 1995.
Fig. 71. Mobilised mud from the lower part of the Lønstrup Klint Fomation in the KR02 thrust sheet intruded the turbidite sand beds in the upper part of the formation. Photograph: June 1995. responsible for the fault-bend-fold appearance of the KR01 thrust sheet. Above the frontal part of the MB04 footwall ramp and flat, the KR01 thrust sheet is folded into a flat-topped anticline. In the involute part of this anticline, a splint or horse is present (the KR01 splint). This is a small thrust-sheet wedge tom off during thrust propagation, which created peculiar anticlinal features in the structural profile.

The KR02 thrust sheet takes the form of a major diapir. Initially the diapir was a thrust sheet that was displaced up along the KR01 footwall ramp and above the back of the KR01 thrust sheet. The KR03 and KR04 thrust sheets situated on the back of KR02 are characterised by marked differences in the thickness of the Rubjerg Knude Formation. In the KR03 thrust sheet, the thickness is only about $8 \mathrm{~m}$, whereas in KR04 the thickness of the Rubjerg Knude Formation is up to 20 $\mathrm{m}$. This indicates that the KR04 thrust sheet was thrust over the upper footwall flat of KR03 at an earlier stage compared to a probably longer time of deposition in the piggyback basin of KR04. The c. $20^{\circ}$ northerly dipping inclination of the KR03 footwall flat and related parallel structures is due to the bend caused by the propagation of KR02 along the footwall ramp. The main décollement level below the Kramrende Section is situated at the $30 \mathrm{~m}$ level.

\section{Sedimentary units}

The description of the sedimentary units in the Kramrende Section is mainly based on sedimentological 
logging of the Lønstrup Klint Formation in the KR01 thrust sheet (Fig. 21). The detailed section of the Rubjerg Knude Formation at the top of this log is uncertain due to poor exposure and difficulty of access. The Rubjerg Knude Formation exhibits variations in thickness throughout the Kramrende Section, and the description herein is based on scattered observations. A c. $1 \mathrm{~m}$ thick homogeneous, structureless sandy till caps the Kramrende Section. No preferred clast fabric has been recognised in the till, and its stratigraphic position is uncertain, although the occurrence of rare rhomb porphyry erratics may indicate an affinity with the Norwegian Ice (Kattegat Till Formation).

\section{Lønstrup Klint Formation}

In the Kramrende Section, the lower part of the Lønstrup Klint Formation mainly occurs in the Kramrende diapir, within the KR02-03 thrust sheets. Remobilisation of the mud has obliterated primary sedimentary structures, and the diapirism also affected the thrust sheet KR03, so that only primary bedding is recognisable in the uppermost part of the formation. The primary sedimentary structures of the upper part of the Lønstrup Klint Formation are reasonably preserved in the KR01 thrust sheet (Fig. 20), although the sediments here, dominantly constituting sandy turbidite beds (10$50 \mathrm{~cm}$ thick), are strongly affected by hydrodynamic brecciation creating ball-and-pillow structures (Fig. 68).

The top of the Lønstrup Klint Formation in the Kramrende Section is truncated by the L/R-unconformity, which displays an erosional relief of 1-2 m.

\section{Rubjerg Knude Formation}

The Rubjerg Knude Formation varies in thickness from only 6-8 $\mathrm{m}$ at the top of the KR03 thrust sheet to about $20 \mathrm{~m}$ in the upper part of the KR04 thrust sheet (it is absent in KR02). The main part of the formation comprises thick-bedded, large-scale cross-bedded, medium-grained light yellow-grey sand. Some beds are rich in heavy mineral sand, which occurs in parallel-laminated strata. In the KR04 thrust sheet, the heavy mineral beds are present about $6 \mathrm{~m}$ above the L/Runconformity and again about $15 \mathrm{~m}$ above the base. These beds have a characteristic content of small (0.1$1 \mathrm{~cm})$, grey clayey mud-clasts, which are interpreted to reflect erosion of muddy thrust sheet units in the vicinity of the depocentre.
Pedersen (1987) described deposits, referred here to the Rubjerg Knude Formation, that accumulated syntectonically in footwall growth synclines. The deposits were characterised as 'banana' shaped basins, and a similar type of sedimentary/structural feature occurs in the KR04 thrust sheet (Fig. 69). The Rubjerg Knude Formation at the top of the Kramrende Section can be regarded as a piggyback basin and the footwall syncline as a growth-fault syncline. At the top of the piggyback basin, large-scale trough cross-bedded sand is truncated by small satellite thrust faults (similar to that shown in Fig. 69), which are truncated by superposed c. $1 \mathrm{~m}$ thick trough cross-bedded sand beds. Three succeeding developments of this interference between thrusting and deposition reflect the syntectonic depositional dynamics of the piggyback basin.

\section{Structures}

Structures of significance in the Kramrende Section are described under the following headings: (1) thrust faults, and in particular associated footwall ramps and footwall synclines, (2) the Kramrende diapir, with the diapiric breccias and intrusive structures formed by mobilised mud, and (3) reverse faults, here interpreted as back-thrust faults.

\section{Thrust faults}

The KR01 thrust sheet is bounded by the hangingwall ramp and flat (KR01HWR and HWF) at the base, and the KR01 footwall ramp and flat at the top (KR01FWR and FWF). The wedge-shaped geometry of the KR01 tip implies that the KR01HWR had a low angle of inclination, dipping about $15^{\circ} \mathrm{N}$. Towards the trailing end of the thrust sheet, the ramp passes into a hanging-wall flat which is parallel to bedding in the Lønstrup Klint Formation. This thrust fault now dips at $25^{\circ} \mathrm{N}$, although it is a hanging-wall flat situated on a footwall flat. This is due to the fault-bend folding related to the thrusting in the trailing part of the Martørv Bakker Section.

At its trailing end, the KR01 thrust sheet is folded into a footwall syncline (Fig. 70). The bend of the northern limb in the syncline lifted the L/R-unconformity up to a position nearly $5 \mathrm{~m}$ higher than in the horizontal involute part of the fold, and the bedding in the Lønstrup Klint Formation was tilted into a nearly vertical position (Fig. 70). 


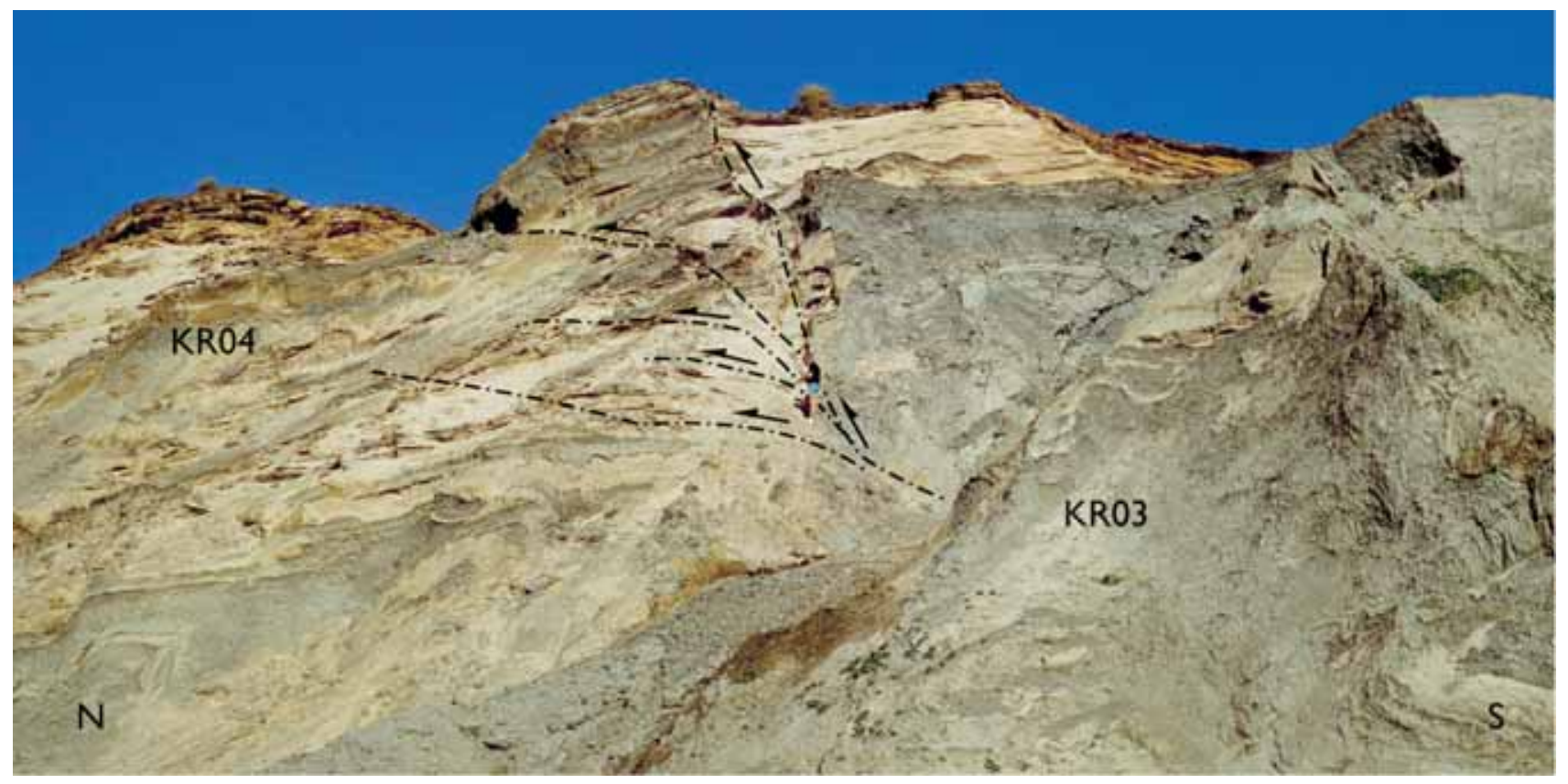

Fig. 72. Reverse fault-splay fan developed on the back of KR03 and also displacing the overlying KR04 thrust sheet. The structure is interpreted as a back-thrust fault-splay formed during the KR03 propagation over the upper footwall ramp situated on the back of KR02. Photograph: July 1994; figure at fault-splay centre for scale.

The KR02 thrust sheet was thrust up along a c. $25^{\circ}$ dipping footwall ramp (KR01FWR) onto the upper footwall flat above the Rubjerg Knude Formation of the KR01 thrust sheet. The KR02 thrust fault is apparently a hanging-wall flat which indicates a rather long displacement for thrusting. The top surface of KR02 is a footwall flat upon which the KR03 hanging-wall flat is situated, only bringing different stratigraphic levels of the Lønstrup Klint Formation into contact. The dip of the thrust fault is parallel to the dip of the KR02KR01 thrust fault. The footwall flat of the KR03 thrust sheet is overlain by a c. $80 \mathrm{~m}$ long hanging-wall flat of KR04. The Lønstrup Klint Formation is only about 8$10 \mathrm{~m}$ thick above the hanging-wall flat (KR04HWF), indicating a fairly long intermediate flat (at the $10 \mathrm{~m}$ level below the reference sufface). At the trailing end of KR04, the thickness increases indicating the presence of a hanging-wall ramp at the base of the thrust sheet, and a footwall syncline similar to that described in KR01 is present. In the upper part of the KR04 thrust sheet, the sediments deposited in the footwall growth syncline became overturned along the northern limb during translation of the hanging-wall ramp of BR01, as described above (Fig. 69).

\section{Kramrende diapir}

The Kramrende diapir constitutes the main part of KR02. The diapirism also affected the trailing end of KR01 (Fig. 70) as well as some parts of KR03. As shown in Fig. 71, mud of the lower part of the Lønstrup Klint Formation in KR02 became mobilised and intruded the overlying turbidite sand beds and also penetrated upwards into the overlying KR03 thrust sheet. Figure 70 illustrates a thrust fault penetrated by intrusive mud at the footwall ramp of KR01. Here, the mobilised mud from the steeply inclined northern limb of the footwall syncline intruded into the mud-breccia along and above the hanging-wall flat of KR02. A large part of the boundary between KR02 and KR03 was deformed in a similar way and the primary layering destroyed.

\section{Reverse faults}

In the Kramrende Section, significant steeply dipping reverse faults occur in the northern part of KR01 (Fig. 67), and in the middle part of the KR03 thrust sheet. The displacement is only about $30-50 \mathrm{~cm}$ on the steep south dipping faults in KR01; the spacing between the faults varies from 3-9 m, and often the faults can be traced down into the tectonic breccia above the 


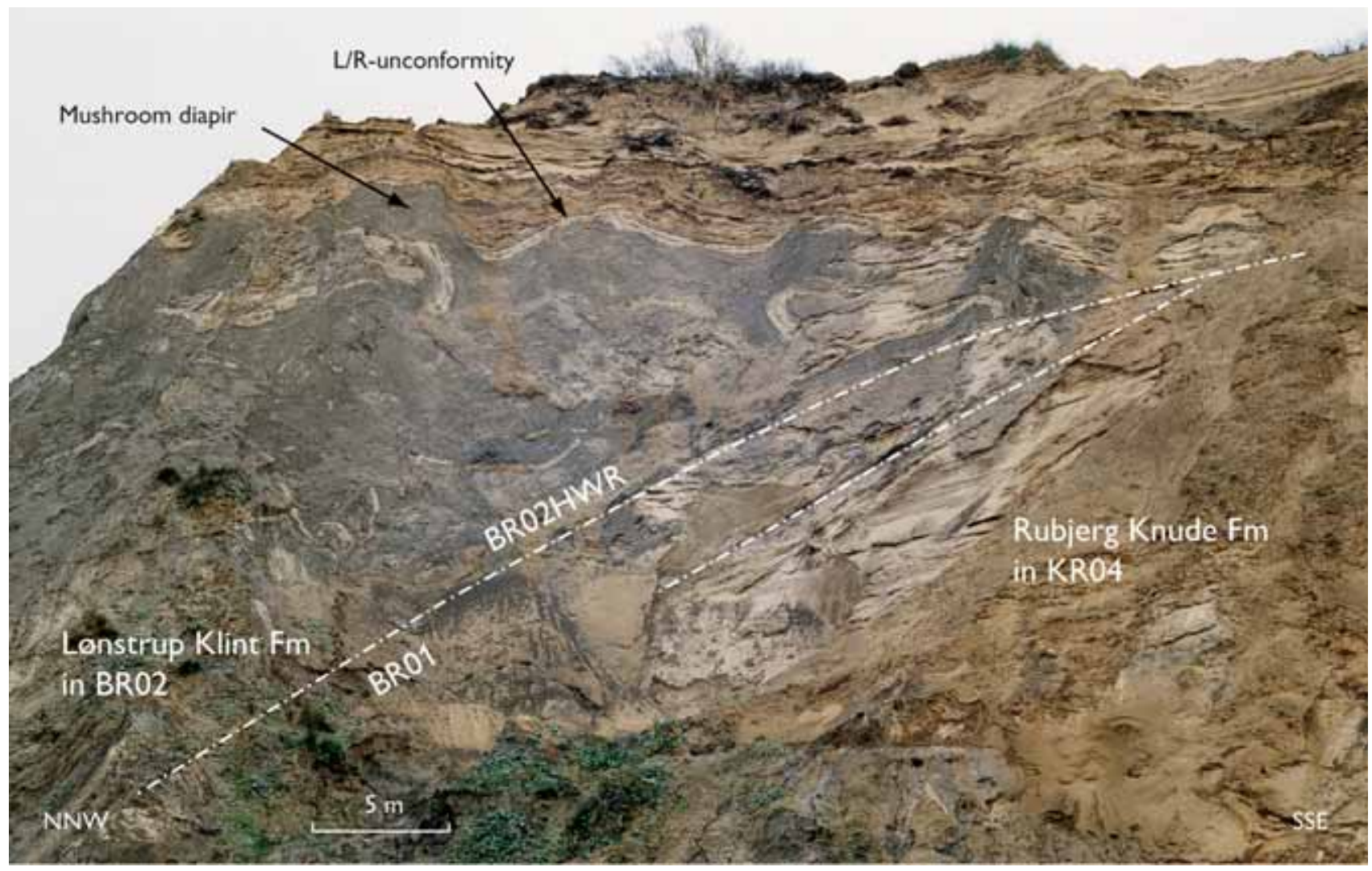

Fig. 73. The Brede Rende diapir in the frontal part of the Brede Rende Section. The frontal part of the BR02 thrust sheet was thrust up on its hanging-wall ramp (BR02HWR) along the footwall ramp, which turned into the KR04 footwall flat (KR04FWF). At an early stage of thrusting, probably while the hanging-wall ramp passed by a lower footwall hinge, diapirism developed. The mobilised mud also intruded the L/R-unconformity and formed mushroom-shaped diapirs in the Rubjerg Knude Formation. Photograph: June 1984.

hanging-wall flat. In the KR03 thrust sheet, the reverse faults form a fault splay fan with individual faults dipping moderately to steeply to the south (Fig. 72); displacement varies from about $20 \mathrm{~cm}$ up to about $3 \mathrm{~m}$.

The reverse faults appear to have formed during thrust-sheet propagation over a ramp hinge and are interpreted as back thrusts. A bend over a shallow dipping ramp will only result in minor displacement on steeply dipping back thrusts, whereas bending over steeply dipping ramps creates low-angle back thrusts with potentially greater displacements.

\section{Interpretation of structural development}

The balanced cross-section indicates that the KR01 thrust sheet was about $350 \mathrm{~m}$ long, of which a major part of the front tip has been eroded away. The amount of displacement is deduced from a series of balanced approximations to be $160 \mathrm{~m}$ (see Plate 2). The footwall ramp of KR01 is interpreted to root in the $30 \mathrm{~m}$ décollement level, which indicates that the lower hanging-wall ramp of KR01 was displaced onto the intermediate footwall flat above the trailing segment of MB04. Thus the lift and steep tilt of the northern limb in the KR01 footwall syncline is interpreted to have formed during the displacement of the lower hanging-wall ramp (KR01HWR) along the trailing-end footwall flat of MB04 (MB04FWF).

The tip of the KR02 thrust sheet has been eroded away. To avoid exaggeration, the thrust fault is interpreted to have continued only about $15 \mathrm{~m}$ up in the air further to the south, which implies that displacement of KR02 was in the order of $50 \mathrm{~m}$. The main part of the KR02 thrust sheet present in the cross-section is above the hanging-wall flat brought up from the 30 $\mathrm{m}$ décollement level. It is evident that the mobilised mud was derived from this low level and that it was activated in diapirism during the thrust-sheet propagation over the footwall ramps (KR01FWR) and its hinge bend.

It is difficult to estimate the displacement for the 


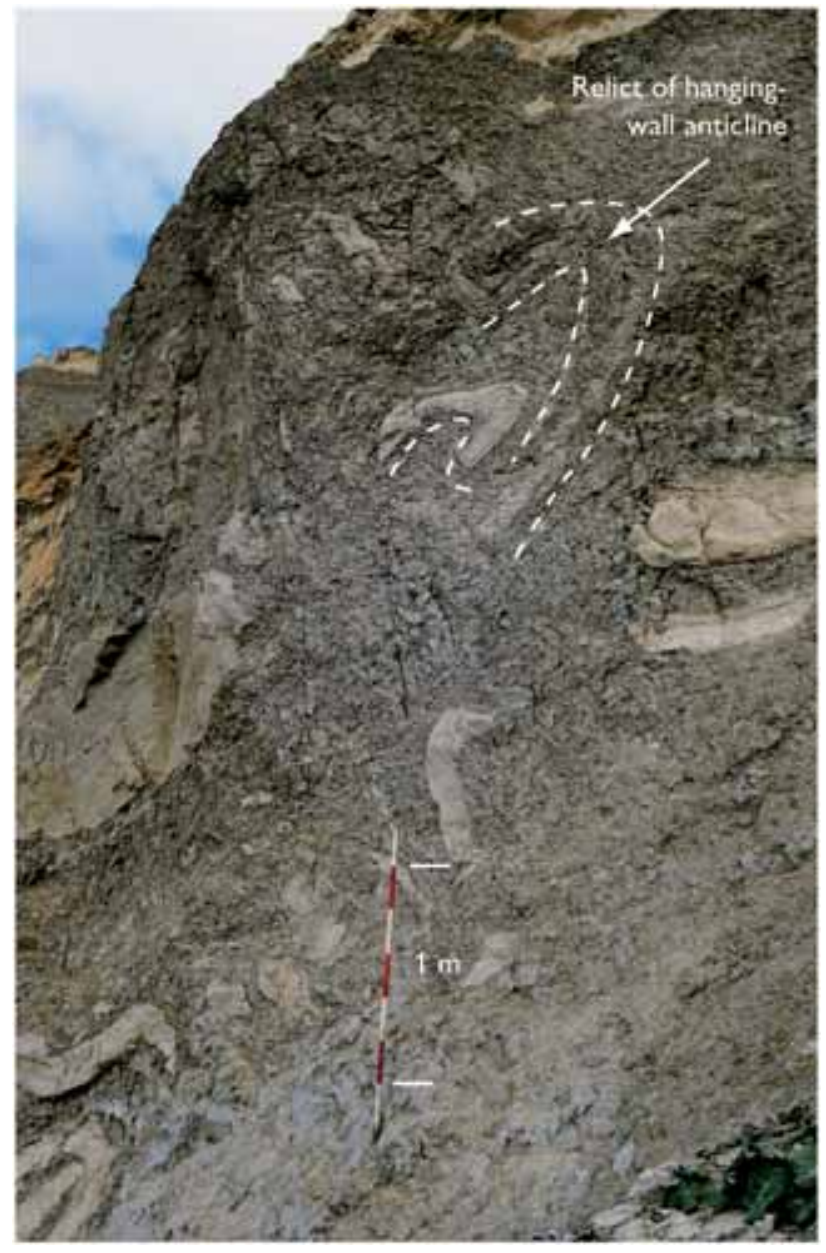

Fig. 74. Detail of the internal structure of the Brede Rende diapir. Although the structure appears as a chaotic mixture of disrupted sand beds 'floating' in a disorganised fashion in the mobilised mud-matrix, some of the features could be interpreted as relicts of hanging-wall anticlines (see dashed lines) formed in a developed stage during thrusting up along steep ramps. Photograph: June 1985.

KR03 thrusting. Its relationship to the footwall flat of KR02 indicates that it was thrust along a hanging-wall flat in the order of $60 \mathrm{~m}$. However, before the KR03 thrusting was complete, the KR04 thrust sheet was already emplaced on its back. The displacement of KR04 can be determined in the cross-section to be 66 $\mathrm{m}$. The implications of KR04 being thrust onto KR03 are that the sedimentation of the Rubjerg Knude Formation on top of KR03 ceased, and with the continued propagation of KR03 over the footwall ramp, the back-thrust splay also affected the KR04 thrust sheet that was being passively transported piggyback on KR03.

\section{Brede Rende Section}

For more than a century, groundwater drainage has been concentrated at a spring at Brede Rende. From the spring, situated at the base of the cliff, a stream has over the years eroded a large funnel-shaped gully behind the cliff facing the sea. Groundwater erosion successively stepping backwards is thus responsible for the wide gully and for the locality name (Danish: brede $=$ wide; rende $=$ gully). The groundwater transmissivity is, of course, governed by the geology of the Brede Rende Section, such that the spring wells out from the unconformity surface between the clayey Lønstrup Klint Formation and the permeable sand of the Rubjerg Knude Formation. The water initially drained in a southerly direction, but the present northerly drainage system is exposing the structures of the northern flank of Brede Rende in an isolated cliff. It is likely that this cliff will be completely removed by erosion by the sea as well as by the stream within the next few years leading to the formation of a broad gully at this location.

Important structural features currently exposed in the Brede Rende Section comprise a polydiapiric complex, the Brede Rende diapir in the frontal part, the prominent Brede Rende normal fault (BRNF) in the central part, and a series of duplexes stacked in the trailing end of the section.

\section{Tectonic architecture}

The Brede Rende Section comprises eight thrust sheets, annotated BR01-BR08 (Plate 2). The southern and frontal boundary of the section is the footwall ramp of KR04. The northern boundary is the thrust fault which partly acts as the BR08 footwall ramp and flat, and partly is the hanging-wall ramp for the SR01 thrust sheet in the Sandrende Section.

The BR01 thrust sheet is a relatively thin sheet that was displaced up along the KR04 footwall ramp, which is c. $30 \mathrm{~m}$ thick and dips about $35^{\circ} \mathrm{N}$. Above BR01, the BR02 thrust sheet was displaced more than $50 \mathrm{~m}$ along its hanging-wall ramp onto the upper footwall flat of KR04. The lower part of the thrust separating BR01 and BR02 has been destroyed by penetrating diapirism, and together with BR03 these frontal thrust sheets in the Brede Rende Section constitute the Brede Rende diapir (Figs 73, 74). The thrust sheets can still be regarded as individual coherent elements, although their 


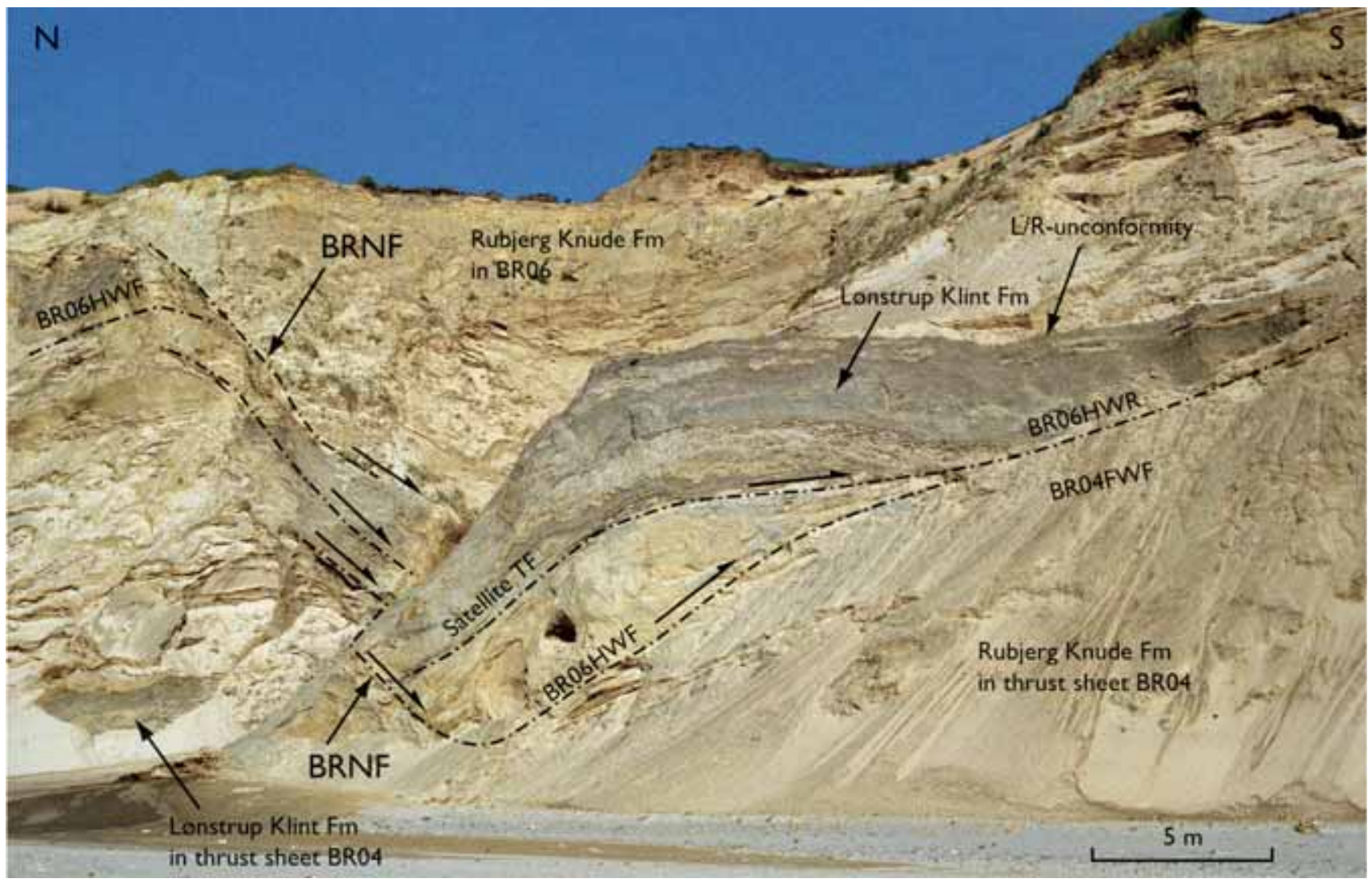

Fig. 75. The Brede Rende normal fault (BRNF). The frontal part of the BR06 thrust sheet has a normal displacement of about $20 \mathrm{~m}$ down through the $45^{\circ}$ dip normal fault, which can be measured from the hanging-wall flat of BR06 (BR06HWF) north of the normal fault to the BR06HWF south of the normal fault. In the footwall block of the BRNF, a series of minor normal faults make a stepwise displacement of the downthrown hanging-wall block. In the hanging-wall block of the BRNF, the bend of the thrust-fault structures may be characterised as a roll-over anticline. Note that the BR06 hanging-wall flat transforms into a hanging-wall ramp (BR06HWR), which was thrust-displaced along the upper footwall flat of the BR04 thrust sheet (BR04FWF). Photograph: June 1984.

boundaries and internal structure have been strongly distorted by diapirism.

BR03 is the longest thrust sheet in the Brede Rende Section, when the trailing lower segment is included (see Plates 1, 2). This is a constructional convention based on the consideration of which of the hangingwall ramps should be traced down to the décollement surface, and thus determine the annotation of the subsurface duplex sheets (Plate 2, see later). The BR04 thrust sheet is about $300 \mathrm{~m}$ long and is displaced by the Brede Rende normal fault (BRNF) (Fig. 75). North of the BRNF, the BR04 thrust sheet was thrust along an intermediate BR03 footwall flat, and south of BRNF the upper hanging-wall ramp and flat of BR04 were thrust over the upper footwall flat of BR03. The amount of displacement along thrust faults in this part of the Brede Rende Section is $50 \mathrm{~m}$ (measured in the crosssection of Plate 1) for BR03 as well as BR04. In BR04, the Rubjerg Knude Formation reaches its maximum thickness of about $20 \mathrm{~m}$ in the Brede Rende Section, whereas the cover of Rubjerg Knude Fomation on the back of BR02 and BR03 is less than $5 \mathrm{~m}$ thick.

The BR05 thrust sheet is relatively short and located between BR04 and BR06. The displacement along its hanging-wall ramp is about $80-90 \mathrm{~m}$ and the initial ramp-angle was c. $12^{\circ}$. The thickness of the Rubjerg Knude Formation on top of BR05 is only about $5 \mathrm{~m}$, which indicates that the thrusting of the BR06 thrust sheet propagated early in the thrust development of the Brede Rende Section. The piggyback thrusting of BR06 on BR05 on BR04 is one of the best examples of a duplex structure in the Rubjerg Knude Glaciotectonic Complex.

The BR06 thrust sheet is a relative long and thin thrust sheet. To the north, the trailing end of BR06 was thrust up over the footwall ramp of BR05. From the footwall ramp hinge, an upper hanging-wall flat (BR06HWF) was displaced along the upper BR05 foot- 


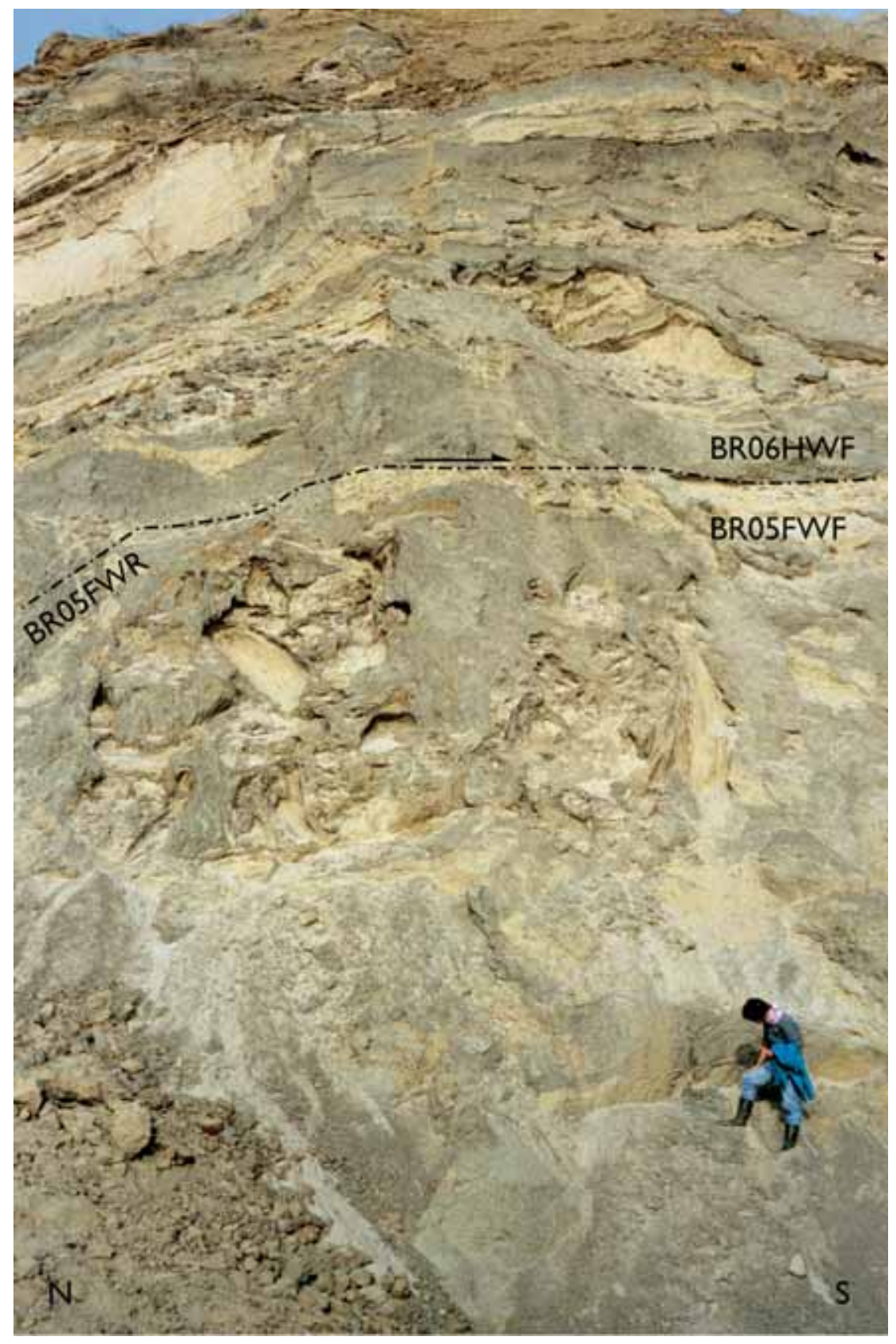

Fig. 76. Ball-and-pillow structures superimposed by chaotic hydrodynamic brecciation in the upper part of the Lønstrup Klint Fomation in the Brede Rende Section. The brecciation was formed by polysequential diapirism during thrusting of the BR06 hangingwall flat (BR06HWF) over the hinge to the upper footwall flat of BR05

(BR05FWF) situated in the left side of the photograph. Photograph: June 1993.

wallflat forabout $200 \mathrm{~m}$. As noted above, the BR06HWF developed above the BR05 thrust sheet at an early stage. The BR06 thrust sheet is divided into two segments by the BRNF (Fig. 75). South of the BRNF, the upper hanging-wall ramp of BR06 was emplaced on the BR04 upper footwall flat (Fig. 75).

The BR07 thrust sheet was thrust piggyback onto the trailing-end segment of BR05 and propagated up along the footwall ramp of BR06. It has very chaotic internal structures dominated by polydiapirism. The position of the reference surface (L/R-unconfomity) at an elevation of 20-30 m above sea level indicates that the BR07 sheet was ramped up onto the flat above a duplex composed of the trailing segments of BR03 and BR05 (see later). There is only a thin cover of less than $5 \mathrm{~m}$ of the Rubjerg Knude Formation on the back of BR07, which is overlain by the BR08 hanging-wall ramp.

The BR08 thrust sheet is the northemmost and uppermost sheet in the Brede Rende Section. It is the smallest thrust sheet in the section, The thin frontal tip of the thrust sheet consists of the uppermost part 


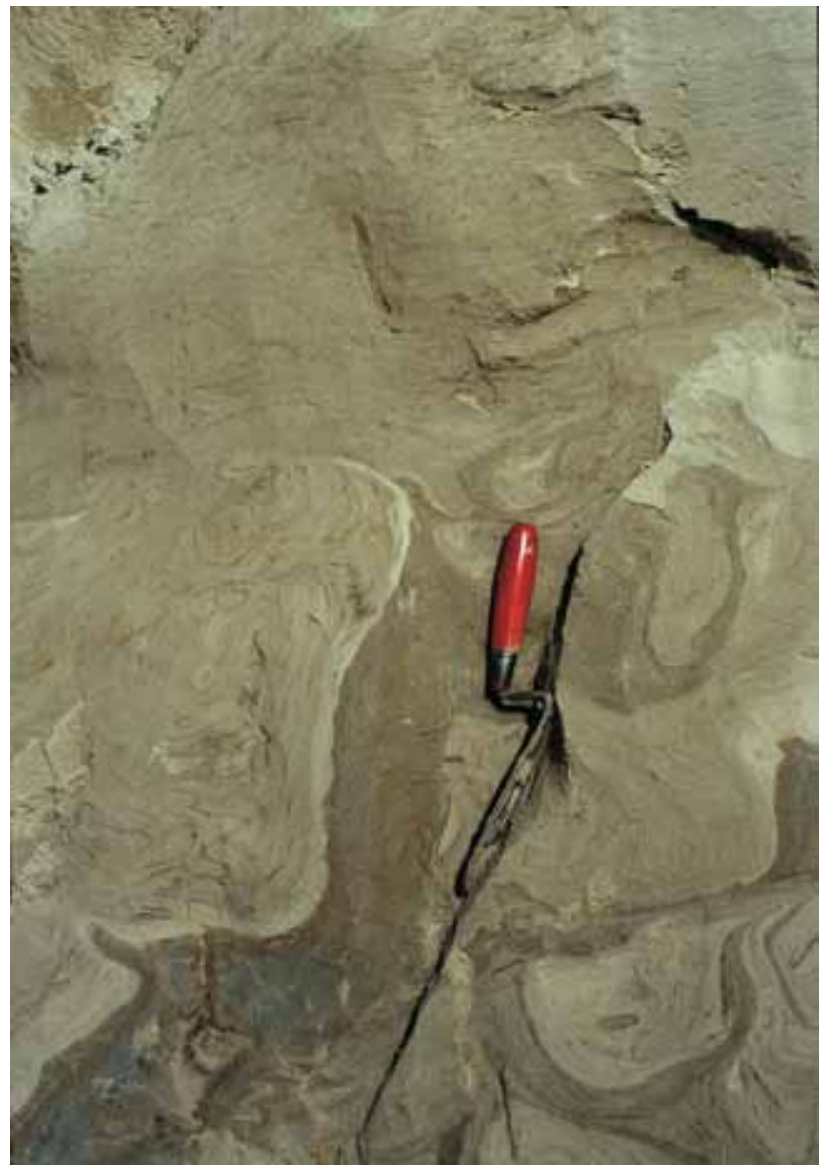

Fig. 77. Small-scale ball-and-pillow structures distorted and intruded by water-escape injection. Note that dish structures were formed above the water-escape pipe. Detail of chaotic brecciation in the upper part of the Lønstrup Klint Formation; frontal part of the BR06 thrust sheet in the Brede Rende Section. Photograph: June 1998.

of the Lønstrup Klint Formation, butwith an up to $12 \mathrm{~m}$ thick succession of the Rubjerg Knude Formation on top of the L/R-unconformity. Due to the bend up along the BR06 footwall ramp, the inclination of the BR07 and BR08 thrust sheets is c. $25^{\circ} \mathrm{N}$.

\section{Sedimentary units}

The Lønstrup Klint Formation is strongly affected by ball-and-pillow load structures and hydrodynamic brecciation. The maximum thickness of the formation exposed is only about $20 \mathrm{~m}$ (tentatively measured in BR02). The thickness of the Rubjerg Knude Formation varies from thrust sheet to thrust sheet, indicating differential thrust-fault movement that either closed the piggyback sedimentation and/or lifted the formation

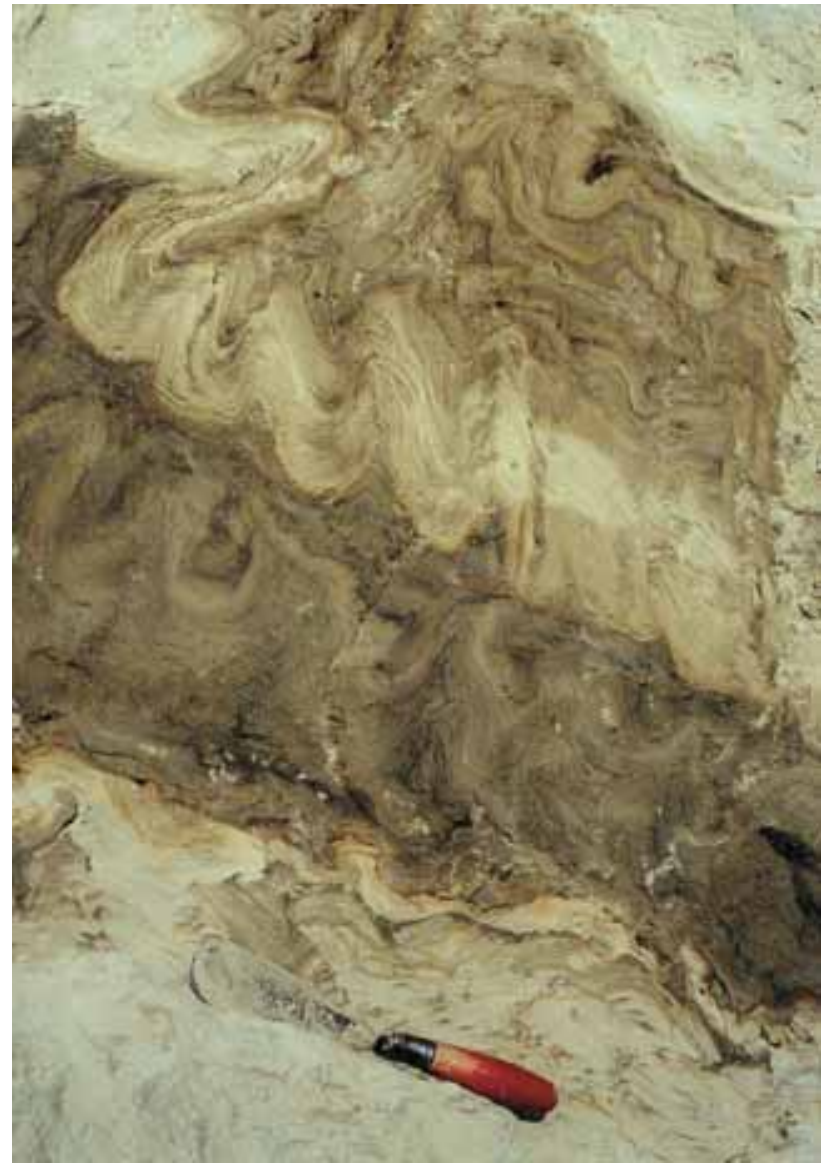

Fig. 78. Small-scale disharmonic undulations formed by polysequential diapirism in the thinly interbedded clays, silts and finegrained sands of the upper part of the Lønstrup Klint Formation. Note the fold accentuation of the climbing ripple lamination in the central part of the figure. Frontal part of the BR06 thrust sheet in the Brede Rende Section. Photograph: June 1998.

up to a position exposed to erosion. The Rubjerg Knude Formation was also subjected to hydrodynamic brecciation. At the top of the central part of the Brede Rende Section, a glacitectonite and associated glaciotectonic imbrications are interpreted to be related to the advance of the Norwegian Ice; the sandy till is interpreted to be the Kattegat Till Formation.

\section{Lønstrup Klint Formation}

The lower and intermediate parts of the Lønstrup Klint Formation are characterised by dark clayey mud. The interval 5 to $10 \mathrm{~m}$ below the L/R-unconformity is dominated by a few thick beds of light coloured sandy turbidites, and the uppermost $5 \mathrm{~m}$ is formed by thinbedded sand beds interbedded with mud. The size of 


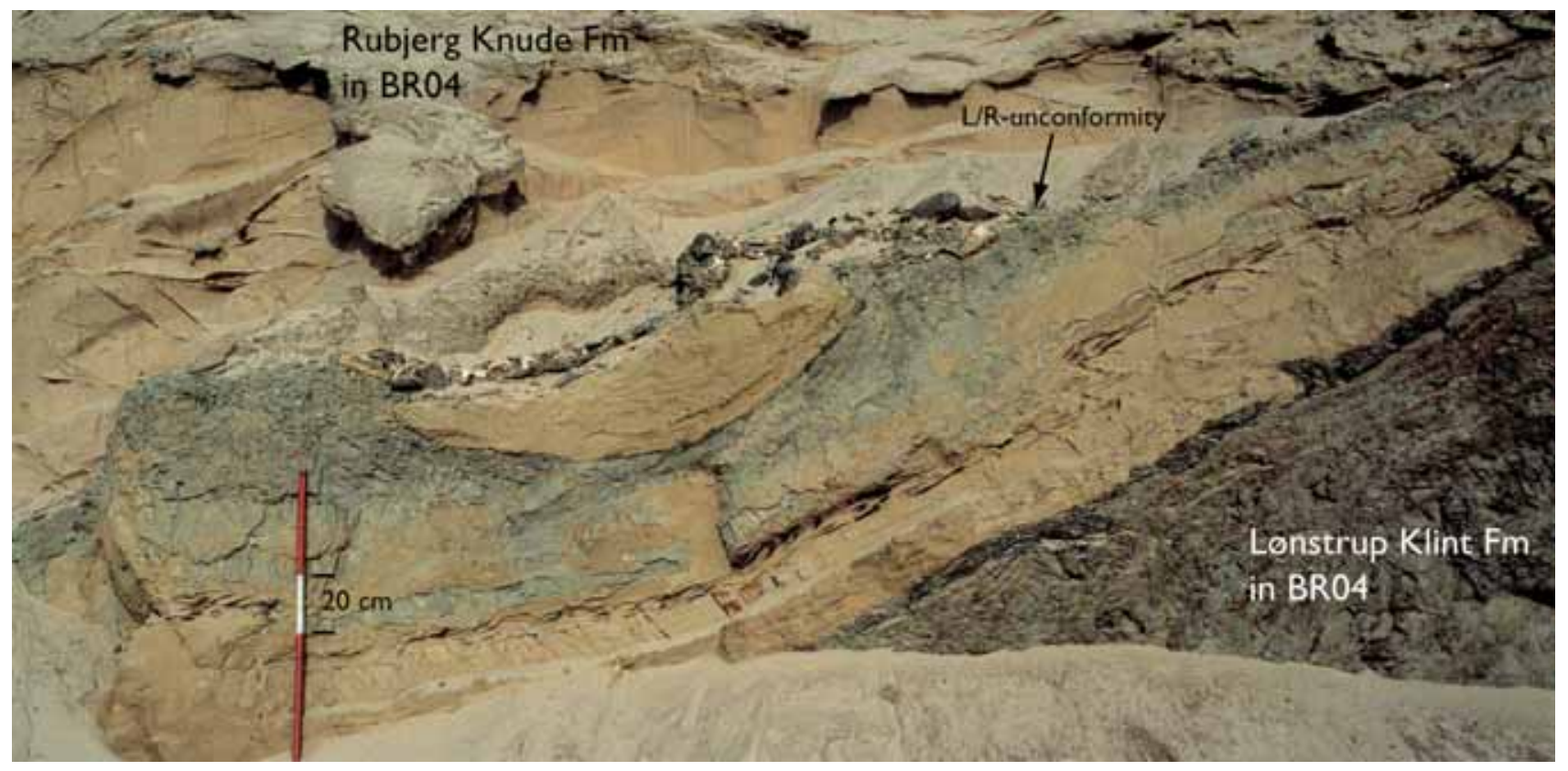

Fig. 79. A large ball-and-pillow structure in the upper part of the Lønstrup Klint Formation, truncated by the L/R-unconformity. This relationship demonstrates that at least part of the loading occurred prior to the thrust-fault emplacement. Photograph: June 1998.

ball-and-pillow structures is typically related to the initial thickness of the sand beds, and the subsequent hydrodynamic brecciation and chaotic structures formed during water-escape activities (Figs 68, 76-78).

The L/R-unconformity at the top of BR04 truncates a large ball-and-pillow structure at the top of the Lønstrup Formation just north of the normal fault (Fig. 79). This implies that some of the load structures, and possibly also initial water-escape dynamics, had commenced prior to the development of the unconformity. It may be that this phase of ball-and-pillow formation was initiated by the drainage of the large lake basin (see Sadolin et al. 1997). Thus the initiation of balland-pillow formation can be viewed as the consequence of vibration created by an increased water transport over the beds. At this locality, the formation of ball-and-pillow structures was clearly not the effect of loading by over-thrusting, but only the result of density variation of the primary sedimentary layers, since the top of the Lønstrup Klint Formation was undergoing erosion and the gravel bed on the L/Runconformity was deposited subsequently.

\section{Rubjerg Knude Formation}

The Rubjerg Knude Formation reaches a thickness of $15 \mathrm{~m}$ in the upper part of the BR04 thrust sheet, but in the rest of the Brede Rende Section it is less than $10 \mathrm{~m}$ thick. The relatively thin nature of the formation (3-5 $\mathrm{m})$ in BR02, BR03, BR05 and BR07 is interpreted to indicate that these basins were over-thrust or thrustelevated at an early stage of thrust propagation. In contrast, deposition persisted in the piggyback basins ofBR04and BR06 before their upper footwall flats were overthrusted and deposition ceased in the basins.

\section{Structures}

Three types of structural features are described from the Brede Rende Section: (1) diapir structures, including mesoscopic-scale sequential polydiapirs and hydrodynamic brecciation, (2) the Brede Rende nomal fault (BRNF), and (3) frost wedges.

\section{Facing page - upper:}

Fig. 80. Nomal fault network in the footwall block of the Brede Rende normal fault developed in the BR04 thrust sheet. Photograph: June 1998.

Facing page - lower:

Fig. 81. Frost wedges recognised in the Rubjerg Knude Formation. The one on the right side of the spade (A) has well-developed, 'upwards-fanning' small-scale normal faults, whereas the one to the left of the spade (B) is a 5-10 cm wide fracture with a sand-fill. Photograph: June 1997. 

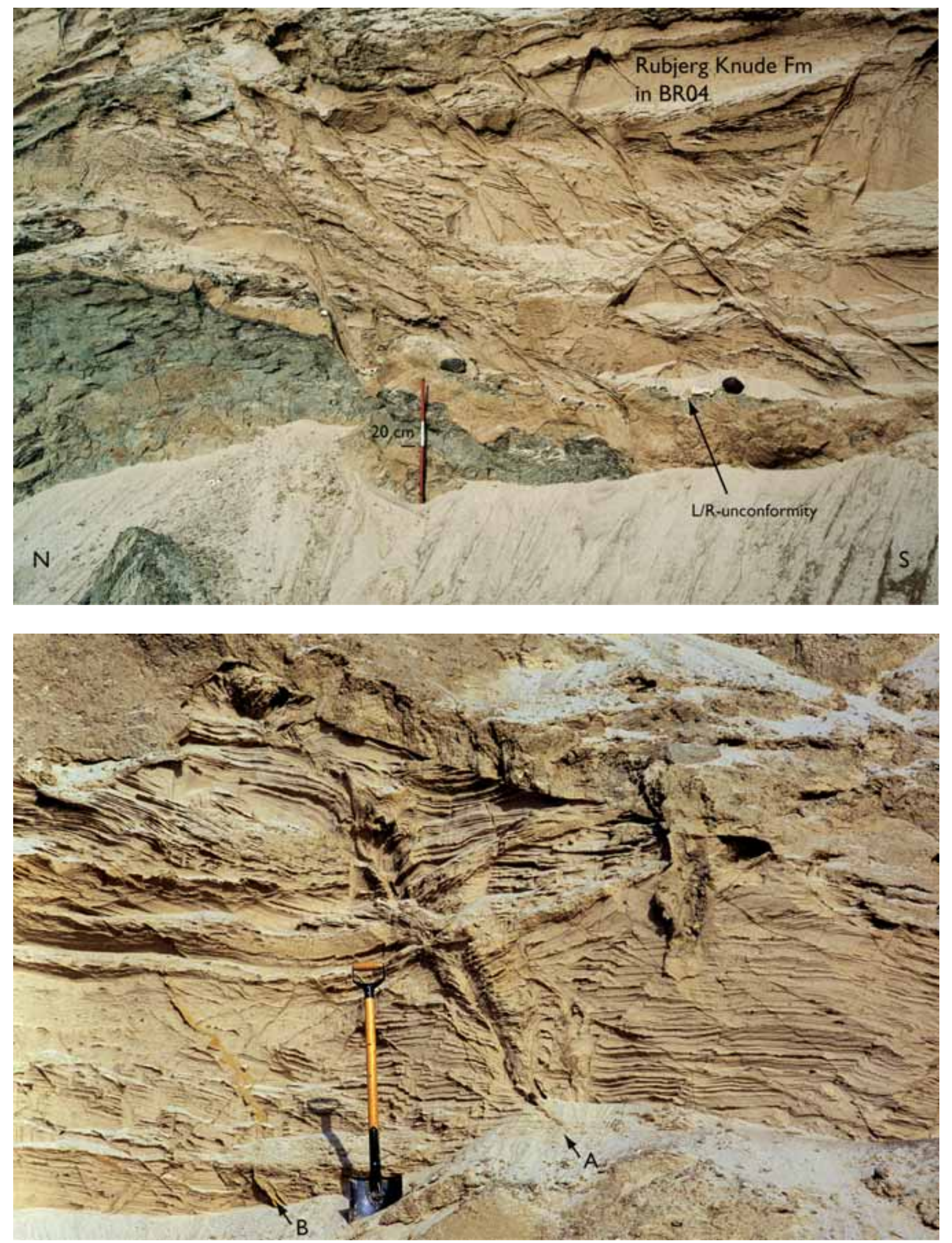

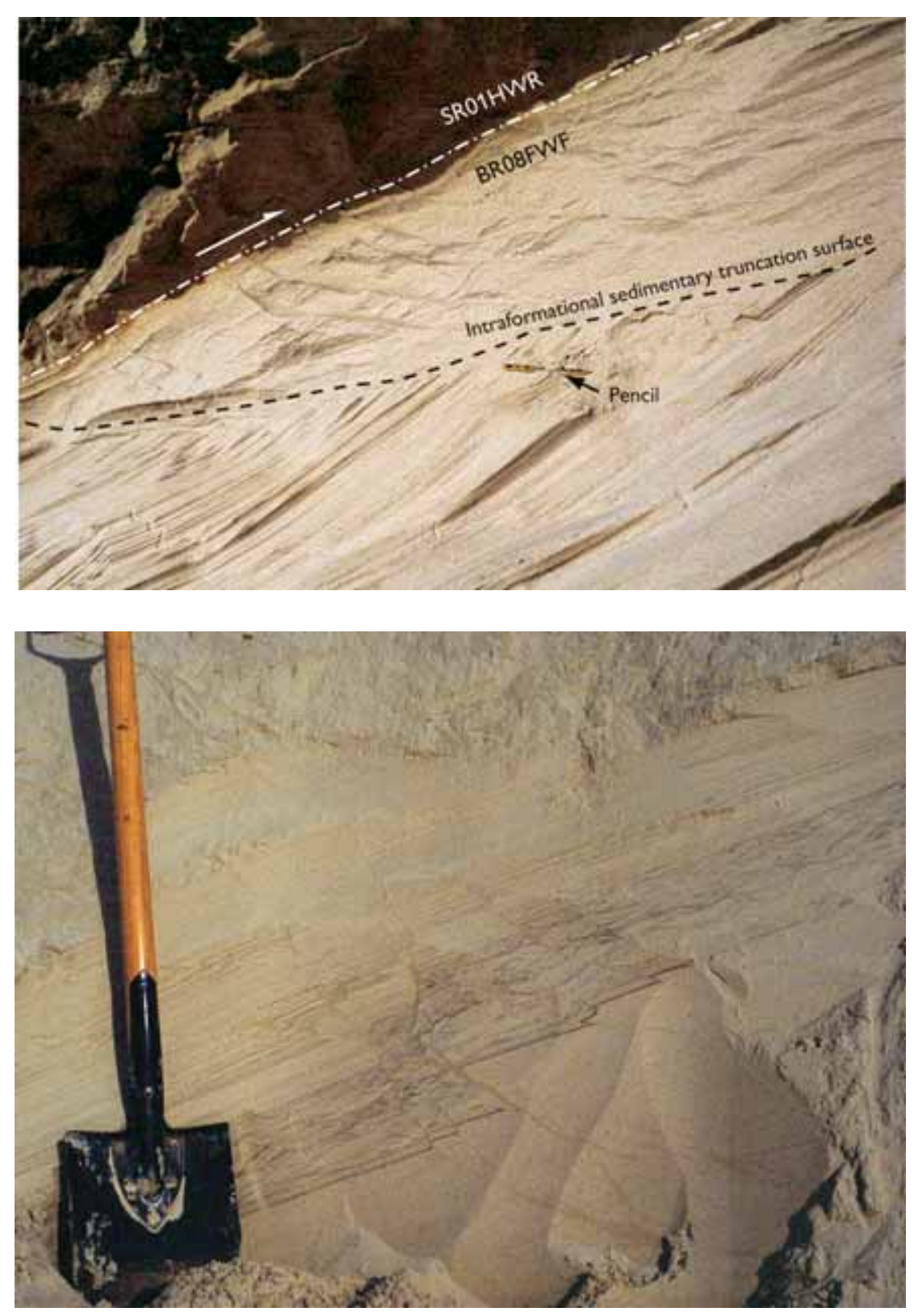

Fig. 82. The shift in tilts of bedding in the piggyback basin of the BR08 thrust sheet is interpreted to reflect the propagation of ramps. The strike is the same $\left(110^{\circ}\right)$, but the dip of the lower sand beds is $40^{\circ}$, corresponding to deposition during propagation along a flat, whereas the dip of beds above the truncation surface is only $28^{\circ}$, corresponding to deposition during ramping. Photograph: June 1997.

Fig. 83. Back-thrust reverse faults displacing the sand beds in the Rubjerg Knude Formation deposited in the piggyback basin of the BR08 thrust sheet. These reverse faults are interpreted to have formed during the thrust propagation of the footwall ramp of BR06/BR05. Photograph: June 1997.

\section{D iapir structures}

The term diapir as used here follows the definition of Weinberg \& Schmeling (1992 p. 425): "Diapir is the non-genetic geological term applied to ductile intrusive structures. Many diapirs may develop due to rise of gravitationally unstable buoyant fluids through denser overburden. Such gravitationally unstable configurations consisting of viscous layers are known as Rayleigh-Taylor instabilities." In the Brede Rende Section, the diapir structures can be divided into two types: (1) small- to medium-scale diapirs that developed into hydrodynamic breccias in which primary sedimentary lamination is locally preserved, although distorted and irregularly folded, and (2) medium- to large-scale diapirs where mobilised mud intrudes overlying stratigraphic levels or thrust units.

The first type of diapirism corresponds to the sequential polydiapirs of Weinberg \& Schmeling (1992). These are initiated as small undulations or even flame structures, that develop into irregular upright folds with numerous minor undulations on their flanks (Figs $76,78)$. When the viscous mud broke through the bedding it formed intrusive pipes (Fig. 77), and either spread out laterally between layers or released water, forming dish-and-pillar structures in the overlying beds 
(Fig. 77). In the Brede Rende Section, this type of diapirism occurs commonly in the upper sand-rich part of the Lønstrup Klint Formation and in the Rubjerg Knude Formation. A good example occurs at the tip of the BR05 thrust sheet, where the thrust fault (BR04FWF/BR05HWR) is completely obscured by hydrodynamic brecciation.

Examples of the second type of diapirism include the Brede Rende diapir and the Kramrende diapir. Here the clay-rich units of the lower part of the Lønstrup Klint Formation became mobilised by over-pressured water (or gas) to form an intrusive grey, homogeneous mud. The diapirism in the Brede Rende Section wasformed syntectonically during ramping (Pedersen 1987). The thrusting displaced some of the feeders in the mushroom-shaped diapirs, and some of the diapirs intruded through the thrust sheets up into the thrust sheet above. Moreover, the mushroom-shaped diapirs penetrate the L/R-unconformity at the top of the diapir (Fig. 73). It may also be noted that some of the diapir feeders have been tilted by the bending produced by ramp propagation (Fig. 4; Pedersen 1987).

\section{Brede Rende normal fault}

The Brede Rende nomal fault (BRHF), in the central part of the Brede Rende Section, is a planar fault that strikes $100^{\circ}$ and dips $45^{\circ} \mathrm{S}$ (Fig. 75). The vertical displacement is c. $20 \mathrm{~m}$ when measured from the hanging-wall (thrust-fault) flat of the BR06 in the footwall block of the normal fault to the same flat in the hanging-wall block of the BRNF. A network of smaller normal faults with minor displacements occurs in the footwall block (Fig. 80) and adds to the monoclinal bend in the footwall block of the BRNF. In the hangingwall block, the BR06 thrust sheet is dragged along the fault plane and the drag is bounded by a minor splay fault. Moreover, a weakly developed rollover-anticline outlined by the BR06 thrust sheet occurs in the hanging-wall block of the BRNF (Fig. 75). Above the northern limb-bend of the rollover-anticline, a minor depression (c. $5 \mathrm{~m}$ deep) was formed. In this depression, a series of minor imbricate sandy mud slumps formed, which may be viewed as syn- to epitectonic deposits at the top of the Rubjerg Knude Formation in BR06 related to faulting of the BRNF.

\section{Frost wedges}

Frost wedges or fossil ice wedges are recognised in the Rubjerg Knude Formation, as preserved in the upper part of the BR04 thrust sheet. The cliff section here became exposed after the cross-section (Plate 1) was drafted and is thus not included. It would have been situated near point $3975 \mathrm{~m}$ in the cross-section. The frost-wedge fractures are $5-10 \mathrm{~cm}$ wide and are filled with structureless sand. Along the sides of the fractures, the bedding in the sand is bent down towards the fracture due to minor displacements along small fanning normal faults; the vertical range of the frost wedges is about 1-3 m (Fig. 81).

The presence of frost wedges in the Rubjerg Knude Formation clearly indicates that the sand was ground frozen, and thus also elevated above water level in the glaciofluvial and glaciolacustrine environment that prevailed during the deposition of the formation. The ground-frozen condition of the sand may be the reason for the excellent preservation of the normal fault network related to the BRNF.

\section{Interpretation of structural development}

The first thrust sheets to move were probably BR03 and BR06, which ramped up to the upper footwall flat and moved southwards over a thin cover of the Rubjerg Knude Formation. In the balanced cross-section, the presence of the long, thin BR03 thrust sheet, and especially BR06, requires that there has to be underlying lower and intermediate duplex sheets. The balanced cross-section model favours a continuation in the subsurface of several segments of the lower thrust duplex. The BR03 thrust sheet is viewed as a coherent thrust sheet, which from the ramp of the minor BR02 thrust sheet, continues along the lower décollement surface at the $30 \mathrm{~m}$ level. The lower trailing-end duplex segment extends northwards to the thrust fault separating the Brede Rende and the Sandrende Sections (SR01HWR/BR08FWR). This trailing segment of the BR03 thrust sheet is estimated to be about $300 \mathrm{~m}$ long, and the remaining five thrust sheets in the Brede Rende Section have all been ramped up onto this segment along which the allochthonous transport and piggyback displacement took place.

The simplest model for understanding the framework of the duplexes is to accept segmentation of the trailing end of the BR05 thrust sheet. It is necessary that BR06 was thrust over BR05 before the trailing 


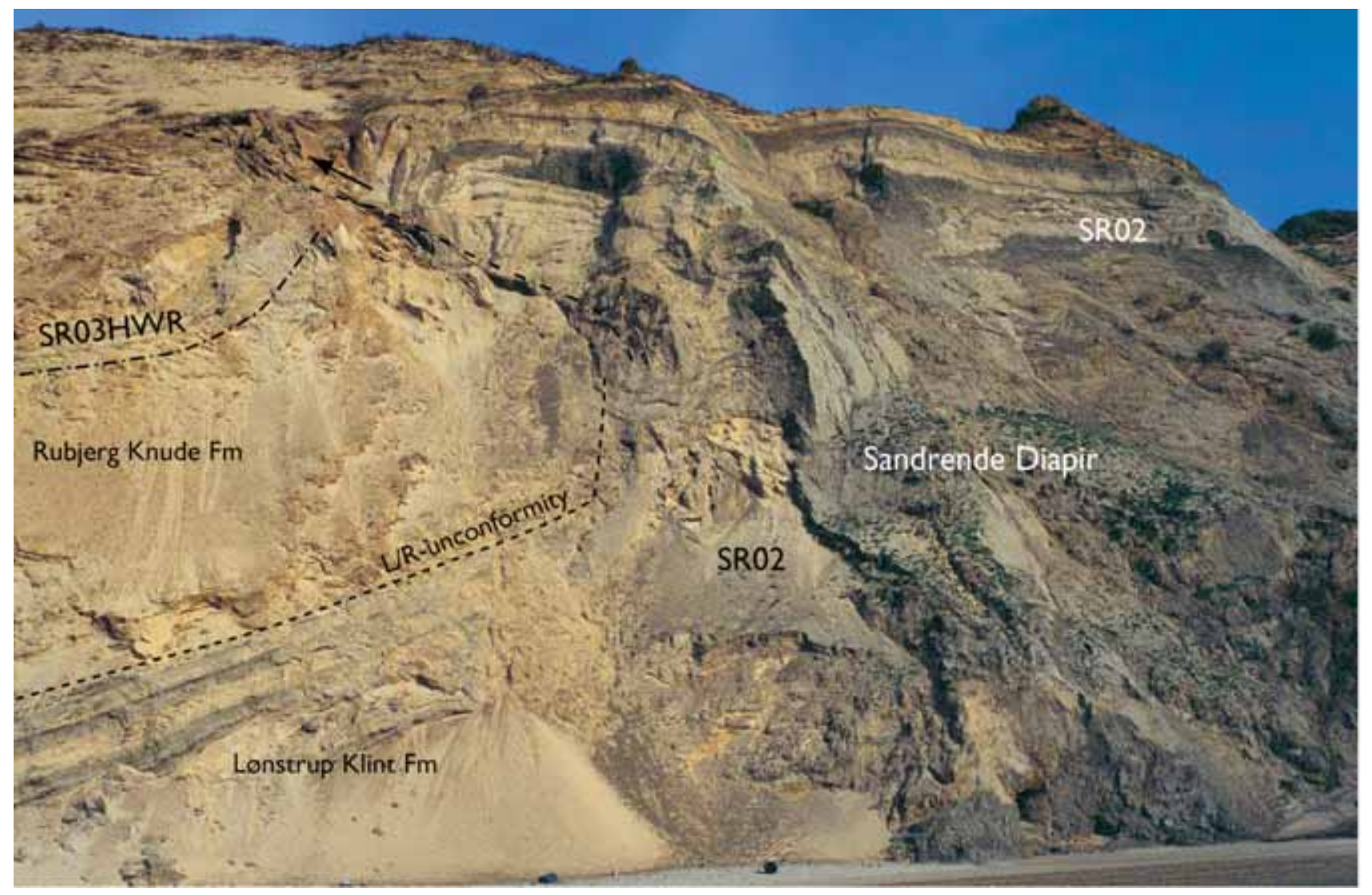

Fig. 84. The Sandrende diapir developed in the SR02 thrust sheet. The arrow indicates the direction of reverse faulting, which marks the prominent back thrust. Along the steep northern flank, the hanging-wall ramp of SR03 (SR03HWR) was bent. The bend of the L/R-unconformity formed due to the fold-bend-folding of SR02 at the lower footwall ramp hinge.

end of BR05 was thrust up over the footwall ramp of BR04. The existence of the intermediate BR04 hanging-wall ramp indicates that BR04 had to ramp up two footwall ramps in different positions of the trailing end of BR03. Thus the model indicates that a lower hanging-wall ramp of BR04 was emplaced along the intermediate footwall flat of BR03. According to the construction of the balanced cross-section, this also necessitates a lower duplex segment to be thrust up in front of the lower hanging-wall ramp and flat of BR04. These differential thrust displacements provide an explanation for the development of the BRNF. The displacement along the BRNF is consequently considered to be due to two factors. The first $10 \mathrm{~m}$ offset was caused by normal faulting in front of BR05, where a foreland-dipping bend of the BR06 hanging-wall flat was created over the nose of the BR05 thrust sheet. The next $10 \mathrm{~m}$ displacement was caused by a foreland-dipping limb of the tip of a duplex segment situated beneath the BR04 thrust sheet causing the BR04 hanging-wall flat to act as a normal fault.
At the north end of the section, the BR07 thrust sheet, which only has 3-4 m of the Rubjerg Knude Formation at the top, was overthrust by the BR08 thrust sheet at an early stage. The thickness of about $10 \mathrm{~m}$ of Rubjerg Knude Formation on top of BR08 indicates that after the two thrust sheets were thrust-separated, deposition of Rubjerg Knude Formation continued in the piggyback basin of BR08. This sedimentation probably took place while BR08 in a piggyback position on BR07 ramped over a lower footwall ramp of BR03 and propagated along an intermediate flat, passing over the footwall ramp of BR05/BR06, before the temporarycessation of thrusting. In the BR08 piggyback basin, the propagation of ramps is reflected in the change in tilt of the bedding (Fig. 82). Moreover, a number of minor back-thrusts have been recognised in these beds (Fig. 83), and are considered to have been related to the ramp propagation.

In the dynamic development of the Brede Rende Section, both the frontal southern and the northern parts were involved in diapirism. In both parts, it is 
evident that the diapirism was active after the emplacement of the thrust sheets, since the hanging-wall flats are penetrated by diapirs rising from a mobilised underlying thrust sheet. However, it is also evident that the diapirism ceased before the maximum compression of thrust sheets had occurred. The termination of thrust compression was reached when the maximum inclination of the flats occurred. This coincided with the conclusive accumulated ramping of piggyback thrust sheets. Thus, the inclined position of the feeders to the mushroom-shaped diapirs indicates a synthrust intrusive emplacement. It is therefore concluded that the diapirism was activated by ramp propagation and that some of the diapirs can be regarded as extreme developments of hanging-wall anticlines created during soft sedimentary deformation (Fig. 74).

\section{Sandrende Section}

The Sandrende Section is one of the most studied parts of the Lønstrup Klint cliff section (Fig. 5; HoumarkNielsen et al. 1996; Sadolin et al. 1997). Even so, the development of this section is not fully understood, and some new and revised details are added here. The main feature of the section is a broad basin containing a thick succession of the Rubjerg Knude Formation deposited in a piggyback basin. To the south, a diapir distorts this basin, and to the north the basin is over-thrust by a thrust sheet of the Stenstue Rende Section. The central part of the section preserves a remarkable development of normal faults. These were formerly regarded to have formed in response to the volume adjustments in the Sandrende diapir (Sadolin et al. 1997), but are now interpreted as elements of a thrust-fault propagation model with differential duplex segments ramping in the subsurface.

\section{Tectonic architecture}

The Sandrende Section comprises four thrust sheets (SR01-SR04). The southern boundary of the section is the trailing-edge ramp of BR07 and BR08 in the Brede Rende Section, and the northern boundary is the rather steep $\left(>60^{\circ}\right)$ trailing-edge ramp of SR04. The boundary with the Stenstue Rende Section to the north is a combination of this trailing-edge ramp and the hanging-wallflat of the frontal southernmost thrust sheet in the Stenstue Rende Section (see below).
The transition between the Brede Rende Section and the Sandrende Section in the subsurface is not clear due to uncertain relationships between BR07BR08 and SR01. The description below is based on the preferred interpretation, which traces the trailingedge ramp of BR08 in the Brede Rende Section down to the décollement surface $30 \mathrm{~m}$ below the reference surface. This implies that the lowermost trailing ends of BR07 and BR03 remain as low-lying segments that SR01 had to ramp over. An extra segment and some smaller adjustment splints of the SR01 thrust sheet were also left in the subsurface. This is reflected in some of the structural features exposed in the section between SR01 and SR02.

At the tip of the SR01 thrust sheet, the Lønstrup Klint Formation forms a thin wedge, which indicates that the initial hanging-wall ramp (SR01HWR) only had a dip of about $10^{\circ}$. However, after ramping was concluded, the thrust fault was steepened to the present dip of $40^{\circ} \mathrm{N}$; the measured orientation of the ramp is $108^{\circ} / 40^{\circ} \mathrm{N}$. The displacement of SR01HWR along the upper footwall ramp and flat of BR08 is C. $53 \mathrm{~m}$. The frontal part of SR01 has a bend, and it only dips about $25^{\circ} \mathrm{N}$ due to the change in thrust-fault inclination passing the upper footwall ramp hinge and the subsequent introduction of a small satellite thrust fault displacing the lower part of SR01 up over the tipwedge. The consequence of thrusting the thin c. $50 \mathrm{~m}$ long frontal part of the thrust sheet is that in the balanced cross-section, a lower duplex segment (SR01u) must be accounted for, and that SR01u at an advanced stage of SR01 thrust propagation was picked up in the thrust translation (see below).

The SR02 thrust sheet was formerly interpreted as a large-scale diapir (Sadolin et al. 1997; Fig. 84). In the present structural analysis, SR02 is treated as one large thrust sheet in which the mobilised mud underwent mud diapirism at a relatively late stage. This assumption permits an approximation of balancing the thrust sheets, accepting that the thrust faulting is evidently the most important part of the dynamic development. The argument for this is based on the fact that SR02 over-thrust the back of SR01 with a displacement of about $100 \mathrm{~m}$. This $100 \mathrm{~m}$ of displacement has to be compensated for by the same amount of displacement along the lower décollement surface, which can be calculated to have taken place at a stratigraphic depth of $30 \mathrm{~m}$ below the L/R-unconformity. The thrusting of SR02 resulted in a considerable amount of elevation during propagation along footwall ramps (SR01FWR and BR03FWR), since the $L / R$ reference surface is sit- 


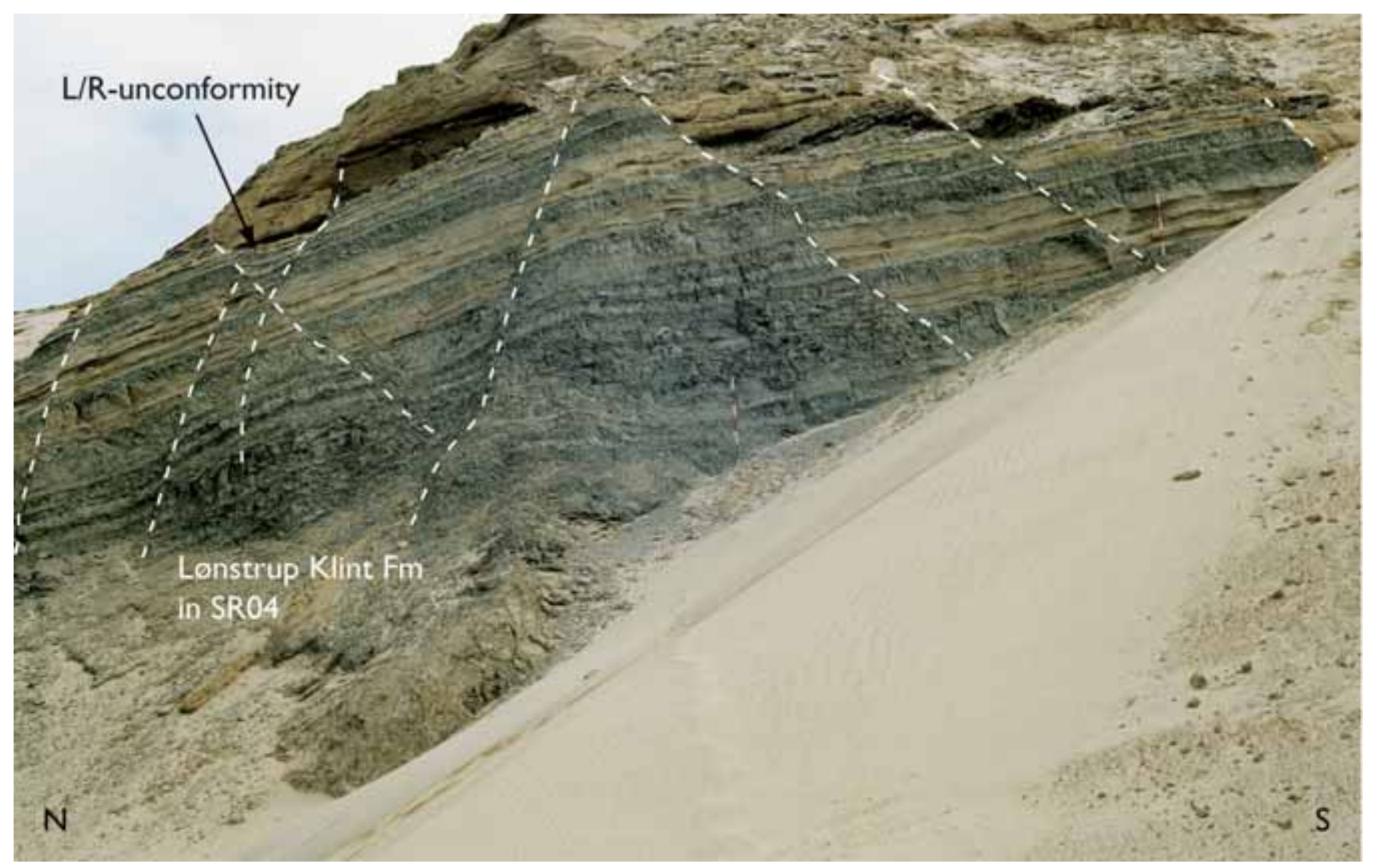

Fig. 85. Conjugate normal faults developed in the Lønstrup Klint Formation in the SR04 thrust sheet. An offset of about $1 \mathrm{~m}$ can be recognised by correlating turbidite sand beds in the footwall block to the same beds in the hanging-wall block. The normal fault framework is interpreted to be due to lateral extension in the SR04 thrust sheet during its propagation over the upper footwall hinge of an underlying duplex. Photograph: May 1995; measuring staff divisions (centre) are $20 \mathrm{~cm}$.

uated about 35-40 m above sea level in the cliff section. Thus the ramping and displacement along the upper flat took place before the final emplacement of the lower duplex segment of SR01, indicated by the normal fault displacement of both SR01 and the frontal part of SR02.

As noted in the Kramrende Section description, steep ramping creates back-thrusting at the hinge of the hinterland-dipping limb. Thus the peculiar mushroom-shaped structure with a wing pointing to the north is considered to be the effect of reverse faulting due to back-thrusting (Fig. 84). The reverse fault feature may have been accentuated by re-orientated internal detachment folding and irregular diapirism in the Sandrende diapir. Furthermore, it should be noted that the L/R-unconformity surface has a steep dip on the northern flank of the Sandrende diapir. Near the beach level, the L/R-unconformity bends into a gentle dip indicating that in the trailing end of SR02, the lower hanging-wall flat rests on the lower footwall flat coinciding with the décollement level at $30 \mathrm{~m}$.
The SR03 thrust sheet is relatively small with a displacement of about $75 \mathrm{~m}$. The tip of the thrust sheet is bent upwards into a nearly vertical position due to drag along the almost vertical northern flank of the Sandrende diapir (SR02). Thus the SR03 thrusting was rather early, but as the Rubjerg Knude Formation is about $10 \mathrm{~m}$ thick in SR02 there was a significant time span before SR03 was thrust up on the back of SR02.

SR03 was displaced up along the upper footwall ramp, which is exposed in the cliff section. SR03 was also displaced along an intermediate flat situated at the $20 \mathrm{~m}$ level, indicated by the thickness of the thrust wedge. During thrust propagation, the trailing end of SR03 was cut off and left as an isolated duplex segment, while the frontal part of SR03 was displaced along the intermediate flat (see Plate 2).

SR03 was over-thrust by SR04 with a relatively short time gap, as indicated by the thin $(3 \mathrm{~m})$ succession of Rubjerg Knude Formation on top of SR03. The thrust displacement of SR04 over SR03 is about $60 \mathrm{~m}$, and 
the accumulated displacement of the trailing end of SR04 relative to SR02 is in the order of $135 \mathrm{~m}$.

The frontal part of SR04 consists of a relatively thin wedge of the upper part of the Lønstrup Klint Formation overlain by an up to $28 \mathrm{~m}$ thick succession of the Rubjerg Knude Formation. In the central and rear parts of SR04, the thickness of the Lønstrup Klint Formation increases to more than $20 \mathrm{~m}$, indicating the existence of a hanging-wall ramp which can be traced down to the décollement zone, $30 \mathrm{~m}$ below the L/R reference surface. The central part of SR04 forms a broad hanging-wall anticline, where a number of extensional normal faults cross-cut the Lønstrup Klint Formation (Fig. 85). The southernmost normal fault in this system is considered to reflect the foreland-dipping features formed due to displacement of the hangingwall anticline along the intermediate flat. Finally, it should be noted that the piggyback basin (Rubjerg Knude Formation) of SR04 is divided into two subbasins, one in the southern frontal part and one in the northern trailing part of the thrust sheet. The area between the sub-basins lacks the Rubjerg Knude Formation because it corresponds to the crest of the hanging-wall anticline.

\section{Sedimentary units}

The type sections of the Lønstrup Klint and Rubjerg Knude Formations, as defined in this bulletin and previously described by Sadolin et al. (1997), are situated at Sandrende. As defined above, this succession is divided here into the Lønstrup Klint Formation and the overlying Rubjerg Knude Formation, which are separated by the L/R-unconformity (Fig. 19). The Rubjerg Knude Formation is covered by an up to $1 \mathrm{~m}$ thick homogeneous sandy till, which is referred to the Kattegat Till Formation (Fig. 30).

\section{Lønstrup Klint Formation}

In the Sandrende Section, the lower exposed part of the Lønstrup Klint Formation is composed of laminated clayey to sandy mud, intercalated with a few thin sandy turbidites that grade up into finely laminated clay-rich mud. In the upper part of the formation, thicker turbidite sand beds with climbing ripples give the formation a banded light/dark coloured appearance (Figs 19, 85). O nly very few load structures and hydrodynamic breccias have been noted in the Sandrende
Section, except in the lower part of the SR04 sheet where ball-and-pillow structures and small-scale polydiapirism have been observed (Fig. 86). The ball-andpillow features are about $20 \mathrm{~cm}$ in thickness, which is probably the thickness of the original beds; they are typically elongated about $50-75 \mathrm{~cm}$ parallel to the strike of the bedding, suggesting they were formed during the thrust deformation.

\section{Rubjerg Knude Formation}

The Rubjerg Knude Formation comprises three units: (1) a lower unit c. $5 \mathrm{~m}$ thick consisting of trough crossbedded sand and gravel, (2) a middle unit dominated by climbing ripple cross-laminated sand, and (3) an upper unit comprising alternating beds of small-scale ripple cross-laminated sand and trough cross-bedded sand (Fig. 19). The units reflect the change from fluvial to lacustrine and back to fluvial depositional environments (Sadolin et al. 1997). The Rubjerg Knude Formation has an onlapping relationship in the frontal part of the SR04 thrust sheet, which reflects initial thrust faulting during sedimentation (Sadolin et al.1997). In the central part of the SR04 thrust sheet, growth-fault sedimentation along normal faults is recorded in the lower part of the Rubjerg Knude Formation. The growth faults coincide with the foreland-dipping limb of the hanging-wall anticline of SR04 (Fig. 87). This syntectonic sedimentation supports the piggyback basin concept for deposition of the Rubjerg Knude Formation. Moreover, a slumped block $0.5 \times 2 \mathrm{~m}$ in size occurs along one of the normal faults indicating that the tip of the satellite thrust in SR04 was exposed to erosion and slumped into the basin. Similar slumped blocks were observed on the northern flank of the Sandrende diapir indicating that the diapir rose above the depositional surface during emplacement and that fragments of the Lønstrup Klint Formation slumped into the piggyback basin. The synsedimentary rise of the vertical diapir wall was also reflected in sedimentation of small point-bar wedges along the vertical flank of the Sandrende diapir.

Towards the top of the Rubjerg Knude Formation, broad trough cross-bedding is observed. Minor thrust faults splaying out from the tip of SSO1 displace the cross-bedded sand, and the base of some of the troughs dramatically truncate the thrust faults, in a similar fashion to that observed in the BR04 piggyback basin of Brede Rende (see above). At the top of the Rubjerg Knude Formation, sand was deposited in a 


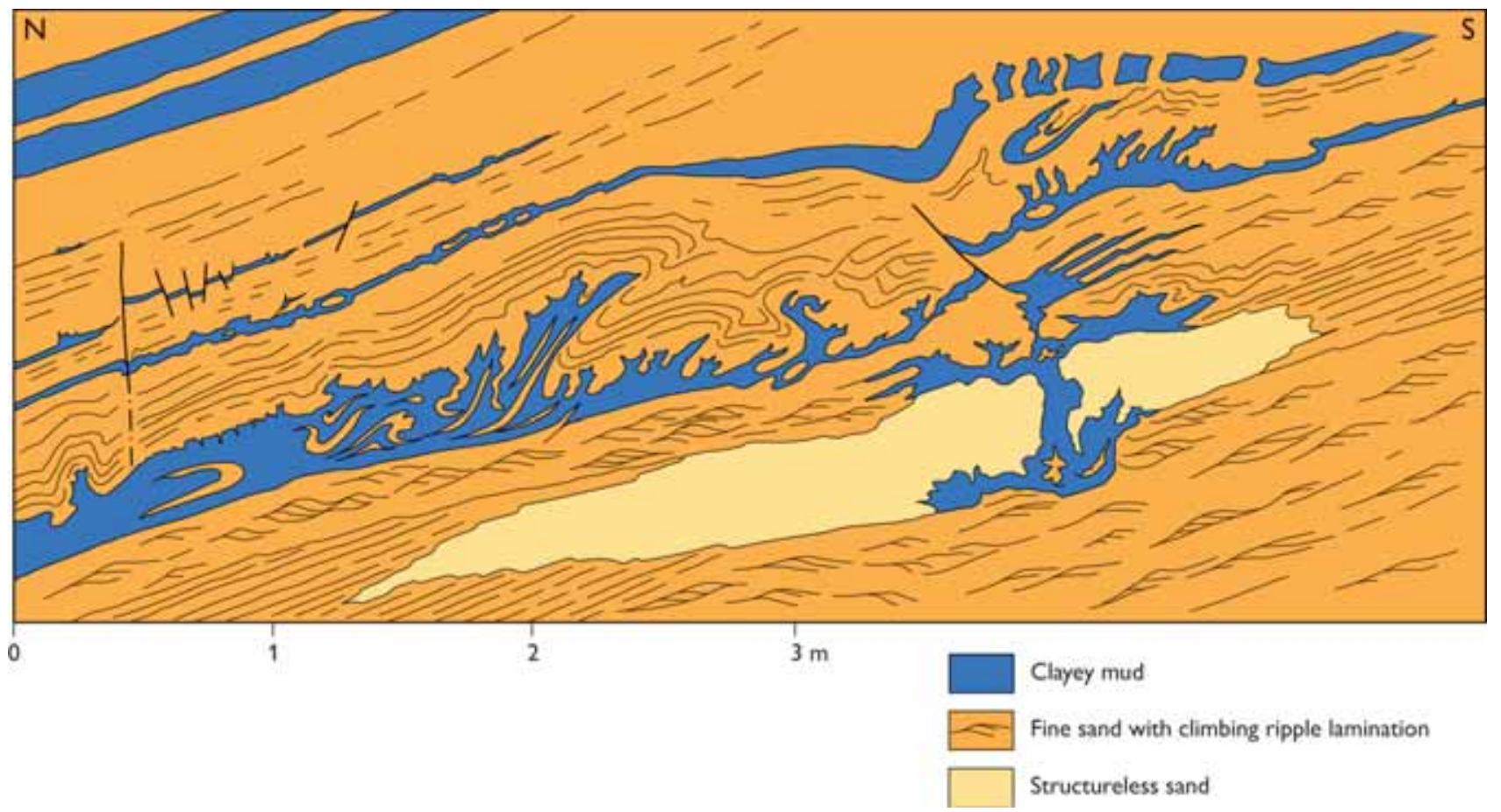

Fig. 86. Mobilisation and small-scale polydiapiric features developed in the upper part of the Lønstrup Klint Formation in the Sandrende Section (trailing end of SR04). The polydiapirs started along a bed of clayey mud as small flames (with small wavelength), which were subsequently folded around the taller diapirs. The sandy beds above and below constitute planar laminated and climbing ripple cross-laminated fine-grained sand with organic debris and mud draping the ripples. Locally in this sand, hydrodynamic mobilisation has created zones of mud-free structureless sand and the accumulation of mud forming dendritic structures. The dynamic development of the structure is illustrated in Fig. 88.

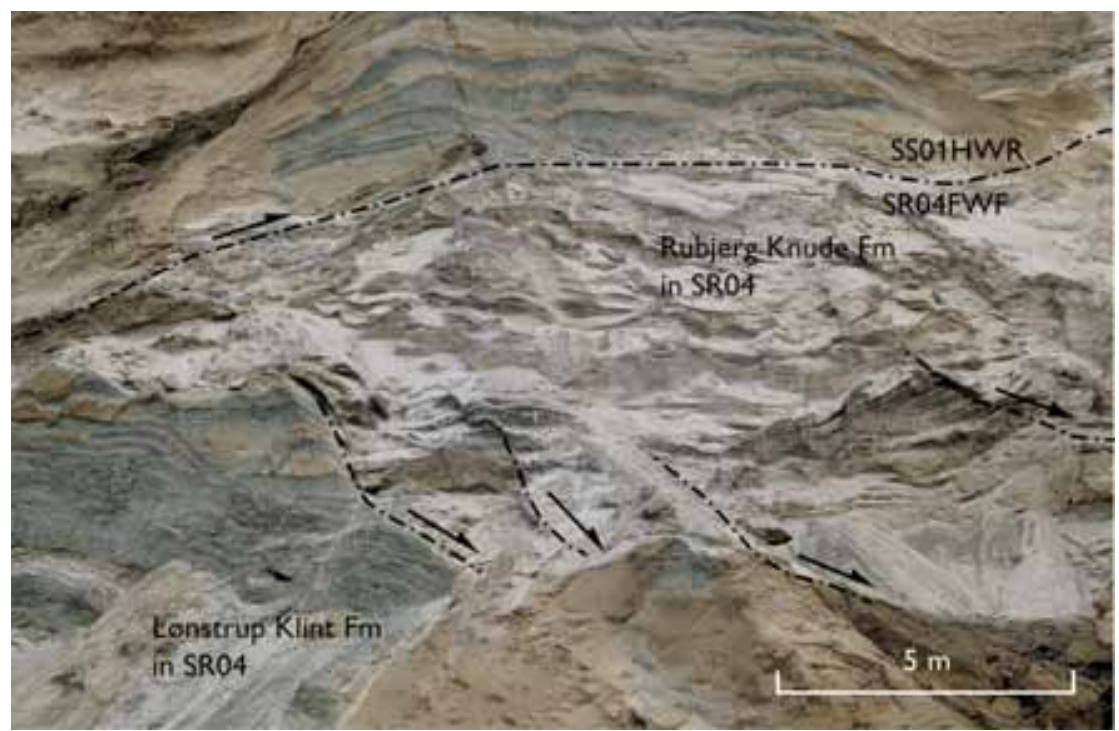

Fig. 87. Extensional nomal faults with related growth-fault sedimentation of sand and gravel in the lower part of the Rubjerg Knude Formation. The growth faults are marked with arrows indicating the direction of displacement. The top of the Rubjerg Knude Formation in the SR04 thrust sheet is over thrusted by the SS01 thrust sheet. The two sheets are separated by a thrust fault that acts as footwall flat of SR04 (SR04FWF) and hanging-wall ramp of SS01 (SSO1HWR). Photograph: May 1995. 
depressionabove the top of the Sandrende diapir. This depression wasprobably formed by relaxation collapse of the diapir during consolidation and dehydration.

\section{Structures and breccias}

Structural investigations in the Sandrende Section focused mainly on the normal faultsand theirrelationship to the thrusting, diapirism in the Sandrende diapir, smallscale incipient polydiapirism, and the record of a deep frost wedge cutting the Rubjerg Knude Formation.

\section{N ormal faults}

The Sandrende Section is an important locality for the investigation of normal faults formed on the forelanddipping limb of hanging-wall anticlines. Thus, one set of normal faults displaces the frontal parts of SR01 and SR02, and another set displaces the central part of the SR04 thrust sheet.

In the frontal part of SR01, a hanging-wall anticline developed due to ramping from the $10 \mathrm{~m}$ to the $20 \mathrm{~m}$ flat level. The normal faults here displace the Rubjerg Knude Formation of SR01 as well as the tip of SR02. The faults now have a dip of about $45^{\circ} \mathrm{S}$, but initially probably had a much steeper dip (up to $80^{\circ}$ ) subsequently reduced during the final bend of the BR08 footwall flat. In the trailing end of SR01, a steep normal fault displaced SR01, as well as the over-thrust SR02, with an offset of $10 \mathrm{~m}$. This probably reflects the influence of a sub-surface duplex, similar to the development of the BRNF.

The normal faults in the SR04 thrust sheet can be

Fig. 88. The polydiapiric structures and hydrodynamic breccias shown in Fig. 86 are interpreted to have developed in the following five steps. 1: Initial sedimentation of a clayey mud bed in a succession of mud and fine-grained sands. 2: First-order formation of small flames can be regarded as micro-diapirs with small wavelength. 3: Second-order small diapirs developed with increased wavelength. Small-scale thrusting and overturned geometry indicates formation during thrust-fault propagation. 4: Increased mobilisation creates small-scale domes with extensional fractures forming in the crest. 5: Liquefaction of the heterolithic sediment results in segregation of the sand and mud components. The mud accumulates in an irregular diapir from the top of which the mud-saturated liquid intrudes laterally along the primary parallel lamination. Some mud and fragments of sand fall to the base of the diapir under gravity.
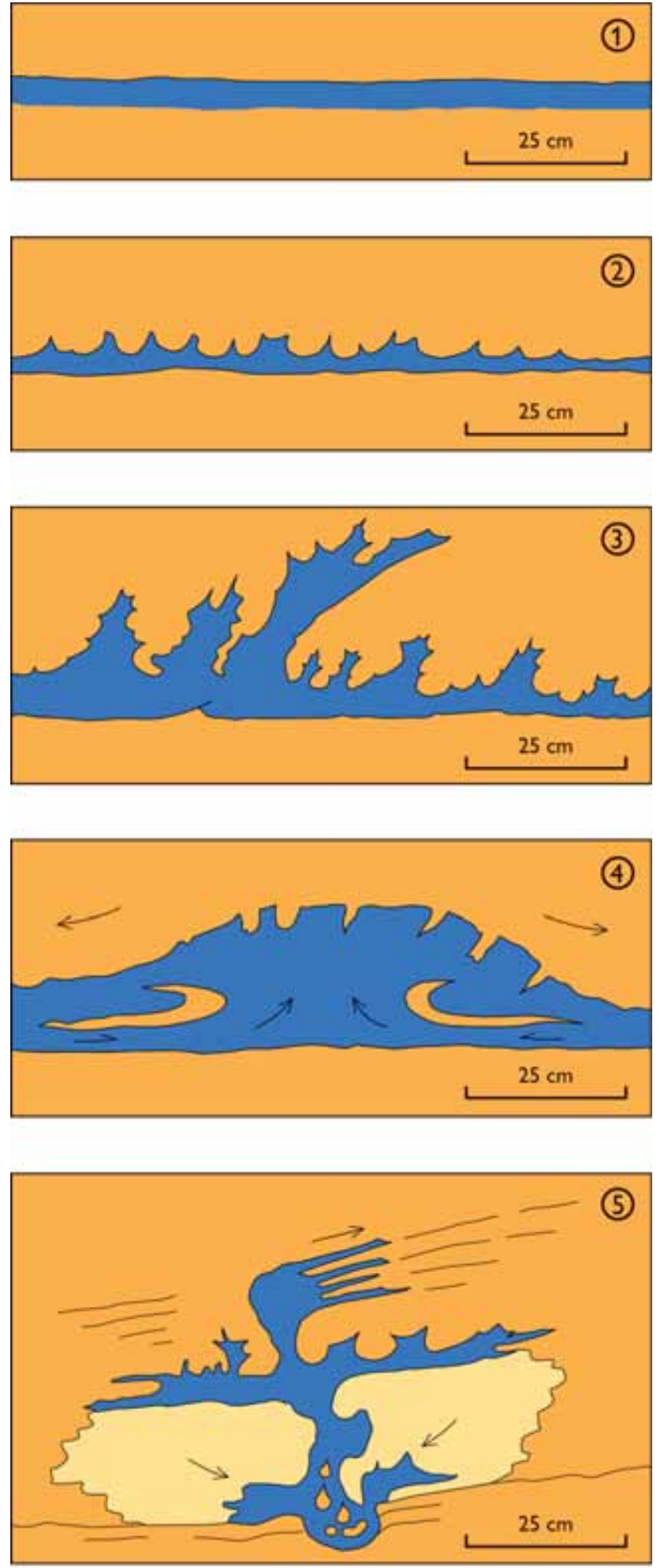

Clayey mud

Fine sand with climbing ripple lamination

Structureless sand

Direction of fluidised sediment flow 
viewed as two sets of a fault framework. The first set formed $45-60^{\circ} \mathrm{S}$ dipping faults with displacements of 1-3 m. The southerly dipping tilt of the L/R-unconformity is regarded as the foreland-dipping limb of the hanging-wall anticline formed in SR04 (Fig. 87). The faults above the foreland-dipping surface developed as growth faults associated with syntectonic sedimentation, as recorded in the lower part of the $\mathrm{Ru}$ bjerg Knude Formation. During displacement along the normal faults, a minor satellite thrust cross-cut the SR04 thrust sheet, and the tip of the satellite thrust sheet was slump-faulted to form slumped blocks in the growth-fault setting of the piggyback basin.

The normal fault network at the crest of SR04 is very impressive (Fig. 85). The strike of the normal faults is $090^{\circ}$ with a dominant dip of $50^{\circ} \mathrm{S}$, although a small number of conjugate faults with a dip of 60 $75^{\circ} \mathrm{N}$ also occur. In view of the angle of conjugate faulting, these normal faults could have formed due to the loading of the SSO1 thrust sheet emplaced above the upper footwall flat of SR04, but could also have formed due to necessary extensional adjustments during propagation over the hinge of the footwall ramp.

\section{D iapir structures}

The Sandrende diapir only affected one thrust sheet (SR02), in contrast to the Brede Rende and Kramrende diapirs where two or more thrust sheets were involved in the diapir formation. The most impressive feature of the Sandrende diapir is the major back-thrust, which has an offset of about $20 \mathrm{~m}$ towards the north. Initially it was probably an almost vertical reverse fault, which was re-orientated and accentuated during thrustfault propagation. A number of smaller reverse faults occur along the steep northern wall of the diapir, which internally is composed of mobilised mud. In the upper part of the diapir, distorted bedding-structures isolated as 'xenoliths' in the upper part of the diapir are interpreted as fragments of hanging-wall anticlines. Judging from the thickness of the diapir feeder, the diapir formed over a hanging-wall ramp where the SR02 thrusting ramped from the upper $10 \mathrm{~m}$ flat to the lower 20-30 m flat level.

The formation of diapirs was evidently initiated by mobilisation on a small scale. An illustrative small-scale example of diapirism was observed in the northern part of the SR04 thrust sheet (Fig. 86) where mobilisation and small-scale polydiapirs developed in the upper part of the Lønstrup Klint Formation in the San- drende Section (trailing end of SR04). The polydiapirs are related to beds of clayey mud deposited between the thicker beds of sandy turbidites. Along the boundary of the $25-75 \mathrm{~cm}$ high diapirs, small flame structures occur and the laminated sandy beds above are irregularly folded. Locally, hydrodynamic mobilisation created mud-free structureless sand and complex mud structures developed. An interpretation of the dynamic development of the structures is given in Fig. 88.

\section{Frost wedge}

A $20 \mathrm{~m}$ deep fracture cross-cuts the Rubjerg Knude Formation in the central part of the southern sub-ba$\sin$ in the SR04 thrust sheet. The fracture is less than $10 \mathrm{~cm}$ across, and can be followed as an irregular trace downwards into the sand sequence with a number of minor lateral jumps. This irregular fracture is one of the few structures that can be interpreted as a frost wedge. It does not penetrate the overlying SSO1 thrust sheet, indicating that it formed within the Rubjerg Knude Fomation from an exposed surface downwards into a freshly frozen sand package. It can be inferred that during the latest phase of thrusting, the SR04 thrust sheetwas elevated to a position such that the top of the Rubjerg Knude Formation was exposed subaerially.

\section{Interpretation of structural development}

A hanging-wall anticline developed c. $40 \mathrm{~m}$ from the tip of SR01 when it passed the footwall ramp and flat of BR08. This initially created a foreland-dipping tilt of the SR01 thrust structures, and was also responsible for the formation of the normal faults described above. However, the frontal part of SR01 has to be accommodated with a duplex segment in the subsurface (SR01u). The trailing end of SR01 is rooted down to the décollement level, where it corresponds to the segment adjusting the c. $80 \mathrm{~m}$ long frontal part of SR02.

When the hanging-wall ramp of SR02 initiated the propagation up along the footwall ramp, a hangingwall anticline was formed that developed into the Sandrende diapir with its marked back-thrust. During the SR02 propagation along the footwall ramp, the SR01u-duplex was pushed up and created a minor hanging-wall anticline, along which foreland-dipping limb a normal fault developed and displaced the SR02 thrust sheet as well as sediments in the piggyback basin of SR01. 


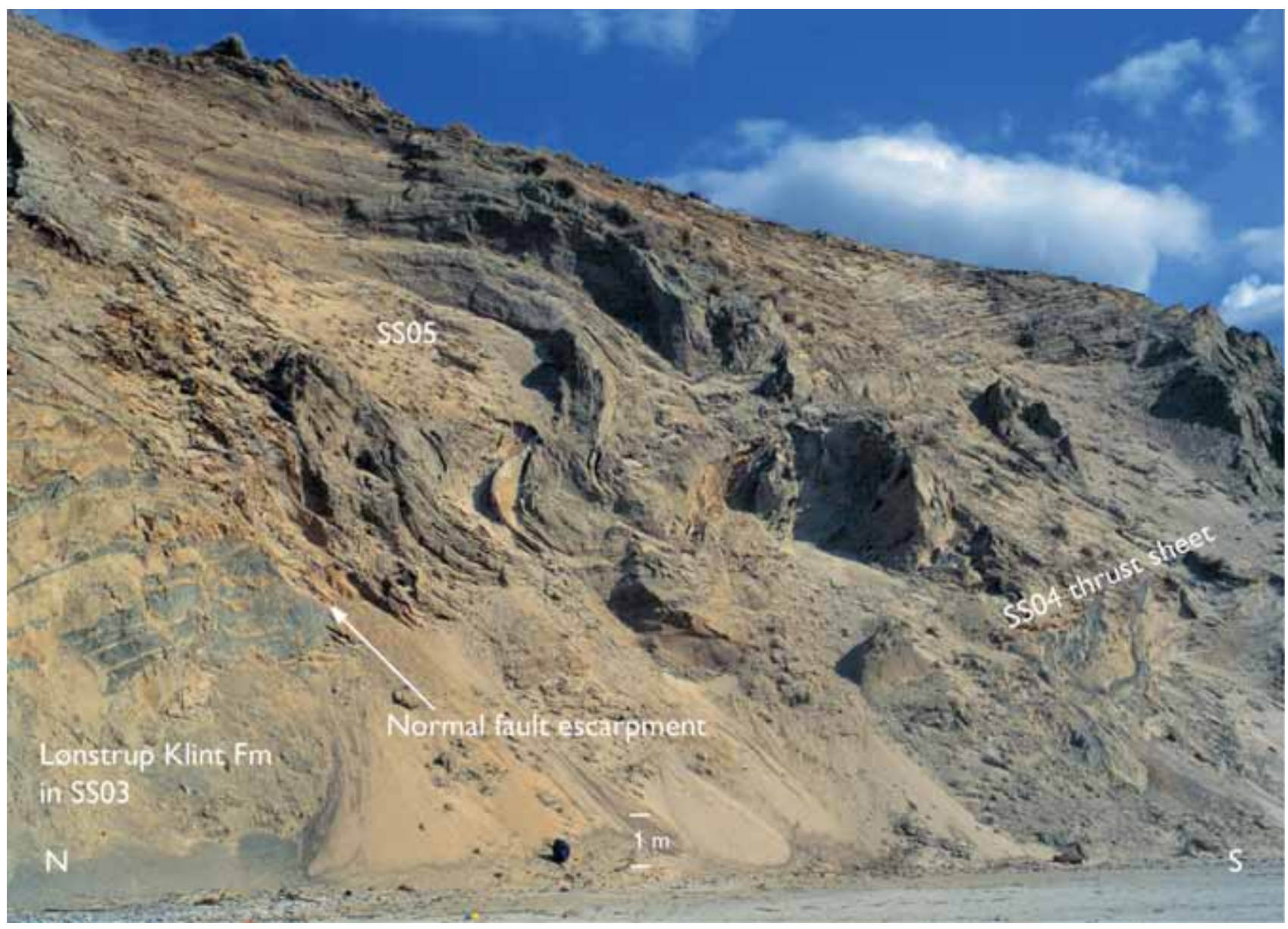

Fig. 89. The large slump fold in the Stenstue Rende Section. The slumping folded the SS05 thrust sheet into an overturned anticline during displacement down the normal fault escarpment. The escarpment was formed during normal fault displacement of the tip of SS04 parallel to the foreland-dipping limb of a hanging-wall anticline in SS03 (see Plate 2 and Fig. 90). Photograph: June 1999.

The lower10 mof the Rubjerg Knude Formation was deposited throughout the Sandrende Section, with the exception of the northern part of SR03, which had already been blocked by thrusting of SR04. Displacement of the lower hanging-wall ramp of SR04 onto the intermediate flat of SR03(and SR02) then took place. Subsequently, the first normal growth faulting was initiated at the margin of the southern part of the piggyback basin above the foreland-dipping L/R-unconformity.

Propagation of the lower SR04 hanging-wall ramp separated the piggyback basin into two sub-basins where deposition of the upper part of the Rubjerg Knude Formation took place, while the crest of the anticline between the sub-basins was probably subjected to erosion. The southernmost thrust of the Stenstue Rende Section (SS01) over-thrust the top surface of the Rubjerg Knude Formation (SR04FWF) as well as the eroded surface of the ramp anticline; this prevented deposition in the SR04 piggyback basin.
Ramping of the lower trailing segment of SR03 was activated in the latest stage of thrusting. The propagation of this duplex segment (SR03u) for a short distance up along the footwall ramp contributed to the flat-topped hanging-wall anticline formed in SR04. This final duplex emplacement may have been one of the causes for the formation of the normal fault framework in the hanging-wall anticline of SR04 (Fig. 85).

\section{Stenstue Rende Section}

In the Stenstue Rende Section, a remarkable and dramatic episode of megaslumping is recorded. Formation of a very large southward-verging anticline was accompanied by chaotic hydrodynamic brecciation (Fig. 89). Another important element related to this section is the c. $200 \mathrm{~m}$ displacement of the frontal thrust sheet over the Sandrende Section to the south. 
The Stenstue Rende Section is named after the gully situated between the Stenstue Rende Section and the Sandrende Section leading inland from the beach. In the northern part of the section is the gully known as the Søndre Grønne Rende. This is reached by a path through the pinewood connecting with the main road between Rubjerg and Lønstrup.

\section{Tectonic architecture}

The Stenstue Rende Section comprises six thrust sheets (SS01-SS06). To the south, the footwall ramp and flat of SR04 in the Sandrende Section bound the section. To the north, the boundary is defined by the footwall ramp of SS06, which coincides with the hanging-wall flat of the southernmost thrust in the Grønne Rende Section (GR01).

The most important thrust sheet in the Stenstue Rende Section is the more than $400 \mathrm{~m}$ long SS01 thrust sheet, the frontal part of which over-thrust the northern part of the Sandrende Section and has a displacement of more than $200 \mathrm{~m}$. The initial ramping of the SS01 thrust sheet was located at a gently dipping hanging-wall ramp. Subsequent to the ramping, part of the tip was eroded away during the uplift exposure of the hanging-wall anticline above the ramp and the final truncation of the glaciotectonic unconformity. Due to the increase in thickness of the SS01 thrust sheet, corresponding to a change from the $10 \mathrm{~m}$ upper flat level to the $20 \mathrm{~m}$ flat level, an intermediate hanging-wall ramp developed about $100 \mathrm{~m}$ from the frontal tip. This hanging-wall ramp rests on top of the footwall flat (SR04FWF) above the prominent normal fault structure in the Sandrende Section. Only a small remnant of the northern part of the upper flat structure is preserved, and this is not very well exposed due to its location in the inner part of the Stenstue Rende. The lower SS01 hanging-wall ramp (SS01HWR, ramping from the 30 to $20 \mathrm{~m}$ flat level) situated in the middle part of the SS01 thrust sheet is now exposed in a steeply dipping position along the SR04 footwall ramp. The propagation of SS01HWR was responsible for the bend of the footwall syncline in the Rubjerg Knude Formation in SR04, and the subsequent tilting of SSO1HWR resulted in the appearance of a more or less vertical boundary between the two sections. Thevertical orientation is a combination of $45^{\circ}$ dip on the footwall ramp added to $45^{\circ}$ dip on the hanging-wall ramp. Note that in the balanced cross-section, there is a c. $200 \mathrm{~m}$ long lower SS01 duplex segment (SSO1u) which needs to be allowed for. This implies that after ramp propagation, the lower hanging-wall flat of SS01 was displaced along the intermediate footwall flat on SS01u.

SSO2 is a small thrust sheet, thrust onto the footwall ramp of SS01; this footwall is composed of the Rubjerg Knude Formation situated in the upper part of SS01. Note that the frontal part of SS02 has a surprising vertical orientation and is displaced by a more or less horizontal extensional fault, the cause of which is discussed below.

The frontal part of the SS03 thrust sheet is shown in the cross-section as a rather simple, upright thrust structure (Plate 1). However, the SS03 thrust sheet is in reality a chaotic load and hydrodynamic breccia complex. At the base of the cliff section is an upright anticline, which is regarded as a key structure in the interpretation of the thrust development (Fig. 90). Above the anticline, a normal fault dipping $40^{\circ} \mathrm{S}$ truncates the c. $30 \mathrm{~m}$ thick Rubjerg Knude Formation.

The thin frontal part of the SSO4 thrust sheet is characterised by chaotic brecciation. The trailing end is $\mathrm{c}$. $10 \mathrm{~m}$ thick, dipping $45^{\circ} \mathrm{N}$, with the hanging-wall flat thrust along the footwall flat of SS03. The tip is separated from the trailing part of the SSO4 thrust sheet by a $40^{\circ}$ dipping normal fault with a displacement of about $50 \mathrm{~m}$. This normal fault fomed an escarpment truncating the Rubjerg Knude Formation on top of the SS03 thrust sheet, upon which deposition of a coarse clastic breccia took place (Fig. 91).

The normal fault escarpment was finally overridden by the frontal part of the SSO5 thrust sheet, which slump-thrusted down the fault plane and formed a major overturned slump fold (Fig. 89). The formation of the megaslump fold took place after the SS05 thrust sheet was thrust up along the footwall flat of SSO4 to the head of the escarpment from where it gravitationally slid down to the depression on the back of the SS04 tip. A soft sedimentary tectonic breccia was formed at the transition between SS04 and SS05, which was cross-cut by a number of minor steeply southward dipping normal faults reflecting the final setthing of the fault-slump structure.

The SS06 thrust sheet is about $30 \mathrm{~m}$ thick, its lower hanging-wall flat resting on the footwall ramp of SS05. It has a steep dip and has been strongly disturbed by mobilisation and internal diapirism. This thrust sheet is included in the Stenstue Rende Section because it involves the trailing lower duplex segments of SS05 and SSO4. From the position of the L/R-unconformity surface, about $30 \mathrm{~m}$ above sea level, it can be inferred that the SS06 thrust sheet was raised up over the low- 
Fig. 90. The crest of the hanging-wall anticline formed in the SSO3 thrust sheet in the Stenstue Rende Section. Photograph: June 1984; the staff divisions are $20 \mathrm{~cm}$.

Fig. 91. The conglomerate/breccia formed along the fault escarpment truncating the SS03 thrust sheet. Photograph: June 1984; the staff divisions are $20 \mathrm{~cm}$.
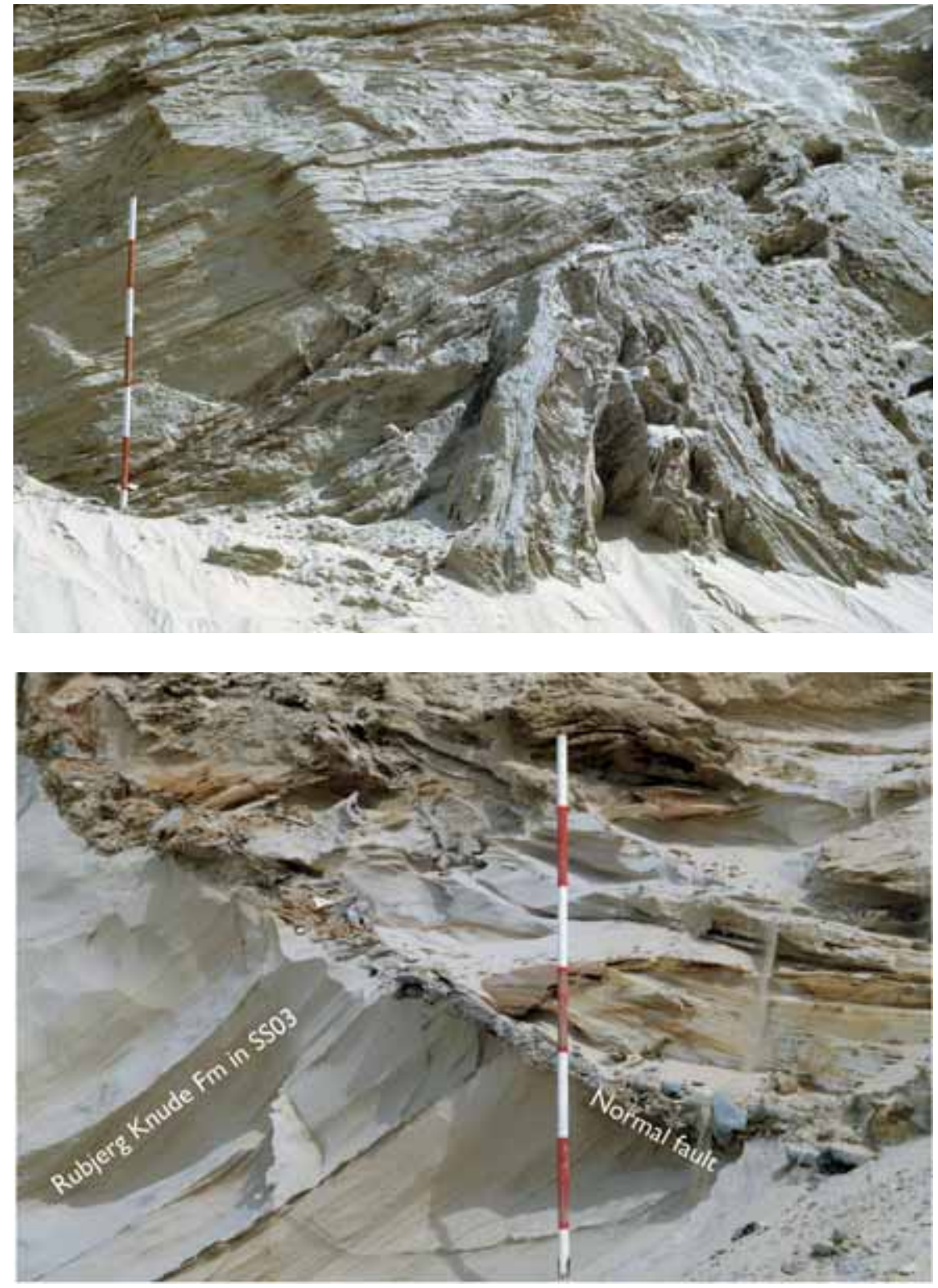

er trailing segments during ramping and subsequent stacking of a subsurface duplex complex.

\section{Sedimentary units}

The most interesting sedimentological feature within the Stenstue Rende Section is the record of syntectonic sedimentation related to normal faulting. This includes slump deposits as well as a gravel bed developed on the escarpment surface of the normal fault. As these sedimentary features are related to deposition in the piggyback basin, they are described below as part of the Rubjerg Knude Formation.

The sediments of the lower Lønstrup Klint Forma- tion have been strongly affected by thrust shearing, and the upper levels were modified by hydrodynamic brecciation. The Rubjerg Knude Formation comprises a confusing mixture of redeposited units together with the main fluvial-lacustrine sediments related to the piggyback basins.

\section{Lønstrup Klint Formation}

The lower part of the Lønstrup Klint Formation is exposed in the SS06 thrust sheet, where the lower hanging-wall flat is thrust up along the footwall ramp of SS05. Here bluish grey clay alternates with dark redbrown clay in a laminated to thin-bedded unit (Fig. 
92). It is evident from the shear structures that this unit acted as a décollement zone during thrusting.

The main part of the Lønstrup Klint Formation exposed in this section comprises the upper sand-dominated part of the succession. The breccias in the SS03 and SSO4 thrust sheets probably initially formed as medium- to large-scale ball-and-pillow structures in sand beds $20-60 \mathrm{~cm}$ thick during initial thrusting; the formation was subsequently deformed during gravity slumping.

\section{Rubjerg Knude Formation}

Nearly $20 \mathrm{~m}$ of fluvial-lacustrine sand were deposited in the piggyback basin of SSO1 and SS03 during the thrust-fault activity affecting the Stenstue Rende Section. However, the most conspicuous unit is the remarkable conglomerate/breccia related to the normal fault. The gravel bed draping the fault escarpment is $10-50 \mathrm{~cm}$ thick and includes clasts up to $10 \mathrm{~cm}$ in size. Locally, the clasts occur in a clayey mud matrix, but the latter has often been removed by recent erosion. It is perhaps surprising that a coarse gravel bed could have accumulated and been preserved along a fault escarpment dipping at about $35^{\circ}$ (Fig. 91). One explanation may be that the escarpment was only exposed for a very short time before the SS04 thrust sheet was displaced down the fault plane; in this case, the redeposited gravel rather represents a tectonic breccia composed of the smeared-out lithologies of the L/R-unconformity and surrounding sediments. The breccia is thus interpreted as the residue of a brecciated thrust sheet. The source of the clasts was probably the L/R-unconformity, and some of the material may have been derived from the unconfomity by successive erosion during exposure at the head of the fault escarpment. This probably only occurred for a brief period before the escarpment was covered by the slump-slide of the SS05 thrust sheet.

The small piggyback basin on top of the SS05 thrust sheet is a double syntectonic basin which was partly carried on the back of a thrust sheet as well as acting as a depression in the hanging wall of a normal fault. A $9 \mathrm{~m}$ thick succession represents the fill of this basin. The lowermost $3 \mathrm{~m}$ consist of large-scale cross-bedded medium-grained sand, rich in clay and silty mud clasts. Towards the upper part of this unit, clay drapes on the cross-bed foresets become more common and the beds are affected by small-scale slumping. The overlying $5 \mathrm{~m}$ thick unit comprises sand beds $30-50 \mathrm{~cm}$ thick, with mud intercalations 5-20 cm in thickness. Clay clasts are common and the sand shows smallscale ripples. The uppemost $1 \mathrm{~m}$ thick bed consists of mainly horizontal laminated sand and mud.

This piggyback basin succession is interpreted to record a fluvial depositional environment that with timedeveloped into a small shallow lake. A number of small south-dipping normal faultsintersect the Rubjerg Knude Formation up to the base of the thinly bedded muds and sands, indicating that the lake first became established when the fault activity ceased.

\section{Structures}

Four types of structures in the Stenstue Rende Section deserve particular mention: (1) mesoscopic thrust-fault structures above the lower hanging-wall flat, (2) hanging-wall anticlines, notably the one in the central part ofthe section, (3) no rmal faults, the most important being the major escarpment-producing fault, and (4) slump folding related to the escarpment of the same fault.

\section{Thrust-fault structures}

Thrust faulting related to the décollement zone in the Stenstue Rende Section has been observed in the lower hanging-wall flat of the SSO6 thrust sheet. Here the décollement zone is located in the $30 \mathrm{~m}$ flat level, which corresponds to the base of the $30 \mathrm{~m}$ thick Lønstrup Klint Fomation where lithologies are mud-dominated, comparing dark blue-green-greyish, clayey or silty mud with a few light grey coloured, fine-grained sand laminae. Two types of structures are distinguished: imbricate duplexes and listric imbricate fans (Figs 92, 93). The duplex imbricates appear within a $1 \mathrm{~m}$ thick unit bounded by thrust-shear surfaces below and above (Fig. 92). The mesoscopic-scale duplex complex consists of sheets about $0.5 \mathrm{~m}$ thick and $1-3 \mathrm{~m}$ long. Some of the duplexes are folded into antiformal stacks and form lensoid networks. The basal and roofing thrust faults occur as $20 \mathrm{~cm}$ thick shear bands penetrated by flat anastomosing jointing (Fig. 92). The listric fans are outlined by 1-2 $\mathrm{cm}$ thick sedimentary layers or tectonically induced sand streaks (Fig. 93). They rise from a narrow thrust plane, recognisable as a joint surface draped by a $1 \mathrm{~mm}$ thick film of black mud, and extend upwards into the muddy lithology where they seem to disappear before being over-thrust 
Fig. 92. Along the lower hanging-wall flat of the SS06 thrust sheet, an imbricate duplex complex has been recognised; bounding thrusts indicated by shear arrows. The thrust-fault imbrication formed in the lowermost part of the Lønstrup Klint Formation during displacement along the décollement surface. The trowel is c. $30 \mathrm{~cm}$ long. Photograph: June 1997.
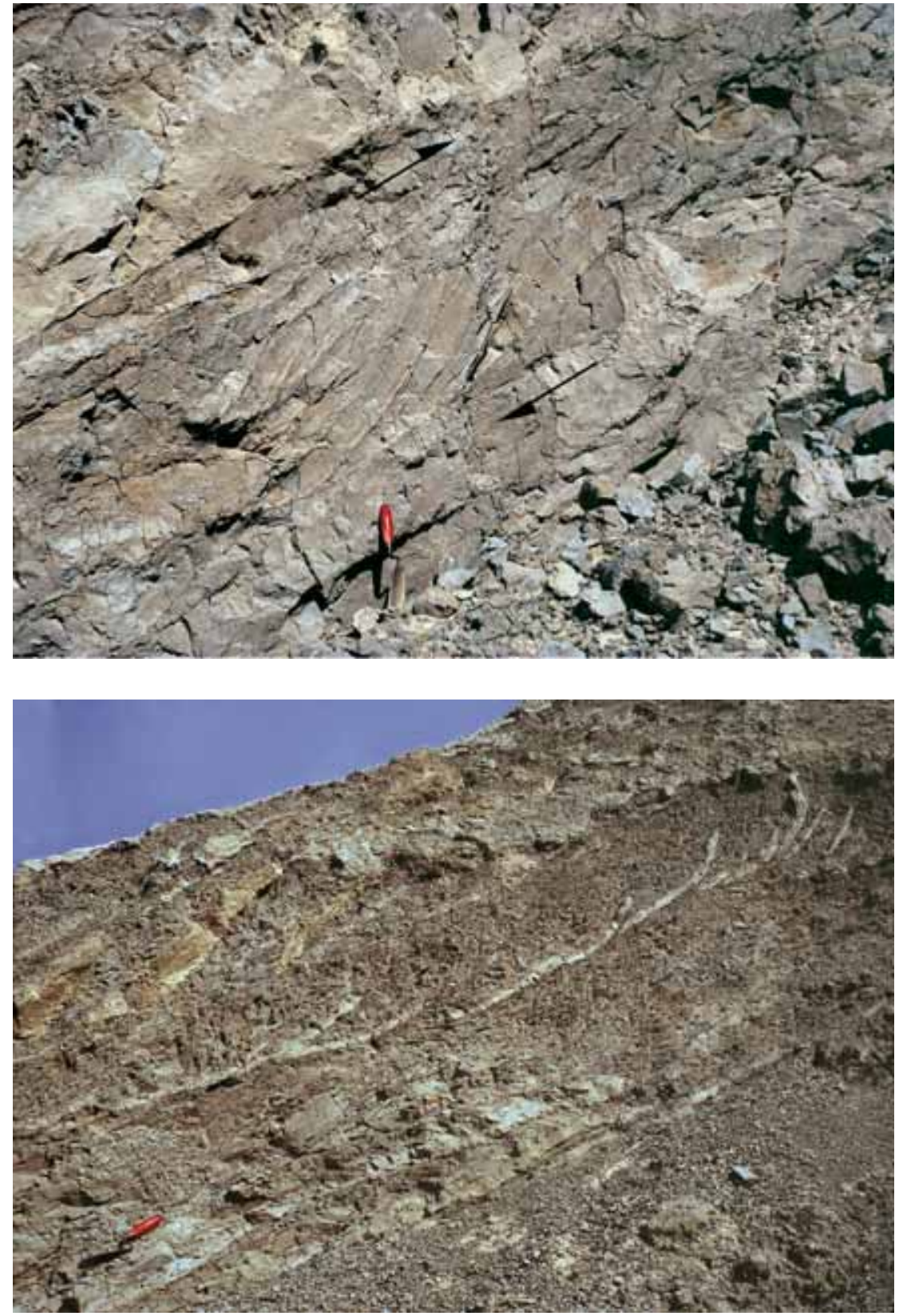

Fig. 93. An imbricate fan formed in the lower part of the Lønstrup Klint Formation in the SSO6 thrust sheet. The trowel is c. $30 \mathrm{~cm}$ long. Photograph: June 1997. by the next thrust joint surface about $1 \mathrm{~m}$ above the basal thrust surface.

\section{H anging-wall anticlines}

Three hanging-wall anticlines have been recognised; the anticline in the frontal part of SSO1 has been commented on above. The second example is not very obvious, but was developed above the intermediate hanging-wall ramp of SS01. The structures related to it were later modified by re-orientation due to the bend of SS01 up along the SR04 footwall ramp. The third hanging-wall anticline is the key structure in the Stenstue Rende Section and is situated in the middle part of the SSO3 thrust sheet. The SSO3 hanging-wall anticline (Fig. 90) was folded due to the ramping in the middle ofthe lower trailing duplex segment (SSO1u). This ramping took place at a mature stage of thrusting, and SSO1u was separated into two segments. The anticline is upright and tight, and the onlapping sedimentation of the Rubjerg Knude Fomation on the northern flank indicates that the SS03 thrust sheet had commenced transport along a footwall ramp and flat prior to the anticlinal folding. 


\section{N ormal faults}

Two normal faults are discussed: (1) the extensional fault with horizontal fault plane that displaces the tip of SSO2, and (2) the major normal fault displacing the SSO4 thrust sheet.

The extensional fault affecting SSO2 was formed north of the hanging-wall anticline developed over the intermediate hanging-wall ramp of SS01. It is interpreted to have formed initially as a normal fault dipping c. $45^{\circ} \mathrm{N}$ on the foreland-dipping limb of the SSO1 hanging-wall anticline. Subsequent to displacement on the normal fault, the SSO2 thrust sheet and the fault were tilted into vertical and horizontal positions, respectively, during the fault-bend folding resulting from the SSO1 propagation up along the footwall ramp. The major normal fault displacing SSO4 is also regarded as a fault that developed on the foreland-dipping limb, here related to the anticline in SSO3. It is observed that the L/R-unconformity dips beneath the beach level, indicating that the reference surface is not elevated and consequently that the underlying SSO3 hanging-wall flat rests on a footwall flat; the normal fault is thus preserved with its initial orientation. The formation of the normal fault is similar to the formation of the BRNF in the Brede Rende Section (see above).

\section{Slump folding}

The large-scale slump fold formed by the SS05 thrust sheet as it was displaced down the foreland-dipping fault escarpment can be compared to the same type of deformation described from the Martørv Bakker Section. However, in the Stenstue Rende Section, the Lønstrup Klint Formation is still preserved as a coherent sheet, deformed into a major southerly overtumed fold with an amplitude of about $15 \mathrm{~m}$ and an irregular fold axis orientated SE-NW (c. 150 ${ }^{\circ}$ ) (Fig. 89). During slumping along the escarpment, the redeposited units were strongly affected by hydrodynamic brecciation resulting in the chaotic disorganised nature of the sediments.

\section{Interpr etation of structural development}

The important question in the development of the Stenstue Rende Section is the time of formation of the ramp bend anticline during thrust-fault propagation. The interpretation given here is based on the description above, and the balanced cross-section and mod- el for ramping in the subsurface given in the ramp cross-section (Plate 2B).

Firstly, it should be remembered that there is evidence of a long translation along the décollement zone, primarily indicated by the considerable distance of SS01 transport over the upper footwall flat in the Sandrende Section (SR04). Secondly, the displacement of the frontal part of SS01 must be balanced with a lower duplex segment (SS01u) in the subsurface. Moreover, the displacement of SS01 also affected the SSO2 thrust sheet by superimposed structural development. The superimposed model here advocated is supported by the following interpretation. As the initial angle of thrust faulting rarely exceeds $30^{\circ}$ (Jaeger \& Cook 1979), superimposed rotation must have affected the SS02 thrust. The angle between the SSO2 hanging-wall ramp and the L/R-unconformity surface is about $30^{\circ}$ indicating a normal type of thrusting when the $\mathrm{Ru}$ bjerg Knude Formation was horizontal. Considering the thrust in this pre-rotated position, it is easy to envisage that the extensional fault offsetting the tip of SSO2 as a normal fault formed over the lower hanging-wall ramp of SS01. To restore the thrust sheet into an upright position, two phases of rotation are necessary. The first one would be the SSO1 ramping on the footwall ramp of SR04, and the second would be the re-orientation of the ramp due to the fault-bend provided by the thrusting of a subsurface segment of SR03 up along its footwall ramp in the Sandrende Section.

The initial ramping of the leading edge of SSO1 probably took place during sedimentation in the lower part of the piggyback basin of SR04. Thrust propagation of SSO2 must have been initiated at the same time, indicating that the SSO3 thrust sheet in the trailing end of SSO2 also participated in the translation along the $10 \mathrm{~m}$ flat level (SS01 intermediate footwall flat). During the translation of the lower footwall ramp in the trailing end of SS01, the $200 \mathrm{~m}$ long lower SS01u segment must also have been thrust, which is interpreted to have caused the ramping in the central part of SSO1u. Above this ramp, a lower hanging-wall anticline developed, which also folded the overlying SSO3 thrust sheet into the exposed anticline in the middle part of SS03, resulting in the foreland-dipping footwall flat of SSO3 and the initiation of normal faulting. Part of the SS04 thrust sheet had by then already propagated over the SS03 footwall flat, and was therefore subsequently displaced by the normal fault with a drag down the fault plane. The displacement on the SSO1u footwall ramp must have been relatively small to create and preserve an upright, close to tight anticline. If the dis- 


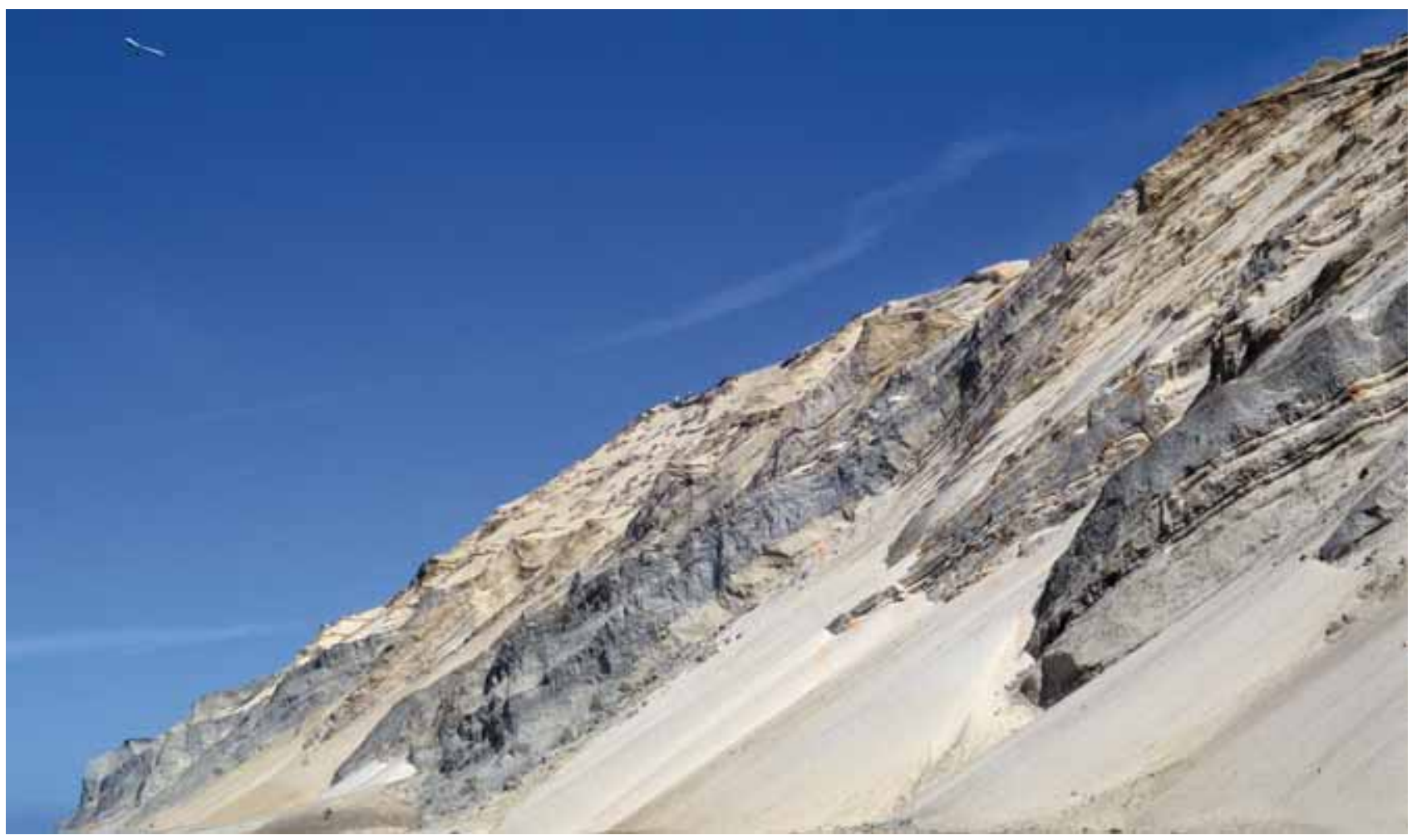

Fig. 94. View along the Grønne Rende Section to the north where the Lønstrup Klint Formation forms thin mud sheets interleaved with thick sand sheets referred to the Rubjerg Knude Formation. In the far distance, Stortorn forms the vertical cliff facing the sea. Height of cliff is c. $50 \mathrm{~m}$. Photograph: August 1984.

placement had continued, it is likely that a more flattopped anticline would have developed and minor normal fault imbricates would have been the result, rather than the marked fault escarpment that actually formed on the southern flank of the anticline.

The slump-thrusting of SSO5 down into the depression on the hanging-wall block of the normal fault is interpreted to have taken place shortly after the SS04 was down-faulted. Propagation of the SS05 thrust sheet was combined with the push on its footwall ramp by thrusting of the SSO6 sheet. During this final thrusting in the Stenstue Rende Section, the trailing lower segments were stacked into a duplex, probably analogous to the mesoscopic-scale duplex structure exposed along the hanging-wall flat of SSO6 (Fig. 92).

\section{Grønne Rende Section}

In the geological cross-section of Lønstrup Klint presented by Jessen (1931), two gullies were indicated south of the Rubjerg Knude Fyr (the lighthouse), namely Søndre and Nørre Grønne Rende. By the year 2000, the cliff profile had no obvious gullies that these names can be attached to, although Søndre Grønne Rende must have been close to the gully so annotated in the northern part of the Stenstue Rende Section. The name Grønne Rende Section is therefore adopted here to cover the section between Stenstue Rende and $\mathrm{Ru}$ bjerg Knude Fyr.

The section comprises twelve nearly vertically orientated thrust sheets, which can be characterised as a listric imbricate fan. Only the frontal parts of the thrust sheets are ramped up into steeply dipping positions, and in these parts of the thrust sheets the Lønstrup Klint Formation is thin, whereas the Rubjerg Knude Formation is relatively thick. The general impression of the section is of thin mud sheets alternating with thick units of sand (Fig. 94).

The points of interest in this section are the means of formation of an imbricate fan of uniform thrust sheets, and the mechanism by which the sheets reached their vertical orientation. Also of interest is the arrangement of the now concealed duplex segments in the subsurface, where balancing of the thrust sheets indicates shortening of about $60 \%$. 


\section{Tectonic architecture}

The Grønne Rende Section comprises a leading-edge thrust sheet (GR01), which consists of a $30 \mathrm{~m}$ thick section of the Lønstrup Klint Formation, succeeded above the L/R-unconformity by about $15 \mathrm{~m}$ of the Rubjerg Knude Formation. North of GR01, a further twelve thrust sheets (annotated GR02-GR13) are exposed, each composed of an average thickness of $\mathrm{c}$. $10 \mathrm{~m}$ of the Lønstrup Klint Formation overlain by about $25 \mathrm{~m}$ of the Rubjerg Knude Formation. To the south, the section is bounded by the thrust fault that separates the lower hanging-wall flat of the Grønne Rende frontal thrust sheet (GR01) from the footwall rampand-flat of the northernmost thrust sheet (SS06) in the Stenstue Rende Section. To the north, the boundary of the Grønne Rende Section is defined by the thrust fault that acts both as the hanging-wall ramp of RF01, the frontal thrust sheet in the Rubjerg Fyr Section, and as the footwall ramp-and-flat of GR13.

In the description of the thrust sheets, it is assumed that the thrust sheets initially involved only the Lønstrup Klint Formation, and that the Rubjerg Knude Formation was deposited syntectonically and separated into small piggyback basins between the sheets. As the imbricate thrust sheets constitute the most important structural element in this section, each thrust sheet is described separately in the structural account below.

\section{Sedimentary units}

In the Grønne Rende Section, the Lønstrup Klint Formation is mainly represented by the upper levels of the formation. The only exception is the southernmost thrust sheet GR01, in which lower stratigraphic levels of the formation are also exposed. In this section, intra-Rubjerg Knude Formation erosional surfaces locally incise the unconformity defining the Lønstrup Klint Formation - Rubjerg Knude Formation boundary. This unconformity is thus composite in places but the term L/R-unconformity is retained as it clearly still forms the boundary between these two formations. During hanging-wall ramping of the thrust sheet tips, the gravel beds on the unconformity were partly removed from the unconformity surface, and desiccation cracks may be present (only observed in the uppermost tips of the thrust sheets) indicating that some of the tips were exposed above water level. The $\mathrm{Ru}$ bjerg Knude Formation mainly comprises the same three units described in the Sandrende Section. However, a number of variations in sedimentary architecture occur due to syntectonic sedimentation.

\section{Lønstrup Klint Formation}

The lower part of the formation exposed along the hanging-wall flat of GR01 consists of dark grey laminated mud with a few c. $0.5 \mathrm{~m}$ thick white sand turbidites; these have been strongly disturbed by thrusting, contortion and mud-mobilisation. The upper part of the formation is dominated by light-coloured sandy turbidites up to $1 \mathrm{~m}$ thick, interbedded with $10 \mathrm{~cm}$ layers of blue-grey clayey mud.

\section{Rubjerg Knude Formation}

It has already been noted that the Rubjerg Knude Formation was deposited in a number of small piggyback sub-basins. In the description of the piggyback basin architecture, four depositional elements are differentiated.

1. Flat-parallel bedding (F-bedding): initially horizontal stratification of a bed deposited on a surface parallel to a flat as well as to the mean level of the L/R-unconformity.

2. Ramp onlap (R-onlap): horizontal stratification or large-scale cross-bedding in a bed deposited on an inclined unconformity surface that had been tilted due to ramping prior to sedimentation.

3. Foreland-dipping onlap (D-onlap): initially horizontal stratification in a bed deposited on an inclined unconformity surface dipping towards the foreland due to the repositioning of a hangingwall ramp on a footwall flat.

4. Climbing ripple stratification (C-bedding): climbing ripple cross-lamination in beds $20-80 \mathrm{~cm}$ thick, commonly limited by F-bedding below and above (Figs 24, 95).

The Rubjerg Knude Formation is interpreted as a glaciolacustrine deposit. Sediment influx was probably relatively constant, and the sedimentary structures developed in the individual thrust sheets were governed by local conditions. During thrusting, the sedimentary base level changed, and the accommodation space varied depending on the size of the piggyback basins. Thus the flow regime fluctuated and a variety of sed- 
Fig. 95. Large-scale cross-bedding displaying D-onlap overlain by planar bedding (D-onlap) and climbing ripple cross-laminated sand (C-bedding) of the Rubjerg Knude Formation in the Grønne Rende Section. Photograph: July 1999; way-up is to the left. L/R-u, L/Runconformity.

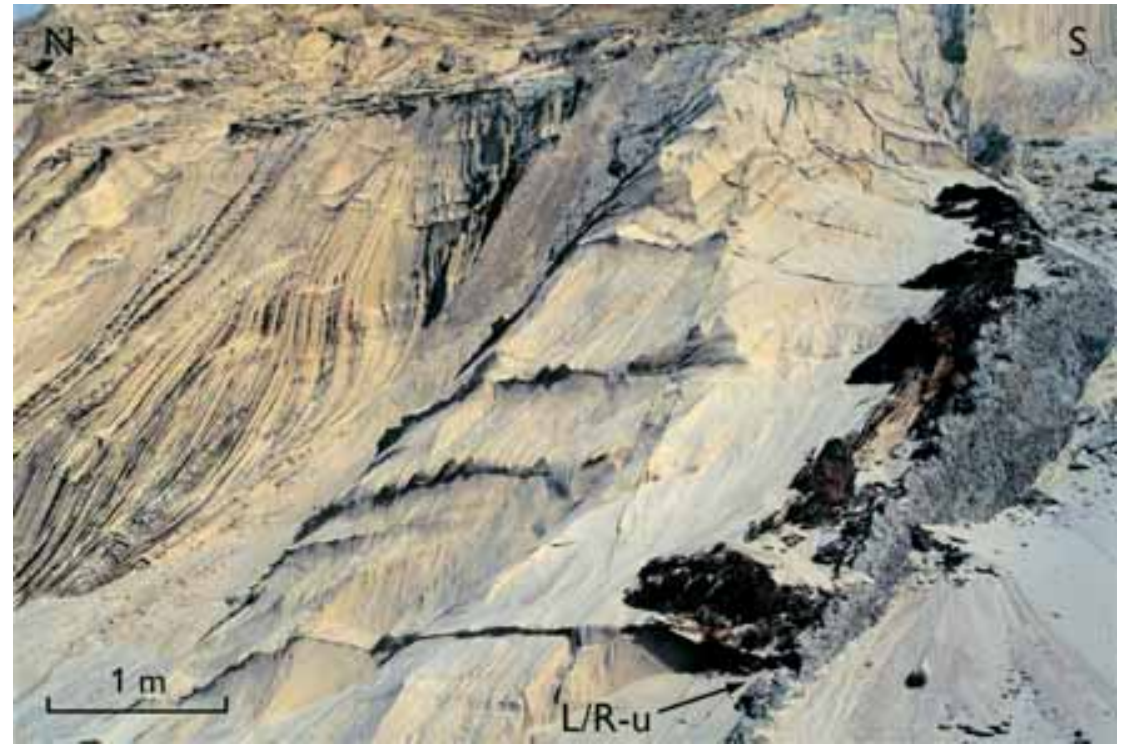

imentary structures formed, which are interpreted to reflect the thrust-fault development.

The syntectonic banana-shaped basin described by Pedersen (1987; Fig. 4) was based on observations in the upper part of these piggyback sub-basins. These structures might also be characterised as footwall synclines that developed as growth-fault synclines, where deposition took place as the hanging-wall block was thrusted up along the footwall ramp dragging the underlying limb up along the thrust fault during the displacement.

\section{Structures}

A systematic description of each thrust sheet in the section is provided below, together with some references to the syntectonic sedimentation. In general, the thrust sheets constitute an upright hanging-wall ramp, which initially had a dip of less than $20^{\circ}$. Hydrodynamic brecciation and mud mobilisation occurred along the hanging-wall ramps and flats. Along the upper footwall ramp, footwall synclines with compressive deformation of climbing ripple cross-laminated sands are very common, mainly developed as growthfault synclines as mentioned above. All the thrust sheets from GR02 to GR13 can be demonstrated to have been carried piggyback on the GR01 thrust sheet.

\section{GR01 thrust sheet}

The accumulated displacement of GR01 is estimated to about $140 \mathrm{~m}$. This includes an interpreted displacement, c. $40 \mathrm{~m}$, of the thrust-sheet tip. The thrust-sheet tip was, at a post-thrust stage, eroded away by the truncation of the glaciotectonic unconformity; calculation of the displacement of the tip follows the principle illustrated in Fig. 11. The total displacement also includes the c. $100 \mathrm{~m}$ displacement along the exposed footwall ramp of SSO6 and its consequent continuation down to the décollement zone in the $30 \mathrm{~m}$ flat level (stratigraphic level from the L/R-unconformity). From the base of the cliff and down into the subsurface, thrusting took place along the GR01 hangingwall flat.

The intemal tectonic structure of the Lønstrup Klint Formation in GR01 is very similar to the thrust structures described from the SSO6 thrust sheet of the Stenstue Rende Section (Figs 92, 93) with intraformational duplex structures, imbrication and strong mobilisation along the hanging-wall flat. As can be seen from the cross-section (Plate 2B), the L/R-unconformity is traceable down to a level c. $5 \mathrm{~m}$ below sea level. This interpretation is supported by field observations, although the base of the cliff is often scree covered, and implies that the hanging-wall flat can be traced down to the décollement surface, and that the thrust sheet has not been elevated up onto, and translated along, intermediate flats in the subsurface. The L/Runconformity rests in its initial stratigraphic position, and the reference level lies below sea level. The accu- 


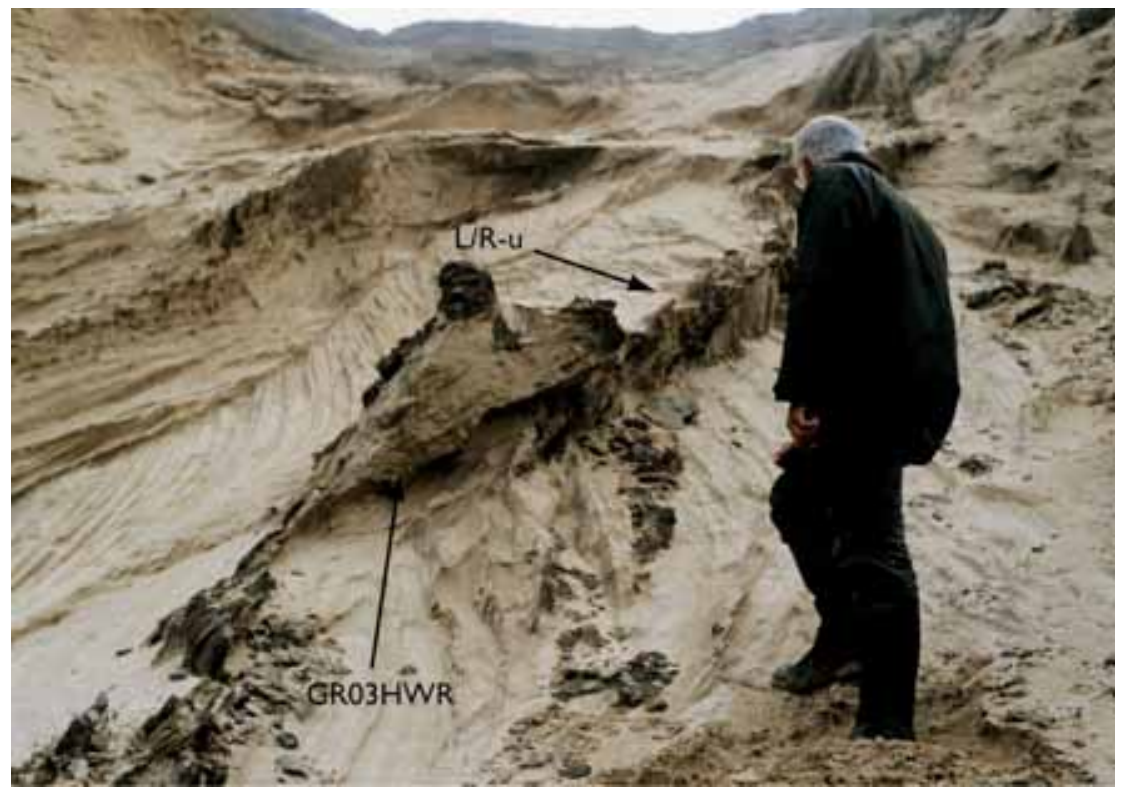

Fig. 96. The composite development of the L/R-unconfomity ( $\mathbf{L} / \mathbf{R}-\mathbf{u})$ resulted in the reduction of the thickness of the GR03 thrust sheet to a very thin horizon interlayered with thick piles of sand referred to the Rubjerg Knude Formation in the Grønne Rende Section. The upper hanging-wall ramp (GR03HWR) displays marked relief due to erosion. Photograph: October 2000.

mulated thickness of the Rubjerg Knude Formation is c. $15 \mathrm{~m}$, and the sand beds were deposited with an onlap onto the northerly dipping L/R-unconformity (R-onlap).

\section{GR02 thrust sheet}

The GR02 thrust sheet is the southernmost imbricate in the imbricate fan of the Grønne Rende Section. It consists of a $10 \mathrm{~m}$ thick section of the Lønstrup Klint Formation overlain by an about $30 \mathrm{~m}$ thick section of the Rubjerg Knude Formation. The main part of the thrust dips at $55^{\circ} \mathrm{N}$, whereas the upper part is somewhat steeper.

The lower 5-8 m thick unit of the Rubjerg Knude Formation is characterised by large-scale trough crossbedding, and R-onlap can be recognised. F-dipping bedding, grading up into D-onlap in the uppermost part of the cliff section overlies this lower unit; this indicates ramp-flat-foreland dipping relationships during ramp and flat propagation. Above this, a middle sand unit with F-bedding was deposited, and finally the upper unit shows R-onlap, which was subsequently folded in a footwall syncline below the GR03 thrust fault.

\section{GR03 thrust sheet}

In the GR03 thrust sheet, the lower part comprising the Lønstrup Klint Formation is a wedge-shaped struc- ture aligned along a vertical thrust fault (GR03 hanging-wall ramp). The thickness varies from c. $15 \mathrm{~m}$ in the lower part to c. $3 \mathrm{~m}$ in the upper part. Above the L/R-unconformity, the Rubjerg Knude Formation consists of a more than $30 \mathrm{~m}$ thick succession, which indicates that the piggyback basin of GR03 (as well as GR02) was a long-lived depocentre. The geometry of the GR03 hanging-wall ramp implies that it can be traced down to the $15 \mathrm{~m}$ (or $20 \mathrm{~m}$ ) level. During ramping, a second stage of erosion affected the L/R-unconformity, which thinned out the Lønstrup Klint Formation (Fig. 96). The R-onlap in the lower half of the Rubjerg Knude Formation probably reflects the ramping on the footwall ramp of GR02, and the middle part of the Rubjerg Knude Formation was deposited during the propagation of the hanging-wall ramp over the footwall flat of GR02. The uppermost $4 \mathrm{~m}$ of the GR03 thrust sheet is very disturbed, probably due to push from the GR04 upper hanging-wall ramp.

\section{GR04 thrust sheet}

In the GR04 thrust sheet, the Lønstrup Klint Formation is relatively thick, c. $20 \mathrm{~m}$ in the lower part of the cliff section and about $7 \mathrm{~m}$ in the top part. The GR04 hanging-wall ramp dips $70-80^{\circ} \mathrm{N}$, and in the middle part of the cliff section a small hanging-wall ramp about $5 \mathrm{~m}$ high is preserved. In front of this ramp, the sand deposited at the top of the GR03 piggyback basin was pushed forward during thrust faulting along the upper footwall flat, as mentioned above. 


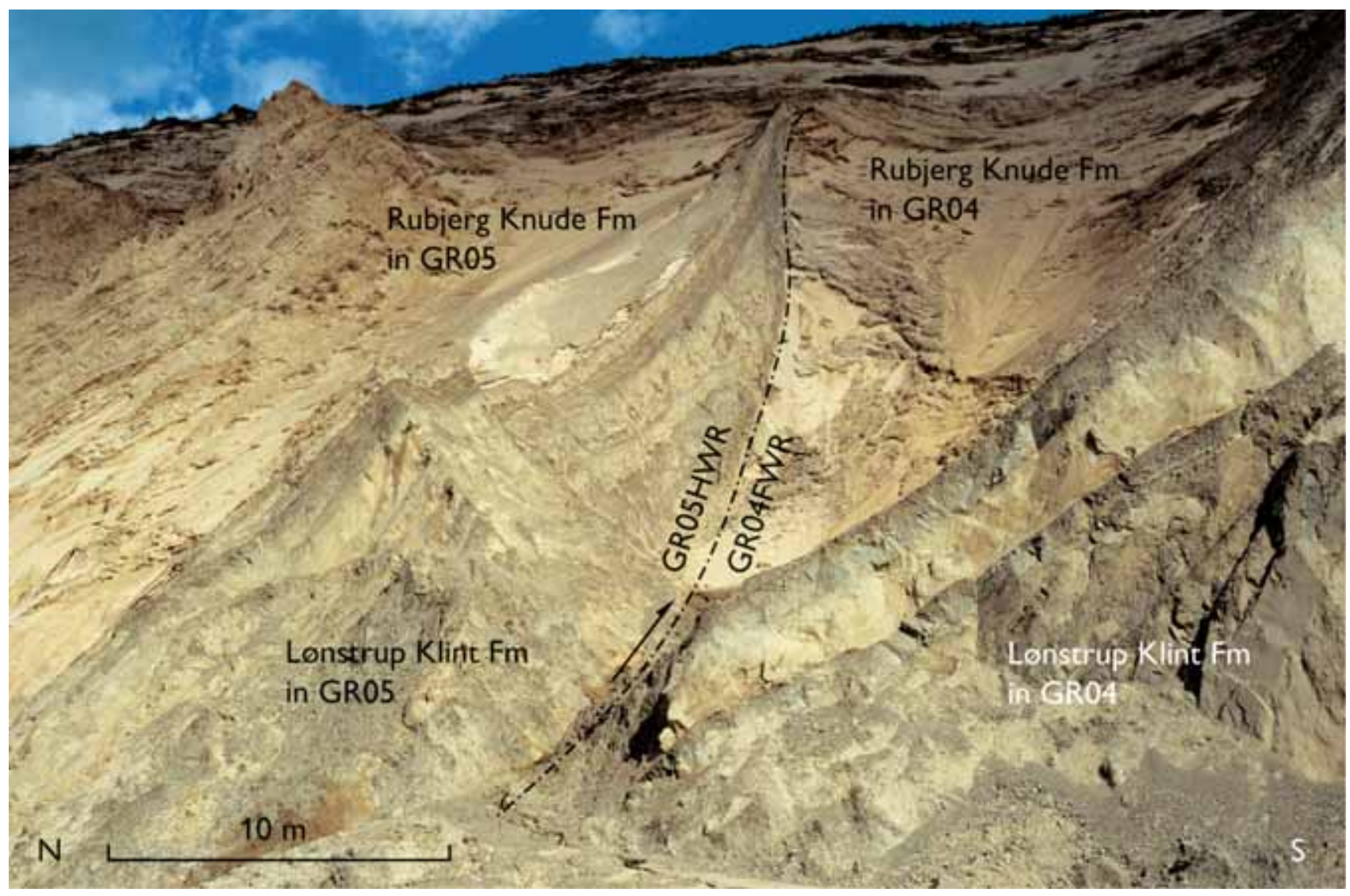

Fig. 97. The thrust-fault structures related to the GR04 and GR05 thrust sheets. The 'overturned' orientation of the GR05 hangingwall ramp (GR05HWR) is regarded as the result of repeated footwall ramping of the GR04 thrust sheet ( GR04FWR = footwall ramp of the GR04thrustsheet), and subsequenttranslation of the imbricate fan along the lower décollement surface. Photograph: July 1999.

The maximum thickness of the Rubjerg Knude Formation in GR04 is similar to the thickness in GR02 and GR03, but the piggyback basin is wedge-shaped due to the footwall ramp produced by the thrusting of GR05. The large-scale trough cross-bedded lower part of the formation tends to show R-onlap towards the upper part of the L/R-unconformity.

\section{GR05 thrust sheet}

GR04 and GR05 initially formed one coherent thrust sheet, with GR05 being carried piggyback during thrust propagation of GR04 before they were separated by the satellite thrusting of GR05 up along the footwall ramp of GR04. The hanging-wall ramp drops from the 5 to the $10 \mathrm{~m}$ flat level along a relatively steep ramp, which lifted GR05 free of GR04. In the lower part of the cliff section the L/R unconformity is situated about $5 \mathrm{~m}$ above sea level, indicating ramping to an intermediate flat in the subsurface. The GR05 thrust fault is overturned to the north, indicating that the thrust plane dips at $75^{\circ} \mathrm{S}$ (Fig. 97).

The uppemost 10-15 $\mathrm{m}$ of sand beds in the GR05 piggyback basin are horizontally orientated. The sand beds show large-scale trough cross-bedding and sedimentation is inferred to have taken place between the GR04 and GR05 thrust tips when these were exposed above the sediment/water interface during the latest stage of dynamic development.

\section{GR06 thrust sheet}

The Lønstrup Klint Formation of GR06 is generally a relatively thick unit (10-15 $\mathrm{m}$ ) although locally in this section deep erosion is evident at the L/R-unconformity. This localised deep erosion at the unconformity was probably due to erosion of a hanging-wall anticline during propagation over the footwall ramp hinge. This suggestion is supported by the presence of R-onlap in the lower to middle part of the cliff. The C- 
bedding observed in the middle part of the Rubjerg Knude Formation may well reflect post-ramp deposition; subsequently, sedimentation briefly took place during displacement on the upperfootwall flat. The thickness of the Rubjerg Knude Formation is $15 \mathrm{~m}$ where the unconformity is deeply incised, decreasing to only $10 \mathrm{~m}$ laterally. This indicates that the basin was partly closed by the GR07 thrust propagating along its hanging-wall flat (back of GR06) in an early phase of development of the section. The uppermost beds show a high-angle R-onlap to the unconformity in GR06, demonstrating that the sand was deposited during the final phase of upthrusting, and just before the last c. $30^{\circ}$ tilting of the thrust sheet into its present upright position.

\section{GR07 thrust sheet}

The GR07 thrust sheet consists of a $10 \mathrm{~m}$ thick unit of the upper part of the Lønstrup Klint Formation with medium-bedded light grey fine-grained sand interbedded with thin mud layers. The L/R-unconformity is parallel with the hanging-wall flat in the main part of the exposed thrust sheet giving the impression that the sheet is of uniform thickness. The topmost part of the sheet is wedge-shaped where the upper hangingwall ramp is preserved, and the irregular structures of the tip can be interpreted as an upper hanging-wall anticline.

The Rubjerg Knude Formation in GR07 is about 15 $\mathrm{m}$ thick and can be divided into three $5 \mathrm{~m}$ thick units, which show the typical characteristics of sedimentation in the formation. In the uppermost part of the piggyback basin, high-angle R-onlap, similar to the bedding in the GR04-GR06 thrust sheets, indicates late syntectonic deposition between the thrust-sheet tips.

\section{GR08 thrust sheet}

The lower part of GR08, comprising the Lønstrup Klint Formation, forms a wedge-shaped structure, with a thickness ofonly $3 \mathrm{~m}$ in the top of the cliff section and about $10 \mathrm{~m}$ at the base. The basal part is characterised by mobilised mud bounded at the thrust sole by a vertical thrust fault. At the top, a hanging-wall anticline and small diapir deformed the tip.

The Rubjerg Knude Formation of the thrust sheet comprises three units. The lowermost unit, up to $10 \mathrm{~m}$ thick, shows R-onlap in the lower part which is also the lower part of the cliff section. Upwards, along the steeply dipping L/R-unconformity, the dip of the Ronlap increases. There is an angular discordance between these beds and the beds occurring above. These beds show planar parallel bedding (F-bedding). In the lower part of this F-bedded unit, clasts of mud occur with sizes from cobbles to boulders ( $1 \mathrm{~m}$ size). These boulder-sized mud-blocks are interpreted as fragments of the GR09 thrust tip that were deposited by gravity slumping in the piggyback basin. The middle unit of the formation is c. $8 \mathrm{~m}$ thick and shows large-scale cross-bedding with sets up to $3 \mathrm{~m}$ thick, and the unit has an R-onlap relationship to the unit below. The upper unit isc. $10 \mathrm{~m}$ thick and the beds show mainly planarbedding with some trough cross-beddingto wards the top. The lower and middle units may be interpreted to represent deposition during two phases of rampflat propagation.

\section{GR09 thrust sheet}

The Lønstrup Klint Formation of the GR09 thrust sheet forms a uniform c. $5 \mathrm{~m}$ thick unit with a vertical orientation. The Rubjerg Knude Formation is about $25 \mathrm{~m}$ thick and can be divided into a lower and an upper part. The lower part displays variable large-scale crossbedding and the unit has a F-bedding relationship, whereas the upper part forms one large R-onlap succession. The lower part may be interpreted as having been deposited while the GR08 hanging-wall ramp propagated over a footwall flat, whereas the upper part was deposited when the GR09 thrust sheet was displaced up along a $45^{\circ}$ dipping ramp during a relatively late phase of deformation. A number of minor horizontal extensional faults are interpreted as foreland-dipping normal faults related to a hanging-wall anticline formed over a hanging-wall ramp during an early or intermediate phase of thrusting.

\section{GR10 thrust sheet}

The Lønstrup Klint Formation of GR10 is very thin, only about 3-4 $\mathrm{m}$ thick, in the exposed part of the cliff section. The Rubjerg Knude Formation is about $25 \mathrm{~m}$ thick, and the lower part shows a poorly exposed F-bedding relationship. The upper part displays marked R-onlap with a $45^{\circ}$ dipping angular discordance to the L/R-unconformity. 


\section{GR11 thrust sheet}

The GR11 thrust sheet is irregularly orientated, but is mainly vertical in the upper frontal part. In GR11, the Lønstrup Klint Formation has a uniform thickness of $10 \mathrm{~m}$, consisting of medium-bedded light coloured sand interbedded with thin mud layers situated above the steeply dipping hanging-wall flat. The Rubjerg Knude Formation is generally not well exposed due to sand scree, but has a thickness of about $15 \mathrm{~m}$.

\section{GR12 thrust sheet}

A large part of the GR12 thrust sheet is covered by sand scree, and detailed data from this part of the Grønne Rende Section are limited. The Lønstrup Klint Formation forms a c. $5 \mathrm{~m}$ thick unit of sand dominated by thick-bedded turbidites, as is typical of the upper part of the formation. The Rubjerg Knude Formation is more than $20 \mathrm{~m}$ thick and displays the typical depositional features of the formation. However, it should be noted that the L/R-unconformity in GR12, as is the case in GR11, has been lifted up to an elevation of 15-20 m a.s.l.; this indicates that these sheets propagated over an upper flat, probably composed of two stacked duplex segments of GR06 and GR08 in the subsurface.

\section{GR13 thrust sheet}

The GR13 thrust sheet is also mainly covered by sand scree at the base of cliff. However, exposures in the upper part of the cliff reveal a rather complex structure. The Lønstrup Klint Formation of the thrust sheet is very thin, and in places only the unconformity is observed; it can thus be difficult to recognise where the stratigraphic unconformity is preserved and where it has been completely replaced by the thrust fault, which is now vertically orientated. Furthermore, the Rubjerg Knude Formation has been subjected to superimposed folding. The thickness of the piggyback basin deposits in GR13 is more than $30 \mathrm{~m}$ and four units of the Rubjerg Knude Formation are differentiated. Unit 1 is about 5-6 m thick, and appears in the frontal and upper part of the piggyback basin; it is characterised by large-scale cross-bedding as well as planar parallel stratification. Towards the trailing end of the thrust sheet, the R-onlap in unit 1 grades up into unit 2, which is folded into a set of overturned folds, originally with a horizontal axial plane, but now re-orientated into an upright position; the overturned folds deform the bedding in unit 1 . Unit 3 is characterised by steeply dipping large-scale foresets that were deposited over the recumbent folds. Finally unit 4, about $7 \mathrm{~m}$ thick, is mainly planar-bedded and was pushed in front of a hanging-wall ramp of the frontal thrust sheet in the Rubjerg Fyr Section.

\section{Interpretation of structural development}

Two types of interpretations are considered prior to the further description of the structural development: (1) in order to estimate the displacement, a geometric construction has been made for each thrust-sheet tip subsequently eroded away at the glaciotectonic unconformity (Fig. 11), and (2) the position of the L/Runconformity below the screes has been constructed from successive approximations (Plate 1). Interpretation of the extent of the thrust tips was carried out as a triangular construction with a best-fit of the intersection of the unconformity and the thrust plane (see Fig. 11). Where these surfaces (lines in the 2-D constructions in Fig. 11) were obscured, the construction was guided by the assumption that the acute angle is close to $18^{\circ}$, which from experience is a general initial thrust ramp angle. According to this geometrical reconstruction, the average displacement of each thrust sheet is about $70 \mathrm{~m}$.

The general impression is that the thrusting of the twelve imbricate sheets in the Grønne Rende fan-structure was broadly contemporaneous. If the experience from the Ulstrup Section near the foreland is taken into consideration, one would expect a long coherent thrust sheet initially displaced along the upper flat level at $10 \mathrm{~m}$ stratigraphic depth (from the L/R-unconformity). From this detachment level, the imbricate thrust-fault fan propagated with fairly equal spacing, and the thrusting progressed during sedimentation of the Rubjerg Knude Formation. However, there are two positions where the piggyback basin has a thinner depositional fill, namely the basin on GR01 and on GR06/GR07. Thus, the first longer displacement along an upper footwall flat took place on the back of GR06 and GR01, subsequently leaving a trailing-end duplex segment below the $10 \mathrm{~m}$ detachment level at the rear of GR06 as well as at the end of GR01. When about half of the displacement along the GR06 had taken place, the level of detachment started to root down to the $20 \mathrm{~m}$ flat level, such that the trailing duplex seg- 
ment of GR06 was free to move along intermediate ramps. Thus, if about $20 \mathrm{~m}$ of the displacement on each of the GR07-GR13 thrusts is accumulated, it amounts to a total displacement of about $140 \mathrm{~m}$ for the GR06 trailing segment (GR06u). It is therefore argued that the GR06u segment started to ramp in the middle phase of thrust propagation, which is reflected in a foreland-dipping tilt in the GR13 basin that created the recumbent folding.

The sequence in ramping follows three angular modes: initial ramping along an angle of about $18^{\circ}$, intermediate ramping along an angle of $30^{\circ}$, and final ramping at close to $45^{\circ}$. However, ramping will never be initiated at an angle of $90^{\circ}$, so the problem is how to explain the vertically orientated thrust faults.

The first c. $20^{\circ} \mathrm{ramp}$ is given by the upper ramping, and progressive ramping will result in a $36-45^{\circ}$ tilt. This would result in progressive steepening of the tilting from south to north, however, which is clearly not the case. It is suggested, therefore, that the GR01 thrust jumped down to the décollement level at the $30 \mathrm{~m}$ stratigraphic depth, and that this caused the reorientation during the final displacement of GR01. Thus, when the imbricate fan with ramp angles up to $40^{\circ}$ was carried along with the lower GR01 thrustsheet segment (GR01u) towards the $45^{\circ}$ inclined frontal ramp, all the thrust sheets were subsequently tilted due to a common megascopic shear. The combination of this large-scale shear tilt and the accumulated ramp steepening is very well illustrated in the GR05 thrust sheet, which was separated from GR04 along a satellite thrust fault. The hanging-wall ramp of GR04 was fixed with a c. $75^{\circ}$ steep dip. Consequently the hanging-wall ramp of GR05, which was carried piggyback on GR04, ended up in an overturned position (dip of about $75^{\circ} \mathrm{S}$ ).

In balancing the Grønne Rende Section, one problem remains to be solved, namely the fate of the trailing-end segment of GR06. However, this is a minor problem compared to the space problem created by the GR01 thrusting along the $30 \mathrm{~m}$ décollement level. The trailing-end thrust-sheet segment of GR01u (a duplex sheet created between the $30 \mathrm{~m}$ and the $20 \mathrm{~m}$ flatlevel) is considered below under the structural and dynamic analysis of the Rubjerg Knude Fyr and Stortorn Sections.

\section{Rubjerg Knude Fyr Section}

This section is situated below the Rubjerg Knude Fyr, and makes up the highest part of the cliff (see cover illustration). The cliff section below the lighthouse comprises the thickest thrust sheets, which are ramped up to the highest footwall flat level. This means that thrust sheets with a décollement level at a depth of about $35 \mathrm{~m}$ are ramped up and thrust along a flat at the $10 \mathrm{~m}$ deep level.

Normal fault structures similar to the Brede Rende normal fault also appear in the Rubjerg Knude Fyr Section. The tip of the prominent thrust sheet in the central part of the section was dropped down into the piggyback basin in front of the thrust fault, and subsequently buried by sediments of the Rubjerg Knude Formation. Structural elements related to the hanging-wall ramp are well illustrated in this section.

\section{Tectonic architecture}

The Rubjerg Knude Fyr Section comprises six relatively thick thrust sheets annotated RF01-RF06. The leading-edge thrust and hanging-wall ramp-and-flat of RF01 terminate all the imbricates in the Grønne Rende Section. To the north, the section is bounded by the footwall ramp of RF06 that coincides with the hanging-wall ramp of the frontal thrust sheet in the Storntom Section. The thickness of the thrust sheets is bounded by the $20 \mathrm{~m}$ flat level in the southern part, and increases in the northern part down to the $30 \mathrm{~m}$ flat. All the thrust sheets in the section are thrust over the lower duplex segment of GR06 and GR01. Translation along an intermediate flat is indicated by the dominantposition ofthe L/R-unconformityat $20 \mathrm{~m}$ a.s.l.

The RF01 and RF02 thrust sheets make up an easily recognisable thrust sheet pair that can also be located on the geological cross-section constructed by Jessen (1918; Fig. 98). The similarity of the remaining part of the Rubjerg Knude Fyr Section to Jessen's cross-section is not so obvious, probably due to the intervening 80 years of cliff erosion and the present poor exposure of the section due to extensive sand scree. The dips of the footwall ramps are about $60^{\circ}$. The angle between the L/R unconformity and the thrusts is about $30^{\circ}$, which means that the thrusts have been rotated about $30^{\circ}$ during ramp propagation in the subsurface. This is illustrated by the angular relationship between the L/R unconformity in RF01 and the footwall ramp of RF02. The thrust-fault displacement of $\mathrm{RF} 01$ and RF02 ranges from $50-65 \mathrm{~m}$. 


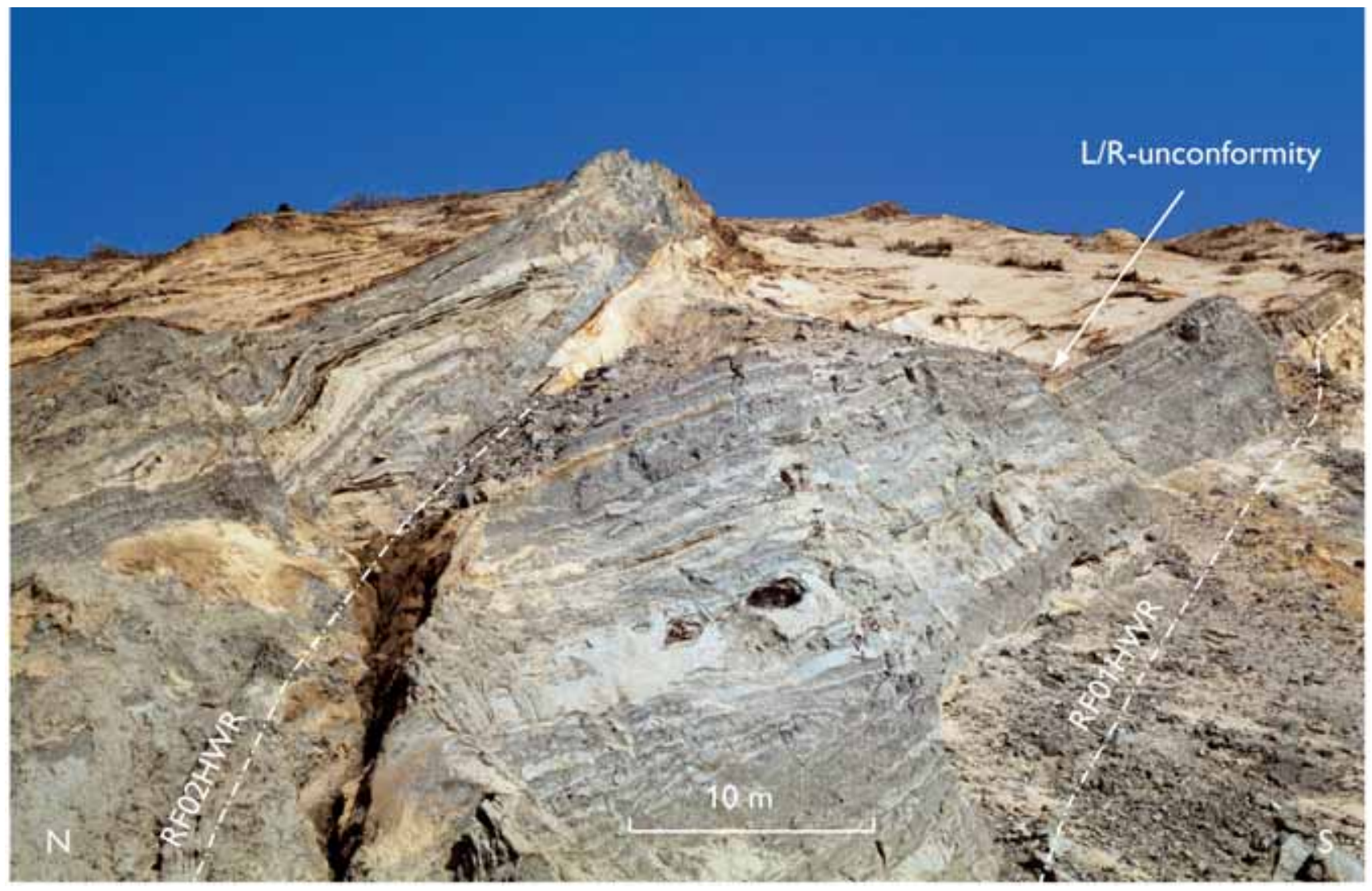

Fig. 98. The thrust sheet pair exposed below the Rubjerg Knude Fyr. To the right, the RF01 thrust sheet is thrust faulted along its hanging-wall ramp (RF01HWR) along the footwall ramp in the trailing end of the Grønne Rende Section. RF01 forms the footwall block for the propagation of the hanging-wall ramp of RF02 (RF02HWR). Note the elevated position of the L/R-unconformity indicating that the thrust sheets were thrusted up on duplex segments in the subsurface. Photograph: July 1999.

At the tip of RF01, a $25 \mathrm{~m}$ long upper hanging-wall flat is preserved. Below this, a 5-7 m thick sheet comprising the top of the GR13 piggyback basin occurs. This upper footwall flat segment of GR13 was displaced an unknown distance $(25-50 \mathrm{~m})$ forwards in front of the upper hanging-wall ramp of RF01.

The Rubjerg Knude Formation in RF02 is poorly exposed due to sand scree at the base of the cliff, but it is interpreted to be $20 \mathrm{~m}$ thick. From the L/R-unconformity up to the overlying thrust fault, the thickness of the piggyback basin is about $40 \mathrm{~m}$. However, it is inferred that a thrust fault situated in the middle part of the basin is responsible for repetition of the $\mathrm{Ru}$ bjerg Knude Formation, and that a normal fault similar to the BRNF, is located in the upper levels of the RF02 sheet. The normal fault is asymptotic, fading out towards the L/R-unconformity in the RF02 thrust sheet.

The RF03 thrust sheet is a small sheet with a truncation structure. The nose of this thrust sheet was obviously exposed to normal faulting at an early stage of development (Fig. 99). After fault displacement, the
RF03 tip was eroded away and the top of the thrust sheet erosionally truncated to form an unconformity, which cut off the sheet at a very steep angle $\left(>70^{\circ}\right)$. The normal fault at the tip of RF03 is the first of two normal faults displaced down on to the piggyback basin of RF02. In the second phase of normal faulting, the c. $45 \mathrm{~m}$ long tip of the RF04 thrust sheet was displaced c. $35 \mathrm{~m}$ down a normal fault plane (Fig. 100 ), which had an angle of $70-90^{\circ}$ relative to the thrust fault and the L/R-unconformity of RF04. The normal faulting may have been initiated by differential translation of hanging-wall ramps along intermediate flats related to one or more subsurface duplex segments. Ina late phase of thrust faulting, the trailing part of RF04 was thrust up over the piggyback basin of $\mathrm{RF} 04 / \mathrm{RF} 03 / \mathrm{RF} 02$, which brought the nearly $45^{\circ}$ dipping lower hanging-wall ramp of RF04 into contact with the footwall ramp of the displaced tip of RF04. The final phase of fault-bend folding tilted this ramp into a $70^{\circ} \mathrm{S}$ dipping position.

The RF05 and RF06 thrust sheets were thrust up 

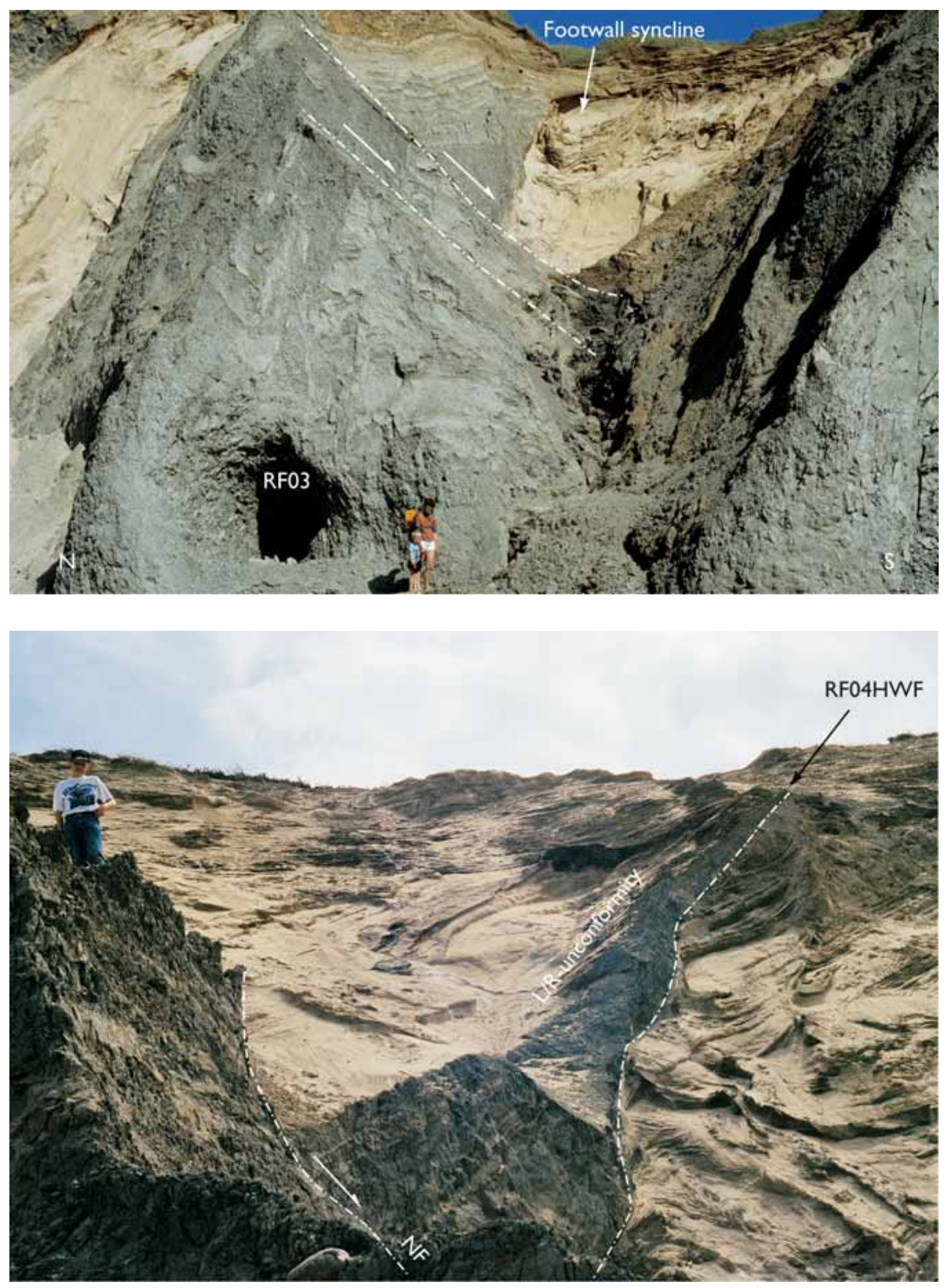


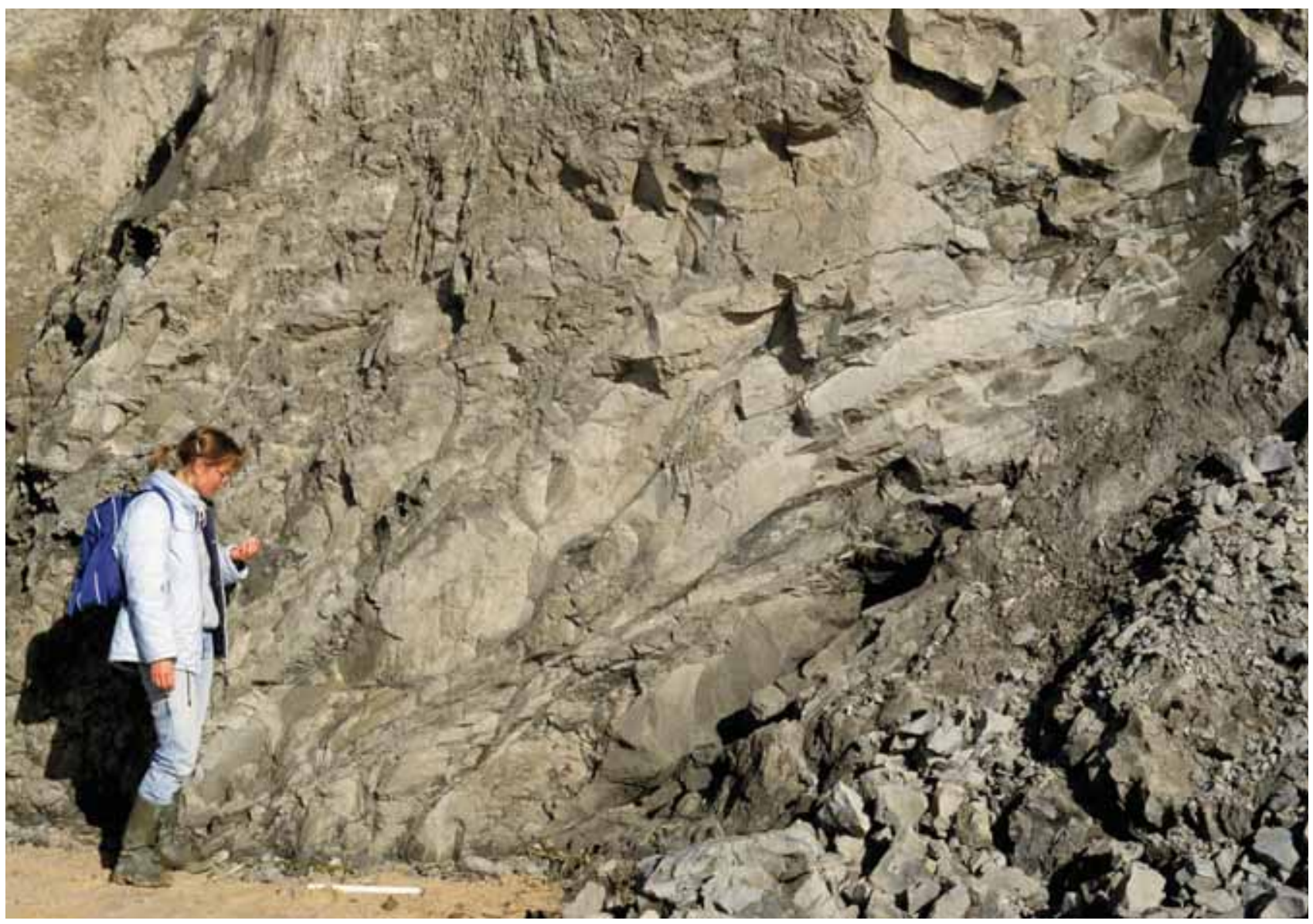

Fig. 101. Thrust-fault brecciation related to the lower hanging-wall ramp and flat in the Rubjerg Knude Fyr Section. The brecciation fabric that is typical of the fine-grained sand turbidites and laminated clayey muds (compare with primary sedimentary features in Figs 22, 23) was produced by low-angle anastomosing shearing. Photograph: September 1985.

from the $30 \mathrm{~m}$ décollement level. The hanging-wall flat of RF06 rests on the upper flat of RF05, where no deposits of the Rubjerg Knude Formation have been recognised. Thus the two thrust sheets occur as a block of Lønstrup Klint Formation $60 \mathrm{~m}$ thick, separated in the middle by a thrust fault. The L/R-unconformity in the RF06 sheet is located at about $10-15 \mathrm{~m}$ above sea level. Thus, the RF06 sheet was faulted up on an in-

Facing page - upper:

Fig. 99. Normal faults displacing the top of the RF03 thrust sheet in the Rubjerg Knude Fyr Section. Note the footwall syncline folded below the hanging-wall ramp at the top of the cliff section. Photograph: June 1984.

\section{Facing page - lower:}

Fig. 100. Normal fault (NF) displacing the tip of the RF04 thrust sheet, which prior to normal faulting was thrusted along the hanging-wall flat of RF04 (RF04HWF). Photograph: July 1994. termediate flat above the trailing edge of RF05, probably while both were transported along the lower footwall flat on top of the lower trailing duplex segment of the Grønne Rende Section.

\section{Sedimentary units}

In the Rubjerg Knude Fyr Section, the lower stratigraphic levels of the Lønstrup Klint Formation are exposed, although they are commonly deformed either by mudmobilisation or thrust-fault shearing. The Rubjerg Knude Formation above is poorly exposed, partly due to sand scree derived in part from the formation itself, and partly from the up to $50 \mathrm{~m}$ high sand dunes above the cliff. No further description of the formations is given here. 


\section{Structures}

Two types of deformation alter the primary sedimentary architecture of the Rubjerg Knude Fyr Section. The first type is anastomosing thrust-fault brecciation related to the zone above the hanging-wall ramp with fine-grained turbidites. The second type is the mudmobilisation and mesoscopic-scale polydiapirism, which is common in the clay-rich lower part of the thrust sheets. These deformation types have to be considered in the evaluation of the balance calculation. Only the anastomosing thrust-fault brecciation will be further described in this section; descriptions of diapirism are given under the Kramrende, Brede Rende, Sandrende and Moserende Sections.

\section{A nastomosing thrust-fault brecciation}

The most significant mesoscopic-scale structure recognised in the Rubjerg Knude Fyr Section is related to thrust-fault brecciation in the lower part of the Lønstrup Klint Formation. The brecciation fabric that is typical of the fine-grained turbidites and laminated clayey muds was created by low-angle anastomosing shearing. The shear surfaces and thrust-fault displacements are located in the clay-rich laminae, whereas the segments bounded by the anastomosing fractures consist of silty mud lithologies (Fig. 101). The brecciation extends from the lower hanging-wall ramp-andflat up to $10 \mathrm{~m}$ above the sole of the sheets.

The anastomosing thrust faulting indicates that significant differential movements developed in the subsurface during thrust-fault propagation, which illustrates the nature of the displacement-related shearing and which may account for some of the volume problems arising from construction of the balanced crosssection.

\section{Interpr etation of structural development}

The compression (shortening) in the Rubjerg Knude Fyr Section is about $48 \%$, calculated from the measured length of the section of $270 \mathrm{~m}\left(=\mathrm{L}_{1}\right)$ and the balanced length of about $520 \mathrm{~m}\left(=\mathrm{L}_{0}\right)$. This implies that the thrust sheets in the section have been displaced upwards at the ramp originally situated at the trailing end of RF04 and transported to the position of the footwall ramp ofGR13. The lower flat is still the footwall flat on top of the lower duplex segment of the
Grønne Rende Section. Thus, a considerable amount of lateral translation is apparent in the Rubjerg Knude Fyr Section.

The appearance of the normal fault with down-faulted noses of the RF03 and RF04 sheets indicates that differential movements, including duplex development of the GR01-GR06 lower segments, may have occurred to create the foreland-dipping features in the RF02RF03 piggyback basin.

The interesting structure in RF05 is the lower hanging-wall ramp, which has to correspond to a footwall ramp at the trailing end of RF04. The footwall ramping probably also included propagation along a footwall ramp of a lower duplex segment of RF04 (RF04u). The present orientation of the RF05 lower hangingwall ramp is more or less vertical, indicating three steps of ramping. The final tilting was due to the ramping of the upper footwall ramp of GR13, the middle phase of ramping was up along the footwall ramp of the piggyback basin in the normal fault displaced RF04, and the initial ramping was probably a complex propagation over several smaller ramp-steps that separated RF06 from RF05.

The uppermost part of RF06 shows a marked topography, indicating that at an early phase of deformation it was elevated up to a level of erosion, before subsequentsedimentation. This sedimentation was probably of relatively short duration before over-thrusting of the Stortorn Section trapped the piggyback basin.

\section{Stortorn Section}

Stortom is the name of the very steep and muddy cliff in the central part of the Rubjerg Knude cliff section. On old drawings of the beach and the coastal cliff, Stortom is depicted as a steep, wild looking castlelike cliff in the distant horizon, emphasising the romantic scenery of this remote place (e.g. engraving by C. Neumann 1884, reproduced in Vendsyssel nu og da, 1981). In recent times, the cliff has also been the location of major landslides, which in some cases travelled more than $100 \mathrm{~m}$ out into the sea. In general, the sea reaches close up to the vertical cliff, and due to the muddy and slippery cliff surfaces and the clay pavement in the zone of breakers, it is the most difficult place to pass along the coast.

In the Stortorn Section, the deepest level of thrusting occurs where the décollement zone is located at a depth of $40 \mathrm{~m}$ stratigraphically below the reference surface of the L/R-unconformity, which is about $45 \mathrm{~m}$ 
below sea level. From this deep level, the thrust sheets were elevated up to the exposed position in the cliff section. Coinciding with this, the thrust sheets contain the deepest levels of the stratigraphy, and beds of marine and glaciomarine clay can be identified by the occurrences of arctic marine fossils. Moreover, the Stortorn Section contains the key features for understanding the structural and dynamic problems of the adjacent Rubjerg Knude Fyr and Grønne Rende Sections. The key features are flat-lying duplex complexes formed by ramping up of the relatively long, lower thrust-sheet segments onto a high flat level. This is reflected in an elevation of the L/R-unconformity up to a height of c. $40 \mathrm{~m}$ above sea level in the cliff section.

\section{Tectonic architecture}

The Stortorn Section is divided into ten thrust sheets annotated ST01-ST10. The southern boundary of the section is the frontal hanging-wall flat of ST01, which coincides with the footwall ramp of the RF06 thrust sheet in the Rubjerg Knude Fyr Section. The northern boundary is the trailing footwall thrust of ST10 along which the frontal hanging-wall ramp of the Moserende Section was thrust.

The southernmost three thrust sheets form a separate group of high-level thrust sheets. The L/R unconformity is here situated at an elevation of $35-40 \mathrm{~m}$ above sea level. The central part of the section is formed by a series of thick thrust sheets of clayey, partly mobilised, mud, which are situated above hidden duplexes in the subsurface. This complex extends about $150 \mathrm{~m}$ along the cliff section at Stortorn. In the northern part of the section, upright mud diapir-dominated thrust sheets occur with complexly developed piggyback basins.

\section{ST01 thrust sheet}

The southernmost thrust sheet in the Stortorn Section (ST01) is wedge-shaped, c. $160 \mathrm{~m}$ long, with an initial $25^{\circ}$ dip of the frontal hanging-wall ramp. The footwall ramp (FR06 trailing edge) dips at about $45^{\circ}$, which creates a problem in the balancing. It is obvious that a splint (or horse) corresponding to a triangle with an acute angle of $20^{\circ}$ must be hidden somewhere in the deeper structure. The trailing end of ST01 is $30 \mathrm{~m}$ thick. However, the Lønstrup Klint Formation is deeply erod- ed in the central part of ST01, which truncates the L/R-unconformity.

\section{ST02 thrust sheet}

The ST02 thrust sheet was also elevated to a height of $35-40 \mathrm{~m}$ in the cliff section. The hanging-wall ramp is vertical and forms a right-angle with the horizontal bedding in the piggyback basin of ST01. This indicates that final up-thrusting of the frontal hanging-wall ramp took place in an upright position during sedimentation on the back of ST01. The ST02 thrust fault was rotated at least three times before propagation up along the footwall ramp of ST01. The initial dip of this ramp was relatively steep, about $40^{\circ}$, as indicated by the angle between the thrust fault and the bedding in the Lønstrup Klint Formation of ST01. Furthermore, the problem related to the change in ramp angle recurs. In the balancing of the thrust structure, a splint volume must be calculated for, corresponding to the triangle created by the initial thrust angle and the final steeply inclined thrust fault.

\section{ST03 thrust sheet}

The ST03 thrust sheet is not elevated as much as ST01 and ST02; the L/R-unconformity is only situated at about $30 \mathrm{~m}$ above sea level. The Lønstrup Klint Formation was deeply eroded before sedimentation in the piggyback basin was initiated, probably due to marked relief during ramp propagation.

\section{ST04 thrust sheet}

The lowestposition of the L/R-unconformity in the ST04 thrust sheet is about 13-15 m above sea level, which demonstrates a shallowerlevel of ramping than in ST01ST03. The $45^{\circ}$ steeply dipping thrust fault between ST03 and ST04 roots down to the décollement zone and propagated up along the footwall ramps of the subsurface duplex segments beyond ST01-ST03. The difference between initial and final angle of ramping also created a balancing problem for ST04. The frontal part of the hanging-wall ramp of ST04 only had a dip of $18-20^{\circ}$, whereas the footwall ramp now dips at c. $45^{\circ}$. Therefore a splint (with an area of $630 \mathrm{~m}^{2}$ in the cross-section) is envisaged in the subsurface. The ST04 ramping over this splint is interpreted as the rea- 
son for the elevation of the L/R-unconformity up to c. $15 \mathrm{~m}$ above sea level.

\section{ST05 thrust sheet}

The ST05 thrust sheet is one of the most important structures, not only in the Stortom Section but also in the Rubjerg Knude Glaciotectonic Complex as a whole. It involved thrusting of the deepest décollement level, which introduced a complex framework due to the large number of duplex segments involved. The ST05 thrust sheet was thrust up along the footwall ramp of ST04. The dip of the thrust fault increases from $35^{\circ}$ at the beach level to $70^{\circ}$ at the top of the cliff section. The tip of the thrust sheet was finally displaced horizontally over the top of the piggyback basin of ST04. The thrustdisplacementalong the hanging-wall thrust fault is estimated to be in the order of $90 \mathrm{~m}$.

The Lønstrup Klint Formation of ST05 is dominated by mud diapirism and polydiapiric structures up to $5 \mathrm{~m}$ in vertical scale. In the middle part of the thrust sheet, where the thickness of the initially wedgeshaped frontal part was $20 \mathrm{~m}$, a deeply eroded trough was formed. The L/R-unconformity on the northem flank of this erosional depression is situated nearly 50 $\mathrm{m}$ above sea level. This is about the highest elevation of the reference surface, and was caused by thrust duplication of the thrust sheet in the subsurface duplex complex.

\section{ST06 thrust sheet}

The ST06 thrust sheet is poorly exposed and mudmobilisation and internal diapirism obscure primary structures. The thickness of the thrust sheet is up to $40 \mathrm{~m}$, measured from the frontal hanging-wall thrust up to a small pocket of Rubjerg Knude Formation sand that forms the remnant of a piggyback basin. The frontal thrust is drawn with some uncertainty, because a large part of it is penetrated by diapirism intruding from the back of ST05. A minimum displacement of $40 \mathrm{~m}$ is inferred, which is incorporated in the modelling of the balanced cross-section. This implies a rather complex structural assemblage of the subsurface lower duplex segments of ST05, ST06 and ST07.

\section{ST07 thrust sheet}

The ST07 thrust sheet is nearly vertically orientated with a frontal ramp rising from $70^{\circ}$ to vertical, along which a displacement of $28 \mathrm{~m}$ is estimated to have occurred. The L/R-unconformity surface is also steeply dipping, and is even overtumed at the top. The lower part of the thrust sheet is mainly covered by scree, but it is possible to trace the line of the unconformity down to the level of the beach in the crosssection. This implies that the thrust sheet has not been thrust up to be displaced along an intermediate ramp but is only tilted due to the main ramping, first along the thrust fault of ST06 and finally on its own hanging-wall ramp. The ramping is also reflected in the deposition in the piggyback basin where three superposed angular discordances are recognised. The deposits in the piggyback basin are c. $15 \mathrm{~m}$ thick; at the base of the succession, the R-onlap starts with an angle of $45^{\circ}$ and terminates with a $90^{\circ}$ angle, indicating deposition in the basin while the thrust sheet was vertically orientated. In the uppermost bed, minor slump folds are present, indicating the effect of the ST08 thrust nose approaching from the north.

\section{ST08 thrust sheet}

A double ramp synclinal structure, similar to the one occurring in the piggyback basin of ST05, is recognised in thrust sheet ST08. The L/R-unconformity incises through the Lønstrup Klint Formation and down into the thrust-fault surface of the hanging-wall ramp. The lateral distance between the ramps is only about $25 \mathrm{~m}$ and the basin is less than $10 \mathrm{~m}$ deep. The sediments in this piggyback basin show large-scale trough cross-bedding accentuated by synclinal folding. The Rubjerg Knude Formation covers a feature that represents the erosional remnants of a detachment anticline on the northern limb of the basin. On the north side of this structure, the initial stratification above the L/R-unconformity shows clear R-onlap, corresponding to the inclination parallel to the tilt of the lower ramp. The unconfomity is elevated up to $20 \mathrm{~m}$ above sea level, indicating that the ST08 thrust sheet was lifted up by at least two subsurface duplex segments. These hidden segments are annotated ST08u1 and ST08u2. The displacement along the footwall ramp of ST08 is estimated at $78 \mathrm{~m}$, mainly along the thrust fault dipping at $30^{\circ}$. 
Fig. 102. Isoclinal upright anticline formed in the lower part of the Lønstrup Klint Formation in the frontal part of the Stortorn Section. The right limb of the anticline constitutes an imbricate duplex formed by connecting thrust-fault splays (white dot-and-dash lines). The fold is interpreted as a hanging-wall anticline developed during fault propagation and successive imbricate stacking (compare with Fig. 59). Photograph: August 2001.

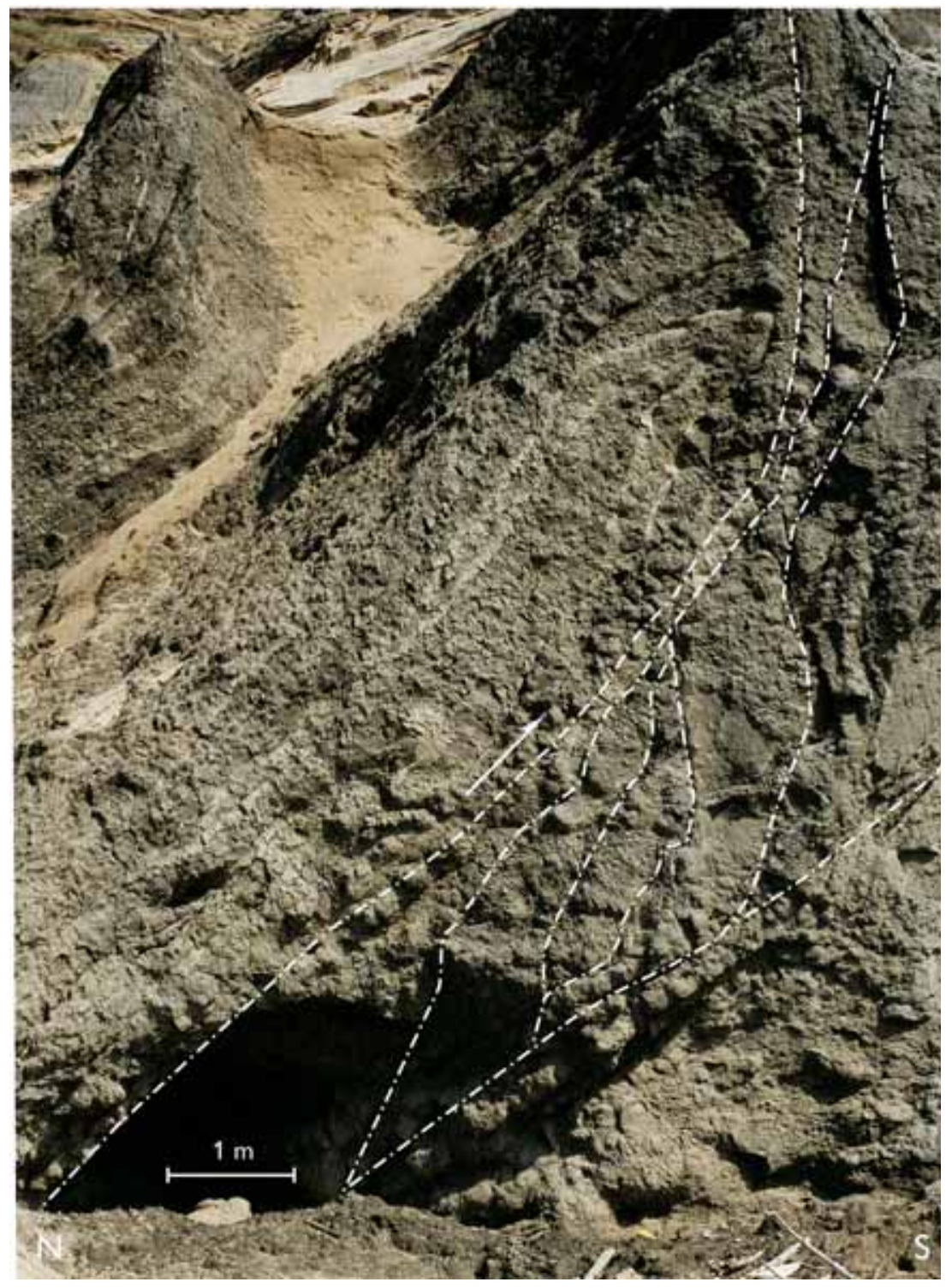

ST10 thrust sheet

\section{ST09 thrust sheet}

The ST09 thrust sheet is a c. $30 \mathrm{~m}$ thick sheet bounded by a $60^{\circ}$ dipping hanging-wall flat thrust up onto the footwall ramp of ST08 back and the $60^{\circ}$ dipping footwall thrust fault of ST10, which truncates the irregular structures in the upper part of the thrust sheet. The displacement along the hanging-wall ramp is estimated at c. $60 \mathrm{~m}$. Although the Lønstrup Klint Formation in ST09 is characterised by internal diapirism, the features of a hanging-wall anticline can be recognised at the top of the cliff section. During translation of two or more footwall ramps, an irregular synform formed and created the depocentre of a piggyback basin. The L/R-unconformity is here elevated to 5-10 $\mathrm{m}$ above sea level, corresponding to propagation up onto the ST08u2 duplex segment.
The ST10 thrust sheet is about the same size as the ST09 sheet, and also has steeply dipping bounding thrust faults. The most remarkable structure in the ST10 thrust sheet is the structural complexity of the piggyback basin. The L/R-unconformity forms an isoclinal recumbent syncline, with the upper limb formed by the mud-mobilised Lønstrup KlintFormation, and above this a minor synclinal trough appears. This structure is best described as a detachment anticline, which developed into a diapir with a reverse fault displacing the northern limb of the structure into a mushroomshaped structure, similar to the diapir in the Sandrende Section. At a late stage of thrusting, the piggyback basin was rotated $60^{\circ}$ and the diapir-developed detachment anticline collapsed into the recumbent struc- 
ture. The L/R-unconformity is elevated up to 15-18 m above sea level indicating a ramping of the ST08u duplex segment as well as the trailing segment of ST09. An estimated displacement of $73 \mathrm{~m}$ along the hanging-wall ramp of ST10 still leaves some subsurface segments to be balanced in the structure below the Moserende Section to the north.

\section{Sedimentary units}

The most important sedimentary feature in the Stortorn Section is the exposure of the Stortorn Formation, which is the lowermost stratigraphic level involved in the Rubjerg Knude Glaciotectonic Complex. The Stortorn Formation is located at the lower hanging-wall ramp of the ST05 thrust sheet, where it forms a duplex segment about 3-5 m thick at the base of the cliff. To date, it has not been possible to measure a sedimentological log of the formation at this locality, partly because the formation is strongly sheared by anastomosing fractures, and partly because landslide activity precludes more detailed stratigraphic description.

\section{Structures}

The contact between mobilised, intrusive mud and stratified mud has been observed in many places, but this characteristic is better illustrated in the Moserende Section (see below). Anastomosing thrust faults and tectonic breccias occur commonly in the ST05 and ST06 thrust sheets. However, due to the difficult field conditions, detailed investigations have not been carried out.

In the dark clayey mud of thrust sheet ST01, an upright nearly isoclinal anticline has been observed (Fig. 102). This fold is considered to represent a hanging-wall anticline that was subjected to an advanced stage of deformation during ramp propagation. This stage compares well with the model of duplex formation described by Mitra \& Sussman (1997), in which the growth of imbricates derived from successive connecting splays results in steepening of antiformal stacks formed by fault-propagation folding of duplexes. Successive growth of duplex elements corresponds well with the interpretation presented below.

\section{Interpretation of structural development}

The cross-section (Plate 2B) provides a model for the structures below the frontal part of the Stortorn Section, which requires four duplex segments forming a duplex complex, on top of which thrust sheets ST01, ST02 and ST03 have been thrust along the footwall flat. The structural interpretation of a duplex stacking of subsurface segments below the frontal part of the Stortorn Section is based on two lines of evidence: (1) the missing balance of the lower segments related to the Grønne Rende Section, and (2) the high elevated position of the L/R-unconformity in this part of the section. Thus the lower duplex complex in the frontal part of the section is interpreted to represent stacking of the trailing lower segment of GR01, although an alternative differential duplex-segment displacement is also possible.

From geometric considerations, it is evident that the $20 \mathrm{~m}$ and $30 \mathrm{~m}$ décollement levels must have been pervasive throughout the proximal part of the thrust structure. Thus the duplex in the Stortorn Section consists of segments c. $10 \mathrm{~m}$ thick. Mobilisation and the intemal polydiapirism have obscured the boundaries of these segments, which are the lower and intermediate footwall and hanging-wall flats respectively. However, in a model for reconstruction, these volumes are regarded as solid thrust sheet, i.e. the duplex segments (represented by annotated areas in Plate 2). In the description and solution of the structural problem related to differential thrust faulting of the lower duplex segments, three main types of fault-bend-folded segments are distinguished (Fig. 103).

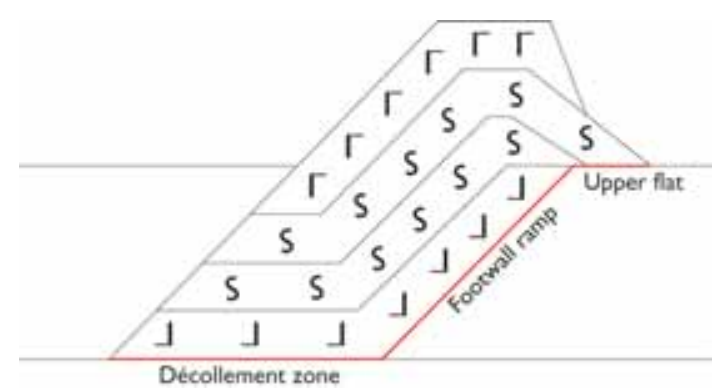

Fig. 103. Schematic illustration of the three types of fault-bend folding of duplex segments. Type 1 is referred to as an L-structure, type 2 as an S-structure and type 3 as a G-structure (G chosen due to similarity with the Greek capital letter gamma $(\Gamma)$ ). The footwall ramp dips at about $45^{\circ}$, the shortening between the underlying footwall ramp and the overlying hanging-wall ramp is $43 \%$, the initial length $\left(\mathrm{L}_{0}\right)$ of the thrust sheet is c. $100 \mathrm{~m}$, compared to a thrust-sheet thickness of $40 \mathrm{~m}$, and a thickness of $10 \mathrm{~m}$ for the individual duplex segments. 
1. A duplex segment with one part of the segment resting on the lower flat and the other parallel with a ramp (L-structure).

2. A duplex segment which has the trailing part parallel with the lower flat, the intermediate part parallel with a ramp, and the frontal part parallel with the upper flat, thus giving the shape of a $\mathrm{S}$.

3. A duplex segment with the trailing part of the segment located parallel with the ramp and the frontal part parallel with the upper flat ( $\Gamma$-structure).

The stacking of the duplex below the ST01, ST02 and ST03 thrust sheets started when the lower segments were thrust up into the first type duplex bend during ramping towards the footwall ramp of RF06 (trailing end of the Rubjerg Knude Fyr Section). This probably marked the end of the lateral translation along the lower flat levels and the initiation of stacking along steeply dipping thrust faults. This resulted in the rotation of all the previously formed structures and created the odd trough structures in the double ramp synclinal troughs. The final up-thrusting along steeply dipping thrust faults, which occurred contemporaneously with the uppermost sedimentation in the piggyback basins, was probably also contemporaneous with theinitiation oframping of ST05 from the lowest level. One way to demonstrate this is to focus on the thrustfault development of ST04. The ST04 thrust fault acted as the ramp that pushed on the trailing end of the duplex below ST01, ST02 and ST03. When the push on this footwall ramp ended and the ST04 thrust sheet was displaced up over the footwall ramp of ST03 it resulted in a shortening of $60 \%$. The balanced length of ST04 is c. $200 \mathrm{~m}$. Thus, the deep level ST05 ramp must be responsible for removing the $120 \mathrm{~m}$ lower long segment originally situated below ST04. Therefore about half of the ST04 thrust sheet also involves thrusting down to the $40 \mathrm{~m}$ décollement level. In the model, this ST04u segment was up-thrust to form a first type of duplex-segment structure as the first lower-segment imbricate in the subsurface of ST05.

However, it should be appreciated that a whole unit of the thrust segments between the $20 \mathrm{~m}$ flat level and $30 \mathrm{~m}$ décollement level has to be incorporated in a differential thrust model. The simplest model for this is to dissect the lower duplex segments into sheets with an average length of c. $100 \mathrm{~m}$. With each segment bend in a type 2 ramping and with an equal distribution of the frontal and trailing part on the upper and lower flat, a series of double ramp synclines would be created - comparable to the piggyback ba- sins seen in ST10, ST09, ST08 and ST05. Similar basins may have existed in ST07 and ST06, but, if present, were removed by glaciotectonic truncation.

One of the central problems in describing the dynamic development of the Rubjerg Knude Glaciotectonic Complex is understanding the formation of the lower ramp below the ST05 thrust sheet. It is known that the hanging-wall ramp is displaced up along the ST05 thrust fault to be exposed in the cliff section at Stortorn. However, a central question is - where was the footwall ramp for the lower hanging-wall ramp of ST05 situated?

According to the balanced cross-section, the ST05 ramp should be situated about $7800 \mathrm{~m}$ from the frontal ramp in the Ulstrup Section and the footwall ramp for the lower ST05 ramping should be situated on the far side (north) of the Lønstrup village. However, this is not the position of the ST05 ramp. The distance to a hidden footwall ramp can only be fixed relative to the displacement in front of the lower ramp when it was activated during the change of décollement level from the $30 \mathrm{~m}$ level down to the $40 \mathrm{~m}$ flat level. The relative displacement on the ST05 thrust fault is c. $90 \mathrm{~m}$, measured from the tip of the thrust sheet along the hanging-wall ramp-and-flat down to the lower décollement surface. The main problem is related to the compression documented south of the Stortom Section. When this is considered in the balanced crosssection, it gives the geometric point for the hangingwall ramp $7800 \mathrm{~m}$ from the frontal ramp in the Ulstrup Section. However, the distance in the Rubjerg Knude cross-section from this ramp to the central part of the Stortom Section is only $3800 \mathrm{~m}$. The solution to this problem is that the ramp was first formed after all the former translation in the higher flat levels had passed. To understand this, one has to imagine that the upper part of the Lønstrup Klint Formation at Grønne Rende (c. $3800 \mathrm{~m}$ from the frontal ramp in the Ulstrup Section) was originally situated above the Stortorn Formation at the ST05 lower ramp. However, the ramp was first formed when the Rubjerg Knude Fyr Section was displaced towards the Grønne Rende Section which itself was compressed against the Stenstue and Sandrende Sections, which were all displaced over the initial position of the Brede Rende and Kramrende Sections. Only then was the ST05 lower ramp activated, and the remaining northern part of the Rubjerg Knude Glaciotectonic Complex was displaced along the lowermost décollement zone. 


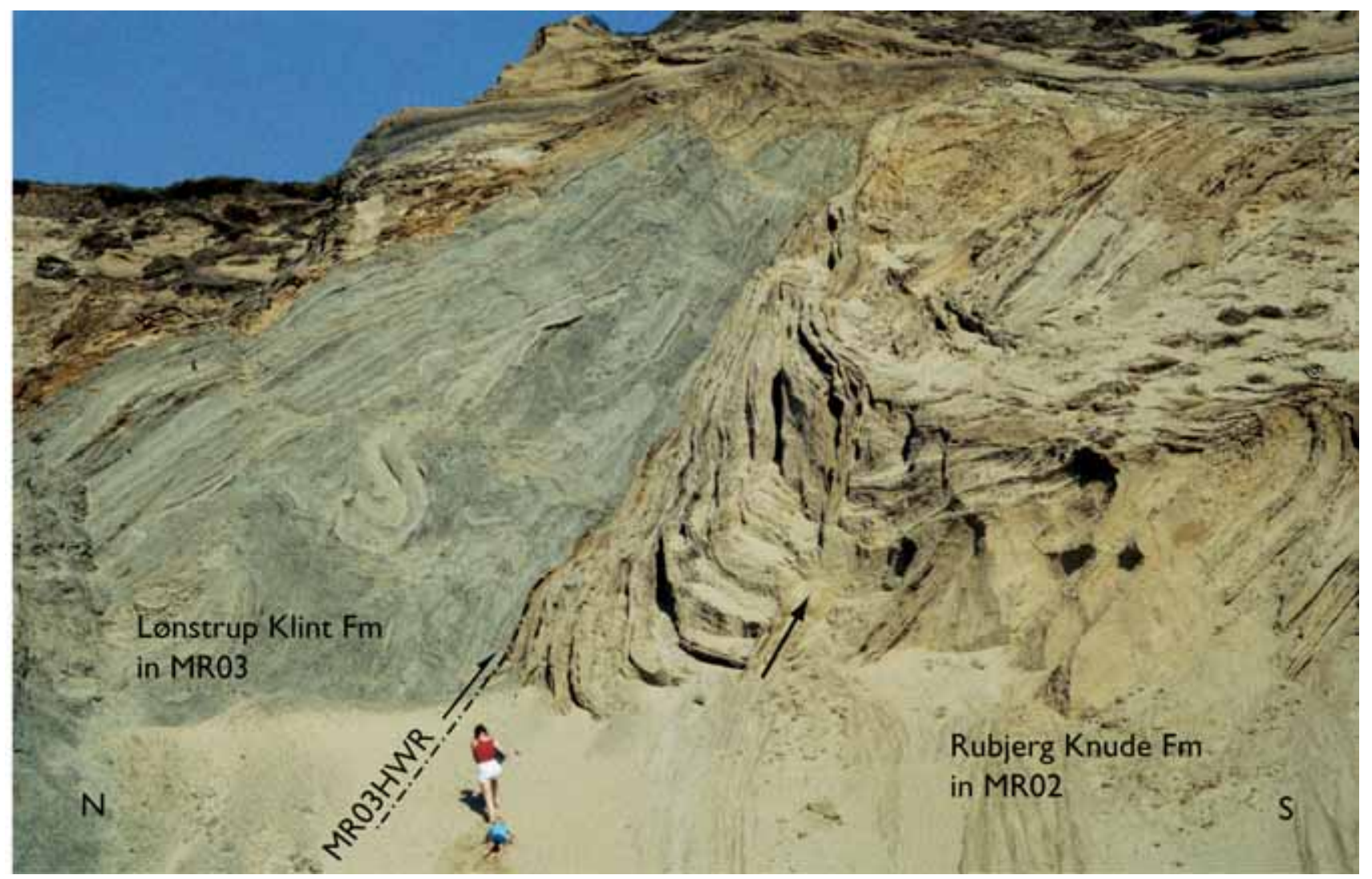

Fig. 104. The piggyback basin of the MR02 thrust sheet. A sequentially developed growth-fault footwall syncline was formed below the hanging-wall ramp of MR03 (MR3HWR). Note the fissure strata cross-cutting the bedding (arrow) in the growth-fault footwall syncline. Photograph: June 1984.

\section{Moserende Section}

Between Rubjerg Knude Fyr and Mårup Kirke, some small peat-bogs occur in depressions in the dune landscape. This area of bog-filled depressions formerly extended to the west, and the present cliff section intersects one of these bogs where peat (martørv) is exposed in the uppermost part of the cliff, similar to the situation in the Martørv Bakker Section. A former gully here was named Moserende, and the name is adopted here for the section north of the Stortorn Section.

The most impressive feature in the Moserende Section is the syntectonic evolution of the piggyback basins during polyphase thrust propagation (Fig. 104). Unusual sedimentological features are developed in the Rubjerg Knude Formation, reflecting the tectonic deformation, notably structures described as fissure strata (Sjørring 1977). These are thin sedimentary beds occurring as discordantly incised wedges in groundfrozen sediment, here present in the growth-fault synclines related to the piggyback basins (Fig. 105).

\section{Tectonic architecture}

The Moserende Section comprises 13 relatively thick thrust sheets annotated MR01-MR13. In the section, three larger piggyback basins are preserved, one in the frontal, southern part and two in the northern part of the section. The L/R-unconformity surface at the base of the piggyback basins was elevated to various levels in the cliff section, reflecting the differentiated type of ramping throughout the section.

The leading-edge thrust in the Moserende Section is the hanging-wall ramp of MR01, which coincides with the footwall thrust fault on the back of the ST10 thrust sheet. To the north, the section is bounded by the hanging-wall thrust at the base of the c. $40 \mathrm{~m}$ thick MK01 thrust sheet, which forms the southem front of the Mårup Kirke Section. The MK01 thrust sheet was thrust up along a steeply dipping footwall ramp and subsequently displaced over the upper footwall flat on top of the piggyback basin of MR13 in the northernmost part of the Moserende Section.

It should be noted that the main frontal part (top- 
Fig. 105. Detail of the fissure strata indicated in Fig. 104, illustrating that climbing ripple cross-laminated sands were deposited in the initially horizontal wedge-shaped fissure extending out into the growth-fault syncline deposits. Photograph: June 1984; notebook (c. 18 cm long) for scale.

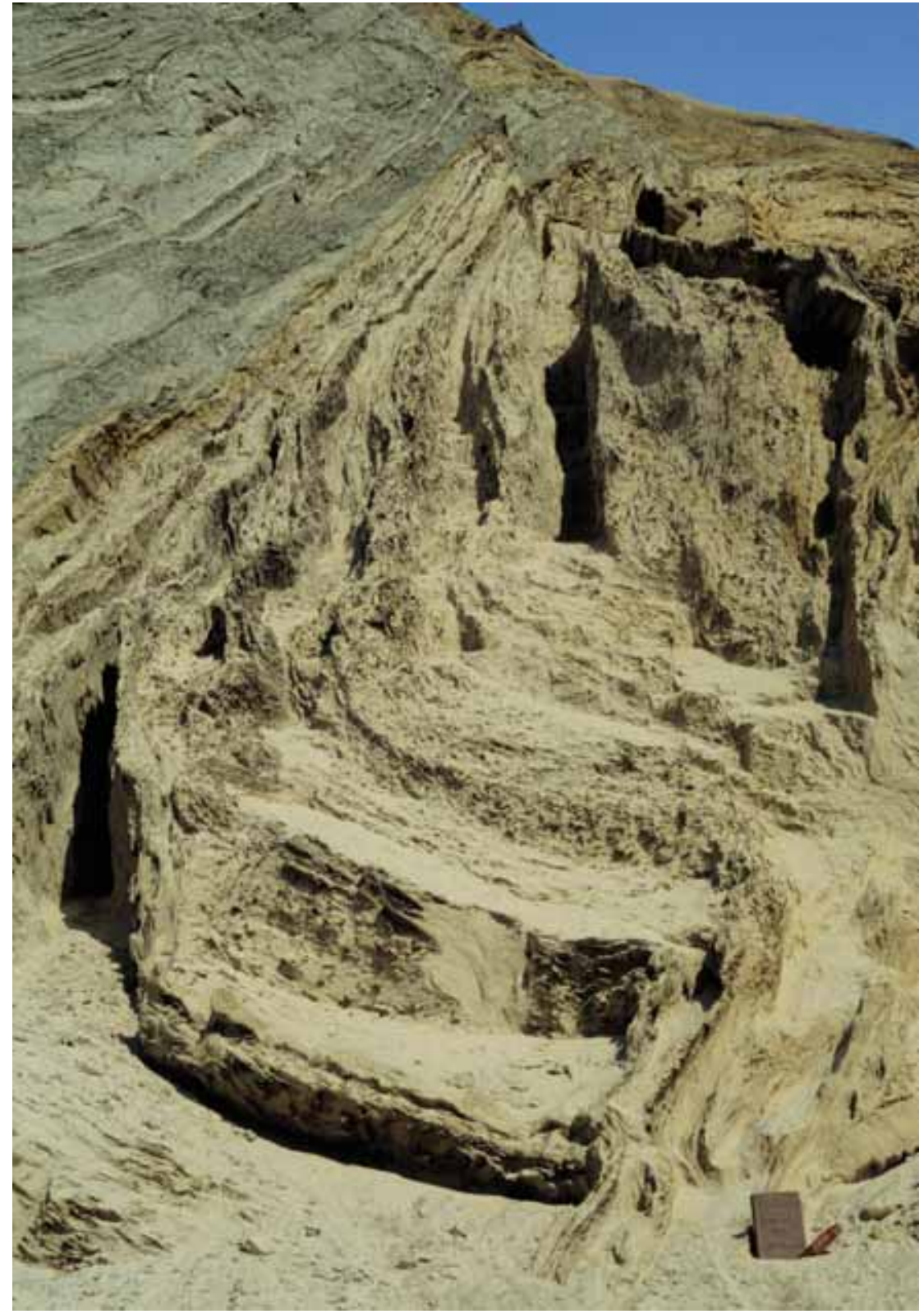

most part) of the thrust sheets shows a marked drag and truncation due to the formation of a glacitectonite on top of the cliff section.

\section{MR01 thrust sheet}

In the cliff section, the MR01 thrust sheet forms a massive unit of mobilised, structureless grey mud. The exposed thickness close to the beach level is nearly $30 \mathrm{~m}$. The hanging-wall thrust dips at about $60^{\circ} \mathrm{N}$, and the unconformity surface, which dips at about $45^{\circ}$, is elevated c. $15 \mathrm{~m}$ above sea level. This indicates that the MR01 thrust sheet is situated above two low- er duplex segments. According to the balancing, these segments constitute a lower segment of the MR01 thrust sheet $(\mathrm{MR} 01 \mathrm{u})$ and a segment originating from the lowest, northern partofthe Stortorn Section. The MR01u segment, which exists as a consequence of the estimated c. $46 \mathrm{~m}$ displacement along the $60^{\circ}$ tilted frontal hanging-wall ramp, is separated into two differently displaced segments in the balanced cross-section. This is a feasible explanation but not the only one of several possible solutions for the displacement structure in the subsurface, which include differential lateral displacement along each lower $10 \mathrm{~m}$ level as well as mud diapirism. 


\section{MR02 thrust sheet}

The MR02 thrust sheet is nearly $40 \mathrm{~m}$ thick and is dominated by mud mobilisation and internal chaotic structures reflecting polydiapirism and internal flow. The sheet is divided internally by a thrust-fault zone with differential thrust movements, which could be interpreted as a separation of the sheet into two individual thrust sheets. However, as the segments are not separated by a piggyback basin they are regarded as a single amalgamated sheet.

The displacement along the hanging-wall ramp is the same order of magnitude as for MR01 (c. $47 \mathrm{~m}$ ) and the ramp is divided into an upper low-angle part with an initial dip of only $20^{\circ}$ and a lower steeply dipping part with an initial ramp-angle of about $45^{\circ}$. Due to subsequent rotation, the upper part of the ramp is now orientated vertically while the lower part has a steep listric dip to the south. The footwall ramp (upper part of MR01) has an initial dip of $45^{\circ}$, which creates a space problem in balancing the section and makes it necessary to introduce a splint segment between MR01 and MR02 in the subsurface. The splint was probably sheared and squeezed out and is likely to have been included in the general mud mobilisation. However, it is included in the balanced profile in order to deal with the ramp-angle-space problem (Plate 2).

The geometry of the L/R-unconformity at the top of the Lønstrup Klint Formation in the MR02 thrust sheet is very irregular with a peculiar c. $8 \mathrm{~m}$ high obstacle. This is very similar to the structure in the ST08 thrust sheet in the Stortorn Section. It was probably formed by a detachment anticline on the northern flank of the piggyback basin in the external part of the MR02 thrust sheet, where it was subsequently buried by the Rubjerg Knude Formation sand. The unconformity is elevated about $5 \mathrm{~m}$ above sea level, indicating that the MR02 thrust sheet has only stepped up one level of the lower segments from where it is bent up along its hanging-wall ramp. The detachment anticline was probably formed during the ramping of this lower segment.

\section{MR03 thrust sheet}

The Rubjerg Knude Formation in the piggyback basin on top of MR02 and MR03 is here envisaged as a single large basin situated in the frontal part of the Moserende Section. The basin extends about $70 \mathrm{~m}$ along the cliff section. Three upright standing peaks represent the tips of three small thrust sheets that disturbed the basin by small displacements. These thrust sheets represent imbricates in the uppermost part of the MR03 thrust sheet. Since the main part of the MR03 thrust sheet can be viewed as one large sheet subjected to a single mode of displacement, the three imbricates are referred to as MR03a, MR03b and MR03c.

The L/R-unconformity in MR03b and MR03c can be traced down below sea level, indicating that the main part of MR03 was displaced along the lower décollement level prior to the displacement up along the $45^{\circ}$ dipping frontal footwall ramp. However, the frontal hanging-wall ramp of MR03 is now vertical. It is only necessary to tilt the initial ramp on another $45^{\circ}$ dipping ramp to achieve this, and although it is a very steep inclination for ramping, there are no obvious reasons for introducing more ramps. The steep ramp angle of the MR03b thrust forms part of the same framework. The initial dip of the MR03b hanging-wall ramp was $18^{\circ}$, and the thrust fault is now vertically orientated due to the ramp-bending mentioned above. The displacement relative to MR03a is only about $10 \mathrm{~m}$ and the sand beds of the Rubjerg Knude Formation were folded in a footwall syncline of MR03a during the hanging-wall thrusting of MR03b.

\section{MR04 and MR05 thrust sheets}

The MR04 and MR05 thrust sheets are closely related and only separated from each other by a relative displacement of about $25 \mathrm{~m}$ along the hanging-wall thrust of MR05. In contrast, the displacement along the MR04 hanging-wall thrust is about $80 \mathrm{~m}$. Both thrust sheets are dominated by mud diapirism, structures that may have originated as one large diapir that was only displaced by the late MR05 hanging-wall ramp. The thickness of the Lønstrup Klint Formation in the thrust sheets is up to $30 \mathrm{~m}$ in the cliff section, and the height of the diapir is $15 \mathrm{~m}$. The diapir has characteristic intrusive contacts with the upper and frontal part of MR04 (Fig. 106). It is evident that the final thrust displacement post-dates the diapirism, and the very steep thrust angle indicates that the ramping is rooted in the deepest levels of the section. The L/R-unconformity is elevated up to $10-12 \mathrm{~m}$ above sea level. From this it is inferred that the thrust sheets were lifted up on the lower segments of the MR03 and MR04 thrust sheets, although most of the lift is related to the ramping on the steep thrust faults. The thickness of the 
Fig. 106. Mud mobilisation and diapirism in the Lønstrup Klint Formation in the central part of the MR04-MR05 thrust sheets of the Moserende Section. Photograph: May 1985.
Fig. 107. Mobilised mud (lower left) in the lower part of the Lønstrup Klint Formation intruded into the bedding of the formation. The mobilised mud probably formed a viscous liquid that facilitated the gravity-spreading deformation mechanism. Photograph: June 1984; staff divisions are $20 \mathrm{~cm}$.
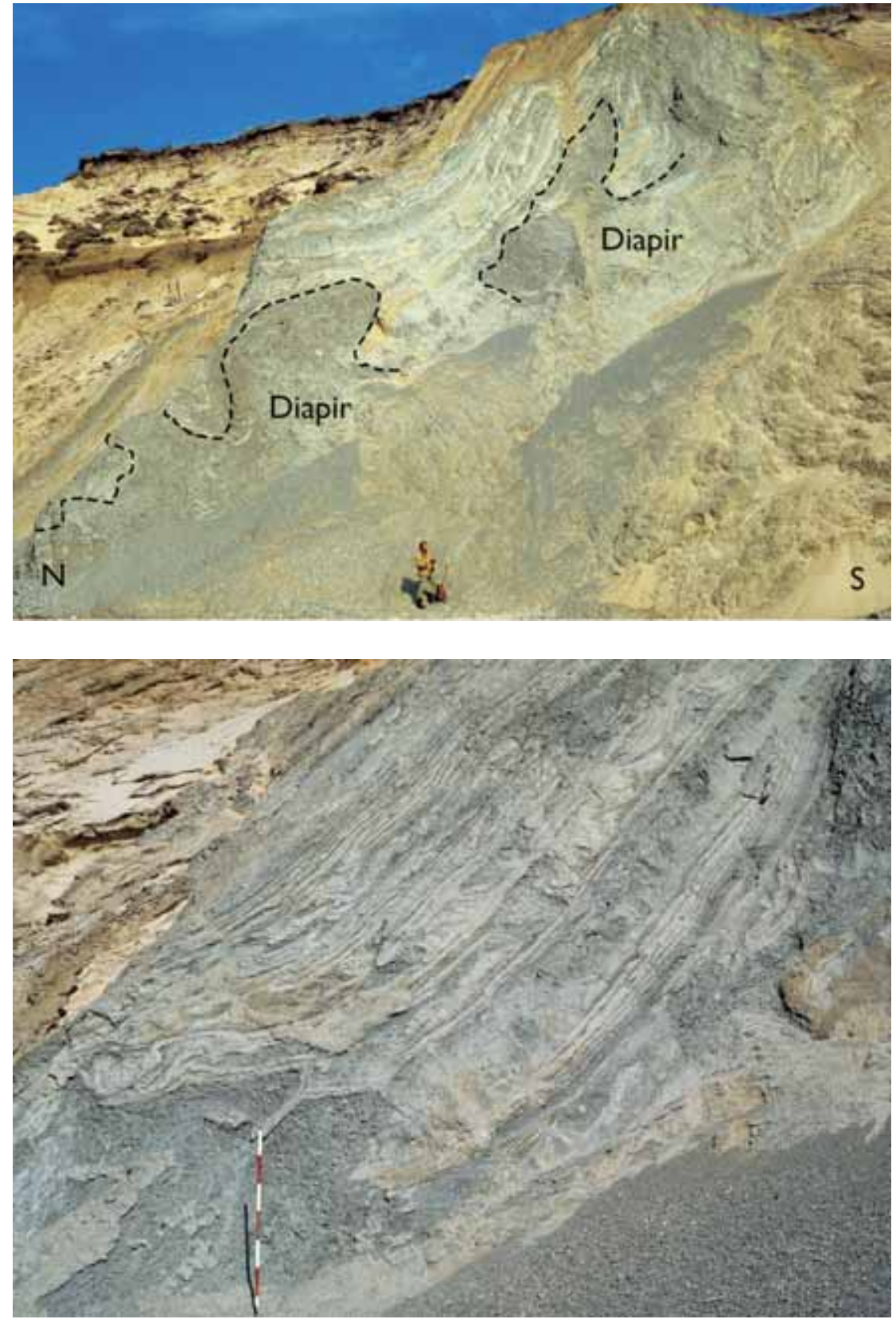

Rubjerg Knude Formation in the piggyback basin of the thrust sheets is about $15 \mathrm{~m}$.

\section{MR06-MR08 thrust sheets}

The main feature of the MR06 and MR07 thrust sheets is that they are lifted relatively high up in the cliff section, such that only a small part of the piggyback basins are preserved. The ramping of MR06 and MR07 is about 22 and $13 \mathrm{~m}$, respectively, corresponding to one level of elevation of the foremost MR06 thrust sheet. The ramping is interpreted to have been a stepwise progression up over the trailing lower part of MR05, which is ramp-bent over the lower segment of MR04. The displacement of MR06, MR07 and MR08 on each hanging-wall thrust fault is about $40 \mathrm{~m}$, indicating that the displacement is of the order of the distance down to the décollement surface.

The general impression is that MR06, MR07 and MR08 initially formed one large thrust sheet, which was stepwise separated during differential thrust movements. This differential thrusting moved MR06 to the highest position, whereas MR08 was left in the trail- 
ing part with its hanging-wall flat still resting on the lower décollement surface. This is implied by the elevation of the L/R-unconformity, which can be traced down to a horizontal orientation about $5 \mathrm{~m}$ below sea level in MR08.

In the frontal part of the MR08 thrust sheet, a very well-developed intrusive contact of a diapir is exposed (Fig. 107). It is evident that the process of thrust faulting was facilitated by the buoyancy and lubricating effects of the water-saturated mud. In addition, the mobilised mud had the effect of pushing the thrust sheets from the rear during the gravity spreading process.

\section{MR09 thrust sheet}

The MR09 thrust sheet is a relatively thick thrust sheet. The angle between the main part of the hanging-wall ramp and the bedding in the Lønstrup Klint Formation within the sheet is c. $30^{\circ}$, and the displacement is estimated to be about $58 \mathrm{~m}$. The L/R-unconformity is elevated to about $7 \mathrm{~m}$ above sea level, and the MR09 thrust sheet must be considered to have been displaced along the rear part of the lower segments in the section.

\section{MR10 thrust sheet}

The MR10 thrust sheet has the same characteristic shape as the ST08 and MR02 thrust sheets, with an obstacle interpreted as a detachment anticline. The final orientation of the hanging-wall ramp is rather steep (c. $\left.70^{\circ}\right)$ implying rotation of an initially steep ramp (c. $35^{\circ}$ ). This corresponds well with the angle between the bedding in the piggyback basin of MR09 and the MR10 hanging-wall ramp. In the cliff section, the Lønstrup Klint Formation within the thrust sheet is up to $35 \mathrm{~m}$ thick. Due to uncertainties in reconstruction of the frontal part, the displacement is estimated to be between 30 and $65 \mathrm{~m}$. The L/R-unconformity can be traced down to about $5 \mathrm{~m}$ below sea level, indicating that the main part of MR10 rests on the lower décollement surface.

The Rubjerg Knude Formation of MR10 is about 25 $\mathrm{m}$ thick. It contains a c. $12 \mathrm{~m}$ thick lower unit with bedding dominated by R-onlap. Above this follow three units, each developed as growth-fault footwall synclines. To obtain the rather large accumulated thickness of deposit in the piggyback basin, as well as folding the three synclines, the order of displacement is more likely to be $65 \mathrm{~m}$ than $30 \mathrm{~m}$. This order of displacement also assumes that the frontal part of the thrust sheet extended nearly $50 \mathrm{~m}$ further 'up in the air' before being removed by erosion. The final implication is that the upper piggyback basin above the anticlinal obstacle was deposited in a syntectonically deeply eroded depression.

\section{MR11 thrust sheet}

MR11 is a small thin thrust sheet with a displacement of $55 \mathrm{~m}$ along the hanging-wall ramp. The thrusting of MR11 is another example of a thrust sheet requiring the formation of a splint in the subsurface. This is due to the low angle of the initial frontal ramp (only $15-18^{\circ}$ ), whereas the ramp angle between the hanging-wall ramp and the original bedding in the piggyback basin of MR10 is $40-45^{\circ}$. The splint was probably trapped as a triangular prism along the $45^{\circ}$ dipping ramp, just below the beach surface.

The L/R-unconformity is elevated to about $7 \mathrm{~m}$ above sea level. The model for balancing this thrust sheet indicates that it had a lower hanging-wall flat situated at the $30 \mathrm{~m}$ level (below the L/R-unconformity). From this level, it ramped up to the $20 \mathrm{~m}$ level onto a footwall flat on MR10, and finally developed an internal duplex of its own lower segment, which separated into MR11 $\mathrm{u}_{1}$ and $\mathrm{MR} 11 \mathrm{u}_{2}$ (see Plate 2).

The piggyback basin of MR11 consists of only a 10 $m$ thick unit of the Rubjerg Knude Formation. The sand beds show a F-bedding relationship to the L/Runconformity with a weak tendency for D-onlap.

\section{MR12 thrust sheet}

The exposed part of the Lønstrup Klint Formation in the MR12 thrust sheet is about $15 \mathrm{~m}$ thick and was displaced c. $58 \mathrm{~m}$ along a hanging-wall ramp dipping $38^{\circ}$. About half of the Lønstrup Klint Fomation here constitutes mobilised mud, without showing any marked tendency towards diapirism. The Rubjerg Knude Formation is typically c. $15 \mathrm{~m}$ thick, with the exception of increased thicknesses in growth synclines, and the MR12 thrust sheet is regarded as only $30 \mathrm{~m}$ thick. This leaves another nearly $60 \mathrm{~m}$ long lower segment to be added to the trailing end of the MR10u duplex segment. The initiation of the MR12 thrusting started relatively early compared to the thrust sheets in front (to the south) and behind. This is based on a 
consideration of the thickness of the Rubjerg Knude Formation in MR11, which only reached a thickness of about $10 \mathrm{~m}$ before it became trapped by the MR12 thrust sheet. In the cliff section, the MR12 hangingwall flat (related to the $20 \mathrm{~m}$ flat level) is positioned on the footwall flat of the MR11 thrust sheet. The L/Runconformity is situated about 5-6 m above sea level, which is compatible with the lift of the thrust sheet up onto the footwall flat of its own lower segment (MR12u).

The Rubjerg Knude Formation of MR12 was deposited in one of the large piggyback basins in the proximal part of the Moserende Section. The width of the basin is about $45 \mathrm{~m}$ and the accumulated thickness of the sand succession is c. $23 \mathrm{~m}$. Four units can be differentiated in the Rubjerg Knude Formation of MR12. The lowest of these is about $10 \mathrm{~m}$ thick, displays Fbedding, and corresponds well to the lower part of the Rubjerg Knude Formation in other parts of the section. Above this follows a trough-shaped unit folded in a gentle syncline. A new trough-shaped unit, which is folded into a tight footwall syncline, truncates the northern limb of this syncline. Finally these two growth synclines are truncated by the upper sub-unit; the latter is mainly F-bedded, except for the northern part which is dragged into a footwall syncline below the hanging-wall thrust of MR13.

\section{MR13 thrust sheet}

The Lønstrup Klint Formation of the MR13 thrust sheet forms an upright, wedge-shaped feature, which was displaced about $42 \mathrm{~m}$ up along a relatively steep $\left(70^{\circ}\right.$ dip) hanging-wall ramp. This thrust surface has a remarkable curved shape, which is interpreted to be the result of erosion in the ramp caused by water flow contemporaneous with the deposition of the two growth synclines in the external part of MR12. Similar features have been observed in places further to the south, but this is one of the best-developed examples. The erosion can be detemined to have taken place in the intervalbetween deposition of the lower $10 \mathrm{~m}$ thick unit of the Rubjerg Knude Formation subsequent to c. $20 \mathrm{~m}$ ramping and before the final displacement along the ramp and deposition of the uppermost unit in the MR12 piggyback basin.

The L/R-unconformity is situated 5-6 $\mathrm{m}$ above sea level. This is close to the elevation of the L/R-unconformity in MR12, and the thrusting follows a similar development style with ramping and displacement along the flat of the lower segment of the trailing end of the thrust sheet in front (to the south). The section balance requires a lower segment of the MR13 thrust sheet (MR13u) in the subsurface, bounded by the flats at the $20 \mathrm{~m}$ and $30 \mathrm{~m}$ levels (Plate 2). The MR13u segment accumulated on the MR10u segment leads to a high ramping of the thrust sheet to the north, as will be demonstrated in the following section.

The large piggyback basin in the Moserende Section is represented by the c. $20 \mathrm{~m}$ thick succession of the Rubjerg Knude Formation in MR13. It is nearly 60 $\mathrm{m}$ wide and the main part is planar parallel bedded (F-bedded); only in the uppermost, rear part of the thrust sheet does a single footwall syncline appear. The external part of MR13 is therefore thought to have been deposited during a relatively long period of transport along a flat, contemporaneous with the ramping that had started in the thrust sheets in the distal part of the section.

\section{Sedimentary units}

In the Moserende Section, only two formations involved in the thrust-fault deformation can be studied. The Lønstrup Klint Formation forms the lower part of the thrust sheets, and the Rubjerg Knude Formation forms the fill of the piggyback basins above the L/R-unconformity.

\section{Lønstrup Klint Formation}

The lower part of the Lønstrup Klint Formation typically consists of clayey mobilised mud. About twothirds of the thrust sheets comprise mobilised mud, which commonly developed into diapirs, rising from the sole thrust up into the formation, where they often truncate bedding with intrusive contacts (Fig. 107). The upper part of the formation is composed of thinto medium-bedded sandy turbidites interlayered with silty mud (Fig. 27). In the majority of layers, the mud and fine-grained sands have been disturbed by balland-pillow breccias or small polydiapiric water-escape structures. During the main thrust faulting, these structures were superimposed by a dense framework of smaller thrust faults (Fig. 27). 


\section{Rubjerg Knude Formation}

The Rubjerg Knude Formation has a maximum thickness of $25 \mathrm{~m}$ in the Moserende Section; such thicknesses are rarely attained, however, either due to overthrusting that sealed the deposits in the piggyback basins before accumulation of this thickness, or to erosion of the upper part of the formation after deposition and deformation. In general, deposition was initiated with a unit of F-bedded sand c. $10 \mathrm{~m}$ thick. Above this are two or three units showing R-onlap and locally foreland-dipping large-scale cross-bedding (D-onlap). The uppermost part typically shows R-onlap.

\section{Structures}

In the Moserende Section, three types of structural elements are described and discussed: (1) diapirs, including mud mobilisation, (2) mesoscale thrust faulting, and (3) growth-fault footwall synclines, including fissure strata. The existence of frozen sand clasts and frost wedges that testify to the ground-frozen condition of some of the sediments in the Rubjerg Knude Glaciotectonic Complex has already been mentioned. Further evidence for ground-frozen conditions is seen in the presence of fissure strata (Sjørring 1977). A fissure stratum is a layer of sand deposited horizontally in a fissure that discordantly cuts into a package of sediment (usually meltwater sand) (Fig. 105). The implication of the occurrence of fissure strata is that not only wasthe hostsedimentaffected by (glacio)tectonic deformation prior to fissure incision, but also that the sediment must have been frozen so that the fissure cavity did not collapse during deposition of the fissure strata. As the fissure strata form wedge-shaped sand layers, they have also been referred to as kilelag (wedge-layers in Danish; Berthelsen 1975). In the Moserende Section, the fissure strata document an intermediate phase of syntectonic deposition, as they have been tilted into a vertical position.

\section{Diapir structures}

In the Moserende Section, the zone above the hanging-wall ramps and flats often comprises mobilised mud (Figs 106, 107). The mud-mobilisation and related diapirs dominate in the thrust sheets from the intermediate hanging-wall ramp and towards the trail- ing end of the sheets. The diapirs are irregularly developed, mainly related to intrusive migration laterally into the bedding. In the example shown in Fig. 107, the intrusive mobilised mud has a contact rim of segregated sandy mud that foms the contact to the truncated bedding. In the thickest thrust sheets, the larger diapirs rose from the hanging-wall thrust fault up to $15 \mathrm{~m}$ above the thrust-fault surface (Fig. 106).

In the construction and calculations of the balanced cross-section (Plate 2), the mobilised mud and polydiapirism create a problem of volume preservation relevant to the approximation and evaluation of the reliability of the balanced model. However, the volumes are not lost but only reorganised and may therefore be treated as part of the thrust sheets and duplex segments. The mobilisation is dominantly developed along the lower part of the thrust sheet, from where the mud intruded the upper part of the Lønstrup Klint Formation of the thrust sheets. It is evident that the thrust sheets were carried on the mobilised mud, which with its high water pressure facilitated the displacement of the sheets. Pedersen (1987) described a model for this process, and with minor modifications this is still considered to be valid (Fig. 4). The model also implies that the muddy liquid formed a pressure agent in the gravity-spreading dynamics, which pushed the thrust sheets forward towards the distal part of the thin-skinned thrust-fault complex.

\section{Thrust faults}

In the structural cross-section, only the thrust faults identified as carrying the major displacements are outlined (Plate 1). A number of smaller thrust faults and bedding-parallel contractional faults that occur in the Rubjerg Knude Glaciotectonic Complex are therefore not included in the cross-section. One example of these less significant faults was described in the Rubjerg Knude Fyr Section (Fig. 101). In the Moserende Section, similar thrusts occur, and were recorded during detailed logging of the upper part of the Lønstrup Klint Fo mation in the MR03 thrust sheet (Fig. 27). Within a $7 \mathrm{~m}$ thick succession, ten minor thrust faults have been recognised. The base of the succession is the hanging-wall ramp of MR03b. Along the base of the succession, 0-1.5 $\mathrm{m}$ above the hanging-wall ramp, the clayey mud is cataclastically brecciated by anastomosing shear fractures. In the overlying part of the formation, the bedding-parallel thrust faults occur with a spacing of 0.5-1.5 m, concentrated in the muddy 
layers, whereas steep connecting ramps are situated in the sandy beds.

It is likely that this type of differential beddingparallel thrust faulting and shear brecciation was an important component in translation in the thin-skinned thrust-fault system. It also implies that the stratigraphic succession in a formation that appears to be well preserved may in fact have experienced significant lateral dislocation.

\section{Footwall synclines}

The dominant structures in the Moserende Section are the footwall synclines, which include the growth syncline basins and re-orientated fissure strata. These synsedimentary folds were formed continuously, beginning with the deposition of the sand in a trough. As the thrusting up over the footwall ramp progressed, the trough deepened; contemporaneous with this deepening of the footwall block, the hanging-wall ramp north of the trough started thrusting, which resulted in a drag bend of the northern flank of the syncline. Some of the synclines were trapped and overthrust, resulting in overturning of the northern flanks, which in a few cases created nearly isoclinal, recumbent folds.

In the piggyback basin of the MR02 thrust sheet, an excellent example of deposition in a growth syncline is preserved. The width of this basin (c. $20 \mathrm{~m}$ ) is of the same magnitude as the thickness of the sequence deposited and deformed. The basin fill can be divided into four sub-units of the Rubjerg Knude Formation separated by angular discordances (Fig. 104). The lowest sub-unit $\left(\mathrm{S}_{1}\right)$ consists of c. $5 \mathrm{~m}$ of trough crossbedded sand deposited in an erosional depression incised into the Lønstrup Klint Formation of the MR02 thrust sheet. It could be argued that in relation to the L/R-unconformity of MR02, this sub-unit shows R-onlap, but it is evident that the trough cross-bedded sand is growth-related to an initial up-thrusting of the MR03 frontal nose.

The second sub-unit $\left(\mathrm{S}_{2}\right)$ was deposited after the first sub-unit was tilted during ramping of the MR02 thrust sheet. The tilting also lifted the $\mathrm{S}_{1}$ sub-unit up to a level at which the $5 \mathrm{~m}$ thick sand package could be subjected to ground-frost. This is deduced from the occurrence of fissure strata emplaced discordantly into the $\mathrm{S}_{1}$ sub-unit. The fissure strata transecting sub-unit $\mathrm{S}_{1}$ show small-scale current ripples, which demonstrates that these fissure strata were deposited parallel to the sides of the wedge (Fig. 105). The fissure strata can be traced into the second sub-unit $\mathrm{S}_{2}$, which consists of stratified sands characterised by climbing ripple cross-lamination, deposited in a growth syncline trough. The thickness of the $\mathrm{S}_{2}$ sub-unit is 5$10 \mathrm{~m}$; this sub-unit is dominated by R-onlap in relation to the L/R-unconformity in MR02.

Deposition of the third sub-unit $\left(\mathrm{S}_{3}\right)$ was first initiated after sub-units $\mathrm{S}_{1}$ and $\mathrm{S}_{2}$ were deformed by compressional deformation due to push from hangingwall thrusting of MR03 over the footwall block of MR02. The fold structure may be described as an inclined S, where the lower bend of the S corresponds to a footwall syncline.

The $\mathrm{S}_{3}$ sub-unit is c. $10 \mathrm{~m}$ thick. The base of $\mathrm{S}_{3}$ is an angular discordance on the folded $\mathrm{S}_{1}$ and $\mathrm{S}_{2}$ sub-units. The $\mathrm{S}_{3}$ sub-unit shows R-onlap onto the L/R-unconformity of MR02 and the uppermost part of this sand package covers the detachment anticline structure of MR02 as well as filling the depression on the northern flank of the structure. Finally the $\mathrm{S}_{3}$ sub-unit was folded into a footwall syncline by thrust propagation of MR03. In the uppermost part of the basin, a small growth syncline comprises the uppermost sub-unit $\left(\mathrm{S}_{4}\right)$. This unit is 1-6 $\mathrm{m}$ thick and may be regarded as recording deposition in a depression formed by a footwall synclinal bend during the general northward tilting of MR02.

\section{Interpretation of structural development}

In the model for the structural development of the Moserende Section, a distal (southern), an intermediate and a proximal (northern) zone are distinguished. The distal zone includes thrust sheets MR01-MR03, which were probably displaced in similar mode. The intermediate zone includes thrust sheets MR04-MR08, and finally in the proximal zone thrust, sheets MR09MR13 probably moved sequentially in one continuous displacement.

The distal MR01-MR03 zone is regarded initially to have formed one coherent thrust sheet, which was split up during the ramping of MR01. The main bend during ramping took place in MR02, while the trailing end of MR03 still rested on the décollement surface without being elevated, and thus represents the root zone of the MR01-MR03 segment. The sequential development of deposition and deformation is very well illustrated in this first segment with the key locality in the piggyback basin of MR02. Here four depositional 
phases $\left(\mathrm{S}_{1}-\mathrm{S}_{4}\right)$ separated by four defomational phases $\left(\mathrm{F}_{1}-\mathrm{F}_{4}\right)$ have been identified.

Depositional phase $\mathrm{S}_{1}$. The $\mathrm{S}_{1}$ depositional phase took place during the initial thrusting. About $5 \mathrm{~m}$ of trough cross-bedded sand was deposited before (or coeval with) the first deformation phase $F_{1}$.

Deformational phase $F_{1}$. The first fold phase culminated with the creation of the hanging-wall anticline or detachment anticline in MR02. This folding must be the effect of ramping up from the $20 \mathrm{~m}$ level (or 30 $\mathrm{m}$ ) to the $10 \mathrm{~m}$ flat level, resulting in folding of the $\mathrm{c}$. $10 \mathrm{~m}$ upper Lønstrup Klint Formation of MR02.

Depositional phase $\mathrm{S}_{2}$. During $\mathrm{S}_{2}$ deposition, the angle between bedding in the Rubjerg Knude Formation and the L/R-unconformity is nearly perpendicular. The ramp is not indicated in the ramp cross-section because it was destroyed by mud-mobilisation in the lower part of MR02 (Plate 2). Deposition of $\mathrm{S}_{2}$ also took place during the exposure of the $\mathrm{S}_{1}$ unit to ground frost conditions as indicated by the presence of fissure strata.

Deformational phase $\mathrm{F}_{2}$. The $\mathrm{F}_{2}$ folding was related to the hanging-wall thrusting of MR03. As this phase includes thrust displacement of the $\mathrm{S}_{1}$ sand and a synclinal drag of the $\mathrm{S}_{2}$ sand below the footwall ramp of MR02, it progressed during $\mathrm{S}_{2}$ deposition. The $\mathrm{F}_{2}$ phase terminated with the final folding and minor thrust truncation of $\mathrm{S}_{2}$. Thus the separation of the imbricate thrust sheet MR02 and MR03 took place during the $\mathrm{F}_{2}$ phase.

Depositional phase $\mathrm{S}_{3}$. Deposition of $\mathrm{S}_{3}$ covered the hanging-wall anticline of MR02, and part of $\mathrm{S}_{2}$ is discordantly inclined relative to $\mathrm{S}_{3}$ bedding. $\mathrm{S}_{3}$ sedimentation is characterised by F-bedding, and displacement probably took place along the $30 \mathrm{~m}$ level on top of MR01u, and also ST09-ST10u.

Deformational phase $\mathrm{F}_{3}$. The $\mathrm{F}_{3}$ fold phase is restricted to folding of a footwall syncline of the $\mathrm{S}_{3}$ unit related to the hanging-wall ramp propagation of MR03. It might be interpreted as a continuation of F2, but the MR03 thrusting definitely propagated after $\mathrm{S}_{3}$ deposition and its extension most likely forms a hangingwall flat over the sand covering the hanging-wall anticline of MR02.

Depositional phase $\mathrm{S}_{4}$. The uppermost growth syncline in the piggyback basin of MR02 was formed by the $5 \mathrm{~m}$ thick uppermost unit of the Rubjerg Knude Formation sand. It probably truncated the F3 thrust, and is thus not interpreted to represent dislocated parts of $\mathrm{S}_{1}$ or $\mathrm{S}_{2}$.

Deformational phase $\mathrm{F}_{4}$. The last fold phase creat- ed the footwall syncline of the $\mathrm{S}_{4}$ deposits. The hanging-wall ramp of MR03 increased its inclination by about $30^{\circ}$ and propagated along a steeper satellite thrust. The footwall syncline was initially overturned to the south, but during the final phase of ramping and steep tilting the syncline became re-orientated into an upright position.

The MR04-MR08 intermediate zone initially formed one coherent thrust sheet, comparable to the MR01MR03 thrust sheets, with a frontal steep ramp, hanging-wall ramp of MR04, and a MR08 trailing-end sheet with the L/R-unconformity below sea level, indicating that this thrust sheet rooted in the décollement zone.

In the proximal zone, the MR09 thrust sheet probably propagated as an individual sheet onto the footwall ramps. The main thrusting was initiated with the MR11-MR13 sheets being thrust along a flat in the 30 $\mathrm{m}$ level, which is on the lower footwall flat of the trailing end of the MR10 thrust sheet. Thus MR11MR13 can be viewed as thrust-sheet imbrications peeling off the back of MR10. At the latest stage of thrusting, the continued displacement along the décollement zone was responsible for the steepening up of the sheets, somewhat similar to the development of the Grønne Rende Section.

For the calculation of the displacement of the individual thrust sheets, the erosionally removed frontal parts have been reconstructed from simple angular geometry, in the same way as the calculation of displacements in the Grønne Rende Section (Fig. 11). When the elevation of the L/R-unconformity is considered, it mainly refers to the position of the lowest part of the L/R surface. Ideally this part should be horizontal, to indicate the main elevation of the thrust sheet. However, this is not always the situation, and therefore the position of the L/R-unconformity in general refers to its position where a hanging-wall ramp or flat truncates it.

\section{Mårup Kirke Section}

One of the locations where landsliding at present is most dramatic is at Mårup Kirke (the old church at Mårup). This attracts much public attention, not least among the local people. The back-stepping of the head of the slides has been very rapid during the last ten years, and it is probable that the coastal protection measures instituted at Lønstrup have increased the erosion of the cliff at Mårup Kirke. Over a number of 


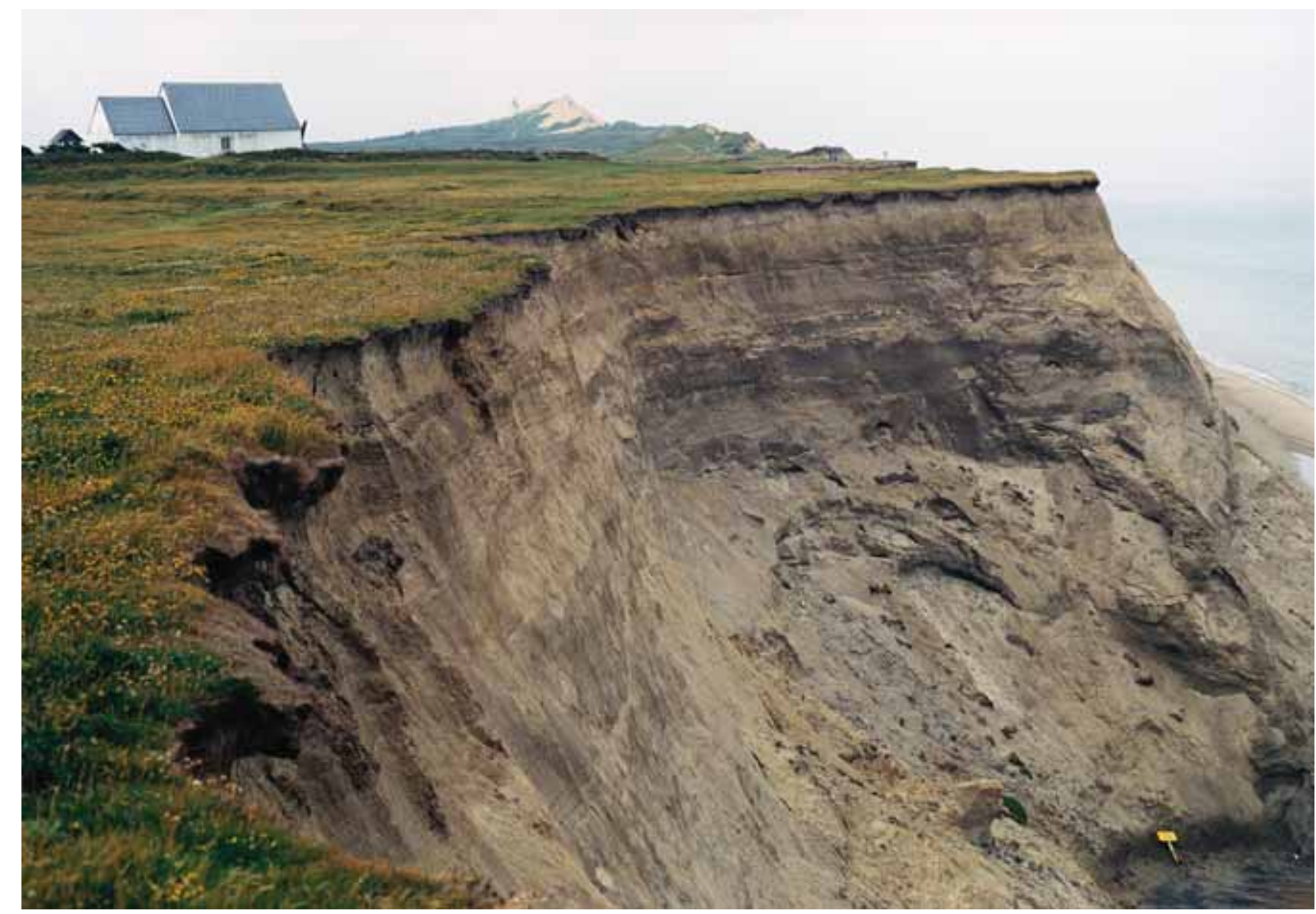

Fig. 108. The Mårup Kirke situated at the head of the cliff in the central part of the Mårup Kirke Section. Note that the flat cliff-top surface, representing the horizontal bedding of the Vendsyssel Formation, is not covered by dunes, reflecting the fact that the cliff consists of clay and mud. In the distance, the Rubjerg Knude Fyr (lighthouse) is being engulfed by sand dunes derived from the sand-rich Rubjerg Knude Formation in the piggyback basins present in the sections to the south. Photograph: July 1994; note that by 2002 cliff erosion had reached the corner of the graveyard.

years the landslides have also obscured the exposures at this location and a lot of interpretation has been necessary to reconstruct the structural framework and the development of the thrusting. The Younger Yoldia clay and Saxicava sand (the Vendsyssel Formation) cap the Mårup Kirke Section. The erosional unconformity at the base of the Vendsyssel Formation acts as a drainage surface, which contributes to the generally poor exposure conditions. However, with the experience gained from the other sections, combined with theoretical structural analysis, it is possible to present a model of the structures in the Mårup Kirke Section.

There is a marked correlation between the occurrences of piggyback basins comprising the sand-rich Rubjerg Knude Formation, and the build-up of aeolian dunes above the cliff. The northern boundary of the dune field is situated about 200 m south of Mårup Kirke in the frontal part of the Mårup Kirke Section. South of this area, the aeolian dunes form features ranging from a few metres in height to nearly $50 \mathrm{~m}$ high dunes above the Rubjerg Fyr Section, which is also the highest point of the cliff section. Thus it is evident that the dunes are formed where a sand source (the Rubjerg Knude Formation) is available (Pedersen 1986b). Above the main part of the Mårup Kirke Section, no dunes are present, as this is a cliff section that consists only of clay and mud (Fig. 108).

The most interesting feature at Mårup Kirke is the packing of the thrust sheets into uniformly developed thrust-fault deformed duplex segments. A theoretical model is presented for the deformation geometry of these duplex units, subjected to extreme compressional development; comparisons with the observations re- 


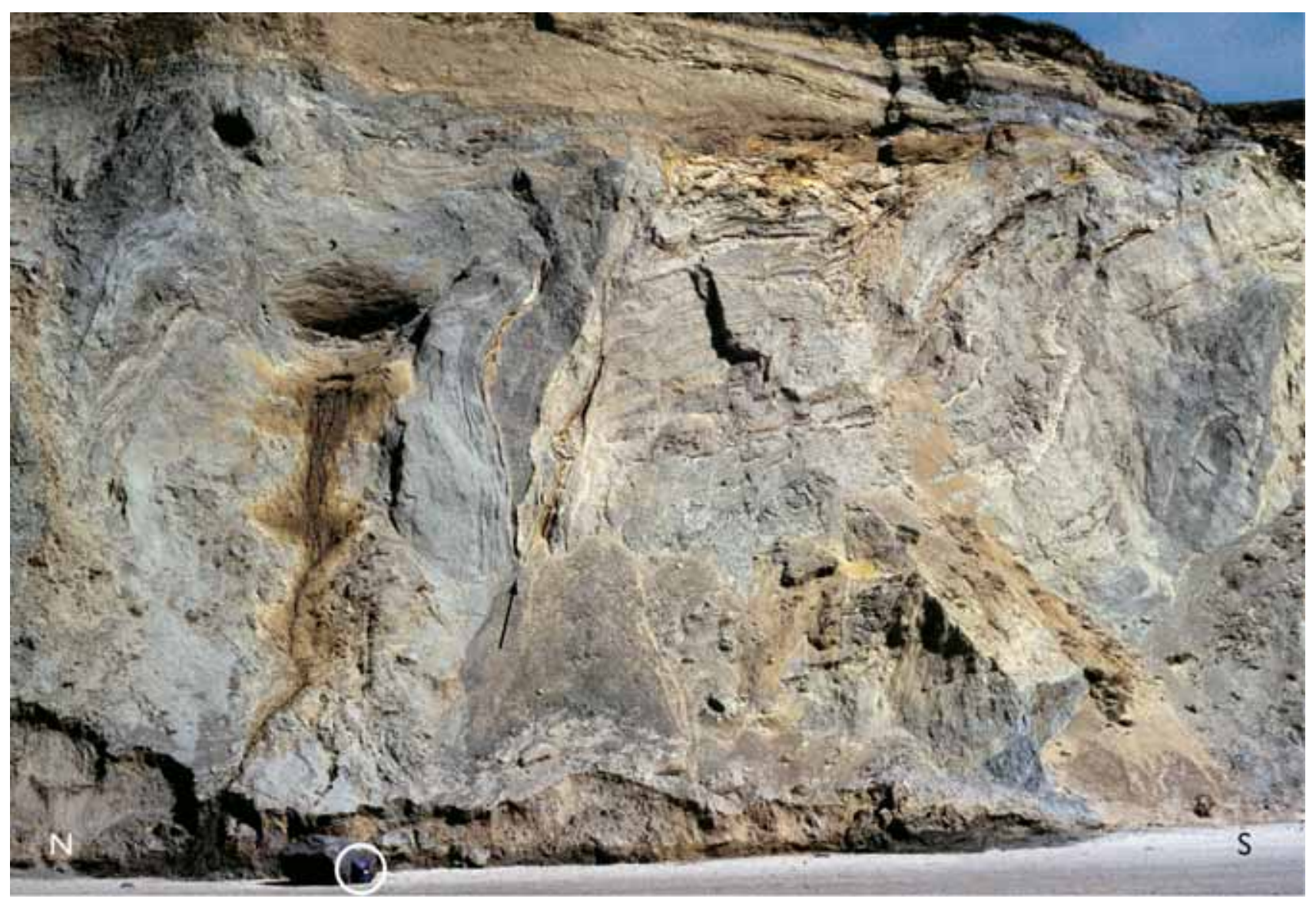

Fig. 109. Upright thrust sheets in the frontal zone of the Mårup Kirke Section (thrust fault arrowed). The difference in lithology between the upper and lower levels of the Lønstrup Klint Formation is illustrated by comparing the sand-rich (upper Lønstrup Klint Formation) footwall block (to the right, south) with the mud-dominated (lower Lønstrup Klint Formation) hanging-wall block (left). Encircled rucksack for scale. Photograph: August 1996.

corded in the cliff section indicate a reasonable match between the theoretical model and cliff observations.

\section{Tectonic architecture}

Due to the variation in the distribution of piggyback basins and the general tectonic architecture of compressional framework, the Mårup Kirke Section is divided into three zones: (1) a leading zone (MK01MK07), (2) a transitional or intermediate zone (MK08MK10), and (3) a trailing zone, including thrust-fault duplex units annotated MK11-MK20.

In the leading zone, the first six thrust sheets have preserved a relatively highly elevated remnant of their strongly eroded piggyback basins. In the transitional zone, only the thrust sheet MK10, just below the Månup Kirke, contains a piggyback basin. North of this thrust sheet, the thrust-fault duplex units only comprise the
Lønstrup Klint and Stortorn Formations. In the intermediate and trailing zones (MK08-MK20), the thrust sheets are defined as duplex units, each comprising four duplex segments, which are annotated d1-d4. Thus the lower duplex segment in unit MK09 is annotated MK09d1 and the upper thrust-sheet segment is annotated MK09d4 (Plate 2).

The southern boundary of the Mårup Kirke Section is the leading-edge thrust fault corresponding to the trailing footwall thrust of MR13 and the hanging-wall ramp of MK01. The boundary is fairly obvious, as it separates the large piggyback basin of MR13 from the c. $50 \mathrm{~m}$ thick MK01 thrust sheet. The trailing end of the section is more loosely defined, due to poor exposure and the increasing mud mobilisation of the thrust sheets. It has therefore been defined in relation to the unconformities above the thrust sheets. Thus the boundary between the Mårup Kirke Section and the Ribjerg Section to the north is placed where the 
unconformity at the base of the Vendsyssel Formation truncates the unconformity between the glaciotectonic unit and the Ribjerg Formation. The glaciotectonic unit is viewed as the unit of deformed deposits related to a glaciotectonic event (Pedersen 1993), here included in the Rubjerg Knude Glaciotectonic Complex. The defined boundary is very close to where $45^{\circ}$ dipping thrust-fault features are obscured both by the mud mobilisation and by superimposed, more or less horizontal, anastomosing jointing.

\section{K01 thrust sheet}

The first thrust sheet in the leading zone of the Mårup Kirke Section is the nearly $50 \mathrm{~m}$ thick MK01 thrust sheet. In the exposed parts of the thrust sheet, the Lønstrup Klint Formation has a thickness of $40 \mathrm{~m}$, which indicates that the deepest level of the section including the lower décollement zone is brought up to the upper flat. The displacement is estimated to be $102 \mathrm{~m}$; this includes construction of the eroded tip of the thrust sheet (Fig. 11). This corresponds well with calculation of the displacement according to the equation $\mathrm{d} \times \sin \alpha=\mathrm{h}$, where $\mathrm{d}$ is the displacement, $\alpha$ is the angle of the thrust ramping from the lower flat to the upper flat, and $\mathrm{h}$ is the distance between the two flats. The distance between the lower and upper flats is 40 $\mathrm{m}$, and assuming an initial thrusting angle of about $23^{\circ}$, the calculated displacement d is c. $100 \mathrm{~m}$.

Most of the Lønstrup Klint Formation of MK01 is mobilised and forms a diapir-like structure. Bedding is only well preserved in the upper 7-10 m of the Lønstrup Klint Formation in this thrust sheet. The bedding is characterised here by medium-bedded sandy turbidites.

The Rubjerg Knude Formation of MK01 comprises a nearly $10 \mathrm{~m}$ thick succession of glaciofluvial sand. The sand layers show R-onlap and are strongly deformed by a footwall syncline. The L/R-unconformity is situated about $15 \mathrm{~m}$ above sea level, indicating an elevation of the lower hanging-wall flat up to the 20 $\mathrm{m}$ level footwall flat. This corresponds well with the balanced model for the Moserende Section, where the trailing-end lower segments MR10u and MR13u still remain to be calculated for. It is thus evident that the MK01 thrust sheet was translated along the $20 \mathrm{~m}$ level flat.

\section{MK02-MK04 thrust sheets}

The MK02-MK04 thrust sheets are three relatively small sheets with only minor displacements, about $30 \mathrm{~m}$ for MK02 and MK03, and c. $40 \mathrm{~m}$ for MK04. The estimates of the displacement for thrust sheets with erosionally removed tips are based on reconstructions following the same principles as applied in the Grønne Rende Section (Fig. 11). The thickness of the Lønstrup Klint Formation in the thrust sheets is only between 10 and $20 \mathrm{~m}$, and the thrust sheets are considered to represent imbricates from the upper part of the MK01 thrust sheet, which roots down to the décollement zone in the $40 \mathrm{~m}$ flat level.

The Lønstrup Klint Formation in MK02 is completely mobilised apart from the uppermost 1-2 m. The mud diapir in MK02 is regarded as an extension of the large mud diapir in MK01. In MK03 and MK04, bedding is partly preserved, and may be compared with the upper sandy bedding seen in MK01.

The L/R-unconformity cuts down to at least 2-3 m below the mean level of bedding on the back of MK02 and MK03, and given this uncertainty in location, the position of the unconformity is at the same elevation as in the MK01 and MK04 thrust sheets. It is therefore inferred that the imbricate thrusting of MK02-MK04 was initiated at an early stage, prior to the subsequent deeper-level up-thrusting of MK01.

Early development of the imbrication is further supported by the thickness of the Rubjerg Knude Formation, which in MK01-MK04 is less than $10 \mathrm{~m}$. The piggyback basin on the back of the non-imbricated MK01 was short-lived relative to those described above in the Moserende Section where the Rubjerg Knude Formation isup to $25 \mathrm{~m}$ thick. Along the footwall ramps, sand of the Rubjerg Knude Formation was deposited in growth synclines indicating syntectonic development of the small piggyback basins in the leading zone of the Månup Kirke Section.

\section{K05-MK07 thrust sheets}

The MK05-MK07 thrust sheets form an imbricate set of upright thrust sheets, now dipping more than $60^{\circ} \mathrm{N}$ (Fig. 109). The thickness of the thrust sheets is about $20 \mathrm{~m}$ in the cliff section. The displacement is $40 \mathrm{~m}$ for MK05, $28 \mathrm{~m}$ for MK06 and only $15 \mathrm{~m}$ for MK07. The Lønstrup Klint Formation, making up most of the thrust sheets, is characterised by a few relatively thick finegrained sand turbidites interbedded with dark blue- 
grey silty mud. The bedding is strongly disturbed by thrusting and jointing, similar to the thrust-fault framework described in MR03, and small- to medium-scale duplexes are common. In the upper half of the MK07 thrust sheet, a major footwall syncline is developed below the hanging-wall ramp of MK08.

The Rubjerg Knude Formation is only represented in MK06, where the L/R-unconformity is elevated up to about $20 \mathrm{~m}$ above sea level. In the MK04-MK05 thrust sheets the elevations are more than $20 \mathrm{~m}$, indicating that these thrust sheets were lifted up and translated along an upper flat resting on three lower segments. The accumulation of these segments forms a subsurface duplex, probably deformed into an intense network of anastomosing thrust faults. The duplex segments constitute the trailing lower segments of MK01-MK04, and for MK06 and MK07 the trailing lower segment of MK05 is also added (see balanced crosssection, Plate 2).

\section{K08-MK10 thrust sheets}

MK08 is the southernmost thrust sheet in the transitional zone of the Mårup Kirke Section. The transitional zone is characterised by the change from thick continuous successions of lithologies into sheet units comprising duplex segments bounded by footwall and hanging-wall flats. Along these flats, lateral translation preceded tilting and steepening during propagation along the ramps.

The thrust fault separating MK07 and MK08 is the trailing-end footwall ramp on top of MK07 and the hanging-wall flat of MK08. At the top, MK08 is bounded by the footwall flat and hanging-wall ramp between MK08 and MK09. The thrust fault and the general bedding in MK08 dips at $35^{\circ} \mathrm{N}$. In the exposed cliff section, MK08 is $40 \mathrm{~m}$ thick, which implies that the hanging-wall flat is a segment of the lower décollement zone. Above this, four segments may be identified corresponding to the four main levels of flats below the L/R-unconformity. Each flat-segment is about $10 \mathrm{~m}$.

The displacement along the hanging-wall thrust is c. $110 \mathrm{~m}$, calculated from the equation $\mathrm{d} \times \sin \alpha=\mathrm{h}$, given that the height $h$ is c. $65 \mathrm{~m}$ (sum of cliff section and distance down to the décollement surface) and $\alpha$ is $35^{\circ}$. The estimate is based on the assumption that the tip of the hanging-wall ramp in the lowest segment (initially located at the $30 \mathrm{~m}$ flat level) only reaches up to the hinge of the footwall ramp at the top of the cliff. In the MK08 thrust sheet, there is no record of the Rubjerg Knude Formation.

Due to the intense development of landslides below the Mårup Kirke, the MK09 thrust sheet is very poorly exposed. The interpretation here is based on the space relationships and the structures exposed in MK08 and MK10. From MK08 it is known that the frontal hanging-wall ramp of MK09 dips at $35^{\circ}$. The bedding is more or less horizontal in the cliff section, judging from the occasional features that can be picked out from the photo-geological interpretation. The distance between the leading and trailing thrust fault is about 70-73 $\mathrm{m}$, and the displacement must therefore be about $50-55 \mathrm{~m}$. The interpretation of the MK09 framework is that the upper segment forms a type 3 fault-bend-fold structure, where the sub-segment resting on the upper flat has been eroded away and truncated by the MK10 hanging-wall flat, the two segments in the intermediate levels form S-shaped type 2 structures, and the lower segment foms a type 1 structure with the trailing end of the segment resting on the lower flat (compare with the model in Fig. 103).

The MK10 thrust sheet is situated below the Mårup Kirke, and preserves the most proximal piggyback basin containing the Rubjerg Knude Formation. The thickness of the Rubjerg Knude Formation is about 10 $\mathrm{m}$ and the basin is defomed into a recumbent footwall syncline. The L/R-unconformity is situated about $10 \mathrm{~m}$ a.s.l., indicating elevation above two lower duplex segments in the subsurface. The increase in the dip of the L/R-unconformity and bedding in the Lønstrup Klint Fomation from $20^{\circ}$ in the frontal part to $35^{\circ}$ in the rear part is interpreted as a bend by the hanging-wall ramp propagating over irregularities in the trailing part of MK09. Thus part of the subsurface structure must include the geometric adjustments of a splint appearing due to the ramp angle change (see Plate 2). This is reflected in the occurrence of a hanging-wall anticline in the trailing end of MK10.

\section{MK11-MK20 thrust sheets}

In the trailing zone of the Mårup Kirke Section, there are no occurrences of the Rubjerg Knude Formation, and the L/R-unconfomity has not been identified. The thrust faults are mainly steeply dipping, about $45^{\circ}$, and at the top of the cliff section the thrust sheets are shear-dragged southwards and reworked into glacitectonites, a truncated glaciotectonic unconformity and local till. 
This trailing zone can be divided into ten fairly uniform thrust-fault duplex units, each about $55 \mathrm{~m}$ long (measured horizontally along the beach level) and separated by $45^{\circ}$ steeply dipping thrust faults. For the characterisation and structural explanation of these thrust-fault duplex units, a thrust-ramp-propagation model is presented below (see Fig. 114).

\section{Sedimentary units}

In the Mårup Kirke Section, no significant additional data have been obtained to supplement the sedimentological descriptions. However, it is evident that the Rubjerg Knude Formation only occurs in the southern part of the section, where it is less than $10 \mathrm{~m}$ thick. It is inferred, therefore, that the piggyback ba$\sin$ in the Mårup Kirke Section was short-lived relative to the thicker successions of the Rubjerg Knude Formation further south. The Rubjerg Knude Formation may never have been deposited in the trailing end of the Mårup Kirke Section.

\section{Structures}

A conspicuous feature of the Mårup Kirke Section is the shear drag at the top of the cliff section. The main structures formed during the subglacial drag are southerly overtumed to recumbent synclines that developed in a sandy glacitectonite about $1 \mathrm{~m}$ in thickness. The glacitectonite is interpreted to have formed by subglacial shear deformation superimposed on the proglacially formed thrust-fault and duplex structures (Pedersen 1988, 1996, 2000).

Over a large part of the Mårup Kirke Section, the amount of mobilisation is not very high. This permits a characterisation and interpretation of the deformation of duplex segments and stacking of duplex units, as described below.

\section{Interpretation of structural development}

The main purpose of this section is to present an analytical structural model that can be used to interpret the thrust-fault framework developed in the Mårup Kirke Section. The basic elements of the model are the duplex segments, and the structural deformation can be characterised as fault-bend folding. The result of the deformation is a compressional stacking of duplex segments into duplex units with a certain geometry and size. The interpretation of these structures adds to the basis for the discussion of structural developments that concludes this section.

\section{Fault-bend-fold model for duplex units}

It was demonstrated in Fig. 103 how a duplex unit developed with type 1-3 duplex-segment structures. However, a number of structural configurations may develop from the deformation of duplex segments stacked into duplex units, depending on the amount of displacement and the initial length of the thrust sheet. For the interpretation of the structures in the northern part of the Mårup Kirke Section, as well as a major part of the Ribjerg Section, the analytical models in Fig. 110 have been constructed.

The premises for the models are: (1) the duplex unit comprises four initially horizontal sheets with a thickness of $10 \mathrm{~m}$ each, (2) the bounding leading and trailing thrust ramps dip at $45^{\circ}$ (maximum angle of thrust-fracture formation), (3) the vertical distance between the lower and upper flat is $40 \mathrm{~m}$, and (4) the lateral compression cannot exceed the packing of the sheets in $45^{\circ}$ dippingimbricates. From the latter premise, it can be predicted by simple trigonometric calculation that the lateral distance between the bounding thrusts of the duplexes should be close to $56.5 \mathrm{~m}$, and this corresponds very well with the thrust features recorded in the cliff section.

To illustrate the model, one ideal case is considered, namely the case where the displacement is to the top of the ramp, which has the same length as the maximum compression distance of $56.5 \mathrm{~m}$ (Fig. 110, type 3). The displacement takes place along the lower footwall flat, and the lower hanging-wall flat propagates up along the $45^{\circ}$ dipping footwall ramp. The resulting structural framework is an L-type fault-bend folding (Fig. 103). In this case, the lower thrust segment will just reach the level of the upper flat. The displacement is c. $42 \mathrm{~m}$ and the balanced length of the duplex unit is $98.5 \mathrm{~m}$, which results in a calculated compression of $43 \%$. Due to the propagation along the upper flat and the ramp-bend folding, a hangingwall anticline is formed, which can be described as a fairly upright, angular antiformal stack.

The case described above is shown as type 3 in Fig. 110. This case might also be called the angular antiformal stack type. Further cases can be considered with decreasing or increasing displacement relative 

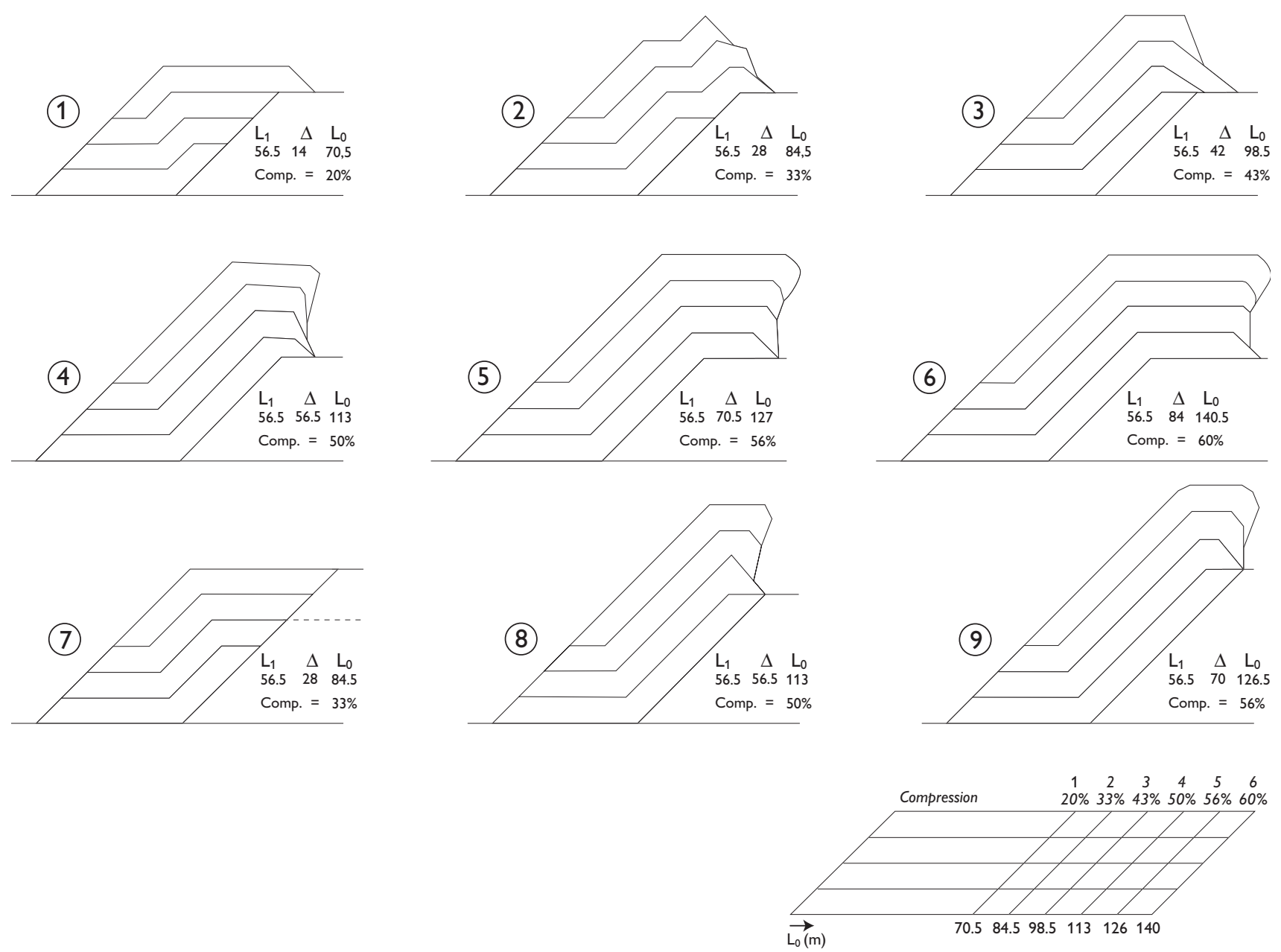

Fig. 110. The duplex-unit model for fault-bend folding of duplex segments. The basic elements for the constructed models are: (1) the duplex unit comprises four initially horizontal sheets, separated by thrust-fault flats, and each sheet is $10 \mathrm{~m}$ thick, (2) the bounding leading and trailing thrust ramps dip at $45^{\circ}$ (maximum angle of thrust-fracture formation), (3) the vertical distance between the lower and upper flat is $40 \mathrm{~m}$ in types 1-6, and in types 7-9 it is extended 10 and $20 \mathrm{~m}$ above the upper footwall hinge, and (4) the compression cannot exceed the packing of the sheets in $45^{\circ}$ dipping imbricates. The cases in the model are selected with steps jumping one $10 \mathrm{~m}$ level from case to case. According to simple trigonometry, this will result in a displacement unit of c. $14 \mathrm{~m}$, and multiples of this. The initial dimensions $\left(\mathrm{L}_{0}\right)$ of duplex units 1-6 are given by the scale in the lower right comer. Type $\mathbf{1}$ is a single monoclinic flexural kink fold. Type $\mathbf{2}$ is a double monoclinic flexural kink fold. Type $\mathbf{3}$ is an angular antiformal stack. Type $\mathbf{4}$ is a flat-topped antiformal stack. Type $\mathbf{5}$ is a lateral extension of the flat-topped antifomal stack. Type $\mathbf{6}$ is a lateral extension of the flat-topped antiformal stack, where it is demonstrated that the frontal limb in the antiformal stack retains its profile, and it is only a lateral translation of duplex segments that responds to the further compression of the duplex unit. Type 7 is a perfect G-S-L structure (Fig. 107). Compression of 33\% in type 7, and an elevation of the ramp by two $10 \mathrm{~m}$ levels, results in the monoclinic flexural kink fold. The effect of increasing compression and propagation up along the extended ramp (types $\mathbf{8}$ and $\mathbf{9}$ ), demonstrates the development of the antiformal stack in a manner comparable to that from type $\mathbf{3}$ to type $\mathbf{4}$. Note that the given maximum stacking of imbricates constrains the size of the balanced length of duplex units. This is demonstrated in the diagram relating balanced length to magnitude of compression. $\mathbf{L}_{\mathbf{1}}$, length after deformation; $\Delta$, shortening; $\mathbf{L}_{\mathbf{0}}$, initial length; comp., compression.

to type 3. If the displacement of the lower thrust-sheet segment is less than the height of the footwall ramp, the duplex segments above have two ramps to pass. Consequently, two ramp-bend folds will be created, which may also be described as a repeated monoclinic flexural kink-fold (Fig. 110, type 2). In the model, the second ramp-bend fold will not develop until the displacementexceeds $20 \%$, corresponding to a displacement lift of only one $10 \mathrm{~m}$ level (Fig. 110, type 1).

With increased compression, the hanging-wall anticline formed in type 3 will develop into a flat-topped antiformal stack (types 4 and 5). Finally, type 6 dem- 
onstrates the lateral extension of the flat-topped antiformal stack resulting from $60 \%$ compression. Note that in this case the frontal limb in the antiformal stack maintains its profile and an increase in compression only results in lateral translation of thrust sheets. Increasing compression also requires increasing length $\left(\mathrm{L}_{0}\right)$ of the duplex unit, which is demonstrated by the diagram in the lower right corner of Fig. 110.

In Fig. 110, the cases with an extended ramp have also been examined. This corresponds to thrusting above the upper hinge of the footwall ramp, which would be the case if syntectonic sedimentary units were deposited on the upper flat preceding ramp propagation. Type 7 is a perfect $\Gamma$-S-L structure, exemplifying this development. It is formed by compression of $33 \%$ and elevation of the ramp by two $10 \mathrm{~m}$ levels, here creating a monoclinic flexural kink-folding.

The effect of increasing compression and elevation of the ramp from type 8 to type 9 demonstrates the development of the antiformal stack in a manner rather similar to that from type 3 to type 4 .

\section{Characterisation of thrust duplex MK11-M K20}

On the basis of the models in Fig. 110, the MK11 thrust sheet is classified as a type 2 structure due to the presence of two monoclinal flexures. However, the structure in MK11 must incorporate the effects of the displacement of the thrust segment of MK10. Consequently, the upper segments of MK11 are stacked on each other as relatively short duplex segments. Moreover, the topmost part of MK11 is dragged out and sheared over the piggyback basin of MK10. This dragged part can be interpreted as the frontal limb of the antiformal stackinitially formed over the upper footwall hinge.

MK12 is the duplex unit situated north of Mårup Kirke. All the structures dip at $45^{\circ}$, except for the uppermost shear-dragged parts, which were reworked into a local till (the Kattegat Till Formation). Thus the structure is interpreted mainly as an L-structure, probably a type 5 or 8 structure with $55 \%$ compression and a balanced length of c. $126 \mathrm{~m}$ (Fig. 110).

MK13 has an undulating flat-lying structure with flexural drag up along the footwall ramp. It is thus interpreted as a type 4 structure with a flat-topped antiformal stack capping the frontal part of the lower thrust segment, which was only displaced up to the reference level of the L/R-unconformity. Compression amounts to $50-55 \%$, and the balanced length is estimated to be $120 \mathrm{~m}$.
MK14 is considered to be similar to MK13. It was probably very close to the modelled type 4 structure (Fig. 110), prior to glaciotectonic shearing and truncation of its flat-topped antiformal stack.

MK15 and MK16 are probably the closest approximation to a perfect $\Gamma$-S-L-structure of type 7 in the model (Fig. 110). MK17 and MK18 may well be inferred to be of the same type. However, the exposures are here too poorfor definitive structural characterisation.

In MK19 and MK20, structures with $45^{\circ}$ steep dips are displayed in the cliff section. These duplex units can thus be interpreted as type 9 duplexes.

\section{D iscussion of structural development}

Although the balanced section is subject to some uncertainties in the Mårup Kirke Section, calculation of the compression from the measured length of the section $\mathrm{L}_{1}=978 \mathrm{~m}$, and a balanced length of about $\mathrm{L}_{0}=$ $1814 \mathrm{~m}$ gives $46 \%$. As described above, the section is divided into three architectural zones: (1) a leading zone (MK1-MK7), (2) a transitional or intermediate zone (MK8-MK10), and (3) a trailing zone that includes thrust-fault duplex units (MK11-MK20). The discussion below attempts to demonstrate the proximal-distal thrust-fault development.

The fault-bend-fold model for duplex units describes the thrust-fault structures in the trailing zone and gives an approximation of the structural framework of the major part of the Mårup Kirke Section. The absence of the Rubjerg Knude Formation in the trailing zone suggests that it was never deposited here. Moreover, the thrust stacking of the duplex units started before, or just at the beginning of, deposition of the Rubjerg Knude Formation in the most proximal part of the glaciotectonic complex. It is further suggested that the thrust levels rapidly shifted to lower levels in progressive steps. So, after the first few hundred metres of peeling off the uppermost thrust segments, the thrusting propagated for the next five hundred metres in the intermediate flat levels. Finally, the main compression started to stack the duplex units up into imbricates during translation along the lower flat level, the décollement zone, and differential displacement between the duplex segments.

The displacements of the duplex units were limited by the maximum shortening between the $45^{\circ}$ steep northward-dipping ramps. It might be suggested that the displacement was much larger and considerable amounts of the leading part of the thrust sheets were 
eroded away from the upper flat. However, this is unlikely for two reasons: (1) the amount of compression is $50-60 \%$ which is considered to be a limiting amount of compression for natural systems, and (2) the structures discemible from the photo-geologically interpreted cross-section support a model with c. 50\% shortening. Another suggestion could be that the duplex imbricates were formed subglacially, bounded by a floor thrust (the décollement zone) and a roof thrust situated in the glaciotectonic unconformity (the sole of the glacier). This is disproved by the fact that the antiformal stack above the duplex units would have required space to be stacked up on the upper flat. Thus, although the antiformal stacks were removed by glacial erosion and the upper part of the Mårup Kirke Section is shear-dragged and truncated by the glaciotectonic unconformity (formed subglacially), the thin-skinned thrust faulting developed in a proglacial setting in front of a progressively advancing ice margin.

MK08 is the leading thrust sheet in the transitional zone of the Mårup Kirke Section. It has a considerable displacement, more than $100 \mathrm{~m}$, and it probably ramped up to the $20 \mathrm{~m}$ flat level along which it was translated for more than $50 \mathrm{~m}$ before its hanging-wall flat propagated up to the uppermost footwall flat. Thus, all the segments in the thrust sheet were earlier translated along the various flats before MK08 was displaced up along the footwall ramp on MK07. There should therefore be a stepping down of the trailingend sheet in the zone. This would correspond to translation along the lower flat level of the MK09-MK10 thrust sheets, which facilitated the formation of a depression above MK10, where the Rubjerg Knude Formation was deposited and preserved in the most proximal piggyback basin of the glaciotectonic complex.

The leading zone is characterised by carrying a relatively high-elevated piggyback basin, where the Rubjerg Knude Formation was deposited on an uneven erosional unconformity. During the early phase of imbrication, this piggyback basin was separated into five sub-basins, before they were finally trapped by overthrusting and deposition ceased. The accumulated displacement in the leading zone is c. $180 \mathrm{~m}$. The thrusting probably started from a detachment level in the upper flat (10 $\mathrm{m}$ level), inferred from the thickness of MK02-MK04. Thrusting then shifted down to the second flat ( $20 \mathrm{~m}$ level). Assuming that the first half of the displacement started as an imbrication of the MK02-MK06 thrust sheets, then lateral translation of the upper $10 \mathrm{~m}$ thrust-sheet segment resulted in lateral displacement of the upper thrust level in the order of $100 \mathrm{~m}$. Subsequently, the detachment surface was lowered down to the $20 \mathrm{~m}$ level, and it is evident that this detachment surface is the next flat level, along which about $100 \mathrm{~m}$ lateral translation occurred. One of the main lines of evidence that this level is another pervasive flat level is that it acted as an upper flat for the displacement ofMK01. The propagation of this thrust sheet probably started with a minor dislocation along the $30 \mathrm{~m}$ flat level, which is known to be a pervasive flat level from the Moserende Section, before it moved down to be a dislocation along the lower décollement level ( $40 \mathrm{~m}$ flat level). From the lower décollementlevel, MK01 ramped up to the $20 \mathrm{~m}$ flat level along which translation occurred over a distance of $80 \mathrm{~m}$ before its hanging-wall flat and ramp was ramped up to the surface along the footwall ramp at the trailing ramp of the Moserende Section. During displacement, the MK01 thrust sheet carried the MK02-MK07 sheets piggyback resulting in over-steepening of these thrust sheets towards the trailing end (MK05 and MK07).

\section{Ribjerg Section}

The northern termination of the Rubjerg Knude Glaciotectonic Complex is the sandy hill at Lønstrup called Ribjerg. Most of the coastal cliff below Ribjerg is now protected, and vegetation covers the cliff exposures at Ribjerg. However, on the south-western side of Ribjerg a funnel-shaped gully has been formed by steady erosion due to high groundwater drainage in the glaciofluvial sand (Fig. 111). At the boundary between the sand and the underlying mud, groundwater wells up and creates quicksand. Thus, although a section through the glaciofluvial sand is well exposed, access is difficult and potentially dangerous. In spite of such obstacles, a detailed log of the succession has been measured, and the locality yields the type section of the Ribjerg Formation. In addition, the section is the site for studying the glaciotectonic unconformity above the Skærumhede Group, cropping out at the 'Lille Blå' (northemmost part of the cross-section in Plate 1).

\section{'Store Blă' and 'Lille Blå'}

North of the Mårup Kirke Section, the unconfomity above the mud-rich Lønstrup Klint Formation dips gently to the north. Jessen $(1918,1931)$ named this part of the cliff 'Det Store Blå' and 'Det Lille Blå' (the 


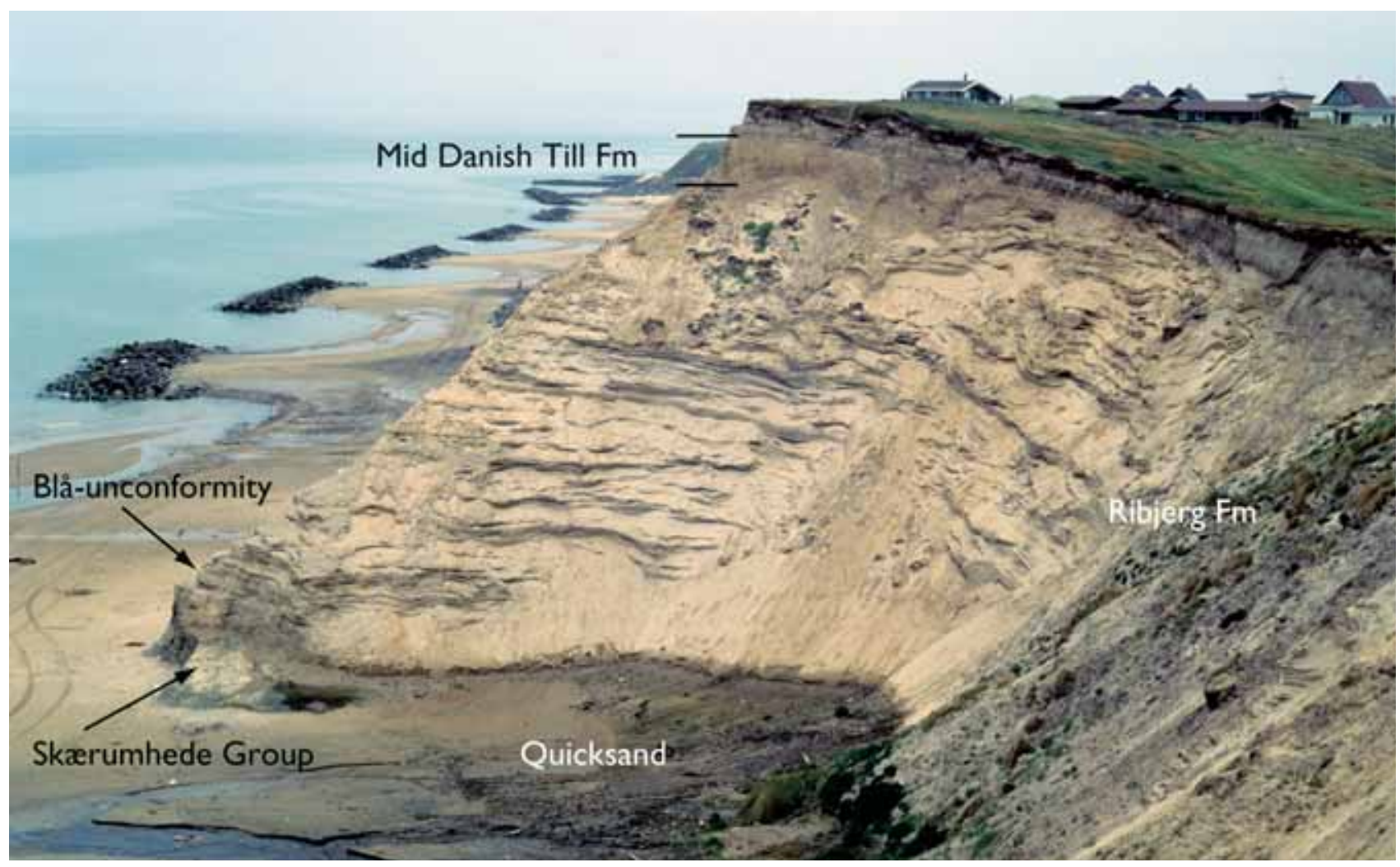

Fig. 111. The Ribjerg Section viewed towards the north. The sandy cliff in the centre of the figure is the type locality of the Ribjerg Formation. Photograph: July 1994.

big blue and the small blue, respectively, a reference to the blue colour of the clayey mud in the mud-rich part of the cliff section). In general, the mud is a mobilised succession with only few bedding surfaces and thrust faults preserved. In the Store Blå cliff section, the structural features recorded accord well with the maximum compressional model described for the duplex units of the Mårup Kirke Section (Fig. 110). In the Lille Blå cliff section, the mud is structureless, and no primary bedding surfaces are preserved. A secondary sub-horizontal planar fabric is recognisable, and pebbles and boulders occur on the unconformity as well as in the uppermost metre just below the unconformity. Jessen (1931) interpreted the Lille Blå as dislocated Older Yoldia clay, which he named Portlandia arctica clay after the occurrence of the identified mollusc species in the unit.

Jessen's description of the clay compares well with the characterisation of the Skærumhede Group and the model of glaciodynamic development presented below. Due to the progressive deformation in the proximal part of the glaciotectonic complex, deeper levels of the Skærumhede Group were thrust up into a position close to the main L/R-unconformity level, such that an increasing proportion of the group has been eroded.

Jessen (1931) also described another important feature related to the Lille Blå cliff section. Before 1895, it could be observed that the unconformity was folded into a syncline with a fold axis directed N-S. This is of course unusual since all structures described until now are assumed to have been formed by compression directed N-S due to the advance of the ice cap from the north, resulting in mainly E-W-trending structural features. The N-S-orientated fold axis is interpreted to be related to deformation by ice advance from the east, an event that also deposited the Mid Danish Till Formation.

\section{Tectonic architecture}

The Ribjerg Section is defined as the section between the northern boundary of the Mårup Kirke Section and the end of the Lønstrup Klint cliff section, which terminates at the vegetation-covered cliffs below the town of Lønstrup. The southern boundary of the section is situated where four unconformities are super- 
imposed upon each other. These are: (1) the L/R-unconformity, (2) the glaciotectonic unconformity below the Kattegat Till Fomation, (3) the unconformity between the Kattegat Till Formation and the glaciodynamic succession related to the NE-Ice Advance, and finally (4) the unconformity between the glaciodynamic successions and the Vendsyssel Formation (Plate 1). The first three unconformities are here collectively termed the Blå-unconformity.

The Blå-unconfomity dips at $2-3^{\circ}$ to the north. The surface is relatively planar, but uneven. A few clasts remain in depressions on the surface, but clasts protruding into the surface from below are more common.

The unconformity between the Ribjerg Formation and the Vendsyssel Formation is an erosional surface dipping gently to the south. The main lithology in the Vendsyssel Formation is the Saxicava Sand, which consists of sandy heteroliths. These beds onlap the unconformity, which probably was subaerially exposed before inundation by the rising Younger Yoldia Sea.

\section{Sedimentary units}

In the Ribjerg Section, four sedimentary units are represented: the Skærumhede Group, the Ribjerg Formation, the Mid Danish Till Formation and the Vendsyssel Formation (Figs 14, 17, 33).

\section{Skærumhede Group}

The Skærumhede Group comprises two formations: the Stortorn Formation and the Lønstrup Klint Formation. In the southernmost part of the section (at the Store Blå), it is possible to distinguish the two formations (Fig. 17). However, in the northern part of the Ribjerg Section, pervasive mobilisation has obliterated the primary lithological differences and the sediments may only be referred, undifferentiated, to the Skærumhede Group.

In the southern part of the section, the Stortom Formation constitutes the lowermost $10 \mathrm{~m}$ of the cliff section (Fig. 17). Here a cataclastic breccia separates the Stortorn Formation from the Lønstrup Klint Formation above. It is inferred that this breccia represents one of the thrust-fault flats that form the boundary of the duplex segments building up the duplex units of the section.

The Skærumhede Group is truncated by the Blå- unconformity, above which the Vendsyssel Formation was deposited.

\section{Blå-unconformity}

The Blà-unconfomity is considered to represent three superimposed unconformities. The firstone is the L/Runconformity, the existence of which is only rarely demonstrable in this section.

The second unconformity is the glaciotectonic unconformity below the Kattegat Till Formation. The Kattegat Till Formation has been almost completely eroded away from the Ribjerg Section, but is present in small, isolated pockets (Fig. 31). However, the glacitectonite related to the subglacial deformation below the Kattegat Till Formation is well preserved in a zone more than $1 \mathrm{~m}$ thick below the Blå-unconformity (Fig. 32). Erratic clasts are common in this zone, probably lodged into the soft sediment from the till above, and an indicator boulder of larvikite has been recognised. A number of clast fabrics have been measured, which show a N-S long-axis orientation (variation from $010^{\circ}$ to $175^{\circ}$ ). The unconformity is preserved at the base of the Vendsyssel Formation in the northern part of the Mårup Kirke Section (Fig. 37).

The third unconformity is the erosional surface upon which the Ribjerg Formation was deposited. The creation of this surface removed much of the evidence of the preceding unconformities; indeed, at the southern extent of the unconformity, the Ribjerg Formation is also absent, and the Vendsyssel Formation rests on the composite surface.

\section{Ribjerg Formation}

The c. $25 \mathrm{~m}$ thick glaciofluvial sand of the Ribjerg Formation dominates the Ribjerg Section (Fig. 33, Plate 1). The formation comprises fine- to medium-grained sand, coarsening upwards into gravel-dominated beds at the top (Fig. 33). The formation was deposited on the erosional unconformity capping the Skærumhede Group (the Blå-unconfomity). At this surface, a residual coarse clastic bed is present, less than half a metre in thickness, dominated by clayey clasts derived from the unit below. The clayey clasts continue to appear in the sand beds in the lowermost $5 \mathrm{~m}$ of the formation.

The middle part of the formation is dominated by trough cross-bedding, and the flow direction indicat- 
ed from measurements of foreset beds was from east to west.

The fill of the large channels incised into the medium-grained sand package also include gravel and slumped diamictite material. Water-escape dykes and sand-filled cracks are common in the sand within the large channels (Fig. 34). The formation coarsens upwards into a trough cross-bedded sandy gravel in the uppermost $3 \mathrm{~m}$, just below the diamictite referred to the Mid Danish Till Formation.

\section{Mid Danish Till Formation}

The Mid Danish Till Formation is a c. $3 \mathrm{~m}$ thick unit of grey brown to lightyellowish brown sandy till that overlies the Ribjerg Formation (Figs 14, 33, 35). The till is divided into lower and upper beds. The lower bed is a laminated to thin-bedded, fine-grained sandy, matrix-supported diamict. Lamination and bedding is deformed into irregular intraformational slump folds with fold axes trending $\mathrm{N}-\mathrm{S}$, indicating a slump-slide direction towards the west, and the unit is interpreted as a sediment gravity flow or flow till (Dreimanis 1988). The upper bed is a massive, structureless and sandy matrix-supported diamict (Fig. 35). The clasts, pebble to cobble in size, occur randomly, and the till fabric shows an a-axis orientation gently dipping towards the east. The unit is interpreted as a basal lodgement till (Dreimanis 1988) superposed on the flow till and deposited by an ice stream moving from east to west.

The Mid Danish Till Formation is truncated by the erosional unconformity upon which the Vendsyssel Formation was deposited.

\section{Vendsyssel Formation}

In the Ribjerg Section, the Vendsyssel Formation truncates the Mid Danish Till Formation, the Ribjerg Formation and the Blå-unconformity. The maximum thickness in this part of the Lønstrup Klint section is about $12 \mathrm{~m}$, decreasing towards the north, where it onlaps the unconformity above the Ribjerg and Mid Danish Till Formations (Fig. 33). The Vendsyssel Formation comprises laminated mud and thin-bedded finegrained sandy heteroliths, which in the southern part of the Ribjerg Section are characterised by well-preserved trace fossils created by the bivalve Hiatella arctica, often with the shells preserved in life position (Fig. 41).

\section{Structures}

In the Ribjerg Section, the most important structures are the anastomosing joints related to the glacitectonite below the Blå-unconformity (Fig. 32). At the Lille Blå locality, the rhomb-shaped segments, 0.5-3 $\mathrm{m}$ in size, bounded by conjugate shear joints, are flatlying. The angle between conjugate joints varies from $10-30^{\circ}$ and the zone-axis is orientated more or less E-W. At the Store Blå locality, the shear joints are more parallel with a spacing of c. $30 \mathrm{~cm}$ between the almost horizontal fractures, and in the southernmost part of the section, sand-fill intruded the fractures to create rhomb-shaped segments in a sandy mud matrix.

\section{Interpretation of glacial geology and stratigraphic development}

In the interpretation presented here, the Blä-unconformity is considered to be a modulation surface or deformational layer below the advancing front of the Norwegian Ice. The unconformity may even be interpreted as the surface onto which the sole of the ice pressed during the propagation towards the glaciotectonic complex developing in front of it. After the ice retreated, a hill-and-hole pair formed. Rubjerg Knude is here viewed as the hill and the depression extending to the north of the northward-dipping unconformity corresponds to the hole. The hole was subsequently filled with glaciofluvial sands (the Ribjerg Formation) that are younger than the Rubjerg Knude Formation. On top of the Ribjerg Formation, Jessen (1931) described a sandy till that is here referred to the Mid Danish Till Formation, but he also recorded a single till-bed intercalated in the meltwater sand. This sandy till as well as the thin diamictite layers related to the slumps in the troughs and channels are interpreted as precursors to the flow till that initiated deposition of the Mid Danish Till Formation. The Ribjerg and Mid Danish Till Formations were formed as proglacial and subglacial units during the advance of the ice from the east towards the west with a source area in central Sweden. This ice advance was also responsible for the gentle folding of the Blå-unconformity and the beds above it into a syncline with a N-S-trending axis, as noted by Jessen (1931). 


\section{Dynamic development of the thin-skinned thrust faulting}

The dynamic development of the thin-skinned thrust faulting in the Rubjerg Knude Glaciotectonic Complex is presented as a sequence of restoration stages. Thus, the progressive deformation of thin-skinned thrust faulting and related syntectonic depositional developments are illustrated in sequentially restored crosssections beginning with the proximal Moserende Section and concluding with the Ulstrup Section in the most distal part of the thrust-fault complex. The basis of each restoration sequence is the balanced profile (Plate 2A), and the end stage is identical with the thrustfault cross-section (Plate 2B), including the interpretation of the unexposed ramps and flats in the subsurface. The mostproximal sections, the Mårup Kirke and the Ribjerg Sections were interpreted individually in the preceding chapters, and are not included here.

In a summary scheme (see Fig. 123), it is concluded that the dynamic development was a process of continuous progressive deformation. Thus, although the following description is concentrated on the individual sections, it should be kept in mind that there is overlap between sections, and that the whole system was mobile. Thus a displacement of $5 \mathrm{~m}$ on one thrust might be followed by $10 \mathrm{~m}$ on a more proximal thrust and $7 \mathrm{~m}$ on a more distal thrust depending on the local conditions. This is the reason why a number of displacements appear to be out-of-sequence, but within limits that respect the lowest décollement level, and that displacements along the most distal, leading-edge thrusts were the last to be activated. It is therefore also evident that displacement along a leading-edge ramp may correspond to a translation along a flat in a proximal section.

\section{Moserende Section}

The thrust-fault development in the Moserende Section is regarded as normal progressive piggyback thrusting from the proximal towards the distal part. The MR12 thrust sheet was probably the first to be thrust onto the relatively thinner piggyback basin on the back of MR11 after a c. 10 m thickness of Rubjerg Knude Formation sediments had been deposited. This is included in the first stage of the sequential restoration (Fig. 112, stage 1). A total of eight stages have been differentiated, of which stages 1-6 are illustrat- ed in Fig. 112. The stage preceding the deformation is shown in Plate $2 \mathrm{~A}$, and the final stage terminating the deformation is reconstructed in Plate 2B.

Moserende stage 1. The initial thrusting started with $40 \mathrm{~m}$ displacement of MR12 over the back of what was to become MR11. This thrusting was rooted down to the $20 \mathrm{~m}$ intermediate décollement level. During accumulation of a $20 \mathrm{~m}$ thick succession of sediments in the piggyback basins above the MR13 and MR12 sheets, the thrusting progressed with ramping of MR11 over the Rubjerg Knude Formation on top of what was to become MR10. This thrusting involved ramping and translation of the lower segments of MR13MR11 from the $30 \mathrm{~m}$ flat level onto the $20 \mathrm{~m}$ flat level. The trailing-end segments of the Moserende Section were contemporaneously over-thrust by MK01, the frontal thrust of the Mårup Kirke Section, which is rooted in the $40 \mathrm{~m}$ décollement level. The accumulated displacement of thrusting of MR13, MR12 and MR11 is estimated at about $150 \mathrm{~m}$.

Moserende stage 2. Thrusting of MR09 initiated this stage. The MR09 thrusting ramped up from the $40 \mathrm{~m}$ décollement level, and a single duplex formed during stacking of the lower MR09 thrust segment. The MR09 sheet was displaced c. $40 \mathrm{~m}$ over the MR08 piggyback basin. Contemporaneously, MR10 was thrusted over MR09 and the MR10 hanging-wall flat extended from the top flat level down to the $40 \mathrm{~m}$ décollement level. The MR13-MR11 thrust sheets were then passively translated on the trailing lower segment of MR10.

Moserende stage 3. Initial imbrication of the MR08MR05 thrust sheets resulted in an accumulated displacement of c. $200 \mathrm{~m}$. The ramping was rooted in the $40 \mathrm{~m}$ décollement level along which the main translation of the trailing-end thrust sheets of the Moserende Section took place. The thrusting involved a complex relationship between MR07 and MR06 that may be interpreted as a connecting splay duplex (Mitra \& Sussman 1997). Above the L/R-unconformity, the deposits of the Rubjerg Knude Formation probably reached a thickness of $20 \mathrm{~m}$.

Moserende stage 4 . The frontal part of the section was activated by c. $40 \mathrm{~m}$ translation of MR1 along the $30 \mathrm{~m}$ 
décollement level over the lowermost trailing-end segments in the Stortorn Section. MR02 and MR03 followed this translation, whereas MR04 ramped up one level from the $40 \mathrm{~m}$ décollement level to the $30 \mathrm{~m}$ flat level that resulted in the initial ramping of MR04 up over the Rubjerg Knude Formation on the back of MR03. The continued displacement consequently reorientated thrust sheets MR05-MR07 into more steeply dipping orientations. The trailing-end thrust sheets from MR08 and northwards were translated passively during this displacement.

Moserende stage 5. The frontal displacement of MR01 continued along the $20 \mathrm{~m}$ flat level over the trailingend segment of the Stortom Section. MR02 ramped up along the footwall ramp at the trailing end of MR01 during a fault-bend rotation, which also included the lower segment of MR01u. A vertical thrust separation of c. $10 \mathrm{~m}$ brought MR02 up along the northern termination of the MR01 piggyback basin. During the passage of two intermediate ramps, an irregular anticline formed on the back of MR02 that had significant implications for the synsedimentary structures formed in the MR02 piggyback basin (see description of the Moserende Section, above).

During MR04 thrusting, MR03 was imbricated along the upper $10 \mathrm{~m}$ flat level and the MR03b and MR03c thrust segments started to break through the piggyback basin. From the rear, MR04 was pushed by MR05 which had to pass up over the fault-bend-folded segment MR04u. Together with MR06 and MR07, the MR05 thrust sheet moved up to the highest level indicated by the L/R-unconformity, situated c. $20 \mathrm{~m}$ above sea level on the back of MR06 and MR07, and their thrust faults were steepened into a nearly vertical position.

Moserende stage 6. In the frontal part of the Moserende Section, MR01 picked up a lower segment and thrust up to the $20 \mathrm{~m}$ flat level, which consequently also elevated the piggyback basin up into its present high level. The trailing-end ramp of MR01 formed the footwall ramp for the MR02 thrusting, which resulted in a fault bend of MR02 as well as MR03. This was followed by the final displacement of $18 \mathrm{~m}$ along the leading MR03 thrust. Minor adjustments and re-orientation of MR04-MR07 followed the ramping of MR03, and the trailing-end thrust sheets MR08-MR13 were passively displaced by translation along the $40 \mathrm{~m}$ décollement level.

Moserende stage 7. During this stage, a complex duplex was formed by thrusting of the frontal lower seg- ments, which also including the trailing-end segments of the Stortorn Section.

Moserende stage 8. The final displacement along the leading thrust-fault ramp in the Moserende Section progressed up along the Stortom trailing-end footwall ramp. Moreover, the fault-bend folding due to thrusting in the Stortorn Section brought the thrust sheets into their present steeply dipping orientation.

\section{Moserende Section: Summary data \\ Balanced length $\left(\mathrm{L}_{0}\right)$ : $\quad 1120 \mathrm{~m}$ Cross-section length $\left(\mathrm{L}_{1}\right): \quad 650 \mathrm{~m}$ Shortening $(\Delta \mathrm{L})$ : $\quad 470 \mathrm{~m}$ Compression: $\quad 40.2 \%$}

\section{Stortorn Section}

The most important development in the Stortorn Section was the change from the lowermost $40 \mathrm{~m}$ décollement level to the $30 \mathrm{~m}$ décollement level. The ramp, or progressive development of lower ramps, which marked the change, is here referred to as the Stortorn lower segment footwall ramp, and was located somewhere near the thrust between ST04 and ST03. Thus, the ST03-ST01 thrust sheets had their lower décollement level at $30 \mathrm{~m}$, whereas the thrust faults related to ST04-ST10 were rooted in the $40 \mathrm{~m}$ décollement level.

Formation of a duplex complex comprising the lowermost thrust segments exposed the Stortorn Formation, the oldest strata involved in the thrusting. In the frontal part of the section, a complex stacking of lower segments, remaining in the subsurface from displacement in the Grønne Rende Section, resulted in duplex formation that elevated ST01-ST03 about $30 \mathrm{~m}$ above the reference level. Due to arguments presented later (see Grønne Rende Section) the duplex stacking had to have been contemporaneous with the shortening of the Grønne Rende Section. In the Stortorn Section, seven stages have been differentiated of which stages 1-5 are illustrated in Fig. 113.

Stortorn stage 1. This stage is a direct continuation of the displacement in Moserende stage 4. In the Stortorn Section, deformation was initiated by imbrication of ST07, ST09 and ST10 with an accumulated displacement of about $50 \mathrm{~m}$. This resulted in a ramping 


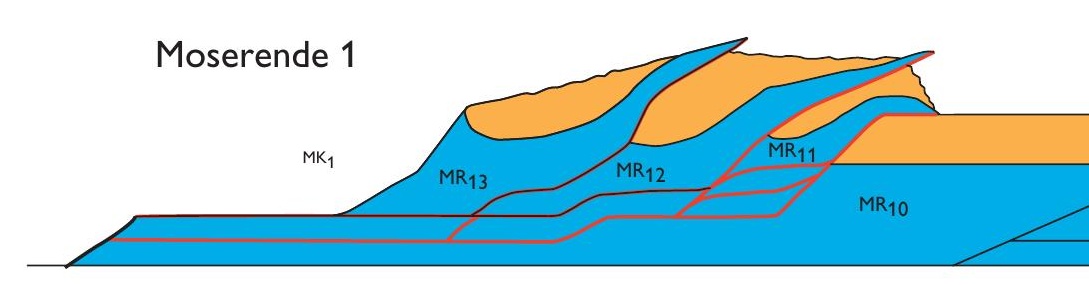

\section{Moserende 2}

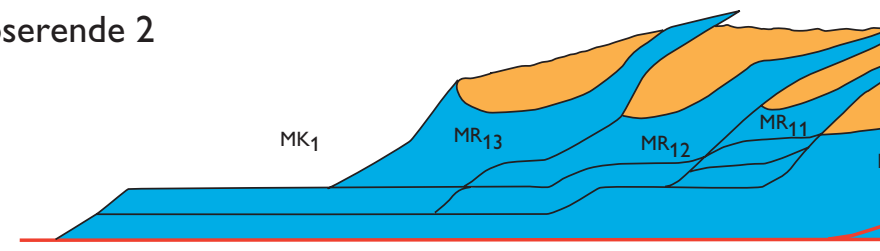

Moserende 3

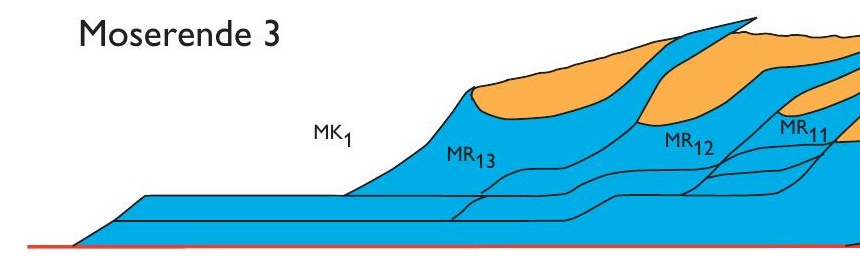

Fig. 112. Dynamic model of progressive deformation in the Moserende Section illustrated in

\section{Moserende 4}

six sequential restoration cross-sections. The six stages demonstrate steps in the development between the balanced cross-section and the structural cross-section (Plate 2); thus the starting and final positions are not shown. The red lines indicate the active displacement surfaces in each deformation stage. The basic décollement surface is the $40 \mathrm{~m}$ flat level. From this, the flat levels rise by $10 \mathrm{~m}$ onto the reference level (L/Runconformity) defined as the 0-level. Note (1) that the final two stages $(7,8)$ discussed in the text are not illustrated, and (2) that the thrustsheet terminology in Figs 112-122 is simplified (i.e. $\mathrm{MR}_{3}$ on Fig. 112 is equivalent to MR03 in the text).

\section{Moserende 5}
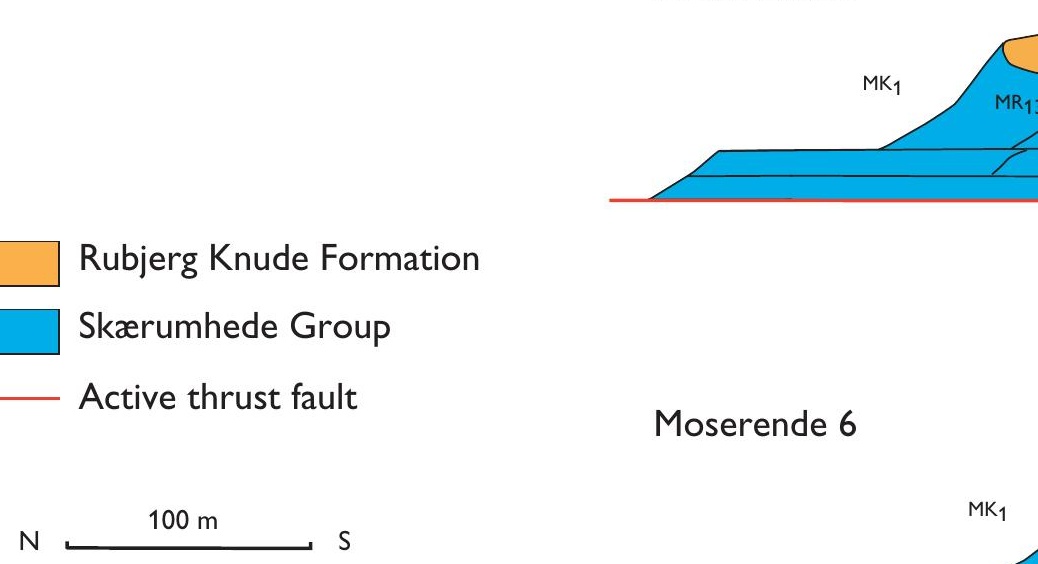

Moserende 6

\section{Rubjerg Knude Formation}

Skærumhede Group

Active thrust fault

$\mathrm{MK}_{1}$ 

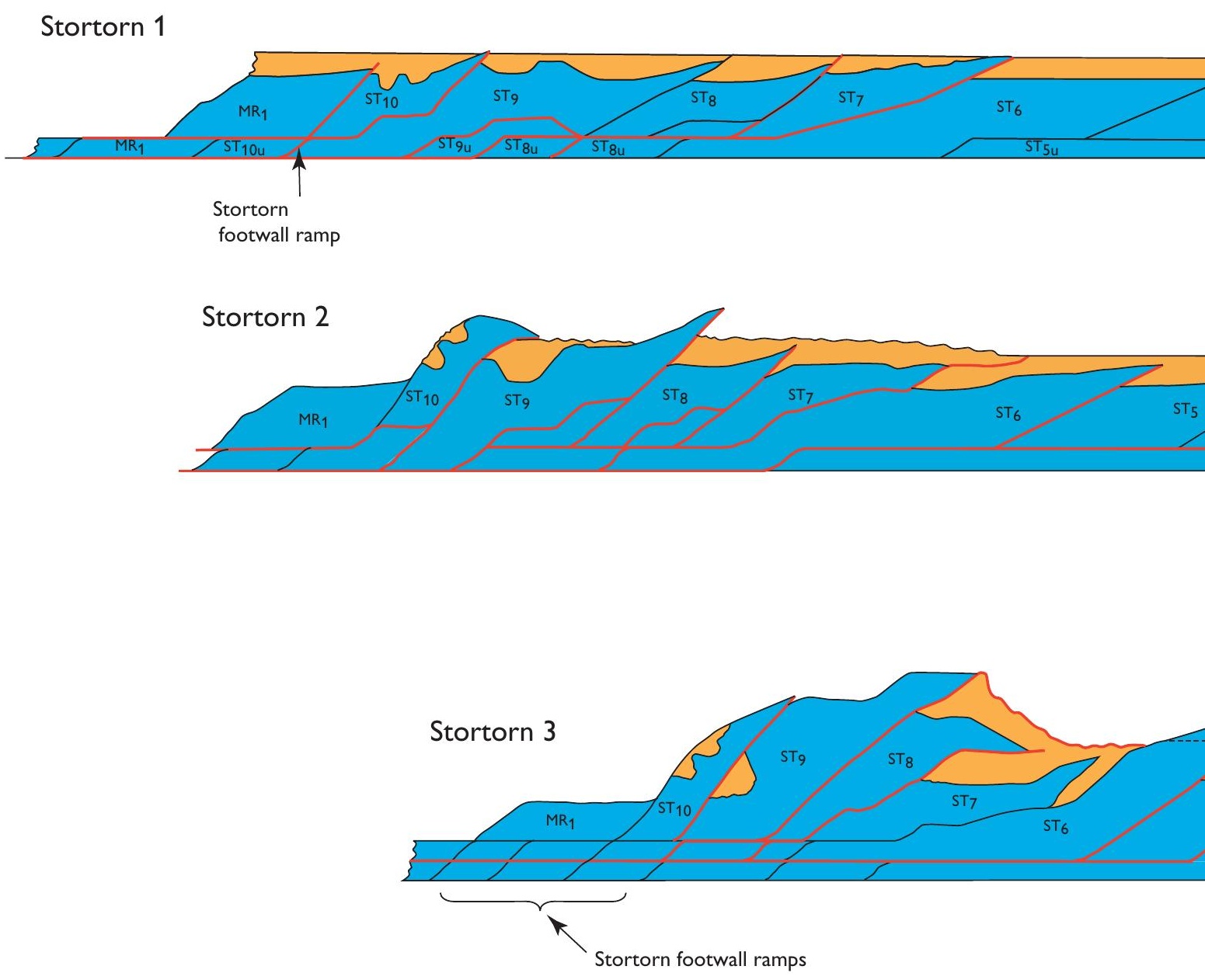

Fig. 113. Dynamic model of progressive deformation in the Stortorn Section illustrated

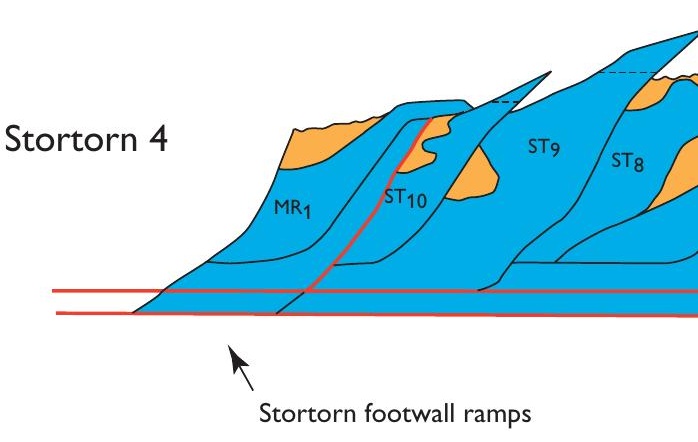
in five sequential restoration cross-sections. The cross-sections demonstrate steps in the development between the balanced crosssection and the structural cross-section (Plate 2); thus the starting and final positions are not shown. The red lines indicate the active displacement surfaces in each deformation stage. Note that the duplex segments $G_{u}$ refer to elements that had to be deformed contemporaneously with the shortening taking place in the Grønne Rende Section; duplex segments ST refer to horse/splint segments. The final two stages $(6,7)$ discussed in the text are

Rubjerg Knude Formation

Skærumhede Group

\section{Active thrust fault}

N $100 \mathrm{~m}$ $\mathrm{S}$

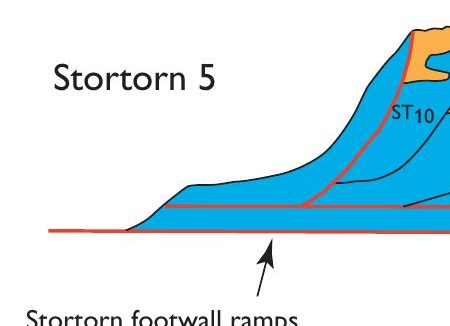

Stortorn footwall ramps 
up of ST10 from décollement level $40 \mathrm{~m}$ to flat level $30 \mathrm{~m}$, along which the translation displacement took place. Most of the ST09 thrust sheet was also ramped up by the formation of a lower duplex structure. Both ST10 and ST09 were affected by fault-bend folding, which created a majordistortion of the L/R-unconformity surface in the uppermost part of the thrust sheets.

Stortorn stage 2. During an accumulated displacement of about $200 \mathrm{~m}$ related to the ST10 and ST09 thrusts, ramping progressed with development of the first imbrications of ST08 and ST06. Due to ramping from the lowest décollement level to the $30 \mathrm{~m}$ flat level in the trailing end of ST06, a fault bend affected the ST07ST10 thrust sheets that were translated piggyback on the ST06 thrust sheet. This contributed to the steepening up of the ST07-ST10 thrust structures.

In the frontal part of the section, the imbricate thrusting was initiated at ST01-ST03. Accumulation of sediments referred to the Rubjerg Knude Formation reached a maximum thickness of about $20 \mathrm{~m}$, notably in the synformal troughs of ST03 and ST09 that formed during the progress over the ramps below.

Stortorn stage 3. At this stage, ST05 was thrust about $40 \mathrm{~m}$ up over the footwall ramp on the back of ST04. The ST05 thrust was rooted in the $30 \mathrm{~m}$ flat level, and during a passage of a lower ramp from flat level $30 \mathrm{~m}$ to $20 \mathrm{~m}$, the initial fault-bend-fold resulted in undulation of the L/R-unconformity at the top of the ST05 thrust sheet. The ST06 thrust sheet progressed over the footwall flat of ST05, and both thrust faults were rooted down to the $30 \mathrm{~m}$ flat level along which the main translation of the sheets emplaced piggyback on ST06 took place. The ST08 thrust sheet was finally displaced along the upper flat at the top of the ST07 piggyback basin. Consequently, most of the $20 \mathrm{~m}$ thick succession in this piggyback basin was preserved and indicates the maximum level of sediment accumulation in the Rubjerg Knude Formation during stage 3. Thrusting of the ST08 sheet along the footwall ramp on the back of ST07 resulted in a further steepening of ST09 and ST10, while the frontal elevated parts of the ST08-ST09 thrust sheets became subject to erosion.

The trailing-end lower segments of ST10-ST07 were over-thrust by the frontal parts of MR01 and MR02, corresponding to stage 7 in the Moserende Section. The accumulated displacement in Stortorn stage 3 was of the order of $320 \mathrm{~m}$.

Stortorn stage 4. During this stage, the ST04 thrust sheet was thrust $40 \mathrm{~m}$ over the piggyback basin of ST03, and ST05 was thrust about $70 \mathrm{~m}$ over the upper flat on top of the piggyback basin of ST04. During this relatively large displacement of ST05, two lower duplex segments were picked up from the lower 40 $\mathrm{m}$ décollement level. After ramping over the Stortorn lower ramp, the duplex segments participated in the thrusting up along the footwall ramp on the back of ST04.

The lower trailing-end segments of the Stortorn Section were finally thrust up along the steep footwall ramp on the back of ST10 and subsequently the frontal parts of the Moserende Section were brought into their present upright orientation. Erosion and redeposition affected the piggyback basins on ST05 and ST08, whereas thrusting over ST07 and ST04 sealed these piggyback basins. The accumulated displacement reached about $410 \mathrm{~m}$.

Stortorn stage 5. A substantial displacement, in the order of $80 \mathrm{~m}$, took place along the leading thrust in the Stortorn Section at this relatively late stage of development of the structures at Stortorn. However, this is only a small amount of the accumulated displacement (c. $500 \mathrm{~m}$ ) which is of the same order of magnitude as that taken up by the duplex stacking of the lower trailing-end segments of the Rubjerg Knude Fyr and Grønne Rende Sections. The ramping and thrusting of ST01-ST04 over this duplex structure explains the high elevation of the L/R-unconformity and overlying piggyback basins in the frontal part of the Stortorn Section. The formation of the duplex stack comprising the lower duplex segments annotated GRu in Fig. 113 would have taken place only after the imbricate thrusting in the Grønne Rende Section developed (see below). The combination of displacement at the leading edge in one section and stacking of lower duplex segments in another, indicates a continuous progressive thrust-fault evolution.

During the propagation of ST05, the trailing end of ST04 was involved in a duplex formation that resulted in fault-bend folding of the earlier formed ST05 lower duplex at the Stortorn lower ramp. The piggyback basin on the back of the ST05 thrust sheet was deformed into a north-verging syncline due to steepening. A similar re-orientation is seen in the thrustisolated piggyback basins in ST10 and ST09.

A marked diapirism and remobilisation of mud in the ST01-ST03, ST05-ST07 and ST09 thrust sheets suggests that the diapirism was related to the intensity of ramping, especially when the ramping involved the 

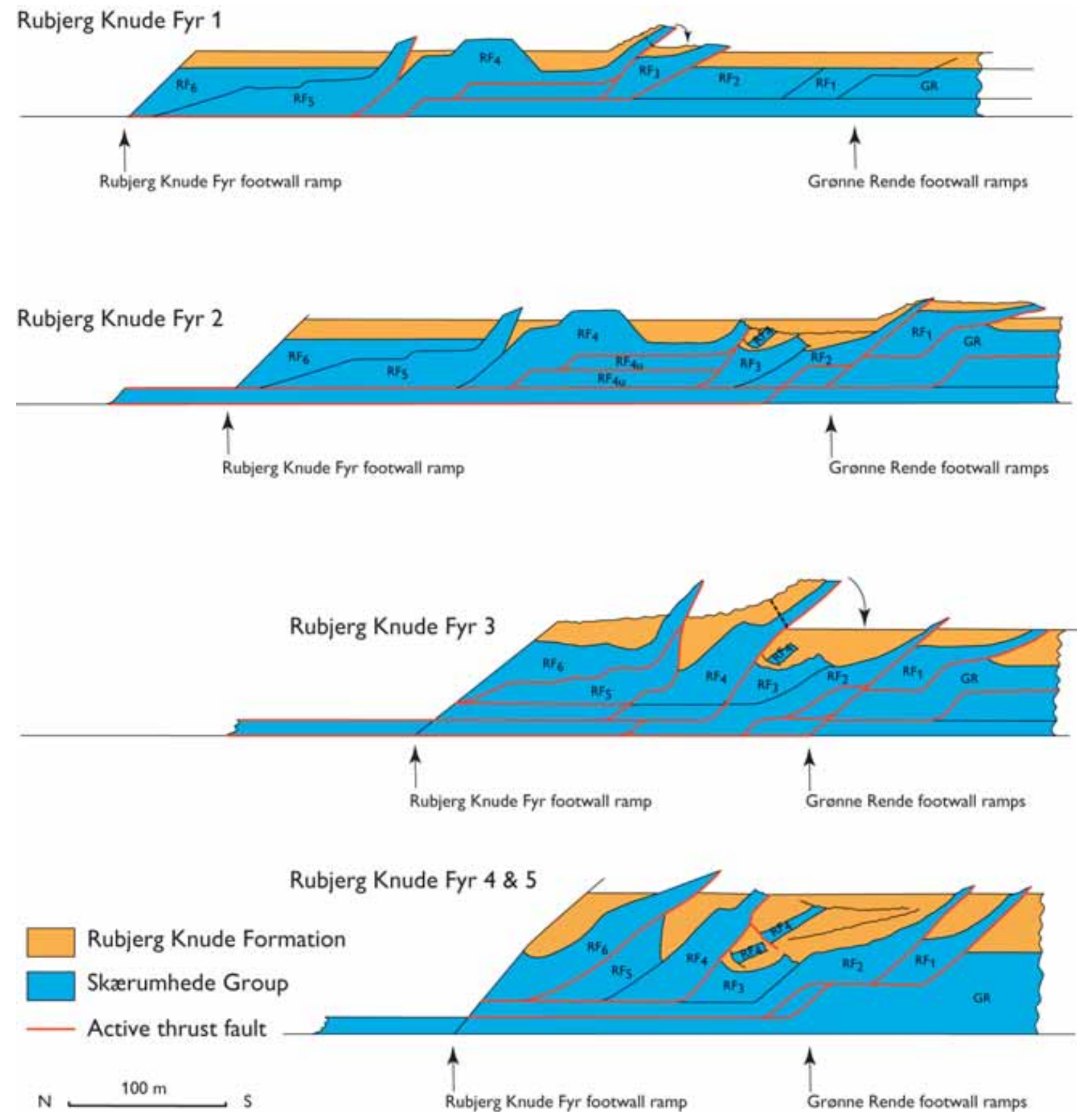

Fig. 114. Dynamic model of progressive deformation in the Rubjerg Knude Fyr Section illustrated in four sequential restoration cross-sections. The cross-sections demonstrate five stages in the development between the balanced cross-section and the structural cross-section (Plate 2). The red lines indicate the active displacement surfaces in each deformation stage. Note that the tip of the RF04 thrust sheet was displaced by normal faulting during syntectonic deposition in the RF03/RF04 piggyback basin.

lower level segments and fault-bend folding of these segments.

Stortorn stage 6 . The final ramping of lower segments from décollement level $40 \mathrm{~m}$ to flat level $30 \mathrm{~m}$ at the base of ST05 terminated the translation along the lowermost $40 \mathrm{~m}$ décollement level. For the sections fur- ther south, the lower décollement level was situated at the $30 \mathrm{~m}$ level. In the frontal part of the section, continued minor compression steepened the thrust structures, and the tips of ST02 and ST03 were eroded and deposited in the piggyback basin of ST01.

Stortorn stage 7. The structural complex, including the 
ST01 thrust sheet and the underlying duplex structure, became fault-bend-folded during the thrust propagation related to the progressive deformation in the Rubjerg Knude Fyr Section.

\section{Stortorn Section: Summary data}

$\begin{array}{lr}\text { Balanced length }\left(\mathrm{L}_{0}\right): & 1125 \mathrm{~m} \\ \text { Cross-section length }\left(\mathrm{L}_{1}\right): & 570 \mathrm{~m} \\ \text { Shortening }(\Delta \mathrm{L}): & 555 \mathrm{~m} \\ \text { Compression: } & 49.3 \%\end{array}$

\section{Rubjerg Knude Fyr Section}

The Rubjerg Knude Fyr Section roots into the $30 \mathrm{~m}$ décollement level. The most striking features developed in the Rubjerg Knude Fyr Section are the large olistoliths in the piggyback basin that were derived from the collapse and gravity gliding of a projecting segment of ST04. Five stages in dynamic development have been distinguished, which are illustrated by four cross-sections in Fig. 114.

Rubjerg Knude Fyr stage 1. During sedimentation of the first $10 \mathrm{~m}$ of sand of the Rubjerg Knude Formation, the RF05, RF04 and RF03 thrust sheets were thrust up along their footwall ramps. RF04 was displaced 90 $\mathrm{m}$ along the upper flat level $(10 \mathrm{~m}$ level) before the frontal part propagated up along the upper ramp. With a displacement of about $30 \mathrm{~m}$, this brought the nose of the RF04 thrust sheet up into the open air, above the sedimentation level of the Rubjerg Knude Formation. The displacementon theo ther two thrustsamounted to c. $20 \mathrm{~m}$, implying an accumulated displacement of $70 \mathrm{~m}$.

Rubjerg Knude Fyr stage 2. The exposed nose of the RF04 thrust sheet slumped down along a normal fault into the piggyback basin of RF03. At the same time, the frontal nose of RF03 was eroded away and sedimentation of the Rubjerg Knude Formation onlapped and covered these features. At the leading edge of the section, thrusting was initiated that brought RF01 and RF02 up over what was to become the trailingend segments of the Grønne Rende Section.

Rubjerg Knude Fyr stage 3. The frontal imbrication of RF01 and RF02 progressed during sedimentation up to about $20 \mathrm{~m}$ above the main L/R-unconformity lev- el. The RF05-RF06 thrust sheet ramped up onto the intermediate flat above the trailing-end segment of $\mathrm{RF} 04$. The RF04 thrust sheet was displaced about 70 $\mathrm{m}$ up along the relatively steep footwall ramp at the trailing end of RF03. Due to the fault-bend folding of RF04, the RF05-RF06 hanging-wall ramp was rotated into a vertical position.

Rubjerg Knude Fyr stage 4. When the second 'drop' of the frontal part of thrust sheet RF04 took place, ac. 45 $\mathrm{m}$ long slab of the relatively thin thrust-sheet nose slumped down along a normal fault with a vertical separation of more than $10 \mathrm{~m}$. The 'drops' may be regarded as two break-back sequences of the RF04 thrust sheet (in the terminology used by Mitra \& Sussman 1997; see Figs 99, 100). Sediment accumulation continued in the piggyback basin to a thickness of more than $30 \mathrm{~m}$, including the 'dropped' noses of RF04. The final accumulation in the piggyback basin took place while the displacement in the Rubjerg Knude Fyr Section was concluded more than 500 m laterally to the south. The translation progressed along the 20 $\mathrm{m}$ flat level on top of what was to become the lower trailing-end segments of the Grønne Rende Section.

Rubjerg Knude Fyr stage 5. The continued displacement of RF04 resulted in structural propagation of this sheet above its own piggyback basin with the 'dropped' thrust noses. Stage 5 in the Rubjerg Knude Fyr Section is interpreted to have been contemporaneous with stage 7 in the Stortom Section in which compression brought the thrust sheets into their final, steeply inclined position.

\section{Rubjerg Knude Fyr Section: Summary data \\ Balanced length ( $\mathrm{L}_{\mathrm{b}}$ ): $\quad 525 \mathrm{~m}$ \\ Cross-section length (L): $260 \mathrm{~m}$ \\ Shortening $(\Delta \mathrm{L})$ : $\quad 265 \mathrm{~m}$ \\ Compression: $\quad 50.5 \%$}

\section{Grønne Rende Section}

The impressive imbricate fan composed of 12 upright thin thrust sheets is the essential element in the Grønne Rende Section. As a consequence of the displacement in the imbricate fan, $550 \mathrm{~m}$ of trailing-end lower segments were left behind to be stacked in a duplex below the frontal part of the Stortorn Section (Fig. 113). 
Four stages have been differentiated in the development of the Grønne Rende Section, the first three of which are illustrated in Fig. 115.

Grønne Rende stage 1. The initial thrust-fault framework was a low-angle imbrication, about $20^{\circ}$ on each upper hanging-wall ramp, which rooted down to the upper $10 \mathrm{~m}$ flat level. During thrusting, the upper thrust sheets were split up into three main segments with leading thrust faults below GR02, GR06 and GR11/ GR12 which ramped down to the main level of detachment in the $20 \mathrm{~m}$ flat level. The initial displacementof the imbricate fan isregarded to have been $20 \mathrm{~m}$ on each thrust. This implies that the accumulated displacement sums up to $240 \mathrm{~m}$. GR01 was not affected by thrusting in the first stage, and $240 \mathrm{~m}$ of its lower trailing-end segment was consequently not displaced during this stage.

The sediments of the Rubjerg Knude Fomation attained a maximum thickness of 15 to $20 \mathrm{~m}$ during this stage, with decreased thicknesses on the back of the GR06-GR08 thrust sheets, which were elevated to the highest position.

Grønne Rende stage 2. The imbricate thrusting progressed with a displacement of $50 \mathrm{~m}$ on each thrust. This implies that the hanging-wall flats were fault-bendfolded while they passed the footwall ramps, resulting in a dramatic steepening of the thrust sheets. Below GR10-GR12, the GR07u and GR08u lower segments formed a duplex structure that resulted in elevation and complex ramp-propagation folding of the sheets above. The accumulated displacement implies an increase in length of the trailing-end segment of GR01 in the order of $500 \mathrm{~m}$, allowing for some adjustments due to the irregular duplex deformation. Sediment thicknesses in the piggyback basin in the frontal part of the section increased to $25-30 \mathrm{~m}$.

Grønne Ren de stage 3. Finally, the leading-edge thrust was activated and GR01 was displaced $50 \mathrm{~m}$ up along its footwall ramp. The GR01 thrust roots in the lower $30 \mathrm{~m}$ décollement level, and the displacement of the hanging-wall flat up along the footwall ramp resulted in steepening of all the early-formed thrust elements (GR02-GR13).

The displacements of the individual thrust sheets range between 60 and $70 \mathrm{~m}$. The thrusting resulted in the final, almost vertical, orientation of the thrust sheets. In the rear part of the section, complex deformation of the duplex below GR10-GR13 was reflect- ed in unusual folding of the beds in the GR13 thrust sheet where folds with horizontal axial planes were formed due to gravity collapse of the piggyback basins.

Grønne Rende stage 4. This stage concluded the thrusting of the leading hanging-wall ramp-and-flat over the footwall ramp in the trailing end of the Stenstue Rende Section and the subsequent final rotation of the GR02GR05 thrust sheets. In the trailing end of the section, the RF01 and RF02 sheets concluded the displacement by thrusting from the trailing-end segments of GR12 up over the footwall ramp onto the back of GR13. Moreover, GR13 was rotated into an upright position whereby the horizontal axial planes became vertically orientated (Plate 1).

\section{Grønne Rende Section: Summary data}

$\begin{array}{lr}\text { Balanced length }\left(\mathrm{L}_{0}\right): & 1080 \mathrm{~m} \\ \text { Cross-section length }\left(\mathrm{L}_{1}\right): & 423 \mathrm{~m} \\ \text { Shortening }(\Delta \mathrm{L}): & 657 \mathrm{~m} \\ \text { Compression: } & 60.8 \%\end{array}$

Comment. The lengths are measured from the footwall ramp between RF01 and GR13 to the footwall ramp between GR01 and SS06, near the thrust truncation of the L/R-unconformity.

\section{Stenstue Rende Section}

Two markedly different structural complexes were formed during the development of the Stenstue Rende Section. They were mainly caused by the displacement of the same thrust sheet (SS01) when it was displaced $200 \mathrm{~m}$ over the upper flat on top of the piggyback basin in the Sandrende Section. The frontal part of SS01 above the footwall flat of the SR04 thrust sheet is one of the complexes. The other structural complex is the chaotic breccia and gravity slumping in the northern part of the section that formed as the piggyback thrust sheets were transported over a minor antiformal stack in the central lower part of the section. The progressive dynamic development in the Stenstue Rende Section is described in terms of five stages, the first four of which are illustrated in Fig. 116.

Sten stue Ren de stage 1. Four minor imbrications with an accumulated displacement of $70 \mathrm{~m}$ initiated the 


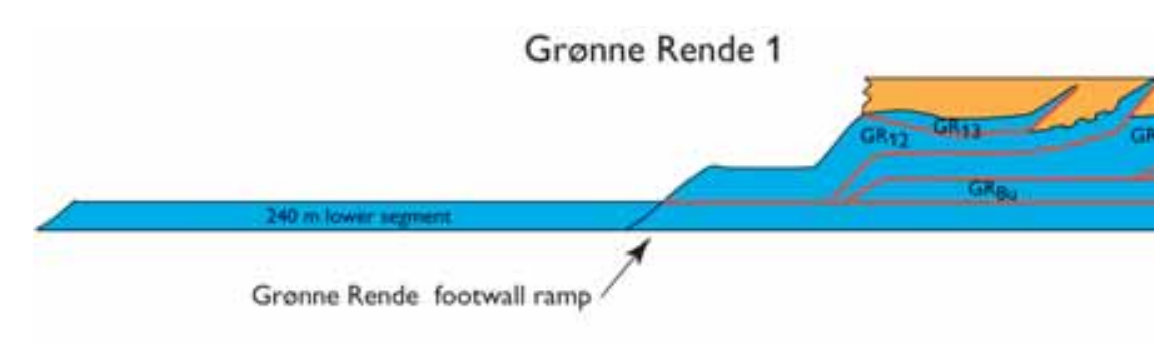

Gronne Rende 2

Fig. 115. Dynamic model of progressive deformation in the Grønne Rende Section illustrated in three sequential restoration cross-sections; the final stage (4) described in the text is not illustrated. The red lines indicate the active displacement surfaces in each deformation stage. Note how the shortening due to the displacement along the $20 \mathrm{~m}$ flat level resulted in the substantial length of the 'left over' lower duplex segment between the 20 and $30 \mathrm{~m}$ flat level.

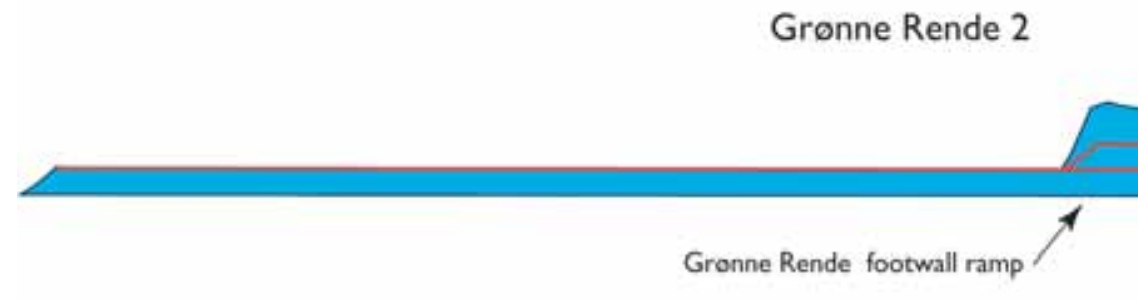

development in the Stenstue Rende Section. At the leading-edge thrust, a minor connection splay separated SSO2 and SS03. Most of the thrusting was located at the upper $10 \mathrm{~m}$ flat level for a distance of about $180 \mathrm{~m}$, in the northern part of which it was eventually rooted down to the lower décollement level. The displacement of the SS05 thrust sheet followed the same system, but with a smaller translation along the upper $10 \mathrm{~m}$ flat level. At the trailing end, SSO6 was thrust up along a steep footwall ramp, and here the formation of duplex structures was probably initiated. The thickness of sediment (Rubjerg Knude Formation) that had accumulated by this stage amounted to $10 \mathrm{~m}$.
Stenstue Rende stage 2. The leading-edge thrusting shifted to the SS01 thrust sheet, which was displaced $20 \mathrm{~m}$ up along the footwall ramp (the trailing end of SR04 in the Sandrende Section). The SS01 thrust fault extended down via an intermediate ramp to the $20 \mathrm{~m}$ flat level, and about $200 \mathrm{~m}$ from the leading footwall ramp it stepped down the lower ramp to the $30 \mathrm{~m}$ décollement level. At the upper hinge of the lower ramp, SS01 was folded into a fault-bend anticline, a small detachment anticline. Along the foreland-dipping limb of the anticline in the SSO1 thrust sheet, a normal fault was formed that displaced the tip of the SS02 thrust sheet. Furthermore, the SS03 thrust sheet 

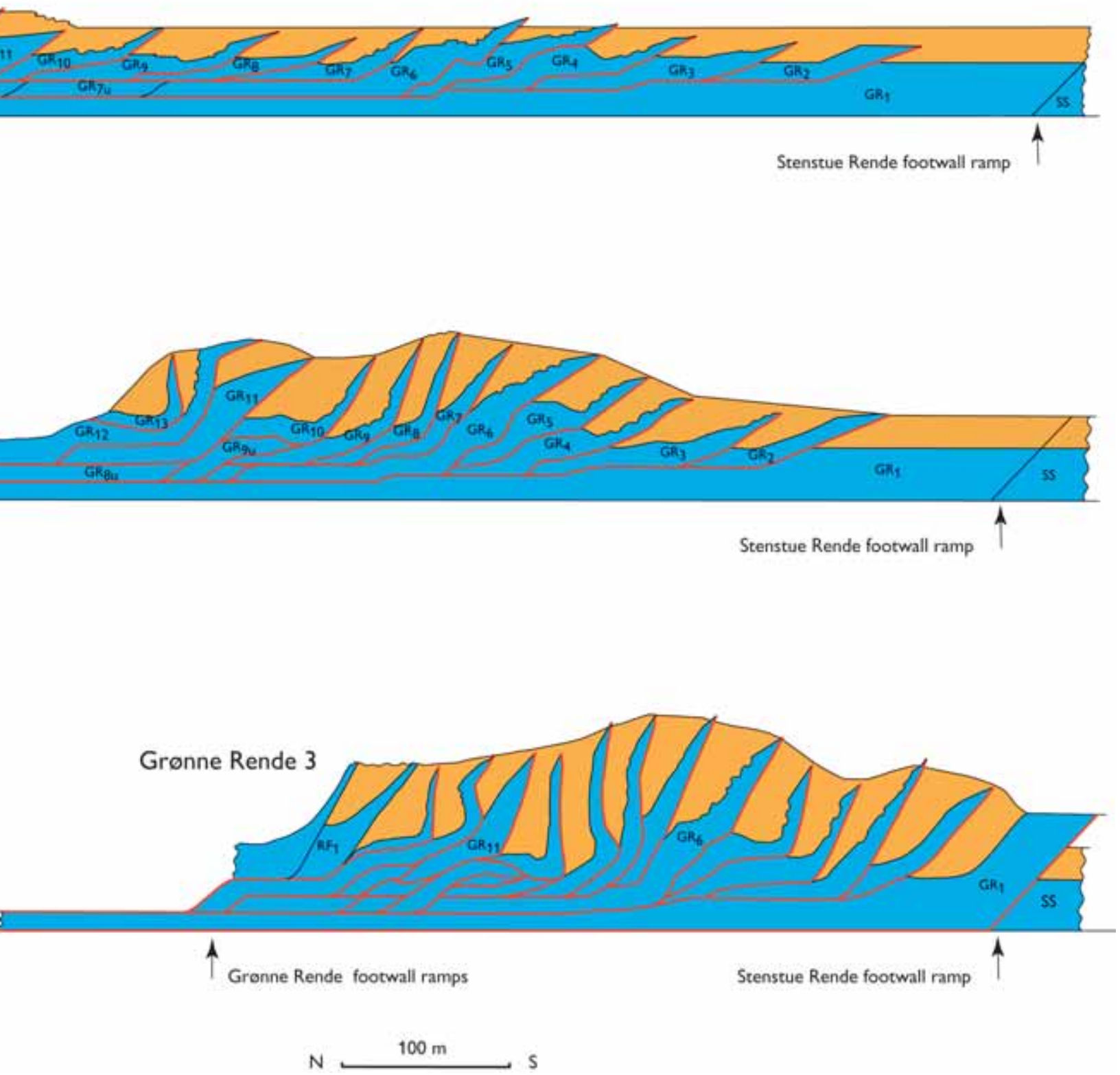

became steeply inclined, and the initial imbrication of the thin SSO3 thrust sheet resulted in the separation of SS03 from SS04.

In the trailing end of the Stenstue Rende Section, duplex stacking of the lower segments in SSO6 resulted in elevation of the L/R-unconformity more than 10 $\mathrm{m}$ above the mean level. The accumulated displacement ranged up to $160 \mathrm{~m}$.

Stenstue Rende stage 3. Thrusting of SS04 progressed on the upper flat over the piggyback basin of SS03 with a frontal displacement of $80 \mathrm{~m}$. The hangingwall flat of SS04 ramped up along the footwall ramp of SSO3 and during this translation the nose of SS05 became fault-bend-folded into a syncline with a steeply dipping southern limb. The trailing end of the SSO4 thrust sheet was translated along the $10 \mathrm{~m}$ flat level; it was pushed from the rear by the ramping of the trailing end of the SS05 thrust sheet whereby the SS06 thrust sheet also steepened up. Sediment thicknesses in the piggyback basins increased to c. $20 \mathrm{~m}$, and the accumulated displacement ranged up to $240 \mathrm{~m}$.

Stenstue Rende stage 4. The dramatic major foreland thrusting of the SS01 thrust sheet, which included about $200 \mathrm{~m}$ displacement of the hanging-wall ramp 


\section{Stenstue Rende 1}

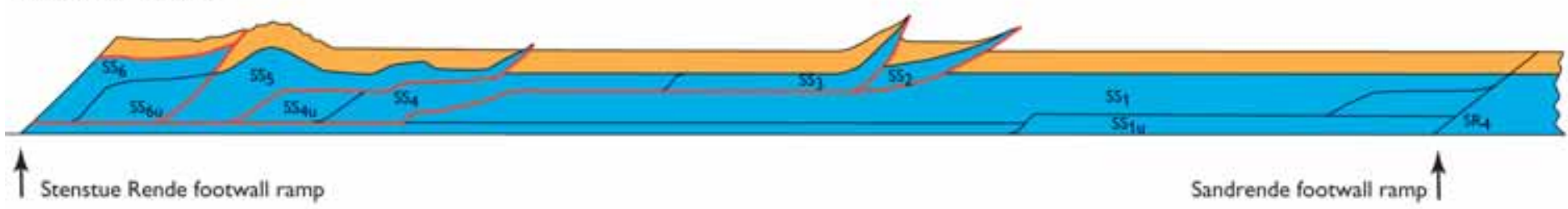

\section{Stenstue Rende 2}

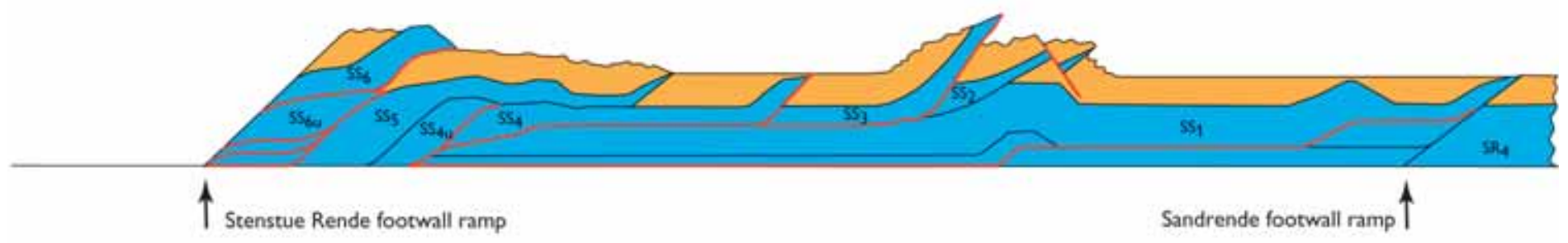

\section{Stenstue Rende 3}

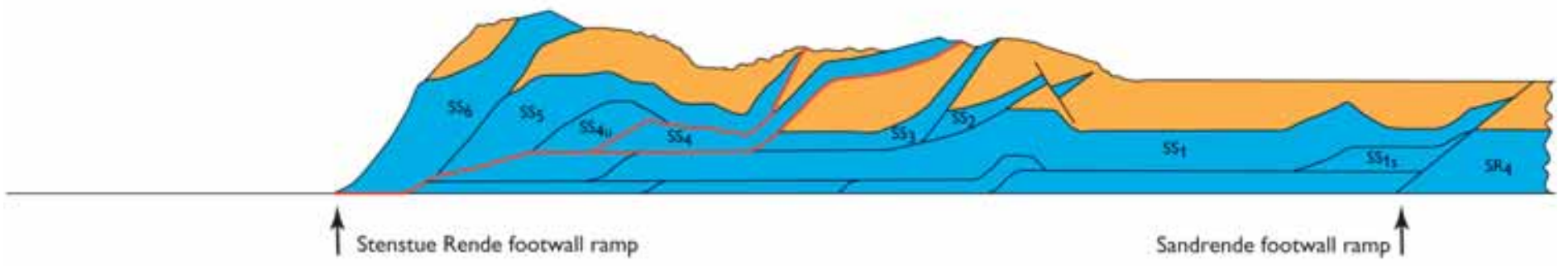

\section{Stenstue Rende 4}

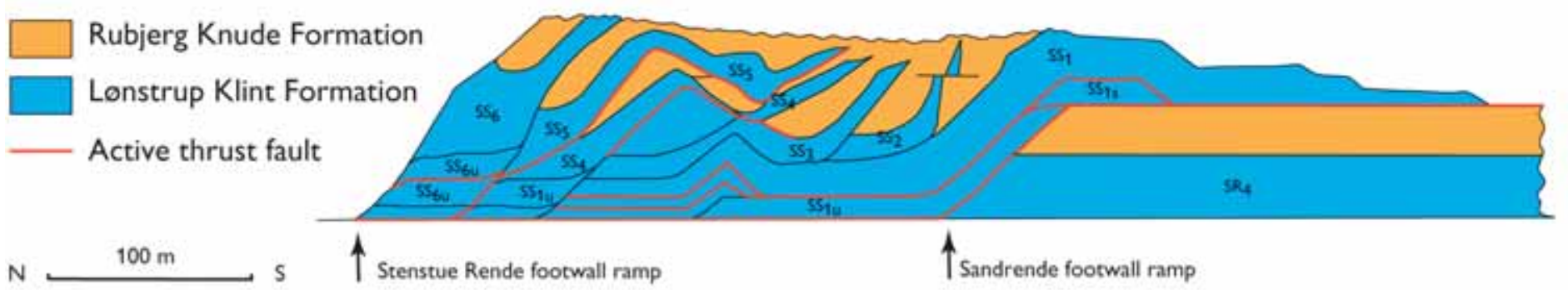

Fig. 116. Dynamic model of progressive deformation in the Stenstue Rende Section illustrated in four sequential restoration crosssections; the final stage (5) described in the text is not illustrated. The cross-sections demonstrate the development stages between the initial and final positions displayed in the balanced and the structural cross-sections in Plate 2 . The red lines indicate the active displacement surfaces in each defomation stage. 
over the piggyback basin of the Sandrende Section, occurred contemporaneously with the formation of an antiformal stack above the trailing end of SSO1. The creation of the antiformal stack had already been initiated by the earlier formation of the minor detachment anticline at the ramp splitting the lower segments of SS01 (the SS01u segments). A duplex duplication of the lower SSO1u segments accentuated the anticline, and finally the SSO3 thrust sheet riding piggyback on SS01 was folded into an anticline with a steep foreland-dipping southern limb (Fig. 90). Along this limb, a normal fault developed that displaced the frontal part of the SSO4 thrust sheet. A chaotic soft sedimentary fault breccia was formed during the stretching and fault separation of SS04 (Fig. 91). Due to an extra push from the rear, the SS05 thrust sheet was displaced a further $30 \mathrm{~m}$ to the south, which resulted in the formation of a huge southerly overturned slump fold above the normal fault zone (Fig. 89).

The accumulated displacement totals about $470 \mathrm{~m}$. The displacement of the SSO1 hanging-wall flat up along the steeply dipping footwall ramp constrains the sequential thrusting of the Stenstue Rende relative to the Sandrende thrusting. Thus stage 4 could not have begun before the maximum sedimentation in the piggyback basin was accomplished in the Sandrende Section. The initial SS01 thrusting could be regarded as a growth fault, whereby the syntectonic accumulation of sand added to the steepening of the footwall ramp. The present vertical to northerly overturned orientation of the SSO1 hanging-wall flat and ramp resulted from differential thrusting and fault-bend of the SS01u lower hanging-wall ramp. Note also the re-orientation of the normal fault at the tip of SSO2, which due to the same deformation was bent into a horizontal position.

Sten stue Rende stage 5. This stage corresponds to stage 6 in the Sandrende Section, wherein the SS01 thrust sheet riding piggyback on SR04 was displaced by normal faulting (Fig. 117, stage 6).

\section{Stenstue Rende Section: Summary data}

$\begin{array}{ll}\text { Balanced length }\left(\mathrm{L}_{0}\right): & 760 \mathrm{~m} \\ \text { Cross-section length }\left(\mathrm{L}_{1}\right): & 285 \mathrm{~m} \\ \text { Shortening }(\Delta \mathrm{L}): & 485 \mathrm{~m} \\ \text { Compression: } & 62.5 \%\end{array}$

Comment. The lengths are measured from the foot- wall ramp between GR01 and SS06 to the footwall ramp between SS01 and SR04. If the compression was calculated from the leading-edge thrust tip of SSO1 to the trailing-end footwall ramp of SSO6, $\mathrm{L}_{1}$ amounts to $455 \mathrm{~m}, \Delta \mathrm{L}=305 \mathrm{~m}$ and the calculated compression would only be $40.1 \%$.

\section{Sandrende Section}

The dynamic development of the Sandrende Section was formerly interpreted as a combination of diapirism and normal faulting caused by volume exchange during thrust propagation (Sadolin et al.1997). The model presented here aims at an explanation of the development purely based on a thin-skinned thrustfault model including differential ramping and duplex formation. Thus, the diapirism is interpreted to be an effect of ramping and fault-bend folding growth, similar to the model of Mitra \& Sussman (1997), but also including mud-mobilisation and exaggeration of backlimb thrusting. The normal faulting occurring in the Sandrende Section is interpreted as the effect of differential ramping of a lower trailing-end segment that created foreland-dipping features above a hangingwall ramp propagation along an intermediate footwall flat. Six stages of dynamic development have been differentiated in the Sandrende Section (Fig. 117).

Sandrende stage 1. After initial deposition of a 3-5 m thick succession of Rubjerg Knude Formation sediments, the SR04 thrust sheet started thrusting about $50 \mathrm{~m}$ over the upper flat. The dip of the footwall ramp was relatively gentle, only c. $14^{\circ}$, and in the $15 \mathrm{~m}$ flat level the thrust fault may be traced along a minor flat segment on top of the lower trailing-end segment of SR03 (SR03u). From the minor intermediate flat, the thrust fault rooted down to the $30 \mathrm{~m}$ décollement level along a $20^{\circ}$ dipping footwall ramp of SR03u. Note that an upper and lower SR04 hanging-wall ramp was introduced subsequently.

Sandrende stage 2. Translation of the lower SR04 hanging-wall ramp along the intermediate flat established the anticline in the central part of the SR04 thrust sheet. The SR03 thrust sheet started to propagate towards its foreland along the upper $10 \mathrm{~m}$ hanging-wall flat, and the frontal part of SR03 was displaced $50 \mathrm{~m}$ over the upper flat on top of the piggyback basin of SR02. The tip of the SR02 thrust sheet propagated up along a growth-fault ramp, which caused the steeply dipping 


\section{Sandrende 1}

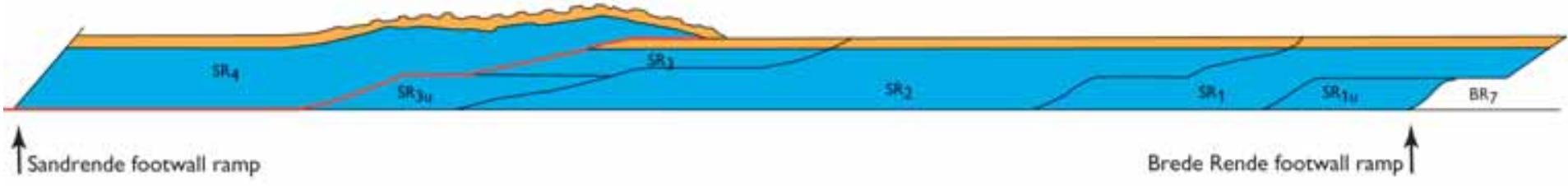

Sandrende 2 \& 3

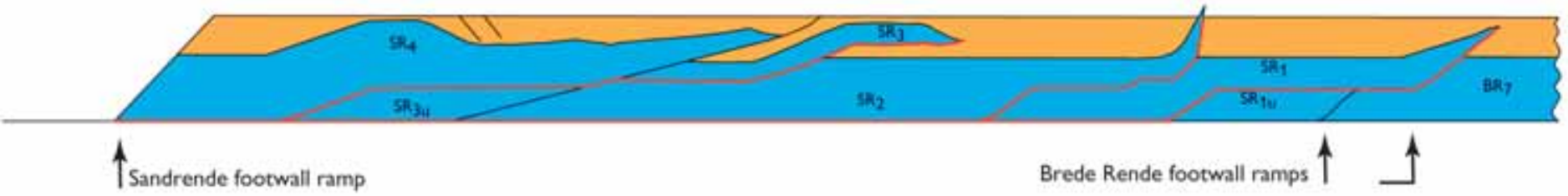

Sandrende 4

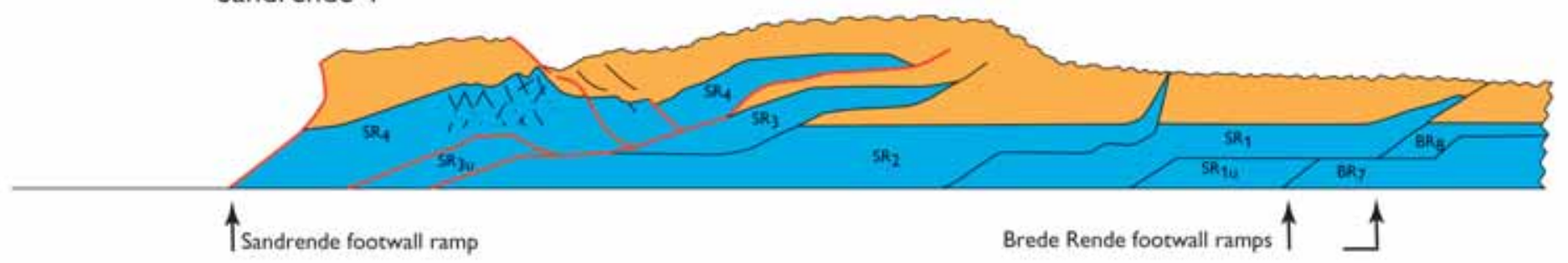

Sandrende 5

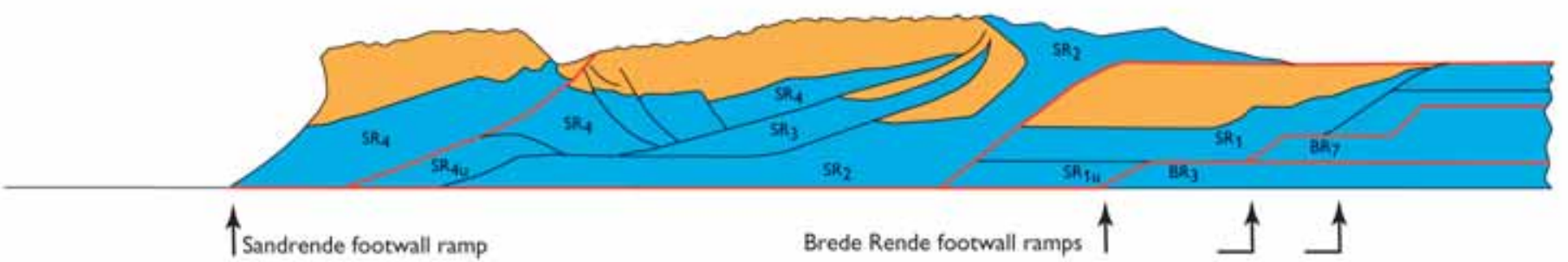

Rubjerg Knude Formation

Lønstrup Klint Formation

Active thrust fault

Sandrende 6

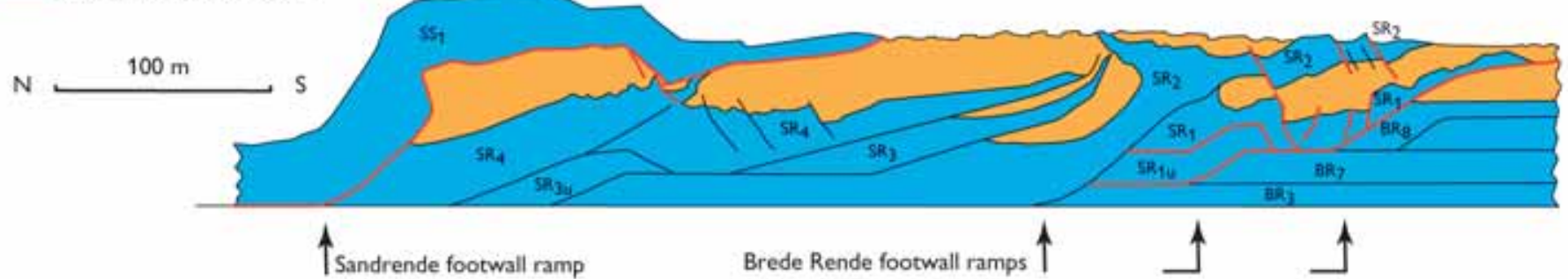


orientation of the northern boundary of the piggybackbasin at the top of the SR01 thrust sheet. Theaccumulated displacement ranged up to about $150 \mathrm{~m}$, including the initial thrusting of SR01.

Sandrende stage 3. During stage 3, the thickness of the sediments of the Rubjerg Knude Formation reached $20 \mathrm{~m}$ in the piggyback basins in the Sandrende Section. In the basin at the top of the SR04 thrust sheet, the thickness varied considerably. The reason for this variation is that the top of the anticline above the SR04 lower hanging-wall ramp was subjected to erosion while deposition continued in the frontal part, south of the anticline, as well as in the basin north of the anticline. On the foreland-dipping flank of the anticline, minor sets of normal growth faults govemed sedimentation (Fig. 87). The tip of the SR04 thrust sheet suffered minor erosion before deposition resumed during thrust propagation. This is documented by the angular onlap relationships described by Sadolin et al. (1997).

Sandrende stage 4 . The thrusting of SR04 continued with $50 \mathrm{~m}$ further displacement. Below the trailing end of the SR04 thrust sheet, the SR03u lower segment was picked up and displaced onto the footwall ramp of SR02. This minor duplex and ramp thrusting accentuated the SR04 hanging-wall anticline, and normal faulting on the foreland-dipping limb progressed. Above the crest of the SR03u detachment anticline, a significant normal fault complex developed. Here in the SR04 thrust sheet, a dense network of conjugate normal faults (Fig. 85) resulted from lateral extension due to flexural slip bend over the upper hinge of the lower footwall ramp.

Sandrende stage 5. The thrusting of SR01 propagated up along the lower and intermediate footwall ramp of the trailing segments of the Brede Rende Section. Dur-

\section{Facing page:}

Fig. 117. Dynamic model of progressive deformation in the Sandrende Section illustrated by five restoration crosssections. Note that stages 2 and 3 include syntectonic sedimentation of the Rubjerg Knude Formation, mainly related to stage 2 , and the thrust-fault configuration concluding stage 3. The cross-sections demonstrate the development stages between the initial and final positions displayed in the balanced and the structural cross-sections in Plate 2. The red lines indicate the active displacement surfaces in each deformation stage. ing this ramping, the hanging-wall flat of SR02 progressed up over the piggyback basin of SR01. The tips of the SR03 and SR04 thrust sheets thus experienced fault bending up along the footwall flat of SR02. The atypical northerly overturned tip at the top of the SR02 sheet probably formed due to accentuated reverse faulting along a former established back-thrust. In the trailing part of the section, a minor satellite splay thrust developed, which broke through the SR04 thrust sheet from thehanging-wall flatto the footwallflat below SS01.

Sandrende stage 6. The final development of the Sandrende Section was dominated by complex duplex formation and fault-bend folding of the SR01 thrust sheet below the frontal part of SR02. During the thrust propagation over the footwall ramp of the trailing-end segments of the Brede Rende Section, a fault-bendfolded syncline was formed in SR01, which resulted in normal fault displacement of the SR01 piggyback basin and the overlying frontal part of the SR02 thrust sheet. Similar normal faulting affected the SS01 thrust sheet, which had over-thrust the piggyback basin on the back of SR04. Due to the intense ramping and folding of SR01 and its underlying duplex (SR01u) into an antiformal stack, mud of the Lønstrup Klint Formation was remobilised in SR01, which intruded through the hanging-wall flat of SR02 to form the diapir in the Sandrende Section.

\section{Sandrende Section: Summary data}

$\begin{array}{ll}\text { Balanced length }\left(\mathrm{L}_{0}\right): & 775 \mathrm{~m} \\ \text { Cross-section length }\left(\mathrm{L}_{1}\right): & 440 \mathrm{~m} \\ \text { Shortening }(\Delta \mathrm{L}): & 335 \mathrm{~m} \\ \text { Compression: } & 43.2 \%\end{array}$

Comment. The lengths are measured from the footwall ramp between SS01 and SR04 to the footwall ramp between SR01 and BR08, at the level where the ramps cut the L/R-unconformity. The volume lost in diapirism has not been considered, and a reduced amount of compression would result by measuring $\mathrm{L}_{1}$ from the tip of the SR01 thrust sheet to the SR04 footwall ramp.

\section{Brede Rende Section}

The development of normal faults associated with foreland-dipping features of hanging-wall ramps trans- 
lated along footwall flats has already been demonstrated in the previous sections. One of the best examples of such a normal fault relationship occurs in the Brede Rende Section. An essential element for this development was the formation of a long thrust sheet, translated laterally more than $150 \mathrm{~m}$ along the upper flat. This is demonstrated by the seven stages of development recognised in the Brede Rende Section, as illustrated by the five cross-sections in Fig. 118.

Brede Rende stage 1. The first stage differentiated here is the initial sedimentation of about 3-5 m of the Rubjerg Knude Formation. This corresponds well with the thickness of sediments deposited initially above the L/R-unconformity in the Sandrende Section; this unit is considered to represent pre-thrust sedimentation, i.e. the sediment record prior to piggyback basin formation.

Brede Rende stage 2. Accepting that the thinnest preserved section of the Rubjerg Knude Fomation indicates the timing of the earliest thrusting, then thrusting in the Brede Rende Section was initiated with the displacement of the BR03 thrust sheet. The frontal part of BR03 was displaced about $50 \mathrm{~m}$ over the upper flat corresponding to the relative foreland in front of the leading edge of thrusting. The BR03 thrust fault probably rooted down to the $30 \mathrm{~m}$ décollement level. However, translation in the upper $10 \mathrm{~m}$ flat level cannot be excluded, and in this case the beds disturbed by hydrodynamic brecciation might be interpreted as thrust flats. In the trailing end of the section, the BR06 hanging-wall ramp was the next thrust to break through and initiate the translation along the upper flat.

Brede Rende stage 3. The BR06 thrust sheet was further displaced c. $50 \mathrm{~m}$ over the upper flat. The trailing end of BR06 was separated by a splay thrust at the footwall ramp, along which the BR07 thrust sheet propagated contemporaneously with piggyback thrusting of BR08. This stage is equivalent to the frontal thrusting during stage 5 in the Sandrende Section.

Brede Rende stage 4. Sediment accumulation in the piggyback basins increased up to about $15 \mathrm{~m}$. The marked difference in thickness of deposits is clearly seen by comparing the BR05 thrust sheet with the BR06 thrust sheet. The roof of BR05 was obviously capped at an earlier stage than BR06 where sediments accumulated to more than twice the thickness of that in BR05.
Brede Rende stage 5 . With a displacement of about 60 $\mathrm{m}$, the BR05 thrust sheet propagated up along the footwall ramp of BR04 and onto the upper flat on top of the BR04 thrust sheet. Translation of the BR06 thrust sheet progressed c. $60 \mathrm{~m}$ along the upper flat. The thrusting rooted down to the $20 \mathrm{~m}$ flat level on top of the trailing-end segment of the BR03 thrust sheet (BR03u). The accumulated displacement amounted to $150 \mathrm{~m}$, including the ramping and translation of the BR07 thrust sheet along the same $20 \mathrm{~m}$ flat level.

Brede Rende stage 6 . After the thrusting of BR05 and BR06 ceased, the BR04 thrust sheet was translated c. $80 \mathrm{~m}$. The BR04 thrust fault included three ramps: an upper gently dipping ramp from the upper flat to the 5-10 m flat level, an intermediate ramp-bend of the BR03 thrust sheet due to the presence of the formerly established BR02 footwall ramp, and a lower ramp from the $10 \mathrm{~m}$ to the $20 \mathrm{~m}$ flat level. The translation of the BR04 lower hanging-wall ramp along the footwall flat of BR03 created the foreland-dipping bend that, combined with the bend due to the BR03 ramping, formed a syncline in front of the BR04 ramp anticline. The normal fault created parallel to the foreland-dipping features displaced the tip of the BR06 thrust sheet. The vertical offset on the normal fault amounted to $\mathrm{c}$. $20 \mathrm{~m}$, which also included the displacement caused by the offset in front of the BR05 thrust tip.

Brede Rende stage 7. Finally, the leading-edge thrusting of the section propagated over the trailing end of the Kramrende Section. Above the footwall ramp of BR01, a minor antiformal stack was formed and subsequently an irregular duplex formation affected the BR01 thrust sheet during the last stage of deformation in the Brede Rende Section. This phase developed into diapirism that intruded towards the thrust fault between BR01 and BR02.

\section{Facing page:}

Fig. 118. Dynamic model of progressive deformation in the Brede Rende Section illustrated in five sequential restoration cross-sections. The cross-sections demonstrate seven stages in the development between the balanced cross-section and the structural cross-section (Plate 2). The red lines indicate the active displacement surfaces in each deformation stage. Note that significant normal faulting occurred in the Brede Rende Section during stages 5 and 6 while the hanging-wall anticline in the middle part of the BR04 thrust sheet was formed. 
Brede Rende 1 \& 2

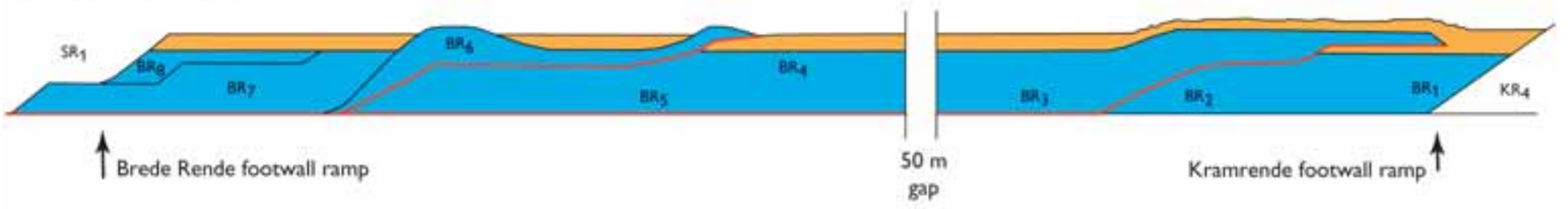

Brede Rende 3 \& 4
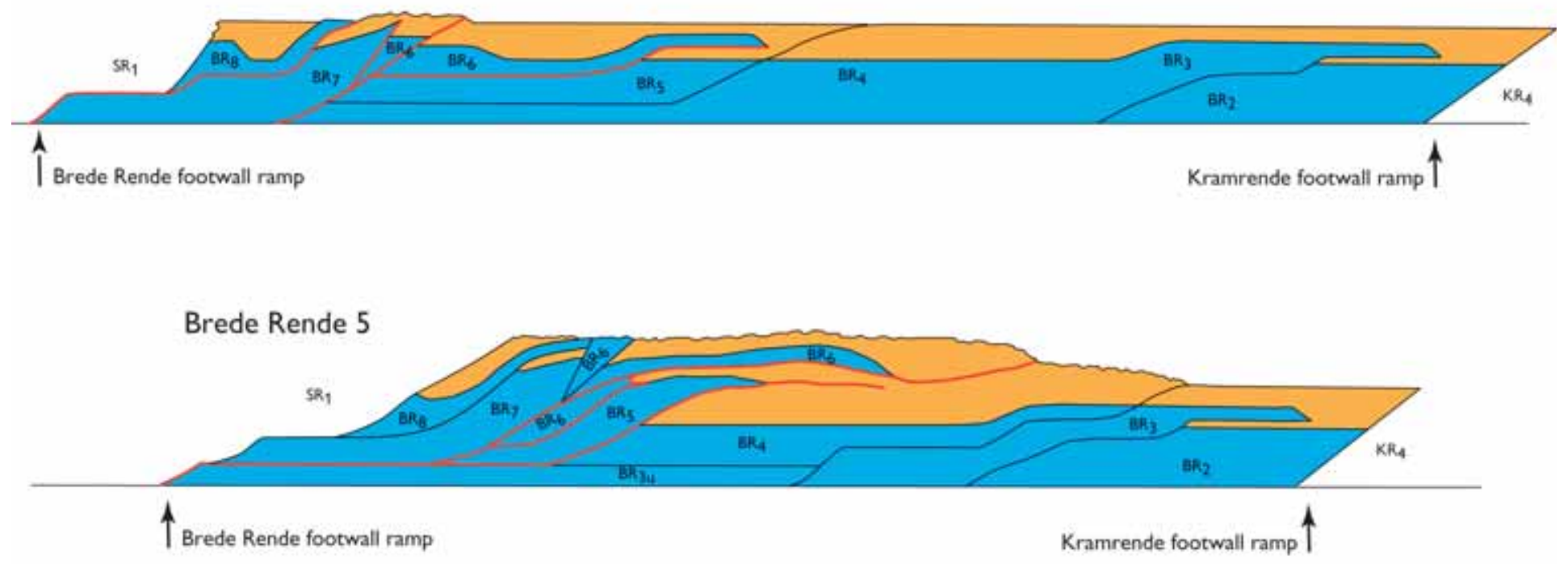

Brede Rende 6

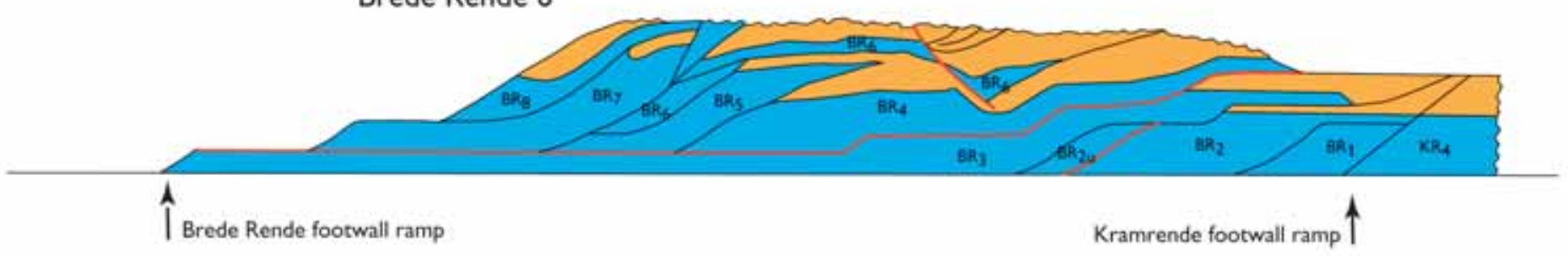

Rubjerg Knude Formation

Lonstrup Klint Formation

Active thrust fault

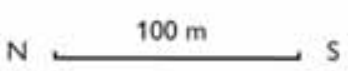

ᄂ

Brede Rende 7 


\section{Brede Rende Section: Summary data}

$\begin{array}{ll}\text { Balanced length }\left(\mathrm{L}_{\mathrm{b}}\right): & 815 \mathrm{~m} \\ \text { Cross-section length }\left(\mathrm{L}_{\mathrm{H}}\right): & 440 \mathrm{~m} \\ \text { Shortening }(\Delta \mathrm{L}): & 375 \mathrm{~m} \\ \text { Compression: } & 46.0 \%\end{array}$

\section{Kramrende Section}

In the central part of the Kramrende Section, a major diapir developed during the progressive thrusting. The Kramrende diapir was the most distally located diapir in the thin-skinned thrust-fault system indicating that a certain amount of ramp propagation from a deeper décollement level (at least $30 \mathrm{~m}$ flat level) was needed for macroscopic-scale diapirism. South of the Kramrende Section, the décollement level gradually changed to a shallower position and the intensity of ramping decreased. Seven stages of dynamic development have been differentiated in the Kramrende Section, as illustrated in the five cross-sections in Fig. 119.

Kramrende stage 1. The thrusting in the Kramrende Section was initiated with leading-edge propagation along the KR01 thrust fault, which constituted an upper footwall ramp with a dip of $10^{\circ}$, a minor intermediate flat at the $15 \mathrm{~m}$ flat level, and a c. $15^{\circ}$ dipping lower ramp connecting the thrust fault to the $30 \mathrm{~m}$ décollement level. The displacement was in the order of $100 \mathrm{~m}$ along the upper flat, where almost no sedimentation of the Rubjerg Knude Formation took place.

Kramrende stage 2. Subsequent to the early stage thrusting, the lowermost $10 \mathrm{~m}$ of the Rubjerg Knude Formation was deposited; the sediment thickness in the KR01 piggyback basin was probably a little less.

Kramrende stage 3. The KR01 thrusting progressed about $60 \mathrm{~m}$ over the upper footwall flat of what was to become the MB04 thrust sheet, and the trailing end of the KR01 thrust sheet was elevated to the $15 \mathrm{~m}$ flat level by ramp propagation over the lower footwall ramp of MB04. A small duplex segment (KR01s) under the middle part of the KR01 thrust sheet was picked up in the thrusting and displaced to the upper footwall ramp hinge, where it formed a minor angular anticline. In the syncline between the anticline and the footwall ramp of KR01, the thickness of piggyback basin sediment accumulation increased to about $15 \mathrm{~m}$ before the KR02 thrust sheet propagated c. $50 \mathrm{~m}$ up along the ramp, and the KR02 hanging-wall ramp partly capped the KR01 piggyback basin. The accumulated displacement ranged up to about $260 \mathrm{~m}$.

Kramrende stage 4 . Thrusting of the KR03 thrust sheet was initiated up along the northerly dipping footwall flat of KR02. The KR03 thrust fault included an upper and a lower relatively steep (c. $23^{\circ}$ ) ramp. The top of the KR02 thrust sheet was probably exposed to erosion, and the Rubjerg Knude Formation is thus missingin this part of the section. The piggyback sediment pile increased to a thickness of $20 \mathrm{~m}$, as indicated by the sedimentary section preserved above the L/R-unconformity at the top of the KR04 thrust sheet. From the trailing end of the KR01 thrust sheet, diapirism intruded through the footwall ramp and irregular mud diapirism developed in the KR02 thrust sheet.

Kramrende stage 5. With a displacement of c. $30 \mathrm{~m}$, KR03 thrusting propagated over the two ramps that resulted in the fault-bend folding of two anticlines separated by an intervening syncline.

Kramrende stage 6. The KR04 thrust sheet was thrust over the fault-bend-folds formed in stage 5, simultaneously with limited continuation of KR03 thrusting. Minor irregular duplex formation started to develop into mud mobilisation at the trailing end of the KR02 and KR04 thrust sheets.

Kramrende stage 7. The final thrust propagation of the KR03 thrust sheet concluded with a displacement of $30 \mathrm{~m}$ up along the footwall flat of KR02. At the bend between the footwall flat and the footwall ramp of KR02, a remarkable set of reverse faults developed (Fig. 72). The KR04 thrust sheet, carried piggyback on KR03, was also displaced by the reverse faulting, a fact that testifies to the relative timing of KR04 piggyback thrusting and KR03 ramp propagation. The reverse faults are regarded as back-limb thrusts similar to the back-thrust features mentioned in stage 5 of the Sandrende Section. Minor back-limb reverse faults

\section{Facing page:}

Fig. 119. Dynamic model of progressive deformation in the Kramrende Section illustrated in five sequential restoration cross-sections. The cross-sections demonstrate seven development stages, of which stage 2 represents a purely depositional phase and stage 4 only includes minor displacement. The red lines indicate the active displacement surfaces in each deformation stage. 
Kramrende 1 \& 2
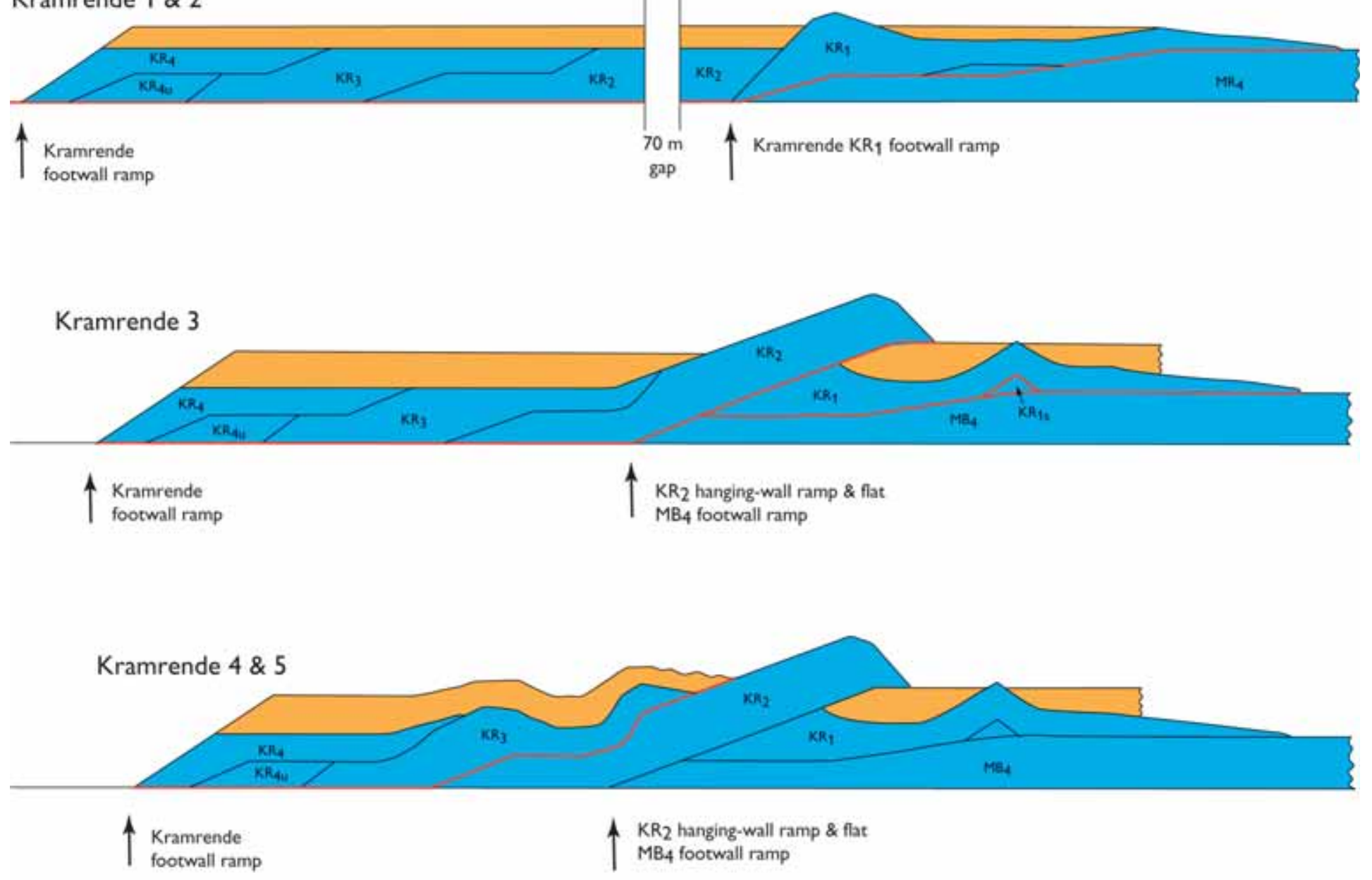

Kramrende 6
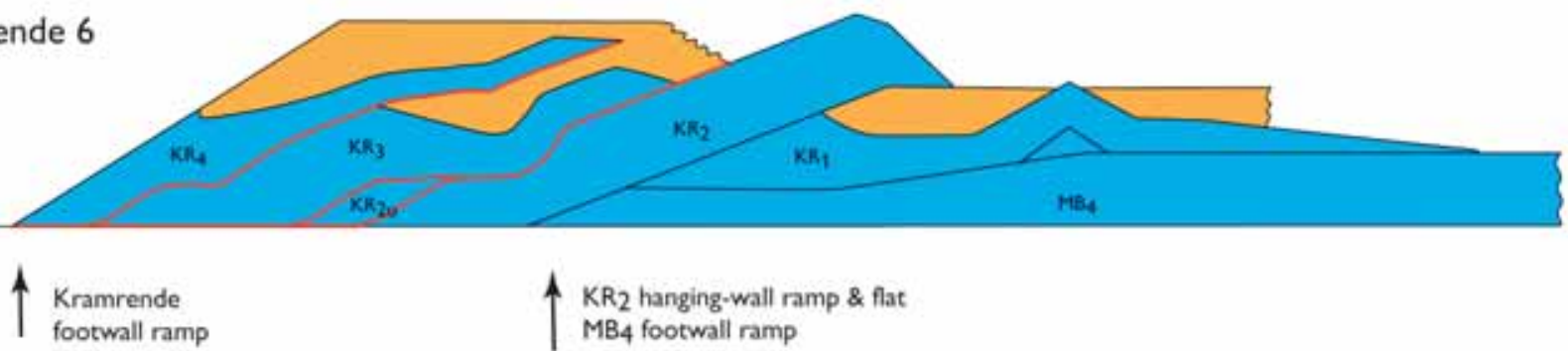

$K_{2}$ hanging-wall ramp \& flat

$\mathrm{MB}_{4}$ footwall ramp

Rubjerg Knude Formation

Lønstrup Klint Formation

Kramrende 7

Active thrust fault

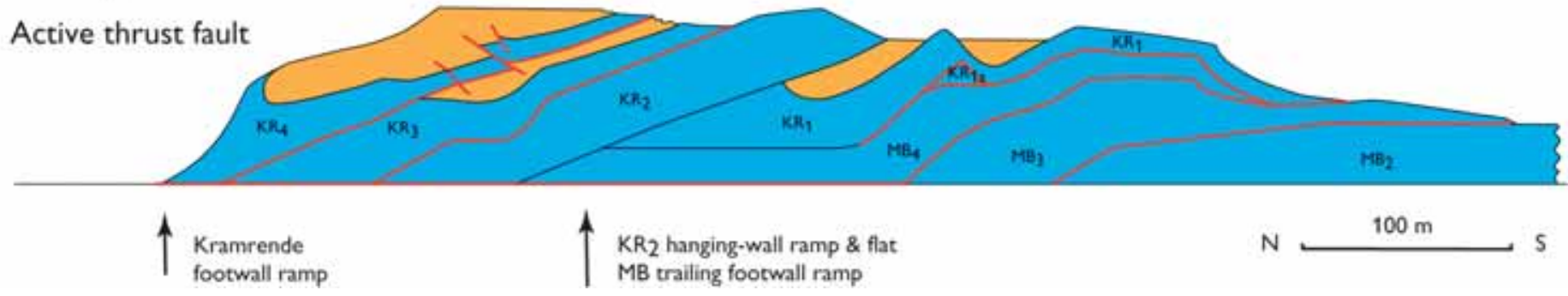




\section{Martørv Bakker 1}

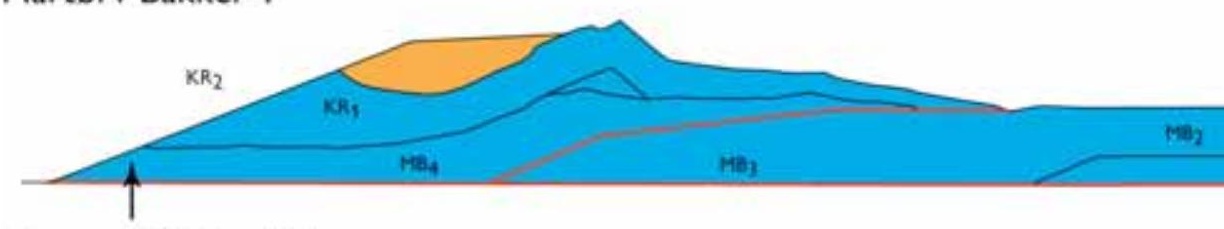

Kramrende / Martorv Bakker

footwall ramp

Fig. 120. Dynamic model of progressive deformation in the Martørv Bakker Section illustrated in three sequential restoration cross-sections. The cross-sections demonstrate four stages in the development between the balanced cross-section and the structural cross-section (Plate 2). The red

lines indicate the active displacement surfaces in each deformation stage. Note the significant depression formed in the hanging-wall block south of the Martørv Bakker normal fault. In this depression, diamictites interlayered with slump-slides were deposited.

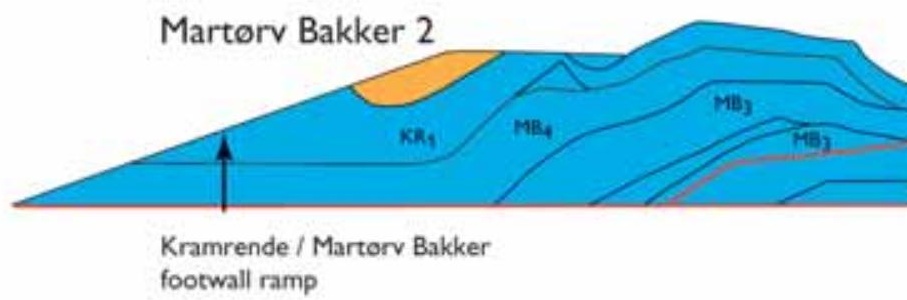

Martørv Bakker 3 \& 4

Kramrende / Martorv Bakker footwall ramp also developed at the crest of the fault-bend-folded KR01 thrust sheet. Polyphase diapirism evolved in the trailing end of the KR03 and KR04 thrust sheets, such that the primary thrust-fault framework was partially destroyed.

\section{Kramrende Section: Summary data}

$\begin{array}{ll}\text { Balanced length }\left(\mathrm{L}_{0}\right): & \text { c. } 600 \mathrm{~m} \\ \text { Cross-section length }\left(\mathrm{L}_{1}\right): & \text { c. } 300 \mathrm{~m} \\ \text { Shortening }(\Delta \mathrm{L}): & \text { c. } 300 \mathrm{~m} \\ \text { Compression: } & \text { c. } 50 \%\end{array}$

Comment. The lengths are measured from approximate positions on the footwall ramps bounding the Kramrende Section and the data must therefore be regarded as tentative estimates.

\section{Martørv Bakker Section}

The development in the Martørv Bakker Section was dominated by the translation of a thrust sheet that was more than $600 \mathrm{~m}$ long and only $20-30 \mathrm{~m}$ thick. During nearly $400 \mathrm{~m}$ of displacement towards the foreland, a lower segment transformed into a duplex that ramped at a relatively late stage and created a fault- 

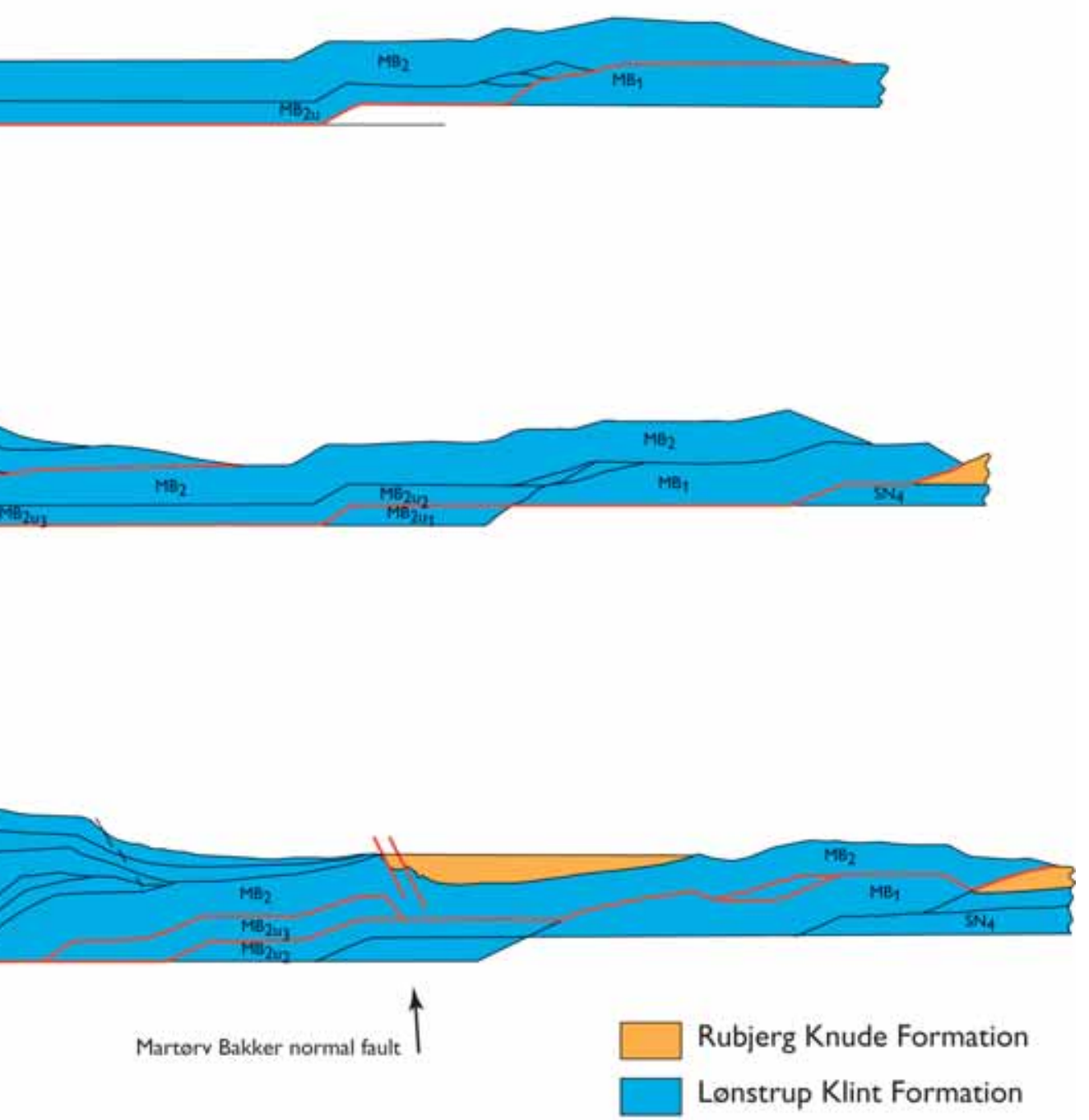

Active thrust fault

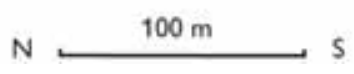

bend-fold anticline and syncline pair. At the upper surface of the intervening limb between the fold pair, a foreland-dipping normal fault was formed, rather similar to the structural complex formed in the Brede Rende Section. Simultaneously with the sedimentation of a diamictite, three slump-slides filled the piggyback basin developed in a syncline created at the top of the hanging-wall block of the normal fault. The sequential restoration stages are illustrated in three cross-sections in Fig. 120.

Martørv Bakker stage 1. Thrusting in the Martørv Bakker Section started with foreland thrusting of MB02, and translation of the trailing-end duplex that consti- tuted the KR01 thrust sheet emplaced piggyback on the MB04 thrust sheet, thrust up along the footwall ramp of MB03. The more than $600 \mathrm{~m}$ long MB02 thrust sheet was displaced c. $105 \mathrm{~m}$ over the footwall flat of MB01. The MB02 thrust fault included two ramps, an upper footwall ramp of MB01 and a lower ramp between the $20 \mathrm{~m}$ flat level and the $30 \mathrm{~m}$ décollement level. The lower ramp was located below the central part of the MB02 thrust sheet, where it acted as the final step for the décollement level change to the 20 $\mathrm{m}$ footwall flat level. It is thought unlikely that significant sedimentation occurred in the section during this stage. 
Martørv Bakker stage 2. The MB01 thrust sheet was displaced about $100 \mathrm{~m}$ over the foreland of the Stensnæs Section along the leading-edge thrust. The MB01 thrust was rooted down to the $20 \mathrm{~m}$ flat level, and it can be traced further on to the $30 \mathrm{~m}$ décollement level by passing the central lower footwall ramp of MB02. Minor adjustments along the hanging-wall flat resulted in formation of small duplexes along the thrust fault. In the trailing end of the section, the MB03 thrust sheet was thrust up over the footwall ramp of MB02, whereby an antiformal stack was formed due to the folding that also involved the MB04 and KR01 thrust sheets. At the base of the MB03 thrust sheet, the lower segments formed an irregular duplex, which accentuated the antiformal stack. The accumulated displacement ranged up to $290 \mathrm{~m}$.

Martørv Bakker stage 3. The final thrusting of the Martørv Bakker Section was concluded by nearly 100 $m$ displacement of the MB02 thrust sheet. The frontal hanging-wall ramp-and-flat was thrust over the piggyback basin of the SN04 thrust sheet in the Stensnæs Section. During the thrusting, the lower segment $\mathrm{MB} 02 \mathrm{u}$ was activated and formed a fault-bend-folded lower duplex. Above the hanging-wall ramp of the trailing-end segment (MB02u3), an anticline was formed at the surface of MB02 and a subsequent syncline above the hanging-wall/footwall flat became a piggyback basin.

Martørv Bakker stage 4. The foreland-dipping limb of the fold pair at the top of the MB02 thrust sheet developed into a southerly dipping normal fault. The c. 10 $\mathrm{m}$ deep piggyback basin was filled with diamictitic deposits and slump-sheets that glided down from the top of the antiformal stack. Deformation in the Martørv Bakker Section concluded with the steepening up of the leading-edge thrust structures due to ramp bending in the Stensnæs Section.

\section{Mar tørv Bakker Section: Summary data}

$\begin{array}{lr}\text { Balanced length }\left(\mathrm{L}_{0}\right): & 1065 \mathrm{~m} \\ \text { Cross-section length }\left(\mathrm{L}_{1}\right): & 675 \mathrm{~m} \\ \text { Shortening }(\Delta \mathrm{L}): & 390 \mathrm{~m} \\ \text { Compression: } & 36.6 \%\end{array}$

Comment. The lengths are measured from the tip of the leading-edge hanging-wall ramp to the upper bend of the footwall ramp of the MB04 thrust sheet.

\section{Stensnaes Section}

In the Stensnæs Section, a number of conspicuous flexural slip folds occur which are interpreted to have resulted from the deformation that accompanied sequential footwall ramp collapse and subsequent ramp displacement of minor duplexes. It is significant that they occur in relation to the final ramping from the lower $20 \mathrm{~m}$ flat level to the upper $10 \mathrm{~m}$ flat level. Eight stages have been differentiated in the development of the Stensnæs Section, of which stages 2, 4 and 6-8 are illustrated by the cross-sections in Fig. 121.

Stensnæs stage 1. In contrast to the Martørv Bakker Section, an initial sediment thickness of $5 \mathrm{~m}$ of the Rubjerg Knude Formation is thought to have covered the Stensnæs Section. It should be noted, however, that typical Lønstrup Formation facies grade upwards into typical Rubjerg Knude Formation facies in this distal part of the Rubjerg Knude Glaciotectonic Complex; the L/R-unconformity is not clearly developed, and location of the formation boundary can be difficult. The affinities of the sediment packet referred to above are thus debatable.

Stensnæs stage 2. Thrusting in the Stensnæs Section was initiated with c. $100 \mathrm{~m}$ displacement of the SN02 thrust sheet over the upper flat. The thrust fault ramped down to the $10 \mathrm{~m}$ flat level, which separated the upper and lower segments of the SN04 thrust sheet, simultaneously with stacking the SN03 thrust sheet into a northerly dipping duplex complex along the footwall ramp of SN01.

Stensnæs stage 3. Accumulation of the Rubjerg Knude Formation increased to a sediment thickness of $10 \mathrm{~m}$. Sedimentation was restricted to the piggyback basin of the SN04 thrust sheet, as well as on the foreland south of the frontal tip of the SN02 thrust sheet.

Stensnæs stage 4 . The piggyback basin on the back of SN04 was sealed in by the overthrusting of the MB02 thrust sheet; this is equivalent to stage 3 in the Martørv Bakker Section.

Sten snæs stage 5. As a trailing-end structural complex to the Ulstrup Section, the thrust sheets of the Stensnæs Section were translated together with the UL02 thrust sheet over the Ulstrup footwall ramp onto the hanging-wall flat of the foreland. During ramping, the SN01 and SN03 thrust sheets were separated into small duplex segments. Flexural-slip folding and polyphase 


\section{Stensnæs 2}

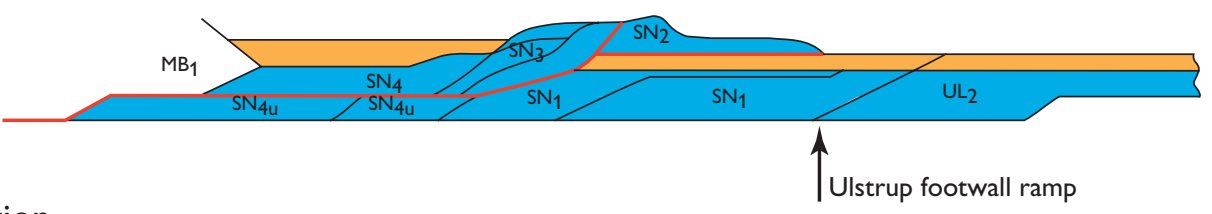

\section{Rubjerg Knude Formation}

\section{Lønstrup Klint Formation}

\section{Active thrust fault}
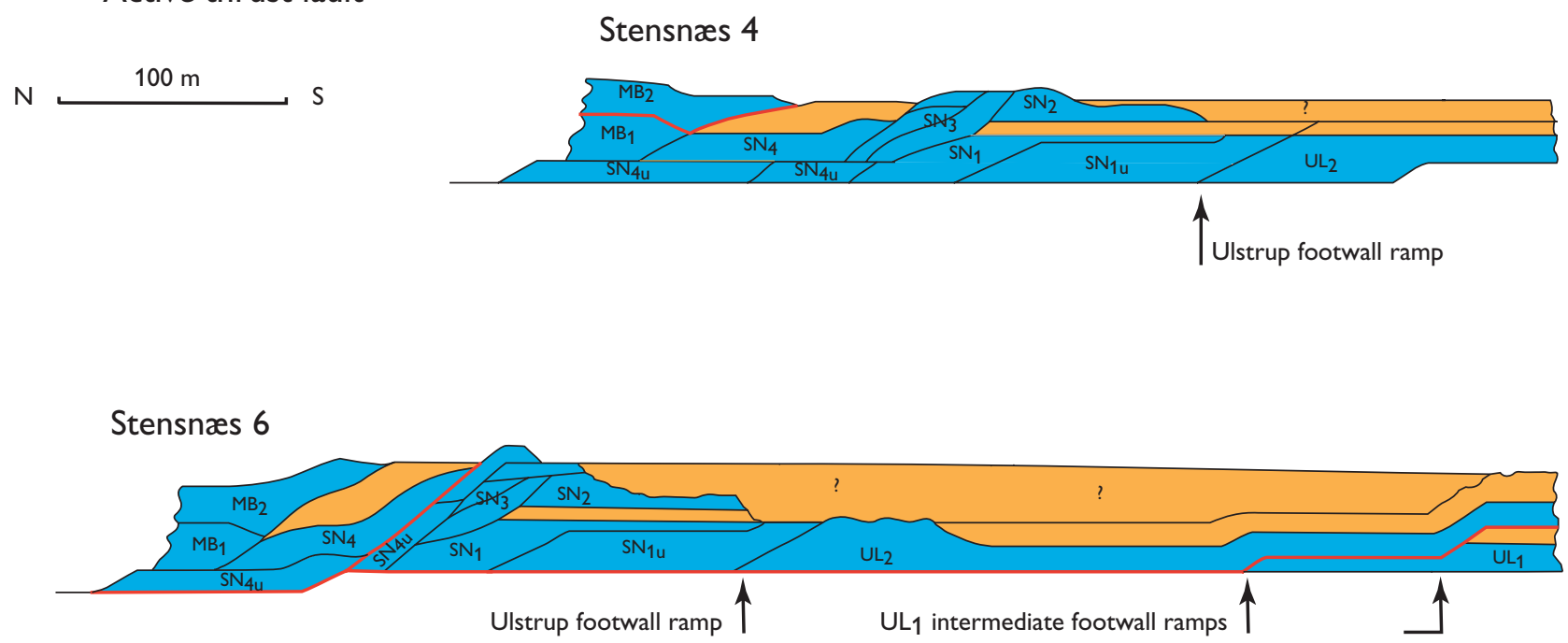

Stensnæs 7 \& 8

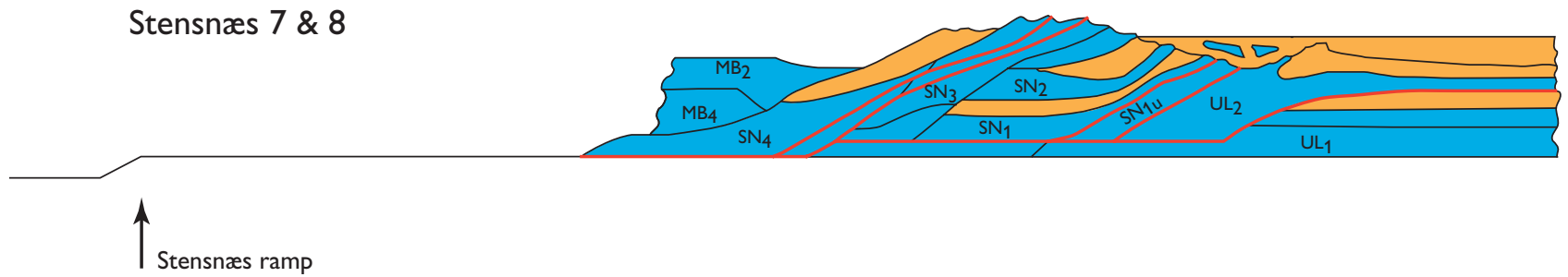

Fig. 121. Dynamic model of progressive deformation in the Stensnæs Section illustrated in four sequential restoration cross-sections. The cross-sections demonstrate five of the eight stages in the development described in the text between the balanced cross-section and the structural cross-section (Plate 2). The red lines indicate the active displacement surfaces in each deformation stage.

hydrodynamic brecciation resulted from the ramping (Figs 53, 57, 58). The accumulated displacement ranged up to $35 \mathrm{~m}$, whereas the length of the hanging-wall flat in the $10 \mathrm{~m}$ flat level amounted to $500 \mathrm{~m}$. At the leading edge of thrusting, the UL02 thrust sheet initiated the thrusting up over a stepwise ramp.

Sten snæs stage 6 . During this stage, about $10 \mathrm{~m}$ of the Rubjerg Knude Formation was deposited in the piggyback basin at the top of the SN02 thrust sheet. The sedimentation level was probably up to $20 \mathrm{~m}$ above the L/R-unconformity, inferred from the elevated position of the SNO2 thrust sheet. However, this is uncertain and the sediments were either never deposited or eroded away during later thrust elevation. In the northern part of the section, the SN04 thrust sheet propagated up along the footwall ramp of the earlier created SN02-SN03 duplex. This resulted in fault-bend folding of the SN04 thrust sheet and its piggyback basin as well as the overlying MB02 thrust sheet. This 


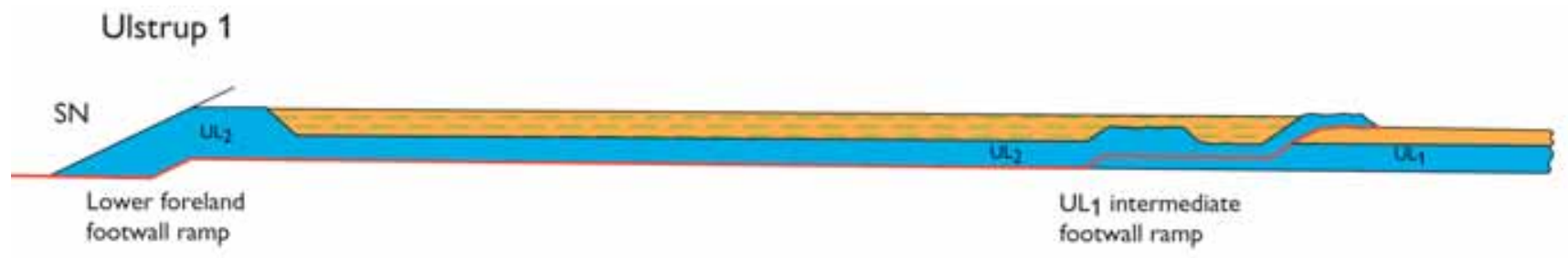

Ulstrup 2

Ulstrup 3

\section{Ulstrup glaciolacustrine beds}

\section{Ulstrup glaciofluvial beds}

Rubjerg Knude Formation

Lonstrup Klint Formation

\section{Active thrust fault}

$N \longleftarrow$ S

\section{Ulstrup 5}

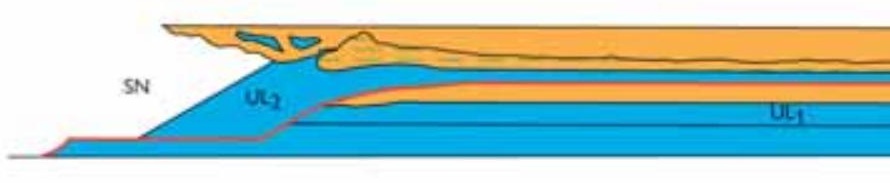

stage correlates with stages 3-6 in the Martørv Bakker Section.

Sten snæs stage 7. The SN01 thrust sheet was displaced about $50 \mathrm{~m}$ overits lower segment (SN01u), and together they were thrust onto the footwall ramp-and-flat ofthe UL02 thrust sheet. During the thrust-fault propagation of the UL02 thrust sheet over the footwall ramp of UL01, the SN01 and SN02 thrust sheets, piggyback translated on UL02, were bent into c. $30^{\circ}$ dipping position. Finally, the SN04 thrust sheet was displaced up along the footwall ramp of SNO3 during differential duplex formation along the SNO4 hanging-wall ramp.

Sten snæs stage 8. The frontal parts of the SN01, SN02 and SN03 thrust sheets, as well as the anticlinal crest of the UL02 thrust sheet (formed above the upper hinge of footwall ramp of UL01), were significantly eroded, and a local piggyback basin was fomed above the transition between the Stensnæs and Ulstrup Sections. To the north of this piggyback basin, the elevated and exposed tips of the SN02-SN04 thrust sheets gravity-slumped out into the basin, where they were deposited as olistoliths, 1-5 $\mathrm{m}$ in size.

\section{Stensnæs Section: Summary data}

Balanced length $\left(\mathrm{L}_{0}\right): \quad 350 \mathrm{~m}$

Cross-section length (L): $180 \mathrm{~m}$

Shortening $(\Delta \mathrm{L})$ : $\quad 170 \mathrm{~m}$

Compression: $\quad 48.6 \%$ 
Fig. 122. Dynamic model of progressive defomation in the Ulstrup Section illustrated in four sequential restoration crosssections. The cross-sections demonstrate four of the eight stages in the development described in the text between the balanced cross-section and the structural cross-section (Plate 2). The red lines indicate the active displacement surfaces in each deformation stage.
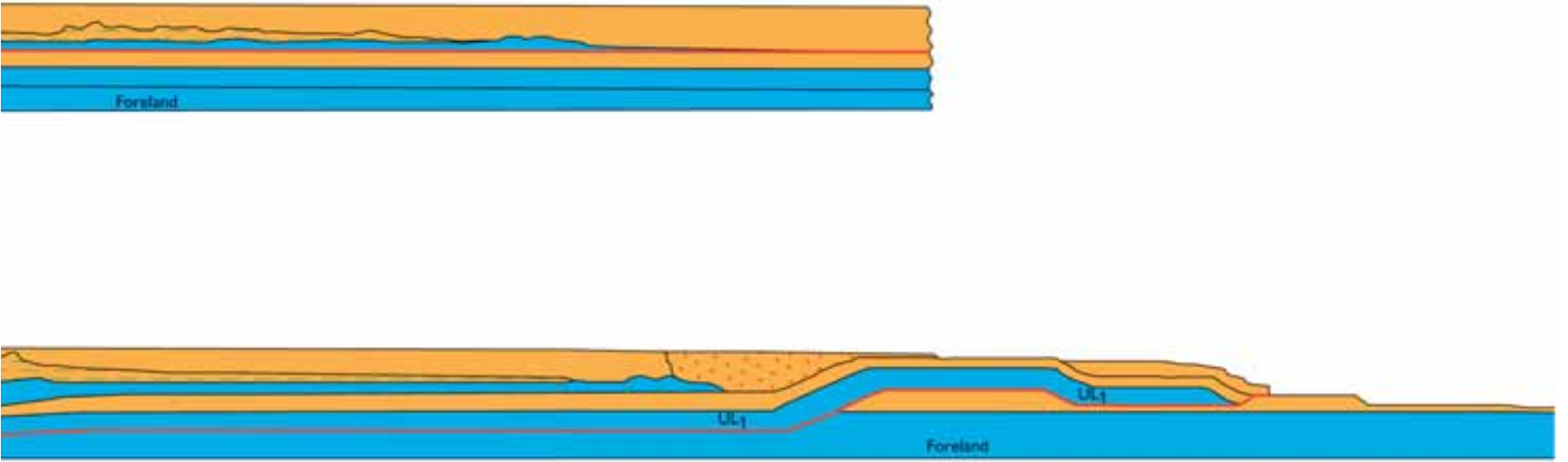

\section{Ulstrup Section}

Thin-skinned thrusting in the Ulstrup Section involved the remarkable translation of extensive, thin thrust sheets over the footwall flat of the foreland. Cohesion of the thrust sheet was probably increased by ground frost in the upper part of the thrust sheet, while the hanging-wall ramp-and-flatslid on a thin zone of mobilised mud. During translation, piggyback sedimentation varied considerably. Six stages have been differentiated in the development of the Ulstrup Section; stages 1-3 and 5 are illustrated by the cross-sections in Fig. 122 (see also Fig. 121).

Ulstrup stage 1. Thrusting in the Ulstrup Section initiated with frontal ramping of the UL02 thrust sheet over a two-stepped footwall ramp of what was to become the UL01 thrust sheet. This ramping resulted in the formation of two, fault-propagating folded anticlines, which were separated by a shallow, broad syncline. The leading edge of the UL02 hanging-wall ramp was displaced about $25 \mathrm{~m}$ over the c. 5-10 m thick Rubjerg Knude Formation deposited in the foreland (at the top of UL01). The UL02 hanging-wall flat extended along the upper $10 \mathrm{~m}$ flat level for about $400 \mathrm{~m}$, terminating to the north at the foreland footwall ramp rooting down to the $20 \mathrm{~m}$ décollement level. Thrust propagation up over this ramp formed a hanging-wall anticline at the trailing end of the UL02 thrust sheet. Between the anticline at the trailing end and the anticline at the upper footwall ramp of UL01, a piggyback basin formed in which glaciolacustrine sediments were deposited to form the small, ephemeral Ulstrup lake. 
Ulstrupstage 2. Thrusting along the UL02 hanging-wall ramp-and-flatprogressed with an accumulated displacementof $230 \mathrm{~m}$. The glaciolacustrinedeposits of the ephemeral Ulstrup lake participated in the ramp-propagating-folding. During translation along the upper $10 \mathrm{~m}$ flat level, the trailing end of the UL02 thrust sheet was probably covered by sediments, which subsequently became eroded. This event in the Rubjerg Knude Formation corresponded to stage 6 in the Stensnæs Section.

Ulstrup stage 3. The long lateral thrusting of the UL02 thrust sheet along the upper flat resulted in $550 \mathrm{~m}$ of displacement, and at the lower trailing end, the hanging-wall ramp became detached to the upper footwall ramp of UL01. Above this ramp, conspicuous flexuralslip folds, similar to the folds developed in the Stensnæs Section, were formed in the UL02 thrust sheet.

Ulstrup stage 4. Glaciofluvial sands were deposited upon an erosional surface capping the Ulstrup lake sediments (all Rubjerg Knude Formation). Depositional base level was probably equivalent to that experienced in stage 8 in the adjacent Stensnæs Section (see above).

Ulstrup stage 5 . The final foreland thrusting took place as the UL01 thrust sheet was thrust over the upper ramp of the foreland and propagated about $200 \mathrm{~m}$ to the south. When the anticline above the UL02 hanging-wall ramp approached the footwall ramp of the foreland, where a fault-bend formed continuously during the propagation of the UL01 thrust sheet, a narrow channel was formed in which coarse-grained glaciofluvial gravel was deposited (Figs 27, 122). The gravel also included redeposited frozen blocks of sand, testifying to the ground-frozen conditions of the environment (Fig. 28).

Ulstrup stage 6. At the leading edge of the UL01 thrust fault, the deformation concluded with $150 \mathrm{~m}$ of displacement over the upper footwall flat of the foreland. During the translation of the UL01 thrust sheet over a minor depression in the foreland, a sandy mud volcano developed due to trapping of the high water pressure close to the leading-edge thrust. The sediment extrusion resulted in chaotic disturbances in the central part of UL01.

Ulstrup stage 7. The last stage of development in the Ulstrup Section involved sedimentation of the uppermost post-tectonic deposits of the Rubjerg Knude Formation. The conglomerate (of stage 5) was covered
Fig. 123. Summary scheme of the syntectonic sedimentary development in the Rubjerg Knude Glaciotectonic Complex. The deformation stages for each section, as described in the text, are indicated here by the symbol \#.

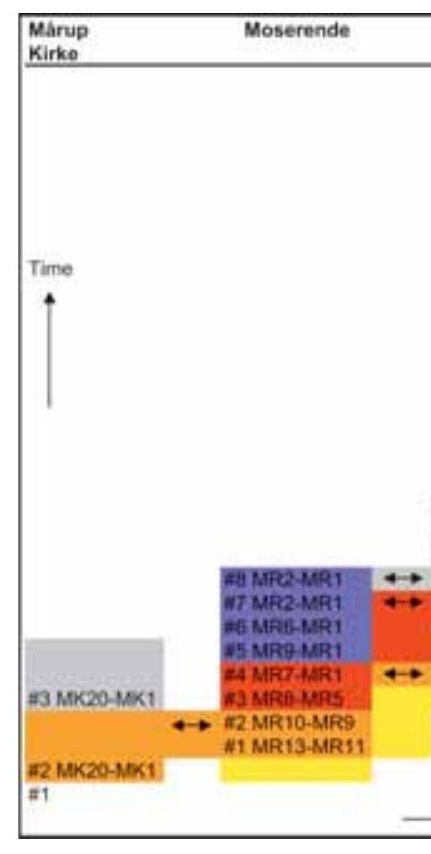

by sand, and deposition in the foreland covered the leading-edge thrust at Tvonnet Rende (for location see Plate 1).

$\begin{array}{ll}\text { Ulstrup Section:Summar y data } \\ \text { Balanced length }\left(\mathrm{L}_{0}\right): & \text { c. } 1350 \mathrm{~m} \\ \text { Cross-section length }\left(\mathrm{L}_{1}\right): & \text { c. } 850 \mathrm{~m} \\ \text { Shortening }(\Delta \mathrm{L}): & \text { c. } 500 \mathrm{~m} \\ \text { Compression: } & \text { c. } 37 \%\end{array}$

\section{Summary of dynamic development}

The dynamic development of the complex is summarised in Figs 123 and 124. From the scheme in Fig. 123, it is clear that the Rubjerg Knude Glaciotectonic Complex developed in sequential progressive stages during syntectonic sedimentation of the Rubjerg Knude Formation.

The thin-skinned thrust-fault complex developed mainly as piggyback thrusting with proximal thrust sheets being displaced contemporaneously with activation of the distal thrust fault. During the advance of the thrust-fault complex, the position of the décollement zone shifted progressively to deeper levels. The dynamic development can be summarised in eight steps that resulted in the formation of eight characteristic thrust-fault structure types (Fig. 124). 


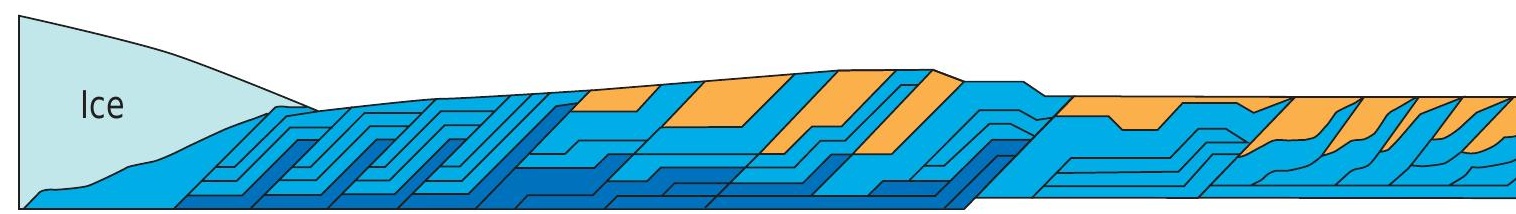

Fault-bend-folded duplex

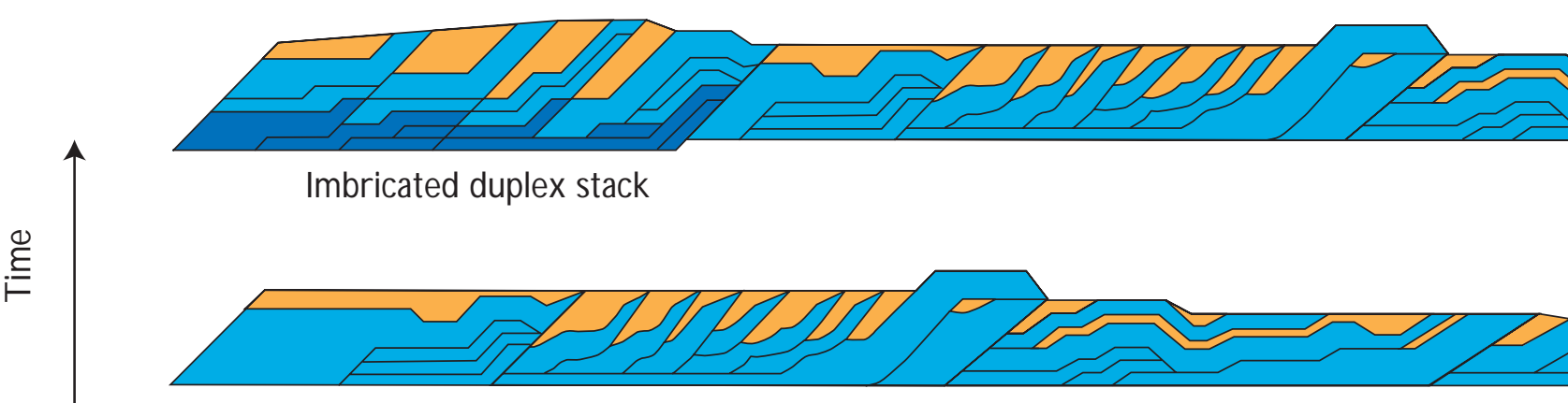

Duplex stack

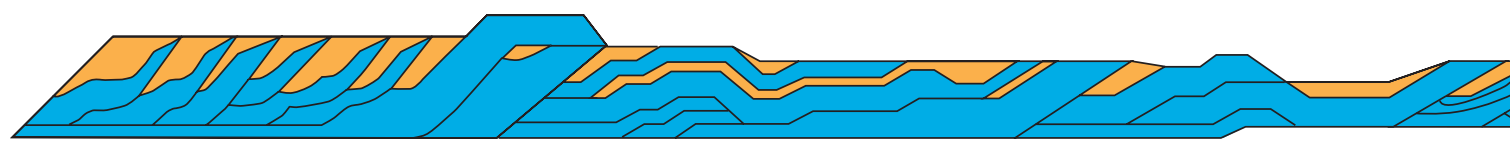

Imbricate fan

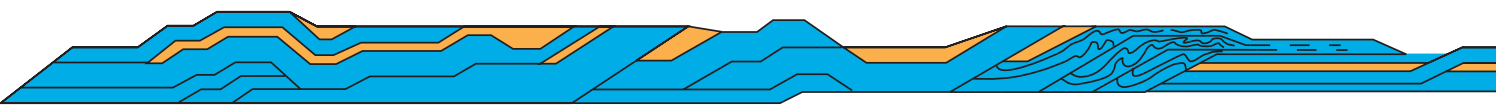

Antiformal stack

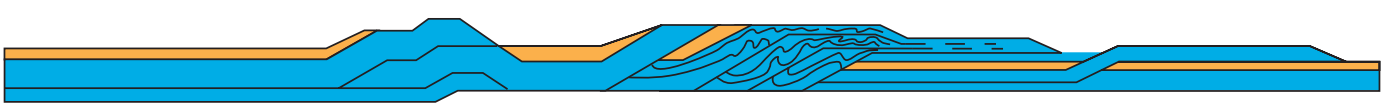

Hanging-wall anticline

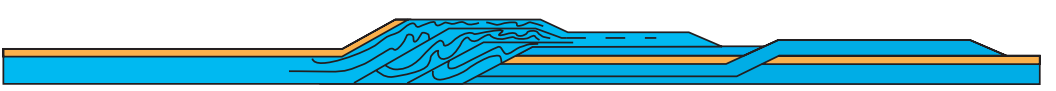

Duplex folds at ramp collapse

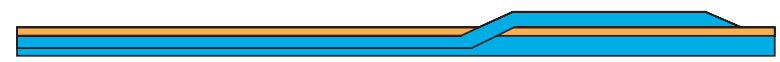

N

Foreland translated thrust sheet

\section{Distance}

Fig. 124. Model of thrust-fault structure types formed during the progressive deformation of the thin-skinned glaciotectonic thrust-fault complex. The model outlines a progressive development in eight steps resulting in the formation of eight characteristic thrust-fault structure types, the first to develop earliest and continuously in the distal part of the complex, and the last to be formed in the most proximal part of the complex (see text for details). 

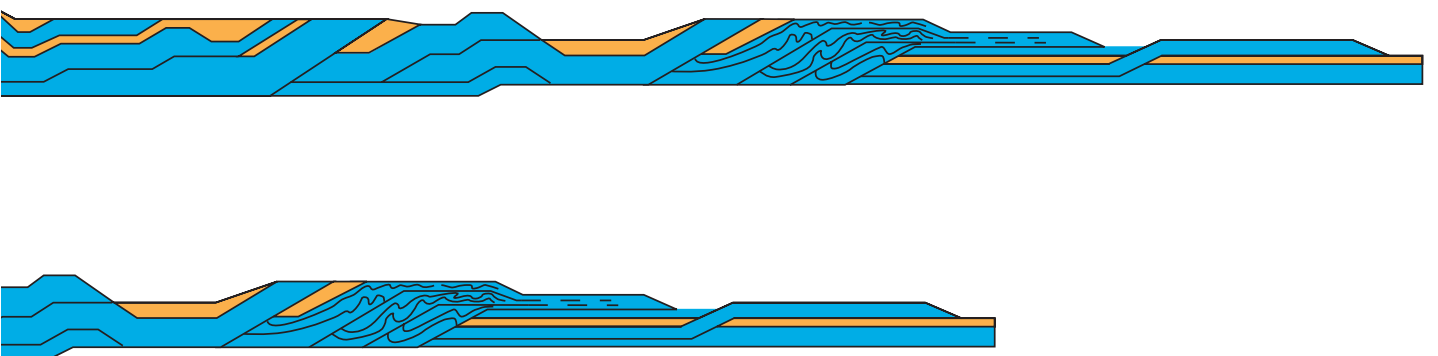

Rubjerg Knude Formation

Lønstrup Klint Formation

Stortorn Formation 


\section{Discussion}

The observations that form the basis for the description of the structural geology, mechanical behaviour and dynamic development of the Rubjerg Knude Glaciotectonic Complex, raise important questions with respect to understanding the framework and nature of thin-skinned thrusting related to glacial deformation; seven topics have been selected for further discussion below. The basis for understanding a structural complex is to describe the tectonic architecture and the range of structures it contains from microscopic to macroscopic scale. The discussion of thrust-faultarchitecture leads to evaluation of the reliability of the balanced cross-section. Consideration of thrust brecciation and diapirism leads naturally to a focus on the thrustfault dynamics, and the significance of the rate of deformation. The dynamics associated with the syntectonic deposits and the formation of piggyback basins merit discussion, as does the interpretation of a proglacial contra subglacial deformational setting. The final topic deals with the geological setting of the complex, including the timing of the event that created it.

\section{Thrust-fault architecture}

A prerequisite for understanding the thrust-fault architecture is a familiarity with the terminology (see Appendix 2). The macroscopic structures encountered in thin-skinned orogenic beltsareall recognisable in the glaciotectonic complex. Mesoscopic structures such as folds and faults are similarly recognisable. However, small-scale structures such as joints, cleavage and fabric are more difficult to recognise (except for hydrodynamic brecciation), and this may be one of the major differences between soft sedimentary deformation and hard-rock deformation.

It seems likely that joints and fractures in soft sediments would be able to re-heal after deformation. Thus, a large number of minor reverse faults must have formed in thrust sheets during ramp propagation (Fig. 67), but appear to have disappeared again after subsequent thrust sheet propagation along the flat, as they havenotbeen observed with the exception of the in situ positions related to ramp bend (Fig. 85). There is an approximation to a right-angle relationship between the footwall ramp and the back-thrust faults, which indicates that an increase in the dip of the footwall ramp results in a decrease in the dip, in the opposite direction, of the back thrust. Moreover, a steeper and higher footwall ramp also corresponds to an increase in displacement along the back-thrust fault. Thus one can regard the KR01 (Kramrende) back-thrust faults as structures related to initial faulting in the progressive deformation (Fig. 67), and the KR04 back-thrust splay faults as a structural element related to a developed phase of progressive thrust-fault deformation (Fig. 72). Major back thrusting at the back of SR02 (Fig. 84) represents a mature phase in the progressive thrust faulting. The apparent lack of joints and fractures reflecting ramp propagation could probably be explained as having been absorbed in the hydrodynamic brecciation process.

Among the structural elements analysed during the interpretation of the balanced cross-section, the duplex structures create the most interesting problems. Firstly, the interpretation of the duplex imbricates in the Stensnæs Section provides an explanation for the complicated fold framework. Secondly, the interpretation of the duplex below the frontal part of the Stortorn Section links the hidden duplex segments at the base of the Grønne Rende Section with the duplex stacking below ST01-ST03. Thirdly, the normal faults can be interpreted to have been related to the ramping of lower duplex segments. If the normal faults are regarded as foreland-dipping faults or part of a foreland-dipping duplex, the model for duplex formation suggested by Contreras \& Sutter (1997) may be relevant for the understanding of the foreland-dipping faults. In their model for formation of foreland- or hinterland-dipping duplexes, they considered two factors: $\mathrm{u}=$ distance of displacement along the upper flat, and $s=$ length of duplex segment. In a regime where the ratio $\mathrm{u} / \mathrm{s}$ is greater than one $(\mathrm{u} / \mathrm{s}>1)$, foreland-dipping duplexes are formed; in a regime where $\mathrm{u} / \mathrm{s}<1 / 2$, hinterland-dipping duplexes are formed. In regimes where $1 / 2<\mathrm{u} / \mathrm{s}<1$ or $\mathrm{u} / \mathrm{s}=1$, antiformal stacks or angular antiformal stacks, respectively, are formed. This corresponds well to the interpretation presented here of the Rubjerg Knude cross-section, where most thrust sheets are displaced by less than their length, and consequently the main orientation of thrust sheets is hinterland dipping. According to the model of Contreras \& Sutter (1997), foreland-dip- 
ping duplexes are formed when a duplex segment is displaced along an intermediate or upper flat for a distance equal to, or more than, its length. A consequence of this is that a roofing thrust sheet will be displaced in front of the foreland-dipping upper footwall flat, where nomal faulting will take place. This is interpreted to be the case for the normal faults in the Martørv Bakker and Brede Rende Sections (see Fig. 66). The normal fault developed in the Stenstue Rende Section may also be regarded as an expression of the latter regime in the suggested model. A foreland-dipping feature may well reflect the foreland-dipping limb of a hanging-wall anticline formed above a laterally displaced hanging-wall ramp. However, the normal fault-displaced thrust sheet must be thrust over the duplex segmentbefore it was thrust faulted together with its roofing thrust sheet, and then as translation continued attached to the hanging-wall flat until the displacement was concluded by the normal faulting over the tip of the duplex segment.

The consideration of duplex formation naturally leads to a focus on the changes in décollement levels. When a duplex segment is formed, there would normally be an early décollement surface at a shallow level, succeeded by a shift to a deeper level connected with a new footwall ramp. The upper décollement level (the $10 \mathrm{~m}$ level or corresponding gently dipping ramp to the leading edge) was probably the first to be formed in the proximal part of the complex and probably also the last to form in the distal part (Fig. 124). From the cross-section, it is indicated that the $10 \mathrm{~m}$ décollement level extended for about $1 \mathrm{~km}$, but ended up with a distance of only $600 \mathrm{~m}$. The $20 \mathrm{~m}$ décollement level was the next to take over, and during the establishment of a related ramp, footwall ramp imbrication progressed, modifying the ramp transition connecting the two décollement levels. The length of this décollement level might have been of the same scale, but only c. $400 \mathrm{~m}$ is preserved as a lower footwall flat. The $30 \mathrm{~m}$ flat level is the dominant décollement level extending from the middle of the Martørv Bakker Section to the middle part of the Stortorn Section, where finally the $40 \mathrm{~m}$ décollement level was developed. Note that the present-day position of the lowermost décollement surface is at about $45 \mathrm{~m}$ b.s.l. due to the regional, very gentle dip to the north of the L/R-unconformity that serves as the reference level, corresponding to the $0 \mathrm{~m}$ flat level. From the cross-section, it can be seen that the dips of the ramps increase from gentle $\left(5-15^{\circ}\right)$ in the zone between the upper surface flat to the $10 \mathrm{~m}$ flat level, to $25^{\circ}$ dips between the 10 and $20 \mathrm{~m}$ levels, and reaching up to $35^{\circ}$ between the 20 and $30 \mathrm{~m}$ flat levels. The ramp dips with steeper angles in the cross-section, arise from over-steepening or superimposed tilting during ramp propagation (Fig. 9). Thus, in the proximal part of the complex, dips between $35^{\circ}$ and $45^{\circ}$ are interpreted as the primary dips of ramps rooting down to the deepest décollement level at $40 \mathrm{~m}$, which is incorporated in the model for the fold-imbricate duplex units. The increasing dips of ramps are interpreted to have resulted from the increase in fracture angle as a function of increase in normal stress (change of levels) and increase in shear stress (increasing force required to move thrust sheets). This is implied from the shape of the Mohrenvelope in the Mohr diagram (Hobbs et al. 1976), and itissuggested to be a basic relationship for glaciotectonic fracture and faultdeformation(Pedersen 1996).

\section{Balanced cross-section}

In the balanced cross-section, the changes in dip angles are responsible for the insertion of a number of small triangular-shaped duplex segments, which are incorporated in the geometric construction and annotated as splints (horses) (Plate 2). It is not known how many splints exist in reality. A few have been recognised as structural identities (KR01 ${ }_{\mathrm{S}}$ in Kramrende), but it is likely that space deficits or excesses have been absorbed in mud-mobilisation or differential small-scale anastomosing fracturing. Differential fracturing and thrust-fault formation with a spacing of only $1 \mathrm{~m}$ has been documented in the Moserende Section (Fig. 27), indicating that the duplex segmentation does exist. Hence it is probable that a much more differential translation to ok place than is indicated in the crosssections of the dynamic model of thrust-fault propagation (Fig. 112).

The reliability of the approximations in construction inherent in a balanced cross-section is founded in the area balance. The main calculation of the balance indicates that the shortening amounts to approximately $50 \%$, with $\mathrm{L}_{0}=12 \mathrm{~km}$ and $\mathrm{L}_{1}=6 \mathrm{~km}$. The area of the $\mathrm{L}_{0}$ cross-section ( $\mathrm{L}_{0}$ multiplied by stratigraphic thickness) amounts to $340000 \mathrm{~m}^{2}$, and the area of the $\mathrm{L}_{1}$ cross-section ( $\mathrm{L}_{1}$ multiplied by measured thickness of the retrodeformed cross-section) is $382500 \mathrm{~m}^{2}$. The difference amounts to $11 \%$, which is interpreted as a consequence of the erosion of the thrust sheets in the proximal part of the complex (Grønne Rende Section - Ribjerg Section). The detailed calculations of areas 
for the area balance are summarised in Table 1, and documented in Plates 2A and 2B. The amount of erosion indicated from the area balance differs markedly from the 80\% erosion estimate by Gry (1941), and supports the argument that Gry's cylindrical thrust-fault model was incorrect.

Considering the amount of erosion, the question arises: why is the preservation potential so great? Three factors are suggested here to answer this: (1) the steeply orientated thrust sheets were partly packed by the sand fill in the piggyback basins, (2) the thrust-fault deformation resulted in a strain hardening that consolidated the complex, and (3) as the sole of the approaching ice sheet advanced across the proximal part of the complex, the over-pressured pore water migrated from the hanging-wall ramps and flats of the thrust sheets to the hanging-wall flat of the ice sheet, facilitating the over-thrusting of the footwall block which subsequently comprised the thrust-fault complex.

\section{Thrust brecciation and diapirism}

In order for a thrust sheet to move, a fracture must be created that can develop into a plane of thrusting. The initial fracture is fomed when the failure limit is reached in a system subjected to pressure (loading and lateral compression). A recurring question, and an apparent conflict in reasoning, is why fault planes develop, leaving the rest of the thrust sheet preserved? Since the sedimentary unit forming a thrust sheet is subjected to the same amount of confining pressure, it might be expected that a muddy mass of collapsed sedimentary units just as well could have been the result?

It is well known that an increase in pore-water pressure results in failure and initialisation of fractures along surfaces of anisotropy, as described for orogenic systems by Hubbert \& Rubey (1959). However, in soft sedimentary deformation with lower confining pressure and smaller shear strength, as well as smaller coefficient of internal friction, the limits of fracture formation and complete collapse are much narrower. The structures developed in the Ulstrup Section reflect these conditions. The anastomosing jointing and mud mobilisation at the tip of the UL01 thrust sheet reflect the stage of near collapse (Fig. 49). The thick zone of hydrodynamic brecciation along the hangingwall flat reflects the same tendency towards collapse, and speculations about the influence of ground-frozen conditions on the preservation of the thin thrust sheets during translation over the foreland are relevant. Ground-frozen conditions are interpreted to have affected that part of the thrust sheets elevated above the ground surface; the freezing of the sediments in the thrust sheet may result in more brittle behaviour, whereby cracks formed (Figs 44, 46). However, due to the high pore pressure maintained along the hanging-wall flat, the cracks were filled with sand pumped into the cracks by the over-pressured pore water from the base of the thrust sheet.

Hydrodynamic brecciation is evidently related to the hanging-wall ramp-and-flat. Brecciation was initiated at an episedimentary stage with the formation of ball-and-pillow structures due to sediment loading. When the loading increased by over-thrusting, the ball-and-pillow formation progressed further and hydrodynamic brecciation was concentrated at the hanging-wallflat. Small-scale mud diapirism took place, with chaotic folding developing into polydiapirs (Figs $54,55,77,78,86,88)$. Polydiapirism and mud-mobilisation are considered to have developed simultaneously and with an increasing degree of disordering and size of diapir in progressive stages of deformation. Many of the mesoscopic diapir structures recognised in the Rubjerg Knude Glaciotectonic Complex can be compared with the multi-wavelength gravity structures described in the model analysis by Weinberg \& Schmeling (1992). The formation of large-scale diapirs is suggested to have been related to thrustfault deformation of a deep-seated hanging-wall flat that propagated up to surface level along a set of relatively steep footwall ramps. During propagation up along a lower ramp to an intemediate flat, and ramping from the $20 \mathrm{~m}$ intermediate flat level to the $10 \mathrm{~m}$ flat level, polysequential hanging-wall anticlines formed, and were subsequently destroyed by mudmobilisation initiated from the deep-seated thrust zone of the hanging-wall flat. Some of the soft sedimentary xenoliths floating in the mud diapirs can be viewed as relicts of anticline crests (Fig. 74). Staircase-like ramp propagation is indicated for the Kramrende diapir and the Sandrende diapir, but is not so obvious in the case of the Brede Rende diapir. Intrusive remobilised mud is evidently related to the footwall ramp propagated hanging-wall flat of GR01, and the mud mobilisation in the thrust sheets of the Stortorn and Moserende Sections are all easily identified with sequential ramping from the deepest décollement level. 


\section{Thrust-fault dynamics}

The difference in thrust-fault development that relates to the upper flat level $(10 \mathrm{~m})$ is very marked when the Ulstrup Section is compared to the Grønne Rende Section. Thus the foreland regime in the latest stage of deformation is characterised by thin, very long sheets subjected to horizontal translation over the footwall flat of the foreland. In contrast, the Grønne Rende Section probably fomed an imbricate complex of smaller, moderately dipping thrust sheets when this section was adjacent to the foreland. There is no obvious reason for this difference, although minor differences in lithology and differences in environmental conditions (frozen or unfrozen ground) could be viewed as contributing factors. However, there is an invisible condition which must be considered, namely the velocity of deformation. At the initiation of any deformation, the velocity is zero; the velocity then increases until the displacement is brought to a halt at the edge of the foreland during decreasing velocity. Fast deformation results in more fractures than slow deformation. It is therefore suggested that the imbricate structures in the central part of the thrust-fault complex were initiated during the fastest advance towards the foreland and that the long-distance translation of unbroken thrust sheets relates to decreasing velocity or slow advance.

In a discussion of the velocity of thrust-fault propagation, the question of rates and timing is inevitable. Theyoungest dating of the Stortorn Formation is 30000 years B.P., while the oldest dating of the Rubjerg Knude Formation is about 29000 years B.P. and the oldest dating of the Ribjerg Formation is 26000 years B.P. Thus, a time span of 3000 years is estimated for the calculated shortening of $6 \mathrm{~km}$, which indicates an average velocity of $2 \mathrm{~m}$ per year.

The peak velocity of the deformation must evidently have been more than $2 \mathrm{~m}$ per year, taking into account the acceleration and deceleration. However, the velocity would also have been much higher if deformation had progressed in periodic steps rather than continuously. A step-like process would have involved periods of no movement alternating with higher velocity in the periods of advance. With respect to the Rubjerg Knude Glaciotectonic Complex, the summary of the dynamic development suggests that a continuous progressive deformation process characterised the formation of the complex (Fig. 123). Although the developments of the sections are described separately above, the deformational overlap from one section to thenextlinks the sections in a continuous dynamic development.

\section{Syntectonic deposition}

The concept of piggyback basins was originally related to large-scale regionalorogenic settings (Ori \& Friend 1984; Ricci Lucchi 1986). However, as applied here the term is used for the syntectonic deposits of the Rubjerg Knude Formation that were laid down in basins structurally overlying moving thrust sheets. The initial depositional environment of the Rubjerg Knude Formation was a relatively flat lowland, dominated by shallow lakes in an outwash plain bounded by an ice margin to the north. The plain was probably gently dipping towards the north due to isostatic loading of the ice cap. Judging from the variation in thickness of the Rubjerg Knude Formation (30 $\mathrm{m}$ in the proximal part to only about $10 \mathrm{~m}$ in the distal), the dip of the plain was not more than $2^{\circ}$.

As the thrust belt propagated southwards, the plain became separated into smaller, more or less isolated basins characterised by steep slopes and uneven relief. The most distinctive deposits in these basins are the sedimentary breccias and slumped thrust sheets derived from the tips of up-thrust thrust sheets.

Three types of syntectonic slump/slide deposits can be differentiated. The first type involves deposition of coarse clasts up to metre size, which were rotated indicating transport as sedimentary clasts enveloped by sandy mud. This deposit type is regarded as being related to the distal part of the thrust-fault system, and is exemplified by the piggyback basin in the Stensnæs Section (Fig. 56). The second type is characterised by isoclinally folded slump sheets interlayered with matrix-supported coarse clastic diamictite. This indicates that the source was very close to the depocentre, although the slump sheets were detached from their roots and were transported independently by gravity gliding into the basin. The piggyback basin in the Martørv Bakker Section represents this deposit type (Figs 23, 64). The third type comprises slump-folded sheet segments that can be traced directly, or correlated over short distances, back to the source of the thrust sheet; this type is regarded as being related to the proximal part of the system. The next step in the development would be that of thrust sheets displaced by normal faulting, but lacking depositional features such as sedimentary breccias. However, this type of dynamic development is strictly tectonic. The major 
slump fold occurring in the Stenstue Rende Section (Fig. 89) may be regarded as a transition from a sedimentary to a tectonic regime. The deposition of recognisable thrust-sheet tips in the piggyback basins supports the concept of a continuous thrust-fault process.

\section{Proglacial and subglacial deformation}

Glaciotectonic analyses distinguish between deformation generated in proglacial and in subglacial regimes (Aber 1982; Croot 1988; Aber etal. 1989; Pedersen 1993, 1996, 2000). It has already been argued that the thinskinned thrust-fault deformation of the Rubjerg Knude Glaciotectonic Complex is an example of proglacial deformation. Thekey evidence for this is the presence of intimately associated syntectonic piggyback basins. These basins must have been situated in front of the ice margin, with sedimentation taking place under open water, simultaneously with thrust-fault propagation.

However, the subglacial deformation is represented locally by the $1 \mathrm{~m}$ thick glacitectonite occurring below the glaciotectonic unconformity that truncated the thrust-fault complex. This is found in the glaciolacustrine beds at the top of the UL02 thrust sheet in the northern part of the Ulstrup Section. It can be argued that here the subglacial defomation penetrated down a depth of c. $5 \mathrm{~m}$ below the glaciotectonic unconformity. Mud diapirism and hydrodynamic brecciation occurred in this setting, probably caused by loading when the ice sheet overrode the sediments. The focus of subglacial deformation is at the Blå-unconformity (Fig. 32). In the northernmost $300 \mathrm{~m}$ of the cross-section, the effects of mud mobilisation increase to a point at which primary sedimentary as well as early structural features are completely destroyed. This phase of deformation is interpreted to have taken place while the sole of the frontal part of the ice sheet was fixed to the trailing end of the thrust-fault complex. This also implies that the velocity of the thrust faulting was equal to the advance of the ice sheet. The advance of the ice-sheet load corresponds to the mechanics of gravity spreading (Pedersen 1987). The increasing propagating stress resulted in increasing mud mobilisation, and subsequently the overpressure was transmitted laterally by the mud fluid towards the foreland. The mechanism might well be compared to squeezing toothpaste out of its tube.

At a certain stage, the fluid pressure was released, probably due to migration of all the hydrodynamic breccias, and the mobilised mud consolidated. Sub- sequent to consolidation, the frontal sole of the icesheet released contact with the Blå-unconformity and propagated over the thrust-fault complex formed in the foreland of the ice margin. During this process, subglacial shearing affected the top of the structureless consolidated mud, and anastomosing as well as plane-parallel shear fractures were formed (Fig. 32).

In soft sediment structural geology, the gravityspreading model has been successfully applied to the geological setting of the mud lumps in the Mississippi Delta (Morgan et al. 1968; Pedersen 1987; Aber et al. 1989). It could therefore be suggested that a gravityspreading model due to clastic progradation might be the deformation mechanism. However, there is no known delta setting at this time/place that could have provided the basis for this model, and furthermore, the sand units observed here only reach a third of the thickness of the $100 \mathrm{~m}$ delta-sand units in the Mississippi Delta setting. Finally, the presence of the glaciotectonic unconformity and related glacitectonite is incompatible with a sand sediment-spreading process.

Although a delta setting has not been documented, it might be suggested that a slope similar to that of a megascopic delta foreset existed, and that the deformation was caused by major gravity gliding on this slope, or was simply due to uplift in the hinterland. However, this is not considered likely. The isostatic rebound documented from the elevation of the Vendsyssel Formation reaches $60 \mathrm{~m}$ a.s.l. To this must be added the uplift due to the lowering of sea level; the area in the hinterland was thus an area of subsidence rather than uplift. Structurally, a gravity-gliding model would provide extensional normal fault systems in the trailing end of the thrust-fault complex (Pedersen 1987). This is not compatible with the observed increase in compressional structures in the hinterland, as documented in the cross-section and indicated by the balanced cross-section; a gravity-gliding model for the complex can therefore be rejected.

Such larger glaciotectonic complexes are often so impressive that some geologists suggest that they were formed by orogenic activity (Lykke-Andersen 1992; K. Binzer, personal communication 1997). Disregarding the obvious glacial geological indications, there are two features that distinguish glaciotectonic complexes from basement-involved deformation: (1) the superficial detachment, and (2) the rate of translation. In the Rubjerg Knude Glaciotectonic Complex, there are no infracrustal rocks involved and the thrust sheets are not rooted down into a deep-seated hinterland source. The lowermost detachment level is $40 \mathrm{~m}$ be- 
low the reference level, which is more or less coincident with present sea level, and there are no indications that the deformation extended below the $40 \mathrm{~m}$ level. The velocity of thrust-sheet motion in orogenic mountain ranges is of the order of $1 \mathrm{~cm}$ per year (Wiltscko \& Dorr 1983). In glaciotectonic systems, the velocity can be up to 100 times as fast, as documented by the velocity estimate of $2 \mathrm{~m}$ per year for the $\mathrm{Ru}$ bjerg Knude Glaciotectonic Complex.

\section{Glacial geological conditions}

The Rubjerg Knude Glaciotectonic Complex is interpreted to have formed due to the advance of the Norwegian Ice in the late Middle Weichselian. The Norwegian Ice melted back at the beginning of Late Weichselian time and was succeeded by a renewed advance of the Scandinavian Ice Sheet from central Sweden. In that part of Denmark east and north of the Main Stationary Line (Figs 1, 12), the direction of this advance was towards the south-west and the advance is thus referred to as the NE-Ice (Houmark-Nielsen 1987). The eastward advance of this ice towards Vendsyssel probably formed the N-S-trending hilly landscape named Jyske Ås, the formation of which was contemporaneous with deposition of the outwash plain represented by the Ribjerg Formation. When the NE-Ice advance reached the Rubjerg Knude Glaciotectonic Complex, it only resulted in minor superimposed deformation. The oblique orientation of the fold axis of the megaslump in the Stenstue Rende Section might be due to such superimposed deformation, but in general very few glaciotectonic disturbances can be related to the NE-Ice advance. That overriding by the NE-Ice had so little effect may be attributed to strain hardening due to the preceding deformation, or the smoothing out of the landscape by the former glaciotectonic unconformity, which would facilitate the second overriding of the complex. Ground-frozen conditions could also have been a factor, since this would have prevented drainage from the ice sheet through the substratum, resulting in high pore-water pressures at the sole of the ice. The effect of this would have been to facilitate easy and fast propagation over the complex, although it by then formed a hill in the landscape.

The Norwegian Ice produced a hill-and-hole pair with Rubjerg Knude as the hill and the depression extending from Lønstrup northwards as the hole. Immediately after the melting back of the NE-Ice, the landscape was covered by the Vendsyssel Formation. A contour map of the base of the Vendsyssel Formation (Fig. 125) thus provides a picture of the geomorphology of the young glacial landscape unaffected by the succeeding 15000 years of erosion. In Fig. 125, the hill-and-hole pair is readily identified and the general E-W morphological trends are well represented. To the east, this trend is truncated by a strong SE-NW hill-and-hole geomorphology, related to the NE-Ice. The trend of the thrust-fault belt of the Rubjerg Knude Glaciotectonic Complex can be followed from the coastline to the east for about $2.5-5 \mathrm{~km}$. The eastern fringe of the complex has been eroded down to sea level, probably by the NE-Ice, and subsequently concealed by the Vendsyssel Formation. 


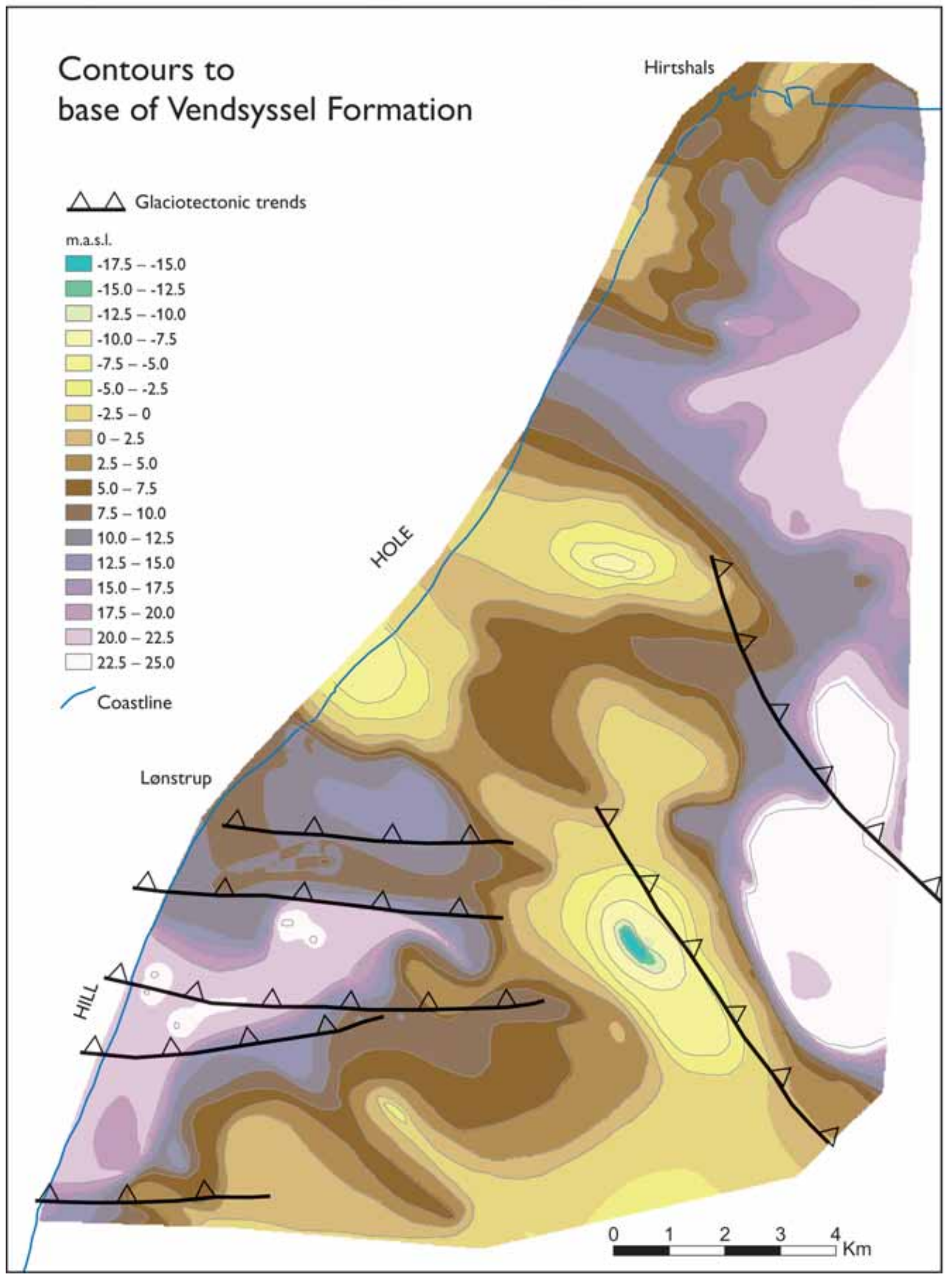




\section{Conclusions}

Structural analysis of the Rubjerg Knude Glaciotectonic Complex, based on detailed photogrammetric measurements and field investigations, provides a geological cross-section through a low-friction thrustfault system. Interpretation of the entire thrust-fault architecture included unexposed parts of the complex, and is based on the construction of a balanced crosssection. A model for the dynamic development demonstrates that deformation progressed continuously and involved formation of duplexes and mud diapirs. Although the thrust-fault structures were formed in a proglacial regime related to the advance of the Norwegian Ice (30 000 - 26000 B.P.), the structures can be viewed as representing an almost complete model of thin-skinned thrust-fault systems.

For descriptive purposes, the complex is subdivided into 13 sections, which demonstrate the structural development from a proximal to a distal position in the thrust-fault system. Investigation of these sections provided the following main conclusions.

1. The structural elements in the Rubjerg Knude Glaciotectonic Complex comprise ramps and flats related to hanging-wall and footwall positions, respectively. Hanging-wall anticlines and footwall synclines were formed due to thrust-fault propagation. Back-thrust faults were formed during upper ramp-hinge propagation, and an irregular fold framework developed in relation to sequential duplex imbricate formation during footwall ramp collapse. Foreland-dipping normal faults were formed in relation to translation of duplex segments.

2. From the balanced cross-section, the shortening during thrust-fault deformation is calculated to have been c. $50 \%$. About $11 \%$ of the initial stratigraphic unit subjected to thrust faulting is estimated to have been lost due to erosion. The décollement zone was at its deepest position $(40 \mathrm{~m})$ in the proximal

\section{Facing page:}

Fig. 125. Contour map of the pre-Vendsyssel Formation landscape; for location, see Fig. 13. Note the depression north of Lønstrup which represents the hole in the hill-and-hole pair morphology of a glaciotectonic complex; the corresponding hill is represented by the high at Rubjerg Knude. The map isbased on data from theGEUS well database and from Plate 1. sections, becoming shallower towards the foreland. Stacking ofduplex segments is correlated with space problems created in the subsurface due to initial displacements at the upper levels. Stacking of duplex segments correlates well with the elevation of the reference level in the system.

3. Hydrodynamic brecciation was dominantly related to the hanging-wall ramps and flats. Polydiapirism and mud mobilisation characterise the thrust zones. Mud mobilisation resulted in the formation of larger mud diapirs, and preferentially evolved during hanging-wall propagation from the décollement level up above sets of intermediate and upper footwall ramps.

4. Syntectonic deposition took place in piggyback basins overlying the thrust sheets. Thrust sheets exposed to erosion provided sediment to the basins, and in some cases major lumps derived from the tips of thrust sheets slumped and slid as megablocks into the piggyback basins.

5. The thrust-fault deformation was caused by gravity spreading at the front of an advancing ice sheet. Over-pressured mud formed an important part of the stress transfer. The average velocity of the thrust-fault displacement is estimated to have been $2 \mathrm{~m}$ per year. A $40 \mathrm{~m}$ thick succession of flat-lying sediments, extending for $12 \mathrm{~km}$, was compressed into a thrust-sheet complex that was $6 \mathrm{~km}$ in length and up to $80 \mathrm{~m}$ thick.

\section{Acknowledgements}

The Geological Survey of Denmark and Greenland is thanked for supporting this project during the last 10 years. Initial investigations were carried out while the author held a senior stipend at the Geological Institute, University of Copenhagen. The Carlsberg Foundation supported the project with a one year research grant, which is gratefully acknowledged; the Danish Research Agency is thanked for financial support for printing this bulletin. Keld Dueholm and the Institute of Survey and Photogrammetry are thanked for their co-operation and willingness to provide time and fa- 
cilities at the photogrammetric instrument at the Technical University of Denmark.

Frants von Platen-Hallermund is thanked for assistance with the ARC-INFO transformation and ARC-VIEW editing, which provided the graphic display of Plates 1 and 2. Alice Rosenstand and Benny M. Schark helped in drafting the figures, and the staff of the Graphic
Section at GEUS are thanked for technical support.

I am indebted to A.K. Higgins for reading the first draft of this manuscript, to two anonymous referees and the editor, Jon R. Ineson, for their constructive and helpful comments on the manuscript, and to my wife, Gunver K. Pedersen, for support and inspiring discussions during the progress of this work.

\section{References}

Aaris-Sørensen, K. 1995: Palaeoecology of a Late Weichselian vertebrate fauna from Nørre Lyngby, Denmark. Boreas 24, 355-365.

Aaris-Sørensen, K. \& Petersen, K.S. 1984: A late Weichselian find of polar bear (Ursus maritimus Phipps) from Denmark and reflections on the paleoenvironment. Boreas 13, 29-33.

Aber, J.S. 1982: Model for glaciotectonism. Bulletin of the Geological Society of Denmark 30, 79-90.

Aber, J.S. (ed.) 1993: Glaciotectonics and mapping glacial deposits. Canadian Plains Proceedings 25(1), 310 pp. Canadian Plains Research Center, University of Regina, Canada.

Aber, J.S., Croot, D.G. \& Fenton, M.M. 1989: Glaciotectonic landforms and structures. In: Bentley, C.R. (ed.): Glaciology and Quaternary geology, 200 pp. Dordrecht: Kluwer Academic Publishers.

Abrahamsen, N. \& Readman, P.W. 1980: Geomagnetic variations recorded in older ( $>$ or $=23000$ B.P.) and younger Yoldia Clay (approximately 14000 B.P.) at Nørre Lyngby, Denmark. Geophysical Journal of the Royal Astronomical Society 62(2), 329-344.

Bahnson, H., Petersen, K.S., Konradi, P.B. \& Knudsen, K.L. 1974: Stratigraphy of Quaternary deposits in the Skærumhede II boring: lithology, molluscs and foraminifera. Danmarks Geologiske Undersøgelse Årbog 1973, 27-62.

Banham, P.H. 1977: Glacitectonites in till stratigraphy. Boreas 6, 101-105.

Banham, P.H. 1988: Thin-skinned glaciotectonic structures. In: Croot, D.G. (ed.): Glaciotectonics: forms and processes, 2125. Rotterdam: A.A. Balkema.

Bard, E., Arnold, M., Fairbanks, R.G. \& Hamelin, B. 1993: ${ }^{230}$ Th${ }^{234} \mathrm{U}$ and $14 \mathrm{C}$ ages obtained by mass spectrometry on corals. Radiocarbon 35, 191-199.

Bendsen, N. 1981: Rubjerg Knude Fyr fra 1899 til 1980. Vendsyssel nu og da 1981, 5, 6-21. Hjørring, Denmark: Vendsyssel Historiske Museum.

Bennett, M.R. 2001: The morphology, structural evolution and significance of push moraines. Earth-Science Reviews 53, 197236.

Berthelsen, A. 1973: Weichselian ice advance and drift succes- sions in Denmark. Bulletin of the Geological Institute, University of Uppsala, New Series 5, 21-29.

Berthelsen, A. 1975: Lærebog for den lille tektoniker, 202 pp. Copenhagen: Varv.

Berthelsen, A. 1978: The methodology of kineto-stratigraphy as applied to glacial geology. Bulletin of the Geological Society of Denmark 27, 25-38.

Berthelsen, A. 1979: Recumbent folds and boudinage structures formed by subglacial shear: an example of gravity tectonics. Geologie en Mijnbouw 58, 253-260.

Boulton, G.S. 1986: Push-moraines and glacier-contact fans in marine and terrestrial environments. Sedimentology 33, 677698.

Boulton, G.S. \& Hindmarsh, R.C.A. 1987: Sediment deformation beneath glaciers: rheology and geological consequences. Journal of Geophysical Research 92, 9059-9082.

Boyer, S.E. \& Elliott, D. 1982: Thrust systems. American Association of Petroleum Geologists Bulletin 66, 1196-1230.

Bucher, W.H. 1956: The role of gravity in orogenesis. Geological Society of America Bulletin 67, 1295-1318.

Cheel, R.J. \& Rust, B.R. 1986: A sequence of soft-sediment deformation (dewatering) structures in Late Quaternary subaqueous outwash near Ottawa, Canada. Sedimentary Geology 47, 77-93.

Contreras, J. \& Sutter, M. 1997: A kinematic model for the formation of duplex systems with a perfectly planar roof thrust. Journal of Structural Geology 19, 269-278.

Croot, D.G. 1987: Glaciotectonic structures: a mesoscale model of thin-skinned thrust sheets? Journal of Structural Geology $\mathbf{9}$, 797-808.

Croot, D.G. 1988 (ed.): Glaciotectonics: forms and processes, 212 pp. Rotterdam: A.A. Balkema.

Dahlström, C.D.A. 1969: Balanced cross sections. Canadian Journal of Earth Sciences 6, 743-757.

Dennis, J.G. 1972: Structural geology, 532 pp. New York: Ronald. Dreimanis, A. 1988: Tills: their genetic terminology and classification. In: Goldthwait, R.P. \& Matsch, C.L (eds): Genetic classification of glacigenic deposits, 17-84. Rotterdam: A.A. Balkema. 
Dueholm, K. 1992: Geologic photogrammetry using standard small-frame cameras. In: Dueholm, K. \& Pedersen, A.K. (eds): Geological analysis and mapping using multi-model photogrammetry. Rapport Grønlands Geologiske Undersøgelse 156, 7-17.

Ehlers, J. (ed.) 1983: Glacial deposits in North-West Europe, 470 pp. Rotterdam: A.A. Balkema.

Erickson, S.G. \& Jamison, W.R. 1995: Viscous-plastic finite-element models of fault-bend folds. Journal of Structural Geology 17, 561-573.

Fairbanks, R.G. 1989: A 17000 year glacio-eustatic sea level recond: influence of glacial melting rates on the Younger Dryas event and deep-ocean circulation. Nature 342, 637-642.

Fredericia, J. 1982: Geologisk basisdatakort, 1:50.000, map sheet 1318 I, Skagen. København: Danmarks Geologiske Undersøgelse.

Fredericia, J. 1983a: Geologisk basisdatakort, 1:50.000, map sheet 1217 I, Løkken. København: Danmarks Geologiske Undersøgelse.

Fredericia, J. 1983b: Geologisk basisdatakort, 1:50.000, map sheet 1318 III, Hjørring. København: Danmarks Geologiske Undersøgelse.

Fredericia, J. 1984: Geologisk basisdatakort, 1:50.000, map sheet 1317 I + IV, Brønderslev. København: Danmarks Geologiske Undersøgelse.

Goldthwait, R.P. \& Matsch, C.L. (eds) 1988: Genetic classification of glacigenic deposits, 294 pp. Rotterdam: A.A. Balkema.

Gripp, K. 1929: Glaziologische und geologische Ergebnisse der Hamburgischen Spitsbergen Expedition. Abhandlungen der Naturwissenschaftlichen Verein Hamburg 22, 147-247.

Gry, H. 1940: De istektoniske Fohold i Moleret. Med Bemærkninger om vore dislocerede Klinters Dannelse og om den negative Askeserie. Meddelelser fra Dansk Geologisk Forening 9, 586-627.

Gry, H. 1941: Diskussion om vore dislocerede Klinters Dannelse. Meddelelser fra Dansk Geologisk Forening 10, 39-51.

Hart, J.K. 1990: Proglacial glaciotectonic deformation and the origin of the Cromer Ridge push moraine complex, North Norfolk, England. Boreas 19, 165-180.

Hart, J.K. \& Watts, R.J. 1997: Comparison of the styles of deformation associated with two recent push moraines, south Van Keulenfjorden, Svalbard. Earth Surface Processes and Landforms 22, 1089-1107.

Hobbs, B.E., Means, W.D. \& Williams, P.F. 1976: An outline of structural geology, 571 pp. New York: John Wiley \& Sons, Inc.

Houmark-Nielsen, M. 1987: Pleistocene stratigraphy and glacial history of the central part of Denmark. Bulletin of the Geological Society of Denmark 36, 189 pp.

Houmark-Nielsen, M. 1988: Glaciotectonic unconformities in Pleistocene stratigraphy as evidence for the behaviour of former Scandinavian icesheets. In: Croot, D.G. (ed.): Glaciotectonics: forms and processes, 91-99. Rotterdam: A.A. Balkema.

Houmark-Nielsen, M. 1999: A lithostratigraphy of Weichselian glacial and interstadial deposits in Denmark. Bulletin of the Geological Society of Denmark 46, 101-114.
Houmark-Nielsen, M. 2003: Signature and timing of the Kattegat Ice Stream: onset of the Last Glacial Maximum sequence at the southwestern margin of the Scandinavian Ice Sheet. Boreas 32, 227-241.

Houmark-Nielsen, M., Bennike, O. \& Björck, S. 1996: Terrestrial biotas and environmental changes during the Late Middle Weichselian in North Jutland, Denmark. Bulletin of the Geological Society of Denmark 43, 169-176.

Hubbert, M.K. \& Rubey, W.W. 1959: Role of fluid pressure in mechanics of overthrust faulting. Geological Society of America Bulletin 70, 115-166.

Jaeger, J.C. \& Cook, N. 1979: Fundamentals of rock mechanics, 585 pp. London: Chapman \& Hall.

Jakobsen, P.R. 1996: Distribution and intensity of glaciotectonic deformation in Denmark. Bulletin of the Geological Society of Denmark 42, 175-185.

Jamison, W.R. 1987: Geometric analysis of fold development in overthrust terranes. Journal of Structural Geology 9, 207-319.

Jessen, A. 1899: Beskrivelse til geologisk Kort over Danmark i Maalestok 1:100.000. Kortbladene Skagen, Hirshals, Frederikshavn, Hjørring og Løkken. Danmarks Geologiske Undersøgelse 1. Række 3, 368 pp. +5 maps.

Jessen, A. 1918: Vendsyssels Geologi. Danmarks Geologiske Undersøgelse V. Række 2, 260 pp. + atlas.

Jessen, A. 1931: Lønstrup Klint. Danmarks Geologiske Undersøgelse II. Række 49, 142 pp. + atlas (with summary in English).

Jessen, A. \& Nordmann, V. 1915: Ferskvandslagene ved Nørre Lyngby. Danmarks Geologiske Undersøgelse II. Række 29, $66 \mathrm{pp}$.

Jessen, A., Milthers, V., Nordmann, V., Hartz, N. \& Hesselbo, A. 1910: En Boring gennem de kvartære Lag ved Skærumhede. Danmarks Geologiske Undersøgelse II. Række 25, 175 pp. + atlas.

Johnstrup, F. 1874: Über die Lagerungsverhältnisse und die Hebungs-Phänomene in den Kreidefelsen auf Mön und Rügen. Zeitschrift der deutsche geologische Gesellschaft 1874, 533585.

Johnstrup, F. 1882: Om de geologiske Forhold i den nordlige Del af Vendsyssel. Indbydelsesskrift til Universitetets Aarsfest til Erindring om Kirkens Reformation, 43 pp. + 1 plate (map). Kjøbenhavn.

Kitagawa, H. \& van der Plicht, J. 1998: Atmospheric radiocarbon calibration to $45.000 \mathrm{yr}$ BP: late glacial fluctuations and cosmogenic isotope production. Science 279, 1187-1189.

Klint, K.E.S. \& Pedersen, S.A.S. 1995: The Hanklit thrust fault complex, Mors, Denmark. Danmarks Geologiske Undersøgelse Serie A 35, $32 \mathrm{pp}$.

Knudsen, K.L 1978: Middle and Late Weichselian marine deposits at Nørre Lyngby, northern Jutland, Denmark. Danmarks Geologiske Undersøgelse II. Række 112, 44 pp.

Knudsen, K.L 1994: The marine Quaternary in Denmark: a review of new evidence from glacial-interglacial studies. Bulletin of the Geological Society of Denmark 41, 203-218.

Knudsen, K.L. \& Lykke-Andersen, A.L. 1982: Foraminifera in Late Saalian, Eemian, Early and Middle Weichselian of Skærumhede I boring. Bulletin of the Geological Society of Denmark 30, 97-109. 
Krog, H. \& Tauber, H. 1974: C-14 chronology of Late- and Postglacial marine deposits in North Jutland. Danmarks Geologiske Undersøgelse Årbog 1973, 93-105.

Larsen, E., Sejrup, H.P., Janocko, J., Landvik, J.Y., Stalsberg, K. \& Steinsund, P.I. 2000: Recurrent interaction between the Norwegian Channel Ice Stream and terrestrial-based ice across southwest Norway. Boreas 29, 185-203.

Larsen, G., Jørgensen, F.H. \& Prisholm, S. 1977: The stratigraphy, structure and origin of the glacial deposits in the Randers area, eastern Jutland. Danmarks Geologiske Undersøgelse II. Række 111, 36 pp.

Lykke-Andersen, A.-L. 1971: Foraminifera from the Older Yoldia Clay at Hirtshals. Bulletin of the Geological Society of Denmark 21(2-3), 159-184.

Lykke-Andersen, A.-L. 1987: A Late Saalian, Eemian and Weichselian marine sequence at Nøre Lyngby, Vendsyssel, Denmark. Boreas 16, 345-357.

Lykke-Andersen, A.-L \& Knudsen, K.L.1991: Saalian, Eemian and Weichselian in the Vendsyssel-Kattegat region, Denmark. In: Andersen, B.G. \& Köningsson, L-K. (eds): Late Quaternary stratigraphy in the Nordic countries 150000 - 15000 B.P. Striae 34, 135-140.

Lykke-Andersen, H. 1992: Massebevægelser i Vendsyssels og Kattegats kvartære aflejringer. Dansk Geologisk Forening Årsskrift 1990-91, 93-97.

Madsen, V. 1916: Ristinge Klint. Danmarks Geologiske Undersøgelse IV. Række 1(2), $32 \mathrm{pp.}$

Martinsen, O. 1994: Mass movements. In: Maltman, A. (ed.): The geological deformation of sediments, 127-165. London: Chapman \& Hall.

McClay, K.R. 1992: Glossary of thrust tectonics terms. In: McClay, K.R. (ed.): Thrust tectonics, 419-433. London: Chapman \& Hall.

Medwedeff, D.A. \& Suppe, J. 1997: Multibend fault-bend folding. Journal of Structural Geology 19, 279-292.

Mertz, E.L. 1924: Oversigt over de sen- og postglaciale Niveauforandringer i Danmark. Danmarks Geologiske Undersøgelse II. Række 41, 20 pp.

Milthers, V. 1909: Scandinavian indicator boulders in the Quaternary deposits. Danmarks Geologiske Undersøgelse II. Række 23, $153 \mathrm{pp}$.

Mitra, G. \& Sussman, A.J. 1997: Structural evolution of connecting splay duplexes and their implications for critical taper: an example based on geometry and kinematics of the Canyon Range culmination, Sevier Belt, central Utah. Journal of Structural Geology 19, 503-534.

Morgan, J.P., Coleman, J.M. \& Gagliano, S.M. 1968: Mudlumps: diapiric structures in Mississippi delta sediments. In: Braunstein, J. \& O'Brien, G.D. (eds): Diapirism and diapirs. American Association of Petroleum Geologists Memoir 8, 145-161.

Nielsen, L.H., Johannessen, P.N. \& Surlyk, F. 1988: A Late Pleistocene coarse-grained spit-platform sequence in northern Jylland, Denmark. Sedimentology 35, 915-937.

Nordmann, V. 1928: Marine Aflejringer. In: Madsen, V. (ed.): Oversigt over Danmarks Geologi. Danmarks Geologiske Undersøgelse V. Række 4, 95-99.

Oftedahl, C. 1981: Norges geologi, 171 pp. Trondheim: Tapir.
Ori, G.G. \& Friend, P.F. 1984: Sedimentary basins formed and carried piggyback on active thrust sheets. Geology 12, 475478.

Ozkaya, S.I. 1994: Autofault. A balanced cross section program for modelling thrust faults, $62 \mathrm{pp}$. + disc. Golden, Colorado, U.S.A.: Rockware, Inc.

Pedersen, S.A.S. 1979: Photogrammetric/geological mapping compared with field geological mapping of the area Freja Fjord, central Peary Land, North Greenland. Meddelelser Institute of Surveying and Photogrammetry 10, 174-181. Lyngby, Denmark: Technical University of Denmark.

Pedersen, S.A.S. 1981: The application of computer-assisted photogrammetric methods in the structural analysis of part of the North Greenland Fold Belt. Journal of Structural Geology 3, 253-264.

Pedersen, S.A.S. 1982: Structural analysis of the southern margin of the North Greenland Fold Belt in Peary Land, 230 pp. Unpublished Ph.D. thesis, University of Copenhagen, Denmark.

Pedersen, S.A.S. 1986a: A transverse, thin-skinned, thrust-fault belt in the Paleozoic North Greenland Fold Belt. Geological Society of America Bulletin 99, 1442-1455.

Pedersen, S.A.S. 1986b: Rubjerg Knude. Varv 1986-3, 84-98. København: Københavns Universitet.

Pedersen, S.A.S. 1987: Comparative studies of gravity tectonics in Quaternary sediments and sedimentary rocks related to fold belts. In: Jones, M.E. \& Preston, R.M.F. (eds): Defomation of sediments and sedimentary rocks. Geological Society Special Publication (London) 29, 165-180.

Pedersen, S.A.S. 1988: Glacitectonite: brecciated sediments and cataclastic sedimentary rocks formed subglacially. In: Goldthwait, R.P. \& Matsch, C.L. (eds): Genetic classification of glacigenic deposits, 89-91. Rotterdam: A.A. Balkema.

Pedersen, S.A.S. 1989: Jordartskort over Danmark, 1:200 000, Nordjylland, map 1. København: Danmarks Geologiske Undersøgelse (with English and German legend).

Pedersen, S.A.S. 1993: Glaciodynamic event and glaciodynamic sequence. In: Aber, J.S. (ed.): Glaciotectonics and mapping glacial deposits. Canadian Plains Proceedings 25(1), 67-85. Canadian Plains Research Center, University of Regina, Canada.

Pedersen, S.A.S. 1996: Progressive glaciotectonic deformation in Weichselian and Palaeogene deposits at Feggeklit, northem Denmark. Bulletin of the Geological Society of Denmark 42, 153-174.

Pedersen, S.A.S. 2000: Superimposed deformation in glaciotectonics. Bulletin of the Geological Society of Denmark 46, 125144.

Pedersen, S.A.S. \& Petersen, K.S. 1988: Sand-filled frost wedges in glaciotectonically deformed mo-clay on the island of Fur, Denmark. In: Croot, D.G. (ed.): Glaciotectonics: forms and processes, 185-190. Rotterdam: A.A. Balkema.

Pedersen, S.A.S. \& Petersen, K.S. 1995: West Scandinavian traverse; NW-Jutland. In: Schirmer, W. (ed.): Quaternary field trips in central Europe, 20-31. Pfeil, München: INQUA International Congress Berlin.

Pedersen, S.A.S. \& Petersen, K.S. 1997: Djurslands geologi, 96 
pp. København: Danmarks og Grønlands Geologiske Undersøgelse.

Pedersen, S.A.S., Petersen, K.S. \& Rasmussen, LA. 1988: Observations on glaciodynamic structures at the Main Stationary Line in western Jutland, Denmark. In: Croot, D.G. (ed.): Glaciotectonics: forms and processes, 177-183. Rotterdam: A.A. Balkema.

Petersen, K.S. 1978: Application of glaciotectonic analysis in geological mapping of Denmark. Danmarks Geologiske Undersøgelse Årbog 1977, 53-61.

Petersen, K.S. 2004: Late Quaternary environmental changes recorded in the Danish marine molluscan faunas. Geological Survey of Denmark and Greenland Bulletin 3, 268 pp.

Puggaard, C. 1851: Møens Geologie. Universitetets Guldmedaille Priisskrift, 287 pp. København: Reitzel.

Rasmussen, L.Aa. 1975: Kineto-stratigraphic glacial drift unit on Hindsholm, Denmark. Boreas 4, 209-217.

Rawson, P.F. et al. 2002: Stratigraphical procedure. Geological Society Professional Handbook, 57 pp. London: Geological Society.

Ricci Lucchi, F. 1986: The Oligocene to Recent foreland basins of Northern Apennines. International Association of Sedimentologists Special Publication 8, 105-139.

Richard, N. 1996: Sedimentological examination of the Late Weichselian sea-level history following deglaciation of northern Denmark. In: Andrews, J.T et al. (eds): Late Quaternary palaeoceanography of the North Atlantic margins. Geological Society Special Publication (London) 111, 261-273.

Rosenkrantz, A. 1944: Nye Bidrag til Forståelsen af Ristinge Klints Opbygning. Meddelelser fra Dansk Geologisk Forening 10, 431-435.

Sadolin, M., Pedersen, G.K. \& Pedersen, S.A.S. 1997: Lacustrine sedimentation and tectonics: an example from the Weichselian at Lønstrup Klint, Denmark. Boreas 26, 113-126.

Schirmer, T.W. 1988: Structural analysis using thrust-fault hanging-wall sequence diagrams: Ogden Duplex, Wasatch Range, Utah. American Association of Petroleum Geologists Bulletin 72, 573-585.

Schou, A. 1949: Atlas over Danmark 1. Landskabsfomerne. København: Det Kongelige Danske Geografiske Selskab.

Seidenkrantz, M.-S. \& Knudsen, K.L 1993: Middle Weichselian to Holocene palaeoecology in the eastern Kattegat, Scandinavia: foraminifera, ostracods and C14 measurements. Boreas 22, 299-310.

Sejrup, H.P., Aarseth, I., Ellingsen, K.L, Reither, E. \& Jansen, E. 1987: Quaternary stratigraphy of the Fladen area, central North Sea: a multidisciplinary study. Journal of Quatemary Science 2, 35-58.

Sejrup, H.P., Haflidason, H., Aarseth, I., King, E., Forsberg, C.F., Long, D. \& Rokoengen, K. 1994: Late Weichselian glaciation history of the northern North Sea. Boreas 23, 1-13.

Sejrup, H.P., Landvik, J.Y., Larsen, E., Janockos, J., Eiriksson, J. \& King, E. 1998: The Jæren area, a border zone of the Norwegian Channel Ice Stream. Quaternary Science Reviews 17, 801-812.

Sejrup, H.P., Larsen, E., Landvik, J.Y., King, E., Haflidason, H. \& Nesje, A. 2000: Quaternary glaciations in southern Fennos- candia: evidence from southwestern Norway and the northern North Sea region. Quaternary Science Reviews 19, 667685.

Sjørring, S. 1974: Klinterne ved Hundested. Dansk Geologisk Forening Årsskrift 1973, 108-117.

Sjørring, S. 1977: The glacial stratigraphy of the island of Als, southern Denmark. Zeitschrift für Geomorphologie. N.F. Supplement-Band 27, 1-11.

Sjørring, S. 1981: Weichselian till stratigraphy in the southern part of Denmark. Quaternary Studies in Poland 3, 103-109.

Sjørring, S. 1983: The glacial history of Denmark. In: Ehlers, J. (ed.): Glacial deposits in north-west Europe, 163-179. Rotterdam: A.A. Balkema.

Sjørring, S., Nielsen, P.E., Frederiksen, J., Hegner, J., Hyde, G., Jensen, J.B., Mogensen, A. \& Vortisch, W. 1982: Observationer fra Ristinge Klint, felt- og laboratorieundersøgelser. Dansk Geologisk Forening Årsskrift 1981, 135-149.

Slater, G. 1927: The disturbed glacial deposits in the neighborhood of Lönstrup, near Hjörring, north Denmark. Transactions Royal Society Edinburgh 55(2), 303-315.

Smed, P. 1995: Sten i det danske landskab, 181 pp. Brenderup, Denmark: Geografforlaget.

Stephan, H.-J. 1980: Glazialgeologische Untersuchungen im südlichen Geestgebiet Ditmarschens. Schriftenreihe des Naturwissenschaftlichen Vereins Schleswig-Holstein 50, 1-36.

Suppe, J. 1983: Geometry and kinematics of fault-bend folding. American Journal of Science 283, 684-721.

Suppe, J. 1985: Principles of structural geology, 537 pp. Englewood Cliffs, New Jersey: Prentice-Hall, Inc.

Tauber, H. 1966: Danske kulstof-14 dateringsresultater. Meddelelser fra Dansk Geologisk Forening 16, 153-176.

Ussing, N.V. 1903: Danmarks Geologi i almenfatteligt Omrids. Danmarks Geologiske Undersøgelse III. Række 2, 358 pp.

van der Meer, J.J.M. (ed.) 1987: Tills and glaciotectonics, 270 pp. Rotterdam: A.A. Balkema.

van der Wateren, D.F.M. 1985: A model of glacial tectonics, applied to the ice-pushed ridges in the central Netherlands. Bulletin of the Geological Society of Denmark 34, 55-74.

van der Wateren, D.F.M. 1992: Structural geology and sedimentology of push moraines, $230 \mathrm{pp}$. Unpublished thesis, University of Amsterdam, the Netherlands.

Vendsyssel nu og da 1981: Rubjerg Knude, 34 pp. Hjørring, Denmark: Vendsyssel Historiske Museum.

Weinberg, R.F. \& Schmeling, H. 1992: Polydiapirs: multiwavelength gravity structures. Joumal of Structural Geology 14, 425-436.

Wiltschko, D.V. 1979: A mechanical model for thrust sheet deformation at a ramp. Journal of Geophysical Research 84, 10911104.

Wiltschko, D.V. \& Dorr, J.A. 1983: Timing and deformation in overthrust belt and foreland of Idaho, Wyoming and Utah. American Association of Petroleum Geologists Bulletin 67, 1304-1322. 


\section{Appendix 1}

\section{Thrust-fault terminology}

Thrust fault: A surface along which an overlying block is displaced relative to an underlying block. Relative to bedding, two different elements are distinguished in a thrust fault: the ramp and the flat.

Ramp: A thrust-fault ramp cuts up-section in the direction of slip and dips towards the hinterland. The angle between bedding and the ramp is in general between $20^{\circ}$ and $30^{\circ}$ and will not exceed $45^{\circ}$ due to general rules of initial fracturing. A ramp is linked to a lower flat at the lower ramp hinge and to an upper flat atthe upper ramp hinge. A ramp may become foreland-dipping in special cases, mainly related to transport along an upper flat.

Flat: A thrust-fault flat is a bedding-parallel slip surface along which lateral displacement takes place. The lowermost thrust-fault zone in deformation complexes is in general referred to as the décollement surface, décollement zone or décollement level. In the present description the 'décollement level' is the term used for the thrust fault between a thrust sheet and an undisplaced footwall block below a footwall flat. As flats develop at different levels, the flats above the décollement level are referred to as intermediate flats and the upper flat (identical with the roof thrust fault). The thrust-fault flats are referred to by their depth from the upper reference zero-level indicated from the balanced section. Thus the $20 \mathrm{~m}$ flat level is the horizontal thrust faultsituated $20 \mathrm{~m}$ below the top reference level and 10 or $20 \mathrm{~m}$ above the décollement level.

Thrust sheet: A thrust sheet is the block displaced over a thrust fault. In this study, the thrust sheets are annotated according to the section in which they occur with two capital letters, referring to the named section, and a number referring to its position from leading edge to trailing end of the section. Thus, KR01 is the thrust sheet nearest to the foreland in the Kramrende section. A thrust fault is referred to according to the thrust sheet it displaces. A thrust sheet is synonymous with the hanging-wall block.

Hanging-wall block: The rock mass displaced over a thrust fault is a hanging-wall block. At the base, a hanging-wall flat and a hanging-wall ramp bound the hanging-wall block. At the roof, the hanging-wall block is capped by a top surface or a roof thrust fault. The roof thrust fault may constitute a footwall flat as well as a footwall ramp.

Footwall block: The rock below a thrust fault is a footwall block. The footwall block is bounded by a footwall ramp, and the top of the footwall block constitutes a top surface and/or a footwall flat.

Hanging-wall ramp: The segment of a ramp that bounds the hanging-wall block is a hanging-wall ramp. At the incipient displacement along a ramp, the hanging-wall ramp is thrust along a footwall ramp. When the hanging-wall ramp passes the upper ramp hinge, the hanging-wall ramp is thrust along a footwall flat. A hanging-wall anticline is always formed above a hanging-wall ramp.

Hanging-wall flat: The bedding-parallel thrust-fault boundary below the hanging-wall block is a hangingwall flat. When a hanging-wall flat is thrust up along a footwall ramp, the hanging-wall flat is re-orientated and becomes inclined towards the hinterland. When the hanging-wall flat is thrust along an upper footwall flat, the thrust fault again becomes bedding parallel. Footwall ramp: The inclined thrust-fault boundary of a footwall block is a footwall ramp. The footwall ramp is either the ramp boundary to the undisplaced foreland or it forms the trailing ramp boundary of a thrust sheet. In this study, the trailing footwall ramp is referred to using the annotation of the thrust sheet/ footwall block that underlies it. Thus the KR02 hanging-wall ramp is displaced up along the KR01 footwall ramp.

Footwall flat: A footwall flat is always the top of a footwall block. A footwall flat is more or less horizontal unless it is re-orientated during the displacement of a thrust sheet up along a ramp.

Hanging-wall anticline: When a hanging-wall block is thrust over an upper ramp hinge, the hanging-wall block is folded into an anticline with a foreland-dipping forelimb and a hinterland-dipping backlimb. This fold may also be termed a ramp anticline. During the progress of thrusting along the upper limb, the hanging-wall anticline develops into a flat-topped anticline. The flat-topped anticline may altematively be regarded as a flat-lying thrust sheet with a foreland-dipping forelimb or a frontal thrust-sheet nose. However, it is important to note that above a hanging-wall ramp thrust along a footwall flat, a foreland-dipping surface is formed. 
Footwall syncline: When a thrust fault propagates up along a ramp, an anticline-syncline pair is formed above, and in front of, the tip of the thrust fault, identical to the formation of a fault-propagation fold. When the thrust fault finally breaks through the folded layers, the fold pair is separated into a hanging-wall anticline and a footwall syncline. A footwall syncline therefore represents the gentle deformation below the footwall ramp; this deformation does not add significantly to the displacement along the thrust fault. The footwall syncline may also be regarded as a drag fold. The case where this is the only correct interpretation is along a growth fault. Here the sediments deposited syntectonically up against a hanging-wall ramp are successively bent into an overturned syncline. The footwall syncline is identical to a trailing syncline.

Duplex: A duplex is one or more thrust-sheet segments entirely bounded by thrust faults and thus overlain by a thrust sheet. A thrust sheet bounded by thrust faults is called a horse, originally regarded as a minor rootless thrust-sheet segment. Some of the lower thrustsheet segments described in this study are identical to horses, although the more neutral term 'segment' is adopted here. The fomation of a duplex is related to the 'footwall ramp collapse' (Boyer \& Elliott 1982), whereby progressive failure during thrust-fault propagation creates successively younger thrust faults below older ones. A parcel of thrust-sheet segments may be stacked to form a duplex complex.
Imbricate fan : A branching thrust-fault complex in which the individual thrust faults reach the surfaces or top level is called an imbricate fan. An imbricate fan is termed a duplex if the upper boundary is a roof thrust.

Antiformal stack: When a duplex is fault-bend-folded over a footwall ramp, an antiformal structure similar to a hanging-wall anticline is formed. Due to the complex stratigraphic relationship within such a structure, it is referred to as an antiformal stack.

Piggyback thrusting: When an older thrust sheet rests on the back of a younger thrust sheet and is transported due to the displacement along the thrust faults bounding the younger thrust sheets, it is called piggyback thrusting.

Piggyback basin: Just as piggyback thrusting refers to transport of a thrust sheet, the term is also applied to a basin that accumulates sediments during translation on the back of an active thrust sheet: the piggyback basin (Ori \& Friend 1984; Ricci Lucchi 1986). In this study, the term is mainly used in the description of an area of sedimentation between two thrust sheets. In general, the piggyback basin is deposited between a fault-bend thrust-sheet tip in the distal part of a thrust structure and bounded by a hanging-wall ramp at the proximal boundary of the basin. The term piggyback basin can only be applied to successions identified as having been deposited syntectonically. 


\section{Appendix 2}

\section{Specification of photogrammetric work}

The construction of the Rubjerg Knude cross-section (Plate 1) is based on a multi-model photogrammetric investigation of the cliff section, with the application of the method described by Dueholm (1992). A series of oblique photographs were taken from a Cessna fixed-wing aircraft in June 1993. The camera used for the photography was a Minolta XG2, which had been tested and calibrated for its optical specifications at the laboratory of photogrammetry at the Danish Technical University. The films used were standard $24 \times 36$ $\mathrm{mm}$ colour diapositive. The photographs were taken with $66 \%$ overlap from a distance of $200-300 \mathrm{~m}$ with an inclination angle of c. $35^{\circ}$. From the series of photographs, 70 samples were selected for setting up three sets of templates, which included 67 stereoscopic models.

In the laboratory, the orientation of the stereo-models was carried out based on ground control points adapted from two sets of vertical aerial photographs at a scale of 1:25 000, namely D9202 G 1365-66 and KMS 9203 A509-10 taken in May 1992. The strike of the section line is $\mathrm{N} 15^{\circ} \mathrm{E}$ from Rubjerg Knude and southwards. North of Rubjerg Knude, the strike is $N 24^{\circ} \mathrm{E}$, which is nearly parallel to the direction of the coastline along the beach. Fortunately, this is also a reasonable approximation of being perpendicular to the main concentration of structural strikes (bedding, thrust faults and fold axes; Fig. 10). A minor adjustment of the northem and southern section lines was subsequently implemented to make the cross-section fit to the general plane of orthographic projection with a projection axis striking $107^{\circ}$.

The stereoscopic instrument used for the investigation was a Kern DSR 15 analytical plotter with a DEC VMS operating system and the special attached GEOPROGRAM developed by Dueholm (1992). Five different labels were used for the features outlined by the floating mark: line type 1 includes bedding traces, line type 2 includes the main unconfomities, line type 3 was used for the contacts between geological units (members and formations), line type 4 outlines thrust faults, and finally line type 5 was used for topographic features (dunes, scree cones, strandplain, rockfalls etc.). Digitalisation of the geological structures in the stereo-models was administrated in data files, each covering a plot-area. The plot-areas covered $500 \mathrm{~m}$ of the Rubjerg Knude cross-section, and 13 plot-areas were used for the analogue plotting of data digitised in the stereo-model. The digital data were stored for the later construction of the cross-section and the transformation for other programs applied for the management of the cross-section display.

The orientation of models and setting up the system for the cross-section investigation took about one week, and the photo-geological compilation work was made over a period of three months in the autumn of 1993. The average progress was two models per day. The benefit of the multi-model analytical stereo-plotter is that features can be traced continuously from one model to the adjacent models. Thus one is not restricted to working model by model, but the compilation can be extended over several models using the same set of templates. By January 1994, the cross-section could be plotted out in a normal vertical projection profile plan from the stored digital data with the application of the program facilities prepared by Dueholm (1992). The scale of the Rubjerg Knude crosssection in the draft versions is 1:500, and the accuracy of the plotted data is estimated to be better than 25 $\mathrm{cm}$.

In 1995-1996, the cross-section details observed in the photo-geological models were checked in the field, and in 1997 the templates were set up again for correction, adjusting and compilation of details in the cross-section. 